\title{
ARQUEOMETALURGIA INKA EN EL NOROESTE ARGENTINO.
}

\section{ESTUDIO DEL SITIO QUILLAY (CATAMARCA) Y ABORDAJE TECNO-ESTILÍSTICO DE PIEZAS DE COLECCIÓN.}

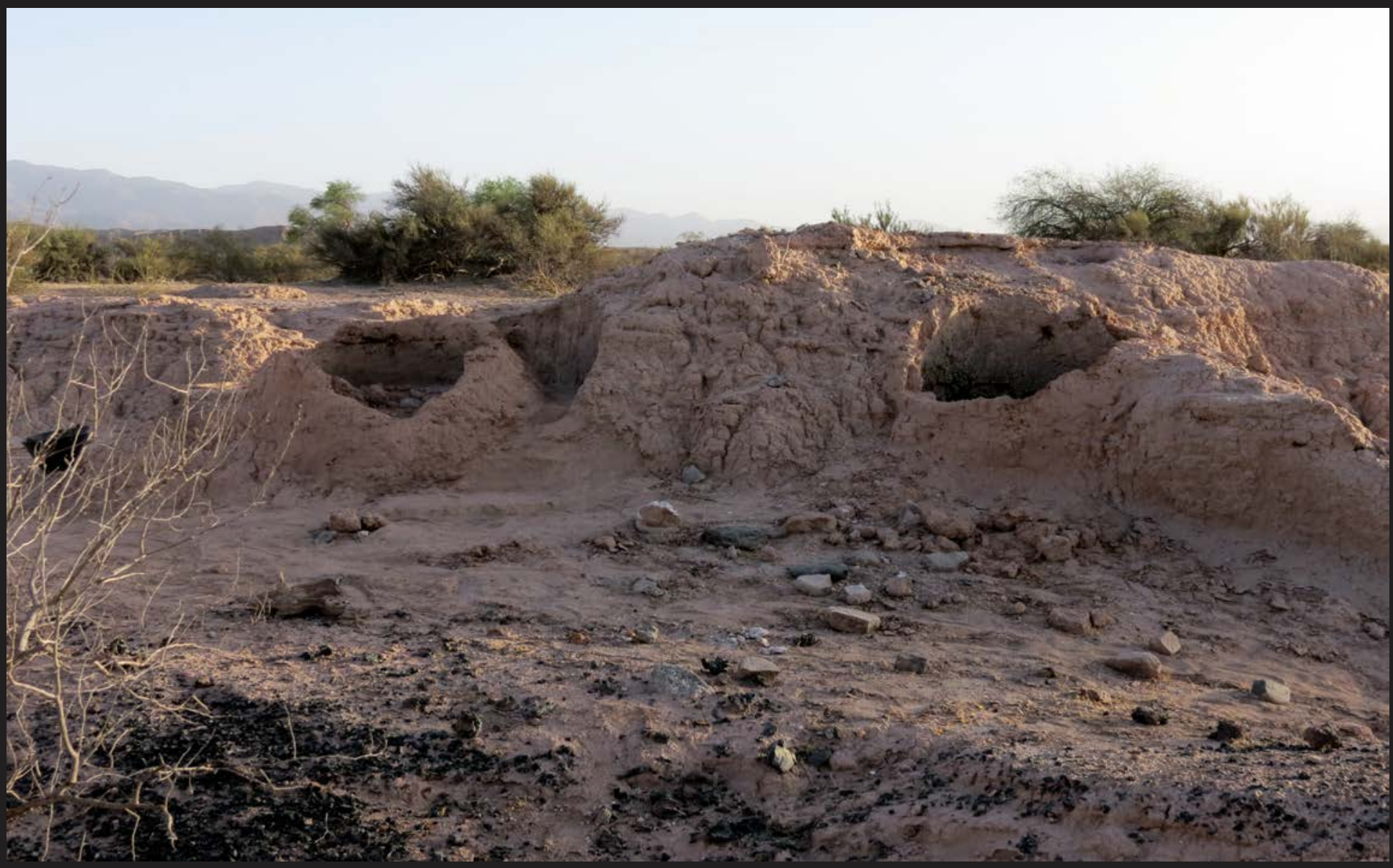

Josefina Spina

Director: Luis R. González Co-Director: Marco A. Giovannetti

Facultad de Ciencias Naturales y Museo Universidad Nacional de La Plata 
ARQUEOMETALURGIA INKA EN EL NOROESTE ARGENTINO. ESTUDIO DEL SITIO QUILLAY (CATAMARCA) Y ABORDAJE TECNO-ESTILÍSTICO DE PIEZAS DE COLECCIÓN.

Tesis para optar al grado de Doctora en Cs. Naturales

Facultad de Cs. Naturales y Museo

Universidad Nacional de La Plata

Lic. Josefina Spina

2018 


\section{ÍNDICE TEMÁTICO}

Agradecimientos...........................................................

Resumen................................................................

Abstract....................................................................

\section{Capítulo 1. INTRODUCCIÓN}

1.1. Presentación de la problemática de estudio y los objetivos de la investigación......1

1.2. Organización de la Tesis............................................4

\section{Capítulo 2. MARCO TEÓRICO GENERAL}

2.1. Introducción....................................................... 7

2.2. Tecnología como dimensión social.......................................11

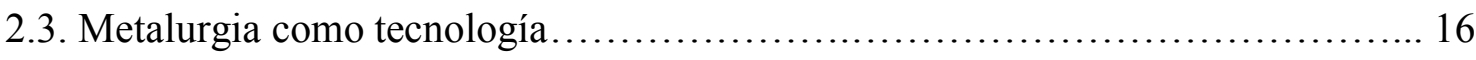

2.4. Cosmovisión Andina........................................................ 21

\section{Capítulo 3. ANTECEDENTES}

3.1. Estudios sobre metalurgia en el noroeste argentino (NOA) .................... 24

3.2. Sitios con evidencias de actividades minero-metalúrgicas en la región andina ..... 31

3.2.1. Sitios en el actual territorio peruano.................................. 32

3.2.2. Sitios en el actual territorio boliviano.................................... 38

3.2.3. Sitios en el actual territorio chileno ................................ 43

3.2.4. Sitios en el actual territorio argentino............................... 48

3.3. Metalurgia en el valle de Hualfín.......................................... 57

3.4. Las investigaciones arqueológicas en el sitio Quillay........................... 59

3.5. Consideraciones generales sobre las políticas del Tawantinsuyu............... 61

\section{Capítulo 4. EL SITIO ARQUEOLÓGICO QUILLAY}

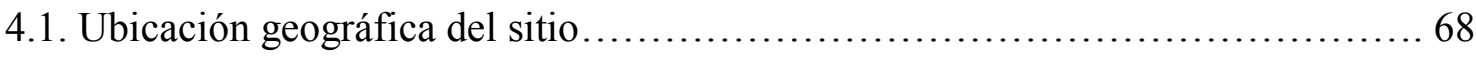

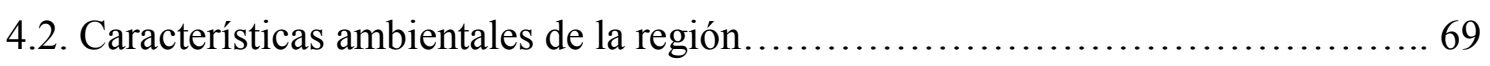

4.2.1. Red de drenaje, clima y biogeografía de la zona de estudio.................. 69

4.2.2. Geología y petrología.......................................... 75 
4.2.3. Caracterización de los suelos............................................ 78

4.3. Mineralizaciones cercanas a la región de estudio............................... 79

4.4. Nuestros primeros relevamientos en el sitio Quillay........................... 83

4.5. Mapa del sitio y sectorización del espacio .................................. 84

4.5.1. Sector A: descripción de los recintos................................. 87

4.5.1.1. Discusión sobre la arquitectura de los recintos..........................94

4.5.2. El sector B: descripción de las estructuras del espacio productivo.............. 96

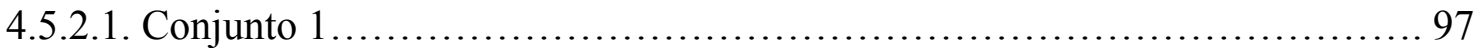

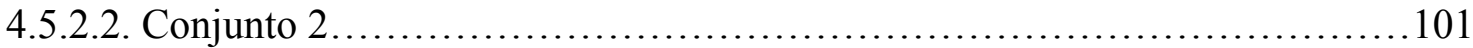

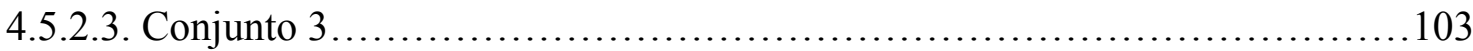

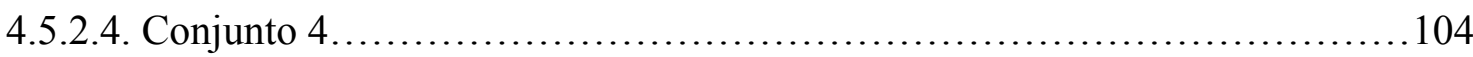

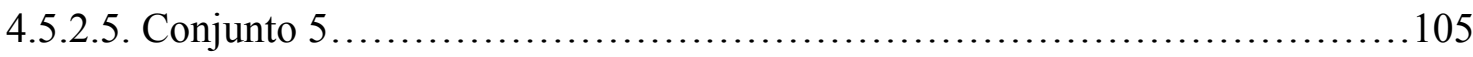

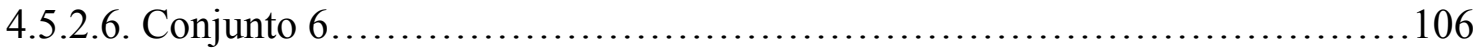

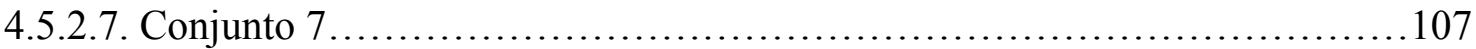

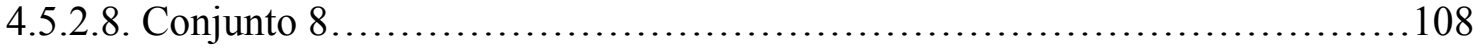

4.6. Análisis de la varianza para variables morfométricas de hornos.................112

4.7. Estado de conservación de hornos y agentes de deterioro...................... 113

\section{Capítulo 5. SECTOR A: ANÁLISIS DE RECINTOS}

5.1 Presentación del capítulo............................................. 122

5.2. Primera etapa: el trabajo de campo....................................... 122

5.2.1. Metodología de recolección superficial y materiales recuperados............. 122

5.2.2. Metodología de excavación y registro..................................... 124

5.3. Segunda etapa: trabajo de gabinete ........................................ 125

5.3.1. Análisis del material cerámico......................................... 125

5.3.2. Análisis del material refractario....................................... 128

5.3.3. Análisis del material lítico......................................... 131

5.3.4. Análisis del material arqueobotánico........................................ 132

5.3.5. Análisis del material zooarqueológico.................................. 133

5.4. Caracterización de la cerámica de superficie del sector A...................... 133

5.5. Materiales refractarios: tipos artefactuales y sus características ................ 142

5.5.1. Primera aproximación para la caracterización de las pastas refractarias........ 148

5.5.2. Análisis de los materiales adheridos a los refractarios.................... 152

5.5.3. Integración y evaluación de los resultados obtenidos en muestras refractarias...156 
5.6. Lámina de metal ......................................................... 158

5.7. Materiales y contextos de excavación en las estructuras arquitectónicas......... 159

5.7.1. Recinto 3. Re- evaluación del material cerámico obtenido en 1952 ............. 159

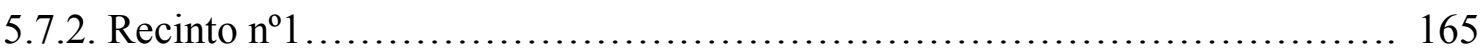

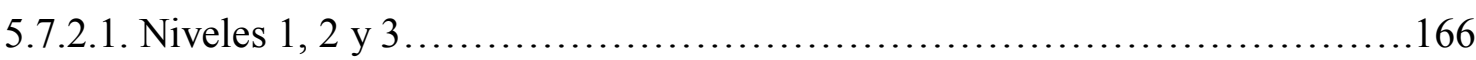

5.7.2.2. Nivel 4............................................................ 167

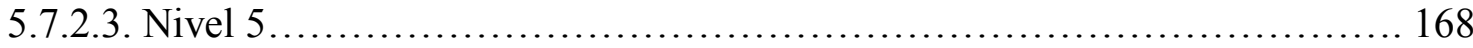

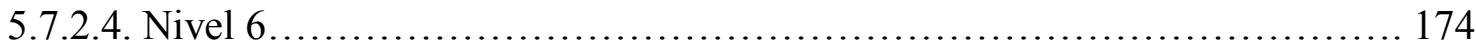

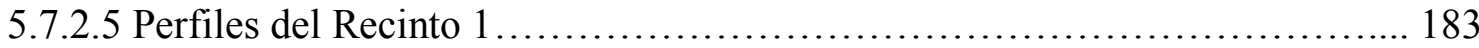

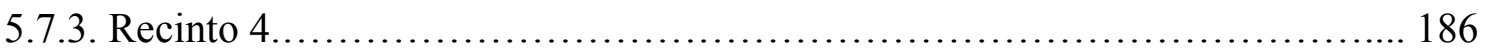

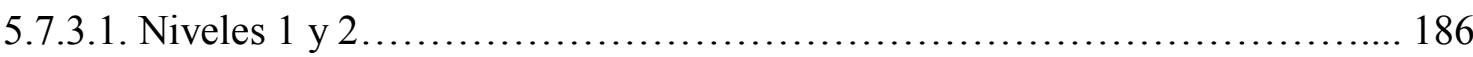

5.7.3.2. Nivel 3...................................................... 187

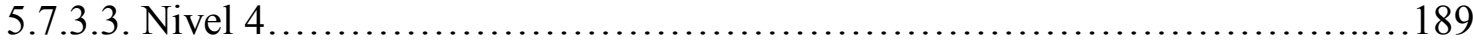

5.7.3.4. Nivel 5......................................................... 190

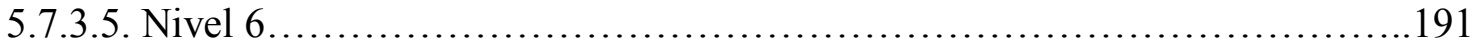

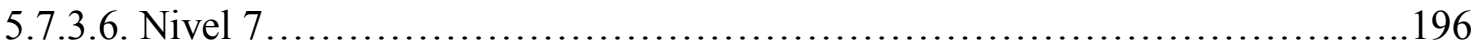

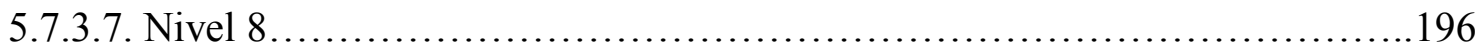

5.7.3.8. Perfiles del Recinto 4.................................................. 199

5.7.4. Integración y discusión de resultados obtenidos en los recintos................ 200

\section{Capítulo 6. EL SECTOR PRODUCTIVO. LOS HORNOS METALÚRGICOS}

6.1. Presentación del capítulo................................................. 209

6.2. Los materiales de recolección superficial.................................... 210

6.2.1. Cerámica................................................................. 210

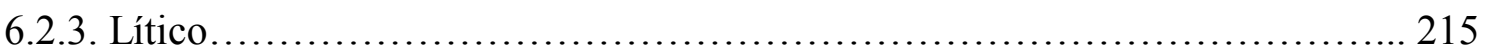

6.3. Hornos: excavación, materiales y morfología............................... 218

6.3.1. Metodología de excavación.......................................... 218

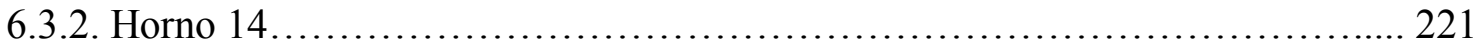

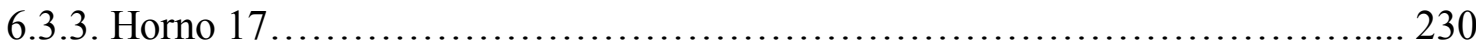

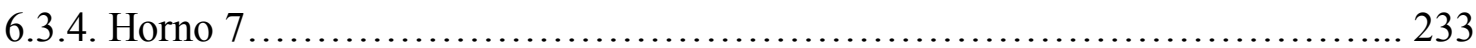

6.4. Análisis de Laboratorio................................................... 236

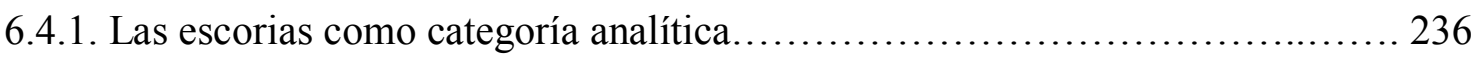

6.4.1.1. Clasificación de las escorias metalúrgicas................................ 238

6.4.2. Muestreo y metodología para el estudio de escorias......................... 239 
6.4.2.1. El reconocimiento macroscópico de las escorias: hacia una primeraclasificación. 241

6.4.2.2. Características químicas y microestructurales de las escorias 244

6.4.2.2.1. Limitantes en la identificación de fases y criterios adoptados. .244

6.4.2.2.2. Resultados del análisis por microscopía óptica y electrónica 245

6.4.2.2.3. Resultados del análisis por difractometría de rayos X..................... 254

6.4.2.2.4. Resultados del análisis por fluorescencia de rayos X................... 256

6.4.3. La información que nos brindan las escorias.

Integración y discusión de resultados..................................... 258

6.4.4. La identificación del sedimento blanco...................................262

6.4.5. Análisis de paredes de hornos.

El material constructivo de las estructuras de combustión.................. 264

6.4.6. Análisis de macrorestos botánicos: el combustible de los hornos............... 267

6.4.7. Dataciones radiocarbónicas............................................. 277

6.4.8 ¿Qué nos dice el fragmento textil registrado en el horno 14?........................... 280

6.5. Sintetizando las características de los hornos metalúrgicos.................... 282

6.6. Algunas propuestas sobre dinámica de funcionamiento de hornos .............. 283

6.7. Breve debate en torno a las categorías de hornos............................. 286

6.8. Los hornos de Quillay en el contexto andino............................... 289

\section{Capítulo 7. APORTES BREVES SOBRE ALGUNOS OBJETOS DE METAL.}

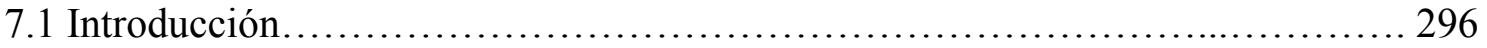

7.2. Colecciones museológicas estudiadas..................................... 297

7.3. Metodología de relevamiento y criterios adoptados.............................299

7.3. Caracterización de los objetos museísticos analizados......................................

7.3.1. Las piezas metálicas de la colección Moreno $\mathrm{n}^{\circ} 1$ y Museo (MLP - D25) ......304

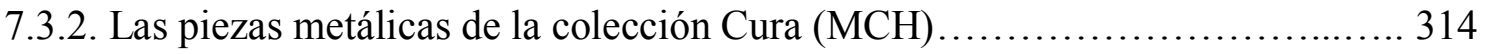

7.3.3. Las piezas metálicas del museo de sitio de El Shincal de Quimivil............. 319

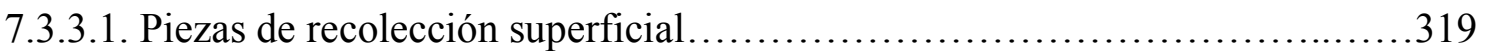

7.3.3.2. Piezas de excavación con contexto de hallazgo............................ 321

7.3.3.3. Piezas sin contexto de hallazgo....................................... 327

7.4. Datos sobre la funcionalidad de las piezas.............................. 332

7.5. Discusión y conclusiones del capítulo.................................. 337 


\section{Capítulo 8: CONCLUSIONES GENERALES}

8.1. Quillay: un taller de extracción metalúrgica en el valle de Hualfín (Catamarca)..342

8.1.1. La organización de la producción metalúrgica.............................. 350

8.2. La actividad metalúrgica en la dinámica sociopolítica del estado Inka............352

BIBLIOGRAFIA ............................................................. 361

ANEXO I. Tablas de Análisis

ANEXO II. Informes Técnicos del Fragmento Textil

ANEXO III. Fichas de Análisis de Piezas de Metal

ANEXO IV: Imágenes 


\section{AGRADECIMIENTOS}

Esta investigación fue posible gracias a muchas personas e instituciones que han contribuido directa o indirectamente en diferentes etapas del proceso. A todos ellos quiero expresarles un sincero agradecimiento.

En primer lugar, deseo agradecer a mis directores de tesis, Luis González y Marco Giovannetti quienes me guiaron en todo el proceso, brindaron bibliografía específica y discutieron conmigo varios de los datos obtenidos en este trabajo que permitió enriquecerlo. También porque me alentaron continuamente a la culminación de la tesis y por la lectura crítica de este manuscrito. A Marco específicamente, porque con él comencé a trabajar siendo estudiante de grado y me enseñó el camino de la arqueología. Gracias por abrirme las puertas al campo de la metalurgia confiándome el estudio del sitio arqueológico. Por los trabajos de campo, congresos y actividades compartidas y las amplias conversaciones sobre el Tawantinsuyu que han sido pilares fundamentales para el desarrollo de esta investigación. Por la escucha de mis inquietudes y el impulso constante. A Rodolfo Raffino, Luis González, Gustavo Politis y Mariano Bonomo por aceptar dirigir mis becas y responder a mis pedidos. A Gustavo y Mariano les doy las gracias por brindarme su ayuda cuando más lo necesitaba, por sus consejos, acompañamiento y buenos deseos.

A mis compañeros de laboratorio: Gregoria Cochero, Mariana Valderrama, Lucía Aljanati, Eduardo Ferrari y Gustavo Corrado, por su compañía en los extensos trabajos de campo y el espacio de laboratorio, por las numerosas charlas y los mates lavados. Gustavo y Mariana contribuyeron específicamente en esta investigación con el mapeo del sitio y el análisis de material faunístico de excavación, respectivamente. A Edgardo, le agradezco, además, las inmunerables preguntas sobre metalurgia y hornos andinos que me realizó durante los fogones de campaña, que me hacían pensar y evaluar una y otra vez las evidencias obtenidas en Quillay. A Gregoria, coequipera y amiga, le agradezco especialmente por haber transitado juntas este camino. Sin su compañía los seminarios de doctorado, las campañas, los congresos, las actividades de divulgación, las largas horas de laboratorio y mi vida en general no hubiese sido la misma. Gracias por tu amistad, tus masajes y tu apoyo constante que me permitió superar dificultades académicas y personales. También quisiera agradecer a otro conjunto de personas que participaron en 
algunas de las campañas arqueológicas: Camila Salama, Narella Marini Spadaccini, Macarena Molaro y César Carrizo.

Una mención especial merece la Familia Cedrón que reside en el sitio, a quienes agradezco por abrirnos las puertas de su casa, esperarnos siempre con un plato de comida - aún en momentos de crisis - y por las enseñanzas que me dejaron: Griselda, Hugo, Rita, Marcela y a sus hijos e hijas, gracias por su hospitalidad y reciprocidad, tan característica de la vida andina.

También me gustaría expresar mi gratitud a una serie de personas que colaboraron directa o indirectamente en diferentes estudios técnicos y que, sin su apoyo, esto no habría sido posible. Los análisis de escorias fueron realizados gracias a la capacitación que me brindó inicialmente Horacio De Rosa, primero a partir de un seminario de posgrado dictado por él y luego guiándome y prestándome las instalaciones para realizar la primera experiencia sobre estudios metalográficos en materiales originarios del sitio. Estos fueron cimientos fundamentales para los análisis que realicé posteriormente. En ese marco, agradezco también a Carlos Llorente y a todo el equipo técnico de LIMF (UNLP) por la paciencia en los turnos de microscopía electrónica de barrido para la caracterización de fases minerales. También a Daniel Poiré y Germán Kürten del CIG (CONICET-UNLP) y a Rodrigo Álvarez del INTI por haber aportado de forma gratuita algunos de los análisis químicos. A Carola Castiñeira y Adriana Blasi porque desinteresadamente me capacitaron en la lectura de difractogramas $\mathrm{y}$ en análisis mineralógicos $\mathrm{y}$ sedimentológicos, les agradezco mucho su tiempo, paciencia y dedicación. A Julieta Lynch y María Julia Solari por colaborar en el análisis de cortes delgados de paredes de hornos. A Maite Romero por enseñarme el camino de la antracología y acompañarme en el estudio de leños. A Geraldine Gluzman por realizar los estudios petrográficos de cerámicas refractarias, por los debates sobre metalurgia, sus consejos y aliento y por la amistad que iniciamos. También, a Cecilia Pérez de Micou y Silvana Di Lorenzo, quienes, sin conocerme, apenas toqué a sus puertas accedieron a realizar los estudios del textil, gracias por sus valiosos aportes y por su cariño. A Cecilia Páez por brindarme un importante corpus de bibliografía sobre tecnología. A Florencia Becerra y Martina Renzi por su tiempo para responder a mis consultas sobre análisis de escorias. Sin embargo, ninguno de ellos es responsable de las interpretaciones volcadas en esta tesis. 
A nivel institucional, quisiera agradecer a la Universidad Nacional de La Plata por la financiación para realizar este estudio mediante el sistema de becas doctorales y subsidios. A CONICET por la financiación otorgada a mi co-director que permitió realizar los primeros trabajos de campo. A las autoridades de la Facultad de Ciencias Naturales y Museo por brindarme el espacio físico para realizar los trabajos de investigación a lo largo de estos años. También a las autoridades de la dirección provincial de Antropología de Catamarca, Lic. Martín Lucas Rodríguez y Sergio Álvarez, quienes otorgaron los sucesivos permisos para el estudio del sitio y para el análisis de piezas de colección de museos en la provincia. También al Dr. Raffino por permitirme realizar el estudio de piezas de colección en el Museo de La Plata como jefe de División. Asimismo, agradezco a todos los responsables y técnicos que me recibieron amablemente en cada deposito, me brindaron el acceso a las piezas solicitadas y su documentación: Claudia Yapura, Hortensia Ignes, Teresa Purulla, César Carrizo, Paula Espósito y Jorgelina Collazo.

Por otro lado, deseo agradecer a mis amistades de toda la vida y amigos antropólogos, quienes a lo largo de estos años me escucharon atentamente, me dieron su aliento y me brindaron nuevas perspectivas frente a mis constantes dudas y cambios de ánimos. Especialmente quisiera nombrar a Gregoria, Jimena, Federico, Tamara, Marcela y Aldana.

A las personas que son mi fuente de alegría y me apoyan incondicionalmente en todos mis proyectos, confían ciegamente en mí, perdonan mis ausencias y siempre me dan su hombro, mi familia: gracias a mi papá, José Luis y a mis hermanos, cuñados y sobrinos: Leandro, Julieta, Carolina, los Fernando, Lissette, Joaquín, Carola, Nicolás, Emma, Andrés, Lorenza, Victoria y Santiago; y a mis primos, sobre todo a Juliana y a Hugo.

Especialmente agradezco a Lisandro, mi compañero, por estar siempre y recorrer juntos los caminos de la vida que están llenos de vicisitudes, por leer una y otra vez varios de estos renglones, por su confianza, por impregnarme de su fuerza, su paz y sacarme siempre una sonrisa. Gracias por impulsarme a ser cada día una mejor persona, por esta casi década juntos y por los años y proyectos que vendrán. Finalmente, deseo dedicar esta tesis a la memoria de mi madre. 


\section{RESUMEN}

La presente tesis tiene como propósito contribuir al conocimiento sobre la tecnología metalúrgica en tiempos del Tawantinsuyu. Para ello se planteó como objetivo conocer las maneras de producción metalúrgica en la provincia de Catamarca a través de un abordaje arqueológico. Por un lado, se estudiaron las evidencias de producción registradas en el sitio Quillay (valle de Hualfín, dpto. Belén, Catamarca) que presenta un importante conjunto de hornos. Por otro lado, se recurrió al análisis de piezas de metal disponibles en colecciones de museos (Museo de La Plata, Museo Cóndor Huasi y museo de sitio de El Shincal).

Los antecedentes de estudios sobre metalurgia en la República Argentina se remontan a los primeros estadios de la disciplina arqueológica, principalmente de la mano del análisis de objetos de metal incorporando desde las últimas décadas del siglo XX, estudios de sitios arqueológicos con contextos productivos. No obstante, aún resultan escasas las evidencias sobre hornos metalúrgicos. Es por ello que, se realizó una revisión sobre estructuras pirotécnicas empleadas en las distintas etapas del proceso metalúrgico en la región Andina, con el fin de contrastar y evaluar las estructuras de Quillay.

Esta investigación siguió una perspectiva antropológica sobre la tecnología, entendiendo a la metalurgia como un fenómeno holístico que vincula todas las dimensiones de la vida social, al ser un sistema integrado por lo político, lo social y lo sagrado. Por lo tanto, se indagó sobre distintos aspectos: recursos materiales, implementos y herramientas, funcionalidad, procedimientos técnicos de fabricación, secuencias de comportamiento, elecciones tecnológicas, identidad y rol de los artesanos, gestión de recursos y organización social del trabajo, todos ellos contextualizados en el sistema socio-cultural que les otorga sentido.

Durante los trabajos de campo se realizaron prospecciones en el sitio que resultaron en la detección de más de una treintena de hornos asociados a desechos metalúrgicos, instrumentos de molienda, materiales cerámicos y refractarios, entre otros. Se efectuó un ordenamiento zonal dividiendo al sitio en un sector productivo con varios conjuntos de hornos y se realizó un mapeo más preciso del espacio de recintos. Se analizó el material cerámico, refractario y lítico obtenido en las recolecciones superficial de ambos sectores. Con posterioridad, se realizaron excavaciones en hornos y recintos. A partir de los primeros, fue posible determinar la morfología completa de las estructuras 
pirometalúrgicas, que no se conocían hasta el momento y entender su funcionamiento. Por otra parte, las evidencias registradas en el sector de recintos permitieron considerarlo como un espacio de habitación y de producción de comida, donde fueron procesados elementos vegetales y animales a juzgar por los restos óseos y botánicos.

Desde una aproximación arqueometalúrgica, se procedió a la caracterización macro y microscópica de las principales evidencias de producción. Entre los indicadores de producción metalúrgica se reconocieron hornos y escorias metalúrgicas, resto de leños carbonizados, materiales refractarios con inclusiones metálicas, fragmentos de mineral y metal e instrumentos de molienda. Mediante estudios especializados de laboratorio sobre estos materiales, se buscó dar respuesta a inquietudes vinculadas a las etapas de transformación de las materias primas, las modalidades de producción y de organización. Esta información fue complementada con estudios técnicos sobre piezas de metal inkaicas para indagar la forma en que los objetos fueron fabricados.

Entre las principales conclusiones, se propone a Quillay como un taller metalúrgico a gran escala, donde se llevaron a cabo las primeras etapas del proceso productivo, es decir la metalurgia extractiva de metal de cobre. Los metalurgistas eran de la zona a juzgar por los materiales recuperados y algunas soluciones tecnológicas, que no difieren de las identificadas en otros sitios cercanos. La presencia Inka está materializada a través de elementos sutiles pero presentes, como la parafernalia cerámica estatal, la magnitud en la escala productiva, la utilización de hornos para la fundición y la salida externa del producto metálico obtenido, entre otros.

Por otro lado, los hornos de Quillay presentan un diseño único dentro de las estructuras pirometalúrgicas conocidas hasta el momento para la región Andina. Por consiguiente, se propone que la práctica de fundición en este taller adquirió una modalidad tecnológica distintiva producto de innovaciones realizadas en el marco de las nuevas relaciones socio-políticas imperantes con la llegada de los Inkas a la región. Se considera a este taller como un espacio especializado inserto en una logística macroregional de producción de metales, dónde no produjeron objetos, sino que se llevaban el metal de cobre obtenido para su trabajo posterior en otras regiones. Por último, las piezas de metal participarían dentro de estrategias políticas vinculadas a prácticas sagradas, que permitieron legitimar la estructura social y afianzar el tejido social del Tawantinsuyu. 


\begin{abstract}
The purpose of this thesis is to contribute to the knowledge about metallurgical technology in the times of Tawantinsuyu. For this, the objective was to know the ways of metallurgical production in the province of Catamarca through an archaeological approach. On the one hand, the production evidences registered at the Quillay site (Hualfín valley, Belén department, Catamarca) that presents an important set of furnaces were studied. On the other hand, metal pieces available in museum collections were analyzed (La Plata Museum, Condor Huasi Museum and El Shincal museum site).

The history of studies on metallurgy in Argentina goes back to the first stages of the archaeological discipline, mainly from the analysis of metal objects, incorporating since the last decades of the 20th century, studies of archaeological sites with production contexts. However, there are still little evidences of metallurgical furnaces. That is why, it was made a review of the pyrotechnic structures used in the different stages of the metallurgical process in the Andean region, in order to contrast and evaluate the Quillay structures.
\end{abstract}

This research followed an anthropological perspective on technology, considering metallurgy as a holistic phenomenon that links all dimensions of social life, being a system composed of the political, the social and the sacred. Therefore, we inquired about different aspects such as: material resources, tools and implements, functionality, technical manufacturing procedures, behavioral sequences, technological choices, identity and role of craftsmen, resource management and social organization of work, all of them contextualized in a socio-cultural system that gives them meaning.

During the field works, site surveys were conducted that resulted in the detection of more than thirty furnaces associated with metallurgical waste, grinding instruments, ceramic and refractory materials, among others. Besides, a zonal ordering separating the site into a productive sector with several sets of furnaces and a more precise mapping of the space of enclosures were made. The ceramic, refractory and lithic material obtained in the superficial collections of both sectors was analyzed. After that, excavations in furnaces and enclosures were carried out. On one hand, from the furnaces, it was possible to determine the complete morphology of this pyrometallurgical structures, which were not known until the moment and to understand in detail their operation. On the other hand, the evidences registered in the enclosures sector (e.g. skeletal and botanical remains) 
allowed to consider it as a housing and food production space, where vegetable and animal elements were processed. From an archeometallurgical approach, we proceeded to the macro and microscopic characterization of the main evidence of production. Metallurgical production indicators included metallurgical furnaces and slags, charcoal, refractory materials with metallic inclusions, mineral and metal fragments and grinding instruments. Through specialized laboratory studies conducted on these materials, we sought to respond to concerns related to the stages of transformation of raw materials, production methods and organization. This information was complemented with technical studies on Inka metal pieces to investigate the way in which the objects were manufactured.

Among the main conclusions, we propose Quillay as a large-scale metallurgical workshop, where the first stages of the production process were carried out, i.e. the extractive metallurgy of copper metal. The metallurgists were from the area judging by the recovered materials and some technological solutions, that do not differ from those identified in other nearby sites. The Inka presence is materialized through subtle but present elements, such as: the state ceramic paraphernalia, the magnitude in the productive scale, the use of furnaces for the smelting and the external output of the obtained metallic product, among others.

The furnances of Quillay present a unique design within the pyrometallurgical structures known so far for the Andean region. Therefore, it is proposed that the smelting practice in this workshop acquired a distinctive technological modality as a result of innovations carried out within the framework of the new socio-political relations prevailing with the arrival of the Inkas to the region. This workshop is considered as a specialized space inserted in a macroregional logistics of metal production, where no objects were produced, but rather the copper obtained for their subsequent work was taken to other regions. Finally, the pieces of metal would participate in political strategies linked to sacred practices, which allowed to legitimize the social structure and strengthen the social system of Tawantinsuyu. 


\section{INTRODUCCIÓN}

\subsection{Presentación de la problemática de estudio y objetivos}

La arqueología de la región Andina ha destinado grandes esfuerzos para el estudio de la metalurgia de las sociedades prehispánicas. El noroeste argentino (NOA), como parte integral de esta área, compartió históricamente este mismo interés y las investigaciones han generado una cantidad significativa de información. Los arqueólogos pioneros se focalizaron en los objetos metálicos provenientes en general de colecciones y en casos menos frecuentes de contextos arqueológicos. Desde perspectivas tipológicas y estilísticas incursionaron en aspectos tecnológicos principalmente en relación con la composición química y técnicas orfebres-, aspectos funcionales, simbólicos y de pertenencia cultural (Lafone Quevedo 1890; González 1979, 1992; Mayer 1986; Ambrosetti 2011 [1904]). Recién hacia fines del siglo XX, las investigaciones en Argentina recibieron la influencia de la perspectiva de la “antropología de la tecnología" (Lechtman 1977; Lemonnier 1992; Dobres y Hoffman 1994, 1999). De esta manera se inclinó la mirada hacia el estudio de los procesos metalúrgicos del noroeste, analizando diversos aspectos tecnológicos y organizativos a partir de las evidencias arqueológicas (González 1992, 2002, 2004b, 2010, Scatollin y Williams 1992; Earle 1994; Pifferetti 2001; Angiorama 2004, 2006, 2011; Gluzman 2008; Angiorama et al.2014; Angiorama y Becerra 2017; entre otros).

A pesar de las numerosas contribuciones de las investigaciones de las últimas décadas, si consideramos el corpus arqueológico total producido en Argentina, resultan escasas las menciones a sitios de producción metalúrgica y son menos frecuentes aún los estudios que refieren a hornos metalúrgicos. Incluso esto último, parecería ser una problemática recurrente en amplios sectores de la región Andina. Esto puede deberse a la baja visibilidad arqueológica de este tipo de estructuras de combustión dado que los hornos son susceptibles a una fuerte alteración e incluso destrucción durante los mismos procesos pirometalúrgicos. A esto se le sumarían los efectos de los procesos de formación de sitios. 
En este marco, el sitio Quillay, ubicado en el sector medio del valle de Hualfín $\left(27^{\circ} 25^{\prime} 54.60^{\prime \prime} \mathrm{S} ; 6^{\circ} 56^{\prime} 59.80^{\prime \prime} \mathrm{O}\right)$, se constituye como un referente empírico de gran valor para abordar la tecnología metalúrgica prehispánica en esta región de Catamarca. El sitio posee un conjunto importante de hornos metalúrgicos con un alto grado de preservación, que los posicionan como ejemplares idóneos para un estudio minucioso. Varios de los hornos de Quillay fueron reconocidos por el Dr. Raffino y su equipo (Raffino et al. 1996) quienes basados en observaciones de campo y análisis técnicos de escorias propusieron un modelo estructural y funcional de los mismos y los situaron dentro del periodo inkaico. Este modelo generó algunos interrogantes que plasmaron la necesidad de profundizar su estudio mediante excavaciones sistemáticas.

De ahí que el proyecto presentado por la doctoranda y cuya expresión final es el presente escrito, se formuló frente a la necesidad de dar respuesta a interrogantes suscitados respecto a la tecnología metalúrgica desarrollada en Quillay y su relación con la sociedad inkaica. Para ello, se focalizó en la reconstrucción arqueológica de las prácticas de producción metalúrgica durante la ocupación Inka en la provincia de Catamarca, el cual fue el objetivo general del proyecto de tesis. Por supuesto que este objetivo supera ampliamente el trabajo específico de esta investigación, sin embargo, el presente escrito pretende aportar datos e interpretaciones que contribuyan en ese sentido.

La problemática planteada se encaró desde un doble abordaje de la evidencia arqueológica: por un lado, desde el estudio sistemático del sitio arqueológico Quillay y por el otro, a partir del análisis de piezas metálicas de colección. En función de esto, se establecieron los siguientes objetivos específicos que permiten acercarnos a las expectativas concretas de esta investigación:

1) Identificar las prácticas tecnológicas de producción metalúrgica a través del análisis de hornos y desechos materiales;

2) Caracterizar los implementos y herramientas utilizadas en el emplazamiento que remitan a actividades productivas; 
3) Conocer las actividades cotidianas en Quillay a partir de la excavación y análisis de recintos próximos a la zona de hornos, en la búsqueda de las interrelaciones con las prácticas de producción metalúrgica;

4) Evaluar el grado de intervención Inka en las actividades metalúrgicas del sitio a partir de las diversas materialidades presentes en el mismo;

5) Establecer el modo de inserción del sitio Quillay dentro de la dinámica regional en relación con los periodos Tardío-Inka;

6) Analizar las piezas de metal asignadas al periodo Inka provenientes de colecciones de museos de la zona de estudio. Desde un enfoque morfológico, tecnológico y estilístico, es posible introducirse en aspectos centrales de la práctica de producción a través de objetos manufacturados y vincularlos a la especialización productiva y estandarización de piezas.

Los primeros tres objetivos se centran en caracterizar la tecnología metalúrgica intrasitio desde los distintos parámetros que permiten indagar acerca de las etapas de transformación de la materia prima, sus formas operativas y organizativas. Esto se realizó a partir del estudio de los distintos sectores, áreas y hornos metalúrgicos, así como desde el análisis de los materiales asociados (escorias, combustibles, refractarios, líticos, entre otros). El objetivo 6 pretende complementar este estudio, indagando sobre la diversidad de prácticas manufactureras a partir del análisis de objetos de metal.

Para comprender los objetivos 4 y 5 es preciso contextualizar el sitio dentro de la dinámica de ocupación regional e introducirnos en algunas de las propuestas generadas por otros investigadores en relación con la expansión inkaica. En primer lugar, es necesario remarcar que el valle de Hualfín es una región trascendental para la arqueología del NOA, y se han realizado numerosos estudios en la zona debido al establecimiento de poblados de larga duración. Los mismos se remontan a los periodos Temprano ( $c a .500 \mathrm{aC}-650 \mathrm{dC}$.) y Medio ( $c a$ 650-900 d.C) con el desarrollo de las entidades socio-culturales Ciénaga y Aguada, hasta el período Tardío (ca. 900-1476 dC.) (González y Cowgil 1975) dónde las sociedades denominadas Belén dominaron este contexto social. Hacia mediados del siglo XV, el Estado Inka incursionó en el NOA e incorporó distintos pueblos locales a la dinámica del Tawantinsuyu. Las evidencias 
arqueológicas muestran que, en este valle, los Inkas establecieron vinculaciones con las poblaciones locales a partir de dinámicas socio-políticas variables, por lo tanto, los grupos sociales experimentaron de manera diferencial su presencia. Asimismo, erigieron centros administrativos y ceremoniales con clara planificación Inka como Hualfín Inka al norte del valle y El Shincal de Quimivil hacia al sur, por fuera de este valle.

Los estudios arqueológicos han aportado diferentes explicaciones sobre la dinámica expansiva del Tawantinsuyu y la articulación de las diversas entidades sociopolíticas con la mecánica estatal (Raffino 1982; Acuto 1999, 2009; Williams y D'Altroy 1998; Williams 2000; Malpass y Alconini 2010). También han sido motivo de debate las intenciones de los conquistadores cuzqueños para incorporar la región del noroeste de la actual Argentina. Una de las propuestas más difundida es aquella que pone el foco en la búsqueda de recursos mineros (González 1979; Earle 1994; Raffino 1994; Raffino et al. 1996; D’Altroy 2003; Angiorama 2005), así como de saberes y habilidades artesanales propias de los pueblos locales (González 2002, 2010).

En este marco, el sitio Quillay es paradigmático, no sólo porque contiene hornos metalúrgicos sino también porque posee una localización estratégica. El mismo está inserto en un contexto rodeado de numerosos poblados tardíos, cercano a bosques de algarrobales, a pocos kilómetros de grandes yacimientos mineros de la región de Andalgalá y a corta distancia entre importantes centros administrativos inkaicos. Por estas razones se transforma en un referente para estudiar la tecnología metalúrgica y su relación con la dinámica de articulación local-estatal (objetivo 4). Finalmente, con los datos obtenidos a nivel micro-local se ampliará la escala para examinar la relación de este emplazamiento con el contexto social mayor en el cual está inserto (objetivo 5).

\subsection{Organización de la Tesis}

El presente escrito fue segmentado en ocho capítulos para un mejor ordenamiento y seguimiento de la estructura que guió la investigación. De esta manera los apartados versan sobre los temas que se describen a continuación.

En el capítulo 2 se presentará el marco teórico adoptado en esta investigación. Para ello se reflexionará sobre diversas propuestas referidas al estudio de la tecnología 
en general y de la metalúrgica en particular. Se adoptan las perspectivas que provienen del campo de la antropología que entiende a la tecnología como un "hecho social total" (sensu Mauss 1979) y se describen los conceptos operativos principales utilizados para el presente estudio.

En el capítulo 3 se desarrollan los antecedentes de estudios sobre metalurgia prehispánica. En primera instancia se buscó historizar las investigaciones sobre metales y metalurgia llevadas a cabo en nuestro país, para reflexionar sobre las maneras en que el conocimiento fue producido. Posteriormente se recuperaron los estudios sobre producción metalúrgica realizados en amplios sectores de la región Andina, remarcando los indicadores arqueológicos - con foco en los hornos metalúrgicos- y las propuestas sobre dinámica social generadas por los diversos autores. Este registro siguió una lógica territorial abarcando sitios desde Perú hasta Argentina. Sin embargo, se puso especial énfasis en el noroeste argentino y en especial en aquellos yacimientos localizados en la actual provincia de Catamarca para luego puntualizar en el valle de Hualfín, información que permite dar cuenta de una antigua tradición metalúrgica regional. Finalmente se dan a conocer los antecedentes de investigaciones en el sitio Quillay, objeto de estudio de la presente tesis. Para cerrar, se realiza una breve caracterización de las políticas implementadas por el Tawantinsuyu. Se aclara que la misma no pretende ser exhaustiva dada la abundante bibliografía que refiere a la temática. Simplemente se resaltan aquellos puntos fundamentales que contribuyan a contextualizar la discusión final de la tesis.

Los capítulos 4, 5 y 6 versan exclusivamente sobre las investigaciones desarrolladas en Quillay en el marco del presente estudio. Se presentan brevemente las características ambientales de la zona de emplazamiento del sitio arqueológico, a partir de información registrada en estudios provenientes de otros campos disciplinares. Esto permitió obtener datos para analizar, por un lado, los procesos de formación de sitio y por el otro, los recursos naturales disponibles en la zona que posibilitaron evaluar el acceso a ciertas materias primas y productos necesarios para las actividades desarrolladas en Quillay. A lo largo de los tres capítulos, se plasman los trabajos arqueológicos específicos de esta investigación: trabajos de campo, prospecciones, levantamiento planialtimétrico, áreas de recolección, sectores excavados y los análisis de laboratorio. Se presentan las evidencias arqueológicas disponibles, así como las 
metodologías de análisis empleadas en el laboratorio. Para ello, se explicitan las técnicas de análisis específicas a cada soporte material (metalúrgico, cerámico, botánico, óseo, lítico y textil). Fundamentalmente se exponen y analizan los resultados parciales obtenidos y las interpretaciones realizadas.

En el capítulo 7 se presentan los análisis realizados a objetos de metal resguardados en el Museo de La Plata (FCNyM, UNLP), en el museo arqueológico “Cóndor Huasi” en Belén y en el museo de sitio de El Shincal de Quimivil en Londres (Catamarca). Se consideraron aquellos objetos que, por poseer datos contextuales o por aspectos tipológicos, pertenecieran a objetos de raigambre Inka. Los resultados obtenidos fueron comparados con la información arqueológica y etnohistórica disponible sobre manufacturas inkaicas, que reflejan las prácticas orfebres predominantes durante tiempos del Tawantinsuyu.

Finalmente, se destina el capítulo 8 para la integración de los resultados parciales con el fin de reconstruir la secuencia de producción metalúrgica en el sitio Quillay y su integración regional dentro de la dinámica de organización socio-política del estado Inka en el Qollasuyu. 


\section{MARCO TEÓRICO GENERAL}

\subsection{Introducción}

Para alcanzar una comprensión adecuada sobre la metalurgia andina es necesario tener en cuenta las relaciones sociales que involucran los procesos tecnológicos. Lechtman fue la primera arqueóloga que, desafiando los planteos dominantes sobre tecnología metalúrgica, propuso en sus estudios que los objetos son los productos de "sistemas tecnológicos complejos que vinculan gente, energía y recursos de una manera organizada y coherente con los imperativos culturales y ecológicos de la escena Andina" (Lechtman 1976: 1-2) ${ }^{1}$. A partir de esta premisa se vislumbra que para abordar la problemática de esta tesis no se pueden disociar la cosmovisión andina y el significado que adquirieron en este contexto los metales, de aquellos procesos puramente operativos. Por ello, en esta investigación se adoptó una perspectiva antropológica sobre la tecnología que la concibe como práctica cultural (en sentido sociológico moderno), y sitúa su mirada en las interacciones sociales entre actores, objetos y procedimientos técnicos que se encuentran imbricados en una trama sociocultural que los estructura (Lechtman 1976, 1993, 1999; Pfaffenberger 1988, 1992a y b; Lemonnier 1992; Dobres y Hoffman 1994, 1999). Se contrapone de esta manera a aquellas nociones tradicionales que conciben a la tecnología como parte de una lógica industrial occidental propia del capitalismo europeo (Pfaffenberger 1988; Ingold 1990). El interés de esta investigación es tomar distancia de aquellos postulados clásicos y naturalizados que sostienen que los objetos son construidos bajo un lógica donde "la necesidad es la madre de la invención, el significado de un artefacto es una cuestión superficial de estilo, y por último que la historia de la tecnología es un proceso lineal de desarrollo de las herramientas a las máquinas" (Pfaffenberger 1992a: 514)².

Este enfoque tradicional, desarrollado en la primera mitad del siglo XX, tuvo un gran impacto en la manera de investigar e interpretar las sociedades prehistóricas,

\footnotetext{
1 “(...) system that unites people, resources, and energy in an organized way consistent with the cultural and ecological imperatives of the Andeans scene.” (Lechtman 1976: 1-2)

2 "'Necessity is the mother of invention', 'the meaning of an artifact is a surface matter of style' and 'the history of technology is a unilinear progression from tools to machines'" (Pfaffenberger 1992a: 514).
} 
específicamente en los numerosos estudios sobre metalurgia, tanto en el viejo, como en lo que ha sido llamado "nuevo mundo" (Tylecote 1987; Mohen 1992; Ambrosetti 2011 [1904]). Sin embargo, desde la primera mitad del siglo XX a través de discusiones dentro de la disciplina arqueológica y antropológica, se puso en cuestión los enfoques del modelo tradicional, aquellos que Pfaffenberger identifica como un "sonambulismo" y determinismo tecnológico, que forman parte de la manera clásica de concebir la tecnología (Pfaffenberger 1988, 1992a y b).

La tesis del sonambulismo tecnológico puede remitirnos a nuestra cotidianidad, debido a que impera en el discurso de la ciencia moderna. Según este modelo, el concepto de tecnología refiere a un conjunto de instrumentos, herramientas y máquinas disponibles en una sociedad para su empleo en beneficio de la calidad de vida y desarrollos productivos. Es decir, la tecnología remite a elementos concretos y materiales funcionando en torno a los fines prácticos de un grupo humano. La problemática del sonambulismo, según Pfaffenberguer, es que reduce la tecnología al "hacer" y "usar" objetos. De esta manera, en el momento en que las personas actuamos como "seres sonámbulos" queda fuera de toda reflexión racional aspectos relativos a la construcción social de las necesidades, al impacto social y ambiental de las elecciones tecnológicas, a los significados políticos y relaciones de producción, etc. Percibir la tecnología como un producto que, reflexivamente, solo interesa a quienes construyen los artefactos, tiene como consecuencia relegar al resto de la población al rol de meros usuarios (Pfaffenberger 1988, 1992a y b). En consecuencia, numerosas opciones y decisiones humanas puestas en juego durante su producción y uso "son enmascaradas, por lo que la tecnología parece operar más allá del control humano y parece encarnar el resultado de un sistema automático, de un proceso inevitable" (Winner 1977 en Pfaffenberger 1988: 238) ${ }^{3}$.

El segundo enfoque, el determinismo tecnológico, otorga a la tecnología un papel central en las sociedades sobre la base de la premisa de que todo cambio es producto de una innovación tecnológica. Asimismo, propone que la tecnología se desarrolla de manera autónoma sin que los sujetos tengan ningún rol ni poder de decisión en su desarrollo (Pfaffenberger 1992a, 1992b). Este modelo es concordante con las posturas

\footnotetext{
${ }^{3}(\ldots)$ are masked, so technology seems to operate beyond human control and appears to embody the result of an automatic, inevitable process" (Winner 1977)
} 
antropológicas evolucionistas, estructuradas bajo supuestos de cambios tecnológicos y sociales correlacionados, que tienen lugar desde lo simple a lo complejo (Ingold 1997)

En definitiva, la visión tradicional de la tecnología ubica a los procesos tecnológicos en un campo externo a la red de relaciones sociales, ya sea bajo el modelo del determinismo o del sonambulismo, los sujetos están ausentes en las decisiones, siendo meros receptores pasivos de la tecnología. Reiteramos que, de esta manera, se ocultan los intereses puestos en juego, las relaciones de poder y un sin número de acciones y decisiones que realizan los actores y los colectivos sociales desde la producción hasta el consumo de sus productos (Pfaffenberger 1988, 1992a y b).

Las ideas de ambos postulados se sustentan en un pensamiento polarizado de la realidad (Ingold 1990) relacionado a un conjunto de dicotomías occidentales: aquella entre tecnología y sociedad que plantea la externalización de la tecnología y se vincula con el desarrollo del capitalismo (Ingold 1990, Pfaffenberger 1988). Por otro lado, encuentra su fundamento en la oposición entre naturaleza y cultura, que jerarquiza las capacidades de raciocinio y simbolización humana propia de una ontología naturalista (Descola 2012). En este marco, la naturaleza impone restricciones y presiones para la vida, que el ser humano buscaría controlar para el beneficio colectivo (Ingold 1990). Thomas (2006) propone que esta idea supone en sí misma otros presupuestos dicotómicos que son: la distinción cartesiana entre mente/materia y la aristotélica entre forma/sustancia. Ambas refieren a la situación en la cual, un material natural (sustancia) es un receptor pasivo de la acción humana que genera un cambio en su estructura (forma) para lograr un fin determinado, como la realización de un artefacto. Éste fue previamente diseñado en la mente humana con un objetivo específico: satisfacer una necesidad humana. Como señala Pfaffenberger (1992a) según este pensamiento la forma está subordinada a la función, ya que existen una relación clara entre la forma de la herramienta con la necesidad que satisface, al ser pensada e ideada para cumplir esa función; relegando al estilo a una cuestión superficial de simbolización. Por lo tanto, "la cultura material de una sociedad se convierte en un registro físico de su adaptación de supervivencia" (Pfaffenberger 1992a: 494) .

\footnotetext{
4 "A society's material culture becomes a physical record of its characteristic survival adaptation" (Pfaffenberguer 1992a: 494)
} 
En estrecha relación a esta dicotomía se encuentra la distinción entre técnica y tecnología, relacionado a la noción aristotélica de tekhné que refiere a la habilidad de los sujetos en alguna actividad práctica (Ingold 1990). Bajo este modelo una práctica técnica es considerada como puramente mecánica, dónde no mediaría ningún tipo de saber cognitivo. Visto así, la tecnología fuerza una división entre saber y hacer reflejando la idea occidental-capitalista de la relación entre el trabajo intelectual y el trabajo manual. Ingold crítica esta división sobre la base de la existencia de conocimiento práctico de los sujetos, dado que la habilidad es tanto una forma de conocimiento como de práctica, es poner el cuerpo, movimientos, decisiones, saberes, sentimientos y sentidos en acción (Ingold 1990).

En contraposición a la distinción moderna entre prácticas cognoscitivas y prácticas operativas, dentro del campo de la metalurgia, varios autores han resaltado que la práctica de conocer en el mundo andino tiene un matiz más sensorial y experiencial, dado que los saberes y habilidades son adquiridos por observación y experimentación (González 2002, 2004b; Comendador Rey 2010). Se trata de no asumir que las distinciones entre técnica y tecnología modernas hayan tenido el mismo significado en el pasado. Además, la producción de conocimiento tiene lugar en un contexto de estrechas relaciones recíprocas entre los seres humanos y entidades no humanasllamadas naturales y sobrenaturales desde un lenguaje occidental-. No es la ontología naturalista, ni tampoco el sonambulismo cosificante moderno, en el contexto andino se pone en juego otro tipo de relaciones en donde se conjugan los conocimientos técnicos y sagrados y los saberes, son práctica y acción al mismo tiempo. Por ejemplo, en el proceso metalúrgico se trabaja con diversos elementos naturales (minerales, arcillas, maderas) y procesos físicos y químicos (oxidación, combustión, calcinación) con sus propiedades medibles en la actualidad gracias a técnicas modernas, pero en el pasado el metalurgo utilizó sus sentidos, sus percepciones sobre los materiales y su experiencia, para identificar estos procesos y reconocer la forma "adecuada" de hacer las cosas según su perspectiva cultural. Con esto se quiere remarcar la no operatividad de la distinción entre tecnología y técnica, en el pasado fueron conocimiento y práctica al mismo tiempo, subjetivos, experienciales y adquiridos por medio de la observación y experimentación, es decir en la propia acción.

Con lo dicho se pretende haber desnaturalizado aquellos preconceptos occidentales en un intento explícito de evitar ser extrapolados al pasado y enfatizar que 
la tecnología atraviesa todas las dimensiones sociales. A continuación, se recorrerán algunas de las ideas más relevantes con relación a los conceptos de tecnología, metalurgia y cosmovisión andina que fueron adoptadas en este estudio. Con respecto a la metalurgia se advierte que muchos de los conceptos empleados son de índole operativos pero que, al considerar que la tecnología es indisociable del entramado cultural, el desafío del arqueólogo es lograr su integración. En este sentido en los próximos capítulos quedará demostrado cómo esto fue alcanzado.

\subsection{Tecnología como dimensión social}

Desde las últimas décadas del siglo XX la mirada antropológica enfatiza en la dimensión social de la tecnología y la cultura material, es decir que posiciona las prácticas tecnológicas como parte integral de la matriz de sociabilidad humana (Pfaffenberger 1988, 1992a; Ingold 1990, 1997; Lemonnier 1992; Dobres y Hoffman 1994). Desde este enfoque sistémico cualquier comportamiento considerado de tipo tecnológico es al mismo tiempo simbólico, político y social (Pfaffenberger 1992a). Para entender la tecnología como un conjunto de prácticas culturalmente determinadas y relaciones sociales, resultan operativas las propuestas de Lemonnier (1992) sobre tecnología que incluyen la noción de châine opératoire de Leroi-Gourhan (1971), así como las propuestas norteamericanas sobre estilo tecnológico de Lechtman (1977) y la agencia social de la tecnología de Dobres y Hoffman (1999).

Lemonnier (1992) plantea que la tecnología incluye acciones físicas intencionadas que transformen la materia, que recuerda a la definición de técnica propuesta por Mauss $(1971)^{5}$. Sin embargo, amplía esta idea al incorporar el conocimiento y las habilidades necesarias para efectivizar una acción técnica. Desarrolla así, los cinco elementos relacionados entre sí que componen una técnica. El primero de ellos refiere a las materias primas sobre los cuales actuar; en segundo lugar, se necesitan personas que activen fuerzas para transformar los materiales mediante el empleo de herramientas, las cuales constituyen el tercer elemento. El cuarto son los gestos técnicos aplicados que permiten mover los artefactos. Para finalizar, señala que estas acciones dependen de un conocimiento específico sobre la forma de llevar a cabo estas operaciones. Los saberes serían la resultante de elecciones tecnológicas entre un continuum de posibilidades y de

\footnotetext{
5 En sus estudios sobre los movimientos corporales Mauss define a la técnica como un "acto eficaz tradicional" (1971: 342), una práctica o hábito de tipo mecánico o físico que es aprehendido socialmente.
} 
la evaluación de sus alcances y limitaciones respecto al fin que se desea obtener (Lemonnier 1992). Dichas elecciones no necesariamente están condicionadas por la disponibilidad y acceso a los recursos naturales, sino más específicamente, por las maneras en que los recursos y las técnicas son percibidas por la sociedad. Lemonnier llama al conjunto de posibilidades percibidas, elecciones y conocimiento específico como "representaciones sociales" que influyen en los sistemas tecnológicos (Lemonnier 1992).

El concepto de châine opératoire o cadena operativa proviene del campo de la etnografía francesa (Mauss 1971) siendo Leroi-Gourhan y Lemonnier los principales referentes de esta aproximación tecnológica en arqueología. El primero sostiene que "la técnica es a la vez gesto y útil, organizados en cadenas por una verdadera sintaxis que da a las series operatorias a la vez su fijeza y su flexibilidad" (Leroi-Gourhan 1971: 116). Entonces, esta serie de operaciones consisten en un conjunto de ideas, tareas y acciones encadenadas que mediante gestos técnicos y herramientas permiten transformar la materia prima en productos acabados. Asimismo, propone que estas cadenas de gestos son incorporadas por las diversas vías de aprendizaje: imitación, experimentación y lenguaje articulado, que permiten adquirir y aprehender las formas de hacer socialmente consensuadas (Leroi-Gourhan 1971).

Como se planteó anteriormente, a estas secuencias de herramientas y gestos técnicos Lemonnier (1992) le agrega un nuevo eslabón de análisis de tipo cognitivo, concerniente al conjunto de conocimientos técnicos compartidos por todos los miembros de un grupo. Relacionado a esta idea, están las propuestas realizadas por Lechtman (1977) quien enfatiza que cada una de las actividades técnicas y saberes están insertas en un entramado socio-cultural, históricamente situado, que les da sentido y que constituye "estilos tecnológicos" (Lechtman 1977). Estos estilos no sólo implican formas particulares de transformar los materiales, sino también, un conjunto de actores participantes que detentan los conocimientos necesarios, organizaciones productivas, relaciones sociales, intereses y sobre todo actitudes hacia los materiales. Estos aspectos encuentran su fundamento en el entramado simbólico-cultural y en las particulares formas de concebir el mundo (Lechtman 1977, 1978, 1984)

En este punto, cabe aclarar que algunos investigadores han sugerido que la noción de cadena operativa tiene fuertes afinidades con el concepto de behavioral chain o 
cadena conductual propuesto en la década del '70 por el arqueólogo norteamericano Schiffer (Sellet 1993; Schlanger 2005). El autor, desde un enfoque procesual, define a la cadena conductual como una serie de actividades "que pueden ser agrupadas en un conjunto de procedimientos básicos y representada por un modelo de flujo. Estos procesos incluyen la adquisición, fabricación, uso, mantenimiento y descarte" (Schiffer 1976: 46) $)^{6}$.

En definitiva, la perspectiva antropológica sobre la tecnología brinda a la arqueología un marco teórico - metodológico desde el cual abordar el registro arqueológico para abordar las dinámicas sociales. Desde este enfoque, se pueden estudiar secuencias de comportamientos interrelacionadas, que implican diversas cadenas de operaciones mediante la puesta en marcha de gestos y acciones técnicas de acuerdo a formas de hacer compartidas por un grupo social a través del tiempo, las cuales conforman tradiciones tecnológicas. Dentro del corpus de investigaciones se encuentran varios estudios sobre tecnofacturas metalúrgicas que han logrado integrar estas perspectivas (Shimada 1996; Heather y Miller 2007; Shimada et al. 2007; Shimada y Craig 2013).

Shimada et al. (2007) sintetiza estos enfoques desde lo que denomina una aproximación holística de la tecnología metalúrgica. La misma implica atender a todas las dimensiones de la organización social y tecnológica del proceso de producción, contextualizadas en un determinado sistema político, ideológico y cultural. Contempla así un abordaje integral sobre las relaciones entre las materias primas requeridas en cada etapa, las secuencias de fabricación, el equipamiento, las propiedades y cualidades de los productos terminados. Todo esto sin dejar de lado la comprensión de las convenciones sociales, el sistema de representaciones y valores que orientan la forma de trabajar los materiales, su diseño, la distribución, sus diferentes usos y los significados otorgados (Shimada et al. 2007). En estos sentidos, la presente investigación se desarrolló buscando alcanzar esta integración.

Con relación a todo ese mundo detrás de una cadena operativa que incluye en las interpretaciones arqueológicas aspectos referidos a las relaciones sociales, son varios los

\footnotetext{
6 "The sequence of activities in the systemic context of any durable element can be grouped in a set of basic processes and represented by a flow model. These processes include procurement, manufacture, use, maintenance and discard" (Schiffer 1976: 46)
} 
aportes desde los estudios de la tecnología que buscan recuperar el dinamismo social, comprendiéndolo como un aspecto intrínseco de cada fenómeno humano. Dobres y Hoffman exploran cómo las prácticas tecnológicas son modeladas por estrategias sociales y visiones del mundo (Dobres y Hoffman 1994, Hoffman y Dobres 1999). Las investigadoras recuperan así, la agencia social de la tecnología y otorgan, a la historicidad de los procesos tecnológicos, un cuerpo teórico sólido para abordar tanto continuidades y transformaciones en las prácticas sociales como los significados y sentidos sociales puestos en juego (Hoffman y Dobres 1999). En este sentido, consideran que las actividades tecnológicas transforman simultáneamente materiales y relaciones sociales, ya que durante los actos técnicos se expresan y negocian percepciones y concepciones sobre acciones y productos culturales, identidades individuales y colectivas, relaciones de poder, símbolos y metáforas culturales. Esto se debe a que durante las actividades productivas se materializan las nociones de las personas y sociedades sobre las formas correctas de proceder. Es por ello que, el proceso tecnológico, es entendido en sí mismo como un acto de comunicación. Un discurso que es al mismo tiempo un acto tecnológico, político, ritual y cosmológico durante el cual se expresan ideas sobre el mundo, se reestructuran relaciones, se impugnan prácticas y se crean otras nuevas sobre la base de las existentes (Pfaffenberger 1992b; Dobres 1999; Hoffman y Dobres 1999; Lechtman 1999). En otras palabras, la tecnología, como toda práctica social, es una "arena en el cual los agentes construyen identidades sociales y forjan relaciones de poder mientras producen y usan objetos utilitarios con fines prácticos" (Dobres 1999: 129)7 . Pfaffenberger, llama a esta capacidad de negociación política “dramas tecnológicos” (Pfaffenberger 1992b: 285).

Lo dicho hasta aquí supone que las prácticas tecnológicas tienen un aspecto "performativo", dado que pueden "devenir en fuentes por las cuales ganar - o perderestatus y prestigio" (Pfaffenberger en Hoffman y Dobres 1999: 213) ${ }^{9}$ mediante la creación de categorías sociales o "etnocategorias" que refieren a cosas, eventos, conductas y relaciones significantes que ayudan a hacer el mundo inteligible (Lechtman 1999: 223). Como plantea Bourdieu estas categorías generan esquemas de percepción y

\footnotetext{
7 “Technologies are arenas in which agents construct social identities and forged power relations while also producing and using utilitarian objects for practical ends" (Dobres 1999: 129)

${ }^{8}$ Hoffman y Dobres (1994) en la conclusión que realizan sobre el volumen referido a los nuevos enfoques sobre la dinámica social de las prácticas tecnológicas, señalan que de las investigaciones emerge el carácter performativo de los actos y prácticas tecnológicas (1994: 217).

9 “(...) become a source by which to gain (or lose) status and prestige” (Hoffman y Dobres 1999: 213)
} 
de acción que son incorporados, y al mismo tiempo reproducido por los sujetos en sus propias prácticas, pero bajo una "forma transformada" (2007: 151). Entonces, bajo este modelo del accionar performativo los actores pueden modificar su situación y posicionamiento dentro de la estructura social porque toda práctica implica elecciones y decisiones.

En este punto, cabe aclarar que, el concepto de performance utilizado por Hoffman y Dobres (1994) proviene del campo artístico y está ligado al accionar transformador, al movimiento, siendo el sujeto - y no el objeto- el elemento constitutivo del arte. En el mismo sentido, en los sistemas tecnológicos el foco está puesto en los actores y sus relaciones y como arqueólogos buscamos ingresar a este mundo desde la cultura material. En este marco, las propuestas de la teoría social contemporánea sobre prácticas culturales de Bourdieu (2007) y de la estructuración de Giddens (1995) fueron incorporadas al análisis de la tecnología desde las propuestas de Dobres y Hoffman (1994). Las autoras enfatizan que los conceptos propuestos por estas teorías sirven para comprender a través de las prácticas cotidianas, las negociaciones de los sujetos respecto a los roles, comportamientos esperados y categorías sociales prescriptas en la estructura social y el rol de los artefactos para habituar a los individuos a dichas categorías (Dobres y Hoffman 1994).

Uno de los conceptos centrales es el de hábitus, que los términos de Bourdieu son “disposiciones duraderas y transferibles, estructuras estructuradas predispuestas a funcionar como estructuras estructurantes, es decir, como principios generadores y organizadores de prácticas y de representaciones que pueden ser objetivamente adaptadas a su meta sin suponer el propósito consciente de ciertos fines (...)" (2007: 86). Precisamente, como se viene señalando, la producción de artefactos tiene lugar en contextos sociales específicos bajo modelos de accionar socialmente consensuados que establecen los modos adecuados de hacer y trabajar. Es decir, estas prácticas se inscriben en hábitos creados según los cánones culturales, siendo los procedimientos técnicos parte de las prácticas estructuradas que son aprehendidas durante los procesos de sociabilización. Además, se enfatiza que los actores sociales no son reproductores autómatas de las practicas aprehendidas, por el contrario, en su propio "hacer" tienen cierta libertad para transformarlas, siendo los sujetos agentes constitutivos de la realidad en la que viven (Giddens 1995; Bourdieu 2007). 
En este marco, ¿qué papel cumpliría la cultura material en la praxis social? Como manifiesta Miller (2005), Bourdieu demostró que los objetos tienen la gran habilidad de pasar desapercibidos en la cotidianeidad, pero que, al actuar en todos los ámbitos de la vida condicionan a los sujetos sociales y son el medio primario de sociabilización (Miller 2005). Las personas habitan un mundo repleto de artefactos que tiene la potencialidad de expresar no solo su propia materialidad sino lo inmaterial, los roles sociales, lo simbólico, las percepciones, lo cosmológico. Así, se transforman en mediadores entre prácticas y principios políticos, sociales y cosmológicos. Basta con recordar las diversas formas en la que la cosmovisión de un grupo social fue expresada materialmente, por ejemplo, en la arquitectura y en los artefactos, y cómo éstos condicionan las prácticas cotidianas y extraordinarias de las personas que circulan por esos espacios. Los sujetos emplean objetos determinados que denotan relaciones, roles y posicionamientos sociales. Pero esto no se da por una cualidad intrínseca de los objetos, dado que ellos existen porque son construidos y objetivados por los sujetos; sujetos que al mismo tiempo son el producto del mismo acto de objetivación que crea los objetos (Miller 2005). De esta manera, las relaciones y roles sociales son cristalizados, legitimados y reforzados a través de la creación, el uso y la circulación de los objetos.

\subsection{Metalurgia como tecnología}

En este apartado se presentarán las secuencias de operaciones del proceso de producción metalúrgica, así como las categorías analíticas que serán utilizados en el presente estudio. Para ello, en primer lugar, es necesario realizar una aclaración con respecto al concepto de metalurgia dado que en la literatura existe un uso más inclusivo y otro restringido.

En el primer caso, el término suele emplearse para hacer referencia a la actividad humana de producción de metales e incluye todas las acciones necesarias para obtener el producto final deseado. Esta cadena de operaciones metalúrgicas involucra las etapas de minería, tratamiento de minerales, fundición y manufactura (González 2004b, 2006; Heather y Miller 2007). Cada una de estas tareas conlleva la puesta en práctica de acciones, elecciones y variables técnicas, cuyo desempeño implica generar y utilizar numerosos materiales -herramientas de distintas materias primas, estructuras de combustión- las cuales forman parte del registro arqueológico y que, mediante estudios 
técnicos específicos, permiten obtener datos para comprender cómo estaba organizado el proceso de producción (González 2004b).

No obstante, existen otras propuestas que prefieren restringir el uso del concepto de metalurgia únicamente al proceso de reducción de minerales para obtener el metal en bruto (Pifferetti 1999; Campbell y Latorre 2003). El trabajo sobre metal nativo no es considerado como metalurgia propiamente dicha, ya que no supone complejos procesos tecnológicos en su obtención (Campbell 2004: 11; Latorre 2009: 16). Es por ello que consideran más adecuado emplear el término de "trabajo en metal" ya que "englobaría tanto el trabajo sobre metal nativo como la metalurgia" (Campbell y Latorre 2003: 48; Latorre 2009: 16).

Sin dejar de lado esta consideración, para la presente investigación se siguieron las propuestas de González (2004b), debido a que resulta operativa la distinción de etapas, actividades y los indicadores arqueológicos propuestos por el autor (Figura 1.1) En este sentido la presencia de hornos metalúrgicos en Quillay nos sitúa frente a un panorama en el cual los materiales eran trabajados mediante la aplicación de calor en cámaras diseñadas para tal fin. Por ello, en la presente tesis se utilizará el término de "metalurgia extractiva" o "fundición" para hacer referencia a la etapa de reducción del mineral a metal (González 2004b: 81; Mohen 1992: 37). Destinando el uso del término metalurgia -sin ningún adjetivo- para designar toda la secuencia de operaciones, y trabajo del metal para referirnos a la manufactura de objetos finales, una vez obtenido el metal base.

Con respecto a las actividades metalúrgicas, siguiendo lo propuesto por González (2004b, 2006) y Heather y Miller (2007), se distinguen una serie de principios operativos que se ordenan secuencialmente (Figura 1.2). En primer lugar, la producción se inicia con la minería o extracción del mineral desde su yacimiento original. La segunda instancia involucra la preparación mecánica del mineral con la finalidad de separar la parte más valiosa (mena) del segmento de roca estéril (ganga). Esta tarea se realiza a través de procedimientos como lavar, triturar y concentrar a mano el material rico en metal (Mohen 1992; González 2004). En el caso de tratarse de metal nativo el paso siguiente sería la etapa de manufactura, en caso contrario, la tercera etapa es la fundición o metalurgia extractiva. 
La fundición, en términos generales, consiste en la aplicación de fuego y la generación de una atmósfera reductora, así como temperaturas lo suficientemente elevadas para extraer el elemento metálico de la roca mineral que lo contiene $(>1000$ $\left.{ }^{\circ} \mathrm{C}\right)$. Este sería el caso para óxidos y carbonatos; sin embargo, si la mena empleada es un sulfuro, se hace necesario una instancia previa de tostación para eliminar el contenido de azufre. Para ello es necesaria una atmósfera oxidante, donde el oxígeno se combina con el azufre y es eliminado de forma volátil, procedimiento que transforma el material metálico en un óxido (González 2004b). Según la eficacia del procedimiento técnico empleado, la fundición puede requerir de nuevas instancias de reducción hasta obtener un metal base libre de impurezas. Se suele referir a estas etapas de refundición bajo el término de fundición secundaria. Las resultantes de estas tareas son desechos de fundición (escorias) y metal puro, materiales que serán abordadas con mayor detalle en los próximos capítulos. Las actividades pirometalúrgicas pueden llevarse a cabo de dos formas: por un lado, exponiendo directamente el mineral al fuego contenido en una cámara de combustión. Por el otro, depositando el mineral en un crisol y aplicando calor a éste último (González 2004b).

La etapa siguiente es el trabajo del metal para manufacturar objetos, proceso conocido como orfebrería. Esta instancia puede incorporar tareas previas de aleación, es decir de fusión de metales para obtener un producto nuevo, por ejemplo, el bronce es una aleación binaria de cobre y estaño o cobre y arsénico. Una vez obtenido el metal deseado, se aplicarían distintas técnicas que permiten conformar el objeto final. Estas pueden agruparse en dos conjuntos según sirvan para dar forma al objeto o bien para su acabado y decoración. En relación al primero, el metal puede trabajarse como material sólido en frío, mediante eventos de martillado con intervalos de recocido para evitar su fractura; o a elevadas temperaturas como un líquido (Carcedo de Mufarech 1998). En el último caso priman las técnicas de moldeado (González 2004b). Para dar la forma final al objeto, se despliegan un conjunto de técnicas como martillado, laminado, trefilado, ensamblado (Carcedo de Mufarech 1998; Pifferetti 1999; González 2004b) y entre las técnicas de acabado y decorativas se puede destacar el pulido, bruñido, repujado y grabado. Estas acciones dejan distintas huellas a nivel micro y macro estructural en las piezas finales cuyo estudio arqueométrico permite su identificación (Scott 1991).

Una vez finalizado el objeto, éste será utilizado en múltiples ámbitos de la vida y para los metales se conoce que circularon por esferas con un alto prestigio y ritualidad. 
Por último, remarcamos que, cada una de las etapas de producción metalúrgica se conecta con otras secuencias de producción de materiales. Esto se debe a que en ellas se conforman las herramientas e implementos que serán utilizados durante la producción de metales.

1. MINERÍA $\left\{\begin{array}{lll|}1.1 . & \text { Instrumentos mineros } \\ \text { 1.2. } & \text { Minerales metálicos }\end{array} \begin{cases}1.1 .1 . & \text { Martillos líticos } \\ 1.1 .2 . & \text { Cornamentas } \\ 1.1 .3 . & \text { Bolsas de cuero }\end{cases}\right.$

\begin{tabular}{l} 
2. TRATAMIENTO \\
$\begin{array}{l}\text { MINERALES } \\
\text { TIN }\end{array} \quad\left\{\begin{aligned} 2.1 . & \text { Equipos de molienda } \\
\text { 2.2. } & \begin{array}{l}\text { Instalaciones de } \\
\text { concentración }\end{array}\end{aligned} \quad\left\{\begin{array}{l}\text { 2.1.1. Manos y morteros } \\
2.1 .2 . \text { Maray }\end{array}\right.\right.$ \\
\hline
\end{tabular}

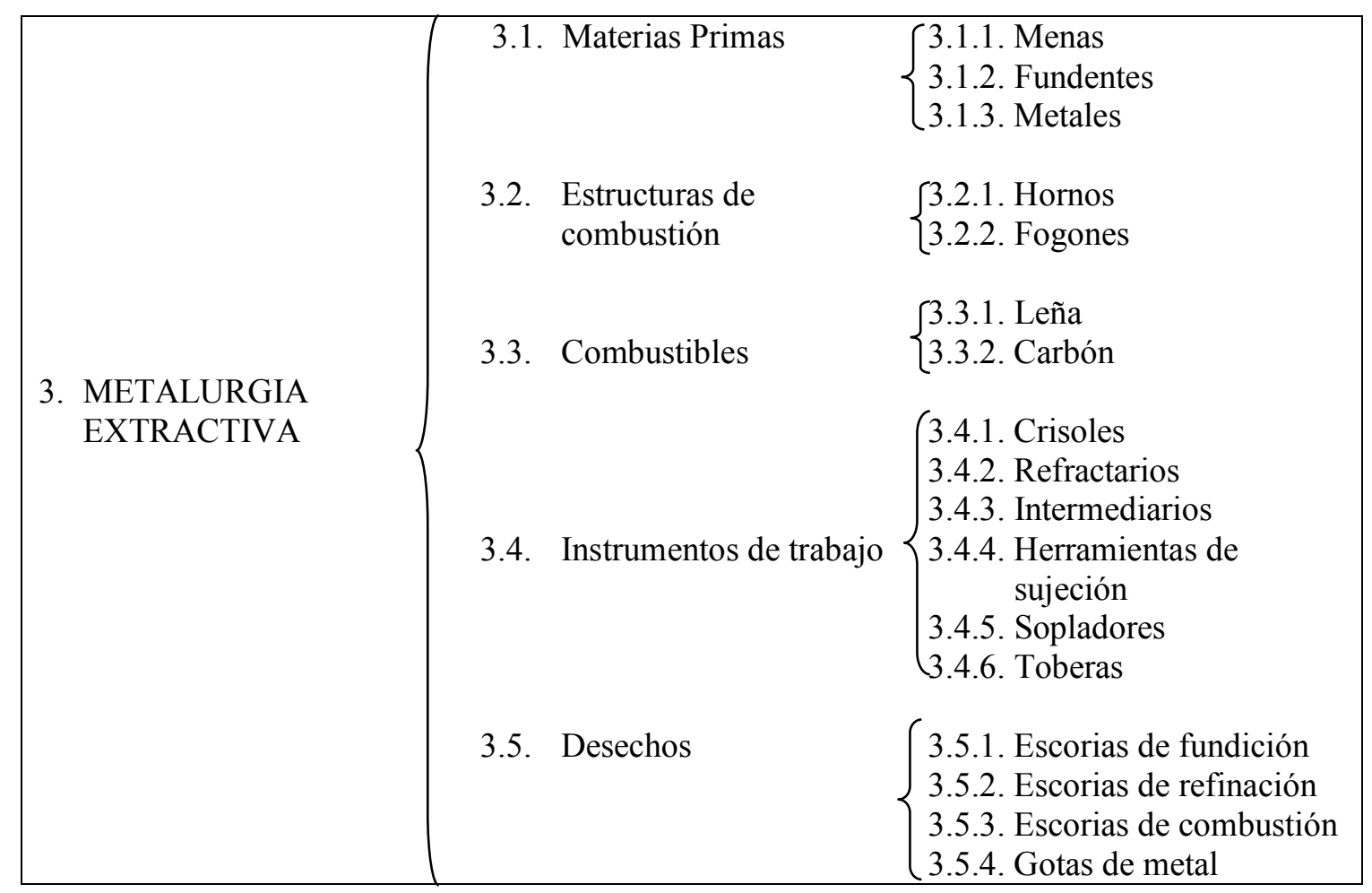

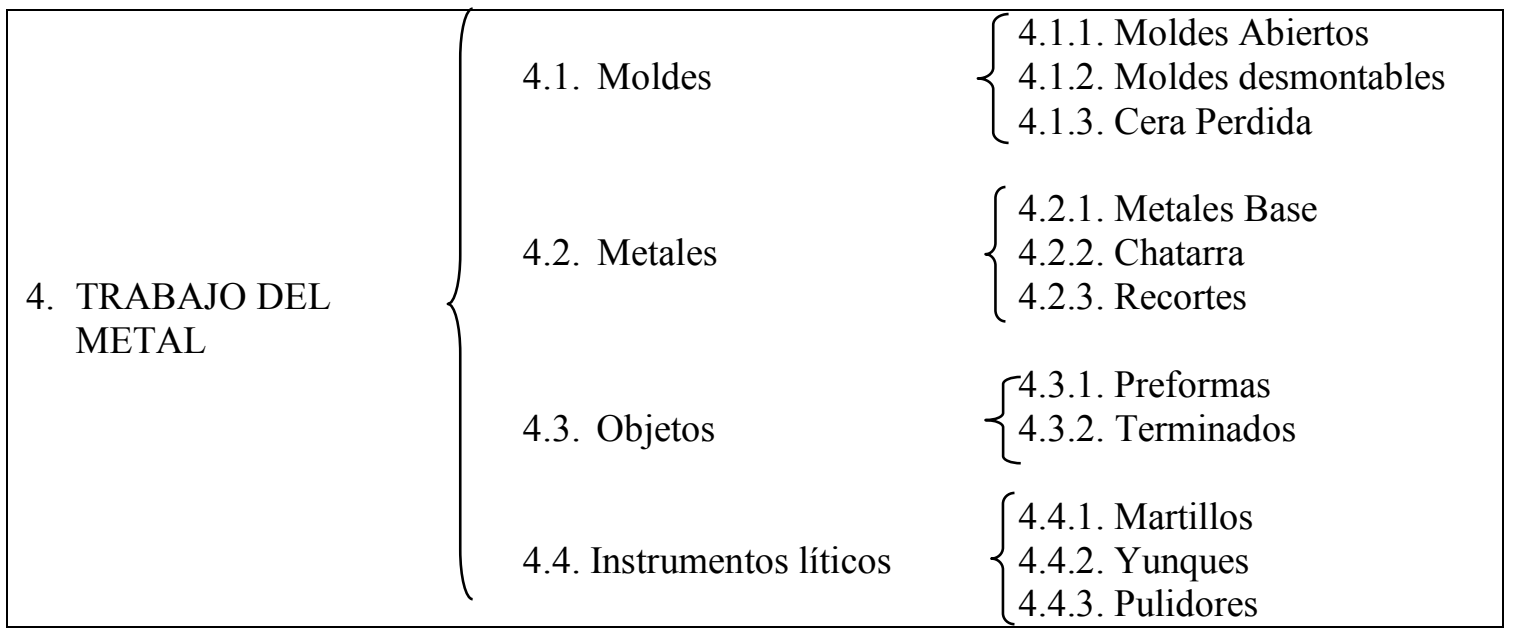

Figura 1.1. Etapas de la cadena operativa metalúrgica y los implementos necesarios que sirven como referentes arqueológicos. Tomados y modificado de González 2004b: 53. 


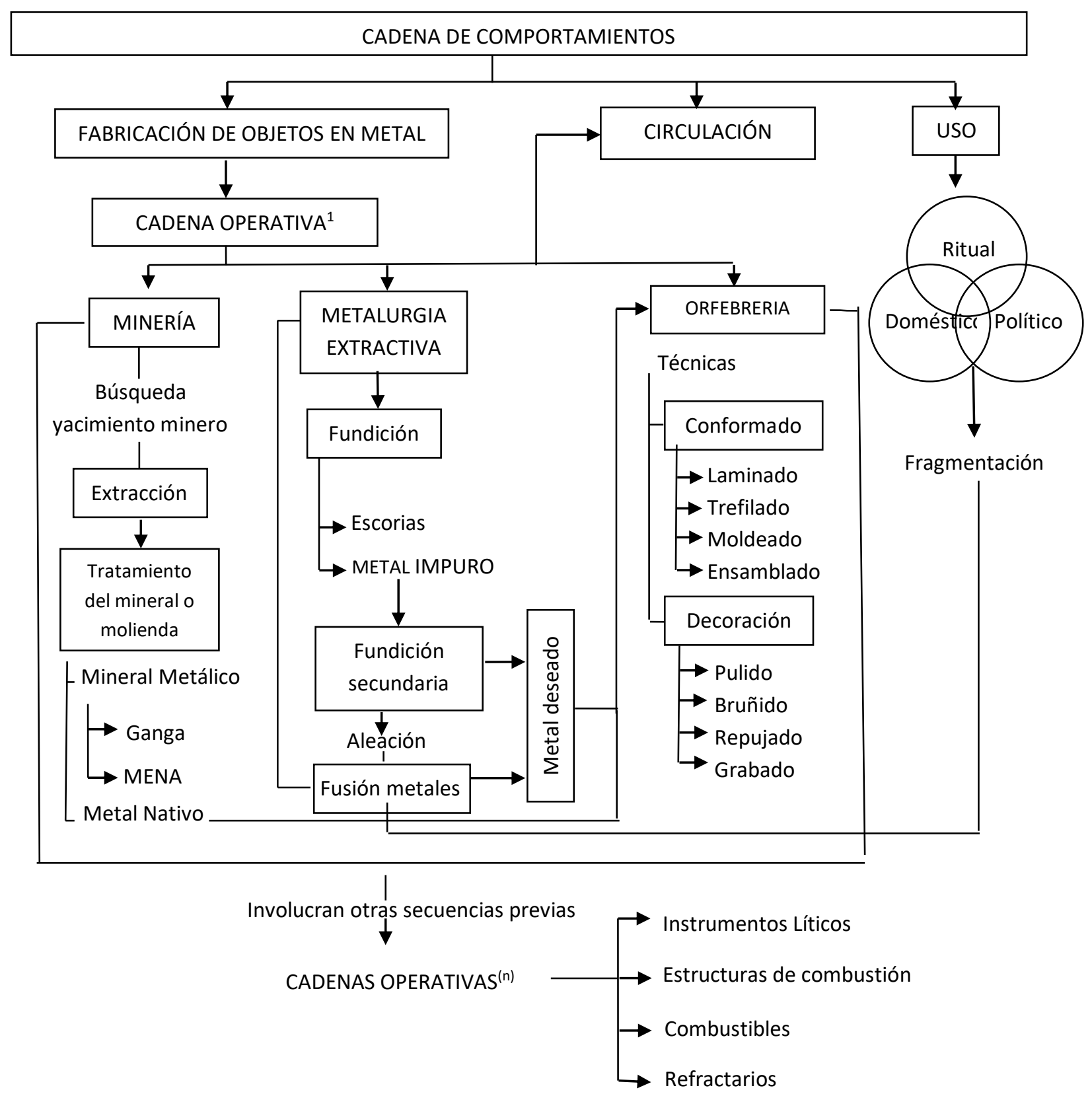

Figura 1.2. Diagrama de flujo para la producción metalúrgica y circulación de productos en el contexto sistémico. 


\subsection{Cosmovisión Andina}

Al principio del capítulo se ha enfatizado que, para comprender las dimensiones sociales de la tecnología, es necesario analizar cómo esta práctica es modelada por las concepciones del mundo vigentes en cada sociedad (Lechtman 1984, 1988, 1999; Dobres y Hoffman 1994, 1999). Con respecto a las percepciones y representaciones andinas sobre los metales, los estudios etnohistóricos y etnográficos disponibles resaltan la estrecha relación establecida entre los sujetos humanos y no humanos, así como la sacralidad y los ritos que permean las actividades cotidianas, entre ellas los procesos productivos. Si consideramos en especial la producción metalúrgica, Lechtman (1999) recuperó de las crónicas tempranas, relatos donde se aprecia cómo la gente andina considera este tipo de mineral. Ellos son pensados como productos de la Pachamama y de "forma análoga a las plantas, nacen, crecen dentro de la tierra y de allí mismo son minados" (Lechtman 1999: 228) ${ }^{10}$.

Asimismo, se han recuperado diversos relatos etnohistóricos y etnográficos con relación a prácticas mineras y actitudes hacia los minerales metálicos (Absi 2005; Berthelot 1984; Bouysse-Cassagne 2004, 2005; Lechtman 1978, 1993). Allí se aprecia que los mineros realizan numerosos ritos de pasajes de iniciación, ceremonias y festividades; ofrendas de hojas de coca, tabaco y alcohol a Muki, Supay o Tío, el cual es considerado un ser poderoso del inframundo asociado a las vetas mineras y que protege o castiga a los mineros; también dan cuenta de prácticas de frotar coca en las vetas más duras para ablandarlas y de tabúes relacionados a la circulación femenina por las minas, posiblemente para evitar recelos dada la concepción de la montaña como un ser gestante. Por otro lado, aquellos minerales metálicos con cualidades excepcionales como su riqueza en metal, tamaño o color, eran considerados mamas (Berthelot 1984: 961) y se resguardaban en la mina para asegurar el crecimiento de los demás metales (Bouysse-Cassagne 2005). De esta manera eran considerados rocas sagradas o waqa (Lechtman 1999).

En este sentido, Lechtman exhibe, con datos etnográficos de mineros de Julcani en Perú, que para ellos el oro era el mineral considerado mama por ser el único que alcanzó el estado madurativo. El resto de los minerales metálicos no habrían

\footnotetext{
10 "Metallic mineral, like plants, were believes to be born and to grow inside the earth, from which they are harvested (mined)" Lechtman 1999: 228.
} 
completado su crecimiento y los consideraban como nacidos muertos (Salazar Soler 1992 en Lechtman 1999). Es probable que, por esta razón, los minerales de plata, cobre, estaño y arsénico, hayan sido sometidos a complejos procesos de transformación mediados por fuerzas sobrenaturales. El fuego, considerado en el mundo andino como una entidad transformadora, fue primordial en los procesos de fundición, y este proceso fue una metáfora de gestación y nacimiento de un nuevo ser (González 2012). Para Lechtman otro agente de transformación fue el cobre, dado que los estudios técnicos efectuados sobre objetos metálicos del Perú, indican delicados procedimientos de alteración de brillos y colores durante los procesos de aleación, en los cuales el cobre siempre existía como mediador (Lechtman 1999). En definitiva, la tecnología metalúrgica en los Andes estuvo orientada a la búsqueda de colores brillantes y sonidos que rememoran el valor simbólico de los objetos metálicos asociado a las divinidades celestiales (Lechtman 1984; González 2004a, 2006; Hosler 2013).

Por otro lado, es importante señalar que durante la hegemonía Inkaica los relatos revelan que el oro fue el símbolo que representaba del sol y sirvió como emblema para legitimar el poder de la nueva dinastía cusqueña. En los diversos mitos de origen, fundacionales y de posesión de territorios, aparece el oro como representante de la divinidad solar y legitimadora del accionar de los lideres (Pease 2004; BouysseCassagne 2005). También se consideraba al metal de plata como símbolo de la luna y dentro de una concepción dual, junto al oro, simbolizaban lo masculino y lo femenino y la potencialidad de fecundidad (Lechtman 1999; D'Altroy 2003). El uso de piezas metálicas en algunas de las prácticas sociales permitió de esta manera, establecer vínculos con los seres sobrenaturales participando en el entramado simbólico que sostenía el poder cusqueño (Lechtman 1979; D’Altroy 2003, González 2004a y b). Posiblemente, por ello, es común encontrarlos en espacios circunscriptos a una alta ritualidad como los santuarios de altura, ushnus, tumbas y en grandes centros ceremoniales-administrativos inkaicos.

Con respecto a prácticas sacro-culticas imbuidas en la etapa de fundición es destacable la apreciación realizada por el clérigo Bartolomé Álvarez, quien manifestó que "los guayradores se confesaban antes de emprender su trabajo y ofrecían coca y algún aborto de llama o cuy a la guayra" (Álvarez 1998 (1588): 356 citado en BouyseeCassagne 2005). Estas prácticas de ofrendar coca a los hornos también fueron registradas etnográficamente en estudios etnográficos realizados por Van Buren (2003) 
en Bolivia. Por su parte, Valencia (1978) realizó investigaciones etnoarqueológicas con artesanos plateros en Cusco, Perú y remarca que todas las etapas de trabajo están acompañadas de ofrendas rituales, música y ceremonias. Resulta más difícil identificar prácticas de esta clase en el registro arqueológico, aunque poseemos casos de ofrendas fundacionales en los hornos de Batán Grande en la costa norte de Perú (Shimada 1987) y en el NOA para en el Sitio 15 de Rincón Chico (González 2004a, 2010).

En el Noroeste de Argentina desde los objetos finales se han realizados abordajes sobre sus simbolismos, en especial de las famosas placas decoradas de la sociedad Aguada, pero también pueden apreciarse en discos y campanas de Periodos Tardíos (Lafone Quevedo 1980, González 1992, Llamazares y Martínez Sarasola 2006). En estos estudios se han propuesto diversas formas iconográficas de representar principios rectores de la cosmología Andina (Llamazares y Martínez Sarasola 2006).

Con estas apreciaciones se puede percibir que, en el mundo andino, la producción metalúrgica y los metales en sí mismos, no eran meros procesos técnicos y objetos simplemente utilitarios. Dentro del abundante repertorio de la cultura material, eran justamente, los metales los representantes de las divinidades y del orden cósmico y poseían el poder para incidir sobre los hombres. Su manipulación implicó actitudes específicas hacia los materiales y el establecimiento de vínculos rituales con los otros seres sobrenaturales para propiciar el buen destino de los procedimientos tecnológicos.

Estas concepciones andinas no debemos perderlas de vista cuando se aborda el estudio de las prácticas de producción metalúrgica dado que estructuraron las acciones de las personas en el pasado. Cerramos este capítulo, reiterando que en esta investigación abogamos por una perspectiva holística de la tecnología que la concibe como un entramado de relaciones dinámicas que involucra actores sociales humanos y no humanos, saberes técnicos y ceremoniales, secuencias de comportamiento, cadenas operativas, elecciones, percepciones, valores culturales, intenciones y negociaciones que permean todos los aspectos de la vida social. 


\section{ANTECEDENTES}

\subsection{Estudios sobre metalurgia en el noroeste argentino (NOA)}

En la introducción adelanté dos grandes enfoques que guiaron las investigaciones sobre la metalurgia en nuestro país. Por un lado, encontramos aquellos estudios que se focalizaron en los objetos acabados. Por el otro, los que indagaron sobre aspectos relativos a cadenas productivas y elecciones tecnológicas a partir de las evidencias halladas en contextos estratigráficos. Se presentará una síntesis de ambas perspectivas de investigación para luego focalizar en las investigaciones en sitios arqueológicos con indicios de actividades metalúrgicas. Muchos investigadores ya han enfatizado en la abundancia de trabajos focalizados en objetos terminados y que las tendencias actuales se orientan al estudio de sitios de producción, campo que no ha tenido el mismo interés en los primeros momentos de desarrollo de la disciplina (Lechtman 1978; Scatollin y Williams 1992; González 2004a; Gluzman 2008).

El interés por las piezas metálicas prehispánicas se desarrolló muy tempranamente, previo a la conformación de la arqueología como disciplina científica en Argentina. Por lo tanto, para poder reflexionar sobre las propuestas, aportes y limitaciones de los primeros estudios se hizo necesario situarlos, es decir, enmarcarlos en sus condiciones socio-históricas, los modelos interpretativos y los paradigmas científicos vigentes que posibilitaron los discursos académicos (Bourdieu y Wacquant 2005; Gadamer 2005 [1975]).

Con relación al primer grupo, si bien son numerosos los investigadores que realizaron estudios de objetos metálicos (Lafone Quevedo 1890; Sánchez Díaz 1909; Nordenskiold 1921; Quiroga 1929; Truco 1965; Mayer 1985; Boman 1991 [1908]; González 1992 y Ambrosetti 2011 [1904], entre otros) se focalizará en aquellos que a mi parecer aportaron grandes avances en los estudios metalúrgicos en la provincia de Catamarca. Principalmente destaco los trabajos de Samuel A. Lafone Quevedo, Juan B. Ambrosetti y Alberto Rex González. Los dos primeros formaron parte de la pionera generación de intelectuales del siglo XIX que, formados en otros campos disciplinares, se interesaron tempranamente por las sociedades prehispánicas. Estos estudios se 
producen en pleno proceso de creación del relato histórico para la conformación de una "identidad" nacional Argentina. Como señala Bovisio, en este marco seguramente "se sintieron interpelados ante el problema de la definición del pasado nacional y la preocupación por definir a los sujetos hacedores de las piezas arqueológicas" (Bovisio 2014: 152). Lafone Quevedo y Ambrosetti provenían de familias acaudaladas que les permitió vincularse con personas que detentaban por aquellos años gran poder económico, social y político, e ingresaron en espacios científicos y universitarios de las ciudades de Buenos Aires y La Plata (Bovisio 2014). González en cambio, oriundo del interior de la provincia de Buenos Aires, estudió inicialmente medicina, para luego formarse en Norteamérica dentro del campo de la antropología y arqueología. Dedicó su vida al estudio de las sociedades prehispánicas del NOA y contribuyó con perspectivas teóricas y metodológicas que profesionalizaron la disciplina en Argentina. Integró prestigiosas instituciones científicas y educativas de Buenos Aires, La Plata y Córdoba desde las cuales impulsó numerosos proyectos de investigación, programas de formación profesional y políticas públicas (Baldini 2012; Tarragó 2012).

Dentro del campo de la metalurgia, el aporte fundamental de Samuel Lafone Quevedo fue dar a conocer una placa de bronce que hoy día es resguardada en el Museo de La Plata. La pieza fue adquirida en 1881 como mercancía en Chaquiago en la actual provincia de Catamarca. Allí, Lafone Quevedo tenía a su cargo la empresa minera familiar de Pilciao y exploraba regularmente territorios en busca de minas metálicas. Posiblemente esta actividad le permitió familiarizarse con las costumbres de los pobladores y los vestigios arqueológicos de la región. En una nota específica, divulga un estudio detallado del disco metálico (Lafone Quevedo 1980). Su análisis, considerado por Haber (1994: 36) de "corte filológico", se focalizó en la interpretación de los símbolos presentes en el objeto. Utilizó una metodología comparativa, mediante la cual identificó y discriminó los signos de la placa que luego análoga a jeroglífícos egipcios y les asigna una fonética griega. Influenciado por su formación en lingüística, Lafone Quevedo identificó letras que codificarían la palabra Cuanti y basándose en datos etnohistóricos propuso que en América existieron formas diversas para referirse a su Dios: Pirua, Viracocha o Cuanti (Lafone Quevedo 1980). 
A pesar de sus intentos por acercarse al sentido de este objeto, Lafone Quevedo no logra romper con la brecha cultural y muchas de sus conclusiones están dominadas por las ideas difusionistas y etnocéntricas de la época. En su escrito se percibe que el presupuesto que guió el estudio fue el postulado sobre la existencia de una misma base lingüística de las poblaciones prehispánicas (Bovisio 2014), la cual sería oriunda del viejo mundo, considerado por los paradigmas científicos imperantes como la cumbre de la civilización (Trigger 1992). De esta manera, les quitó capacidad de invención a los pueblos americanos.

Sin embargo, la calidad técnica y el diseño de esta placa de bronce no pasaron desapercibidos por los científicos posteriores y se convirtió en uno de los ejemplares arqueológicos más famosos del NOA. Su estudio fue retomado en épocas recientes, dónde, a partir de análisis técnicos puntuales y nuevos abordajes simbólicos, han dado a conocer la tecnología empleada en su fabricación y el estilo característico de la entidad sociocultural Aguada (Biloni et al. 1990; González 1992). Incluso se retoma la hipótesis de Lafone Quevedo respecto a que la figura antropomorfa sería una representación de la deidad solar pero basada en estudios iconográficos comparativos y en datos etnohistóricos de la región andina (González 1992). Actualmente, Cruz (2009-2011) realizó una revisión de los diseños de esta placa junto a otras piezas similares de la región andina, y propone una interpretación alternativa sugiriendo una posible pertenencia a periodos Tardío e Inka.

Por su parte, Juan B. Ambrosetti realizó varias referencias a objetos de metal y destinó un libro completo a ellos: "El Bronce en la Región Calchaquí" (2011 [1904]). En este escrito rechaza la creencia generalizada en relación a la existencia de un único centro de invención del bronce que se situaba, según los postulados de la época, en los Andes Centrales (Uhle 1908). Propone en cambio, que la región del NOA desarrolló independientemente su tecnología del cobre estannífero, empleando incluso minerales locales. Esta propuesta estableció un quiebre con respecto a los enfoques difusionistas de la época. Es importante destacar que Ambrosetti fue el primero en hacer referencia a la secuencia de operaciones necesarias para la conformación de objetos. No obstante, como veremos su estudio continuó con la tradición normativa descriptiva aplicada a los bienes metálicos. 
Un análisis minucioso del discurso y los tipos artefactuales construidos por el autor, vislumbra indicios sobre los preconceptos que guiaron su investigación. Al analizar su tipología, los artefactos pueden re-agruparse en dos categorías más inclusivas según a los cuales Ambrosetti: 1) le pudo asignar por su morfología una función práctica o utilitaria; y 2) aquellos objetos a lo que no pudo otorgar una función evidente, los cuales además suelen presentar algún tipo de decoración. Se considera que allí, se asocia por analogía la forma a la función y se reduce el estilo a un rol pasivo y residual, ya que, si carece de utilidad técnica entonces, es un mero objeto decorativo (Mc Guire 1981) llamado por Ambrosetti “de adorno” (Ambrosetti 2011 [1904]: 69). Esta relación estrecha entre forma y función separada de consideraciones de estilo se puede relacionar con la visión de tecnología asociada a un discurso ideológico occidental (Pfaffenberger 1988, 1992a; Ingold 1990) y con la perspectiva europea sobre los desarrollos metalúrgicos del viejo mundo. Como reflexiona Lechtman (1991) bajo este modelo los metales fueron considerados sólo como materias primas de herramientas necesarias para el trabajo agrícola, militar y el transporte.

A pesar de los sesgos, hay ciertos puntos a rescatar de su trabajo. En primer lugar, sus propuestas invitan a restituir a los pueblos aborígenes locales su capacidad de invención. Por otro lado, es importante remarcar que Ambrosetti realizó los primeros estudios técnicos que permitieron determinar la composición química de los bienes metálicos en el país, datos que en los años siguientes se fueron incrementándose en número con los provenientes de otras regiones (Sánchez Días 1909, Nordenskiold 1921; Fester y Retamar 1956; Trucco 1965, entre otros) y que permitieron generar propuestas sobre los minerales empleados y saberes sobre las operaciones técnicas de manufactura. Al respecto, Trucco (1965) realizó análisis composicionales, de dureza y metalográficos de piezas de metal alojadas en el Museo de La Plata. De las piezas analizadas por el autor, 12 provienen de Catamarca y por su tipología pertenecerían a momentos y sociedades distintas ( 3 tokis, 1 Disco, 1 campana, 1 brazalete, 1 botón, 2 fragmentos de pinzas y 3 collares). Los análisis cuali y cuantitativos demostraron que las piezas fueron fabricadas en cobre (con proporciones de entre 70 y $95 \%$ ) y dada la variabilidad en el contenido de estaño (de entre 0,15 y $7 \%$ ), el autor no considera que se trate de una aleación intencional (Trucco 1965). 
A mediados del siglo XX aparecen en escena los trabajos realizados por Alberto R. González que contribuyeron a delimitar y profesionalizar la disciplina arqueológica en Argentina. A partir de sus propuestas se sistematizaron las metodologías para el trabajo en el campo mediante prospecciones sistemáticas y excavaciones estratigráficas y análisis de laboratorio combinando técnicas de datación relativas y absolutas. Sus extensas investigaciones permitieron dar cuenta de la gran diversidad cultural prehispánica, reconstruir contextos, asignar cronologías a sitios y materiales para poder indagar sobre las transformaciones sociales, políticas y tecnológicas de las sociedades (González 1955, 1975, 1979, 1992; González y Cowgill 1975; González y Lagiglia 1973). En este marco aportó la primera periodización de las culturas precolombinas del NOA empleando como indicador cronológico la cerámica arqueológica, la seriación en tumbas y las dataciones radiocarbónicas (González 1955, 1979, González y Cowgill 1975).

En este mismo sentido encaró el estudio de objetos metálicos con especial énfasis en la dimensión simbólica, que fue plasmado en su obra "Las placas metálicas de los Andes del Sur. Contribución al estudio de las religiones precolombinas" (González 1992). Un punto a destacar de este trabajo fue la búsqueda de información contextual de las piezas de colección, ya sea mediante registros arqueológicos o por comparación estilística con otros soportes materiales. Gracias a ello pudo deducir la pertenencia cultural de cada placa y ubicarlas dentro de la secuencia cronológica preestablecida para las sociedades del NOA. Llevó a cabo un análisis iconográfico de las piezas empleando una metodología de análisis semiótica, la cual considera los signos o representaciones como expresiones de actores sociales que desean comunicar un mensaje social (González 1979, 1992). Asimismo, integró los datos obtenidos con la información etnohistórica y etnográfica disponible, que le permitió demostrar que estos objetos de metal, más que meros adornos, eran piezas con un alto significado simbólico y religioso, con roles fundamentales en diversos rituales (González 1992).

A partir de la observación de cambios morfológicos, iconográficos y tecnológicos propone una secuencia histórica de desarrollo para las placas metálicas. Asimismo, postula que pese a las transformaciones se dio una continuidad del sentido simbólicoreligioso asociado a estos objetos, donde en general se expresan principios centrales 
para la cosmología andina como la dualidad. Según este esquema, las placas características del periodo Temprano son discos ovales, con formas de ocho o doble "I" fabricadas por técnicas de laminado y repujado, con diseños de rostros antropomorfos y otros geométricos. González identificó que en ellos se manifestaba el principio de dualidad a partir de situaciones de duplicación y cuatripartición. Al ser este principio característico de las divinidades andinas, interpreta que mediante estas placas se representaría a una deidad celestial. Durante el periodo Medio se dio un cambio tecnológico e iconográfico. El primero consistió en el uso de la técnica de cera perdida para la manufactura de placas de bronce. El segundo quedó manifestado en la representación de un personaje antropomorfo central (personaje de las manos vacías) cuyos elementos iconográficos le permitieron asociarlo a una divinidad solar. El otro diseño que predomina es el personaje del sacrificador y las cabezas cercenadas, que son interpretadas como representaciones del shamán oficiante de ritos de sacrificio en cultos destinados a dicha deidad. En el periodo Tardío, en consonancia con una fragmentación político-social de las poblaciones, se observa una disrupción con respecto a las placas de momentos previos, dada la desaparición del personaje central. Aun así, continúan las representaciones de rostros antropomorfos que presentan elementos identitarios. Aparecen diseños de grandes escudos y continúan las representaciones de serpientes, anfisbenas y saurios fantásticos. Lo novedoso es la presencia de placas rectangulares y circulares lisas con superficies intensamente pulidas. González asocia estas placas al desarrollo de un culto de reflexión solar, siendo utilizadas en los rituales agrícolas. En momentos tardíos predominó el uso de moldes bivalvos para la fabricación de placas metálicas (González 1992).

En las últimas décadas del siglo XX se observa un aumento en las investigaciones sobre la metalurgia del NOA que va acompañado de una apertura disciplinaria. Esta implicó estudios interdisciplinarios e investigaciones en sitios arqueológicos con evidencias de contextos productivos metalúrgicos (Scatollin y Williams 1992; Earle 1994; Williams 1995; Pifferetti 2001; González 2002, 2004b, 2010; Angiorama 2004, 2006, 2011; Angiorama et al. 2014). Estos trabajos recibieron la influencia de las perspectivas de la antropología de la tecnología (Lechtman 1976, 1977; Lemonnier 1992; Dobres y Hoffman 1994, 1999; Pfaffenberger 1988, 1992a; Shimada 1996). Así comenzaron a explorarse diversos aspectos de la tecnología metalúrgica a través de las 
materialidades identificadas en contextos arqueológicos como estructuras de combustión, materiales refractarios y desechos de fundición.

En Argentina se destacan las investigaciones lideradas por Carlos Angiorama en la Quebrada de Humahuaca en Jujuy, por Luis González en el Valle de Santa María en Catamarca y por el Ingeniero Adrián Pifferetti en Alamito, también en Catamarca, dado que han establecido una tradición de investigaciones arqueometalúrgicas en nuestro país. Junta a sus equipos han realizado nuevos estudios técnicos sobre piezas arqueológicas desde perspectivas antropológicas (Angiorama et al. 1999; Angiorama 2001, 2004, 2013; González y Vargas 2000; Pifferetti 2001, 2006; González 2003, 2006; Cabanillas et al. 2006-2009; González y Buono 2007). También han aplicado técnicas de las ciencias de los materiales para realizar tareas de conservación, prevención y detectar la autenticidad de objetos metálicos que forman parte de colecciones museológicas (Pifferetti 1993; González 2011). Han encarado proyectos sistemáticos que dieron a conocer los primeros talleres metalúrgicos regionales como la Unidad 400 de Los Amarillos en Jujuy (Angiorama 2004, 2011), el Sitio 15 de Rincón Chico (González 2002, 2010) y el sitio Alamito (Pifferetti 2001), estos últimos en la provincia de Catamarca. Allí se recuperaron diversos indicadores arqueológicos que posibilitaron abordar las distintas etapas de la cadena productiva de bienes metálicos, caracterizar las prácticas metalúrgicas locales y delimitar estilos tecnológicos particulares, las cuales serán tratados en detalle más adelante.

Asimismo, abordaron temas como la especialización artesanal (González y Tarrago 2004a; González 2007, 2010; González y Gluzman 2009; Gluzman 2017) y la producción en contextos domésticos (Angiorama 2005; Angiorama y Taboada 2007); la relación entre tecnología metalúrgica y religiosidad (González 2002, 2003, 2004a) así como entre las prácticas metalúrgicas y el poder político (González 2002, 2006, 2010; Angiorama 2004, 2005; Angiorama y Taboada 2007; Gluzman 2008); indagaron sobre el impacto de la conquista Inka en el campo metalúrgico, en términos de cambios y continuidades en las técnicas operativas y modos de organización social, preguntándose también sobre la transferencia de saberes mutuos y las modalidades de articulación del Estado con las sociedades locales (González 2002, 2010; Angiorama 2004, 2005, 2011, 2013; González y Tarragó 2004a, 2004b; González y Gluzman 2007; Gluzman 2017). 
Incluso investigaron sobre las logísticas de apropiación, circulación e intercambio de materias primas y objetos manufacturados desde épocas prehispánicas hasta coloniales (Angiorama 2001, 2005; González 2002, 2010; Becerra 2014). Propuestas específicas de estas investigaciones serán retomadas a lo largo de todo el trabajo para evaluar los resultados obtenidos en el sitio Quillay.

\subsection{Sitios con evidencias de actividades minero-metalúrgicas en la región andina}

En este segmento se busca dar cuanta de sitios con evidencias de prácticas metalúrgicas en la extensa región Andina. Es por ello que, se seguirá una lógica espacial para la presentación de estos contextos arqueológicos y las propuestas sobre tecnología generadas por los investigadores. De esta manera se comenzará por sitios presentes en el actual Perú, siguiendo con Bolivia y Chile para alcanzar territorios del noroeste de Argentina (figura 3.1). El motivo de este relevamiento bibliográfico es la visualización de una serie de centros independientes de trabajo metalúrgico que adquirieron modalidades y técnicas particularizadas para el trabajo de la plata, cobre y sus aleaciones. Cabe aclarar que, dentro de los indicadores de prácticas minero-metalúrgicas que serán presentados, se pondrá especial énfasis en las estructuras pirotécnicas ya que muchos de estos asentamientos fueron incorporados a la dinámica del Tawantinsuyu y servirán como referencia para reflexionar, evaluar y contrastar resultados obtenidos a lo largo de la presente tesis en relación a tecnología metalúrgica y dinámica social. 


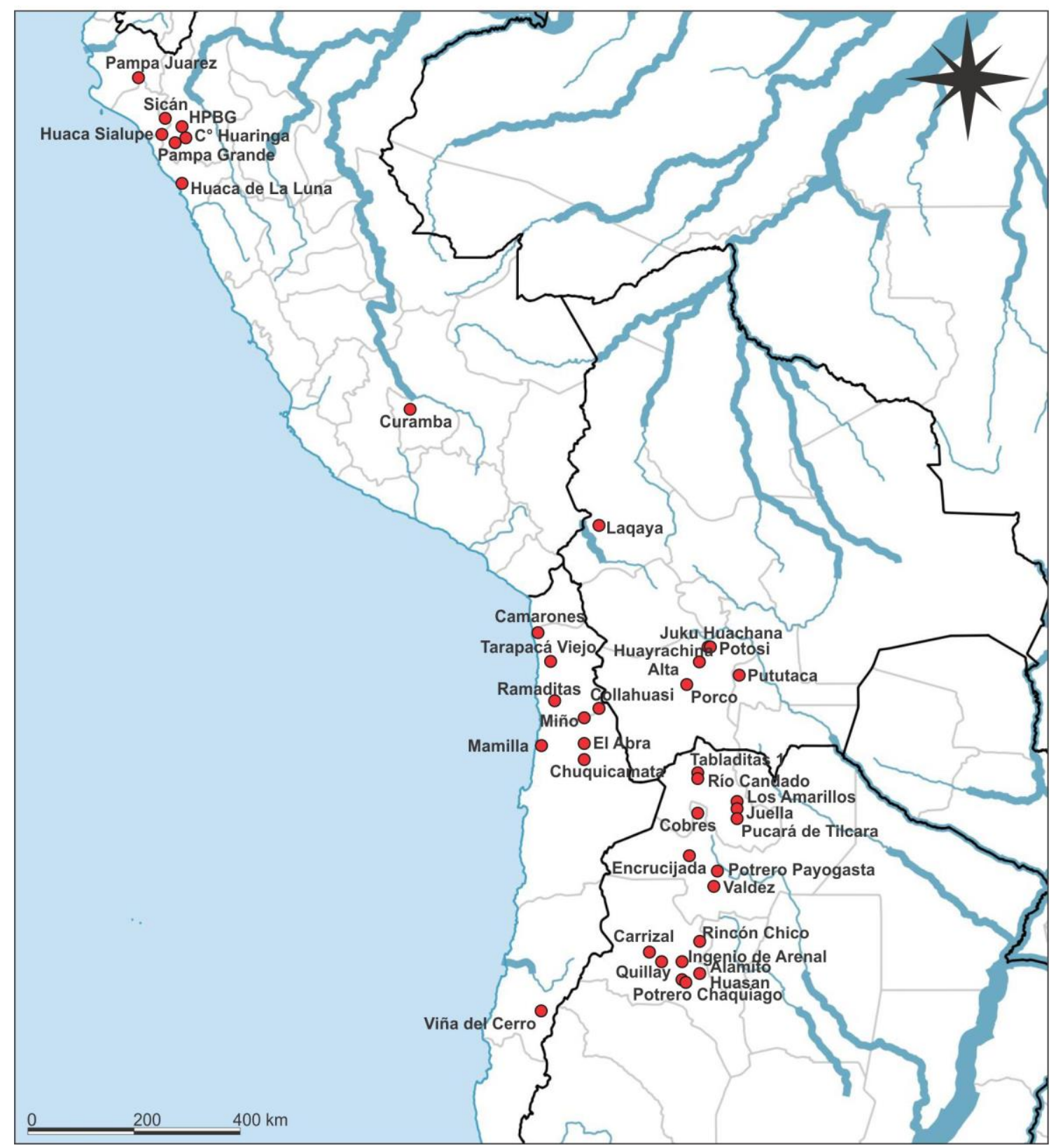

Figura 3.1. Mapa con la localización de los sitios nombrados en el texto.

\subsubsection{Sitios en el actual territorio peruano}

En la costa norte de Perú, se identificó en el sitio Pampa Juárez un taller orfebre Vicus que funcionó entre los siglos III y IV de nuestra era. Entre las evidencias pirometalúrgicas se destaca la presencia de un horno de arcilla con forma de bóveda de $37 \mathrm{~cm}$ de diámetro y $21 \mathrm{~cm}$ de altura, con zonas para introducir sopladores (figura 3.2). Asimismo, se identificaron fogones aledaños con restos de ceniza y escorias de combustión, restos de nódulos y láminas recortadas de cobre, escorias adheridas a 
tiestos cerámicos y varios objetos terminados de carácter ornamental y utilitario (Makowski y Velarde 1996). Los investigadores proponen que las estructuras de combustión habrían sido utilizadas para la refinación de metales de cobre, siendo posteriormente trabajadas con técnicas de laminado y dorado. El taller se identificó cercano a cementerios con gran variabilidad de ofrendas, entre las que se destacan objetos metalúrgicos de distinta índole. La diversidad de estilos alfareros presentes en el sitio, conduce a los autores a proponer el carácter poliétnico de los artesanos que producirían de manera esporádica estos bienes para ser ofrendados en prácticas mortuorias (Makowski y Velarde 1996).

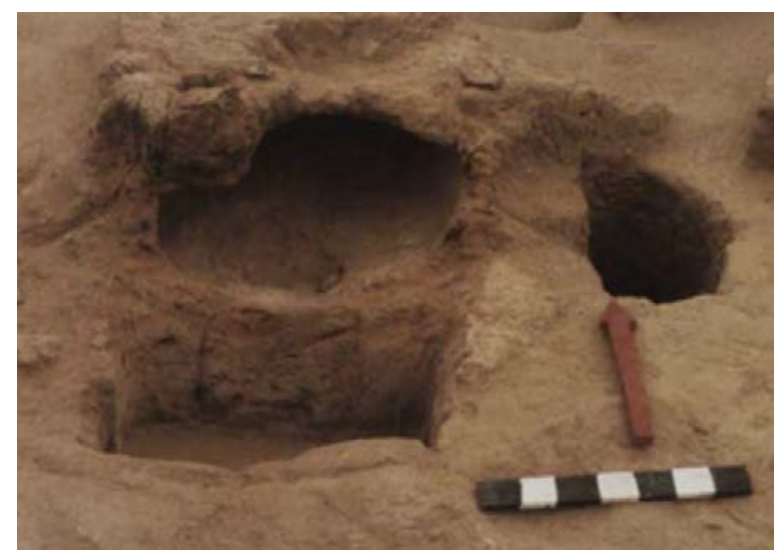

Figura 3.2. Fotografia del horno metalúrgico de Pampa Juárez. Tomada de Makowski y Velarde 1996: Foto 15.

Otro sitio en la costa norte que posee evidencias de un taller orfebre es el complejo CA-17 del centro urbano Moche de Huaca de la Luna. El componente con evidencias de actividades metalúrgicas está datado entre el 600-700 dC. Allí se identificaron vestigios diversos, cuyos estudios técnicos permiten postular el desarrollo de distintas etapas de la cadena de operaciones para la manufactura de objetos a base de cobre (Fraresso 2010). La autora distingue al menos dos etapas del trabajo del metal, por un lado, identifica una estructura de combustión abierta considerada un horno de fusión (figura 3.3), crisoles con inclusiones metálicas y toberas, como vestigios que darían cuenta del fundido de metal para refinar cobre y producir aleaciones tumbaga (Cu-Au-Ag). Por el otro, la diversidad de instrumentos líticos (martillos, yunques y pulidores), recortes de metales, gotas de cobre, piezas sin terminar y un único objeto final, le permiten postular que allí se habrían manufacturado piezas simples empleando 
técnicas de martillado y dorado, cuyo acabado final y decorado podría ser realizado en otras regiones (Fraresso 2010).

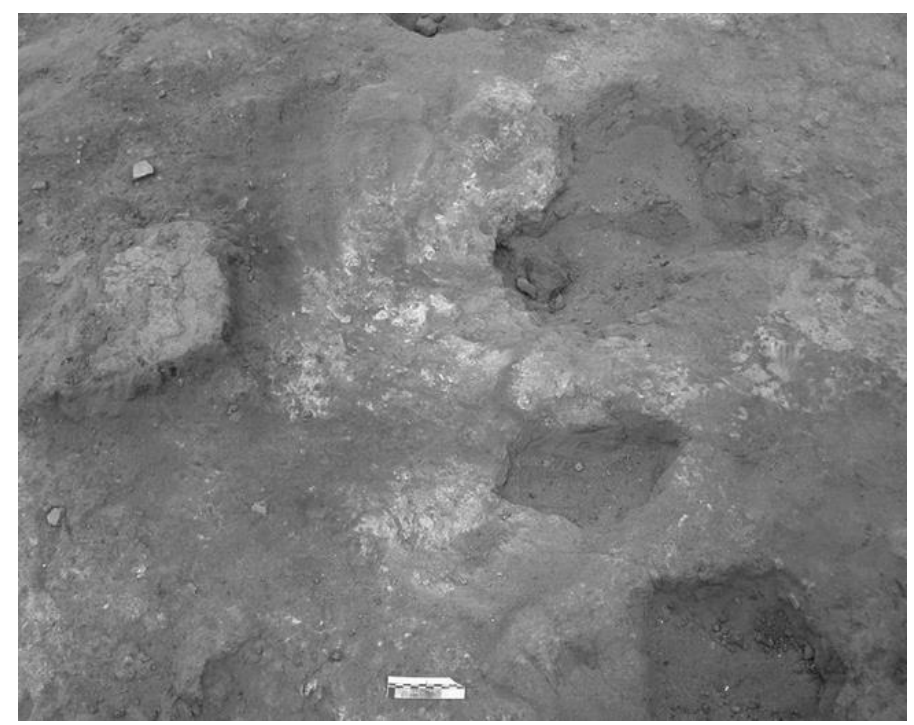

Figura 3.3. Fotografía del horno de fusión de Huaca de la Luna. Tomada de Fraresso 2010: Figura 5, p. 361.

Finalmente destacamos los hallazgos del complejo arqueológico de Batán Grande, en el departamento de Lambayeque. Se han dado a conocer tres sitios: Huaca del Pueblo de Batán Grande, Cerro Huaringa (también llamado de los Cementerios) y Cerro Sajino, con evidencias pirometalúrgicas que indican que funcionaron de manera continua durante los periodos Sicán, Chimú y Chimú-Inca, esto es desde el 800-850 dC. hasta 1532 dC. (Shimada 1987; Shimada et al. 1982; Shimada et al. 2007). En todos los sitios se han identificado nódulos amorfos y recortes de metal, pequeños lingotes de cobre arsenical, escorias enteras y fragmentadas, crisoles, toberas e instrumentos líticos junto a unos pocos restos de objetos terminados. Shimada (1987) resalta que serían los contextos con presencia de hornos de fundición de minerales de cobre de cámara simple más antiguos que se conocen para la región.

Para Huaca del Pueblo y Cerro Huaringa se calcula la existencia de una centena de hornos de arcilla cocida con forma de pera, que se disponen agrupadas en conjuntos de tres a cuatro estructuras alineados entre sí y conectadas por depresiones para el vaciado de desechos metalúrgicos (Shimada 1987; Shimada et al. 1982). La excavación de 24 hornos en el sector III de Huaca del Pueblo, permitió el registro y estudio 
minucioso de su morfología. Consisten en hornos cavados en el suelo, de 30-35 $\mathrm{cm}$ de largo, 20-25 de profundidad y 25-30 de ancho con un recubrimiento de arcilla refractaria en el interior (Shimada et al. 1982) (figura 3.4). Los investigadores han propuesto que allí, se produciría la fundición de menas oxidadas o carbonatadas de cobre que alcanzarían las temperaturas necesarias mediante ventilación forzada, dando como resultado escorias con prills metálicos que necesitarían de intensas actividades de molienda para su extracción final (Shimada et al. 1982). Otro punto a destacar es el hallazgo de ofrendas rituales distribuidas por debajo de toda el área de trabajo metalúrgico. Las mismas consistieron en fetos y neonatos de camélidos en posición flexionada y hoyos con cerámica, todos cubiertos con una capa de material orgánico. Este hallazgo permitió imbuir a las prácticas productivas de religiosidad y de un alto valor simbólico (Shimada 1987)

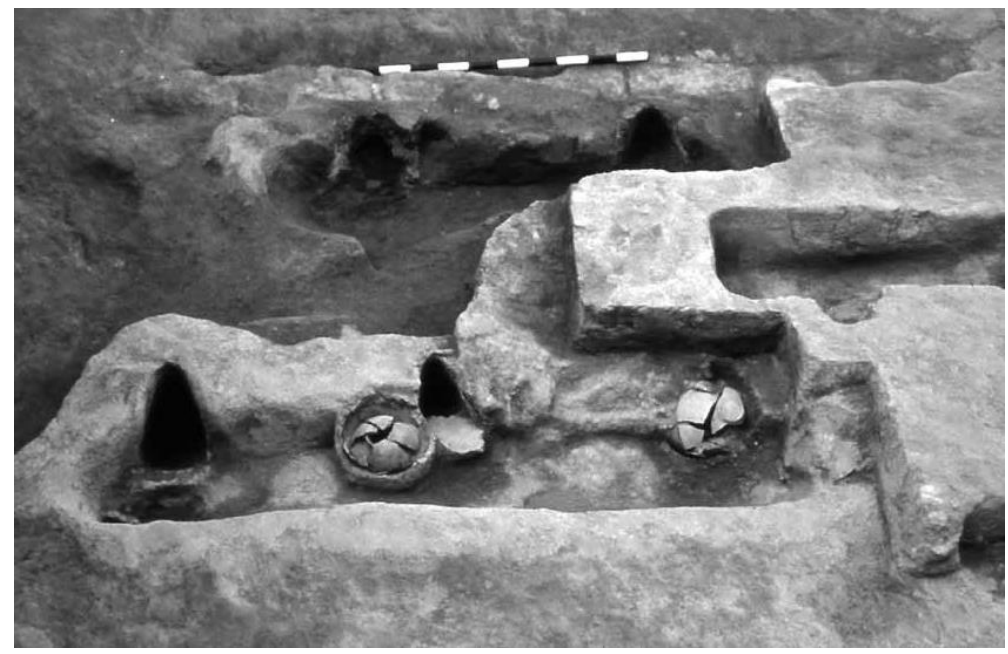

Figura 3.4. Fotografía de los conjuntos de hornos de fundición de Huaca del Pueblo en Batan Grande. Tomada de Shimada y Craig 2013: Figura 11.

Huaca del Pueblo es considerado un taller de extracción y producción de lingotes de aleaciones de cobre arsenical, a escala industrial, que abastecería con esta materia prima a otros sitios para el posterior trabajo orfebre. En este marco, la logística de aprovisionamiento de materias primas y la organización de la producción metalúrgica habría funcionado bajo un control administrativo estatal (Shimada et al. 1982). Incluso los autores señalan una diferencia de control entre el estado Chimú y el Inka. Mientras que la mampostería y la presencia cerámica indican un fuerte control estatal en el primer 
caso, el incario habría empleado un control indirecto relegando la tarea a los líderes locales más leales a la nueva administración política (Shimada et al. 1982).

En Huaca Sialupe, se halló un horno de morfología diferente. Se trata de una vasija de cerámica invertida y parcialmente enterrada con una apertura en la cima que actúa como chimenea (figura 3.5). Presenta forma cilíndrica y fondo cónico con 45-55 $\mathrm{cm}$ de diámetro y 50-60 $\mathrm{cm}$ de profundidad. Lo distintivo de esta estructura es la presencia de dos canales laterales para la entrada de aire natural aprovechando los vientos predominantes en la zona (Shimada et al. 2007). Análisis químicos, estudios experimentales y la evidencia contextual (ausencia de minerales y escorias de fundición) permiten proponer que el horno habría sido utilizado para la aleación de cobre y de cobre-oro y como brasero para procesos de re calcinación durante el trabajo orfebre (Shimada et al. 2007).

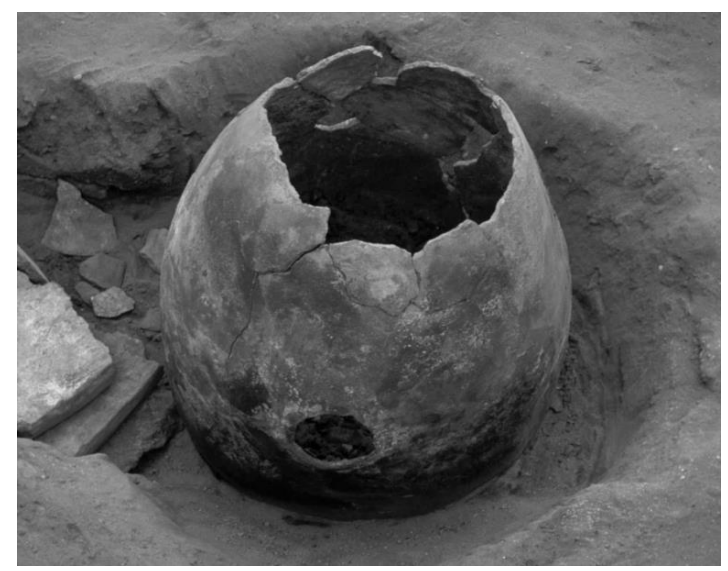

Figura 3.5. Fotografía del horno vasija de Huaca Sialupe. Tomada de Shimada et al. 2007: Figura 3.

Se puede condensar esta información remarcando que, la metalurgia de cobre en la costa norte de Perú durante tiempos prehispánicos tardíos involucró al menos cuatro estructuras de combustión diferentes y dos principios de ventilación. Por un lado, dentro de los hornos empleados para la fundición, se cuenta con el horno abierto del centro urbano mochica (Fraresso 2010); el ejemplar de Pampa Juárez es una cavidad de forma abovedada construida de arcilla y paredes alisadas (Makowski y Velarde 1996); y aquellos presentes en los sitios Huaca del Pueblo y Cerro Huaringa son hornos de arcilla con forma de pera (Shimada et al. 1982). Todos ellos habrían funcionado bajo el principio de ventilación forzada por acción humana mediante el empleo de sopladores. 
El último caso representa una estructura pirometalúrgica empleada para el trabajo del metal, son los ejemplares de Huaca Sialupe, conformados por una vasija horno, construida con una cerámica invertida que empleó el principio de ventilación por tiro natural (Shimada et al. 2007). Otro dato a destacar es que, para el complejo de Batán Grande, los estudios indican que durante la ocupación inkaica estos hornos continuaron funcionando sin mayores modificaciones (Shimada et al, 1982).

Por último, en la región serrana de Perú, en el departamento de Apurímac, se halla el sitio arqueológico de Curamba. Es un asentamiento netamente Inka que presenta numerosas estructuras arquitectónicas estatales como una plaza central o aukaipata, un ushnu, kallankas y diversos sectores residenciales, así como abundantes ceramios de estilos incaicos (Lechtman 1976; Del Mar 2006; Veter Parodi et al. 2008). Para este estudio, se destaca la presencia de un sector productivo metalúrgico. El mismo consta de una amplia estructura residencial y decenas de hornos ubicados en terrazas localizadas en una loma hacia el sur. Los hornos fueron construidos con roca caliza y mortero de barro y un enlucido interior de material refractario con signos de termoalteración. Son estructuras subterráneas que atraviesan las terrazas, las cuales sirven para el aprovechamiento y circulación de los vientos naturales (Lechtman 1976; Veter Parodi et al. 2008). Tienen formas rectangulares con dimensiones que alcanzan 3 $\mathrm{m}$ de largo, 0,7 m de ancho y $0.3 \mathrm{~m}$ de profundidad (Lechtman 1976; Del Mar 2006). (figura 3.6). Están agrupados en conjuntos de tres hornos, finalizando los laterales en un espacio circular abierto que le otorga al conjunto "la forma de una cerradura vista de planta" (Veter Parodi et al. 2008: 459). Si bien en el sitio no se han identificado escorias ni minerales, tradicionalmente se asoció a estos hornos con prácticas metalúrgicas de fundición de plata (Lechtman 1976; Del Mar 2006; Veter Parodi et al. 2008). Sin embargo, estudios técnicos recientes en muestras de fragmentos rocosos y arcillas vitrificadas del interior de los hornos, indican únicamente el procesamiento de menas ricas en plomo (Brooks y Vetter Parodi 2012). 


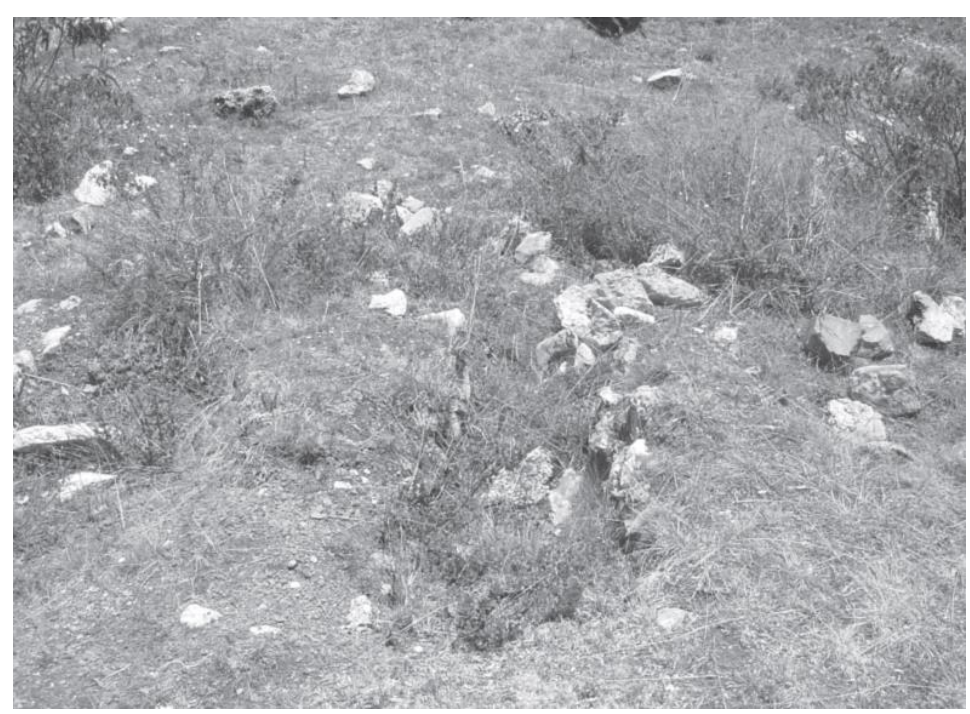

Figura 3.6. Fotografía de la serie de tres hornos de Curamba. Tomada de Veter Parodi et al. 2008: figura 9a, p. 460.

\subsubsection{Sitios en el actual territorio boliviano}

El altiplano boliviano fue una región de fuerte interés por parte de los conquistadores españoles debido a las grandes riquezas metálicas que poseían - y aún poseen- los yacimientos mineros de Porco y Potosí. Es ampliamente conocido que la plata extraída de estas minas financió desde los inicios a la actividad colonial europea (Bakewell 1989). Los registros escritos de esta época han remarcado que hasta 1572 , cuando el virrey Toledo introdujo la técnica de amalgama con mercurio, la producción de plata estuvo en manos de los mineros-metalúrgicos aborígenes (Bakewell 1989). La tecnología de fundición empleada fueron los hornos de viento llamados "huayrachinas" y otras estructuras de copelación denominadas "tocochimbos" (Barba 1817 [1640]; Cieza de León 1922 [1553]; Capoche 1959 [1585];). Frente a las numerosas descripciones sobre la morfología y el funcionamiento de estas estructuras por parte de los cronistas (para una síntesis ver Bargalló 1967) las evidencias arqueológicas resultan escasas. Esto se debe en gran medida a la continuidad en el tiempo de estas actividades que conllevan a la superposición o eliminación de rastros o evidencias de las prácticas metalúrgicas prehispánicas.

A pesar de la dificultad en discriminar las actividades metalúrgicas pre-coloniales de las coloniales, las intensas prospecciones arqueológicas realizadas en el área de Porco-Potosí han logrado detectar sitios prehispánicos en las cercanías de la ciudad de 
Potosí. Al respecto, en la mayoría de los cerros aledaños se han identificado vestigios de explotaciones mineras y del procesamiento metalúrgico de minerales plata y galena (Cruz y Absi 2008; Cruz y Téreygeol 2014). Incluso, algunos estudios han logrado detectar fragmentos de "huayrachinas" de posible asignación prehispánica. Estos vestigios son fragmentos curvos de arcilla cocida, fuertemente vitrificados en su interior, con orificios para el pasaje de aire cercanos a los $7 \mathrm{~cm}$ de diámetro (Van Buren y Mills 2005) (figura 3.7). Este sería el caso para el cerro Juku Huachana, localizado al noroeste de la ciudad de Potosí (Cohen et al. 2008; Téreygeol y Castro 2008) y para el sitio Huayrachina Alta en el área de Porco (Cohen et al. 2008). Si bien estos sitios presentan indicios de ocupación colonial, los hornos se hallaron asociadas a escorias metálicas y a vestigios arquitectónicos y cerámicos de factura inkaica. Estos contextos conducen a los investigadores a proponer que los restos podrían corresponder a este periodo de ocupación (Cohen et al. 2008; Cruz y Absi 2008).
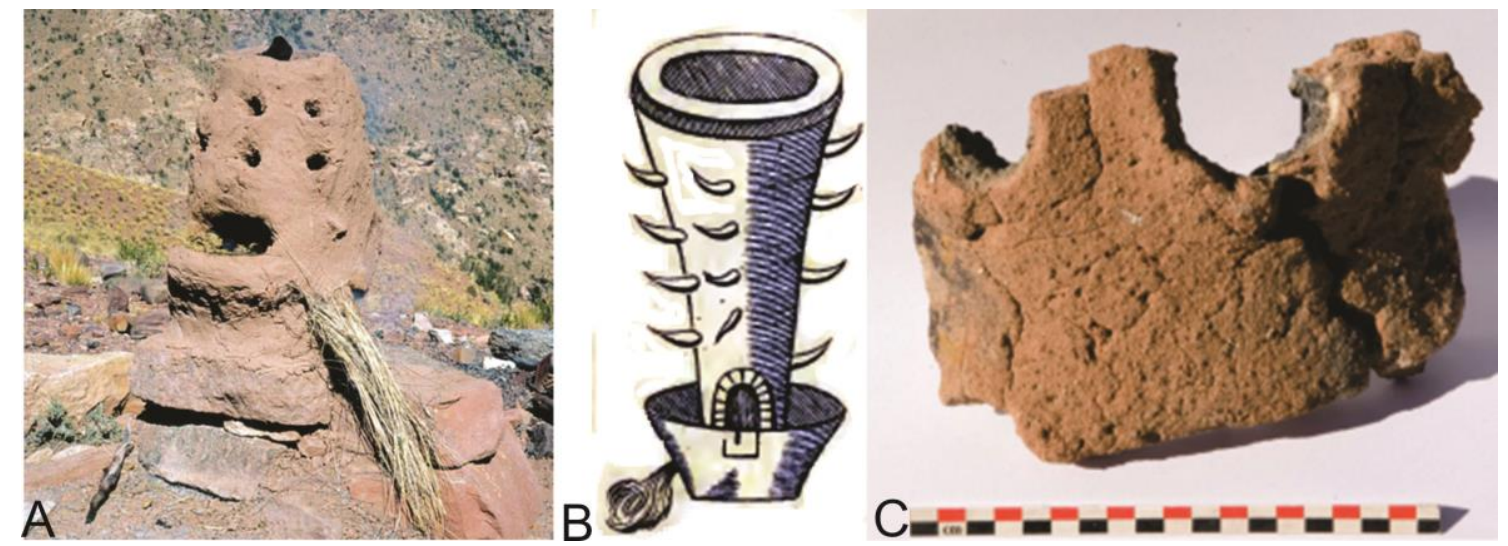

Figura 3.7. A. Huayrachina etnográfica (tomada de Van Buren y Cohen 2010: Figura 4). B. Dibujo de Huayra indígena según Barba (Barba 1817: 167) y C. Fragmento de huayras arqueológicas (tomada de Téreygeol y Cruz 2014: Figura 2).

En Juku Huachana, se suman a las evidencias de actividades extractivas, fragmentos cerámicos cuyos estudios técnicos reconocen vestigios de plomo que permite asociar estos tiestos a tareas de refundición y afino del metal (Téreygeol y Castro 2008). Asimismo, los análisis efectuados en los segmentos vitrificados de los hornos indican que habrían estado en contacto con un material líquido con alto contenido en plata y plomo, alcanzando temperaturas cercanas a los $1200{ }^{\circ} \mathrm{C}$ (Téreygeol y Castro 2008). Estos resultados son concordantes con aquellos brindados por los estudios técnicos en los fragmentos hallados en el sitio Huayrachina Alta que indican 
condiciones redox altamente oxidantes y el empleo de minerales de galena argentífera (Cohen et al. 2008).

En los últimos años se han llevado a cabo estudios etnoarqueológicos (Cohen et al. 2008; Van Buren 2003; Van Buren y Mills 2005; Van Buren y Cohen 2010) y estudios experimentales (Téreygeol y Cruz 2014) sobre "huayrachinas" que permitieron obtener datos de gran relevancia sobre el funcionamiento de estos hornos, las composiciones de las cargas, las temperaturas de fusión, las reacciones físico químicas que suceden al interior de las estructuras así como las composiciones y proporciones de los materiales resultantes. La información brindada por estos estudios es de gran importancia ya que sirve de base para contrastar las evidencias arqueológicas con la finalidad de reconstruir etapas del procesamiento y los procedimientos técnicos involucrados (Cohen et al. 2008).

Además de los casos mencionados, en la literatura arqueológica, disponemos de otros dos sitios con evidencias de procesamiento de minerales metálicos de época inkaica, pero donde el metal procesado fue el cobre. El primero de ellos es el sitio Laqaya que se localiza en el norte de Lípez en el departamento Potosí y está compuesto por un conjunto de recintos con evidencias de procesamiento cuprífero, cuyas dataciones lo posicionan en épocas prehispánicas tardías, desde 1270 hasta $1460 \mathrm{dC}$. (Nielsen y Angiorama 2008: 123). Los autores presentan indicadores de actividades metalúrgicas, entre los que se destaca la presencia de un crisol y de fragmentos de escorias de crisol - ambas con inclusiones metálicas - gotas de fundición y tejuelas de cobre, fragmentos de malaquita y cuprita, así como objetos terminados de bronce estannífero (anillo, agujas y piezas laminares). A estas evidencias se le suma la presencia de goethita en los recintos de ocupación colonial (R1 de Bajo Laqaya) junto a tres objetos de cobre - dos cinceles y un punzón- y otros de morfología prehispánica un topu y un cincel- pero fabricados en hierro (Nielsen y Angiorama 2008). Los autores proponen que durante épocas prehispánicas tardías se habría llevado a cabo tareas de refinación de cobre metálico, con la finalidad de obtener un metal puro que luego podría ser aleado y formatizado. Sin embargo, pese a la presencia de objetos terminados, la ausencia de moldes y de indicios de actividades de aleación pone en duda si la 
manufactura de objetos fue realizada en el mismo asentamiento (Nielsen y Angiorama 2008).

El segundo sitio lleva el nombre de Pututaca y se ubica en los valles interandinos de la Región de San Lucas, en el área denominada Palacio Tambo (Rivera Casanovas 2008). Presenta evidencias claras de fundición y trabajo orfebre durante el periodo Inka y Colonial Temprano. Ambas tareas se encontraban segregadas espacialmente, la primera etapa fue llevada a cabo en una lomada al oeste del sitio, donde se identificaron fragmentos de hornos, escorias, sedimentos quemados y refractarios junto a ceramios de estilos locales - Huruquilla y Altiplánica- que indican actividades de extracción. El segundo sector con evidencias del trabajo de metal se identificó en la zona central del asentamiento. Allí recuperaron escorias de cobre y un molde junto a objetos de base cobre y de estirpe inkaica (placas, bolas y un laureke). En una de las estructuras residenciales, detectaron vestigios circulares de arcilla cocida que asignaron una función metalúrgica, posiblemente asociados con actividades de refino y/o aleación de metales (Rivera Casanovas 2008). Asimismo, en áreas montañosas de esta región han detectado hornos clasificados como "huayrachinas". Las observaciones de campo realizadas por la investigadora, indican que son estructuras de pequeñas dimensiones, construidas con barro y piedra en forma de U (Rivera com. personal 2013). Incluso, asociados a estructuras domésticas se identificaron hornos de igual material constructivo, pero de forma circular y mayores dimensiones, siendo clasificados como "tocochimbos" (Rivera com. personal 2013) (figura 3.8). Sin embargo, cabe aclarar que las investigaciones son preliminares y no se han realizado excavaciones para un conocimiento detallado de estas estructuras.

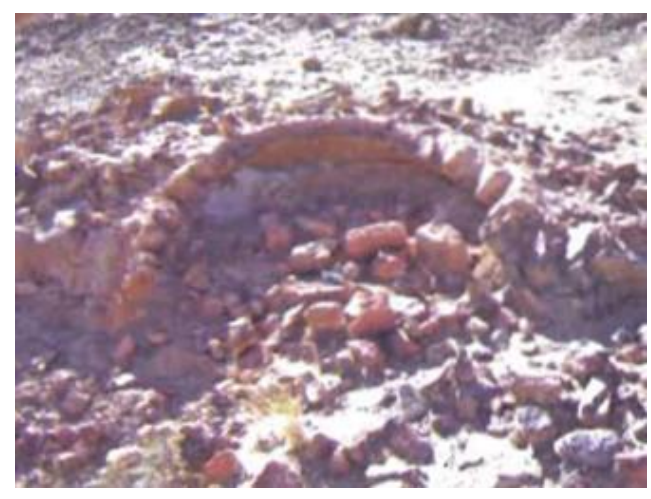

Figura 3.8. Horno identificado en Pututaca. Tomada de Rivera 2008: Figura 14, p. 158 
Por últimos, daremos cuenta del sitio Pulac 050, un asentamiento de ocupación temprana, cuyas dataciones radiocarbónicas (P050 A UR1 R1: 1330 +/- 83 AP) y objetos materiales lo ubican en el Horizonte Medio (Lechtman et al. 2010: 12). El sitio consta de dos sectores diferenciados que dan cuenta de las distintas etapas de producción metalúrgica. El primer sector es un área con morteros, yunques y fragmentos de minerales de cobre que darían cuenta de la etapa de preparación de la mena a fundir. En un espacio cercano se identificaron indicios de actividades de fundición primaria y el refinado del metal. Las evidencias de estas tareas se hallan en la presencia de bases circulares de tres hornos de tipo wayras junto a fragmentos de pared con perforaciones y escorias de extracción diseminadas en los alrededores. Además, los investigadores identificaron un horno (H1) de refinación en crisoles con una arquitectura desconocida hasta el momento (Lechtman et al. 2010: 18). Este ejemplar consta de una cámara rectangular de metro y medio de largo, construida con roca y argamasa de arcilla. La misma posee en sus extremos más angostos dos banquetas con canales de ventilación, cercano a los cuales se acomodarían los crisoles y cuya función sería la de conducir el calor desde la cámara de combustión (figura 3.9). Allí, el fuego sería avivado por el ingreso de aire natural desde otros dos conductos dispuestos en los laterales del horno. Los análisis químicos indican que alcanzaron temperaturas superiores a $\operatorname{los} 1100{ }^{\circ} \mathrm{C}$, siendo el combustible utilizado madera de tola (Paratrephia lepidophylla). El segundo sector, $\mathrm{R} 1$, consta de dos recintos con estructuras de combustión, depósitos con minerales de cobre e instrumentos líticos como martillos, alisadores y bloques de piedra pómez, que sirvieron para el procesamiento de metales (Lechtman et al. 2010). 


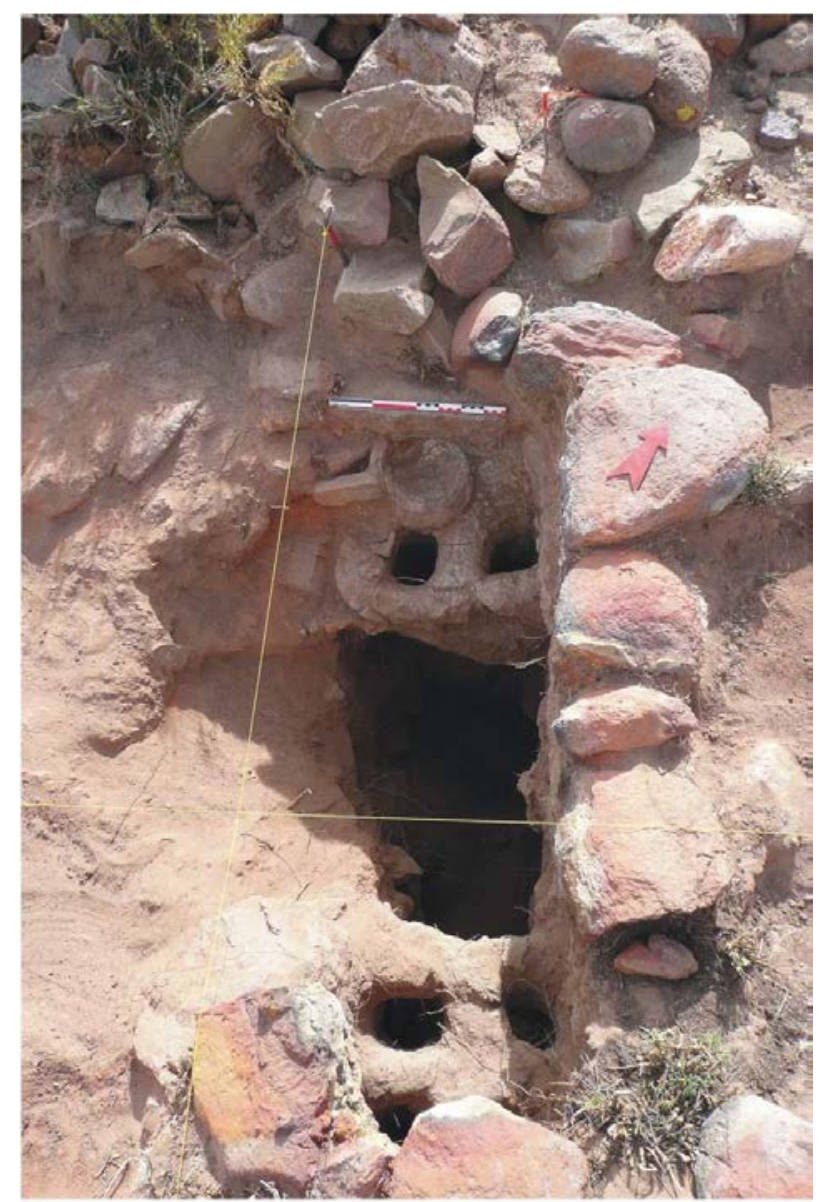

Figura 3.9. Horno de refinación de Pulac 050. Fotografía tomada de Lechtman et al. 2010: Figura 12, p.18.

\subsubsection{Sitios en el actual territorio chileno}

La región chilena es un territorio que dispone de grandes mineralizaciones que son explotados desde épocas muy tempranas (Salazar y Vílchez 2014). Estudios recientes han permitido discriminar sitios de laboreo y minas trabajadas en momentos prehispánicos de aquellos contextos de minería colonial y republicana (Núñez et al. 2003; Salazar et al. 2010; Salazar et al. 2013). Uno de estos casos es el campamento de Chuquicamata (Chu-2), aledaño a la mina homónima con mineralizaciones de cobre (Núñez et al. 2003). Los estudios sedimentológicos, tafonómicos y las evidencias materiales indican que habrían sido ocupados por grupos caravaneros-mineros estacionales desde el Formativo hasta el Intermedio Tardío (400-1400 dC) (Núñez et al. 2003). El material más representado, tanto en superficie como en las excavaciones de los recintos, son fragmentos molidos de atacamita y en menor medida de azurita y 
crisocola. La presencia de estos minerales junto a martillos líticos - de carácter expeditivo- con vestigios de polvos de coloración verde, indican que allí se habría triturado el mineral para separar la porción estéril y trasladar aquella más valiosa por las rutas caravaneras hacia otras regiones (Núñez et al. 2003). Se puede asociar a este contexto, el hallazgo fortuito de un minero aborigen momificado en la mina de Chuquicamata. El minero quedó atrapado producto del derrumbe de la galería, acompañado de sus implementos de trabajo. Entre ellos se destacan grandes martillos líticos enmangados, palas y barretas de madera, bolsas de cuero y cestos tejidos (González 2004b). Un poco más al norte, se ubica el complejo minero de El Abra donde se hallaron evidencias de prácticas mineras locales consolidadas para la explotación de turquesa y menas de cobre, que luego fueron reorganizadas con la llegada del Estado Inka a la región (Salazar et al. 2013)

En cuanto a sitios con contextos que den cuenta de las etapas de metalurgia extractiva posteriores a la minería se destacan en el norte de Chile los complejos arqueológicos de Ramaditas, Mamilla, Tarapacá Viejo, Miño, Camarones, Los Nogales y Collahuasi. El primero es la aldea más antigua con evidencias de tareas pirometalúrgicas localizada en el desierto de Atacama (Graffam et al. 1997). Cronológicamente asociado al Formativo Tardío (500 aC. - 300 dC.) posee tres aglomerados de recintos circulares con estructuras anexas y patios. El hallazgo de fragmentos minerales en las estructuras excavadas posibilitó relacionar el asentamiento a sitios aledaños con indicadores de fundición de menas (Graffam et al. 1997). En ellos se destaca la presencia de minerales sulfurados de cobre como brochantita y antlerita; escorias de fundición cuyos estudios técnicos indican temperaturas de fusión de $1100^{\circ} \mathrm{C}$ y vestigios de cobre purificado, así como fragmentos de metal fundido. Por último, identificaron restos de hornos de reducción con escorias adheridas. Estas estructuras fueron construidas con base de roca arenisca y paredes de caliza, presentan formas circulares con $80 \mathrm{~cm}$. de diámetro, en promedio, y habrían funcionado aprovechando los vientos naturales de la región (Graffam et al. 1997).

El complejo de Mamilla presenta cuatro sitios (Mamilla 1, Mamilla 3, Mamilla 7 y Mamilla 10) con contextos productivos de metales de la región costera del norte de Chile (Salazar et al. 2010). Los fechados radiocarbónicos revelan que fueron ocupados 
durante el periodo Intermedio Tardío (900-1400 dC) y el Tardío (1400-1532 dC). Las evidencias halladas en contextos superficiales y estratigráficos junto a los numerosos análisis químicos y metalográficos efectuados en los materiales recuperados, indican que en ellos los grupos cazadores, recolectores y pesqueros locales habrían llevado a cabo tareas metalúrgicas para la fabricación de objetos de cobre con fines de subsistencia (principalmente anzuelos). Asimismo, proponen la obtención de objetos suntuarios y minerales foráneos por medio de intercambios con grupos de otras regiones (Salazar et al. 2010). Se recuperaron evidencias de actividades de molienda y fundición de menas metálicas de minerales diversos, principalmente de cobre; martillos-percutores con polvos de coloración verdosas, gotas de metal puro y fragmentos amorfos de cobre. Estos últimos también pueden ser interpretados como evidencias de actividades orfebres, junto al hallazgo de gotas aleadas de cobre-estaño, lingotes, artefactos rotos y objetos terminados (Salazar et al. 2010). Estos contextos son los primeros reconocidos para la región costera dando cuenta de un histórico desarrollo metalúrgico local y de saberes técnicos que posibilitaron aprovechar los ricos yacimientos mineros de esta zona (Salazar et al. 2010).

Los otros cinco complejos arqueológicos: Tarapacá Viejo, Miño (Miño 1 y 2 y Miño 19 al 22), Camarones, Los Nogales y Collahuasi (Collahuasi 37, Ujina 8, 9, 10 y 11) presentan contextos metalúrgicos de poblaciones locales que recibieron el impacto de la expansión inkaica. Sus estudios permitieron a los investigadores indagar sobre las transformaciones y continuidades acontecidas, en función de las cuales propusieron modalidades diversas de articulación con el Tawantinsuyu (Álvarez Miranda 1993; Salazar et al. 2013; Plaza y Martinón-Torres 2015; Zori et al. 2013; Figueroa et al. 2018). En los tres primeros sitios los autores indican la fundición en hornos del tipo "huayras" dado que funcionarían con ventilación natural (Álvarez Miranda 1993: 69; Salazar et al. 2013: 94; Zori et al. 2013: 4). La publicación para Tarapacá Viejo es la que brinda mayores detalles sobre las evidencias de estas estructuras: son hornos de arcilla de morfología columnar con 20-35 cm de diámetro y cuyas paredes poseen de 6 a 9 orificios de ventilación con diámetros variables de entre 2 y $7 \mathrm{~cm}$. (Zori et al. 2013: 56). Se encontraron asociadas a escorias y fragmentos de paredes vitrificadas cuyos análisis técnicos dan cuenta de la fundición de menas sulfuradas de cobre (Zori et al. 2013). En Camarones se destaca asimismo la presencia de moldes con evidencias de 
termoalteración por el contacto con metal fundido y objetos de raigambre inkaica (tumi de hoja semilunar y topu) junto a piezas locales (anzuelos, arponcillos y púas para arpones), un lingote de cobre y un laureque. Este último fue considerado un indicador de contacto con poblaciones del altiplano boliviano (Álvarez Miranda 1993).

Además, en Tarapacá Viejo y Los Nogales fueron recuperados fragmentos de crisoles y moldes cuyos estudios indican la apropiación por parte de los metalurgos locales de algunas ideas técnicas que circularon por la expansión inkaica. Se destaca, la presencia de perforaciones en la base de los crisoles y el empleo de hueso molido para cubrir refractarios que son innovaciones técnicas propias del norte de Chile y el Noroeste de Argentina (Plaza y Martinón-Torres 2015; González 2004b; Zori et al. 2013). Incluso el uso de hueso como antiplástico en los moldes es considerado una adaptación local de grupos habitantes de Los Nogales (Plaza y Martinón-Torres 2015).

En cambio, en el distrito de Collahuasi se utilizó otra tecnología de fundición de minerales de cobre. En general son estructuras construidas de rocas granitoides con forma de banco y orientadas de forma perpendicular a los vientos predominantes. Sus bases presentan entre 4 y $10 \mathrm{~m}$ de largo y la pared posterior no supera el metro de alto (Figueroa et al. 2018) (figura 3.10). Se identificaron más de 50 hornos en los sitios Urija $8,9,10$ y 11, localizados hacia el sur y norte del campamento minero-metalúrgico de Collahuasi 37, constituyéndose como el taller de mayor envergadura dentro del norte de Chile (Figueroa et al. 2018). Alrededor de los hornos, se registraron montículos de escorias con prills de cobre, fragmentos minerales de malaquita, crisocola y brochantita, cobre metálico, combustibles de maderas locales, martillos y piedras de moler. A partir de sus estudios los autores proponen que los Inkas aprovechó el sistema de producción tecnológica pre-existente, pero reorganizó espacialmente la producción transformando a Collahuasí 37 en un tambo inka para asegurar su control. En él se materializa la arquitectura y materialidad estatal con estructuras tipo RPC, plazas públicas, collqas, cerámica inkaica, etc, donde tuvieron lugar actividades de comensalismo político (Figueroa et al. 2018). Además, proponen que a través del camino Inka, el cobre metálico obtenido sería trasladados a otros centros administrativos como Miño, para su aleación y manufactura de objetos finales. 


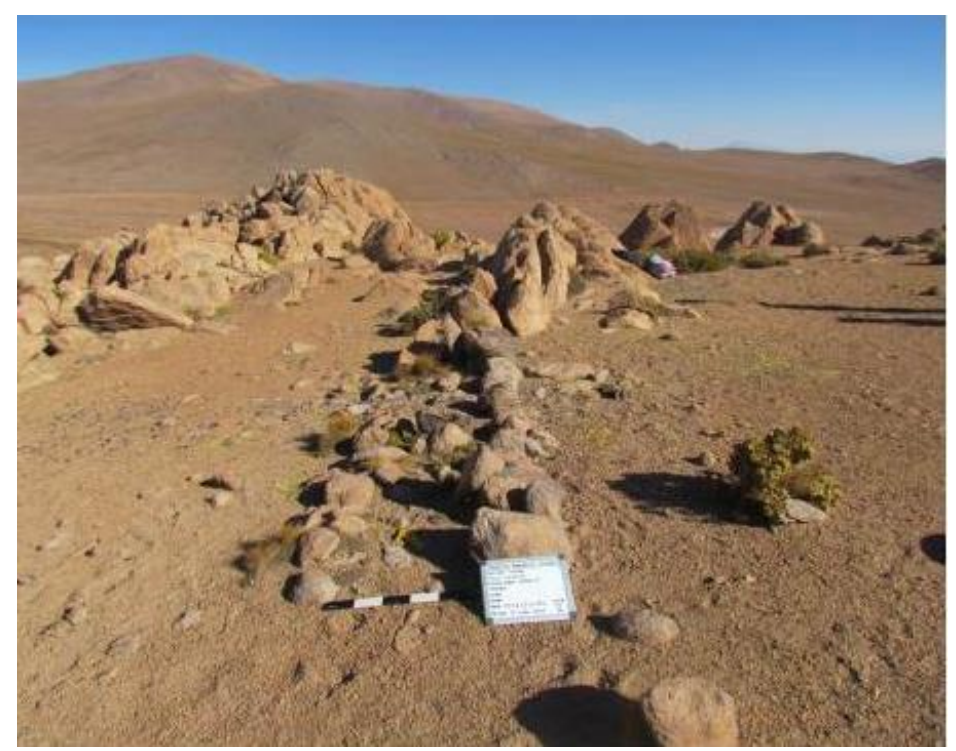

Figura 3.10. Horno de fundición de Urija. Fotografía tomada de Figueroa et al. 2018: Figura 7.

Por último, en el valle de Copiapó, el sitio Viña del Cerro es un enclave especializado para la fundición de cobre implantado por el estado Inkaico (Niemeyer et al. 1983). Presenta varios sectores con edificios con un patrón arquitectónico inka manifestado en los RPC, los depósitos o qollqa y la plataforma ceremonial o ushnu. En la zona más elevada del sitio se identificó un conjunto de 26 hornos metalúrgicos clasificados como "huayras" andinas (figura 3.11). De ellos sólo se preservan cimientos de roca de 2-3 m de diámetro y 0,30 $\mathrm{m}$ de altura con fragmentos de escoria y minerales de cobre en los alrededores. El combustible empleado fue carbón vegetal de maderas de espino, algarrobos, pimiento boliviano y chañar (Niemeyer et al. 1983). También se hallaron otros materiales relacionados a prácticas metalúrgicas como molinos y manos de moler, fragmentos de cucharas, moldes de arcilla y objetos terminados de cobre (Niemeyer et al. 1983). 


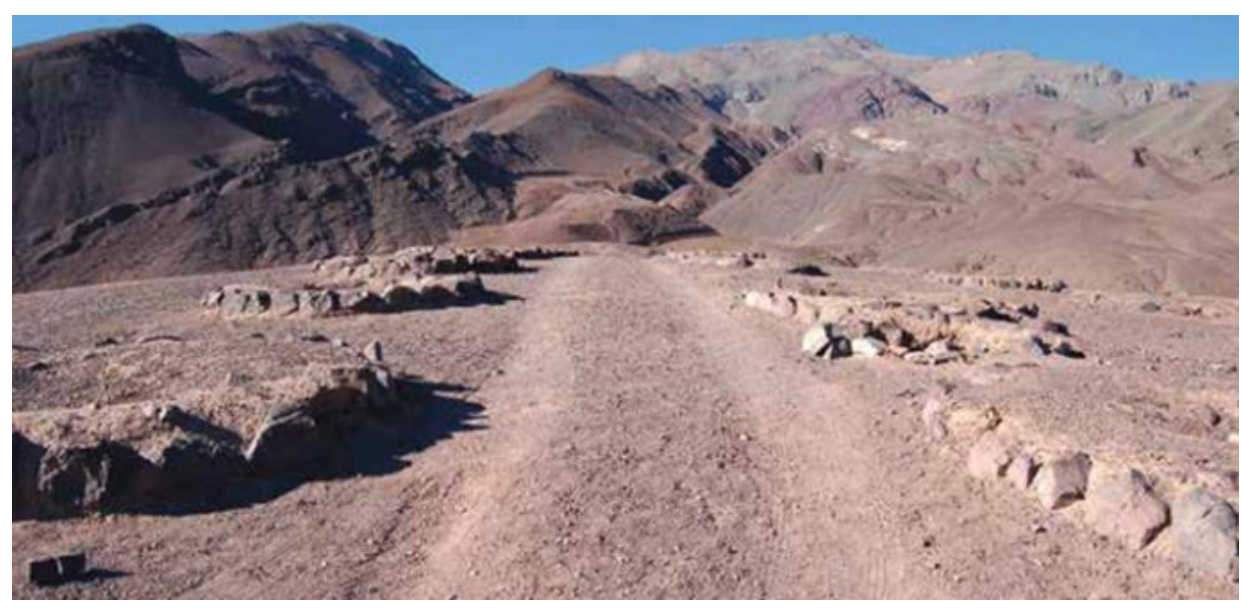

Figura 3.11. Hornos metalúrgicos de Viña del Cerro. Fotografía tomada de "Qhapaq Ñan. El Sistema Vial Andino y los Incas en el Norte de Chile". Consejo de Monumentos Nacionales Programa Qhapaq Ñan - Chile. 2015

\subsubsection{Sitios en el actual territorio argentino}

En las distintas regiones geográficas del actual territorio de Jujuy se despliegan un número de evidencias que dan cuenta de una antigua tradición metalúrgica. En el altiplano puneño Eric Boman (1991 [1908]) identificó una explotación minera prehispánica de crisocola en ganga de cuarzo llamada San Antonio de Cobres. Asimismo, en las lomadas aledañas halló un maray (estructura para moler minerales) y vestigios de dos hornos de fundición. La presencia de bases rocosas y escoriadas de 1,50 $\mathrm{m}$ de diámetro junto a fragmentos curvos de arcilla vitrificada llevó al autor a clasificarlos como "huayras" andinas (Boman 1991 [1908]). Estas se incrementarían hasta una decena según las fuentes orales. Estudios químicos de los materiales indican que allí se habrían refinado los minerales de crisocola obtenidos localmente (Boman 1991 [1908]).

Al igual que sucede en Chile, aquí también es difícil discriminar las minas pre coloniales dada la explotación continuada hasta la actualidad. Sin embargo, intensas prospecciones efectuadas en la puna jujeña permitieron identificar en el área de Coyahuayma socavones y restos de maray para la explotación aurífera (Angiorama y Becerra 2010). La presencia de cerámicas de estilos inkaicos, recuperadas en superficie, conduce a los autores a postular una posible asignación a este periodo para las actividades mineras efectuadas en la región. Asimismo, fueron ubicados varios hornos 
en su mayoría de momentos coloniales (Angiorama y Becerra 2010). Sin embargo, un par de sitios: Tabladitas 1 y Quebrada del Rio Candado, mostraron la presencia de hornos de roca con forma de " $\mathrm{T}$ " de 1,2 $\mathrm{m}$ por $0,8 \mathrm{~m}$ que se diferencian estructuralmente de los clásicos hornos de reverbero coloniales, razón por la cual le han asignado una cronología prehispánica (Angiorama y Becerra 2010; Becerra et al. 2014). Análisis arqueométricos en las escorias recuperadas indican que fue empleado para la fundición primaria de menas ricas en plomo y plata (Becerra et al. 2014). Estos datos junto a las evidencias etnohistóricas y arqueológicas conducen a Angiorama a proponer que la puna fue una región de intensa explotación minera desde los 900 dC. Incluso sostiene que "habrían sido los puneños los que explotaron los yacimientos de oro, estaño y plata localizados en el altiplano y los que se habrían encargado de la distribución de los minerales mediante el sistema de caravanas" (Angiorama 2006: 158).

Ya en la Quebrada de Humahuaca contamos con tres grandes asentamientos multicomponentes con evidencias de prácticas metalúrgicas. De norte a sur son: Los Amarillos, Juella y el Pucará de Tilcara. Los dos primeros dan cuenta que durante el periodo Tardío estas prácticas se desarrollaron a nivel doméstico en conjunto a otras actividades de subsistencia, empleando minerales locales y otros provenientes de la puna (Angiorama 2005, 2006, Angiorama y Taboada 2007; Leibowich y Jacob 2011). En Juella la lectura de las evidencias pirometalúrgicas como minerales cupríferos, fogones, escorias, prill, crisoles, moldes y martillos líticos, lleva a los autores a proponer que en el marco de las actividades cotidianas se habrían llevado a cabo, a escala familiar, la fundición de minerales de cobre en crisoles posicionados sobre fogones y la formatización de objetos simples mediante vaciado en molde (Leibowich y Jacob 2011)

El sitio arqueológico de Los Amarillos fue ocupado desde el siglo X de nuestra era con una gran expansión durante el periodo de Desarrollos Regionales y sujeto a intervenciones del estado Inka (Angiorama 2004, 2011). Las investigaciones realizadas en la estructura residencial denominada Unidad 400 y en el espacio público-ritual ubicado en el sector central del asentamiento, han permitido establecer que en el primero tendrían lugar el trabajo de cobre en ámbitos domésticos junto a tareas de subsistencia y de producción textil en menor grado, aunque segregadas espacialmente 
(Angiorama 2004; Angiorama y Taboada 2007). Allí se identificaron fragmentos de malaquita, fogones, restos de fundición, yunques y martillos, cuencos líticos, preformas de bronce, una asta de taruca y objetos terminados de base cobre. Estos materiales indican actividades de minería y fundición, pero principalmente dan cuenta del trabajo del metal mediante eventos de martillado y recocido para la manufactura de objetos (Angiorama 2004; Angiorama y Taboada 2007). Los investigadores han registrado evidencias de producción y objetos metálicos de base cobre en una amplia variedad de contextos y estructuras tanto de tipo ceremonial como domésticas. Por lo tanto, proponen que la producción, circulación y uso de bienes metálicos de cobre no estarían restringidos ni controlados por los grupos de elite (Angiorama 2004, 2006; Angiorama y Taboada 2007). Sin embargo, una situación contraria se dio con los bienes fabricados en oro. Únicamente se recuperaron siete piezas terminadas en este metal en tumbas con ricos ajuares distribuidas en el Sector Central, que indican el alto status de sus difuntos. Por ello, se ha propuesto la posibilidad que la producción de objetos de oro haya sido escasa y controlada por grupos de elite con fines netamente rituales (Angiorama 2004, 2011).

Con la expansión del Tawantinsuyu, la unidad residencial previamente descrita fue abandonada como contexto doméstico y el Sector Central fue sujeto de numerosas remodelaciones arquitectónicas y destrucción de los sectores rituales tradicionales (Nielsen y Walker 1999). Excavaciones en varias estructuras residenciales de época inkaica y en zonas de descarte han identificado restos de prills, reservorios de metal, fogones en cubeta, crisoles y moldes de morfologías del repertorio de objetos incaicos (topu, tumi y lingote) que indican que se llevarían a cabo en el sitio actividades de refundición, aleación y moldeado de piezas (Angiorama 2004, 2011). Sin embargo, en época Inka desaparecen las evidencias que remiten a tareas de reducción de minerales y los objetos terminados. Tal es así que el autor propone para esos momentos un control externo de la producción metalúrgica. El estado habría abastecido a los artesanos de metales ya procesados en otros sitios para la manufactura de piezas inkaicas que serían entregadas como tributo (Angiorama 2011).

Un contexto similar se identificó en el Pucará de Tilcara. En la Unidad Habitacional 1, en el componente preincaico fechado entre el 1050 y 1200 dC., se 
hallaron indicios de actividades metalúrgicas (González 2004b, Otero y Ochoa 2011; Otero 2013). Se recuperaron varios locus de combustión de estructuras variables, martillos de diversos tamaños, yunques y percutores, manos y morteros, prills, crisoles y distintos tipos de moldes (Otero 2013). Todos los refractarios presentaron un recubrimiento de fosfato de calcio, característico de tecnologías locales (González 2004b). Este contexto fue interpretado como un taller especializado en la producción metalúrgica de control centralizado por las élites locales (González 2004b; Otero 2013). El mismo habría continuado su producción durante la ocupación inkaica incluyendo la manufactura de objetos de raigambre inka de la mano de actividades especializadas en lapidaria, y en menor escala de textilería y alfarería (Otero y Ochoa 2011; Otero 2013). A diferencia de las otras tecnofacturas, para la metalurgia se plantea que el incario "habría aprovechado los saberes locales sobre las características de los minerales, su fundición y moldeado, incluso hasta la estructura socio-económica para lograr la obtención de las materias primas” (Otero y Ochoa 2011: 117).

En el valle Calchaquí norte, en Salta, disponemos de tres complejos arqueológicos que datan del periodo inkaico: La Encrucijada, Potrero de Payogasta y Valdéz. Las investigaciones efectuadas en ellos han permitido recuperar evidencias de prácticas metalúrgicas y proponer modelos de organización de la producción especializada, auspiciada y financiada por el estado Inka (D'Altroy 1994; Earle 1994; Rodríguez Orrego 1979). En La Encrucijada, se reconocieron tres sectores de trabajo minero metalúrgico conectados por el capacñam (Rodríguez Orrego 1979). El primero consta de un pozo minero, el segundo presenta estructuras para la molienda de minerales y el último posee cuatro hornos de fundición. Si bien de morfologías similares, sus tamaños varían levemente de entre 1 y 2,71 m de diámetro. Fueron construidos con rocas unidas con mortero, de planta circular y alturas cercanas a los 0,5 m. Algunos de ellos poseían aberturas para la ventilación y escorias en su interior. Esta variabilidad es interpretada por el autor como indicadores de usos en fases diferentes de reducción de minerales de cobre (Rodríguez Orrego 1979), principalmente de cloruros como atacamita y paratacamita (Earle 1994). Asimismo, por los estilos alfareros se propone que los trabajadores serían locales y dada la cercanía al camino imperial, se propuso que el Tawantinsuyu conocería y auspiciaría dichas actividades (Rodríguez Orrego 1979). Posiblemente el metal reducido en este sitio habría sido transportado hacia los 
asentamientos de Valdez y Potrero de Payogasta para su refinación y manufactura (D’Altroy 1994; Earle 1994).

Valdez es un sitio con población local y las excavaciones efectuadas brindaron indicios de producción metalúrgica dada la cantidad de crisoles y moldes principalmente de lingoteras (Earle 1994). D'Altroy (1994) indica la presencia de minerales y sostiene que en Valdez los refractarios superan en número a los presentes en Potrero. Es por ello que proponen que allí los grupos locales realizarían tareas de fundición de metales, a partir de los cuales se producirían lingotes para tributar al estado Inka (D'Altroy 1994; Earle 1994).

En Potrero de Payogasta, las excavaciones realizadas en sectores residenciales de grupos de elite dieron un conjunto de materialidades que dan cuenta de actividades especializadas de producción tanto de bienes en metal como en valvas de moluscos y micas. Entre los primeros se destacan la presencia de fogones, crisoles, moldes y escorias no metalúrgicas junto a unos pocos fragmentos de cobre fundido con evidencias de corte y chatarras (Earle 1994). Se ha propuesto que allí se realizarían tareas de aleación de bronce estannífero y manufactura de piezas por moldeado y martillado. La ausencia de minerales y de objetos terminados en ambos sitios, conduce a los autores a proponer que el estado Inka habría ejercido un estricto monitoreo de la producción metalúrgica controlando la circulación y aprovisionamiento del cobre y estaño necesario para el trabajo y apropiándose de los objetos finales que serían trasladados a otras regiones (Earle 1994). Sin embargo, D'Altroy (1994) aclara que no todos los bienes manufacturados fueron exportados, dado que las excavaciones en La Paya indican que algunos fueron ofrendados en las tumbas de personas de elite.

Por último, en la provincia de Catamarca disponemos de los contextos arqueológicos con evidencias de producción metalúrgica más antiguos que se conocen hasta el momento para el noroeste de Argentina. Sitios como Alamito y Faldas del Cerro de Ingenio del Arenal dan cuenta del trabajo metalúrgico durante el periodo Temprano o Formativo en la región (ca. III y V dC.). En Alamito, los trabajos de campo discriminaron sectores que habrían funcionado como talleres metalúrgicos (Núñez Regueiro 1992; Pifferetti 2001). Entre las evidencias se destacan la presencia de escudillas y tubos lisos de cerámica no refractaria de $70 \mathrm{~cm}$ de altura, $12 \mathrm{~cm}$ de 
diámetro y $0,8 \mathrm{~cm}$ de espesor. Los mismos presentaron evidencias de calcinación y los análisis químicos registraron concentrados de $\mathrm{Cu}, \mathrm{Fe}$ y $\mathrm{Pb}$ (Pifferetti 2001). Se propone que la fundición primaria se habría realizado introduciendo el mineral molido y carbón en una escudilla con el tubo cerámico que serviría para incrementar el tiraje natural. El hallazgo de minerales de silicatos de cobre y plomo indica que la temperatura de fundición necesaria para reducirlos estaría cercana a los $900-1000^{\circ} \mathrm{C}$ (Pifferetti 2001: 123). Posteriormente el metal seria purificado por sucesivos eventos de martillado y recocido según lo demuestran los estudios metalográficos efectuados en las piezas recuperadas (Pifferetti 2011). Considerando los resultados obtenidos por otros investigadores Pifferetti sugiere una serie de transformaciones tecnológicas debido a la incorporación de aleaciones de bronce arsenical y el aumento en las dimensiones de los tubos cerámicos que "estaría evidenciando la búsqueda de alternativas que permitieran mejorar e incrementar la productividad del proceso de fusión" (Pifferetti 2001: 126). Dichas prácticas fueron vinculadas a una producción especializada asociada al culto religioso que, como manifiesta González (2004b: 179) se fue afianzando con en el transcurso del tiempo.

En Faldas del Cerro se han recuperado 14 fragmentos minerales, principalmente de malaquita y en menor proporción de calcosina, junto a escorias metalúrgicas y varios fragmentos cerámicos vitrificados y con escorias adheridas (Scatollin y Williams 1992). Las autoras proponen que se habría realizado la fundición primaria en crisoles dispuestos sobre alguna clase de estructura de combustión. La presencia de suelos enrojecidos podría estar dando cuenta de esta actividad. Pese al hallazgo superficial de una cuchara de cobre, no hay indicio alguno del trabajo de metales (Scatollin y Williams 1992). Asimismo, en el sitio Ingenio de Arenal Médanos se registraron varios minerales de sulfuros y carbonatos de cobre y dos posibles toberas como indicadores de fundición (Scatollin y Williams 1992).

En el asentamiento incaico de Potrero Chaquiago en Andalgalá, las excavaciones en contextos habitacionales, áreas abiertas y basureros brindaron indicios de actividades de fundición de menas cupríferas (Williams 1995). Como evidencia de etapas de fundición primaria, en los alrededores del sitio se registró un horno de fundición dispuesto en una lomada. Según informa Williams el horno posee una "forma externa 
cuadrangular e interna circular. Su diámetro interno es de 1,50 m con una altura de casi $3 \mathrm{~m}$. Por fuera presenta un paramento de piedra recubierto en su interior por una pared de adobe" (1995:449) el cual presenta escorias de tipo fayalíticas (Williams 1995). En las estructuras residenciales del sitio (sector de La Solana y Retambay) se habría realizado la refinación del metal dada la presencia de crisoles, escorias de crisol y fragmentos de moldes con un recubrimiento de hidroxiapatita. Dada la escasa presencia de objetos terminados, se ha propuesto que la producción metalúrgica sería efectuada por artesanos locales "bajo la supervisión estatal y su producción ser exportados para ser usados dentro de la economía imperial" (Williams 1995: 461), como sucede también en el valle Calchaquí norte.

En el Valle de Yocavil, en el centro este catamarqueño se encuentra el complejo arqueológico de Rincón Chico. Las investigaciones sistemáticas permitieron recuperar numerosos vestigios que dan cuenta de la producción de tecnofacturas alfareras y metalúrgicas (González y Tarragó 2004a y b). Indicios de esta última fueron registrados en varios sitios $(12,13$ y 14), destacándose el Sitio 15 por la magnitud de las evidencias (González 2010). Las investigaciones indican que allí operó un taller metalúrgico de manera continuada desde el siglo X hasta el advenimiento europeo (González y Tarragó 2004a y b). El Sitio 15 presenta un recinto rectangular de grandes dimensiones (R1), un espacio poligonal (R2), áreas abiertas (ZN) y dos montículos (MO y MM). Allí han registrado varias estructuras de combustión, bases de huayras, escorias de fundición, de crisol y de combustión, desechos metálicos -chatarras, prills y adherencias en refractarios-, instrumentos líticos para la manufactura de objetos y cientos de refractarios - crisoles, intermediarios y moldes- (González 2002, 2004b, 2010). Estos materiales señalan que en el sitio se llevarían a cabo todas las etapas de producción metalúrgica. Así, los datos obtenidos a partir de análisis técnicos indican que se habrían realizado tareas de fundición de minerales de cobre, refinación del metal, producción de aleaciones con estaño y manufactura por moldeado y pulido (González 2002, 2010). El análisis espacial condujo a proponer que inicialmente se desarrollaron actividades productivas tanto de bienes de subsistencia como artesanales, siendo estas últimas de carácter discontinuo. La producción de metal empleó una pirotecnología basada en el uso de crisoles dispuestos sobre fogones y avivados por ventilación forzada. Asimismo, se desarrollaron innovaciones técnicas locales como el uso de herramientas 
intermediarias - cucharas y tapones - para distribuir el metal a los moldes y el recubrimiento de refractarios con una sustancia de hueso molido (González 2004b, 2010).

Ya en el siglo XII se evidencia un aumento en la escala de producción dada la incorporación de nuevos espacios de trabajo en el área de recintos, pero sin modificaciones en el estilo tecnológico, también se aprecia una separación espacial de las actividades de subsistencia de aquellas de producción especializadas (González 2002, 2010). Según González esto es coincidente con un incremento en la complejidad político social que experimentó la sociedad valliserrana, de la mano al control de las fuentes de aprovisionamiento por parte de unos pocos individuos y demanda de bienes de prestigio (González 2002). Luego la ocupación Inka del poblado quedó manifestada en la apertura de un nuevo espacio de trabajo (MM) y en la incorporación de hornos de fundición. Allí se identificaron rocas termoalteradas dispuestas circularmente que fueron interpretadas como "huayras" andinas (González 2002, 2010). Las áreas de trabajo previas no fueron abandonadas, sino que se articularon al nuevo espacio con actividades relacionadas a tareas de refinación y manufactura. Se propuso que el Tawantinsuyu no introdujo modificaciones en las técnicas de trabajo locales ya que se continuaron empleado fogones en cubeta, crisoles, cucharas y molde de cera perdida, así como las soluciones técnicas locales previamente nombradas y la fabricación de objetos locales tradicionales (González 2002, 2004b, 2010). Pero sí incorporó los hornos metalúrgicos y generó una reorganización de la producción, reasignando nuevas funciones a los espacios, aumentando la escala de producción, demandando nuevos objetos de raigambre estatal - liwi, topus, tumis y lingotes- y apropiándose de los objetos terminados (González 2002, 2010; González y Tarragó 2004b)

Para finalizar, en la Tabla 3.1 se sintetiza las principales evidencias metalúrgicas recuperadas en los sitios del NOA de acuerdo a los indicadores arqueológicos que remiten a las distintas etapas de la cadena de producción de metales (ver capítulo 2). Allí se especifican la cantidad y tipos de objetos recuperados en cada sitio y período, según la información disponible en los trabajos científicos referenciados y cuyas interpretaciones fueron previamente desarrollas. Excepto los sitios del valle de Hualfín que trataremos a continuación. 


\begin{tabular}{|c|c|c|c|c|c|c|c|c|c|c|}
\hline \multirow[b]{2}{*}{ SITIO } & \multirow[b]{2}{*}{ LOCALIDAD } & \multirow[b]{2}{*}{ PERIODO } & \multicolumn{7}{|c|}{ EVIDENCIAS METALÚRGICAS } & \multirow[b]{2}{*}{$\begin{array}{l}\text { REFERENCIA } \\
\text { BIBLIOGRÁFICA }\end{array}$} \\
\hline & & & $\begin{array}{l}\text { INSTRUMENTOS } \\
\text { MOLIENTA }\end{array}$ & MINERALES & $\begin{array}{c}\text { ESTRUCTURAS } \\
\text { DE }\end{array}$ & $\begin{array}{l}\text { INSTRUMENTOS } \\
\text { LITICOS }\end{array}$ & REFRACTARIOS & ESCORIAS & METALES & \\
\hline Cobres & Puna de Jujuy & Prehispánica & 1 maray & crisocola & $\begin{array}{c}10-12 \text { bases de } \\
\text { huayras }\end{array}$ & & & $\begin{array}{c}\sin \\
\text { especificar }\end{array}$ & & $\begin{array}{c}\text { Boman } 1991 \\
{[1908]}\end{array}$ \\
\hline $\begin{array}{l}\text { Tabladitas } 1 \text { y Río } \\
\text { Candado } 13\end{array}$ & $\begin{array}{c}\text { Sur de } \\
\text { Pozuelos, } \\
\text { Puna Jujuy }\end{array}$ & Prehispánica & & & $\begin{array}{c}2 \text { hornos de } \\
\text { roca en forma } \\
\text { de T }\end{array}$ & & & \begin{tabular}{|c|}
$>3$ \\
(fundicion, \\
combustión)
\end{tabular} & & \multirow{2}{*}{$\begin{array}{l}\text { Angiorama y } \\
\text { Becerra 2010; } \\
\text { Becerra et al. } \\
\quad 2014\end{array}$} \\
\hline Coyahuayma & $\begin{array}{c}\text { Sur de } \\
\text { Pozuelos, } \\
\text { Puna Jujuy } \\
\end{array}$ & $\begin{array}{l}\text { Prehispánica- } \\
\text { Inka? }\end{array}$ & 6 marayes & $\begin{array}{c}\sin \\
\text { especificar }\end{array}$ & & & & & & \\
\hline \multirow{2}{*}{$\begin{array}{l}\text { Los Amarillos } \\
\text { (Unidad } 400 \mathrm{y} \\
\text { Sector Central) }\end{array}$} & \multirow{2}{*}{$\begin{array}{c}\text { Quebrada de } \\
\text { Humaguaca, } \\
\text { Jujuy }\end{array}$} & Tardío & & $\begin{array}{c}2 \\
\text { malaquitas }\end{array}$ & 2 Fogones & $\begin{array}{l}10 \text { Martillos } \\
11 \text { yunques } \\
2 \text { recipientes } \\
\text { concavos }\end{array}$ & sin especificar & & $\begin{array}{c}2 \text { cinceles } \\
2 \text { cuchillos } \\
2 \text { barras rectangulares } \\
1 \text { prill } \\
7 \text { piezas de oro }\end{array}$ & Angiorama 2005 \\
\hline & & Inka & & & $\begin{array}{l}\text { Fogón en } \\
\text { cubeta }\end{array}$ & & $\begin{array}{c}1 \text { crisol } 1 \text { molde } \\
\text { y } 39 \text { fragm }\end{array}$ & & $\begin{array}{c}2 \text { hachas de } \mathrm{cu} \\
16 \text { prill de cu y bronce } \\
1 \text { tejuela de bronce } \\
13 \text { chatarras de base } \mathrm{cu}\end{array}$ & $\begin{array}{c}\text { Angiorama 2004, } \\
2011\end{array}$ \\
\hline Juella & $\begin{array}{c}\text { Quebrada de } \\
\text { Humaguaca, } \\
\text { Jujuy }\end{array}$ & $\begin{array}{l}\text { Desarrollos } \\
\text { Regionales }\end{array}$ & $\begin{array}{c}9 \text { manos y } 2 \\
\text { morteros }\end{array}$ & $\begin{array}{l}\text { min de } \\
\text { cobre }\end{array}$ & $\begin{array}{l}\text { fogones en } \\
\text { cubeta }\end{array}$ & & $\begin{array}{c}1 \text { crisol y } 64 \\
\text { fragm }\end{array}$ & $\begin{array}{l}\text { escorias de } \\
\text { fundicion }\end{array}$ & $\begin{array}{c}1 \text { hachas de cu } \\
2 \text { ornamentos } \\
3 \text { prills }\end{array}$ & $\begin{array}{l}\text { Leibowich y } \\
\text { Jacob } 2011\end{array}$ \\
\hline $\begin{array}{c}\text { Pucara de Tilcara - } \\
\text { UH1 }\end{array}$ & $\begin{array}{c}\text { Quebrada de } \\
\text { Humaguaca, } \\
\text { Jujuy }\end{array}$ & $\begin{array}{l}\text { Desarrollos } \\
\text { Regionales/ } \\
\text { Inka }\end{array}$ & $\begin{array}{c}1 \text { molino } 7 \text { manos } \\
2 \text { morteros }\end{array}$ & $\begin{array}{c}3 \text { minerales } \\
\text { de cobre }\end{array}$ & 6 fogones & $\begin{array}{c}7 \text { percutores } \\
8 \text { martillos } \\
3 \text { yunques } \\
2 \text { barretas }\end{array}$ & $\begin{array}{c}>41 \text { ( } 3 \text { moldes } y \\
\text { varios } \\
\text { fragmentos) }\end{array}$ & $\begin{array}{l}\text { escorias de } \\
\text { fundicion }\end{array}$ & $\begin{array}{c}1 \text { cincel bronce } \\
1 \text { lamina de cobre } \\
1 \text { pinza de plata prills }\end{array}$ & Otero 2013 \\
\hline $\begin{array}{l}\text { Potrero de } \\
\text { Payogasta }\end{array}$ & \begin{tabular}{|c|} 
Valle \\
Calchaqui \\
norte, Salta \\
\end{tabular} & Inka & & $\begin{array}{c}\sin \\
\text { especificar }\end{array}$ & fogones & & $\begin{array}{l}4 \text { crisoles y } \\
\text { moldes }\end{array}$ & & 3 fragm oro $1 \mathrm{cu} 1 \mathrm{ag}$ & \multirow{2}{*}{$\begin{array}{l}\text { D'Altroy 1994; } \\
\text { Earle } 1994\end{array}$} \\
\hline Valdéz & $\begin{array}{c}\text { Valle } \\
\text { Calchaqui } \\
\text { norte, Salta }\end{array}$ & $\begin{array}{l}\text { Desarrollos } \\
\text { Regionales }\end{array}$ & & & & & $\begin{array}{l}19 \text { crisoles y } \\
\text { lingotes }\end{array}$ & & & \\
\hline La Encrucijada & $\begin{array}{c}\text { Valle } \\
\text { Calchaqui } \\
\text { norte, Salta }\end{array}$ & Inka & sin especificar & & $\begin{array}{c}4 \text { hornos de } \\
\text { roca de planta } \\
\text { circulary } \\
\text { aberturas }\end{array}$ & & & $\begin{array}{c}\sin \\
\text { especificar }\end{array}$ & & $\begin{array}{c}\text { Rodriguez Orrego } \\
1979\end{array}$ \\
\hline Faldas del Cerro & $\begin{array}{l}\text { Ingenio de } \\
\text { Arenal, } \\
\text { Catamarca }\end{array}$ & Temprano & & \begin{tabular}{|c|}
14 \\
minerales \\
cupriferos \\
\end{tabular} & & & $\begin{array}{l}17 \text { fragm } \\
\text { cuencos }\end{array}$ & 4 escorias & 1 cuchara de cobre & $\begin{array}{c}\text { Scatollin y } \\
\text { Williams } 1995\end{array}$ \\
\hline Alamito & $\begin{array}{l}\text { Andalgala, } \\
\text { Catamarca }\end{array}$ & Temprano & & $\begin{array}{c}2 \text { silicatos } \\
\text { de cobre y } \\
\text { plomo }\end{array}$ & 3 fragm tubos & sin especificar & \begin{tabular}{|c|}
1 escudilla 1 jarro \\
y 1 vaso \\
calciforme
\end{tabular} & & $\begin{array}{c}1 \text { placa subrectangular } \\
1 \text { fragmento pinza } \\
1 \text { lamina } 2 \text { barras }\end{array}$ & Pifferetti 2001 \\
\hline Médanos & $\begin{array}{l}\text { Ingenio de } \\
\text { Arenal, } \\
\text { Catamarca }\end{array}$ & Inka & morteros & $\begin{array}{c}8 \text { minerales } \\
\text { de cobre }\end{array}$ & & 3 ¿pulidores? & 2 toberas? & & & $\begin{array}{c}\text { Scatollin y } \\
\text { Williams } 1995\end{array}$ \\
\hline Potrero Chaquigo & $\begin{array}{l}\text { Andalgalá, } \\
\text { Catamarca }\end{array}$ & Inka & & $\begin{array}{c}2 \text { minerales } \\
\text { de cobre }\end{array}$ & $\begin{array}{c}1 \text { horno } \\
\text { subcuadrangula } \\
\begin{array}{c}r \text { con roca y } \\
\text { adobe }\end{array}\end{array}$ & & $\begin{array}{l}3 \text { molde sy } 1 \\
\text { crisol }\end{array}$ & $\begin{array}{l}\text { esorias de } \\
\text { fundicion }\end{array}$ & $\begin{array}{c}2 \text { cinceles de bronce } \\
1 \text { hacha de bronce } \\
1 \text { punzon }\end{array}$ & Williams 1995 \\
\hline Huasan & $\begin{array}{l}\text { Andalgalá, } \\
\text { Catamarca }\end{array}$ & Inka & 1 maray & & & & & & & \begin{tabular}{|c|} 
Lafone Quevedo \\
1888 \\
\end{tabular} \\
\hline Campo de Carrizal & $\begin{array}{l}\text { Belén, } \\
\text { Catamarca }\end{array}$ & Tardío/inka & & $\begin{array}{c}2 \text { trozos de } \\
\text { mineral }\end{array}$ & & & $\begin{array}{l}19 \text { fragm moldes } \\
12 \text { fragm crisoles }\end{array}$ & $\begin{array}{c}3 \text { residuos de } \\
\text { fundicion }\end{array}$ & $\begin{array}{l}3 \text { fragmento de metal } \\
\text { de bronce esyannifero }\end{array}$ & $\begin{array}{c}\text { Zagorodny et al. } \\
2015\end{array}$ \\
\hline Quillay & $\begin{array}{c}\text { Belén, } \\
\text { Catamarca }\end{array}$ & Inka & molinos y manos & & $\begin{array}{c}14 \text { hornos tipo } \\
\text { huayras }\end{array}$ & & 1 crisol & $\begin{array}{l}\text { escorias de } \\
\text { fundicion }\end{array}$ & & $\begin{array}{l}\text { Raffino et al. } \\
\quad 1996\end{array}$ \\
\hline $\begin{array}{c}\text { Rincón Chico- Sitio } \\
15\end{array}$ & $\begin{array}{c}\text { Santa María, } \\
\text { Catamarca }\end{array}$ & \begin{tabular}{|c} 
Desarrollos \\
Regionales/ \\
Inka
\end{tabular} & & $\begin{array}{l}\text { minerales } \\
\text { de cobre }\end{array}$ & $\begin{array}{c}3 \text { fogones, } \\
\text { varios lentes y } 4 \\
\text { hueyras }\end{array}$ & sin especificar & $\begin{array}{c}500 \text { (6 cucharas, } \\
2 \text { lingotes, } 20 \\
\text { fragm cera } \\
\text { perdida) }\end{array}$ & \begin{tabular}{|c|} 
escorias de \\
fundicion, de \\
cirsol y \\
combustión \\
\end{tabular} & $\begin{array}{c}>31 \text { entre gotas, } \\
\text { adherencias } \\
\text { refractarios, chatarras }\end{array}$ & González 2010 \\
\hline Fuerte Quemado & $\begin{array}{c}\text { Santa María, } \\
\text { Catamarca }\end{array}$ & \begin{tabular}{|c|} 
Desarrollos \\
Regionales/ \\
Inka
\end{tabular} & & $\begin{array}{c}\text { minerales } \\
\text { de cobre }\end{array}$ & Fogón & & & $\begin{array}{c}\sin \\
\text { especificar }\end{array}$ & & Kristcautski 1999 \\
\hline Las Mojarras & $\begin{array}{c}\text { Santa María, } \\
\text { Catamarca }\end{array}$ & \begin{tabular}{|c|} 
Desarrollos \\
Regionales/ \\
Inka
\end{tabular} & & $\begin{array}{c}\text { minerales } \\
\text { cobre }\end{array}$ & Fogón & & sin especificar & $\begin{array}{c}\sin \\
\text { especificar }\end{array}$ & $\begin{array}{l}\text { fragmentos de bronce } \\
\text { estannífero }\end{array}$ & $\begin{array}{l}\text { González y } \\
\text { Tarragó } 2005\end{array}$ \\
\hline
\end{tabular}

Tabla 3.1. Detalles de evidencias de producción metalúrgica presentes en los sitios del NOA 


\subsection{Metalurgia en el valle de Hualfín}

A diferencia de otras regiones de Catamarca como Andalgalá, Ambato o Santa María, en este valle disponemos de unos pocos estudios sobre metalurgia prehispánica. En la década de 1950 se realizaron análisis sobre 32 objetos de metal provenientes de Hualfín que fueron asignados a la fase Aguada (Fester y Retamar 1956; Fester 1962). Los autores, indagaron sobre la composición química de las piezas detectando que la mayoría fueron confeccionadas en base a una aleación de bronce arsenical. Para Fester la presencia de trazas de arsénico y de zinc en algunos de los objetos, indicaba que el metal procedía de la fundición de menas del distrito minero de Capillitas, al ser sus yacimientos ricos en minerales como enargita, tennanita y tetraedrita (Fester 1962). Estos datos suministraron la primera evidencia del uso de bronce arsenical a nivel local durante épocas tempranas, además al plantear el uso de minerales oxidados o arseniatos de cobre supone el empleo de una tecnología que pudiera procesar complejas menas sulfuradas. Aun así, no han sido detectados hasta el momento sitios tempranos con evidencias de este procedimiento a nivel local.

Años más tarde, estos datos fueron retomados por González, quien incorpora una de las placas (MLP $\mathrm{N}^{\circ}$ 9966) a su análisis simbólico y a la secuencia cronológica del valle (González 1992). Asimismo, dio cuenta de otras 28 placas de cobre o bronce provenientes de diversas localidades del valle de Hualfín (Villavil, Los Nacimientos, Las Mazas, Porzo Verde, La Ciénaga, Pozo de Piedra, Corral Quemado, Talamayo, etc.) y en base a sus contextos de hallazgo y materiales asociados fueron asignadas al Período Tardío. Estas piezas son placas circulares y rectangulares lisas o con decoración de cabezas antropomorfas y siluetas zoomorfas (González 1992)

Asimismo, otras evidencias de objetos de metal que circularon por el valle de Hualfín durante los periodos tardíos pueden rastrearse en los registros sobre los objetos de ajuar provenientes de las tumbas excavadas por Weisser y Wolters en la década de 1930. Como se puede observar en la Tabla 3.2 se han identificado una variedad de objetos de metal - elaborados a base de cobre- asociado a piezas cerámicas de estilos locales y a restos de malaquita (datos extraídos de Wynveldt 2009). Su presencia en contextos funerarios sugiere la importancia de estos objetos en la vida ritual de los sujetos. Asimismo, el hallazgo de un "prisma" de cobre y restos de mineral, podrían 
sugerir la producción metalífera a nivel local. Se le suma el hallazgo estratigráfico de un cuchillo semilunar fracturado de base cobre, recuperado entre rocas de derrumbe en un recinto del sector central del Cerro Colorado de la Ciénaga de Abajo, espacio donde se identificaron dos entierros de infantes en urnas en el piso de habitación (Balesta y García Mancuso 2010).

\begin{tabular}{|c|c|c|c|c|}
\hline \multirow{2}{*}{ Localidad } & Tumba & \multicolumn{2}{|c|}{ Ajuar } & \multirow{2}{*}{$\begin{array}{c}\text { Referencia } \\
\text { Las Mazliográfica }\end{array}$} \\
\cline { 3 - 4 } & $\mathrm{s}^{\circ}$ & $\begin{array}{c}\text { Objetos de metal } \\
\text { 3 discos lisos } \\
\text { Hacha con alvéolo } \\
\text { y gancho }\end{array}$ & $\begin{array}{c}\text { Otros elementos } \\
\text { topo de hueso, tejido de lana, } \\
\text { cinto de cuero, collares de } \\
\text { malaquita, panes de ocre }\end{array}$ & González 1992 \\
\hline Azampay & $\mathrm{N}^{\circ} 4$ & $\begin{array}{c}\text { Hacha de cobre } \\
\text { Prisma de cobre }\end{array}$ & $\begin{array}{c}\text { Puco y urna Belén, Tinaja } \\
\text { colorada }\end{array}$ & Wynveldt 2009 \\
\hline Azampay & $\mathrm{N}^{\circ} 9$ & $\begin{array}{c}\text { Placa rectangular } \\
\text { de cobre }\end{array}$ & Puco Belén & $\begin{array}{c}\text { González 1992; } \\
\text { Wynveldt 2009 }\end{array}$ \\
\hline $\begin{array}{c}\text { Carrizal de } \\
\text { Azampay }\end{array}$ & $\mathrm{N}^{\circ} 4$ & $\begin{array}{c}\text { Adorno circular de } \\
\text { oro }\end{array}$ & Puco Belén, Malaquita & Wynveldt 2009 \\
\hline $\begin{array}{c}\text { La Ciénaga } \\
\text { Aislada }\end{array}$ & Disco de cobre & Tinaja, puco y ollita Belén & $\begin{array}{c}\text { González 1992; } \\
\text { Wynveldt 2009 }\end{array}$ \\
\hline $\begin{array}{c}\text { Palo Blanco } \\
\text { Varios } \\
\text { entierros }\end{array}$ & Objeto de cobre & Tinaja & Wynveldt 2009 \\
\hline $\begin{array}{c}\text { San Fernando } \\
\text { de Belén }\end{array}$ & $\begin{array}{c}\text { Varios } \\
\text { entierros }\end{array}$ & Placa de cobre & Tinaja Belén & Wynveldt 2009 \\
\hline $\begin{array}{c}\text { Puerta de } \\
\text { Corral }\end{array}$ & $\begin{array}{c}\text { Varios } \\
\text { entierros }\end{array}$ & $\begin{array}{c}\text { Placas de cobre, } \\
\text { pulseras de metal }\end{array}$ & $\begin{array}{c}\text { Urnas Santa María, Pucos } \\
\text { Belén, Famabalasto negro } \\
\text { grabado }\end{array}$ & Wynveldt 2009 \\
\hline
\end{tabular}

Tabla 3.2. Objetos de ajuar funerario en tumbas del valle de Hualfín.

A pesar de la abundancia de objetos metálicos en el valle, recuperados en su mayoría de contextos funerarios tardíos, actualmente sólo disponemos de dos sitios con contextos de producción metalúrgica. Estos asentamientos presentan diferencias en la escala de la producción y en la organización sociotécnica. El primero, corresponde al sitio Campo de Carrizal, ubicado en el margen derecho del río Hualfín y sobre los espolones del Cerro Durazno. El complejo arqueológico cuenta con una serie de núcleos habitacionales adscriptos a periodos tardíos (S.X y XV). En el recinto 1 del núcleo 2 del espolón 3 y del 2, se registraron algunos fragmentos de metal, desechos de fundición y abundantes refractarios (moldes y crisoles) con el clásico recubrimiento blanquecino, que evidencian actividades metalúrgicas (Zagorodny et al. 2015) (ver Tabla 3.1). Los autores sugieren que los pobladores pudieron trabajar el cobre a nivel doméstico mediante la fundición de sus menas, la aleación de metales para obtener bronces estanníferos y la fabricación de piezas por moldeado y laminado (Zagorodny et al. 2015: 448). Estos datos 
brindan los primeros contextos arqueológicos en el valle que dan cuenta del procesamiento metalúrgico en el marco de la entidad sociocultural Belén. El segundo sitio con una mayor escala de producción y de momentos inkaicos se halla sobre la otra margen del río Hualfín a 14 km al sur de Carrizal y es el sitio arqueológico Quillay

\subsection{Las investigaciones arqueológicas en el sitio Quillay}

Al momento de inicio de este estudio, las publicaciones científicas sobre este sitio eran bastante escasas y discontinuas y el conocimiento sobre sus recintos y hornos era fragmentario. A pesar de ello, se ha convertido en un baluarte de la arqueología del NOA, siendo una referencia indiscutible en los estudios de metalurgia andina y en aquellos que se interesan por la dinámica del Tawantinsuyu. Una exhaustiva búsqueda bibliográfica permitió detectar menciones sobre este sitio realizadas por los dos investigadores que trabajaron en el complejo arqueológico (González 1980; Raffino et al. 1982; Raffino 2007, Raffino et al. 2013). Sin embargo, sólo dos artículos versan exclusivamente sobre sus trabajos de campo y los estudios realizados en los mismos (González 1959; Raffino et al. 1996).

El primer investigador en visitar el sitio fue González en las campañas de 1952 realizadas en el Valle de Hualfín (González 1959). Las mismas respondieron a la necesidad de estudiar de forma sistemática los sitios arqueológicos presentes en la región. Su objetivo era identificar el patrimonio cultural de cada grupo social mediante el análisis cerámico, para luego conformar una seriación cronológica cultural. Así, los estudios en este valle aportaron la primera periodificación de las sociedades del NOA, la cual aún continúa en vigencia (González y Cowgill 1975). En este marco, González visitó las ruinas de Quillay y realizó excavaciones en tres habitaciones: una de planta circular y dos rectangulares. Allí identificó cerámica de estilo Belén en asociación con tiestos de estilos inkaicos. Acorde a sus objetivos, el autor remarca la importancia de este hallazgo dado que "prueba la contemporaneidad de la cultura Belén con el periodo incaico" (González 1959: 83). En superficie, encuentra una urna Sanagasta con un párvulo, una cestería, un cuenco pirograbado y abundante cerámica Aguada. Esto le permitió plantear cierta continuidad en la ocupación de la zona. Otro dato importante es su referencia sobre unas "estructuras tronco-cónicas" (González 1959: 84) ubicadas cercana a los recintos. Aporta datos sobre sus dimensiones, aunque duda de su 
asignación funcional y cronológica. En una publicación posterior (González 1980) considera a este sitio como un tambo secundario por su bajo número de estructuras y escasa inversión arquitectónica. Asimismo, Quillay mereció por sus características, ser incluido en la clasificación de espacios para el almacenamiento secundario, dado que se interpretó a los recintos circulares como depósitos alimenticios o qollqa.

Luego de varias décadas en silencio, Quillay vuelve a aparecer en el escenario científico de la mano de Raffino y su equipo, cuya novedad fue la identificación de las intrigantes estructuras tronco-cónicas. Dieron cuenta de la existencia de 14 de estas estructuras reconocidas desde ese momento como hornos metalúrgicos (Raffino et al. 1996). Los autores clasificaron a las mismas como wayras andinas y sobre la base de mediciones efectuadas en dichas estructuras realizaron un esquema morfológico y funcional de los hornos (figura 3.12). También elaboraron una propuesta acerca de la dinámica de producción y circulación de metales durante el incario, que articularía este sitio con los centros administrativos locales de El Shincal y Hualfín Inka para transportar los metales hacia Cuzco (Raffino et al. 1996). Siguiendo los lineamientos planteados por González (1959) presentaron evidencias cerámicas para sostener una ocupación diacrónica. La primera del periodo Medio, donde las sociedades Aguada se habrían asentado en el sitio denominado Quillay Pampa. La segunda ocupación se daría con la llegada de los Inkas al valle que, según los autores, se manifiesta en dos sitios separados entre sí por 300 metros. El primero, Quillay Tampu, presenta recintos con evidencias arquitectónicas y cerámicas de raigambre estatal. El otro, Quillay Wayras contiene los hornos de fundición previamente nombrados y cuyas dataciones lo posicionan también en ese periodo (Raffino et al. 1996). Los autores presentan un primer mapa del sitio, los resultados de análisis cerámicos, de un crisol refractario y de escorias recolectadas de los hornos dando cuenta de su uso para tareas de obtención de cobre. 


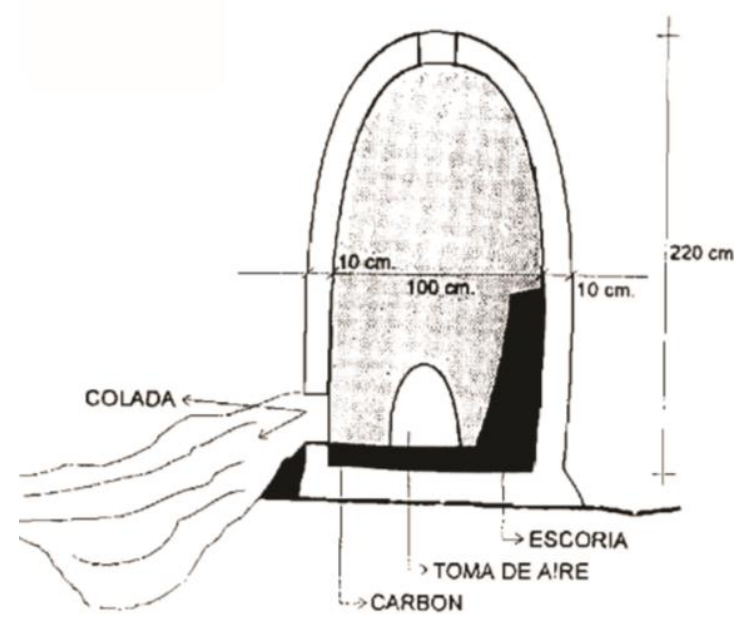

Figura 3.12. Reconstrucción de los hornos de Quillay realizada por Raffino et al. 1996: Figura 7, p.63.

Sus propuestas sobre la estructura de los hornos, produjeron algunos interrogantes en investigadores especialistas en la temática (González 2004b; DeNigris y Puche Riart 2011; Van Buren y Mills 2005), las cuales serán retomadas en la discusión de los resultados alcanzados en la presente investigación. Más allá de estas vacilaciones, no cabe duda que este trabajo constituyó un gran aporte en los estudios sobre metalurgia andina y el Tawantinsuyu, dado que por primera vez se declara la existencia de hornos metalúrgicos en buen estado de conservación, caso único para el noroeste de Argentina. Transformándose así en uno de los trabajos más frecuentemente citados con respecto a esta región.

\subsection{Consideraciones generales sobre las políticas del Tawantinsuyu}

En el apartado anterior, al introducirnos en Quillay a partir de los antecedentes de investigaciones previas, se puede apreciar que este sitio fue asociado al momento de ocupación inkaica en la región central de Catamarca. Como se verá más adelante, esta investigación corrobora lo anterior, por lo que se hace necesario exponer algunos lineamientos generales acerca de las políticas del Tawantinsuyu que serán útiles para las interpretaciones finales sobre este sitio arqueológico.

Es ampliamente conocido que el estado Inka o Tawantinsuyu fue la organización sociopolítica más extensa de la América precolombina. De norte a sur abarcó el territorio que se extiende desde el sur de Colombia hasta el centro de Chile y el valle de 
Uspallata en Mendoza (Argentina) y, de oeste a este, desde el océano Pacífico hasta la región de la selva tropical. Como su nombre lo indica, el estado estaba dividido geopolíticamente en cuatro (tawa) grandes regiones (suyus) de dimensiones variables entre sí pero que convergían en la capital estatal, el Cusco (D'Altroy 2003). De esta manera, la región denominada Chinchaisuyu se extendía desde la capital hacia el noroeste por la costa peruana y ecuatoriana y por las tierras altas. Hacia el noreste, toda la región de tierras bajas, el borde oriental andino y parte del altiplano hasta los llanos de Mojos conformaba el Antisuyu. El Qontisuyu se extendía por todo el sur y sudoeste del Cusco hasta la costa pacífica y, por último, el Qollasuyu, que abarcaba el altiplano y el área circunlacustre boliviana, el norte y centro de Chile y el noroeste y centro-oeste de Argentina (figura 3.13).

Asimismo, para su administración política cada suyu se dividía en numerosas provincias -de las cuales aún no se conocen con precisión sus límites- y poseía cada una de ellas al menos una capital o wamani. Se ha propuesto que cada provincia habría estado relacionada con los dominios de antiguos estados pre-inka u organizaciones étnicas fuertemente jerarquizadas que fueron incorporados al Tawantinsuyu, las cuales habrían otorgado su nombre a cada región (Metraux 1961). Específicamente para el suyu más austral del estado, que abarca los territorios del NOA, se conocen cinco provincias. Siguiendo a Williams (2003), la más septentrional habría sido Humahuaca, con su núcleo en el Pucará de Tilcara, siendo habitada por mitimaes de origen chicha. Además, cuenta con otros sitios políticos de relevancia como Los Amarillos que fue mencionado previamente, Titiconte, Coctaca, La Huerta y Yacoraite (Raffino 2007). Geográficamente le sigue hacia el sur, la provincia denominada Chicoana, que abarcaba los valles Calchaquíes, con su cabecera política en la Paya en la actual Salta. Habría sido habitado en su mayoría por grupos Pulares, aunque se destaca el carácter multiétnico de la región (Lorandi y Boixados 1988-1989; Williams 2003). Más hacia el sur, la provincia de Quire-Quire comprendía los valles de Santa María, Abaucán, Andalgalá y Hualfín. Tenía como centros políticos a Tolombón por el norte y a El Shincal de Quimivil por el sur (Williams 2003). Como hemos presentado esta es una región con numerosos sitios con evidencias de actividades metalúrgicas, entre los que se destacan Rincón Chico y Quillay. Por último, se encontraba la provincia de Tucumán que comprendía los valles orientales y sierras subandinas y finalmente desde el territorio 
de La Rioja hasta Mendoza conformaban la provincia Austral, con su probable centro en la Tambería de Chilecito (Williams 2003).

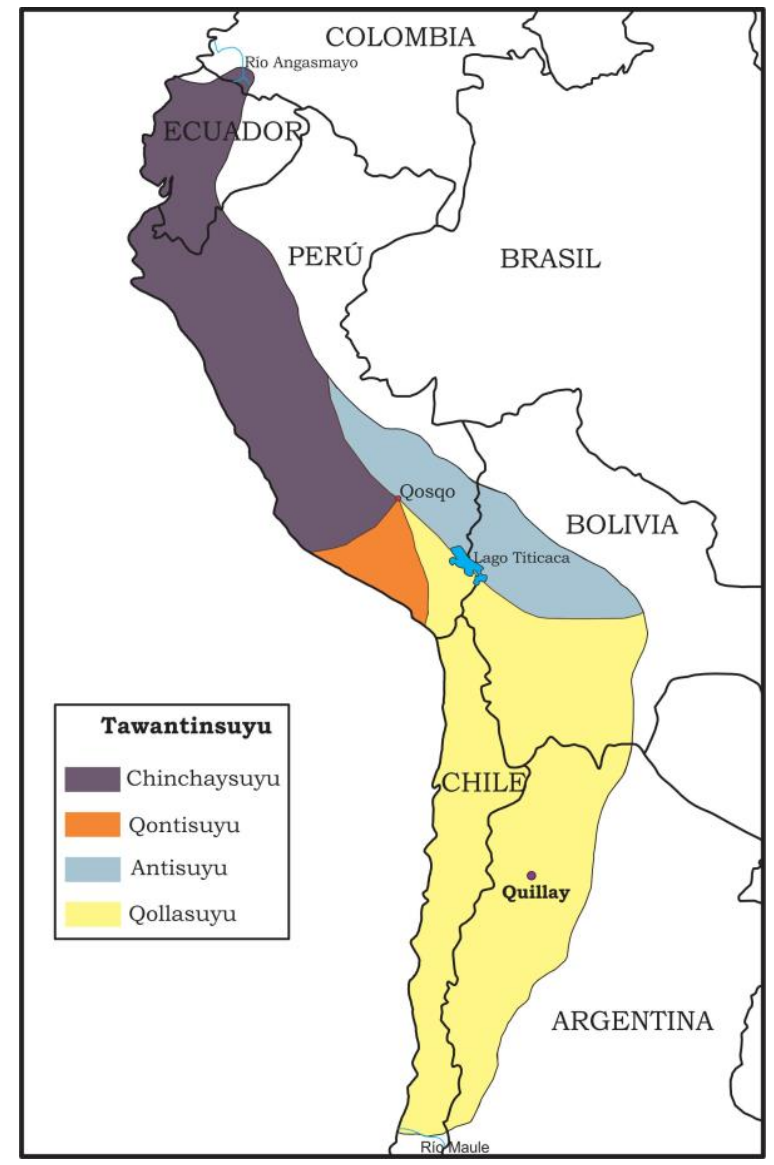

Figura 3.13. División geopolítica del Estado Inka.

En cuanto a la cronología de expansión del estado Inka y llegada al NOA, existen diferentes propuestas que han generado amplias discusiones que aún no encontraron consenso. Tradicionalmente, a partir de las fuentes etnohistóricas y revisión de algunos fechados absolutos, se ubicó la anexión de estos territorios dentro de la segunda mitad del siglo XV (Rowe 1945, Raffino 1981; Bárcena 2007). Mientas que, otras propuestas basadas en datos arqueológicos y fechados radiocarbónicos y termoluminiscencia realizados en más de 50 sitios distribuidos por Jujuy, Catamarca, Salta y Mendoza, proponen un ingreso más temprano situado hacia primera mitad del siglo XV o incluso fines del siglo XIV (Raffino y Stehberg 1997; Williams y D'Altroy 1998; D’Altroy y 
Schreiber 2004; Marsh 2016). Específicamente para el Valle de Hualfín, donde precisamente se encuentra el sitio Quillay, la información obtenida para otros sitios inkaicos considera aceptable este ingreso más temprano. Por ejemplo, el sitio Hualfín Inka presenta fechados por AMS cuyos rangos temporales abarcan entre mitad y fines del siglo XIV hasta el último cuarto del siglo XV (1360-1477 dC.) (Lynch 2013). En el sitio El Shincal al menos uno de los fechados calibrados con 2 sigmas, cae dentro de los rangos de ocupación temprana para la región (Raffino 2004).

Respecto a los motivos de expansión del Tawantinsuyu hacia el NOA, se considera que fueron múltiples y diversos. Algunos investigadores destacan la búsqueda de la ampliación de recursos agro pastoriles y/o mineros-metalúrgicos (Raffino 1981, 2004; Williams 2000, Raffino et al. 2013) otros, la obtención de rentas y mano de obra para financiar las actividades estatales, entre ellas las grandes obras de infraestructura y los bienes artesanales requeridos para la reciprocidad y hospitalidad estatal (D'Altroy et al. 1985; Earle 1994) y más recientemente Acuto (2009) plantea la posibilidad de una expansión que buscó crear un paisaje simbólico y material relacionado con la cosmovisión y ritual Inka que permitiera conformar un orden cosmológico panandino.

Según Williams y D’Altroy (1998) durante la expansión utilizaron políticas variables que combinaron tanto el control político militar como la hospitalidad ceremonial, el montaje de un aparato ideológico, la movilización y relocalización de poblaciones, las negociaciones y tratos preferenciales con algunos grupos en particular y una alta intensificación en la explotación minera y agro pastoril. Para ello, instalaron numerosos centros político-administrativos, ceremoniales, fortalezas y pukaras, talleres productivos y artesanales, tambos, obras hidráulicas y agrícolas, sitios de almacenamiento, santuarios de altura, todos ellos vinculados a través de una vasta red de caminos y wakas sagradas (González 1980; Raffino 1978, 1981, 1994, 2007; Williams 1994, 2000, 2004, 2010; Schobinger 2001; González y Tarragó 2005; Bárcena 2008). En este contexto, tanto la distribución en el territorio como la planificación de los asentamientos y su arquitectura siguieron lógicas y estándares simbólicos utilizados en Cusco que habrían contribuido a la integración y dominación cultural (Acuto 1999; Williams 2000; Raffino 2007). Sin embargo, se considera que la ocupación Inka en el NOA habría sido "selectivamente intensiva” (Williams y D'Altroy 1998: 175) dado que 
si bien construyeron asentamientos de importancia en zonas "vacías" arquitectónicamente pero cercanas a poblados locales (p.e. Potrero de Payogasta, Potrero Chaquiago, Watungasta, El Shincal), también se instalaron sobre asentamientos preexistentes modificando su arquitectura y distribución espacial (p.e. Los Amarillos, Pukara de Tilcara, La Paya, Rincón Chico, entre otros).

Durante su expansión, los Inkas implementaron múltiples estrategias de control político que variaron de acuerdo a la organización sociopolítica de los pueblos anexados, su especialización artesanal y el interjuego entre los intereses estatales y los de los grupos locales. En algunos casos, implicó conquistas violentas instalando una modalidad de control directo sobre los pueblos, como ya fue planteado para el caso de Los Amarillos. En general, esta modalidad implicaba la re-estructuración arquitectónica de asentamientos y la movilización y relocalización de personas leales al estado para el desarrollo y control de las actividades, situación que habrían alterado las estructuras de poder pre-existentes (Lorandi y Boixados 1988-1989). Estos grupos trasladados de sus regiones de origen eran denominados mitimaes o mitmak (Rostworowski 1999). La relocalización de grupos de mitimaes ha sido ampliamente registrada para el valle Calchaquí, generando asentamientos multiétnicos como por ejemplo en La Paya y Angastaco (Lorandi y Boixados 1988-1989).

Sin embargo, en el NOA, la mayor parte de las investigaciones señalan que se establecieron gobiernos indirectos pero efectivos, a partir de negociaciones y pactos con los jefes locales. Así estos grupos habrían mantenido la estructura política pre-existente, pero debiendo cumplir con las obligaciones que imponía el estado. La existencia de negociaciones y alianzas habría generado una integración mucho más fuerte entre el estado y las comunidades locales en los Andes sureños (Williams 2004). Como se ha mostrado para el caso de la metalurgia, el gobierno cusqueño si bien pactó alianzas con los jefes locales permitiendo ciertas continuidades en sus sistemas organizativos sociopolíticos y estilos tecnológicos, intervino fuertemente a través de un estricto control de los recursos mineros y la apropiación de los productos metálicos intermedios o terminados a través del pago de tributo. También demandó la producción de objetos metálicos de raigambre inkaica y en algunos casos el empleo de tecnologías de producción a gran escala, como los hornos metalúrgicos. Estas situaciones fueron 
planteadas por ejemplo en sitios como Potrero de Payogasta, La Encrucijada, Rincón Chico y Potrero Chaquiago.

Por último, para la interpretación de la producción metalúrgica en el valle de Hualfín será necesario entender algunos aspectos de la organización del trabajo en tiempo de los inkas. Por ello, según estudios previos se habrían desplegado un sistema de prestaciones rotativas de trabajo basado en las tradicionales prácticas andinas de reciprocidad (Murra [1978] 1999; Rostworowski 1999). Así, de forma regular y por turnos rotativos, una gran cantidad de miembros de cada grupo étnico aportaban su fuerza de trabajo para realizar distintas labores en beneficio de la comunidad. Sin embargo, existía también otro sistema laboral que excluía el principio de reciprocidad: el yanaconazgo. En este caso, los sujetos eran retirados de sus comunidades de origen para servir de forma permanente y exclusiva a miembros de la jerarquía social inkaica (Rostworowski 1999).

El sistema de relevamiento de personas para la prestación de servicios rotativos de trabajo recíproco, recaía sobre cada ayllu. Es decir, sobre personas unidas en comunidad por vínculos de parentesco consanguíneo o político que funcionaban como la unidad básica de subsistencia económica. Los sujetos mayores de 18 años, de ambos sexos, participaban como mitayos y se tenían en cuanta las posibilidades físicas de cada sujeto para conformar los equipos de trabajo (Espinoza Soriano 1997). Asimismo, se consideraban las cualidades y habilidades prácticas de las personas, destinándolos hacia labores de su especialidad, por ej. en la producción de artesanías (Espinoza Soriano 1997). El estado dispuso de un sistema de control de los tributarios que implicó censos, inspecciones y quipus, un sistema de registro contable decimal basado en cordeles anudados (Murra [1978] 1999).

Espinoza Soriano (1997), distingue tres modalidades de trabajo rotativo en función de sus participantes y beneficiarios directos: ayni, minga y mit'a. Los dos primeros se realizaban hacia el interior de cada ayllu para el beneficio de la propia comunidad y el de su curaca; en cambio la mit'a eran servicios ofrecidos al estado Inka (Rostworowski 1999). Así, el ayni consistía en el trabajo recíproco y cotidiano entre los miembros de cada familia, por ejemplo, para la construcción de las viviendas de cada núcleo familiar. El grupo beneficiario ofrecía como contrapartida alimentos y bebidas 
durante los días de trabajo y su propia fuerza laboral para otras actividades requeridas por los participantes. A diferencia de esta, la minga consistía en trabajos colectivos para el desarrollo de obras requeridas por toda la comunidad, como ser tareas de construcción, cuidado de andenes, cultivo, cría de ganado, etc. (Espinoza Soriano 1997).

Por último, en el caso de la mit'a, cada curaca era responsable de cumplir con las obligaciones y tiempos pactados con los administradores estatales, mediante el aporte de mitayos de su propia comunidad para el desarrollo de distintas actividades requeridas por el Incario. Estas podían consistir en el cultivo de tierras estatales, pastoreo de camélidos, construcción de caminos, tambos, fortalezas, obras hidráulicas y estructuras para la producción agraria y pastoril, también en actividades artesanales de textilería, lapidaria, cerámica, minería, metalurgia y orfebrería, entre otras (Murra [1978] 1999; Espinoza Soriano 1997; Rostworowski 1999). Así, el tributo era otorgado como fuerza de trabajo, donde el Estado era el responsable de aportar la materia prima y todo lo necesario para la producción. Esto incluía, asimismo, ofrecer como contrapartida bebidas y comidas en abundancia, el desarrollo de rituales, fiestas y ceremonias y dádivas como hojas de coca y tejidos para los mitayos que se esforzaran, así como objetos suntuarios para los líderes locales (Murra 1999 [1978], Espinoza Soriano 1997; Rostworowski 1999). El control y organización del trabajo de los mitayos era responsabilidad de los curacas locales, mientras que los miembros del linaje Inka, asentados en cada centro administrativo provincial, se encargaban del cumplimiento de las obligaciones tributarias asignadas a cada curaca (Murra 1999 [1978]; Rostworowski 1999; Sternfeld 2007). No obstante, Murra (1999 [1978]) plantea que no era estrictamente necesario que los administradores estatales estén siempre presentes, dado que el lazo con el Estado se reafirmaba al cumplir los mitayos con sus obligaciones anuales. Por lo tanto, es posible sostener que la articulación entre el estado y las poblaciones locales estuvo, en muchos casos, lo suficientemente afianzada como para no necesitar un fuerte control estatal. 


\section{EL SITIO ARQUEOLÓGICO QUILLAY}

\subsection{Ubicación geográfica del sitio}

El sitio arqueológico Quillay se encuentra en el departamento Belén, en el centro-oeste de la provincia de Catamarca. Esta región forma parte de la faja oriental de las Sierras Pampeanas Noroccidentales del noroeste de Argentina, caracterizada por presentar numerosos cordones montañosos y depresiones que conforman valles y bolsones (Caminos 1979). Quillay se localiza en el valle de Hualfín, sobre la margen izquierda del río Belén (o Hualfín). Sus coordenadas geográficas son 27²5'54.60" de latitud sur y $66^{\circ} 566^{\prime} 59.80^{\prime \prime}$ de longitud oeste (tomado en los recintos arqueológicos) con una altura de $1550 \mathrm{msnm}$ (Figura 4.1).

Con respecto a los centros poblados de la región, siguiendo la Ruta Nacional 40 hacia el norte, el sitio se halla a $40 \mathrm{~km}$ de la ciudad de Belén y a $7 \mathrm{~km}$ del pueblo de La Ciénaga. A pesar de la cercanía a estas zonas urbanas actuales, en el sitio arqueológico vive una única familia extendida criadores de ganado caprino. Sus casas y corrales se encuentran a menos de $100 \mathrm{~m}$ hacia el oeste de los recintos arqueológicos, siendo muchas de las rocas de las viviendas actuales procedentes de los mismos. La familia obtiene agua de pozo producto de una vertiente de agua subterránea y en cada jornada conduce los rebaños hacia los cerros para el pastoreo y hacia el río Belén para el consumo de agua, sus senderos atraviesan amplias zonas del sitio arqueológico que, como veremos más adelante, contribuyen a la erosión de las estructuras y materiales arqueológicos.

No existen caminos o senderos que conduzcan directamente al sitio arqueológico, únicamente por sobre la ruta 40 a la altura del pueblo de Azampay, existe una bajada que conduce al río Belén, una vez allí se debe atravesar el mismo y caminar en dirección a la serranía de Belén cerca de un kilómetro. Luego de pasar el bosquecillo de algarrobo se llega a la casa de la familia Cedrón y a los recintos arqueológicos. 


\subsection{Características ambientales}

\subsubsection{Red de drenaje, clima y biogeografía de la zona de estudio}

El valle de Hualfín tiene aproximadamente $79 \mathrm{~km}$ de longitud en línea recta y discurre en dirección NE-SO. En el norte y hacia el este está limitado por las Sierras de Hualfín y Las Cuevas. Hacia el NO se despliega un espacio de transición hacia la puna catamarqueña. Todos los ríos de este valle forman parte de la cuenca endorreica que desemboca en el salar de Pipanaco (Lobo 2008). Son cursos de agua de origen pluvial que nacen de las serranías que circundan el valle. El río principal es el Belén, que también recibe el nombre de río Hualfín. Tiene un cauce ancho que suele transportar agua de manera permanente durante todo el año. Sin embargo, durante el invierno el caudal es bastante bajo, aumentando significativamente durante el verano gracias al aporte de agua de lluvia de sus afluentes (Figura 4.1 y 4.2). El río Hualfín nace a la altura de la localidad de El Eje, producto de la confluencia de los ríos Nacimientos y Villavil que se originan en las sierras de Chango Real y Hualfín, respectivamente. Luego de norte a sur, sobre la margen derecha del rio por el NO, confluyen los ríos Corral Quemado, Loconte, Ichanga y Las Juntas que nacen de varios cerros que conforman la serranía de Altohuasi y Culampajá. Por la otra margen, los afluentes actualmente secos- son los ríos Quillay (Figura 4.3) y La Villa que se originan en la serranía de Belén ubicadas hacia el este (Lobo 2008). 


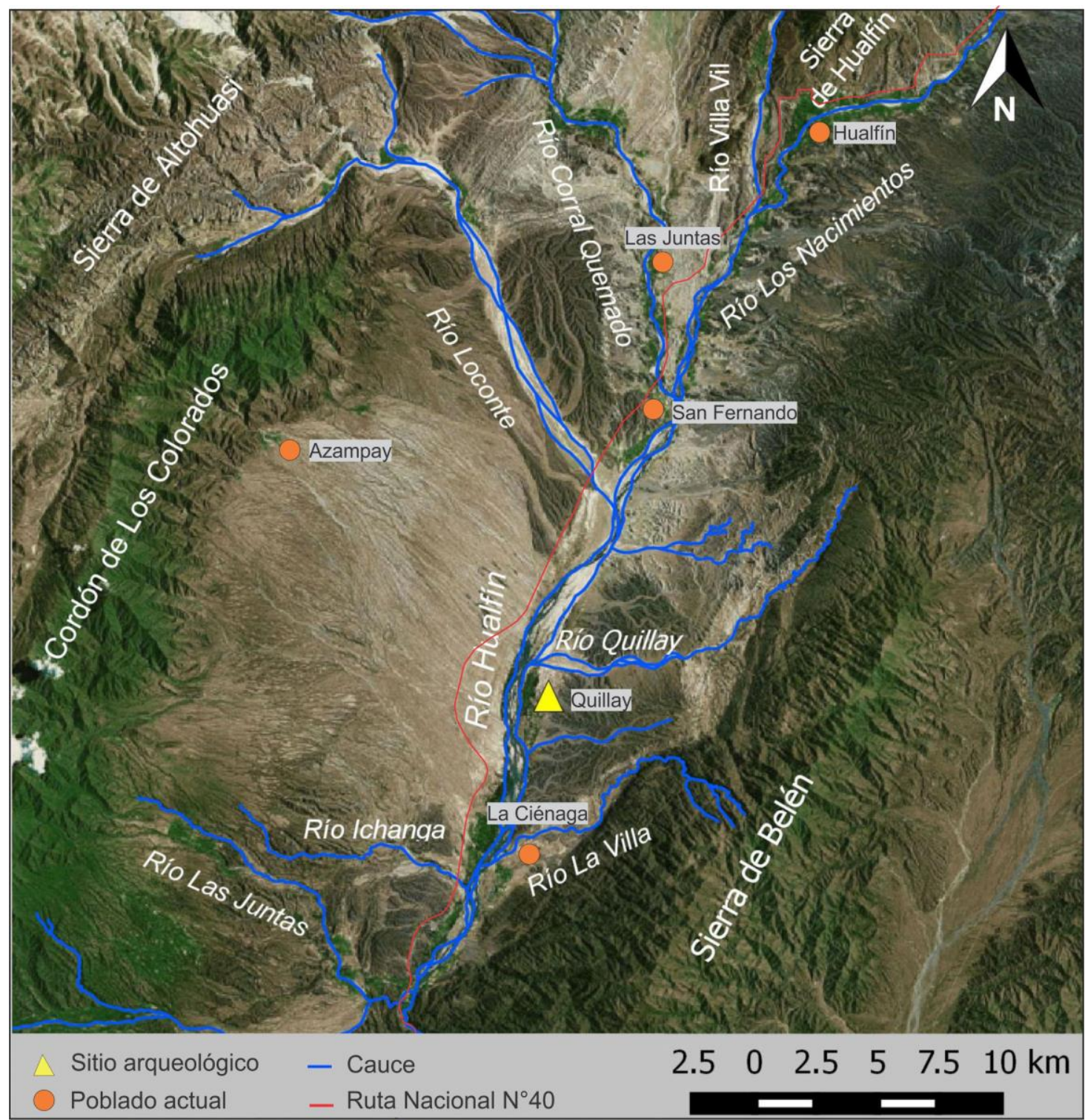

Figura 4.1. Mapa del valle de Hualfín. Se detallan los ríos y poblados actuales. Imagen procesada en QGIS 2.2.0

El rio Hualfín se caracteriza por su baja pendiente $(0.021 \mathrm{~m} / \mathrm{m})$ por lo cual transforma el lecho del río y el ambiente. Esto se debe a que, en la búsqueda de un equilibrio o nivel de base, la corriente de agua erosiona verticalmente el cauce del río aumentando su profundidad, además en zonas de muy baja pendiente se abre en abanicos generando la descarga de los sedimentos acareados e inundando zonas aledañas (Merláns 1995). En este sentido, el río Hualfín se diluye hacia el sur en un campo semidesértico, denominado "Campo de Belén" hasta descargar finalmente en el 
Salar de Pipanaco, depresión de aproximadamente $800 \mathrm{msnm}$ limitada hacia el este por el flanco occidental del sistema del Ambato (Morláns 1995; Lobo 2008).

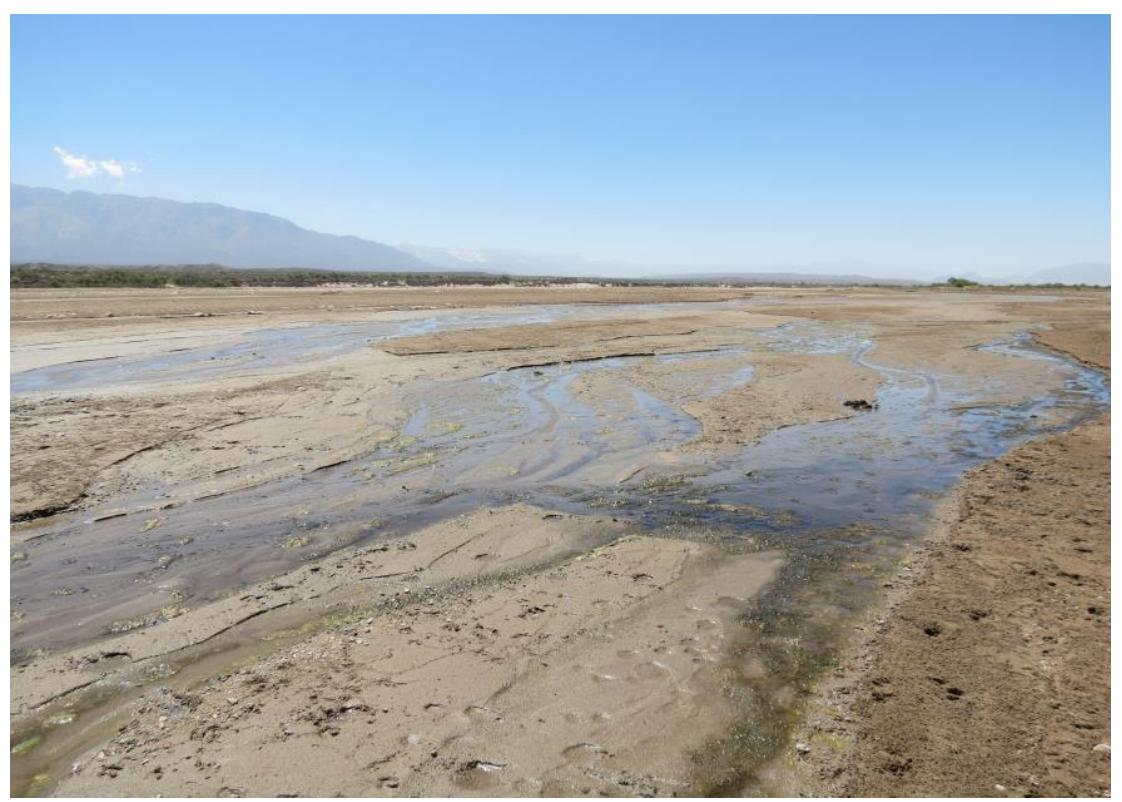

Figura 4.2. Río Hualfín a la altura del sitio Quillay.

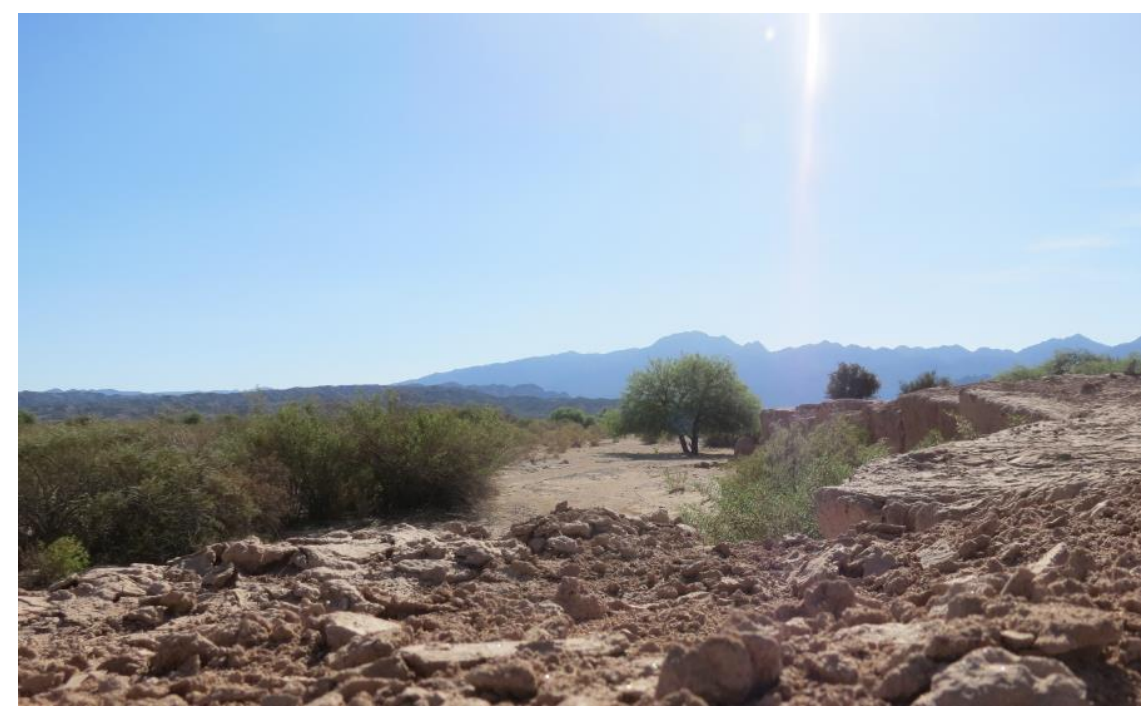

Figura 4.3. Barranca del río Quillay, cauce actualmente seco.

La zona de emplazamiento del sitio se encuentra circundada por varios sistemas montañosos. Específicamente hacia el este, las sierras que discurren en sentido N-S, conforman un sistema de elevaciones crecientes que alcanzan los $5500 \mathrm{~m}$ de altura en la Sierra de Aconquija. Es por ello que, estos cordones montañosos actúan como barreras climáticas frenando los vientos húmedos que provienen del NE, E y $\mathrm{S}$, haciendo que 
descarguen en las faldas orientales de las serranías y que los vientos secos desciendan por la ladera occidental (González Bonorino 1950). Esta situación genera que el valle de Hualfín, presente un clima árido a semiárido con un régimen pluviométrico que no supera los $400 \mathrm{~mm}$ anuales en las zonas más lluviosas, concentrándose gran parte de las mismas en los meses de noviembre a marzo (Morláns 1995). Las temperaturas rondan $\operatorname{los} 24^{\circ} \mathrm{C}$ en promedio durante el verano y $\operatorname{los} 9^{\circ} \mathrm{C}$ en invierno (Figura 4.4).

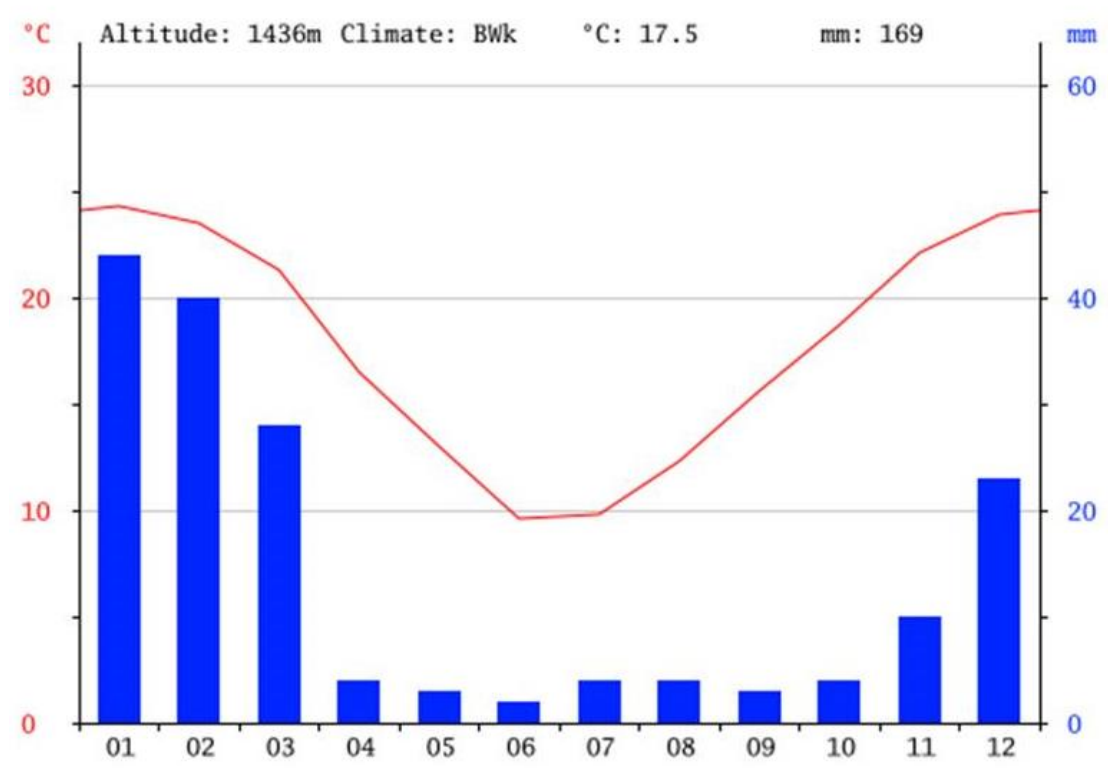

Figura 4.4. Climograma del pueblo de la Ciénaga, localizada a $7 \mathrm{~km}$ al $\mathrm{SO}$ del sitio Quillay. Presenta promedios de $24.6^{\circ} \mathrm{C}$ de temperatura y $44 \mathrm{~mm}$ de precipitaciones en enero y $9.7^{\circ} \mathrm{C}$ y $2 \mathrm{~mm}$ en Junio (Fuente http://es.climatedata.org/ Consultado Septiembre 2016)

Los parámetros climatológicos de temperatura, precipitación y humedad, son factores dinámicos que condicionan fuertemente la biodiversidad presente en la región de estudio. Según estos criterios, el valle de Hualfín ha sido integrado a la provincia fitogeográfica del Monte (Cabrera y Willink 1973). Esta provincia, se caracteriza por ambientes secos que favorecen en la zona de estudio, el desarrollo de una vegetación de tipo xerófila y heliófila, con predominio de arbustos en los piedemontes y las serranías que se transforman en pastos duros hacia las cimas. Entre los arbustos predominan las jarillas (Larrea divoncata, L. cunefolia, L. nitida), la brea (Cercidium praecox), el alpataco (Prosopis alpataco), el retamo (Bulnesia Retama), la tusca (Acacia Aroma), el 
chañar (Geoffroea decorticans) y el Quillay (Bredemeyera colletioides), éste último le otorga nombre al río y al sitio arqueológico. Estas especies suelen formar matorrales con alturas que van de unos pocos centímetros hasta 1 o $2 \mathrm{~m}$. En sus alrededores, también crecen una gran variedad de cactáceas (i.e. Trichocereus terchekii, Trichocereus huascha y Tunilla sohrensii) y un estrato herbáceo con gramíneas perennes de los géneros Pappaphorum, Setana y Trichlons (Cabrera y Willink 1973; Morláns 1995) (Figura 4.5).

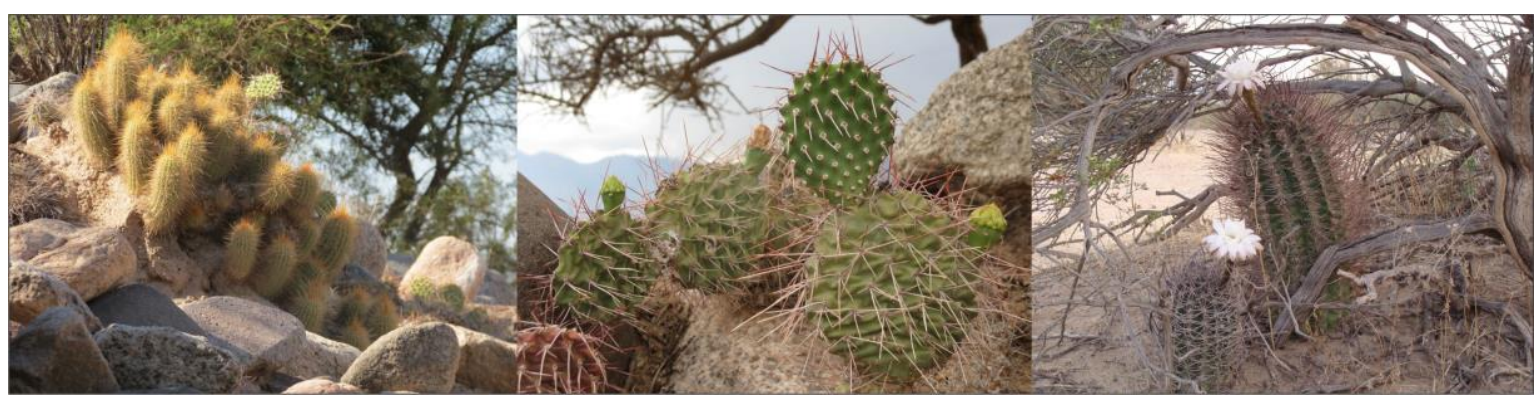

Figura 4.5. Variedad de cactáceas reconocidas en el sitio.

En la cercanía a los ríos de agua permanente o en zonas con acuíferos subterráneos, como es el caso de Quillay, suelen desarrollarse comunidades arbóreas gracias a la disponibilidad recurrente de agua, hallándose bosquecillos de algarrobales (Prosopis alba, P. chilensis, P. fleuxosa) y de churqui (Acacias caven) (Cabrera y Willink 1973; Palmieri et al. 2008) (Figura 4.6 y 4.7). Con respecto a la presencia de pastos blandos, la misma no es regular en el valle, siendo observados

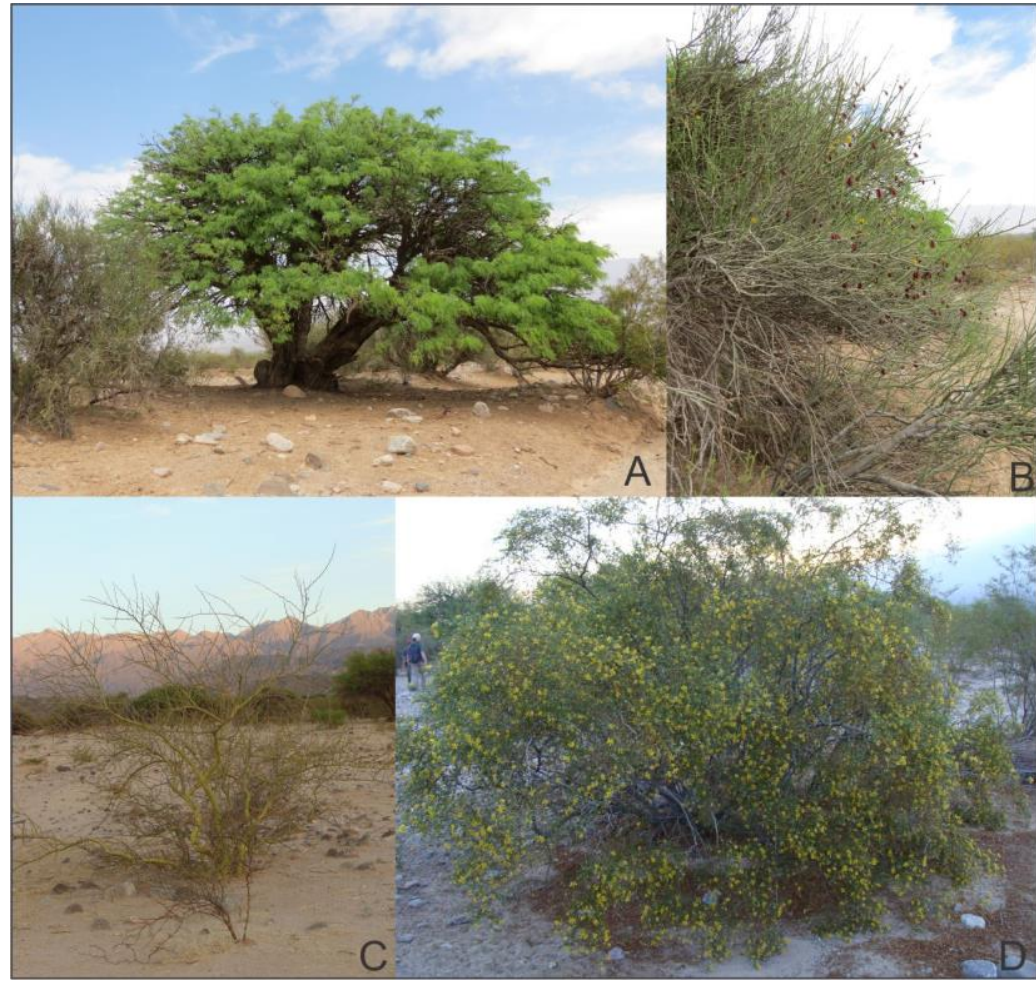

Figura 4.6. Variedad de árboles y arbustos en Quillay: A. Retama y Algarrobo; B. Retama en flor; C. Quillay y D. Jarilla 
únicamente en la planicie de inundación del Río Hualfín durante la temporada de lluvia, que posibilita su uso para el pastoreo (Figura 4.8).

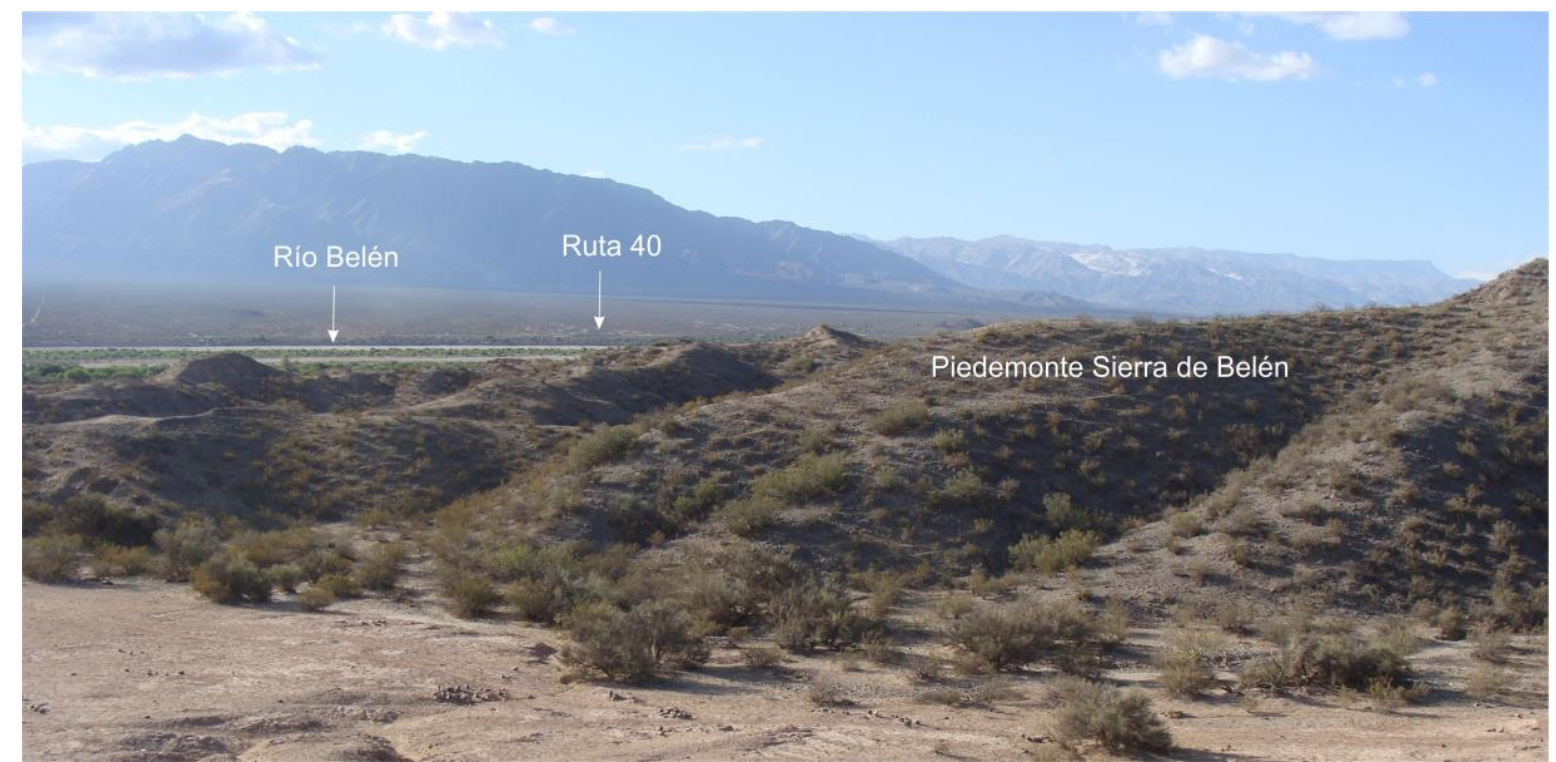

Figura 4.7. Fotografía del ambiente natural en las inmediaciones del sitio. En primer plano se observan los matorrales y arbustos en las lomadas de la sierra de Belén

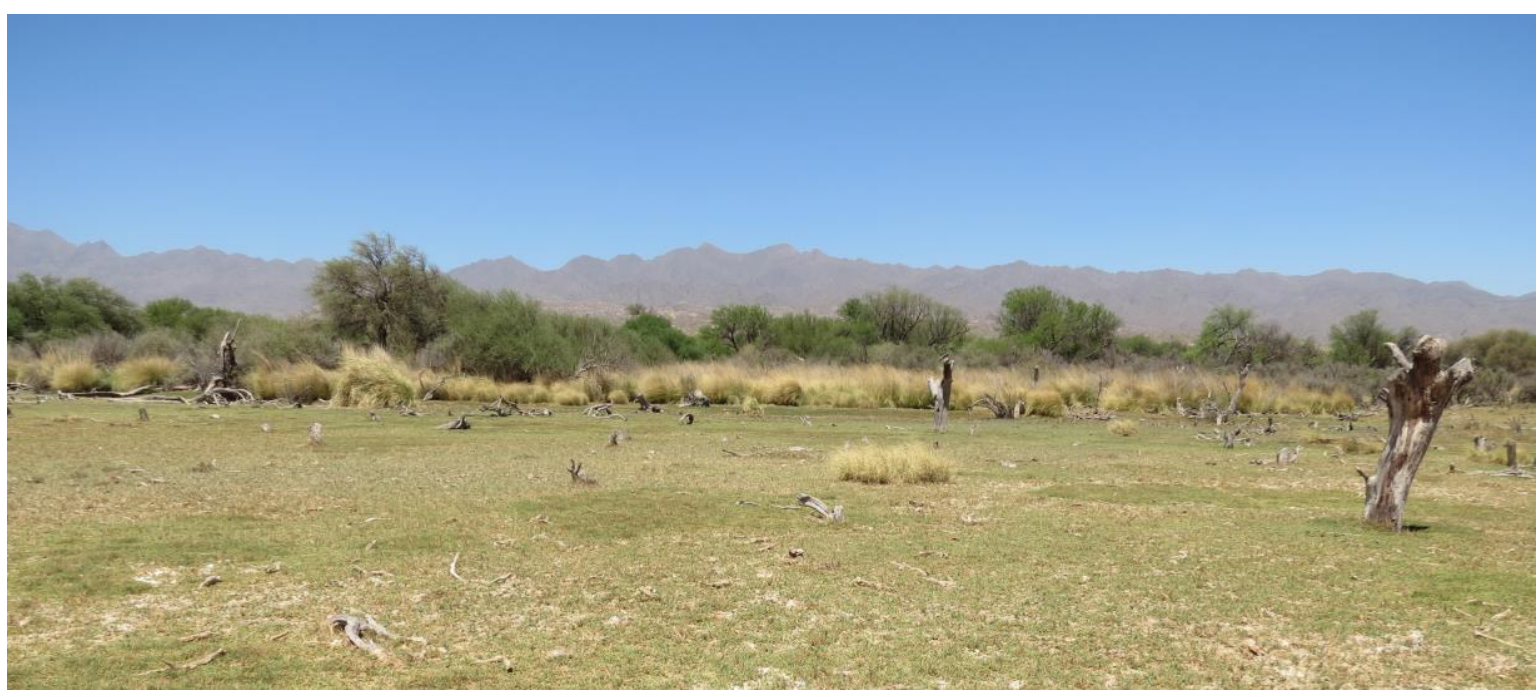

Figura 4.8. Fotografía de la planicie de inundación del río Belén. En primer plano se observan los pastos y las sales precipitadas. Hacia el fondo las gramíneas, el bosquecillo de algarrobos y la serranía de Belén.

En lo que se refiere a la fauna, siguiendo la información disponible en Cabrera y Willink (1973) y Palmieri et al. (2008), en la zona de estudio son comunes los marsupiales como la comadreja overa (Didelphis azarae) y el ratón de palo o achola (Marmosa pusilla). Entre los mamíferos se destacan zorros grises y colorados (Dusicyon 
sp.), zorrinos (Conepatus sp.) y felinos como el puma (Puma concólor) y el gato montés de las salinas y de los pajonales (Felis groffroyn salinarum y Felis pajeros respectivamente). Entre los roedores abundan las vizcachas (Lagostumus sp.), cuises (Microcava sp.) y tuco-tucos (Ctenomys sp.); también se hallan armadillos como el pichi ciego (Sclamyphous truncatus), peludos (Chaetophractus villosus y Ch. vellerosous) y el piche llorón (Zaedyus Pichiy). Entre las aves se nombran las perdices (Nothoprocta cinerascens y Nothura darwini), loros barranqueros (Cyanoliseus patagonum) y regularmente hemos visualizado cóndores andinos (Vultur gryphus). Dentro de los reptiles hay varias especies de boas (Constrictor sp.), víboras de coral (Micrurus sp.), yarará (Bothrops sp.) y una gran variedad de geckónidos (Homonota sp.) y lagartijas (Leyosaurus sp., Liolaemus $s p$. y Tripidurus sp) (Figura 4.9). Si bien la bibliografía da cuenta de la presencia de una gran variedad de especies animales, durante los trabajos de campo sólo hemos podido observar algunos zorros grises, lagartijas, la temida yarará y cóndores. La presencia de armadillos y gato montés ha sido confirmada al ser cazados por los habitantes del sitio.

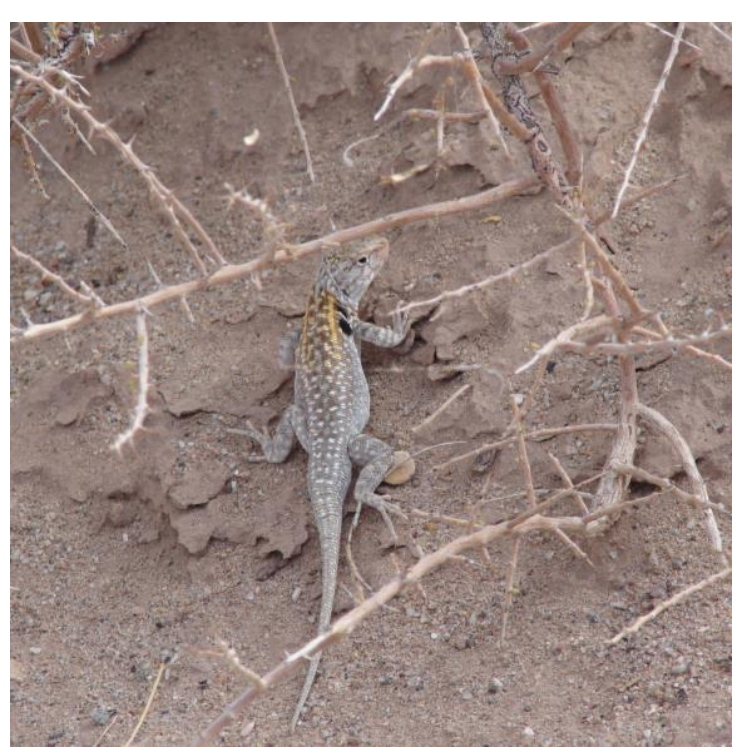

Figura 4.9. Lagartijas registradas en Quillay

\subsubsection{Geología y petrología}

Como fue señalado, el valle de Hualfín está delimitado por un conjunto de estribaciones montañosas y sistemas inter-montanos. Para poder caracterizar nuestra zona de estudio nos basaremos en las descripciones que ofrece las cartas geológicas $12 \mathrm{~d}$ (Capillitas) y 13c (Andalgalá) (González Bonorino 1950), dado que las mismas incluyen el segmento norte de la serranía de Belén, las serranías de Ovejería, Capillitas y Aconquija que en este orden delimitan hacia el este la zona donde se emplaza el sitio. En términos generales estas hojas nos muestran el ambiente geológico de las sierras conformadas por un basamento cristalino de edad precámbrica a paleozoica inferior, por 
encima del cual se identifica una cubierta sedimentaria de tiempos terciarios y cuaternarios (Figura 4.10)

Con respecto a la composición petrográfica del basamento cristalino, González Bonorino (1950) registró dos fases sucesivas de rocas. Por un lado, los esquistos metamórficos de pizarras, filitas y micacitas producidas por metamorfismos de contacto y termodinámicos. Por el otro, rocas graníticas de textura porfídica con predominio de fenocristales de feldespato potásico, localizados en áreas con un metamorfismo bajo. A pesar de esta tendencia, las características litológicas de los granitoides difieren de una zona a otra, presentando composiciones variables de cuarzo, feldespato y plagioclasas pudiendo distinguirse granitos, granodioritas, sienitas y tonalitas. Por ejemplo, la porción de la sierra de Belén situada inmediatamente aledaña al sitio y que finaliza en el Cerro Pampa está constituida totalmente por rocas graníticas, descrito como de textura gnéisica con fenocristales de cuarzo, microclina y biotita (González Bonorino 1950). Sin embargo, gran parte de la serranía de Belén contiene un tipo de granito que lleva su nombre, de grano grueso a fino y textura porfiroide compuesto principalmente por

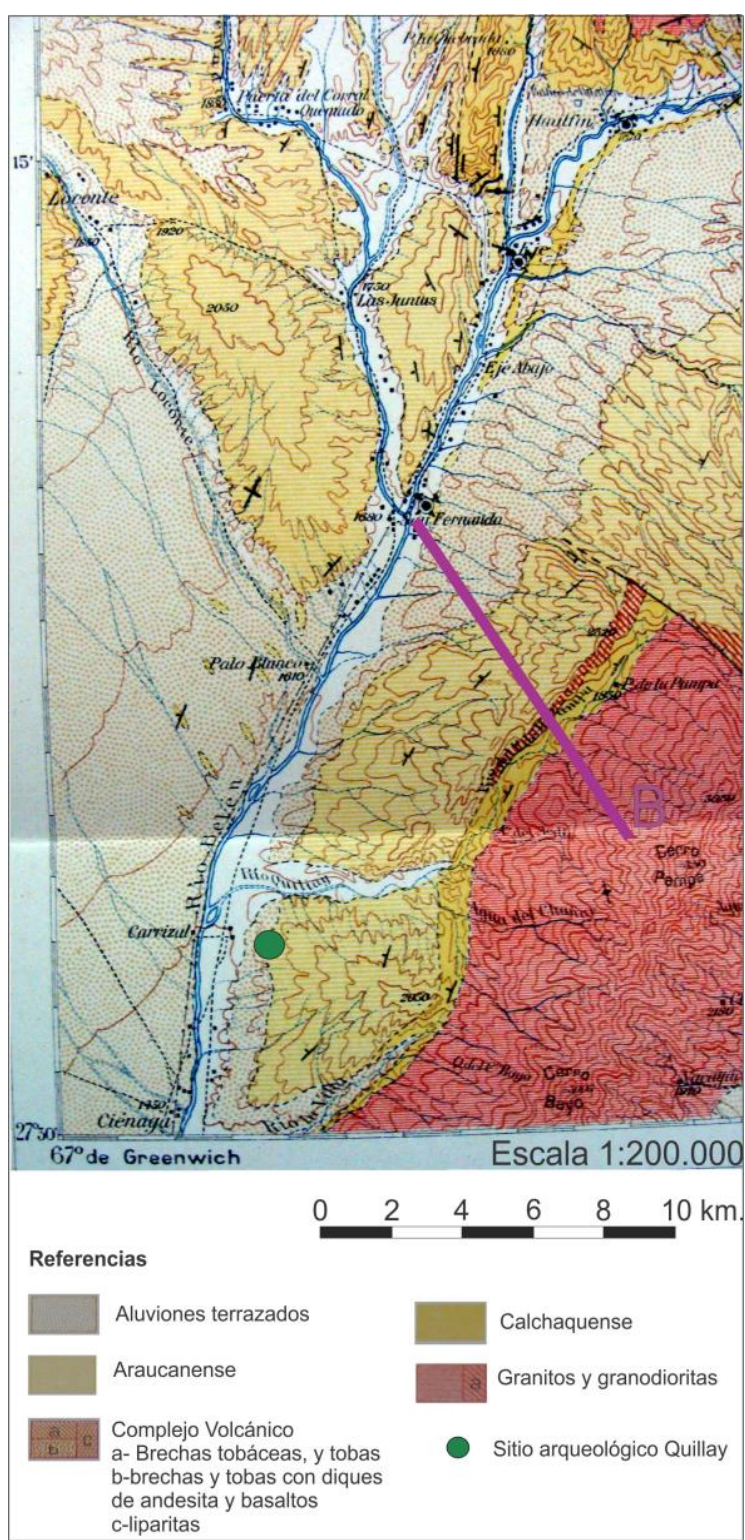

Figura 5.10. Carta geológica Hoja 12d (Capillitas). Segmento del valle de Hualfín. Tomada y editada de González Bonorino (1950) cuarzo, biotita, feldespato potásico, plagioclasas y secundariamente por muscovita, epídoto, circón y opacos (Lazarte y Guidi 1998) 
Sobre las rocas del basamento se apoya la cubierta sedimentaria de origen terciario y cuaternario. Durante el terciario se desarrollaron dos formaciones superpuestas denominadas Calchaquense y Araucanense. La primera está compuesta por areniscas pardo-rojizas y depósitos piroclásticos de andesitas, basaltos y liparitas; estando la segunda formada por depósitos areniscos de tipo tufaceo. González Bonorino (1950), presenta un perfil geológico de esta cubierta realizado en las cercanías del sitio Quillay. El mismo abarca el río Hualfín (Belén) a la altura de San Fernando y atraviesa el Cerro Pampa, de la serranía de Belén, hasta el valle de Ampujaco y de ahí vía Yaciyacu hasta el campo de Andalgalá. Se considerará el tramo del perfil que va desde Cerro Pampa hasta el río por encontrase a escasos $7 \mathrm{~km}$ del sitio y que posibilita conocer la geología local que podrá ser útil a la hora de evaluar el registro arqueológico de Quillay.

Como puede observarse en la Figura 4.11, las montañas están conformadas por rocas granitoideas del basamento cristalino sobre el cual se asienta el Calchaquense compuesto desde la base por areniscas pardas rojizas calcáreas, tobas blanquecinas y areniscas gris rosada de grano fino. Siguiendo el mismo ángulo de desarrollo, se apoya una intrusión volcánica de tobas, brechas y tobas de naturaleza basáltica y andesítica, sólo presente en zonas puntuales del valle. Luego, se halla la formación Araucanense compuesta por areniscas grises con algunos rodados de rocas volcánicas, que es atravesada por el río Hualfín (Belén), el cual levanta las areniscas que conforman las terrazas a ambos lados del cauce (González Bonorino 1950).

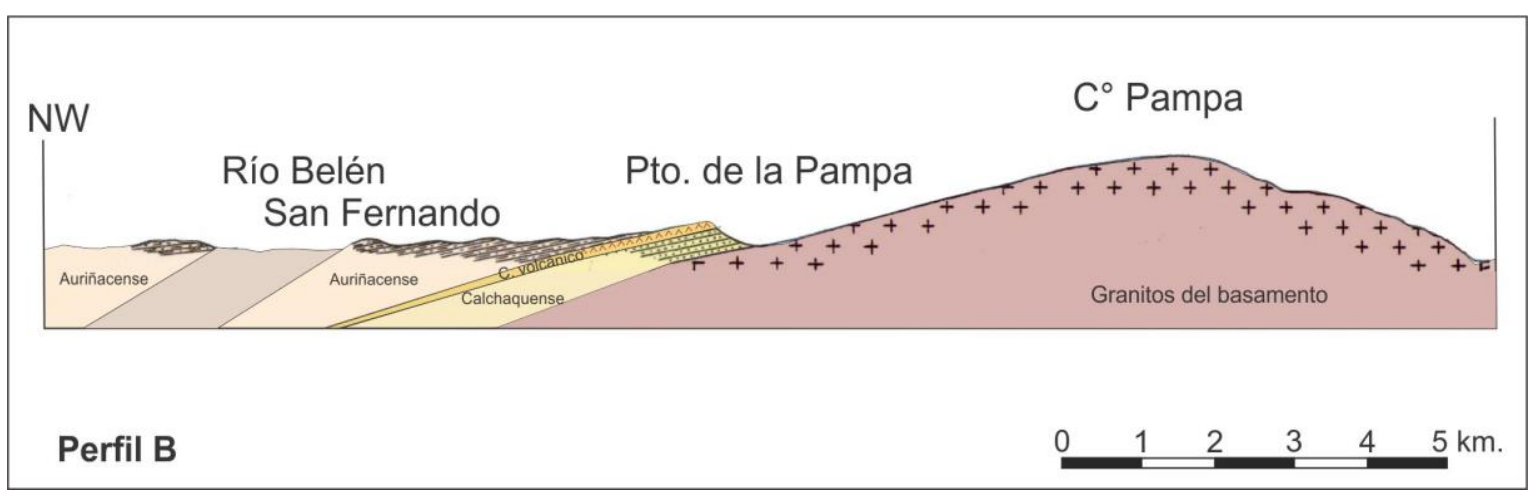

Figura 4.11. Perfil B marcado en la Figura 5.10, tomado y redibujado de González Bonorino (1950) 
Por último, se encuentran los sedimentos de origen cuaternario que conforman depósitos localizados en el pie de sierra. Se originan producto de la erosión eólica de las partículas provenientes de la meteorización del basamento. También la erosión fluvial genera el depósito de materiales en las zonas de baja pendiente conformando llanuras de sedimentación y terrazas fluviales. En este sentido, durante épocas de crecidas, el río Hualfín y sus afluentes, acarrean no sólo arcillas y limos sino también gravas y grandes cantos rodados. A medida que el río pierde capacidad de carga se produce una sedimentación granulométrica en el sentido de la corriente (González Bonorino 1950).

\subsubsection{Caracterización de los suelos}

Los suelos de la región de estudio son semidesérticos, inmaduros y con bajo contenido de materia orgánica que se desarrollan en los piedemontes, abanicos aluviales y en terrazas fluviales (González Bonorino 1950). Sobre la margen izquierda del río Hualfín, en el espacio donde se despliega el sitio Quillay, se han identificado dos tipos de suelo según la clasificación propuesta por Cruzate et al. (2011). De acuerdo a dichos autores, en las riberas, planicies de inundación y zonas aledañas del río Quillay y del Hualfín, el suelo pertenece al orden de Entisoles, subgrupo de los Torriontentes típicos (Entc-24) característico de planicies con arena y sedimentos limo-loéssicos que presentan un drenaje excesivo generando barreales. En el piedemonte de la serranía de Belén, el suelo forma parte del mismo orden pero del subgrupo de los Torriontentes líticos (EnLi-6), es decir presentan un mayor porcentaje de rodados y gravas respecto a los anteriores (http://geointa.inta.gov.ar/suelos/, consultado Septiembre 2016).

Estos suelos son característicos de climas secos con bajas precipitaciones, escasa humedad, pH neutro o calcáreo y están sobre pendientes moderadas. Incluso en las riberas del río Hualfín (Belén), como informamos previamente, se ha observado la presencia de sales que condicionan el desarrollo vegetal. Mineralógicamente, los suelos están compuestos principalmente por cuarzo, micas (muscovita y biotita) y feldespatos (González Bonorino 1950). 


\subsection{Mineralizaciones cercanas a la región de estudio}

En este segmento se comentarán las mineralizaciones metálicas disponibles en los yacimientos mineros más cercanos a la zona de estudio, dado que puede ser una fuente de información importante al momento de analizar el registro arqueológico según los objetivos de esta tesis.

Siguiendo la definición propuestas por la Asociación de Mineralogía Internacional, un mineral es un "elemento o compuesto químico que normalmente es cristalino y que se ha formado como resultado de procesos geológicos" (Nickel 2016) ${ }^{1}$. Dentro de la serie mineral, se encuentran aquellos minerales metálicos que pueden ser explotados para la extracción de uno o más metales. Angelelli (1984) distingue dos grupos de procesos metalogénicos según si el ciclo de formación es endógeno (hipogénico) o exógeno (supergénico). Los primeros son un conjunto de procesos ligados a la energía interna de la corteza terrestre como ser la cristalización y segregación magmática, la alteración hidrotermal subterránea y los metamorfismos de contacto (Angelelli 1984; Maksaev 2001). Los procesos exógenos suceden en la superficie terrestre producto de la acción de agentes meteóricos que generan la alteración de los minerales primarios. De esta manera, se forman nuevos minerales producto de la lixiviación y oxidación de los primarios, así como precipitados secundarios por la acción de aguas termales ascendentes (Angelelli 1984; Maksaev 2001). Por ejemplo, respecto a las mineralizaciones de cobre, existen algunos minerales de origen endógenos, como la calcopirita $-\mathrm{CuFeS}_{2}$ - formada por la cristalización del magma. Sin embargo, la mayor parte de los minerales cupríferos se conforman en los ciclos exógenos por procesos de meteorización (como la malaquita- $\mathrm{Cu}_{2}\left[(\mathrm{OH}) \mathrm{CO}_{3}\right]$, azurita- $\mathrm{Cu}_{3}\left[(\mathrm{OH}) \mathrm{CO}_{3}\right]_{2}-$, crisocola $-\mathrm{CuSO}_{3}$, cuprita $-\mathrm{CuO}-\mathrm{y}$ cobre nativo $\left.-\mathrm{Cu}-\right)$ y por migración del cobre en aguas superficiales, que al entrar en contacto con sulfuros hipogénicos favorecen la precipitación de sulfuros secundarios como la calcosina y covelita -CuS- (Angelelli 1984).

\footnotetext{
${ }^{1}$ https://www2.uned.es/cristamine/min_descr/defmin.htm, consultado Octubre 2016
} 
Cuando los depósitos de minerales metálicos presentan grandes concentraciones de un elemento en particular constituyen un yacimiento minero potencialmente explotable para el ser humano. En el lenguaje técnico, se utiliza el término mena para designar al segmento mineral extraído de una mina, valorizado por ser rico en uno o más elementos metálicos que pueden ser separados para su utilización mediante diversos procesos metalúrgicos. Además, los elementos de interés suelen estar acompañados de minerales no deseados que se desechan durante los tratamientos metalúrgicos, estos segmentos del mineral reciben el nombre de ganga (González 2004b).

Los yacimientos metálicos suelen clasificarse de acuerdo a la morfología del depósito. Criterio que al mismo tiempo condicionará el método de explotación. Siguiendo la propuesta de González (González 1992 citado en Angiorama 2001) los minerales metálicos se encuentran en cuatro tipos de yacimientos:

1- Filones o vetas: son depósitos minerales asociados a zonas de fallas o a fisuras de las rocas de caja que son rellenadas por procesos ígneos. Son depósitos subterráneos de formas tubulares que requieren para su explotación la elaboración de galerías. Estas imponen limitaciones en la profundidad de extracción y requieren soluciones técnicas específicas respecto a los mecanismos de iluminación y drenaje hídrico (González 2004b)

2- Capas o mantos: son depósitos originados en cuerpos de agua con una estratificación horizontal, aunque también pueden presentarse plegados debido a movimientos tectónicos.

3- Bolsones, lentes o impregnaciones: son depósitos discretos de formas irregulares.

4- Placeres: yacimientos secundarios generados por procesos de erosión fluvial de los depósitos primarios, los minerales son transportados y depositados en zonas distantes de la roca madre.

Regresando a los depósitos minerales de la región del centro-oeste de Catamarca, y específicamente en el departamento de Belén, encontramos que hacia el este del sitio Quillay se localizan varios de los distritos mineros más importantes y controversiales de 
nuestro país. A menos de $40 \mathrm{~km}$ en línea recta, atravesando la serranía de Belén hacia el este, se encuentran los yacimientos polimetálicos ricos en $\mathrm{Cu}, \mathrm{Au}, \mathrm{Ag}, \mathrm{Mn}$ y $\mathrm{Zn}$ de $\mathrm{La}$ Alumbrera, Farallón Negro y Capillitas, éste último perteneciente al dpto. de Andalgalá (González Bonorino 1950; Angelelli 1984). Hacia el SW, en el sector norte de la sierra de Zapata, cerca del pueblo de Londres y el sitio arqueológico El Shincal, se hallan mineralizaciones de Sn, W y Fe (Angelelli 1984; Lazarte et al. 2006). En sus alrededores, las serranías de Belén, Papachacra y Altohuasi alojan vetas de W, Fe, Pb, Zn, Cu y Topacio, según el caso (Ávila y Lazarte 2010).

El distrito minero de Agua de Dionisio, se encuentra a $12 \mathrm{~km}$ al SE de Hualfín, predominan las mineralizaciones de $\mathrm{Cu}, \mathrm{Pb}, \mathrm{Mo}, \mathrm{Au}$ y $\mathrm{Ag}$ en ganga de cuarzo, producto de zonas de alteración hidrotermal de tobas (Angelelli 1984). Abarca, entre otros, los yacimientos de Alto La Blenda, Farallón Negro, La Alumbrera, Las Pampitas, el Durazno (Gutiérrez et al. 2006) y Veta la Esperanza (Salado Paz et al. 2011). Los sulfuros hidrotermales son los minerales más característicos de las vetas, en especial aquellos con temperaturas de formación medias de entre $150-300^{\circ} \mathrm{C}$ (hipogénicosmesotermales). Entre estos sulfuros primarios se destacan la galena, esferilita, pirita, calcopirita, bornita, arsenopirita, tetraedrita y enargita; presentan asimismo sulfuros secundarios como la calcosina y covalina y carbonatos cupríferos de origen exógeno como la malaquita y azurita (Angelelli 1984; Gutiérrez et al. 2006). Estudios geoquímicos han demostrado que los yacimientos de pórfidos cupríferos son ricos en minerales de $\mathrm{Cu}, \mathrm{Pb}$ y Mo (principalmente en La Alumbrera y Las Pampitas) y en el caso de los sulfuros epitermales abundan los minerales de Au, Ag y As (en Farallón Negro y Alto la Blenda) (Gutiérrez et al. 2002).

En la región de Andalgalá, también existen numerosos depósitos polimetálicos de $\mathrm{Cu}-\mathrm{Au}-\mathrm{Mo}(\mathrm{Ag}, \mathrm{Pb}, \mathrm{Zn})$. El caso más conocido es el yacimiento de Capillitas ubicado sobre el flanco oriental del extremo norte de la sierra homónima y a $55 \mathrm{~km}$ en línea recta desde el sitio Quillay. Presenta principalmente mineralizaciones de $\mathrm{Cu}$ y $\mathrm{Mn}$ con $\mathrm{As}, \mathrm{Sb}, \mathrm{Au}$ y $\mathrm{Ag}$ como elementos accesorios y W, $\mathrm{Sn}, \mathrm{Bi}, \mathrm{Ge}$ como elementos traza (Márquez-Zavalía 2002). Es uno de los depósitos de la provincia más ricos en sulfuros epitermales $\left(<300^{\circ} \mathrm{C}\right)$ alojados en rocas del Complejo Volcánico o graníticas del batolito. Entre los minerales primarios se destacan la pirita, esfalerita, galena, 
calcopirita, marcasita, pirrotina, tennantita, enargita, bornita, estannita y oro. Todos presentan ganga de cuarzo, rodocrosita o toba (Angelelli 1984). En la zona de oxidación de las vetas, la alteración de la mena primaria rica en $\mathrm{Cu}$, favoreció el desarrollo de sulfatos y carbonatos de cobre como la calcosina y covellina. Por otra parte, las mineralizaciones en filones de la región de Capillitas presentan una marcada zonación en los conjuntos minerales de alta sulfuración. Así, en las partes centrales del depósito, como por ejemplo en vetas de Capillitas, Rosario y La Nueve, los minerales ricos en cobre (con proporciones de entre $18-25 \% \mathrm{Cu}$ ) precipitan con una zonación vertical: en la parte superior hay bornita y calcopirita, en la intermedia enargita y tennanita mientras que la pirita aparece en las partes más profundas (Putz et al. 2009). Sin embargo, la proporción de $\mathrm{Cu}$ en estos sulfuros disminuye a medida que aumenta la profundidad alcanzando valores menores al 5\% (Putz et al. 2009). Con respecto al ambiente externo, la zona de oxidación presenta fundamentalmente minerales secundarios de cobre, manganeso y hierro. Entre los primeros se destacan la calcosina, brochantita, linarita, malaquita, azurita, cuprita y cobre nativo. Entre los segundos la pirolusita, romanechita y criptomelano. Los minerales de Fe se oxidan en su mayoría a limonita (Angelelli 1984; Márquez-Zavalía 2002).

Por último, en el departamento de Tinogasta, sobre la franja occidental de la serranía de Fiambalá, hacia el oeste del valle de Hualfín, se encuentra el yacimiento Pachamama con mineralizaciones de baja ley de calcopirita, galena y pirita en ganga de cuarzo, baritina y calcita, con porcentajes que no superan el $4 \%$ de $\mathrm{Cu}$ y $5 \%$ de $\mathrm{Pb}$ (Angelelli 1984).

La explotación minera en estas regiones presenta una extensa continuidad temporal lo que ha dificultado hallar evidencias de extracción minera realizada por las sociedades prehispánicas. A pesar de ello, se dispone de unas pocas referencias que sugieren, aunque de manera indirecta, que estos yacimientos fueron explotados, al menos, durante los periodos prehispánicos tardíos (ca. 1000-1536 dC.). Por ejemplo, en las cercanías a los yacimientos de Farallón Negro y La Alumbrera, se han identificado sitios arqueológicos cuyas evidencias materiales (arquitectura, estilos cerámicos, pinturas rupestres) sugieren una ocupación prehispánica Tardía, este sería el caso para los sitios AL-AR-01, Cueva el Dijunto y Alero el Dijunto 02 (Delfino et al. 2016). Para 
Capillitas, se cuenta con los comentarios publicados por Lafone Quevedo (1980), quien sugirió que este yacimiento fue explotado por las sociedades prehispánicas al identificar a mediado del siglo XIX, herramientas prehispánicas de trabajo minero como martillos líticos o combos; también marayes para la molienda primaria de minerales y "huayras" para la fundición de minerales de cobre, a lo que se le sumarían los numerosos objetos de cobre hallados en la región (Lafone Quevedo 1888: 53,59). Por último, dentro de las fuentes documentales, el Informe del Gobernador de Tucumán Ramírez de Velazco (1938 [1587-1589]) menciona que durante épocas inkaicas fueron explotados los yacimientos mineros disponibles en las inmediaciones del pueblo de Londres (citado en Delfino et al. 2016), ricos en minerales estanníferos.

\subsection{Nuestros primeros relevamientos del sitio arqueológico Quillay.}

En los años 2011 y 2012 se realizaron los primeros trabajos de campo en el sitio arqueológico en el marco de esta investigación. En ellos, las primeras actividades realizadas contemplaron:

- Prospecciones intensivas, detección y georeferenciación de estructuras arqueológicas. El relevamiento fue acompañado con un registro gráfico (croquis) y fotográfico de los hallazgos y zonas inmediatas.

- Levantamiento planialtimétrico del sitio con Estación Total, el mismo fue realizada por el Lic. Gustavo Corrado, antropólogo y topógrafo, con un equipo marca Pentax 315 NX.

- Registro técnico de los recintos contemplando: materia prima, técnica constructiva, morfología, dimensiones, espesores de muros, aberturas y cálculo de superficies.

- Registro morfométrico de los hornos según las siguientes variables: diámetro de base, espesor de las paredes, altura apreciable interna, asociación entre estructuras y estado de conservación junto a otras observaciones consideradas de importancia.

- Recolección de materiales superficiales en el área de los recintos. La misma se realizó tanto en el sector intramuros de cada estructura como en la zona extramuros. Los 
materiales recuperados corresponden en su mayoría a fragmentos de cerámica y en menor medida a materiales refractarios (ver capítulo 5).

Los trabajos posteriores de gabinete estuvieron orientados al procesamiento de los datos relevados y la confección del mapa del sitio mediante programas específicos como Autocad, MapInfo, QGIS, Topocal y Corel Draw. Asimismo, se efectuaron análisis técnicos de los materiales recolectados cuyos resultados serán presentados en el próximo capítulo. A partir de la información obtenida, se definieron las estructuras arqueológicas que fueron objeto de excavaciones en las campañas posteriores de 2012 a 2015, cuyos estudios y resultados serán presentados en el capítulo 6.

\subsection{Mapa del sitio y sectorización del espacio}

En la Figura 4.12 se presenta el nuevo mapa del sitio volcado sobre una imagen Bing georreferenciada para una mejor visualización del terreno donde se emplaza el mismo. Las estructuras arqueológicas relevadas en Quillay, se encuentran desplegadas en un amplio espacio que abarca desde las antiguas terrazas de los ríos Hualfín y Quillay hasta las primeras lomadas del piedemonte occidental de la serranía de Belén. Como hemos remarcado al inicio del capítulo es un terreno que no supera los 1560 msnm. Por otro lado, en la fotografía satelital del mapa, se pueden apreciar grietas o surcos ramificados que en el campo se visualizan como depresiones de gran profundidad, comúnmente denominadas cárcavas, producidas por erosión pluvial. Al igual que los cauces de ríos, los surcos de individuales confluyen y se abren en sentido de la pendiente hacia el río Hualfín.

Para una mejor descripción del sitio, se lo ha dividido en dos sectores sobre la base del tipo de estructura arqueológica predominante en cada área. Por un lado, el Sector $A$ es aquel espacio donde se despliegan los recintos arqueológicos y toda la zona inmediata hacia el este de los mismos. Hipotéticamente podríamos referenciarlo como un sector "habitacional" teniendo en cuenta las propuestas realizadas por González (1980) y Raffino (1996) quienes - como desarrollamos en el capítulo 3- le asignan la función de tambo inkaico. Sin embargo, se hace necesario avanzar en las excavaciones de estas estructuras para analizar los contextos arqueológicos y materiales específicos y 
sus asociaciones para, de esta manera, contrastar la hipótesis propuesta. Este sector se halla a menos de cien metros de la vivienda actual de una familia, siendo la zona arqueológica un espacio lúdico para los niños y de transición durante las actividades cotidianas de los habitantes.

Por otro lado, el Sector $B$ está conformado por los espacios del sitio donde se hallan los hornos metalúrgicos y aquellas áreas con instrumentos de molienda. Debido al tipo de estructuras y materiales superficiales registrados en este sector se lo ha denominado como "productivo", asumiéndolo como un espacio donde se reconocieron evidencias superficiales claras que remiten a actividades específicas dentro del proceso de producción metalúrgica. 


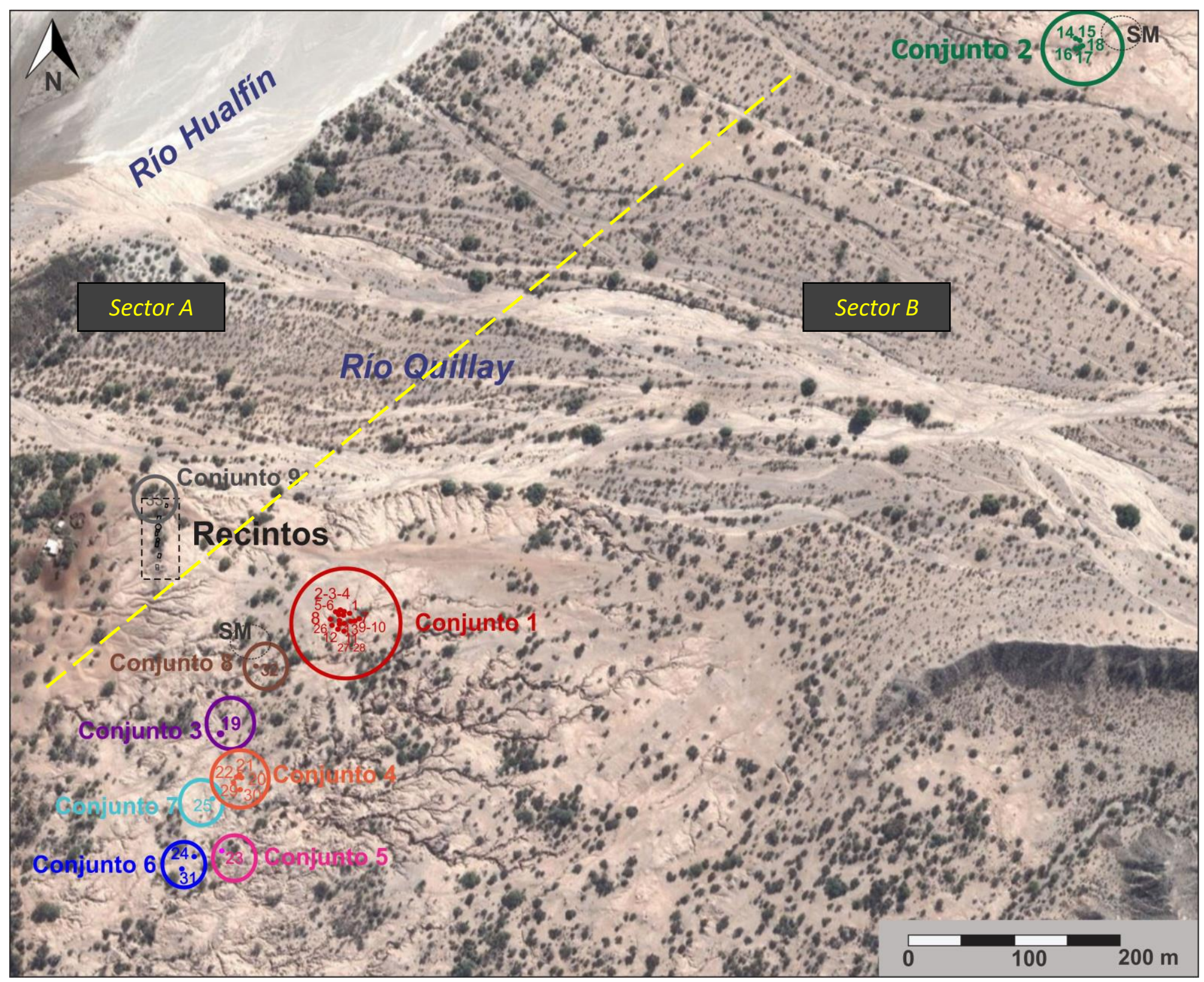

Figura 4.12. Mapa del sitio Arqueológico Quillay. • Hornos; ○ Conjunto de hornos; SM: Sector con instrumentos de molienda 
Por último, señalamos que hacia el noreste del conjunto de hornos 2 , sobre la falda del piedemonte de la serranía de Belén, se han registrado al menos una docena de acumulaciones de rocas, algunas lineales y otras que conforman montículos (Figura 4.13). Respecto a las primeras, las observaciones de campo no han permitido reconocer estructuras cerradas a nivel superficial. En los alrededores se ha detectado abundante material cerámico, principalmente correspondientes a estilos tempranos y tardíos, acordes con la historia ocupacional de la región. Si bien este sector no fue objeto de estudio de la presente investigación, queremos dar cuenta de la existencia de estas estructuras cuyo estudio podrá ser abordado en próximos trabajos.
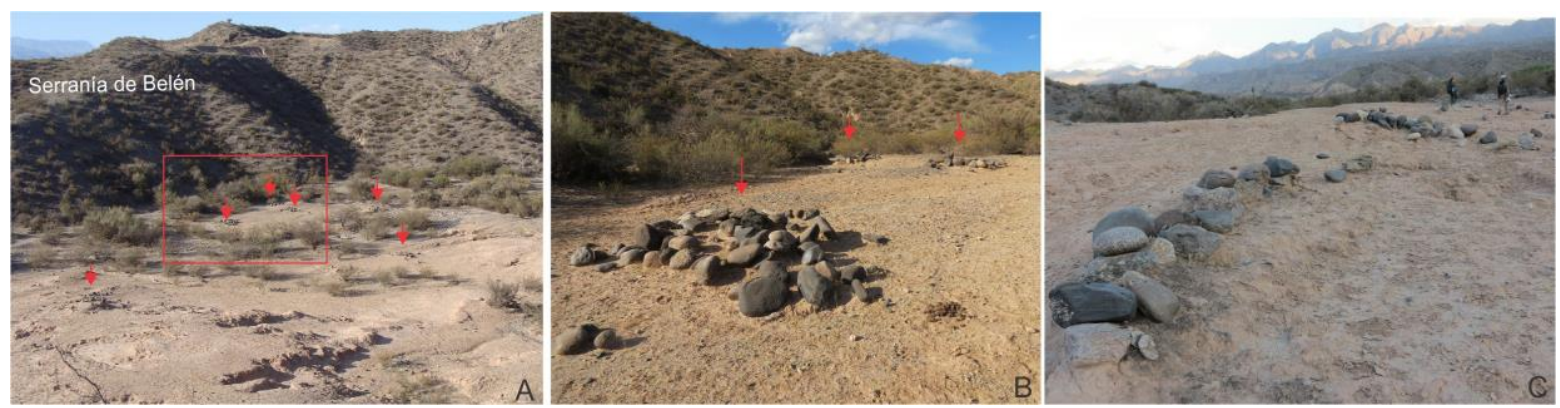

Figura 4.13. A. Zona de estructuras arqueológicas cercanas a la serranía de Belén. B. Estructuras monticulares (ampliación del cuadrado señalado la foto A; C. Estructuras lineales

\subsubsection{Sector A: descripción de los recintos}

Este sector posee un conjunto de 12 unidades arquitectónicas: 8 recintos y 4 estructuras anexas. La distinción entre ambos tipos de unidades radica en el reconocimiento de muros internos transversales que segmentan la arquitectura de los recintos mayores. De esta manera, los anexos son los pequeños espacios resultantes de dicha segmentación, que quedan adosados a recintos mayores y no presentan aberturas que comuniquen al exterior. Al conjugar el tipo de estructura con la morfología de las plantas, las unidades arquitectónicas del sector A fueron agrupadas en tres categorías:

1- Recintos rectangulares con uno o dos anexos (R2, R4 y R8)

2- Recintos cuadrangulares y rectangulares simples (R1, R6 y R7)

3- Recintos circulares (R3 y R5) 
Los recintos presentan una configuración espacial con un marcado alineamiento cardinal N-S de los muros arquitectónicos (Figura 4.14 y Figura 4.15). También, en el campo se observó que estas estructuras se encuentran construidas sobre montículos de aproximadamente dos metros de altura (Figura 4.16).

El recinto 1 es la estructura más septentrional dispuesta a $18 \mathrm{~m}$ de la unidad más próxima. Sin embargo, actualmente la separación está dada por una cárcava de más de $4 \mathrm{~m}$ de profundidad que contiene numerosos rodados y tiestos cerámicos. Los recintos 2, 3 y 4 son contiguos entre sí, es decir, comparten segmentos de los muros de los extremos, lo cuales se encuentran adosados (siguiendo el eje E-O). A casi dos metros le continúan los recintos 5 y 6 también contiguos y le siguen hacia el sur los recintos 7 y 8 con una distancia aproximada de $6 \mathrm{~m}$ entre ellos.

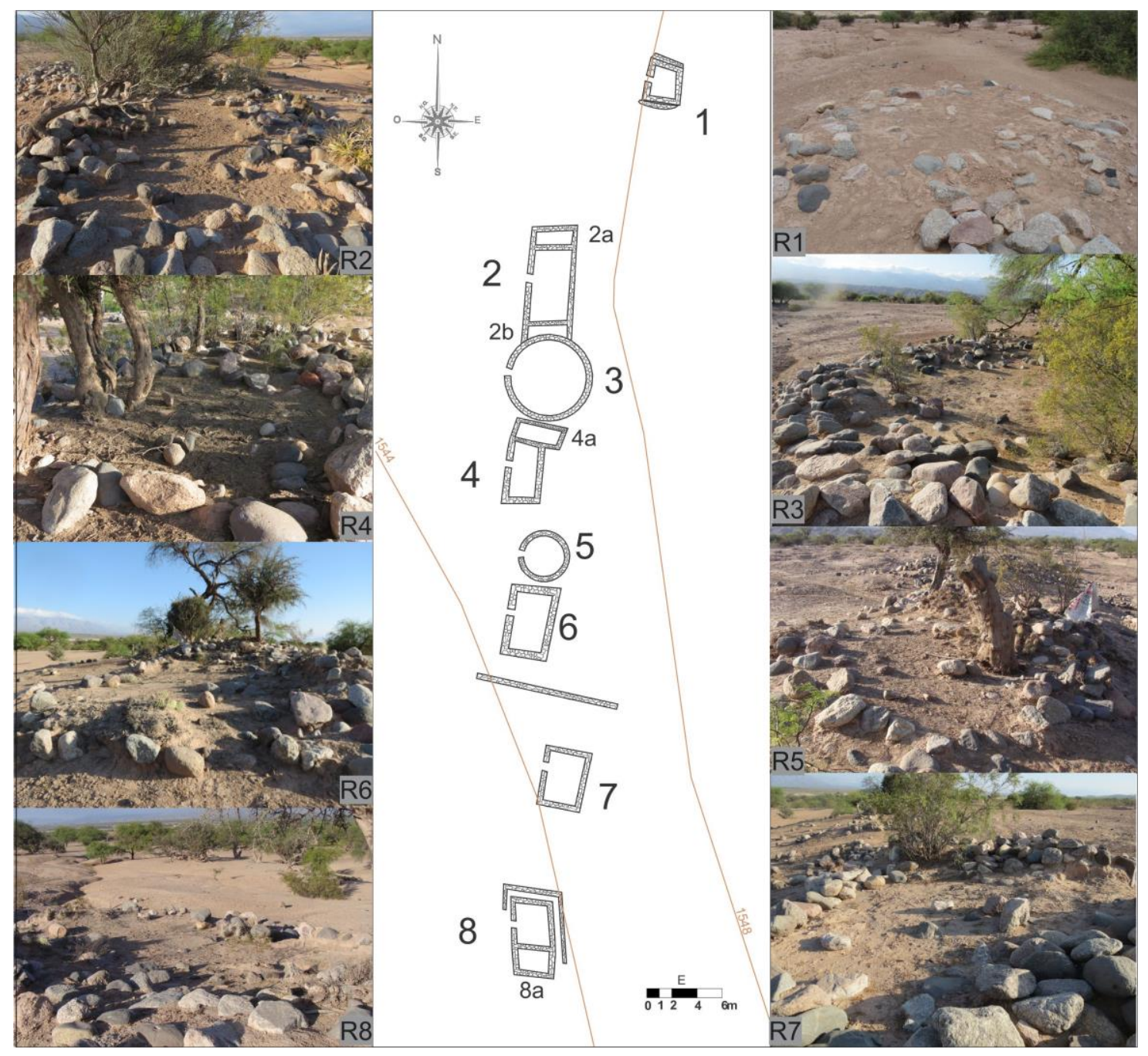

Figura 4.14. Mapa del sector A y fotografías de los recintos arqueológicos. 
Con respecto a las técnicas arquitectónicas, todas las estructuras del sector fueron construidas con rocas de tamaños regulares, conformando muros de tipo doble con relleno de argamasa (Figura 4.17). Sólo dos de los recintos (R1 y R8) presentan muros de contención, posiblemente para asegurar la estructura frente a la pendiente del terreno generada por los montículos. Otro punto a destacar es que las aberturas de todos los recintos están orientadas hacia el oeste con vanos de acceso de entre 0,30 y 0,60 m de ancho (ver Tabla 4.1).

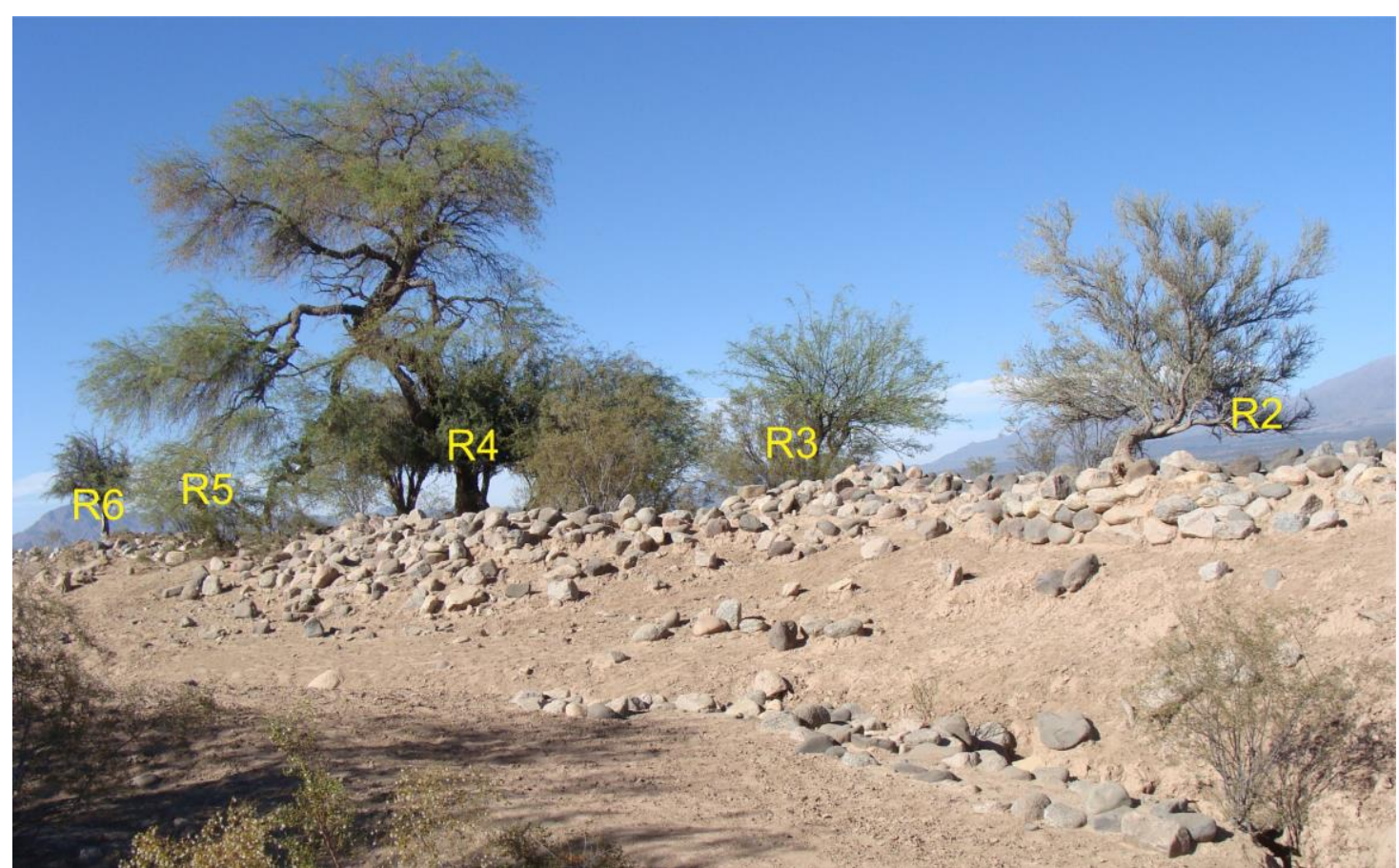

Figura 4.15. Recintos arqueológicos, se observa el alineamiento N-S. Foto tomada desde el este por la mañana.

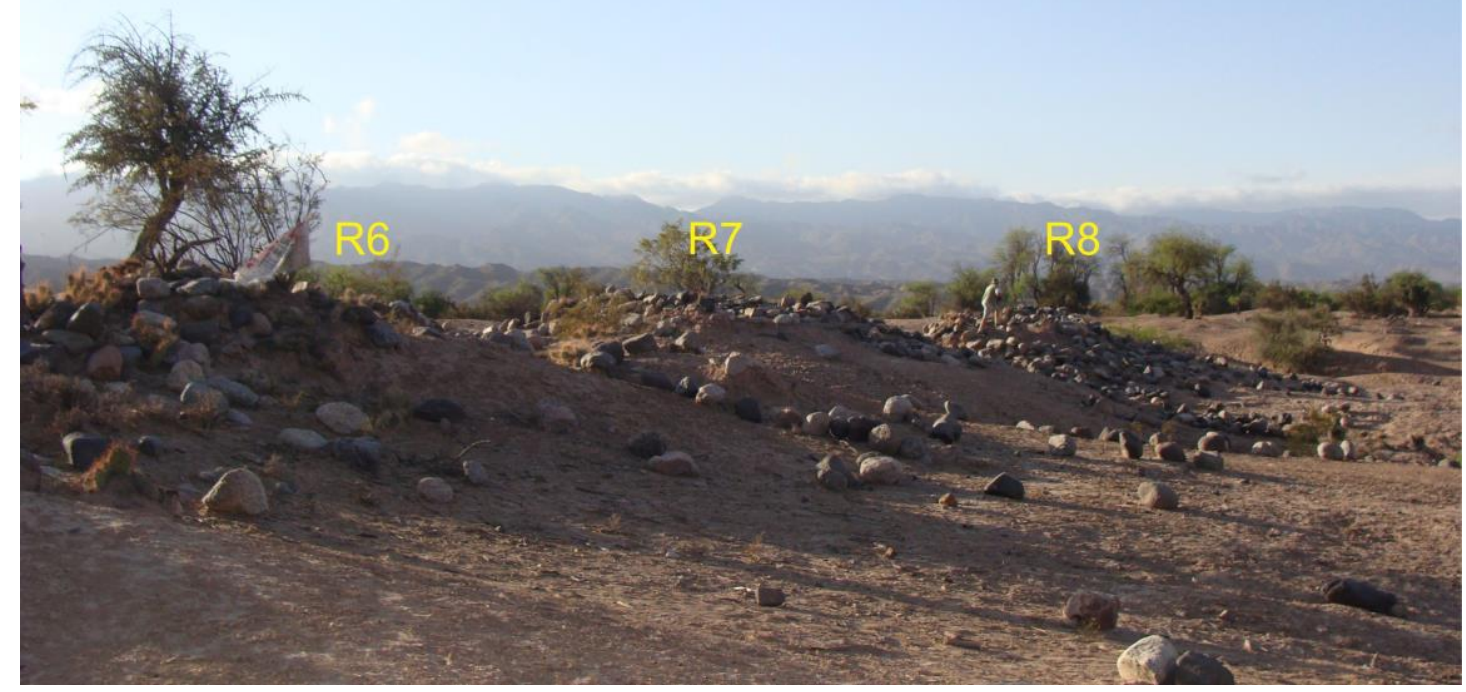

Figura 4.16. Recintos arqueológicos, se observa el alineamiento N-S. Foto tomada desde el oeste por la mañana. 
Las rocas de muro no presentan ningún tipo de canteado, son rodados tipo "piedra bocha" y bloques mayores con gran regularidad en sus tamaños lo que sugiere una selección de la materia prima, posiblemente proveniente de los ríos cercanos. Las observaciones en el campo permitieron identificar que las rocas utilizadas son principalmente andesitas y granitos de coloraciones grises, rosadas y blanquecinas, ampliamente disponibles en la geología local.
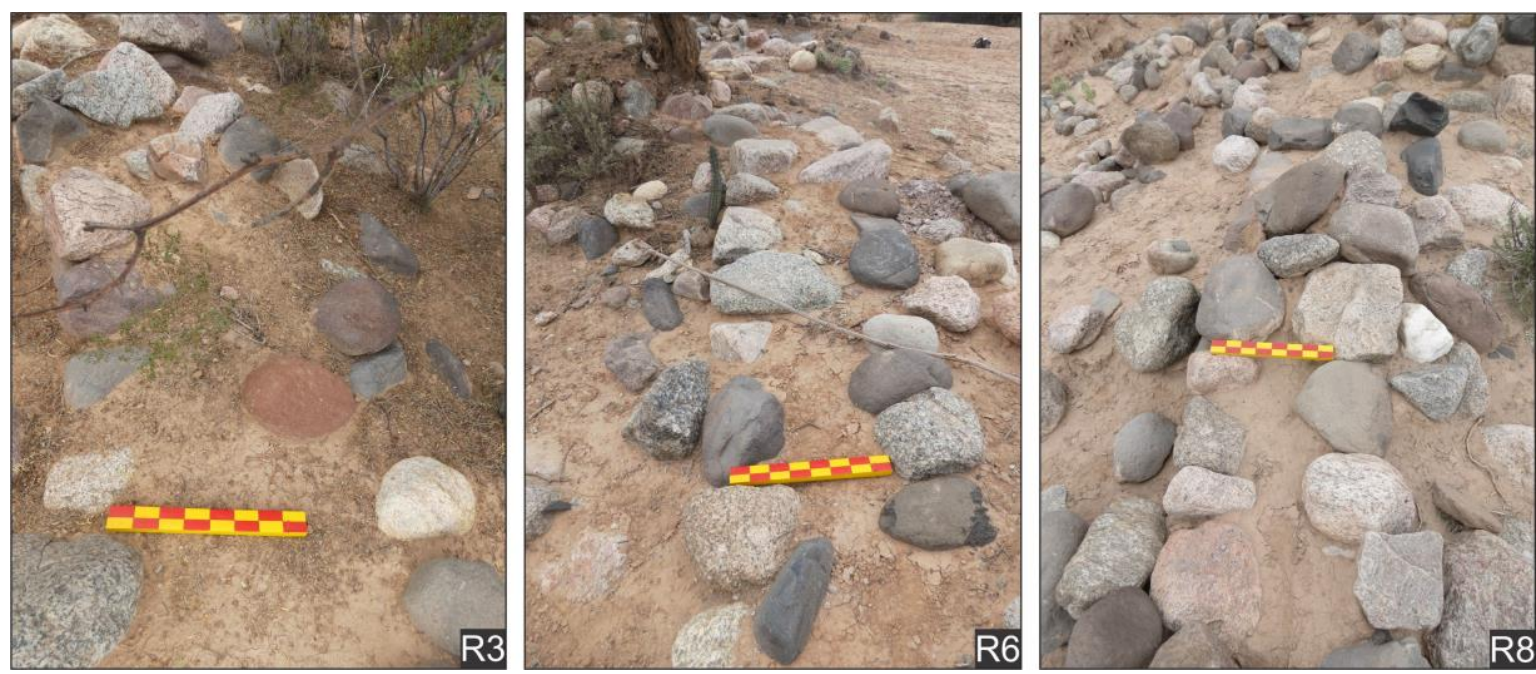

Figura 4.17. Muros dobles con relleno de un recinto circular (R3) y dos rectangulares (R6 y R8). Cada unidad de escala representa $5 \mathrm{~cm}$.

En la actualidad, se han conservado sólo dos o tres hileras de rocas superpuestas que conforman los muros arqueológicos superficiales (Figura 4.18), hallándose numerosas rocas dispersas en un amplio sector más allá de los límites de los recintos que serían parte de los muros originales. Sin embargo, a partir de la fotografía del recinto excavado por González en 1952 (González 1959) y de conversaciones con los lugareños, es posible que en el pasado los muros alcanzaran alturas de $2 \mathrm{~m}$. La destrucción observada en los muros arqueológicos se debe principalmente a acciones de "reclamación", es decir cuando los objetos arqueológicos son reutilizados por personas, incorporándose así a un nuevo contexto sistémico (Schiffer 1991: 40, 2010: 38). Esta acción quedó evidenciada en la utilización de rocas de los muros arqueológicos como materias primas para la construcción de las viviendas actuales. También la disposición original de las rocas ha sido modificada al ser el sector utilizado como espacio recreativo por los niños de la familia. 

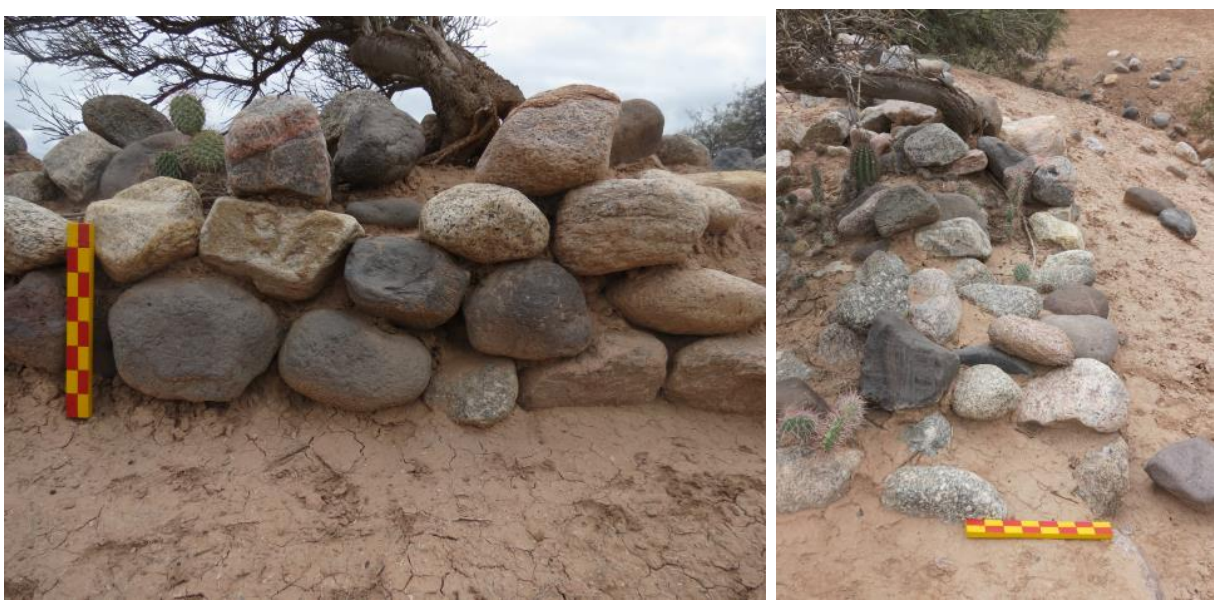

Figura 4.18. Pared externa (izquierda) y muro doble del R2. Cada unidad de escala representa $5 \mathrm{~cm}$.

Respecto a las dimensiones de los recintos, en la Tabla 4.1 se presentan las medidas máximas calculadas. Se puede observar que los recintos angulosos presentan tamaños bastante regulares y dimensiones pequeñas, con superficies $\left(\mathrm{L}^{*} \mathrm{~A}\right)$ que en su mayoría no superan los $10 \mathrm{~m}^{2}$. Excepto los recintos R2 y R4 que abarcan un área de $18 \mathrm{~m}^{2}$ y $15 \mathrm{~m}^{2}$ respectivamente, siendo así, las estructuras rectangulares de mayor tamaño. En el caso de los recintos, las paredes de mayor longitud siempre son aquellas que se proyectan siguiendo el eje cardinal N-S. Sus muros poseen espesores de entre 0,50 y 0,80 m y en aquellos con anexos, éstos mantienen el espesor del muro lateral del recinto al cual se conectan. Con respecto a los recintos circulares, poseen dimensiones distintas, abarcando el mayor (R3) una superficie $\left(\pi^{*} \mathrm{r}^{2}\right)$ de $21 \mathrm{~m}^{2}$ y el menor (R5) de $8 \mathrm{~m}^{2}$, con muros de entre 0,60 y $0,90 \mathrm{~m}$ de espesor. 


\begin{tabular}{|c|c|c|c|c|c|c|c|c|c|c|}
\hline \multicolumn{11}{|c|}{ Sitio Quillay - Sector $A$} \\
\hline \multirow[b]{2}{*}{$\mathrm{N}^{\circ}$ Recinto } & \multirow[b]{2}{*}{ Morfología } & \multicolumn{3}{|c|}{ Dimensiones interior (m) } & \multirow{2}{*}{$\begin{array}{c}\text { Superficie } \\
\left(\mathrm{m}^{2}\right)\end{array}$} & \multirow{2}{*}{$\begin{array}{c}\text { Espesor } \\
\text { Muros (m) }\end{array}$} & \multirow[b]{2}{*}{ Tipo muros } & \multicolumn{2}{|c|}{ Accesos } & \multirow{2}{*}{ Observaciones } \\
\hline & & Eje N-S & Eje E-W & Radio & & & & Orientación & $\begin{array}{l}\text { Ancho } \\
\text { (m) }\end{array}$ & \\
\hline R1 & Cuadrangular & 2,2 & 2,1 & - & 4,62 & 0,66 & Doble con relleno & Oeste & 0,4 & $\begin{array}{l}\text { Muros dobles de } \\
\text { contención }\end{array}$ \\
\hline R2 & Rectangular & 6 & 3 & - & 18 & $0,79 / 0,8$ & Doble con relleno & Oeste & 0,6 & $\begin{array}{c}\text { Se observa altura } \\
\text { pared externa con } \\
\text { rodados }\end{array}$ \\
\hline $\mathrm{R} 2 \mathrm{a}$ & Rectangular & 1,2 & 3 & - & 3,6 & 0,78 & Doble con relleno & $\mathrm{s} / \mathrm{a}$ & - & Anexo \\
\hline $\mathrm{R} 2 \mathrm{~b}$ & Rectangular & 1 & 3 & - & 3 & 0,79 & Doble con relleno & $\mathrm{s} / \mathrm{a}$ & - & Anexo \\
\hline R3 & Circular & - & - & 3 & 28,26 & $0,84 / 0,9$ & Doble con relleno & Oeste & $0,5 / 0,3$ & \\
\hline R4 & Rectangular & 5,1 & 3 & - & 15,3 & 0,72 & Doble con relleno & Oeste & 0,45 & \\
\hline $\mathrm{R} 4 \mathrm{a}$ & Rectangular & 1,2 & 3,3 & - & 3,96 & $0,72 / 0,7$ & Doble con relleno & $\mathrm{s} / \mathrm{a}$ & - & Anexo \\
\hline R5 & Circular & - & - & 1,6 & 8,04 & $0,6 / 0,7$ & Doble con relleno & Oeste & $0,5 / 0,3$ & \\
\hline R6 & Rectangular & 4,2 & 2,7 & - & 11,34 & $0,76 / 0,78$ & Doble con relleno & Oeste & 0,3 & \\
\hline R7 & Rectangular & 4 & 2,7 & - & 10,8 & 0,57 & Doble con relleno & Oeste & 0,55 & \\
\hline R8 & Rectangular & 3 & 2,5 & - & 7,5 & 0,7 & Doble con relleno & Oeste & 0,45 & $\begin{array}{l}\text { Muros dobles de } \\
\text { contención }\end{array}$ \\
\hline R8a & Rectangular & 1,8 & 2,5 & - & 4,5 & 0,5 & Doble con relleno & $\mathrm{s} / \mathrm{a}$ & - & Anexo \\
\hline
\end{tabular}

Tabla 4.1. Características relevadas de las estructuras del sector A

Es importante remarcar que tres de estos recintos fueron excavados por González en la década de 1950. Uno de ellos fue el recinto circular de mayores dimensiones (R3) y otros dos rectangulares, de los cuales el investigador brinda la siguiente información sobre su excavación: "dos habitaciones de planta rectangular $(2,1$ por $3,4 \mathrm{~m})$ y $(6,3$ por $3,3 \mathrm{~m})$. Produjeron únicamente cerámica de tipo Belén” (González 1959: 84). En el campo, se ha observado que los recintos R2 y R6 presentan menor potencia sedimentaria y están más limpios de rodados. Estas observaciones, sumado a la similitud en los datos métricos registradas por nosotros con aquellos brindados por González, posibilitan inferir que estos recintos fueron los intervenidos oportunamente, por lo cual no fueron contemplados en nuestros trabajos de excavación. Con respecto a los materiales recuperados en la excavación realizada por González, únicamente se ha podido tener acceso a los fragmentos cerámicos originarios del recinto circular, los cuales fueron sujetos a una revisión y serán presentados en el próximo capítulo.

Por último, a partir de nuestros estudios arqueológicos en el sector A, se ha detectado una estructura de barro cocido identificada en el flanco de la cárcava que separa los recintos 1 y 2 (Figura 4.19). Es un horno con paredes de coloración rojo-anaranjado de 8 $\mathrm{cm}$ de espesor máximo. Sus paredes son curvas y conforman una cámara de 1,12 $\mathrm{m}$ de 
diámetro y $0,85 \mathrm{~m}$ de altura. En su interior se observó una gruesa capa de carbón y cenizas de 0,12 $\mathrm{m}$ de espesor que apoya sobre la base y luego sedimentos fango-arenosos de relleno. Como veremos más adelante, esta estructura posee características morfométricas y constructivas similares a los hornos identificados en el sector $B$. Por lo cual, ha sido clasificada siguiendo el criterio empleado para las unidades del otro sector. Así, por el momento, y hasta no avanzar en su excavación, fue catalogada como horno n³3 del conjunto $\mathrm{n}^{\circ} 9$.

Por otro lado, en el espacio abierto hacia el este de los recintos y a la altura del R3, se identificó un sector con tierra rubificada por temperatura con sedimento ceniciento. Allí se pudieron delimitar segmentos más compactos y termoalterados que sugieren una forma circular (ver foto 8 en Anexo IV).

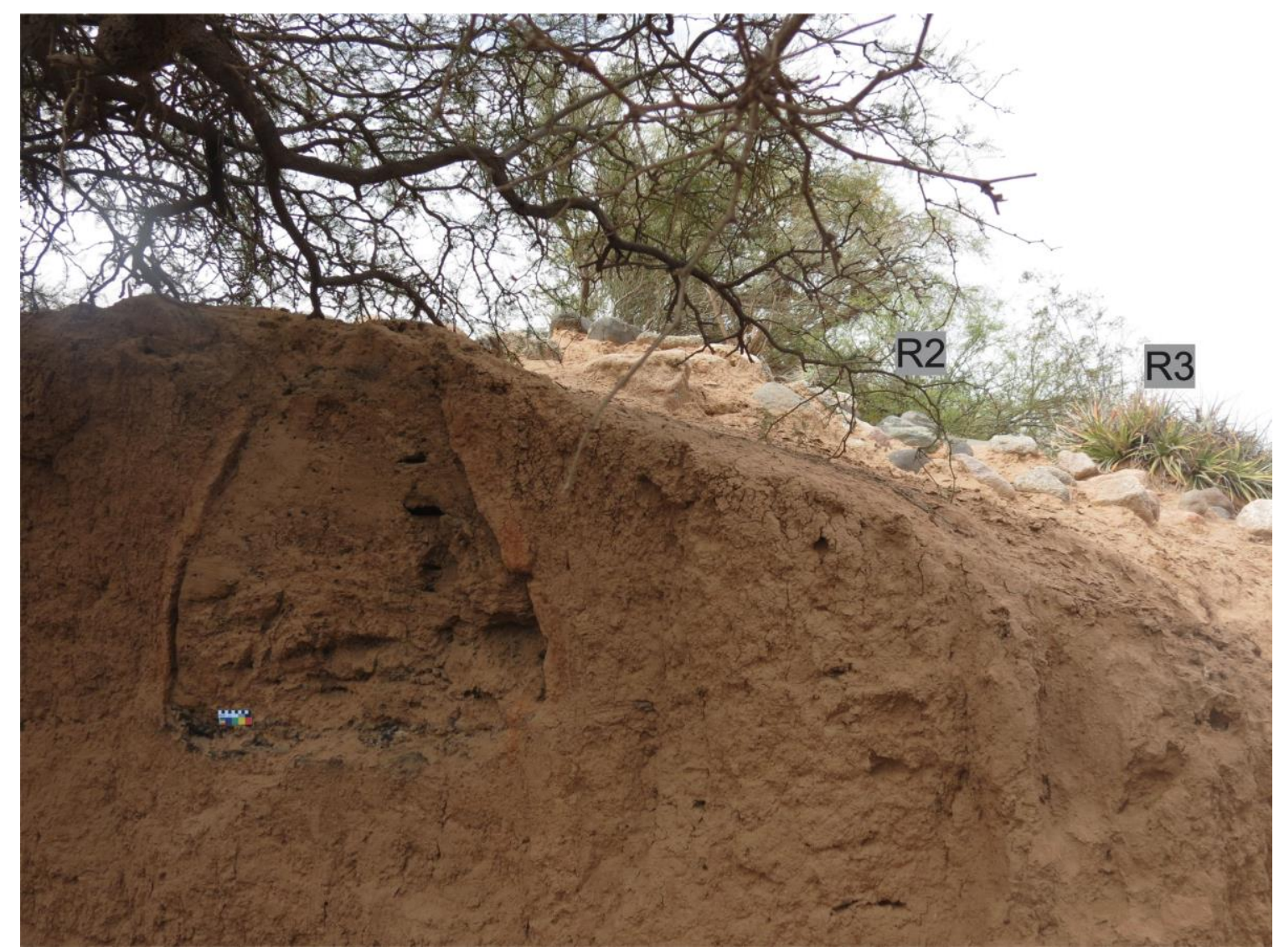

Figura 4.19. Horno $\mathrm{n}^{\circ} 33$. Se observa su localización sobre el perfil de la cárcava y la cercanía a los recintos. 


\subsubsection{Discusión sobre la arquitectura de los recintos}

Como fue descrito, en el sitio encontramos recintos con plantas angulosas y otros circulares, ambas clases construidas con técnicas arquitectónicas similares. En el primer caso, presentaron formas cuadrangulares y rectangulares con anexos. Algunas de estas unidades fueron seleccionadas para su excavación por lo que en el próximo capítulo se avanzará sobre la interpretación funcional de los recintos. Teniendo en cuenta las restantes estructuras del sitio y su cercanía al sector $B$, se parte de la hipótesis que los espacios rectangulares servirían para la habitación de personas y para el desarrollo de actividades relacionadas a la producción metalúrgica.

Respecto a los recintos circulares, es posible que se trate de estructuras de depósito denominadas qollqas. Son espacios destinados exclusivamente al almacenamiento de recursos vegetales y/o productos manufacturados (cerámica, textiles, metales). Se ha planteado que este mecanismo de concentración de productos responde a lógicas organizativas propias del Tawantinsuyu basados en principios de reciprocidad, hospitalidad y redistribución (González 1980; Williams et al. 2005) que implican la construcción planificada de estos depósitos (Raffino 2007). Si bien no se han realizado mayores estudios en los recintos circulares de Quillay, las similitudes en la forma de las plantas, dimensiones y técnicas constructivas con aquellas qollqas conocidas para diversas regiones del Tawantinsuyu, posibilita realizar este diagnóstico preliminar (Williams 1995; Tarragó y González 2003; Cremonte et al. 2005; Raffino 2007). Según estos informes, consisten en bases de piedra circulares de 2 a $5 \mathrm{~m}$ de diámetro, que sólo excepcionalmente adquieren dimensiones mayores, como en el caso del sitio Hualfín Inka (Raffino 2007; Lynch 2013) localizado a $26 \mathrm{~km}$ hacia el norte de Quillay. Por lo tanto, desde un punto de vista estrictamente arquitectónico, es probable que al menos el recinto circular (R5) de Quillay se trate de una estructura para el almacenamiento. Sin embargo, esta hipótesis deberá ser testeada en futuras investigaciones mediante excavaciones.

Al comparar el patrón de asentamiento, trazado urbano y técnicas arquitectónicas presentes en Quillay con la información disponible para otros sitios del valle de Hualfín y aledaños, tanto de momentos de tardío e inkaico, el sector A presenta algunas 
características distintivas respecto a la configuración del espacio. Si bien no se han reconocido las clásicas estructuras arquitectónicas del Tawantinsuyu, como ushnu, RPC, plazas o kallankas, cierta regularidad en las dimensiones de los recintos, pero principalmente, la orientación de los vanos exclusivamente hacia el $\mathrm{O}$ y el alineamiento de los recintos en sentido N-S, parecerían responder a una estandarización que remite a una configuración planificada del espacio en íntima relación con los puntos cardinales y por lo tanto con los cuerpos celestes. Incluso, exactamente hacia el E de los recintos de Quillay, resalta entre las elevaciones de la serranía de Belén, el Cerro Pampa con una altitud de $3266 \mathrm{msnm}$.

Dichas características en la configuración del sitio Quillay, sugieren una planificación que remite a lógicas espaciales inkaicas, donde su concepción del mundo fue expresada en múltiples alineamientos asociados a diferentes fenómenos astronómicos o determinados hitos en el paisaje (Zuidema 1981; Hyslop 1980; Pino Matos 2004). Orientaciones astronómicas de unidades arquitectónicas de distinta clase, en especial de los muros de las estructuras ceremoniales o ushnus, han sido registradas en los sitios con planificación Inka para valle de Hualfín y aledaños como El Shincal de Quimivil (Lynch et al. 2010; Giovannetti 2015b)

Esta situación contrasta con los datos arquitectónicos registrados en los poblados locales del periodo Tardío en este valle (Wynveldt 2009; Balesta et al. 2011; González Dubox et al. 2011). Estos estudios describen sitios con asentamientos conglomerados con indicios defensivos y la existencia de algunos recintos aislados en zonas de baja pendiente. Además, especifican que los recintos fueron construidos con materias primas locales combinando lajas verticales y horizontales junto a rodados de granito. Se aprecia que existe gran variabilidad en los tipos de muros que han sido utilizados, combinando muros simples, dobles y en terraplén (Wynveldt 2009; Balesta et al. 2011; González Dubox et al. 2011). Sin embargo, ninguno de ellos presenta una orientación prefijada ni en la distribución de los recintos en el espacio, ni en la orientación de sus aberturas, situaciones que contrastan con las observadas en Quillay. 


\subsubsection{Sector B: descripción del espacio productivo}

El sector $B$ abarca un amplio espacio de más de 7 hectáreas de terreno en donde se registraron 32 hornos metalúrgicos y áreas de molienda, distribuidos hacia el NE y S-SE del sector $A$ (ver Figura 4.12 más arriba). Entendemos por "horno" a una estructura de combustión semi-cerrada o cerrada. Son cámaras térmicas con un diseño particular que le posibilita cumplir determinadas funciones. En este caso, fueron empleados para el desarrollo de actividades relacionadas al procesamiento de minerales o de metales, dadas la presencia de abundantes escorias metalúrgicas hacia el interior de las estructuras y en sus alrededores.

Para realizar una descripción detallada y ordenada de los hornos metalúrgicos, se los ha agrupado en conjuntos de hornos $(\mathrm{CH})$ en base a criterios de proximidad entre los ejemplares. Así, cada conjunto está conformado por hornos que se encuentran a menos de $25 \mathrm{~m}$ de distancia entre sí, en alguna dirección cardinal. Como se puede observar en el mapa del sitio (Figura 4.12) se han establecido ocho conjuntos de hornos en el sector $B$ y un noveno en el sector $A$. En la Tabla 4.2 se enumeran los hornos que pertenecen a cada conjunto del sector productivo. Se aclara que algunos conjuntos poseen hornos con una numeración no secuencial, debido a que fueron reconocidos y georreferenciados en las últimas campañas, al quedar expuestos en la superficie gracias a la remoción natural de sedimentos. Además, frente a la posibilidad de detectar otros ejemplares en futuras prospecciones, se decidió continuar la numeración iniciada en las primeras campañas para evitar que cada nuevo hallazgo conduzca a una reasignación, lo que dificultaría a futuros investigadores reconocer cada horno en particular.

\begin{tabular}{|c|c|}
\hline $\mathbf{N}^{\circ}$ CONJUNTO & $\mathbf{N}^{\circ}$ HORNOS \\
\hline 1 & $1,2,3,4,5,6,7,8,9,10,11,12,13,26,27,28$ \\
\hline 2 & $14,15,16,17,18$ \\
\hline 3 & 19 \\
\hline 4 & $20,21,22,29,30$ \\
\hline 5 & 23 \\
\hline 6 & 24,31 \\
\hline 7 & 25 \\
\hline 8 & 32 \\
\hline
\end{tabular}

Tabla 4.2. Hornos que conforman cada conjunto. 
Durante el relevamiento de los hornos, se observaron, describieron y cuantificaron las partes morfológicas de cada ejemplar. Asimismo, con el fin de diagnosticar el estado actual de conservación de las estructuras metalúrgicas se examinó el segmento y la proporción de horno preservado en superficie, cuantificándose las siguientes medidas: diámetro de la base, altura interna y espesor de las paredes. Se establecieron así tres grados de conservación:

- Grado 1 (G1): son aquellas estructuras que presentan buen estado de conservación, pudiendo observarse en superficie y cuantificarse gran parte de la misma. Estos ejemplares preservan la totalidad de su base y sus paredes con una altura mayor a $20 \mathrm{~cm}$.

- $\quad$ Grado 2 (G2): son aquellos con un estado de conservación regular, presentan sólo su base mientras que sus paredes se hallan apenas insinuadas o muy fragmentadas. Se incluyen aquí aquellos hornos que han sufrido el desmoronamiento longitudinal de la mitad de su estructura.

- $\quad$ Grado 3 (G3): se agrupan aquí aquellos hornos en mal estado de conservación ya que han perdido prácticamente la totalidad de su estructura, conservándose pequeños segmentos identificados a partir de la presencia de escorias, carbones, fragmentos de pared termoalterados y por su asociación contextual a otros ejemplares.

\subsubsection{Conjunto 1}

Es el conjunto de hornos más cercano al sector $A$, ubicado a $285 \mathrm{~m}$ al SE respecto al Recinto 1. Está conformado por 16 ejemplares de hornos, algunos de los cuales se tratan de aquellos publicados por los investigadores previos (Raffino et al. 1996). A partir de la comparación de fotografías, su ubicación y descripción, pudimos individualizar algunos de los ejemplares reconocidos previamente y se identificaron otros nuevos. Así, nuestro horno 1 (H1) se corresponde con el número 3 de Raffino; el H9 y H10 con el 4 y 2 respectivamente; el $\mathrm{H} 11$ con el 8 y posiblemente nuestros $\mathrm{H} 2, \mathrm{H} 3, \mathrm{H} 4$ y $\mathrm{H} 5$ sean aquellos numerados como 5, 6, 7 y 12 dada su ubicación en ambos mapas. 
El espacio físico en el cual se emplazan estos hornos está surcado por numerosas y profundas cárcavas en cuyos flancos se disponen el $56 \%$ de los ejemplares $(n=9)$. Esta zona también presenta gran cantidad de árboles, principalmente algarrobos y chañares, cuya madera, posiblemente, hayan servido como combustible (Figura 4.20 y 4.21).

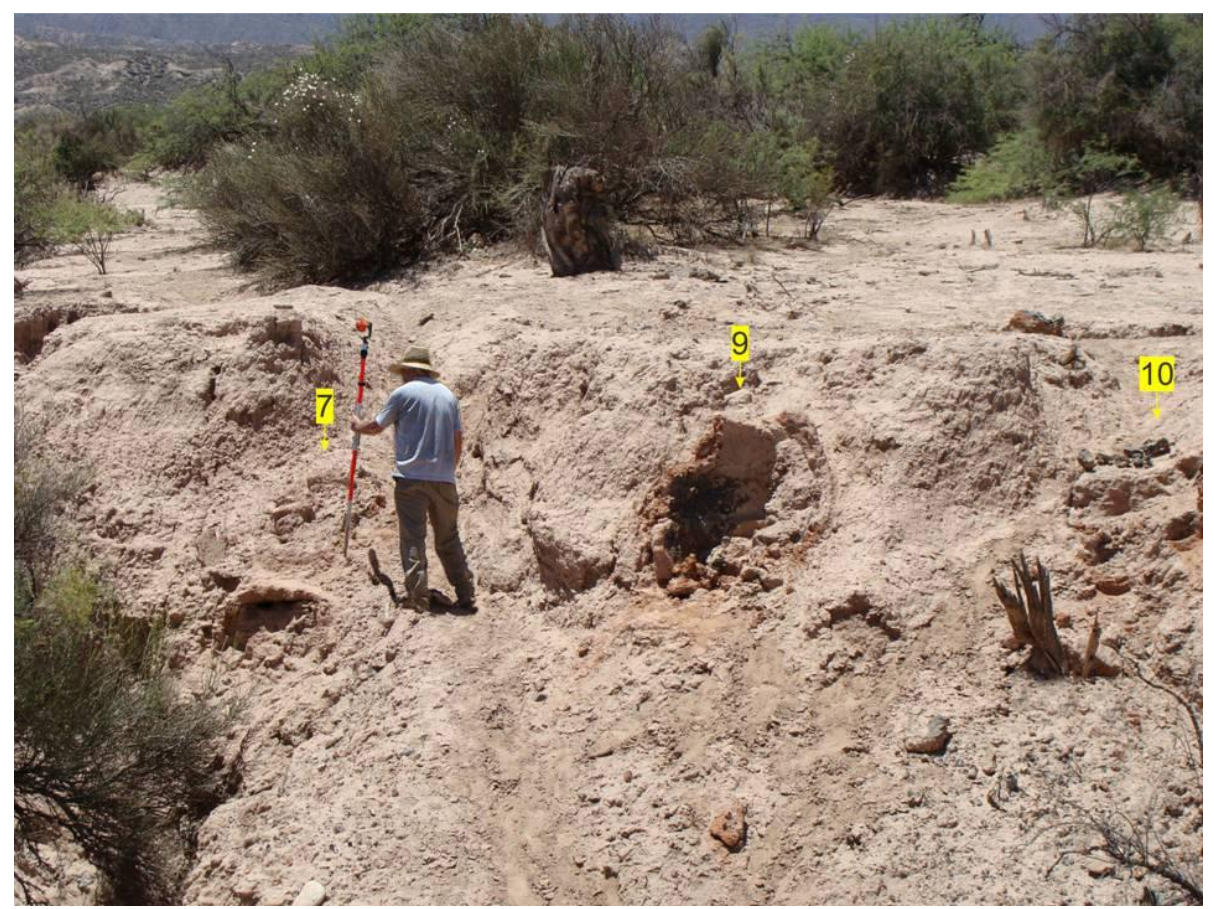

Figura 4.20. Conjunto de Hornos 1, ejemplares localizados muy cerca de la cárcava.

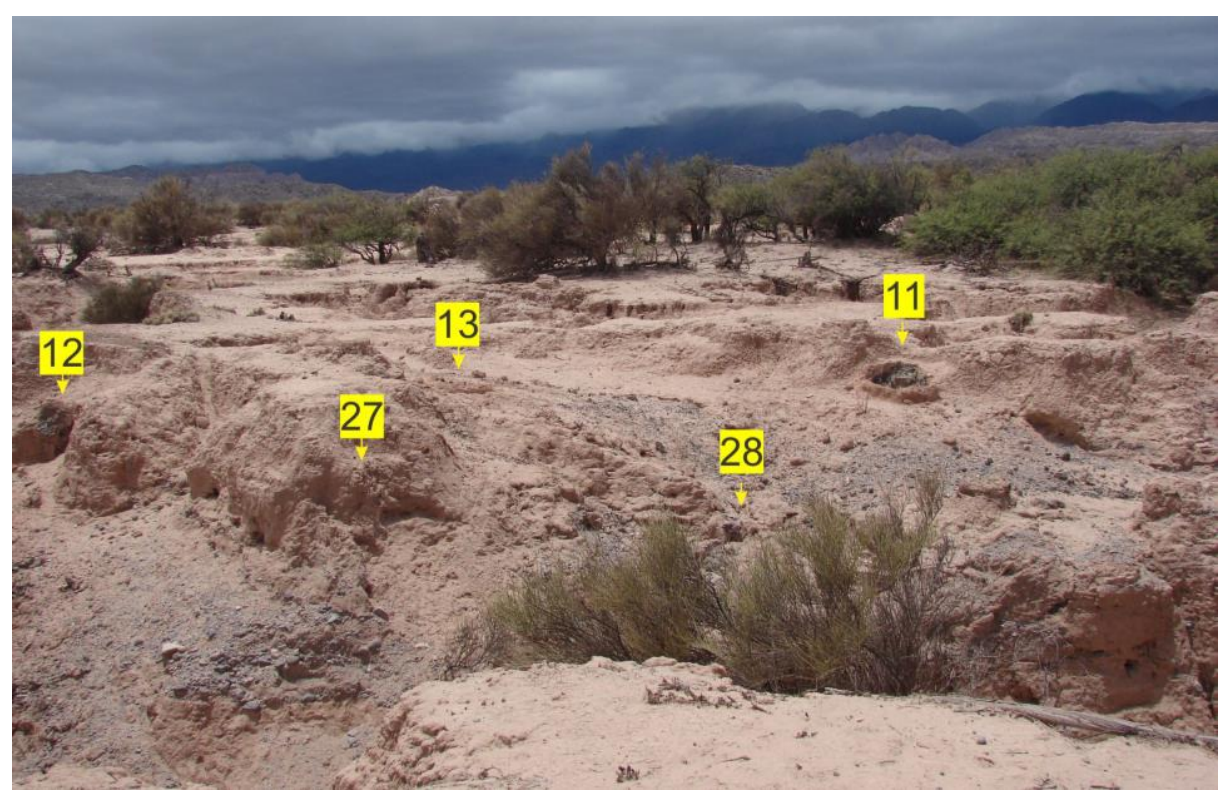

Figura 4.21. Conjunto de Hornos 1, los ejemplares 12, 27 y 28 se localizan sobre el perfil de la cárcava. Presentan un mal estado de conservación. 
Cada horno es una estructura individual e independiente, separada de otras por unos pocos metros. Sólo en tres casos $(\mathrm{H} 2, \mathrm{H} 3$ y H4) sus bases se encuentran adosadas conformando una especie de "ramillete", aunque cada estructura mantiene su individualidad morfológica (ver foto 9 - Anexo IV). El estado de conservación de los ejemplares de este conjunto va de regular (G2) a malo (G3). Aquellos que se disponen en ramillete apenas exponen su base, mientras que los restantes preservan mayores segmentos de sus paredes que han permitido registrar las dimensiones de espesores y alturas observables en superficie (Tabla 4.3).

A pesar de presentar estados variables de conservación, se observó que todos los hornos mantienen una base circular con paredes que se elevan y curvan levemente hacia el interior conformando una estructura tubular-cónica abierta (Figura 4.22 y 4.23). Sus diámetros internos varían entre $90 \mathrm{~cm}$ y $130 \mathrm{~cm}$, y las paredes presentan espesores de entre $9 \mathrm{~cm}$ y $11 \mathrm{~cm}$. Todas las partes observadas de los hornos están conformados por un material cocido de coloración rojiza.

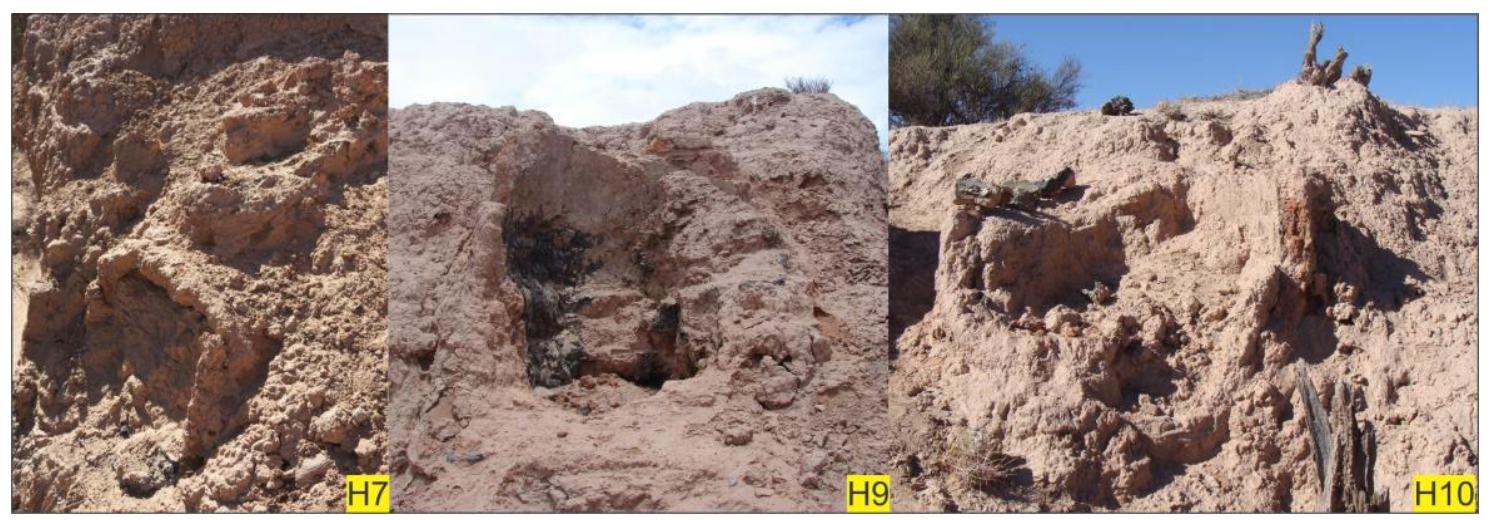

Figura 4.22. Hornos 7, 9 y 10 del conjunto 1. Detalles de la morfología.

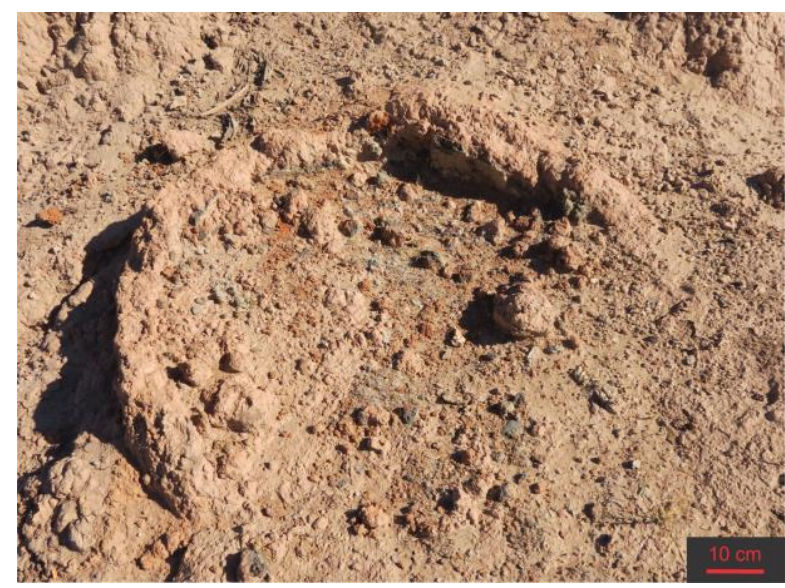

Figura 4.23. Hornos 13 del conjunto 1, se observa su base circular y las paredes insinuadas. 
En los hornos 3 y 11 se han reconocido circunferencias, estando en el primer caso delimitado por material vítreo (Figura 5.24). Asimismo, se han detectado gruesas capas de material fundido negro con tonalidades verdes, a simple vista identificadas como escoria; numerosos fragmentos de pared de horno rodeando algunos ejemplares, escorias de forma arriñonada en los alrededores e incluso una capa de ceniza y carbón por debajo del H1, observada en el perfil de la cárcava.
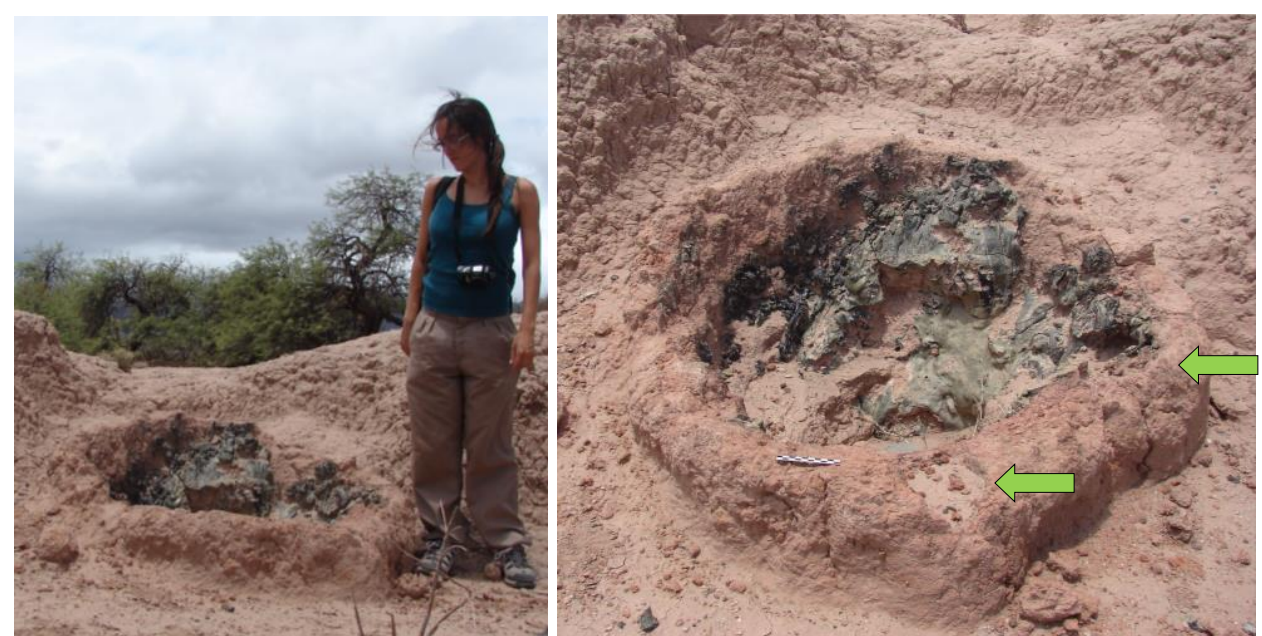

Figura 4.24. Horno $n^{\circ} 11$, la persona sirve de escala (izquierda). A la derecha las flechas señalan las circunferencias.

\begin{tabular}{|c|c|c|c|c|}
\hline $\begin{array}{c}\mathrm{N}^{\circ} \\
\text { Horno }\end{array}$ & $\begin{array}{c}\text { Diámetro } \\
(\mathrm{cm})\end{array}$ & $\begin{array}{c}\text { Altura } \\
(\mathrm{cm})\end{array}$ & $\begin{array}{c}\text { Espesor } \\
\text { Pared }(\mathrm{cm})\end{array}$ & $\begin{array}{c}\text { Grado de } \\
\text { conservación }\end{array}$ \\
\hline 1 & 100 & 18 & 9 & G2 \\
\hline 2 & - & - & 9 & G3 \\
\hline 3 & - & - & 10 & G3 \\
\hline 4 & - & - & 11 & G3 \\
\hline 5 & - & - & 10 & G3 \\
\hline 6 & - & - & 10 & G3 \\
\hline 7 & 107 & - & 11 & G2 \\
\hline 8 & - & 50 & - & G3 \\
\hline 9 & 130 & 110 & 11 & G2 \\
\hline 10 & 108 & 44 & 9 & G2 \\
\hline 11 & $105 / 110$ & 66 & 10 & G2 \\
\hline 12 & - & - & - & G3 \\
\hline 13 & 110 & - & 10 & G2 \\
\hline 26 & 105 & - & 10 & G2 \\
\hline 27 & - & - & - & G3 \\
\hline 28 & 90 & - & 11 & G2 \\
\hline
\end{tabular}

Tabla 4.3. Características de los hornos del conjunto 1. 


\subsubsection{Conjunto 2}

Este conjunto está compuesto por cinco hornos (H14 al H18) localizados a $934 \mathrm{~m}$ al NE del recinto 1, atravesando el cauce del río Quillay. Los hornos se despliegan en una zona libre de cárcavas. Probablemente esta característica haya aportado a una buena preservación de las paredes.

Los hornos se ubican en el terreno en forma de dos grupos enfrentados, delimitando un espacio central donde se identificaron desechos materiales (ver foto 13 y 14 - Anexo IV) como escorias fluidas, fragmentos de pared de hornos y acumulaciones de carbón y ceniza. Con relación a estos últimos, un dato llamativo es la regularidad en su ubicación. Se midió la distancia de la zona central de cada montículo respecto de los hornos. Así, uno de ellos se localizó a 3,2 m hacia el $\mathrm{N}$ de los H17 y H18 (cercanos entre sí) y el mismo montículo mantenía una distancia de 3,3 m hacia el O desde el H16 (Figura 4.25). El segundo montículo observado se halló a la misma distancia, pero hacia el $\mathrm{S}$ respecto al H14. También en las inmediaciones se registraron y recolectaron abundantes fragmentos cerámicos que serán analizadas en el capítulo 6.

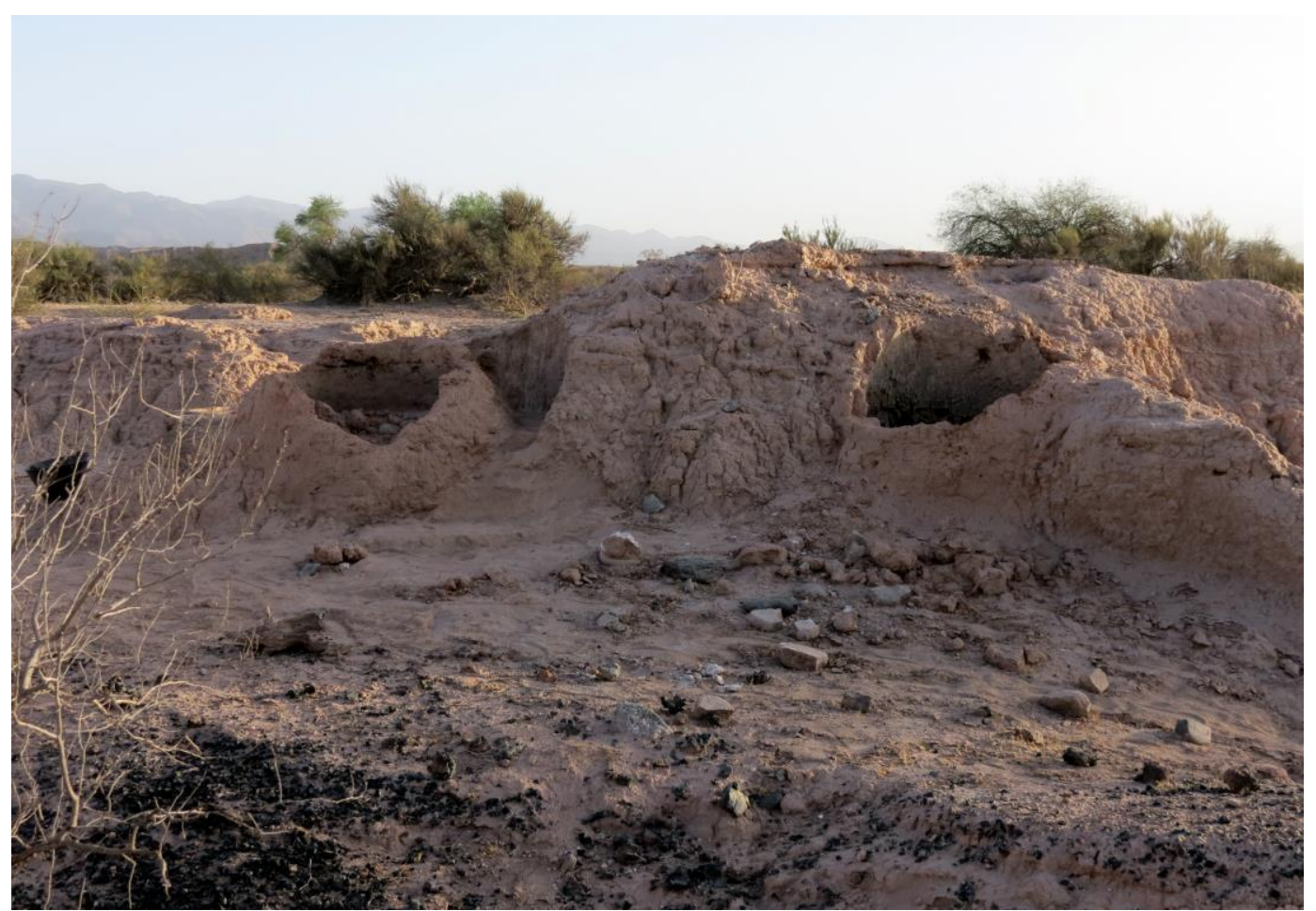

Figura 4.25. Hornos $n^{\circ} 16$ (derecha) y 17 (izquierda) del conjunto $n^{\circ} 2$. En primer plano se observan montículos de carbón, cenizas y fragmento de pared. 
La morfología de los hornos de este conjunto respeta el patrón descrito previamente, confirmando aquí también la presencia de estructura de base circular con paredes altas que, en el extremo superior, se curvan hacia el interior a la manera de un cono, finalizando en una abertura horizontal superior que alcanza aproximadamente $50 \mathrm{~cm}$ o $60 \mathrm{~cm}$ de diámetro (Figura 5.26 y 5.27). Los hornos presentan una mayor estandarización en sus dimensiones con diámetros de bases cercanos a un metro, alturas observables en torno a los $60 \mathrm{~cm}$ y espesores de $10 \mathrm{~cm}$ (Tabla 4.4).

\begin{tabular}{|c|c|c|c|c|}
\hline $\begin{array}{c}\mathrm{N}^{\circ} \\
\text { Horno }\end{array}$ & $\begin{array}{c}\text { Diámetro } \\
(\mathrm{cm})\end{array}$ & $\begin{array}{c}\text { Altura } \\
(\mathrm{cm})\end{array}$ & $\begin{array}{c}\text { Espesor } \\
\text { Pared }(\mathrm{cm})\end{array}$ & $\begin{array}{c}\text { Grado de } \\
\text { Conservación }\end{array}$ \\
\hline 14 & 110 & 60 & 10 & G1 \\
\hline 15 & 105 & 47 & 10 & G1 \\
\hline 16 & 110 & 67 & $8-10$ & G1 \\
\hline 17 & 100 & 67 & 8 & G1 \\
\hline 18 & 98 & 48 & $8-11$ & G1 \\
\hline
\end{tabular}

Tabla 4.4. Características de los hornos del conjunto 2.

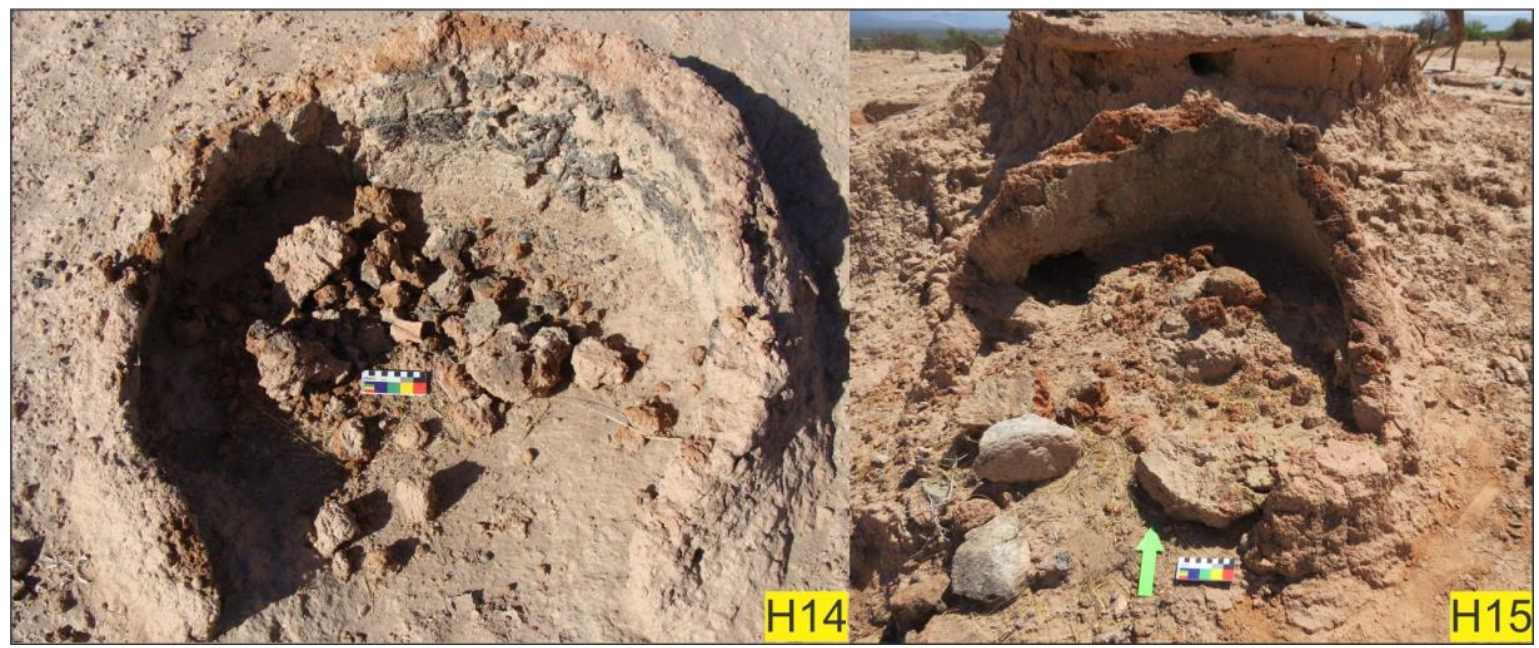

Figura 4.26. Hornos septentrionales del conjunto $n^{\circ} 2$, se observa su morfología y un buen estado de conservación.

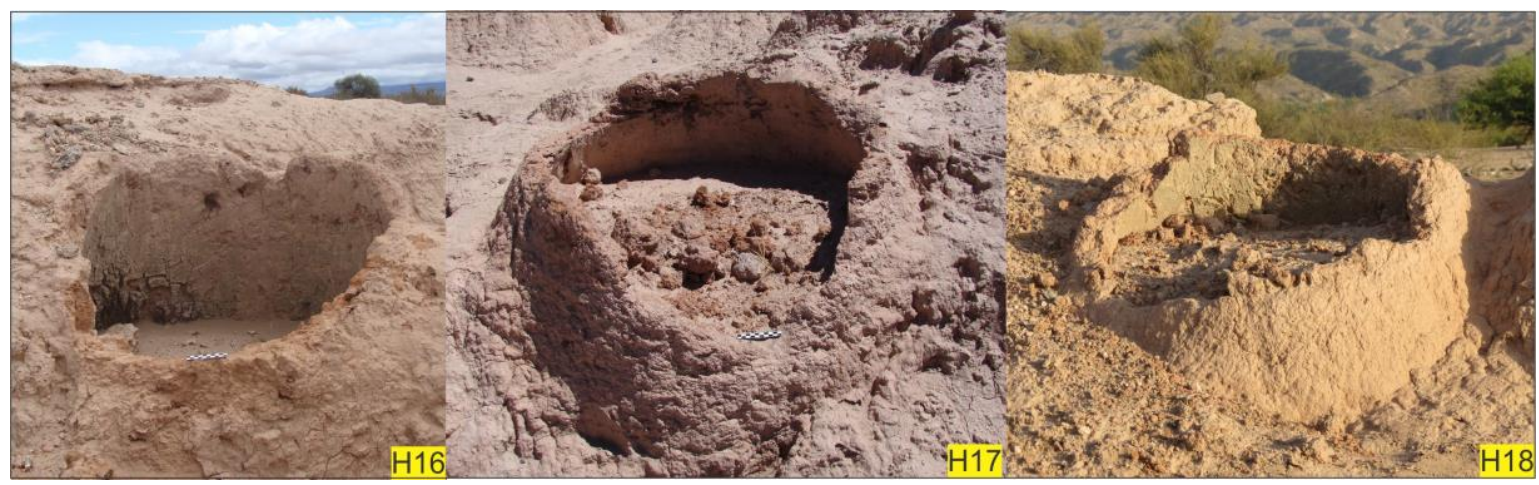

Figura 4.27. Hornos del conjunto $\mathrm{n}^{\circ} 2$, se observa su morfología y un buen estado de conservación. 
En este sector, otro punto a destacar es la presencia de un espacio con instrumentos de molienda a poco más de 40 m hacia el noreste del H15 (SM en Figura 5.12). Allí se registraron morteros transportables de granito y andesita, la mayoría con oquedades en forma de cúpula y en un sólo caso la oquedad se mostraba elongada horizontalmente (sensu Giovannetti 2015a). También se hallaron fragmentos de manos de moler y martillos líticos (Figura 4.28 y 4.29). Si bien no fue posible reconocer vestigios minerales o metales que posibiliten asociarlos indefectiblemente a actividades relacionadas con la producción. Es posible pensar, dada su cercanía a los hornos, su empleo en el marco de las actividades Desarrolladas en el sector.

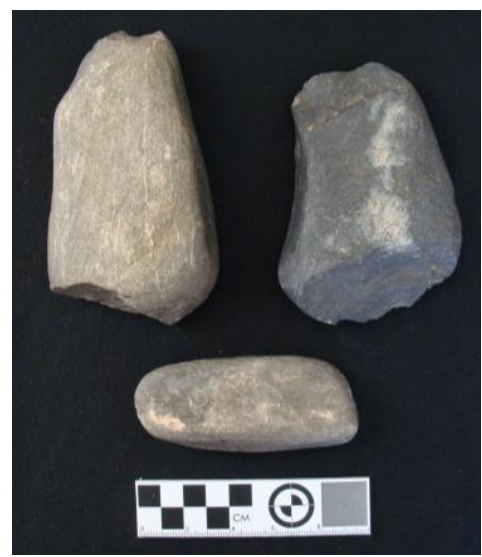

Figura 4.28. Martillos líticos del sector de molienda cercano al $\mathrm{CH} 2$.

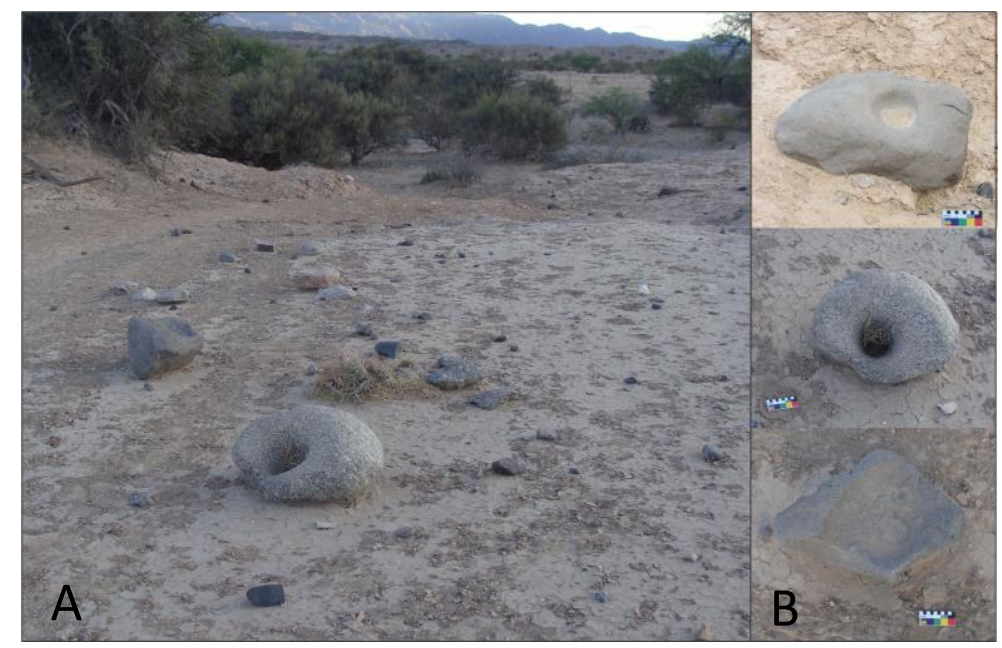

Figura 4.29. A. Sector con instrumentos de molienda cercanos al $\mathrm{CH} 2$. B. Detalles de morteros móviles con oquedades cupuliformes y elongadas.

\subsubsection{Conjunto 3}

En dirección S-SE desde los recintos se ubican varios conjuntos que se componen algunos de ellos de un solo ejemplar. Casualmente, éste es uno de esos casos, ubicado a $395 \mathrm{~m}$ al SE del recinto 1 y a $115 \mathrm{~m}$ al S del conjunto 8. Este ejemplar rotulado como H19, 
presenta gran parte de su estructura destruida, visualizándose en la superficie la circunferencia de su base (Tabla 4.5 y Figura 4.30).

\begin{tabular}{|c|c|}
\hline Medidas (cm.) & Horno 19 \\
\hline Diámetro & 107 \\
\hline Altura & - \\
\hline Espesor & 9 \\
\hline $\begin{array}{c}\text { Grado de } \\
\text { Conservación }\end{array}$ & G3 \\
\hline
\end{tabular}

Tabla 4.5. Características del CH3

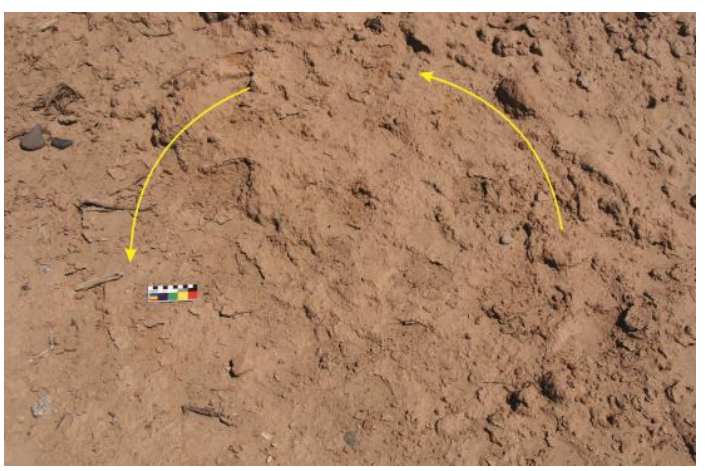

Figura 4.30. Silueta del Horno n 19.

\subsubsection{Conjunto 4}

Se trata de cinco hornos: H20, H21, H22, H29 y H30. Los primeros tres están orientados en dirección E-O separados entre sí por una distancia de 0,73 m entre el H21 y $\mathrm{H} 22$ y de 2 m respecto al H20. Los otros dos ejemplares se proyectan hacia el SE y se disponen enfrentados a los primeros, delimitando un espacio central, situación similar a la observada en el conjunto 2. Incluso, en ese espacio también se identificaron acumulaciones regulares de cenizas y carbón que conforman montículos de aproximadamente 1,5 $\mathrm{m}$ de diámetro. Uno de ellos se aloja a 3,3 m hacia el sur desde los H21 y H22; otro se reconoció a 3 m hacia el sudeste del $\mathrm{H} 20$ y un tercer montículo se halló a poco más de dos metros hacia el sur del H29 (Figura 4.31).
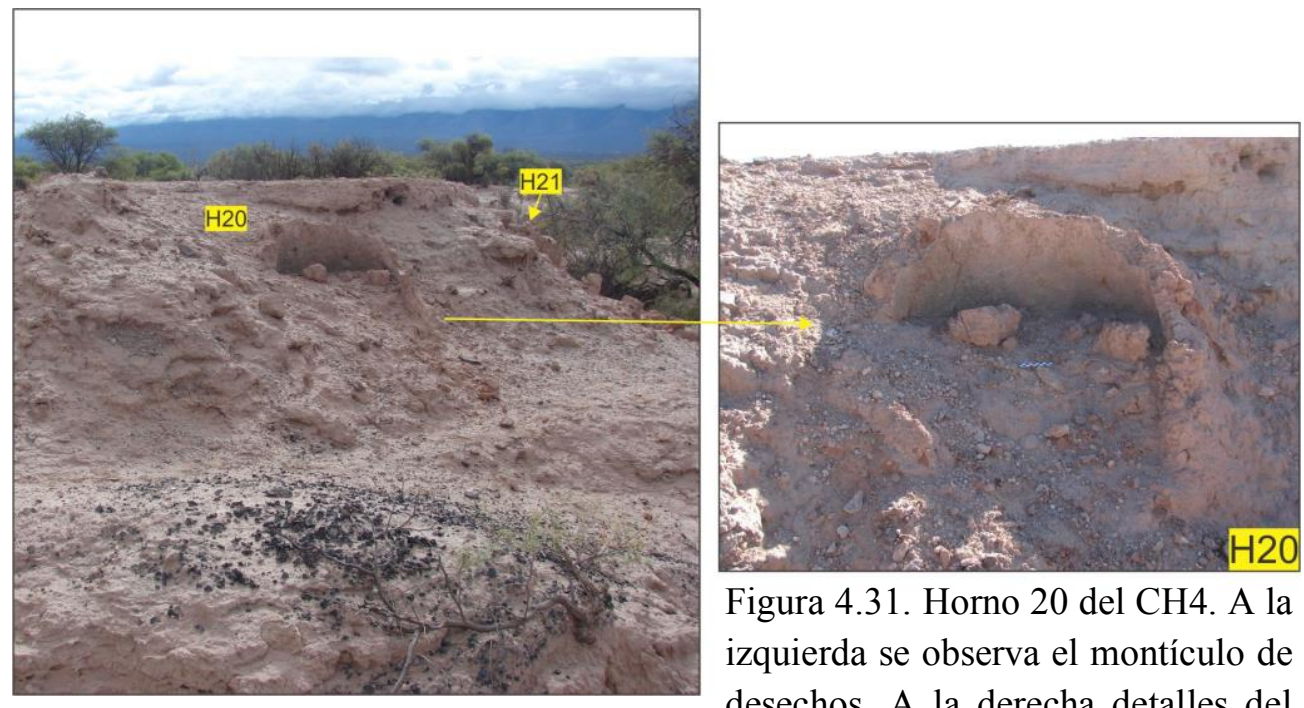

Figura 4.31. Horno 20 del CH4. A la izquierda se observa el montículo de desechos. A la derecha detalles del ejemplar. 
La preservación de dos ejemplares es buena lo que permitió registrar todos sus valores métricos (Figura 4.32). Sin embargo, los otros tres presentan sus paredes muy fragmentadas, incluso el H30 apenas exhibe la circunferencia de la base, hallándose abundantes restos de pared en los alrededores. En ningún caso, dada la deposición de sedimento, pudo observarse restos de escoria hacia el interior de los hornos, pero sí se registraron en sus alrededores. Como indica la Tabla 4.6, los hornos de este conjunto presentan bases que rondan el metro de diámetro con espesores de $10 \mathrm{~cm}$ en promedio y alturas variables dependiendo de la acumulación de sedimento en el interior y del grado de fragmentación de las paredes.

\begin{tabular}{|c|c|c|c|c|}
\hline $\begin{array}{c}\mathrm{N}^{\circ} \\
\text { Horno }\end{array}$ & $\begin{array}{c}\text { Diámetro } \\
(\mathrm{cm})\end{array}$ & $\begin{array}{c}\text { Altura } \\
(\mathrm{cm})\end{array}$ & $\begin{array}{c}\text { Espesor } \\
\text { Pared }(\mathrm{cm})\end{array}$ & $\begin{array}{c}\text { Grado de } \\
\text { conservación }\end{array}$ \\
\hline 20 & 100 & 38 & 10 & G1 \\
\hline 21 & 113 & 54 & 9 & G2 \\
\hline 22 & 108 & 40 & 10 & G1 \\
\hline 29 & 75 & 30 & 11 & G2 \\
\hline 30 & $96 / 100 ?$ & - & 10 & G3 \\
\hline
\end{tabular}

Tabla 4.6. Características de los hornos del conjunto 4.

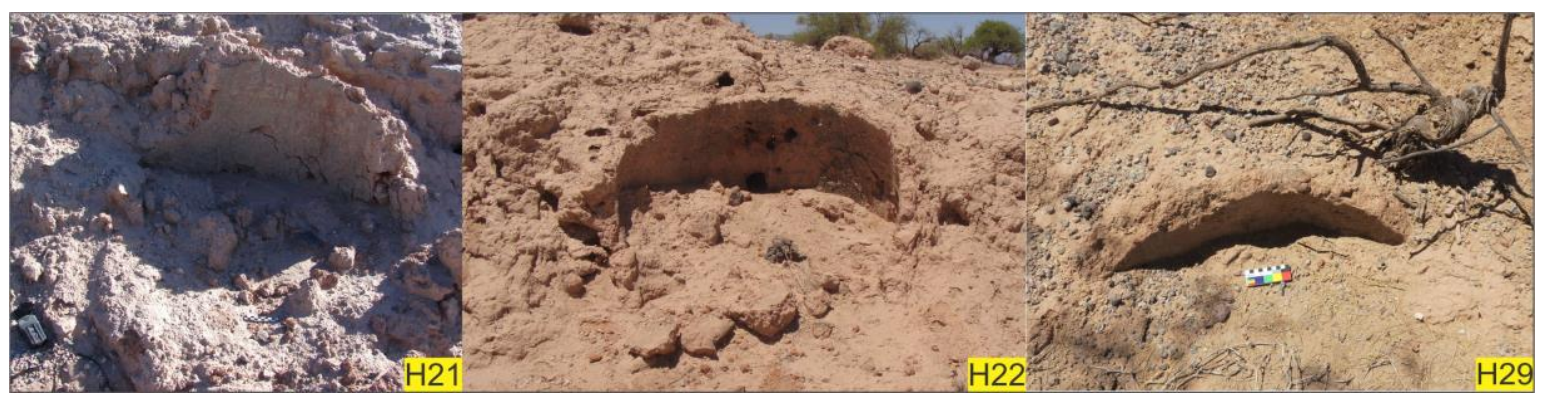

Figura 4.32. Hornos del conjunto $n^{\circ} 4$.

\subsubsection{Conjunto 5}

Se conforma por un único horno (H23) dispuesto a poco más de 128 m en dirección SO del conjunto anterior y a $596 \mathrm{~m}$ al $\mathrm{SE}$ respecto al recinto 1 del sector $\mathrm{A}$. Lamentablemente sus paredes se encuentran prácticamente destruidas, observándose sólo el diámetro de la base circular de $102 \mathrm{~cm}$ y las paredes insinuadas con espesores aproximados de $6 \mathrm{~cm}$ (Tabla 4.5 y Figura 4.33). En sus alrededores se detectaron fragmentos de las mismas y desechos metalúrgicos que ayudaron en el campo a la identificación de vestigios de hornos. 


\begin{tabular}{|c|c|}
\hline Medidas (cm.) & Horno 23 \\
\hline Diámetro & 102 \\
\hline Altura & - \\
\hline Espesor & 6 \\
\hline $\begin{array}{c}\text { Grado de } \\
\text { Conservación }\end{array}$ & G3 \\
\hline
\end{tabular}

Tabla 4.5. Características del CH5.

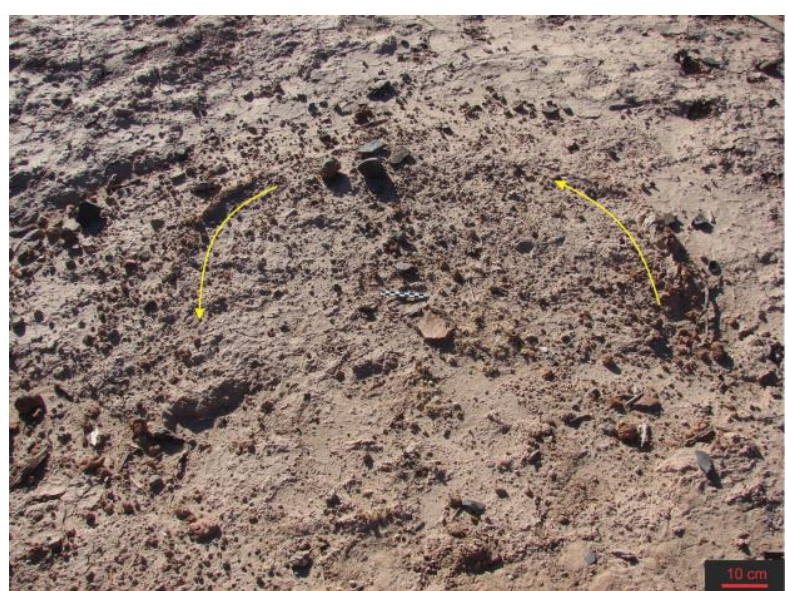

Figura 4.33. Silueta del Horno $n^{\circ} 23$.

\subsubsection{Conjunto 6}

Este grupo de hornos está formado por los ejemplares H24 y H31, localizados a 567 $\mathrm{m}$ al SE desde el Recinto 1 y a $60 \mathrm{~m}$ hacia el SO respecto al conjunto 5. En ambos casos el estado de conservación es regular (G2). E1 H24 conserva su perfil debido al desmoronamiento longitudinal del resto de la estructura al encontrarse en el lateral de una cárcava (Figura 4.34). En cambio, el otro ejemplar conserva segmentos de pared que posibilitaron delimitar la circunferencia de su estructura. A su alrededor se identificaron restos de pared vitrificada, escorias de aspecto fluido, un pequeño fragmento de cerámica refractaria y una base de cerámica tradicional con engobe blanco y pasta rica en inclusiones piroclásticas. Las medidas métricas cuantificadas pueden observarse en la Tabla 4.7.

\begin{tabular}{|c|c|c|c|c|}
\hline Horno & $\begin{array}{c}\text { Diámetro } \\
(\mathrm{cm})\end{array}$ & $\begin{array}{c}\text { Altura } \\
(\mathrm{cm})\end{array}$ & $\begin{array}{c}\text { Espesor } \\
\text { Pared }(\mathrm{cm})\end{array}$ & $\begin{array}{c}\text { Grado de } \\
\text { conservación }\end{array}$ \\
\hline 24 & $90 ?$ & 85 & 7 & G2 \\
\hline 31 & 100 & - & 8 & G2 \\
\hline
\end{tabular}

Tabla 4.7. Características de los hornos del Conjunto 6. 


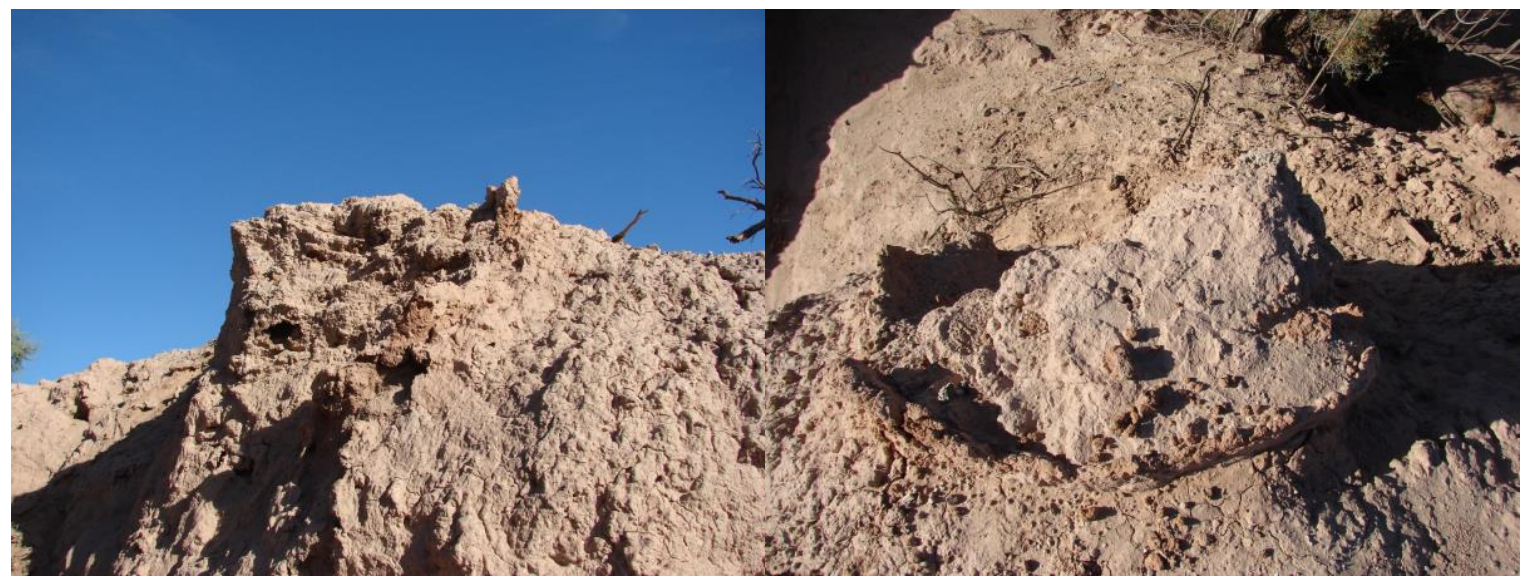

Figura 4.34. Horno $\mathrm{n}^{\circ} 23$ del CH6. A la izquierda se observa el perfil del horno, a la derecha, desde una vista superior se aprecia la estructura circular.

\subsubsection{Conjunto 7}

Es un conjunto de un solo ejemplar. E1 H25 se halla dispuesto a $509 \mathrm{~m}$ al SE del recinto 1 y a $100 \mathrm{~m}$ de distancia tanto del conjunto 4 como del 5. Este ejemplar está apenas insinuado, pudiéndose reconocer segmentos de pared que delimitan su circunferencia (Figura 4.35). Es posible que, por el diámetro calculado, gran parte de la estructura se halle enterrada (Tabla 5.8). En los alrededores se detectaron abundantes restos de carbón.

\begin{tabular}{|c|c|c|c|c|}
\hline Horno & $\begin{array}{c}\text { Diámetro } \\
(\mathrm{cm})\end{array}$ & $\begin{array}{c}\text { Altura } \\
(\mathrm{cm})\end{array}$ & $\begin{array}{c}\text { Espesor } \\
\text { Pared }(\mathrm{cm})\end{array}$ & $\begin{array}{c}\text { Grado de } \\
\text { conservación }\end{array}$ \\
\hline 25 & $90 ?$ & - & 6 & G2 \\
\hline
\end{tabular}

Tabla 4.8. Características del horno del conjunto 7.

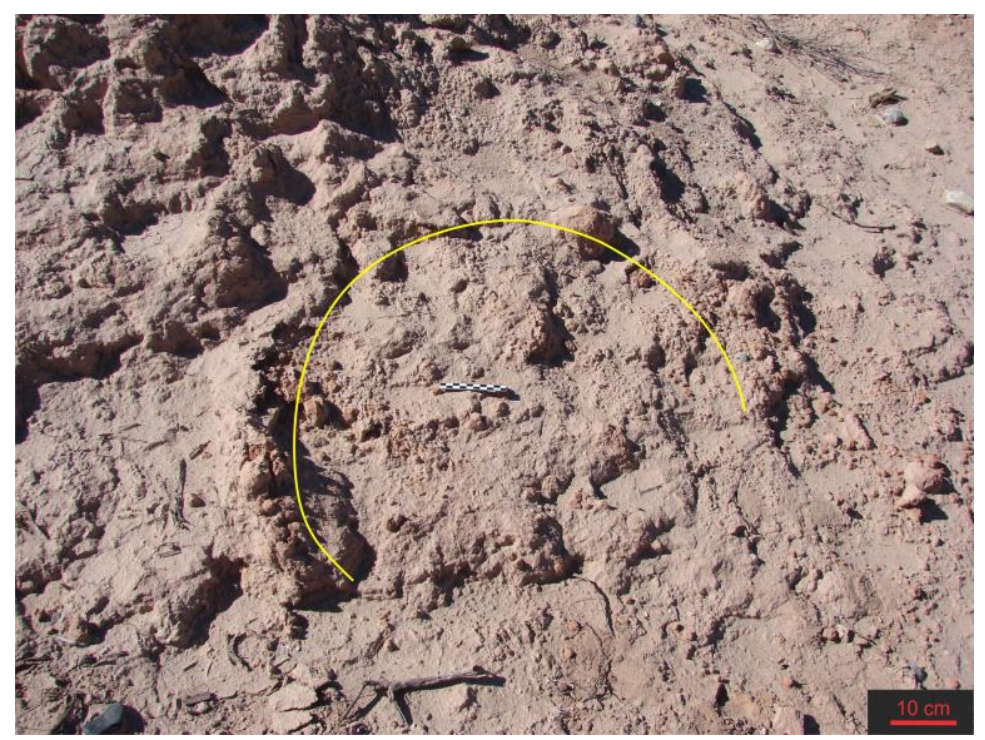

Figura 4.35. Silueta del horno $n^{\circ} 25$. 
Muy cercano al horno se observaron restos cerámicos y un instrumento lítico. Los primeros correspondieron en su mayoría a fragmentos de una olla ordinaria ennegrecida en el interior y a restos de un puco Belén negro sobre rojo que remontaron en gran parte.

Respecto al instrumento lítico, posee $17,9 \mathrm{~cm}$ de largo por 11,8 $\mathrm{cm}$ de ancho, adoptando una forma alargada. Es una hoja unifacial de basalto manufacturada por percusión (Figura 4.36). Sobre el borde curvo se realizaron varios retoques para conformar el filo. En el extremo opuesto se observan huellas de descortezamiento delimitando una zona que posiblemente sirvió para el enmangue. Está fracturada en uno de sus extremos. Por sus características morfológicas y el contexto de hallazgo, se trataría de un hacha empleada posiblemente para la tala de árboles utilizados como combustible, aunque reconocemos que la forma no es un indicador directo de su uso concreto. Para ello es necesario realizar análisis funcionales a partir de estudios de huellas de microdesgaste, que será abordado en el futuro con especialistas en estudios sobre traceología de instrumentos líticos.

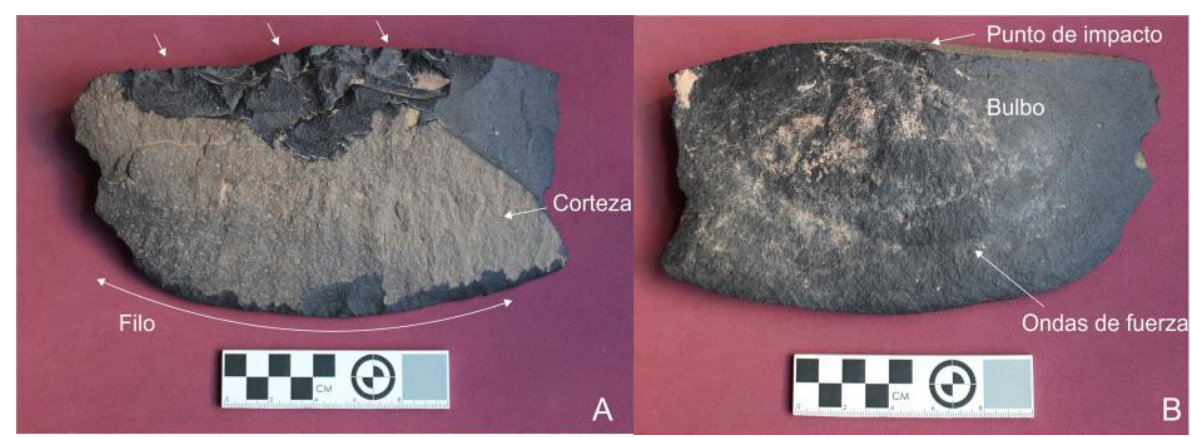

Figura 4.36. Hacha lítica de basalto. A. Cara dorsal; B. Cara ventral. Cada unidad de la escala representa $1 \mathrm{~cm}$.

\subsubsection{Conjunto 8}

Es un único horno (H32) identificado entre los conjuntos 1 y 3. Se localiza a $306 \mathrm{~m}$ al SE del recinto 1. Este ejemplar posiblemente se halle enterrado, observándose en superficie, una circunferencia de $76 \mathrm{~cm}$ de diámetro con paredes de $7 \mathrm{~cm}$ de espesor (Figura 4.37). Teniendo en cuenta los otros ejemplares es probable que lo visualizado corresponda a la porción superior del cuerpo del horno, dado que su diámetro se acerca a las dimensiones tomadas de la abertura del cuerpo en los ejemplares mejor conservados en 
superficie $(\mathrm{CH} 2$ y $\mathrm{CH} 4)$. En sus alrededores se observaron fragmentos de cerámica ordinaria y negro sobre rojo.

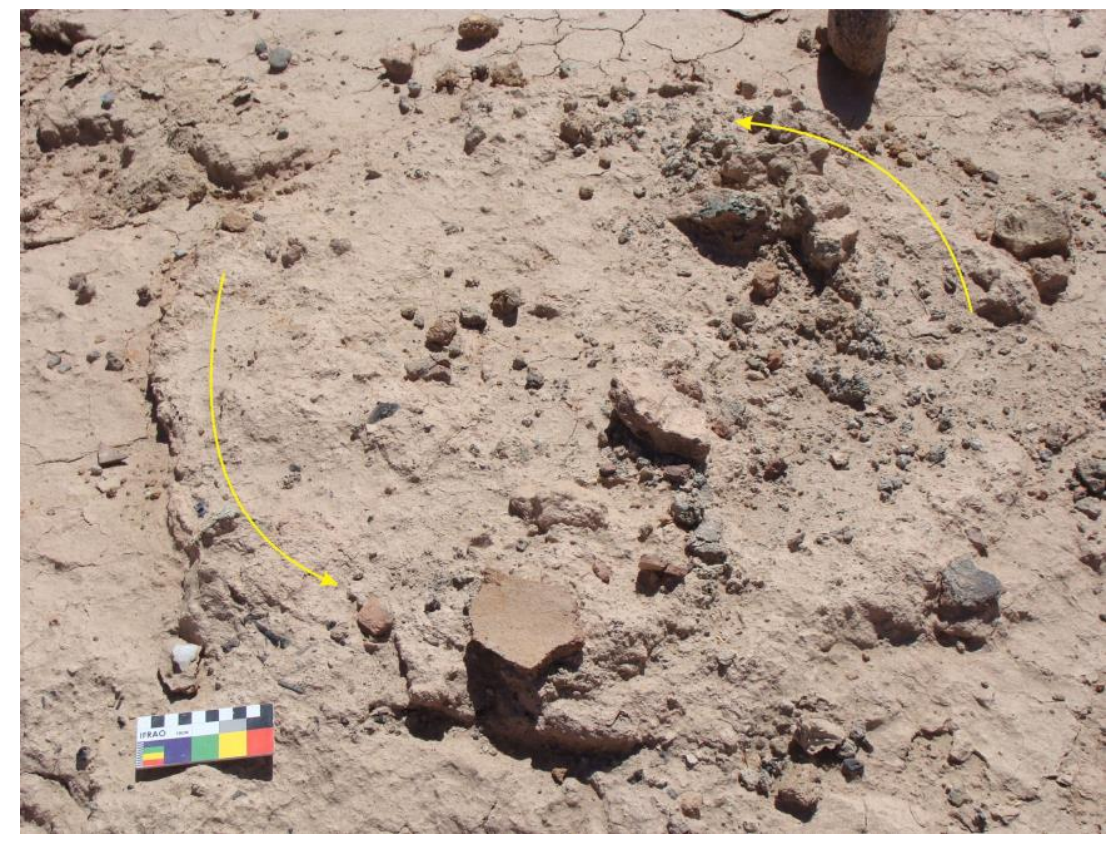

Figura 4.37. Horno 32 del conjunto $n^{\circ} 8$.

Por otro lado, el segundo espacio de molienda detectado en el sitio, se halla a $30 \mathrm{~m}$ hacia el NO de este horno (ver mapa de la Figura 4.12). Allí se reconocieron, además, varios instrumentos líticos: un yunque de andesita, dos morteros cupuliformes, manos de moler de materiales granitoides y martillos construidos con rocas ígneas. El análisis detallado de estos instrumentos permitió detectar vestigios de mineral en una de las manos de moler. Las manos son el elemento activo dentro del conjunto mano-mortero/yunque, cuyo accionar genera repetidos impactos sobre el soporte pasivo. Como consecuencia se producen pulidos, grietas y desprendimientos del material lítico de las manos, huellas de uso que pudieron observarse en sus extremos junto a polvos de coloración celeste y azul. La observación a lupa binocular a grandes aumentos $(10 \mathrm{x})$ permitió detectar vestigios del mineral en varios puntos del extremo de la mano (Figura 4.38). 


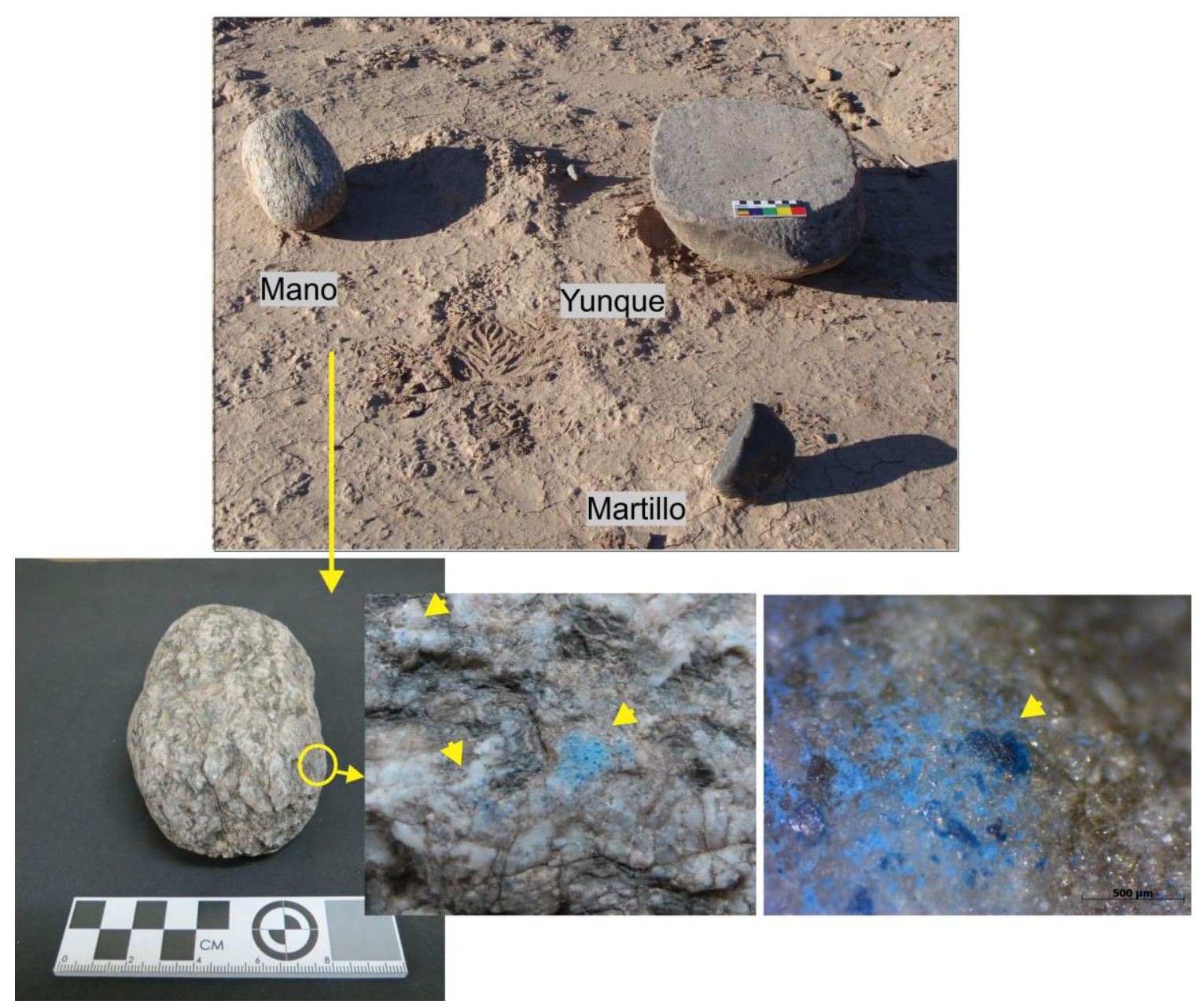

Figura 4.38. Instrumentos líticos del sector de molienda (arriba). Detalle de la mano con marcas de uso y polvos de azurita (abajo).

Si bien existen varias metodologías de análisis para la identificación de minerales análisis macroscópicos, cristalográficos, estructurales, químicos-, el estado pulverizado de la muestra y las fracciones disponibles limitaron las posibilidades de clasificación. Aun así, se consultó la clave para la identificación macroscópica de minerales otorgada por la cátedra de mineralogía de la FCNyM, dónde se detalla que una de las propiedades ópticas a considerar es el color del mineral y sólo unos pocos especímenes presentan tonalidades dentro de la gama de los de azules. Entre los posibles minerales se encuentra la turquesa $\left(\mathrm{CuAl} 2\left([\mathrm{OH}]^{2} \mathrm{PO} 4\right)^{4} 4 \mathrm{H}_{2} 0\right)$ que es de color celeste y la azurita (Cu3 $\left.(\mathrm{OH} \mathrm{CO} 3) 2\right)$ y lapislázuli $\left((\mathrm{NaCa})_{8}\left(\mathrm{Al}, \mathrm{SiO}_{4}\right)_{6}\left(\mathrm{SO}_{4}, \mathrm{SCl}\right)_{2}\right)$, ambas con tonalidades oscuras de azul.

Para alcanzar una identificación precisa del vestigio mineral presente en la mano de moler, se tomó una muestra del polvo con una cinta de carbono de doble faz y se le realizó 
un microanálisis químico por dispersión de energía de rayos X (EDS) en el microscopio electrónico de barrido (MEB) $)^{2}$. Los elementos químicos detectados por el equipo fueron: $\mathrm{C}, \mathrm{O}, \mathrm{Si}, \mathrm{Al}, \mathrm{Fe}, \mathrm{Mn}, \mathrm{Ca}, \mathrm{Cr}, \mathrm{Ni}$ y Cu (Figura 4.39). Cabe aclarar que el alto porcentaje de carbono se debe a la lectura de la cinta de carbono que se empleó como soporte. Así, en la Tabla 4.9 se puede observar la variación en las proporciones de los elementos al no contemplar al carbono en el análisis semicuantitativo.

A partir de la identificación de los elementos químicos de la muestra, la presencia de cobre $(\mathrm{Cu})$, elimina de las posibilidades a la roca lapislázuli y dada la ausencia de fósforo (P), todo parece indicar que el material podría corresponder al mineral azurita (carbonato de cobre). Los restantes elementos identificados pueden provenir de vestigios de sedimento terroso natural ${ }^{3}$ o de restos de material granitoideo de la mano de moler, la cual estaba muy agrietada y fragmentada en la zona muestreada.

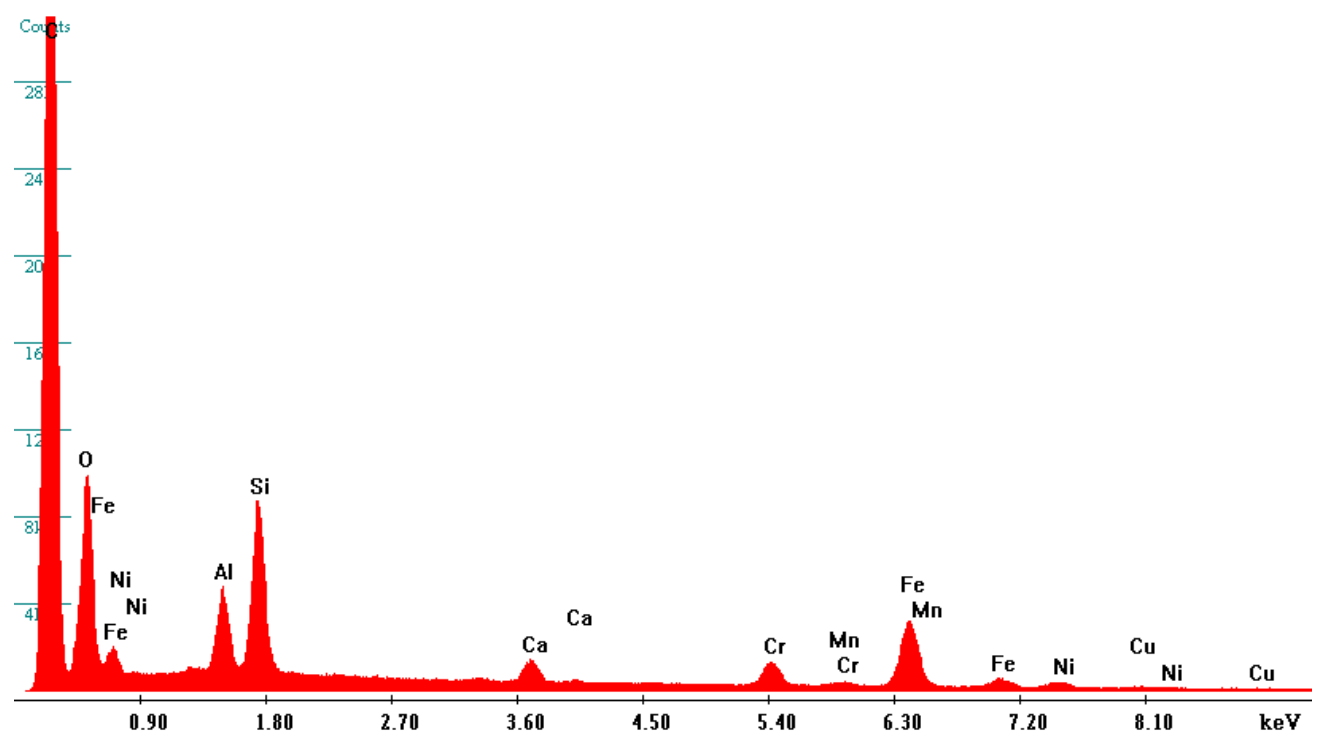

Figura 4.39. Espectro EDS de la muestra de polvo azul de la mano de moler.

\footnotetext{
${ }^{2}$ El análisis químico fue realizado en el Servicio de Microscopía óptica de la Facultad de Ingeniería de la UNLP. Los detalles del equipo serán presentados en los capítulos siguientes.

3 Antes del muestreo se buscó limpiar la superficie de la mano, insuflando aire suavemente para evitar dispersar y perder partículas del polvo mineral. Sin embargo, es posible que el sedimento natural adherido no haya sido totalmente eliminado.
} 


\begin{tabular}{|c|c|c|c|c|}
\hline \multirow{2}{*}{ Elemento } & \multicolumn{2}{|c|}{ Semicuantitativo 1 } & \multicolumn{2}{c|}{ Semicuantitativo 2 } \\
\cline { 2 - 5 } & $\% \mathrm{Wt}$ & $\% \mathrm{At}$ & $\% \mathrm{Wt}$ & $\% \mathrm{At}$ \\
\hline $\mathrm{C} \mathrm{K}$ & 63.27 & 77.16 & - & - \\
\hline $\mathrm{O} \mathrm{K}$ & 17.30 & 15.84 & 30.21 & 51.34 \\
\hline $\mathrm{Al} \mathrm{K}$ & 2.14 & 4.57 & 9.01 & 9.08 \\
\hline $\mathrm{Si} \mathrm{K}$ & 4.57 & 2.38 & 19.20 & 18.59 \\
\hline $\mathrm{Ca} \mathrm{K}$ & 0.99 & 0.36 & 3.38 & 2.30 \\
\hline $\mathrm{Cr} \mathrm{K}$ & 1.97 & 0.56 & 6.37 & 3.33 \\
\hline $\mathrm{Mn} \mathrm{K}$ & 0.17 & 0.05 & 0.57 & 0.28 \\
\hline $\mathrm{Fe} \mathrm{K}$ & 8.18 & 2.14 & 26.65 & 12.98 \\
\hline $\mathrm{Ni} \mathrm{K}$ & 1.10 & 0.27 & 3.62 & 1.68 \\
\hline $\mathrm{Cu} \mathrm{K}$ & 0.30 & 0.07 & 1.00 & 0.43 \\
\hline Total & 100.00 & 100.00 & 100.00 & 100.00 \\
\hline
\end{tabular}

Tabla 4.9. Concentración de los elementos químicos presentes en la muestra de polvo.

Con respecto a los instrumentos de molienda utilizados durante la cadena de producción metalúrgica, las evidencias arqueológicas dan cuenta tanto del uso de grandes molinos líticos denominados marayes como así también de pequeños morteros móviles (González 2004b). Por ejemplo, se han registrado morteros asociados a minerales de cobre en el Pucará de Tilcara (González 2004b) y en otros casos junto a bases de hornos metalúrgicos como en el sitio San Antonio de Cobres (De Nigris y Puche Riart 2013). Incluso, estudios experimentales han demostrado las potencialidades de manos y morteros pequeños para la molienda del mineral. Según han informado otros investigadores, con este tipo de instrumento es posible procesar $8 \mathrm{~kg}$ de mena por hora obteniendo trozos de pequeñas dimensiones útiles para la fundición (Donnan 1994 citado por González 2004b: 78).

\subsection{Análisis de la varianza para variables morfométricas de los hornos.}

El objetivo de este análisis fue evaluar la similitud morfométrica de los hornos metalúrgicos que permitiría proponer la existencia de una estandarización en su construcción. Para ello, se realizó un ANOVA simple para las variables diámetro, espesor 
de paredes y altura en tres conjuntos de hornos $(\mathrm{CH} 1, \mathrm{CH} 2$ y $\mathrm{CH} 4)$ seleccionando los cinco ejemplares mejor conservados de cada uno $(\mathrm{N}=15)$. Los resultados mostraron que no hubo diferencias significativas $(p>0,05)$ entre los tres grupos de hornos para las variables analizadas (Tabla 4.10). Pese a la erosión natural sufrida, las variables más estables (como el diámetro y el espesor original) permiten inferir una homogeneidad métrica que podría indicar una construcción en serie siguiendo un modelo estandarizado.

\begin{tabular}{lcccc}
\hline \multirow{2}{*}{$\begin{array}{c}\text { Fuente de } \\
\text { variación }\end{array}$} & G.L. & \multicolumn{3}{c}{ Cuadrados medios y nivel de significancia } \\
\cline { 3 - 5 } & 2 & Espesor & Diámetro & Altura \\
\hline $\begin{array}{l}\text { Conjunto de } \\
\text { hornos }\end{array}$ & 12 & 0,6 n.s. & 186,2 n.s. & 825,8 n.s. \\
Error & 0,767 & 123,8 & 600,1 \\
\hline n.s.: no significativo & & & & \\
\hline
\end{tabular}

Tabla 4.10. Resultados del análisis de varianza simple de las variables métricas para los conjuntos 1,2 y 4 .

\subsection{Estado de conservación de hornos y agentes de deterioro}

A partir del relevamiento morfométrico de hornos se pudo evaluar el estado de conservación de los mismos, discriminando en los tres grados de conservación previamente descriptos. Asimismo, el trabajo de campo permitió reconocer algunos de los procesos naturales y culturales que conducen al deterioro de los materiales arqueológicos siguiendo las propuestas de Schiffer $(1991,2010)$. Dentro de los procesos culturales, el autor diferencia aquellos que actúan en el contexto sistémico (reuso, reciclaje y uso secundario) de los del contexto arqueológico. Estos últimos, son los procesos de perturbación que suceden una vez que los objetos han sido desechados por procesos de depósito cultural, hayan sido éstos intencionales o no. Muchas veces, los artefactos no vuelven a entrar a un contexto sistémico, pero se destruyen y movilizan en el terreno perdiendo su asociación contextual inicial, fundamental para los fines interpretativos. Intervienen aquí, acciones humanas que tienen intenciones vinculadas, principalmente, a 
actividades de subsistencia o de construcción, pero que exponen los materiales arqueológicos a la superficie y por lo tanto, los alteran. También, otras acciones antrópicas generan que objetos del contexto arqueológico sean reincorporados al sistémico, proceso denominado reclamación (Schiffer 1991, 2010). Dentro de este grupo, el autor distingue tres acciones: la "reincorporación" cuando la reutilización de artefactos se da por los mismos grupos que los descartaron; el "salvamento" en el caso que sean reutilizados en el mismo sitio, pero por personas de una sociedad diferente y por último la "depuración" si intervino la movilización de objetos a localidades distintas (Schiffer 2010: 38-39). Remarcamos nuevamente, que en el sector $A$ de Quillay se observaron principalmente actitudes de salvamento dada la utilización de rocas de muros de los recintos arqueológicos para la construcción de viviendas actuales y en la utilización moderna de los instrumentos de molienda para el procesamiento de maíz y como bebederos para los animales domésticos (Figura 4.40).

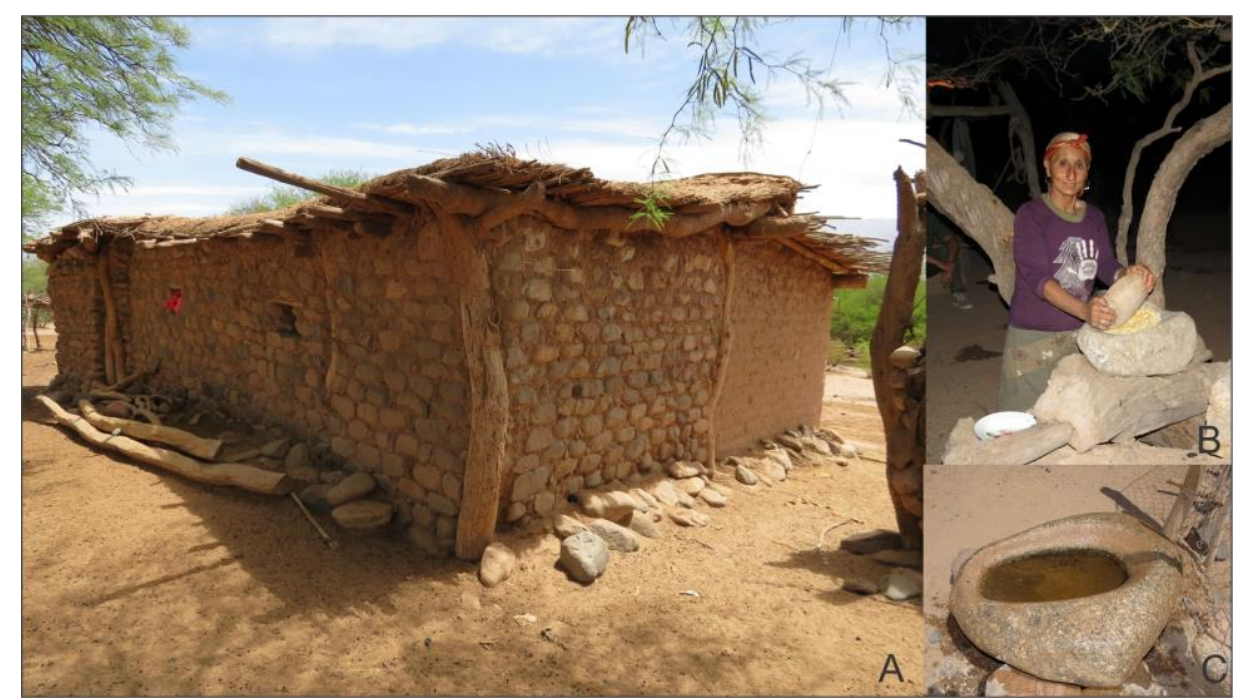

Figura 4.40. Acciones de reclamación en el sector A del sitio. A: vivienda actual; B y C. Utilización actual de morteros y manos. Fotos tomadas por el Dr. Marco Giovannetti.

Por otro lado, para el análisis de los procesos naturales, Schiffer (1991, 2010) diferenció tres niveles de análisis en función de la escala de los efectos de sus agentes, pudiéndose analizar el deterioro a nivel artefactual por procesos físico-químicos; a nivel 
del contexto inmediato de suelos, artefactos y estructuras en unidades estratigráficas (dónde intervienen procesos como la faunaturbación y floriturbación, entre otros); y finalmente a nivel regional. Este último, contempla procesos que afectan los sitios arqueológicos en su totalidad por la acción conjunta del agua, el viento, la flora y la fauna (Schiffer 1987, 1991, 2010). Estos procesos son los que abordaremos especialmente para el caso de los hornos de Quillay, haciendo mención de otros procesos naturales y culturales específicos.

El diagnóstico individual sobre el grado de preservación de los hornos fue presentado previamente en la descripción de cada conjunto. Al integrar estos resultados obtuvimos el gráfico 4.1 que brinda un panorama general sobre el estado actual de conservación de los hornos metalúrgicos. Partiendo de la totalidad de estructuras identificadas en el sector $B$ $(\mathrm{N}=32)$, se observa que un $22 \%$ de la muestra $(n=7)$ mantiene una significativa integridad morfológica (G1), transformándose en ejemplares idóneos para la excavación y para el estudio pormenorizado del proceso tecnológico. El 78\% restante (G2: 44\%, n= 14; G3: $34 \%, n=11$ ) ha sido muy afectados por el transcurso del tiempo, deteriorándose parcial o totalmente con la consecuente pérdida de información.

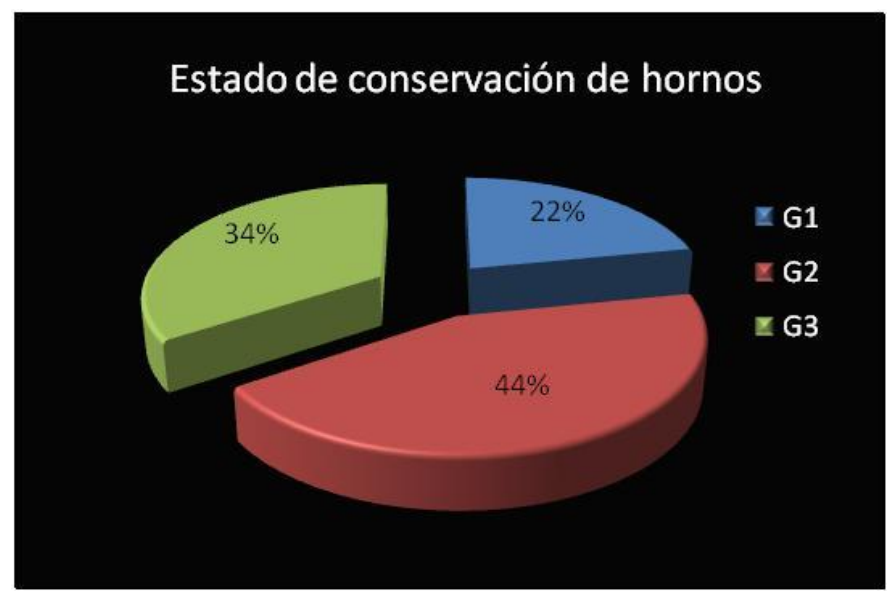

Gráfico 4.1. Frecuencia de hornos según los estados de conservación. G1: bueno; G2: regular; G3: malo.

Luego de identificar el estado de conservación actual, se comparó el registro fotográfico obtenido en distintas instancias de trabajo de campo, propios y de otros 
investigadores, para analizar la dinámica en la erosión de los hornos con el transcurso del tiempo y las causas de su deterioro. El foco estuvo puesto en los ejemplares del conjunto 1 dado que los registros disponibles abarcan una profundidad temporal de casi dos décadas y permiten evaluar la conservación a largo plazo.

Se compararon fotografías de tres momentos temporales:

1- Imágenes tomadas en la década de 1990 cedidas por el Dr. Raffino, estando algunas de ellas publicadas (Raffino et al. 1996);

2- Fotografías realizadas en enero del 2011, en el marco de esta investigación;

3- Fotografías obtenidas en diciembre del 2011, en el marco de esta investigación.

La comparación consistió en una minuciosa evaluación óptica sobre la integridad morfológica de los ejemplares registrados en las series fotográficas. A partir del análisis se observa que la alteración de los hornos se manifiesta principalmente en la reducción paulatina de la altura de sus paredes y en la fragmentación de segmentos de hornos. Incluso, en el caso del H1, la observación pudo ser complementada con los registros métricos disponibles para los tres periodos. En 1996 la altura de este ejemplar estuvo calculada en $40 \mathrm{~cm}$ (Raffino et al. 1996: Cuadro 1), en enero de 2011 no superó los $38 \mathrm{~cm}$ y en diciembre sólo se pudo observar un único segmento de pared que mantuvo una altura de $18 \mathrm{~cm}$. De esta manera, los registros indican que este horno ha perdido en quince años, unos $22 \mathrm{~cm}$ en la altura de sus paredes (Figura 4.41).

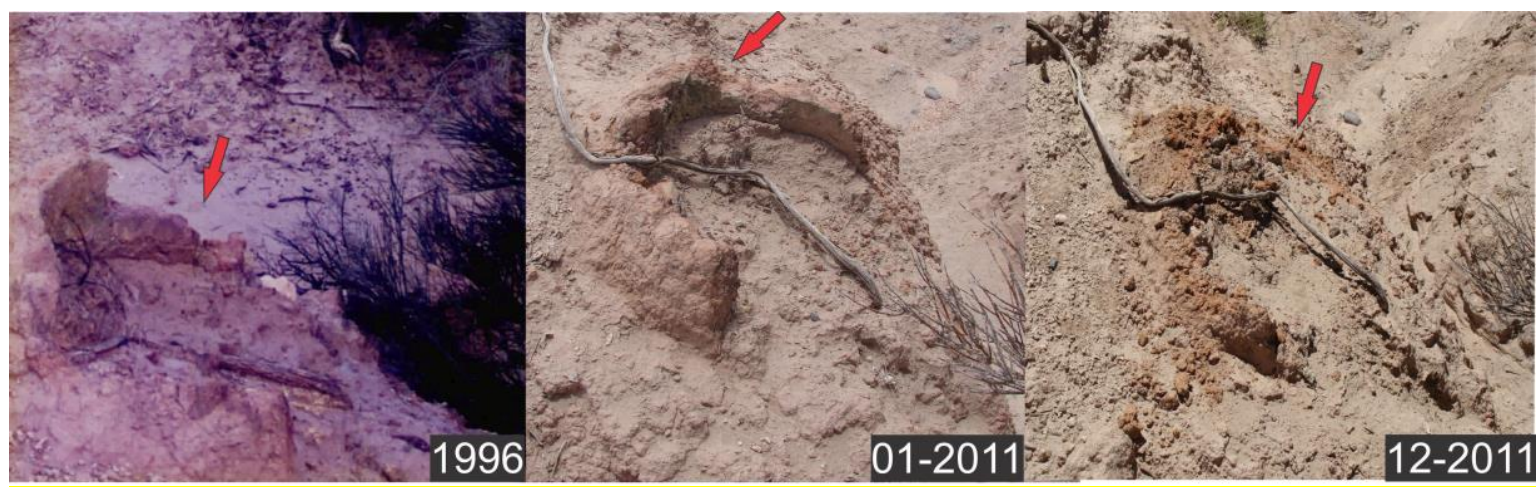

Figura 4.41. Alteración del Horno $\mathrm{n}^{\circ} 1$ del Conjunto de hornos 1 en el periodo analizado. Fotografía de 1996 cedida por el Dr. Raffino y publicada en Raffino et al. 1996: Figura 4. 
Es importante destacar que, si bien el deterioro fue gradual y constante en el tiempo, las imágenes indican que fue altamente significativo en el transcurso del año 2011 (Figuras 4.41, 4.42 y 4.43). Este hecho posiblemente se debió a las inundaciones extraordinarias y localizadas que sufrió la región en dicho año, evento que fue tan disonante y complicado para la zona que fue difundido por los medios de comunicación nacionales. Para contrastar esta hipótesis, se consultaron los registros pluviométricos disponibles en el departamento de Belén para el periodo temporal de análisis (Dpto. Hidrología Superficial 2012) . Específicamente se tomaron los datos de la estación Corral Quemado (O 66 56 4 42, $0^{\prime \prime}$ y S $\left.27^{\circ} 08^{\prime} 48,3^{\prime \prime}\right)$, al ser la estación más cercana al sitio, localizada a $8 \mathrm{~km}$ al noreste en línea recta desde Quillay.

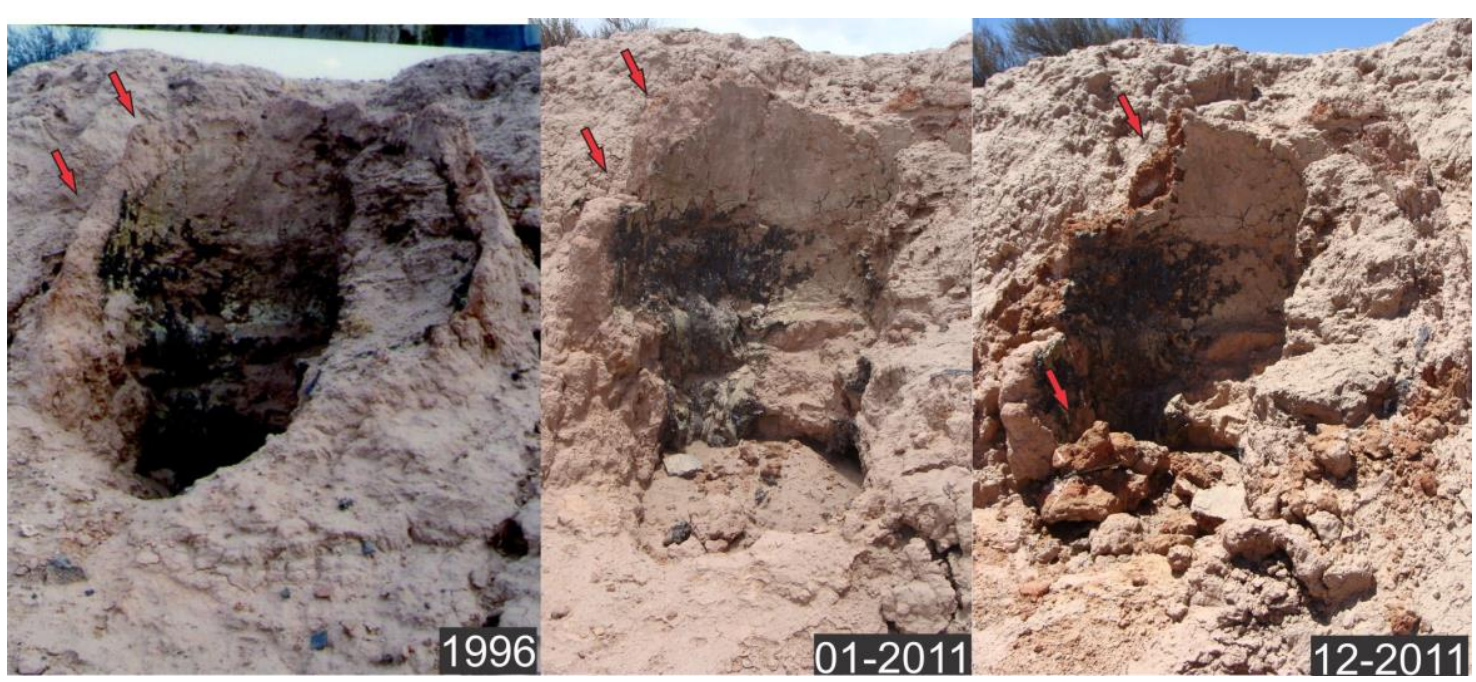

Figura 4.42. Horno $\mathrm{n}^{\circ} 10$ del Conjunto de hornos $\mathrm{n}^{\circ} 1$, las flechas señalan la alteración de las paredes a lo largo del tiempo. Fotografía de 1996 cedida por el Dr. Raffino y publicada en Raffino et al. 1996: Figura 6.

\footnotetext{
${ }^{4}$ Departamento de Hidrología Superficial. 2012. Lluvias mensuales. Departamento Belén. Dirección Provincial de Hidrología y Evaluación de Recursos. http://www.saya.catamarca.gov.ar/dhyerh/dhsup/datos/pdfpluv/pluv belen.pdf (Consultado 3 de Mayo de 2014)
} 


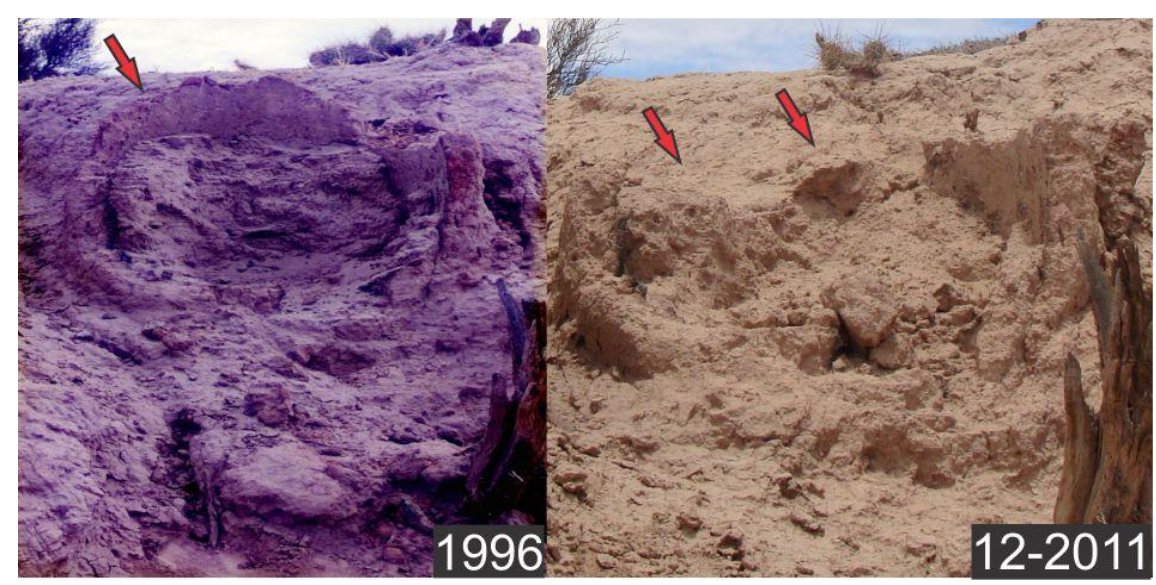

Figura 4.43. Horno $\mathrm{n}^{\circ} 10$ del Conjunto de hornos $\mathrm{n}^{\circ} 1$, las flechas señalan la erosión de las paredes entre 1996-2011. Foto de 1996 fue cedida por el Dr. Raffino.

En el gráfico 4.2 se puede observar que las medias de las precipitaciones anuales se mantuvieron desde 1995-2010 en un rango de 5 a 19 mm/año. Sin embargo, en el periodo 2010-2011 la media anual de precipitación superó ampliamente los $80 \mathrm{~mm}$, situación extremadamente atípica para la zona. Incluso, al observar las métricas de las lluvias mensuales se ve que las precipitaciones se concentraron en el mes febrero de 2011, con valores cercanos a $590 \mathrm{~mm}$ (ver registros mensuales en el Anexo I- Tabla 1). Esto sucedió justamente luego del segundo registro fotográfico y coincide con el avance en la destrucción de algunas estructuras observada en las fotografías tomadas en diciembre.

\section{Precipitaciones en Corral Quemado}

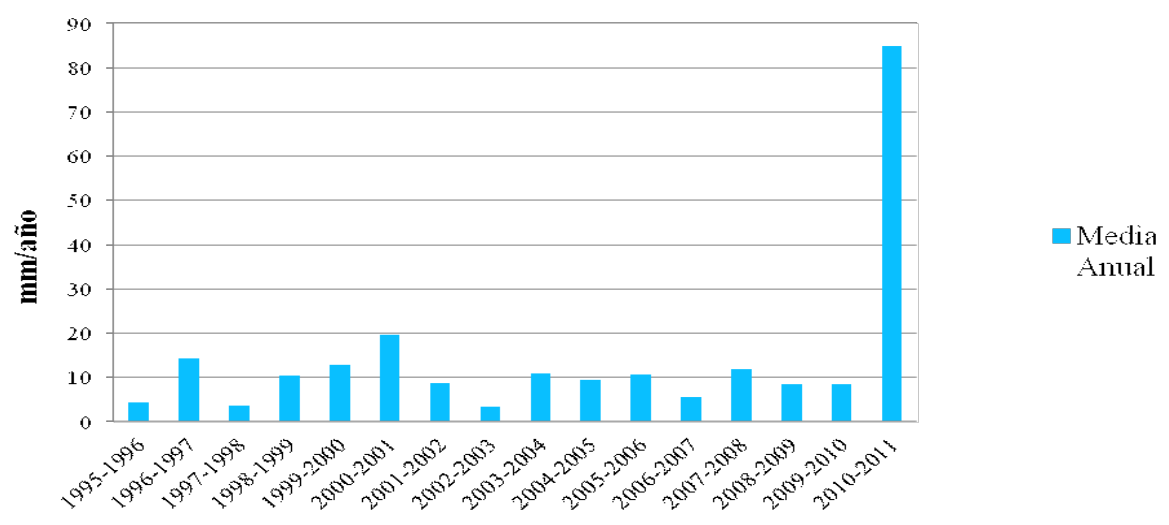

Periodo Temporal (Junio-Julio)

Gráfico 4.2. Régimen pluviométrico histórico de la Estación Corral Quemado. 
Por otro lado, en los hornos identificados en el conjunto 2 y 4 también se reconocieron variaciones en la altura de las paredes entre los años 2012 y 2014. En los casos en que los fragmentos de pared fueron identificados in situ, se interpreta que su alteración se debió fundamentalmente a acciones de pisoteo de animales y en menor frecuencia de personas. Durante los trabajos de campo se ha podido constatar que, al menos el territorio donde se despliegan los hornos del conjunto 2, es una zona de paso durante el traslado de ganado caprino hacia las zonas de pastoreo, acción que determina la destrucción de las paredes de los hornos. Incluso en la zona inmediata a los mismos, fueron visualizados caballos salvajes que posiblemente contribuyan al pisoteo y deterioro de materiales arqueológicos dispersos en el terreno. También en los H16, H17 y H22, las paredes han sido perforadas -aunque en distinto grado- por la acción de animales cavadores, perjudicando el sostenimiento de la estructura.

Por otro lado, en los ejemplares H14 y H16 del conjunto 2, luego de nuestra segunda visita al sitio, encontramos evidencias de perturbación antrópica manifestada en la presencia de pozos en el interior de estos hornos (Figura 4.42), posiblemente bajo intenciones de saqueo en la búsqueda de metales, quizás motivados por nuestra presencia. Sin embargo, se considera que la mayor erosión de los hornos en Quillay se debe a la acción de los agentes naturales, siendo los principales actores erosivos el agua pluvial y el viento.

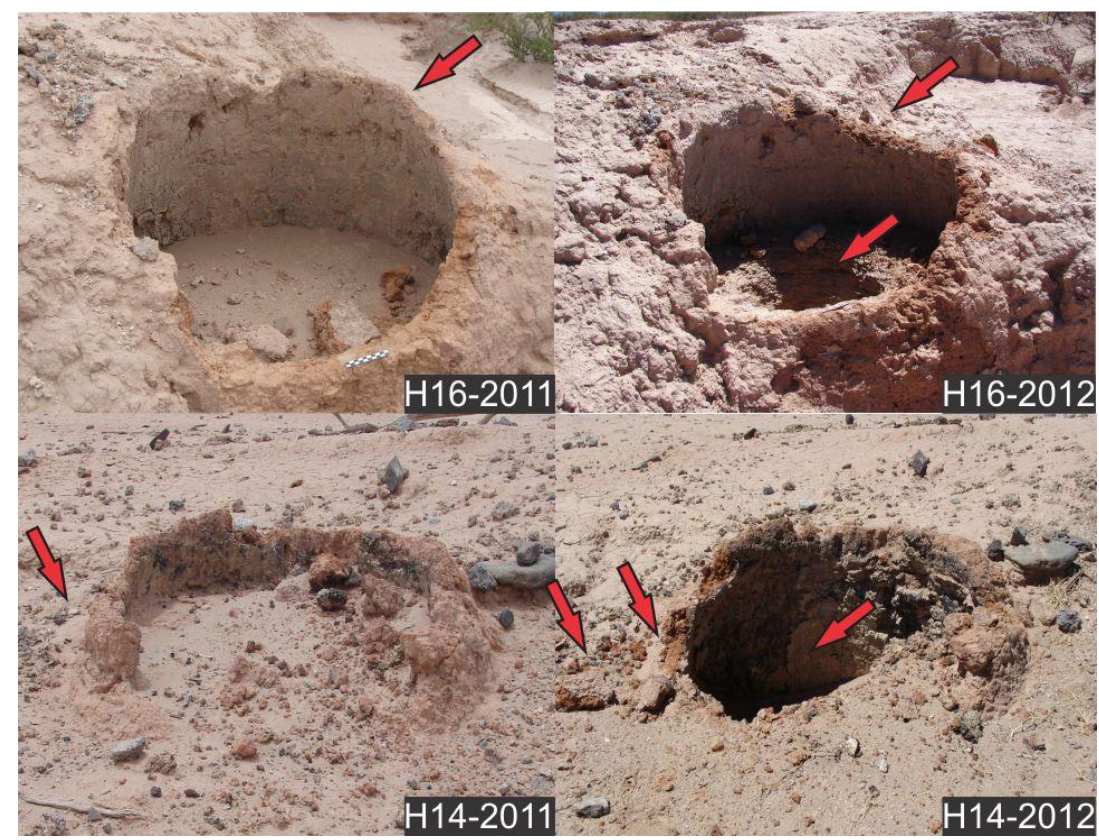

Figura 4.42. Hornos del CH2. Las flechas señalan la alteración antrópica. 
La erosión eólica es un proceso que actúa de forma constante, siendo los vientos particularmente fuertes durante el mes de septiembre. Los vientos acarrean y transportan arenas por saltación, reptación y suspensión (Rostagno et al. 2004) que chocan con elementos naturales y estructuras arqueológicas produciendo una lenta abrasión de los elementos que interactúan entre sí. Esta situación es agravada por el régimen pluviométrico de la región, dónde si bien las lluvias son intermitentes en el valle y presentan un carácter estacional (durante los meses de verano), cuando acontecen suelen ser torrenciales. Tal es así, que el efecto de la brusca caída de las gotas de lluvia genera un impacto destructor sobre el suelo y elementos arqueológicos que hacen saltar partículas y desestabilizar estructuras (Porto Tenreiro 2000), especialmente los hornos dada la naturaleza deleznable de su material constructivo. Una vez en el suelo, el agua fluye en sentido de la pendiente. En la caracterización del ambiente natural del sitio, se ha hecho referencia a la baja capacidad de absorción de estos suelos loéssicos que contribuye al escurrimiento superficial. Cuando el flujo hídrico supera la capacidad de resistencia del suelo, se produce la erosión de partículas que conducen a la formación de grietas en el terreno, así como al ensanchamiento y profundización de las cárcavas ya existentes (Gómez Gutiérrez et al. 2011). El análisis fotográfico permitió detectar que, en el sector productivo más cercano a los recintos, ha aumentado la profundidad de las cárcavas, llegando en la actualidad hasta 4 $\mathrm{m}$ en sentido vertical (Figura 4.43), proceso que contribuyó al desmoronamiento longitudinal del horno $\mathrm{n}^{\circ} 24$ y a la destrucción total o parcial de los ejemplares que se encuentran más cercanos a las cárcavas, en especial dentro del conjunto de hornos 1. En este sentido, se considera que el grado de conservación de los hornos es inversamente proporcional a la cercanía a zonas con cárcavas, debido a que su avance es una de las principales causas que destruye los hornos. 


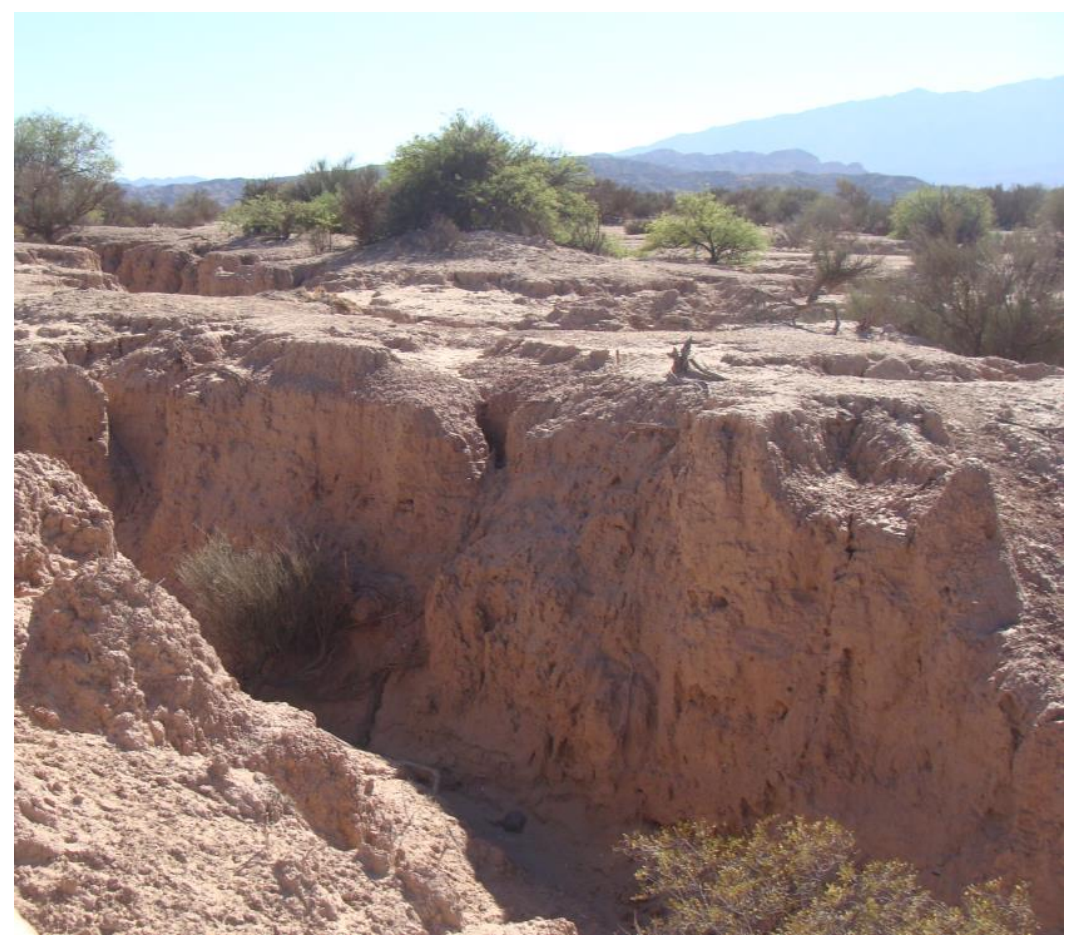

Figura 4.43. Cárcavas observadas en las inmediaciones del conjunto de hornos 1 .

Para cerrar, se considera que el diagnóstico del estado de conservación de los hornos resultó fundamental para la planificación de las excavaciones arqueológicas. Tanto la identificación de los sectores con mayor riesgo de destrucción inmediato como el reconocimiento de hornos que preserven una buena integridad morfológica, sirvieron como criterios para la selección de los ejemplares a excavar dentro del G1 (grupo 1), que serán presentados en el capítulo 6. Además, la identificación de los agentes naturales y culturales de deterioro, su intensidad y los efectos, es información útil para la futura toma de decisiones gubernamentales vinculadas a la conservación del patrimonio arqueológico. 


\section{SECTOR A. ANÁLISIS DE RECINTOS}

\subsection{Presentación del capítulo}

En este capítulo se presentarán los estudios realizados en el sector $A$ del sitio Quillay, caracterizado por la presencia de recintos arqueológicos. Se ha procedido a la intervención de algunas estructuras con el objetivo de identificar contextos arqueológicos que posibiliten reconstruir las prácticas sociales acontecidas en estos espacios para integrarlos con aquellos observados en el sector productivo. Para ello, durante los trabajos de campo se han realizado tanto recolecciones de materiales superficiales como excavaciones estratigráficas. Una vez en el laboratorio, los materiales recuperados han sido estudiados empleando metodologías de análisis estándares para cada clase de soporte material. Para su presentación en este capítulo, se decidió en primer lugar, especificar las metodologías de relevamiento y los procedimientos de análisis utilizados para cada ergología. Posteriormente, se darán a conocer los resultados obtenidos en apartados separados en función de la forma de relevamiento. De esta manera, primero se presentarán los resultados del análisis de los materiales recuperados durante las recolecciones superficiales realizadas en el sector $A$ y luego aquellos obtenidos en las excavaciones arqueológicas de las unidades arquitectónicas. Finalmente, los resultados parciales serán integrados y discutidos en conjunto.

\subsection{Primera etapa: el trabajo de campo}

\subsubsection{Metodología de recolección superficial y materiales recuperados}

En el sector donde se despliegan los recintos se observaron abundantes restos materiales dispersos en el terreno, por lo tanto, se procedió a su relevamiento mediante recolecciones superficiales efectuadas en los años 2011 y 2012. Para ello, se definieron dos sectores de recolección. El primero, hacia el interior de cada recinto (del R1 al R8) empleando sus muros como límite de registro. El segundo, en el sector extramuros, para lo cual se definieron cinco transectas de recolección de 10 × $10 \mathrm{~m}$, que abarcaron un área de $500 \mathrm{~m}^{2}$ ubicada hacia el este de los recintos y cuyos límites externos estuvieron 
situados en el R2 y el R7 que constituyeron, respectivamente, los extremos norte y sur de recolección (Figura 5.1).

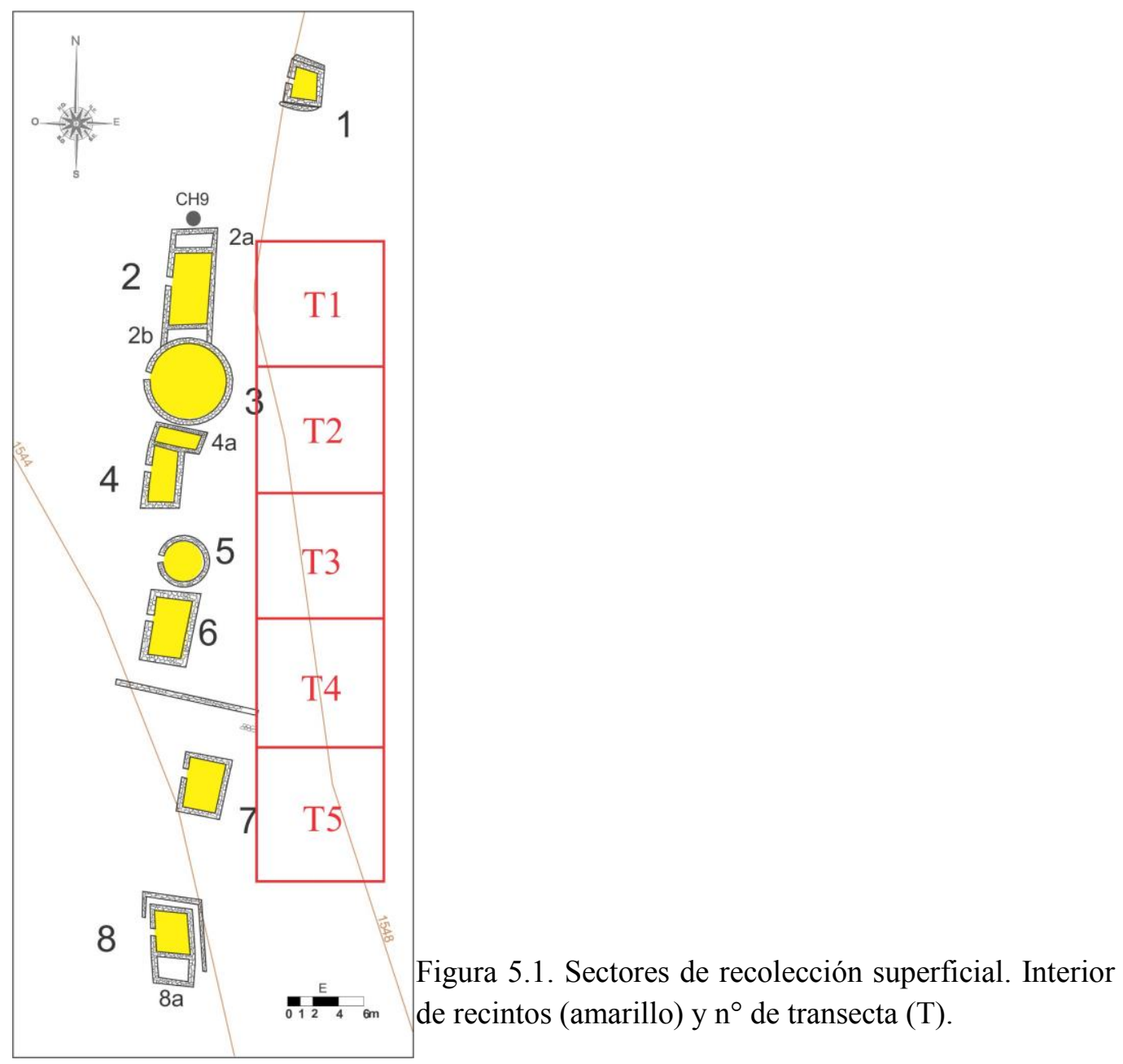

Los materiales registrados por este procedimiento consistieron mayoritariamente en tiestos cerámicos y en menor medida en materiales refractarios. Respecto a estos últimos, en años posteriores se incorporaron para su análisis otras muestras refractarias identificadas en este sector, que fueron recolectadas durante sucesivos trabajos de campo. Las mismas fueron georreferenciadas con GPS y volcadas sobre imágenes satelitales para su contextualización.

Por otro lado, como se comentó en los antecedentes, la zona de recintos también fue objeto de recolecciones superficiales realizadas en los trabajos arqueológicos previos al inicio de esta investigación (González 1959; Raffino et al. 1996). De estos materiales, se ha podido tener acceso únicamente a los tiestos cerámicos recuperados 
por el equipo del Dr. Raffino en la década de 1990 que serán presentados en el segmento correspondiente.

\subsubsection{Metodología de excavación y registro}

Como se mencionó en el capítulo 3, tres de los ocho recintos del sitio fueron excavados en la década de 1950. A partir de la información publicada (González 1959) y de nuestras observaciones en el campo, se infiere -dado que aquello publicado resulta un poco confuso- que los recintos intervenidos en dicho momento fueron los R2, R3 y R6 del mapa actual. Las anotaciones de excavación realizadas en aquellos años por González (Repositorio DILA, González, A. R. Cuaderno de campo, expediciones a Catamarca, 1951, 1952 y 1957) señalan que allí se registró tanto material cerámico como restos faunísticos y leñosos. Sin embargo, en los depósitos del Museo de La Plata hemos recuperado únicamente la cerámica hallada del recinto circular mayor (R3) que, como se tratará más adelante, fue re-evaluada en el marco de esta tesis.

Entonces, luego de distinguir cuales fueron los recintos intervenidos previamente, y considerando las restantes unidades arquitectónicas del sector $A$, se seleccionaron dos espacios para su excavación:

1) Recinto cuadrangular $n^{\circ} 1(\mathrm{R} 1)$

2) Recinto rectangular con anexo $n^{\circ} 4(R 4)$.

La primera estructura fue elegida por sus características distintivas. Es el único recinto que presentó una planta cuadrangular, es el de menor tamaño y se ubica en el extremo más septentrional, separado unos metros de las restantes estructuras arquitectónicas. Este recinto fue excavado completamente. En el caso del R4, se seleccionó para su excavación el extremo austral de la estructura, dado que inicialmente se lo consideró como un posible anexo, al observarse en superficie una hilera de rocas alineadas que segmentaban el recinto de mayor tamaño.

Para la excavación del R1, se delimitó una cuadrícula de 3 × 2,77 m alojada de tal manera que abarcase casi la totalidad de la superficie intramuros $\left(8,31 \mathrm{~m}^{2}\right)$. Por su parte, las dimensiones de la cuadrícula del R4 fueron de 2,20 x 1,80 m, abarcando un área de 3,78 $\mathrm{m}^{2}$ correspondiente al segmento sur de la unidad arquitectónica. En ambos casos, durante la excavación se empleó la técnica de decapage siguiendo niveles artificiales de 
$10 \mathrm{~cm}$ y el sedimento extraído fue procesado con zarandas de $1 \mathrm{~mm}$ de malla. Se levantaron perfiles y plantas manuales para la contextualización tridimensional de cada hallazgo, acompañados con fichas de registros de hallazgos, anotaciones en libretas de campo, croquis y fotografías. Respecto a los materiales recuperados se han registrado principalmente restos cerámicos, líticos, faunísticos y botánicos, cuyas metodologías de análisis se presentan a continuación.

\subsection{Segunda etapa: trabajo de gabinete}

\subsubsection{Análisis del material cerámico}

El estudio del material cerámico se realizó con el objetivo de abordar las frecuencias de estilos cerámicos y formas representadas en los distintos contextos arqueológicos. Por un lado, esto posibilita conocer las identidades de los actores participantes en las actividades desarrolladas en cada espacio. En este sentido, no se focalizó en el análisis detallado de parámetros tecnológicos, sino que se consideró aquellos que brindan un marco interpretativo para asociar los tiestos a un estilo cerámico en particular. Como se ha expresado en la perspectiva teórica adoptada (Lechtman 1977; Lemonnier 1992), la regularidad en ciertas características de los objetos (para este caso, en los tratamientos superficiales, patrones decorativos, pastas, etc.) nos remiten a los modos de hacer de los artesanos que están enmarcadas en tradiciones tecnológicas compartidas por los miembros de una sociedad y que conforman así estilos cerámicos particulares y distintivos entre sí, en función del conjunto de elecciones técnicas realizadas por los artesanos. Por otro lado, el reconocimiento de las formas cerámicas permite aproximarnos a su función (ej. transporte, almacenamiento, cocción, servido) e indagar sobre las prácticas de uso en los distintos contextos arqueológicos (Rice 2005 [1987]). Se aclara que el estudio de los materiales cerámicos refractarios se encaró con la misma perspectiva, aunque, como veremos en el siguiente apartado, en ese caso, se indagaron con mayor profundidad algunos parámetros tecnológicos que responden a los objetivos generales de esta investigación.

Para efectuar el análisis cerámico, en primera instancia, los tiestos fueron limpiados, rotulados y se les aplicó la técnica de remontaje y agrupamiento por familia (Orton y Vince 1997). Es decir, aquellos fragmentos con características similares entre 
sí que permitiesen asignarlos a una misma pieza, pese a que sus bordes no remontasen, fueron considerados como partes de un mismo ejemplar y rotulados con el número de pieza seguido de una serie alfabética $(\mathrm{a}, \mathrm{b}, \mathrm{c} \ldots n)$.

Posteriormente, se utilizó una tabla excel compuesta por 15 variables (ver tabla 4 en Anexo I) que abordan datos de procedencia y aspectos tecnológicos, morfológicos, decorativos y utilitarios. La base de datos siguió la metodología delineada por el Dr. Giovannetti (2015a) fundamentada en las propuestas establecidas y consensuadas en la Primera Convención Nacional de Antropología (1966), que fue complementada con la información disponible en textos especializados en análisis cerámico (Balfet et al. 1992; Orton y Vince 1997; Rice 2005 [1987]).

Siguiendo estos lineamientos metodológicos, luego de completar los datos de procedencia y de siglado que facilitan la identificación de las piezas, los fragmentos fueron analizados teniendo en cuenta las siguientes variables:

- Tratamientos superficiales: se trata de las modificaciones realizadas a la superficie interna y externa de las piezas cerámicas. Siguiendo las propuestas de la Convención, las mismas pueden consistir en intervenciones con aplicación de materiales ("engobe" y "pintura"); o bien aquellas que alteran la superficie por desplazamiento del material cerámico (“alisado”, “cepillado”, “incisión” y “escisión”). En las tablas se siguió el orden de aplicación observadas y se diferenciaron aquellas aplicadas sobre la superficie interna y externa.

- Color: esta variable fue determinada ópticamente contemplando ambas superficies y la coloración de la pasta cerámica.

- Compactación: es un indicador del grado de agregación entre las inclusiones y la matriz arcillosa que conforman la pasta cerámica. Se tomaron tres valores para esta variable según la respuesta de la pasta a la fricción con la uña. Si la pasta no se alteró el estado es "compacto", si como resultado se soltaron unas pocas partículas finas, la pasta es "semicompacta" y si se desgranaron fue clasificada como "deleznable". Esta forma alternativa de calcular la dureza está relacionada con la escala de Mohs, según la cual la raya de la uña es equiparable a una dureza 2,5 (Orton y Vince 1997: 262). 
- Fractura: esta variable permite observar la tendencia general de fragmentación. Se siguieron las propuestas de la Convención siendo los valores empelados "regular" e "irregular".

- Estado: nos brinda información sobre los procesos postdepositacionales que afectaron mecánicamente a los fragmentos. Se determinaron tres valores: "angulosos", "semirodados" y "rodados" según el nivel de redondez observado en los bordes del tiesto.

- Tipos de cocción: fue determinada a partir de la coloración de las pastas. Un color rojo a anaranjado indica la circulación libre de oxígeno durante la cocción que es de tipo “oxidante". Cuando se presenta junto a segmentos de coloración grisácea localizados hacia las superficies o hacia el centro de la pasta, esto señala una circulación irregular del aire que genera una cocción de tipo "oxidante incompleta". Cuando la pasta es gris homogéneo, señala que la cocción se desarrolló con falta de oxígeno y fue clasificada como "reductora".

- Inclusiones: son las partículas minerales, arcillosas o vegetales incluidas en las pastas cerámicas. Se realizó el reconocimiento de la naturaleza de los antiplásticos a partir de la observación de fracturas frescas con lupa binocular de bajos aumentos (10 X - 30 X). Cabe aclarar que, dado los objetivos de esta investigación, esta variable sólo fue contemplada en las piezas de excavación.

- Segmento de la pieza: aquí se evaluó la correspondencia del fragmento a los distintos segmentos que componen las formas cerámicas generales, siguiendo las establecidas por la Convención ("base" "asa", “cuerpo", "cuello", "borde”, etc.) y en las siguientes dos variables (tamaño y espesor) se calcularon sus dimensiones con un calibre manual.

- Forma: se estimó la forma completa de la pieza, distinguiendo en primer lugar entre piezas "cerradas" y "abiertas". La diferencia más general es que en el primer caso, el diámetro de la boca es menor al presente en el cuerpo, la relación inversa se da en las piezas abiertas. Además, otro elemento que permite la distinción entre ambos tipos de piezas es la presencia de decoración o engobe en la superficie interna. En el caso que fuera posible, se realizó una identificación más precisa siguiendo como referencia la información disponible en la bibliografía sobre las formas de piezas cerámicas de los períodos Tardío e Inka (González 1955; Calderari y Williams 1999; Bray 2003a, 2004; 
González Carvajal 2004; Wynveldt 2007, 2009; Revuelta et al. 2010-2012; Palamarzuk 2014; entre otros) y de la comparación con piezas de colección alojadas en museos.

- Decoración: en esta variable se especifican los conjuntos de técnicas (tratamientos superficiales) y coloraciones que han sido aplicados con el fin de decorar la vasija.

- Patrón de diseño: se detallan aquí los elementos observables en los fragmentos que constituyen los diseños para ambas superficies (interna y externa). En los casos que fueran posible se determinó el diseño zoomorfo, antropomorfo o geométrico específico según la información disponible en la bibliografía de consulta.

- Rasgos utilitarios: se especifican las huellas que dan cuenta del uso de la pieza en distintas actividades. Se tuvieron en cuenta, vestigios de hollín, superficies quemadas, adherencias de residuos, presencia de picados, superficies descascaradas, escorificaciones y marcas de herramientas.

- Asignación tipológico-estilística: teniendo en cuenta todos los atributos analizados en las variables previas se determinó el tipo estilístico de cada pieza. Cuando el análisis presentó ciertas dificultades para una clara asignación a un estilo cerámico en particular, se aclaró utilizando el rótulo de "posible".

- Asignación tipológico-cronológica: la asignación cronológica se basó en el estilo establecido para cada pieza, tomando como base la seriación cronológica realizada por González y Cowgill (1975) para el valle de Hualfín (Catamarca, NOA).

Luego del análisis, los datos fueron procesados mediante estadística descriptiva y serán presentados siguiendo la sectorización espacial realizada para el sitio. En los casos de bordes y bases, se estimaron diámetros con cartas métricas específicas (Orton y Vince 1997). A partir de ellos, se dibujaron y reconstruyeron algunas piezas cerámicas representadas en el sitio, procesadas con programas de diseño Gráfico como Corel DRAW X6.

\subsubsection{Análisis del material refractario}

En el sector A se han registrado 16 fragmentos de material refractario, uno de los cuales se identificó como un cuenco que fue presentado como un crisol en investigaciones previas (Raffino et al. 1995: 67-68) y pudo ser incorporado al presente estudio. Los fragmentos fueron examinados en tres niveles: análisis morfotécnicos, petrográficos y químicos. 
1- $\quad$ Análisis morfotécnicos: se realizaron a escala macroscópica y submacroscópica con lupa binocular a aumentos de entre 10X y 30X. Para el análisis se diseñó una tabla (tabla 2- Anexo I) con una serie de variables teniendo en cuenta la información disponible sobre esta tecnofactura (Tylecote 1979; González 1992, 2002, 2004b; Campo 2002; Angiorama 2004; Pifferetti 2004; González y Gluzman 2009; Plaza y MartinónTorres 2015; Gluzman 2017; entre otros).

La primera variable utilizada refiere al tipo de materia prima empleada para la fabricación del refractario. Teniendo en cuenta otros estudios de la región andina, estas herramientas han sido en su mayoría construidas con materiales arcillosos, pero también existen ejemplares fabricados con materiales líticos (Mayer 1986; Ambrosetti 2011 [1904]) u óseos (Latorre 2013). Dado que en Quillay todos los fragmentos fueron realizados con materiales arcillosos, las siguientes variables contempladas en el análisis permitieron realizar una caracterización general de las pastas cerámicas. Para ello, se observaron distintos parámetros como el color, la porosidad, la compactación, la presencia de vitrificaciones y el tipo de antiplásticos. Todos ellos, en términos generales, brindan información indirecta sobre parámetros térmicos.

El color de las pastas refractarias suele variar desde el marrón hasta distintas intensidades de grises y sirve como indicador de la temperatura y atmósferas a la que estuvo sometida la pieza, tanto durante la cocción de manufactura, así como en su utilización posterior. En relación al último punto, la coloración varía principalmente en función de la interacción del material arcilloso con el metal caliente.

Por otro lado, se determinó la presencia de vitrificaciones a partir de la observación de inclusiones granulares alteradas que suceden en zonas sujetas a mayor temperatura (Campo 2002). Para esta variable se establecieron dos valores, "ausencia" o “presencia”, expresando en el último caso el sector de la pieza dónde fueron observadas.

La variable porosidad refiere a la presencia de cavidades en las pastas que pudieran ser observadas a escala submacroscópica. El grado de compactación y la determinación de antiplásticos fueron analizados siguiendo los mismos criterios establecidos para las cerámicas no refractarias. Sin embargo, para la compactación se estableció un nuevo valor, "muy compacta" cuando al rayar con la uña, fue ésta la que se alteró sin producir impacto alguno en el material refractario. 
Finalmente, se procedió a la identificación de los tipos artefactuales, para ello se realizó una descripción morfológica y se los clasificó en función de la distinción realizada por González entre moldes, crisoles y refractarios intermediarios (González 1992, 2004b). Siguiendo esta clasificación, los moldes son piezas que presentan cavidades en negativo utilizadas para la recepción del metal fundido que posibilita la configuración morfológica de objetos. Existen moldes complejos llamados de cera perdida; moldes cerrados con dos superficies que entran en contacto para conformar el objeto y finalmente los moldes abiertos compuestos por una única base con la/s forma/s o preforma/s en negativo de la/s pieza/s a fabricar. Respecto a los crisoles, son piezas abiertas con forma de cuenco que suelen ser utilizados para operaciones de fundición de minerales o fusión de metales. Las piezas intermediarias están conformadas por la dupla cuchara y tapón, que fueron empleadas para el vaciado y distribución del metal hacia los moldes. En este punto cabe aclarar, que los crisoles y cucharas presentan morfologías y sistemas de sujeción similares, por lo cual su diferencia radica, principalmente, en que los últimos presentan en su base un orificio de perforación para controlar la dosificación del metal (González 1992, 2002, 2004b; Gluzman 2017). Se ha sugerido que la oclusión y apertura de dicha perforación se realizaría con el tapón o espiche regulador (Niemeyer 1981; Pifferetti 2004; González 2002), de los cuales se han reconocidos tres formas principales: rectos, en codo o en arco (Gluzman 2017). Respecto a los mecanismos de sujeción de crisoles y cucharas, los datos disponibles dan cuenta de la utilización de rebordes pronunciados, acanaladuras perimetrales externas o canales perimetrales internos que posibilitan su manipulación y transporte (González y Gluzman 2009).

De cada una de las piezas analizadas en Quillay, fueron calculadas sus dimensiones segregadas en las siguientes variables: anchos y longitudes máximas y mínimas; profundidad, espesores promedios (cm) y peso (gr). Finalmente, se especificaron las huellas de uso observadas, es decir, vestigios que remitan a actividades metalúrgicas y procedimientos técnicos.

2- $\quad$ Análisis petrográficos de la pasta: este análisis fue realizado por la Dra. Geraldine Gluzman. Se observaron láminas delgadas de cerámicas metalúrgicas en un microscopio petrográfico de luz plana y polarizada con el objetivo de identificar la naturaleza, proporción y orientación de las inclusiones, así como caracterizar y 
cuantificar la porosidad de las pastas (Orton y Vince 1997). El análisis fue realizado sobre cuatro muestras refractarias representativas de las clases de artefactos reconocidos en el sitio y en otras dos cerámicas no refractarias con fines comparativos. Este análisis forma parte de un primer estudio comparativo a nivel regional y como veremos más adelante aportó datos interesantes para evaluar parámetros y elecciones tecnológicas relativas a prácticas metalúrgicas.

3- Análisis químicos: fueron realizados sobre los materiales adheridos a las piezas refractarias. Se empleó la técnica de Difracción de Rayos X para la identificación de los compuestos cristalinos del recubrimiento blanquecino. El análisis químico fue realizado en el servicio de Difracción de Rayos X del Centro de Investigaciones Geológicas de La Plata (CIG-CONICET). Estos estudios, se complementaron con microanálisis elemental del material blanquecino en aquellas muestras que no aportaron los gramos necesarios para análisis por difractometría. Asimismo, con esta misma técnica fueron analizadas las adherencias metálicas para determinar los elementos composicionales y conocer los metales procesados. Para ello se empleó un detector de rayos $\mathrm{X}$ dispersivo en energías (EDS), acoplado a un microscopio electrónico de barrido (MEB) disponible en el servicio de microscopía óptica de la Facultad de Ingeniería de la UNLP.

\subsubsection{Análisis del material lítico}

El conjunto de material lítico analizado en el sector $A$ del sitio, proviene principalmente de la excavación realizada en el recinto 1 . A este material se le efectuó un análisis general de carácter morfotecnológico basado en las propuestas de Aschero (1975) y Civalero (2006). La tabla utilizada para el análisis siguió las variables de análisis utilizadas por Giovannetti (2015a) con dos niveles de abordaje: por un lado, observaciones cuali-cuantitativas de los fragmentos líticos, por el otro, inferencias sobre el instrumento formatizado (tabla 10- Anexo I).

Las observaciones efectuadas sobre los fragmentos estuvieron orientadas en primer lugar a determinar la naturaleza petrográfica de las materias primas de cada una de las piezas. La clasificación tecno-tipológica del fragmento se realizó a partir de los atributos morfológicos presentes en el mismo que permiten discriminar entre núcleos y productos de talla (lascas u hojas). Los "núcleos" son bloques de material lítico seleccionado de las fuentes, de los cuales se extraen preformas para la confección de 
instrumentos o bien sirven ellos mismos como forma base para algunas clases de artefactos (Paulides 2006). Estos suelen presentar vestigios de corteza y negativos de extracciones, que brindan información sobre los procedimientos y las estrategias empleadas en la reducción del material. Las preformas extraídas durante la talla son de dos tipos básicos: "lascas" y "hojas". Ambas clases, presentan ciertos atributos en común (cara dorsal y ventral, talón, bulbo, ondas de percusión y estrías) y diferencias en la relación ancho-largo y planos de extracción, siendo las lascas dos veces más anchas respecto al valor de longitud (Aschero 1975; Civalero 2006). Se cuantificaron las dimensiones de los fragmentos como largo, ancho, espesor y peso y se realizó una clasificación general siguiendo las diferencias básicas entre los tipos de lascas propuestas por Aschero (1975).

Finalmente, a partir de las características morfométricas de los fragmentos, en los casos que fuera posible, se infirió el tipo de artefacto buscado, distinguiendo la técnica de manufactura, es decir si la talla se realizó por percusión o presión, el tipo de instrumento, siguiendo la tipología de Aschero (1975) y su forma general.

\subsubsection{Análisis del material arqueobotánico}

También producto de las excavaciones realizadas en este sector se ha registrado abundantes macrorestos vegetales en los recintos. Al identificarse sectores donde esta clase de vestigio era abundante, se separó el sedimento extraído para un tamizado cuidadoso con el fin de obtener la mayor cantidad de muestras, evitando su fragmentación. Una vez en el laboratorio, la identificación botánica fue realizada por el Dr. Marco Giovannetti y por la Srta. Karen Liotta.

La identificación taxonómica se realizó comparando los caracteres morfológicos observados en los restos mediante lupa binocular $(10 \mathrm{X}-30 \mathrm{X})$ con aquellos presentes en muestras de referencias obtenidas del ambiente natural del sitio arqueológico y con ilustraciones presentes en bibliografía especializada siguiendo la metodología delineada en Giovannetti (2015b). Finalmente se discriminaron las estructuras botánicas de los taxones reconocidos y su atributo respecto de su estado seco o carbonizado (tabla 7 Anexo I). Posteriormente, la información obtenida fue procesada con estadística descriptiva. 


\subsubsection{Análisis del material zooarqueológico}

Los restos faunísticos fueron recuperados en contexto estratigráfico de los Recintos 1 y 4b. Los mismos han sido analizados por la Lic. Mariana Valderrama siguiendo los lineamientos aportados por Miotti (1998) y Mengoni Goñalons (2010). En primer lugar, se realizó la limpieza y rotulado de los fragmentos y se efectuó el remontaje mecánico. Se analizaron un conjunto de variables (tabla 3 - Anexo I) orientadas a evaluar la abundancia taxonómica a partir del NISP (Número de Especímenes Identificados por taxón) y \%NISP (el correlato porcentual) (Mengoni Goñalons 1988). Se aclara que otros índices y parámetros propios de los análisis zooarqueológicos (NMI, MNE, edad) no pudieron ser determinados dado el carácter fragmentario de los conjuntos óseos.

Por otro lado, se evaluaron las modificaciones culturales y naturales presentes en la muestra arqueofaunística. Entre las primeras se exploraron indicios de marcas de procesamiento como huellas de corte, puntos de impacto y fracturas intencionales, las cuales pueden evidenciar instancias de despellejamiento, desmembramiento, descarne y extracción (Binford 1981; Lyman 1994; Mengoni Goñalons 2010). También, evidencias de alteración térmica conjugando parámetros de textura, coloración y distribución de la alteración en la muestra (Brain 1981; Shipman et al. 1984; Del Papa 2012). Entre las alteraciones naturales se especificó el estado de meteorización siguiendo la propuesta de Behrensmeyer (1978) como también la existencia de marcas de raíces, acción de roedores y carnívoros, así como de precipitación (Bocek 1986; Behresmeyer 1990; Lyman 1994).

\subsection{Caracterización de la cerámica de superficie del sector $A$}

Se presentarán aquí los resultados del análisis cerámico de las muestras recolectadas en el sector de recintos (ver Figura 5.1) junto a los resultados obtenido de la evaluación de los fragmentos recuperados en la década de 1990 por los investigadores previos. Consideramos que estos últimos son aquellos que fueron oportunamente publicados (Raffino et al. 1996), siendo en el presente estudio re analizados siguiendo los parámetros previamente señalados. 
Aquí, se presentarán los resultados de los materiales obtenidos en las tres recolecciones (ver tablas 4, 5 y 6 - Anexo I) en conjunto, dado que todas ellas pertenecen al sector de recintos. Así, luego de realizarse el remontaje y agrupamiento por familia, se alcanzó un número mínimo de 1194 piezas cerámicas, que se distribuyen como se muestra en la tabla 5.1.

\begin{tabular}{|c|c|c|c|}
\hline \multicolumn{3}{|c|}{ RECOLECCIÓN SECTOR A } & TOTAL \\
\hline \multicolumn{2}{|l|}{ Raffino 1990} & 63 & 63 \\
\hline \multirow{8}{*}{$\begin{array}{l}\text { Recintos (intramuros) } \\
\text { - Diciembre } 2011\end{array}$} & $\mathrm{R} 1$ & 56 & \multirow{8}{*}{572} \\
\hline & $\mathrm{R} 2$ & 38 & \\
\hline & $\mathrm{R} 3$ & 30 & \\
\hline & $\mathrm{R} 4$ & 5 & \\
\hline & $\mathrm{R} 5$ & 78 & \\
\hline & R6 & 125 & \\
\hline & R7 & 166 & \\
\hline & $\mathrm{R} 8$ & 74 & \\
\hline \multirow{5}{*}{$\begin{array}{c}\text { Transectas - enero } \\
2011\end{array}$} & $\mathrm{~T} 1$ & 6 & \multirow{5}{*}{559} \\
\hline & $\mathrm{T} 2$ & 48 & \\
\hline & $\mathrm{T} 3$ & 100 & \\
\hline & $\mathrm{T} 4$ & 199 & \\
\hline & $\mathrm{T} 5$ & 206 & \\
\hline \multicolumn{3}{|l|}{ TOTAL } & 1194 \\
\hline
\end{tabular}

Tabla 5.1. Frecuencia numérica de fragmentos cerámicos recuperados en el Sector A, según la zona y año de recolección.

Los gráficos 5.1 y 5.2 exhiben las frecuencias de los estilos cerámicos registrados en la superficie del sector $A$ y en la tabla 5.2 se particularizan los resultados según el periodo y el área de recolección. En el primer gráfico, se presenta una agrupación de las cerámicas en función de la asignación tipológica-cronológica para evaluar la proporción de grupos cerámicos. Allí se observa que el $43 \%$ de la muestra está conformada por tiestos correspondientes a estilos cerámicos definidos para grupos sociales que habitaron la región desde el período Tardío (900-1470 dC.). En segundo lugar, con un $31 \%$ de representatividad, lo ocupan las piezas ordinarias clasificadas como "Tosco utilitarias" de difícil asignación cronológica. Suelen ser piezas sin decoración, con altas 
proporciones de antiplástico de tamaño relativamente grande y exponen comúnmente indicios de su uso para cocina. Por su parte, los fragmentos de estilo Inka Provincial representan el $2 \%$ de la muestra total, junto a un pequeño porcentaje de fragmentos dudosos para este estilo (1\%). En la categoría de pre-tardíos se agruparon los tiestos de estilos Ciénaga y Aguada los cuales alcanzaron una frecuencia de 3,4 \%. Finalmente, los clasificados como "Belén o Inka" (6,8 \%) consisten en fragmentos pequeños que presentaron una decoración indiferenciada de pintura negra sobre engobe rojo o sólo engobe rojo, característica similar en ambos estilos cerámicos, sin ningún otro atributo claro que permitiera diferenciarlos.

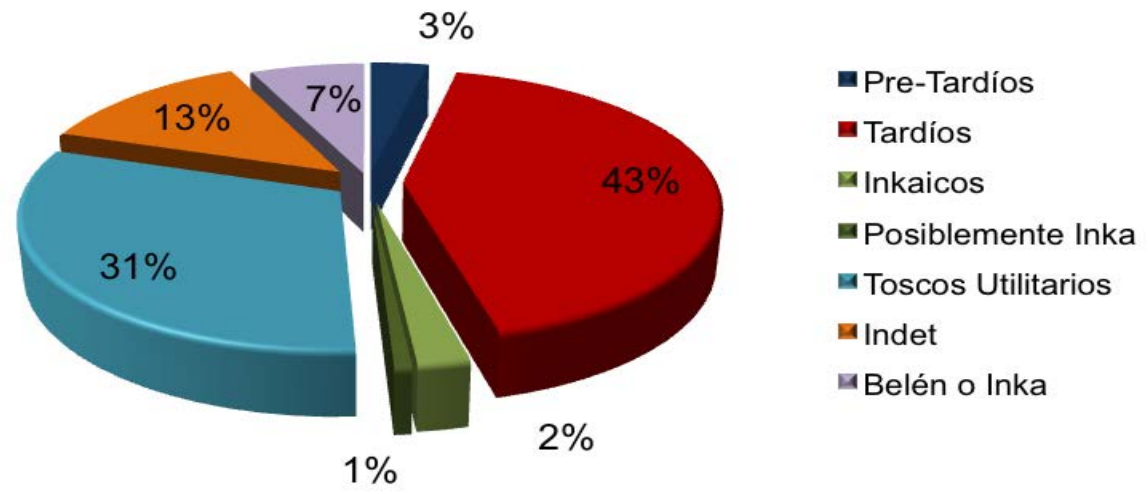

Gráfico 5.1. Porcentaje cerámicos del sector A

\begin{tabular}{|l|c|c|c|c|c|}
\hline \multirow{2}{*}{ Estilos } & \multicolumn{3}{|c|}{ N } & \multirow{2}{*}{ Total } & \multirow{2}{*}{$\%$} \\
\cline { 2 - 4 } & Recintos & Transectas & Raffino & & \\
\hline Pre-Tardíos & 17 & 21 & 3 & 41 & 3,4 \\
\hline Tardíos & 241 & 236 & 40 & 517 & 43,3 \\
\hline Inkaicos & 12 & 8 & 2 & 22 & 1,8 \\
\hline Posiblemente Inka & 5 & 4 & 0 & 9 & 0,8 \\
\hline Toscos Utilitarios & 177 & 180 & 12 & 369 & 30,9 \\
\hline Indet & 81 & 74 & 0 & 155 & 13,0 \\
\hline Belén o Inka & 39 & 36 & 6 & 81 & 6,8 \\
\hline \multicolumn{1}{|c|}{ Total } & $\mathbf{5 7 2}$ & $\mathbf{5 5 9}$ & $\mathbf{6 3}$ & $\mathbf{1 1 9 4}$ & $\mathbf{1 0 0}$ \\
\hline
\end{tabular}

Tabla 5.2. Frecuencia de estilos cerámicos recolectados en el Sector A (numérica y porcentual). Se discrimina por sector de recolección y los recuperados por investigadores previos.

Al discriminar los tipos estilísticos dentro del grupo de cerámicas tardías, se observa que la mayor frecuencia está dada por cerámicas de estilo Belén $(87 \%)$, 
asociadas a un $12 \%$ de vasijas de estilo Santamariano bicolor y tricolor y en menor frecuencia (>1\%) a fragmentos Sanagasta y Hualfín (Gráfico 5.2).

Un caso particular resultó la pieza n¹91 rotulada como "marrón pulido" (Figura 5.2). La misma consta de siete fragmentos con características similares en todos los atributos por lo cual fueron agrupados en la misma familia. Son tiestos de pasta fina y compacta, de fractura irregular y cocción oxidante. Presentan tratamientos de engobe con baños de color marrón y superficies muy bien pulidas. Lo distintivo de la pieza, es que se buscó alcanzar una superficie externa oscura de amplio campo, no siendo posible asignarle una clasificación exacta dentro de los estilos generales conocidos. Por las características de la pasta seguramente se trate de una pieza tardía, quizás alguna variante local de los estilos Hualfín o Sanagasta.

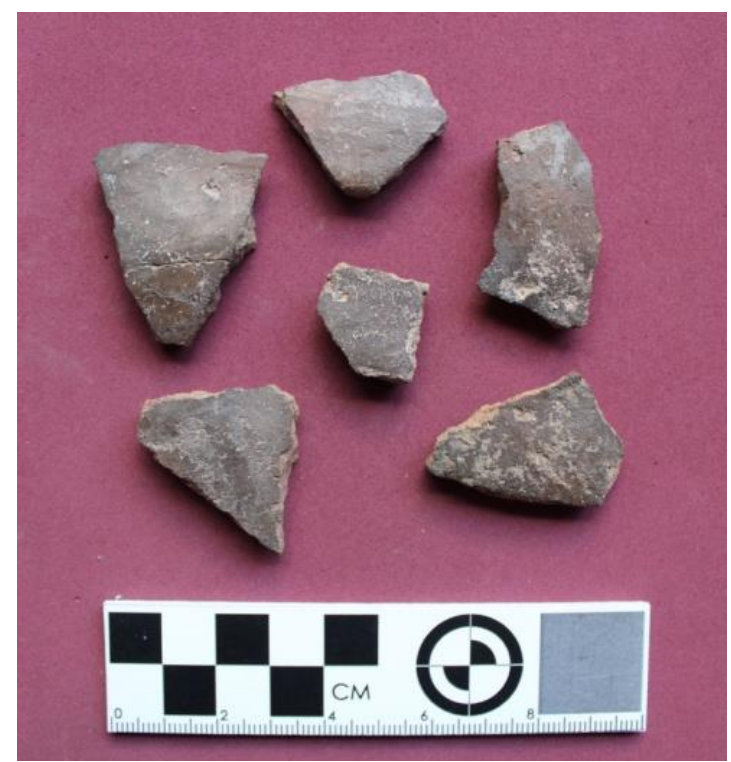

Figura 5.2. Fragmentos cerámicos de estilo dudoso, rotulados como "Marrón pulido". 


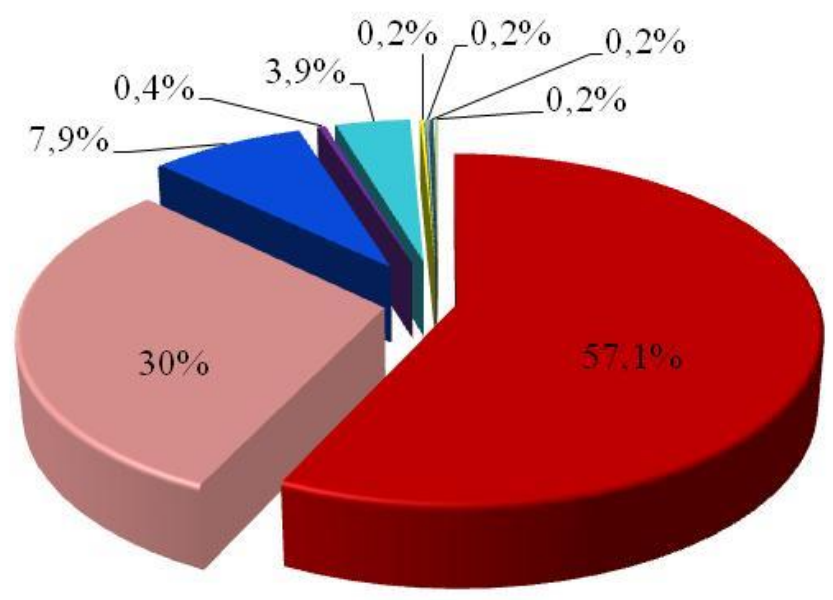

melén

回Posible Belén

- Santamariano

- Santamariano Tricolor

四 Posible Santamariano

14 Sanagasta

四 Sanagasta o Santamariano

a Hualfin

四 Marrón pulido

Gráfico 5.2. Frecuencia porcentual de tipos estilísticos tardíos

Respecto a la morfología de piezas cerámicas tardías (Gráfico 5.3), la mayoría son formas cerradas $(72 \%)$, de las cuales un $22 \%$ han podido identificarse como parte de tinajas. Las correspondientes al estilo Belén son segmentos de cuerpos y cuellos con decoración geométrica conformada por líneas gruesas, cuadriculados, reticulados, grecas, patrones de líneas paralelas que circunscriben puntos y líneas onduladas. También se han observado en los cuerpos aditamentos modelados y líneas excisas que, en algunos casos, conforman rostros antropomorfos (Figura 5.3). Se registraron bases planas y convexas (tipo A y D de la convección) y las típicas asas horizontales remachadas con decoración de líneas perpendiculares al segmento o bien, con un amplio campo de pintura negra en sentido horizontal. El análisis de los fragmentos correspondientes a tinajas Belén permite proponer que sus patrones decorativos siguen la clásica segmentación de los cuerpos observadas en cerámicas de estos grupos analizadas para otros sitios de este mismo valle (Wynveldt et al. 2005; Wynveldt 2007).

Respecto a las 10 tinajas Santamarianas, son pequeños fragmentos de cuerpos y principalmente cuellos con decoración bicolor y tricolor (negro y rojo sobre engobe blanco). En ellos sólo se han observado segmentos de líneas paralelas, en zig-zag, cuadriculados y puntos, que no han permitido reconstruir diseños específicos (Figura $5.3)$

Las piezas abiertas conforman el 19,5 \% del conjunto de formas tardías, la mayoría corresponden al tipo $p^{\prime} u k u$ de estilo Belén y unos pocos Santamariano (Figura 
5.3 y tabla 5.3). Los diámetros calculados de estas escudillas oscilan entre los 6 y 18 $\mathrm{cm}$, todas de contornos simples con bordes invertidos (Figura 5.4). Presentan decoraciones externas con líneas onduladas paralelas y en la superficie interna diseños geométricos más complejos con reticulados, espirales, líneas y puntos. También se registraron apéndices en los bordes que contienen orificios o aplicaciones de carácter amorfo (Figura 5.3 B y C).

Por otro lado, dos tiestos de periodos tardíos, presentaron contornos redondeados por lo que podrían estar dando cuenta de torteros en proceso de fabricación posiblemente - dado sus tratamientos superficiales y tipo de pastas- a partir de piezas cerámicas Belén y Santamariana (Figura 5.5).

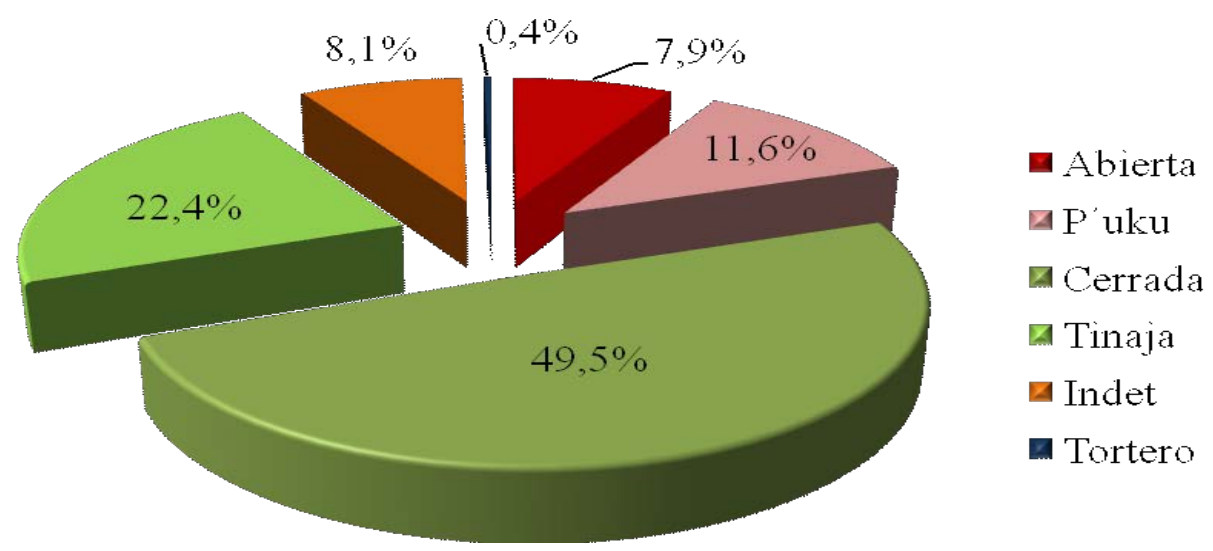

Gráfico 5.3. Frecuencia de formas cerámicas de periodos tardíos 

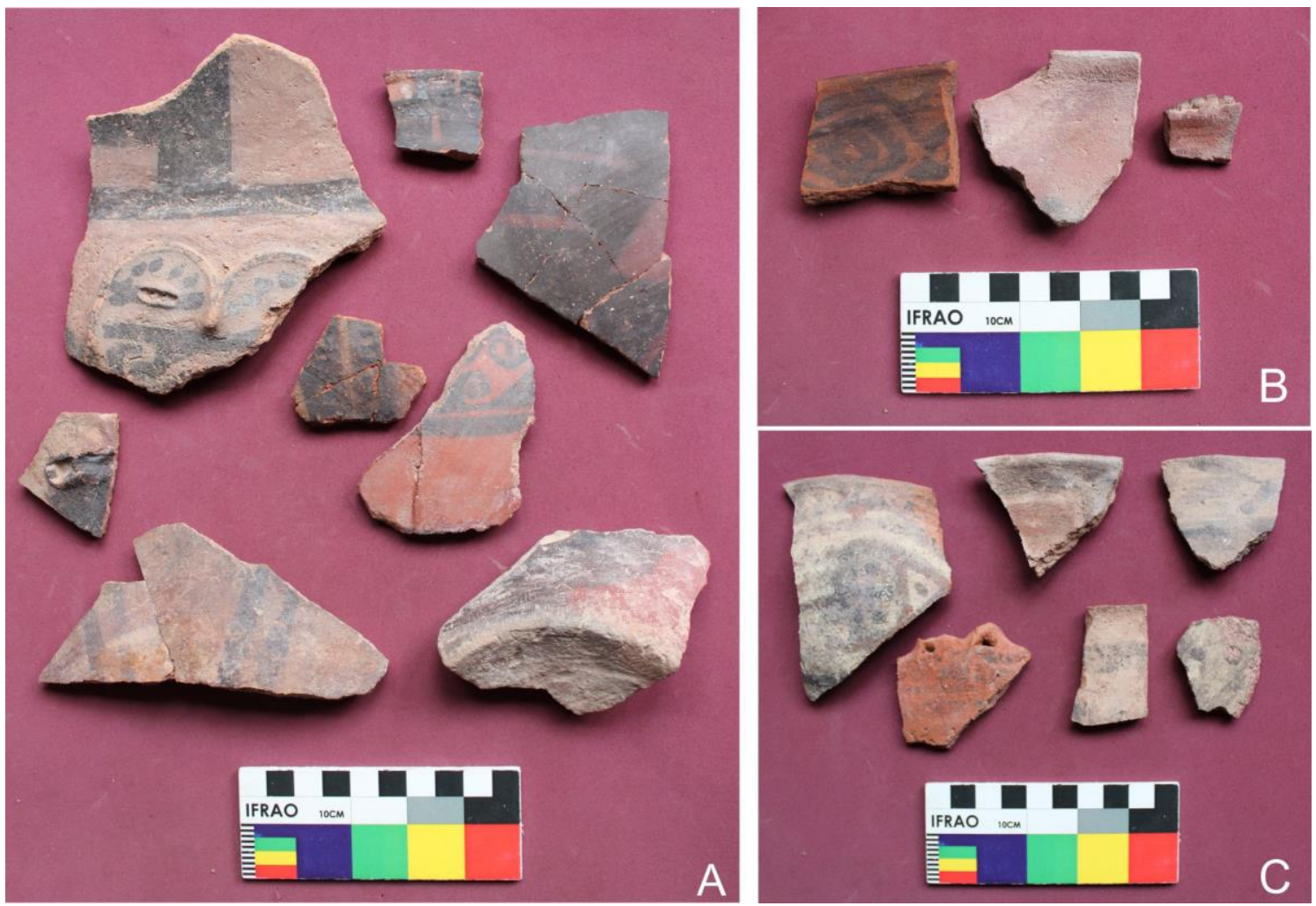

Figura 5.3. Tiestos de estilos tardíos. A. Segmentos de tinajas Belén. B Bordes de pucos Belén. C. Partes de tinajas y pucos Santamarianos.

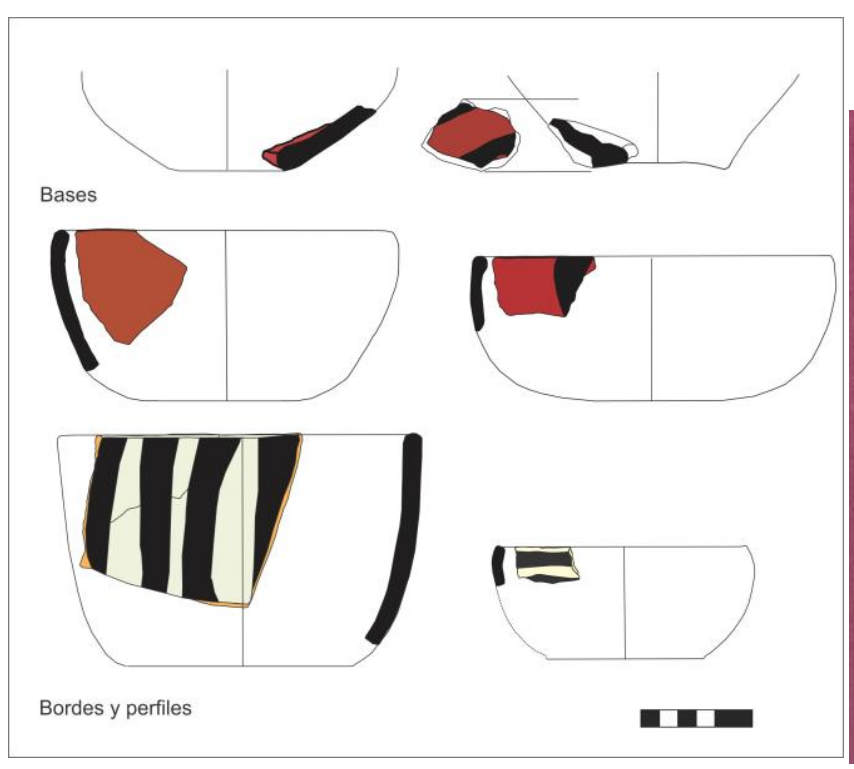

Figura 5.4. Reconstrucción de bases y secciones simples de piezas tipo $p^{\prime} u k u$. Arriba estilo Belén, abajo estilo Santamariano.

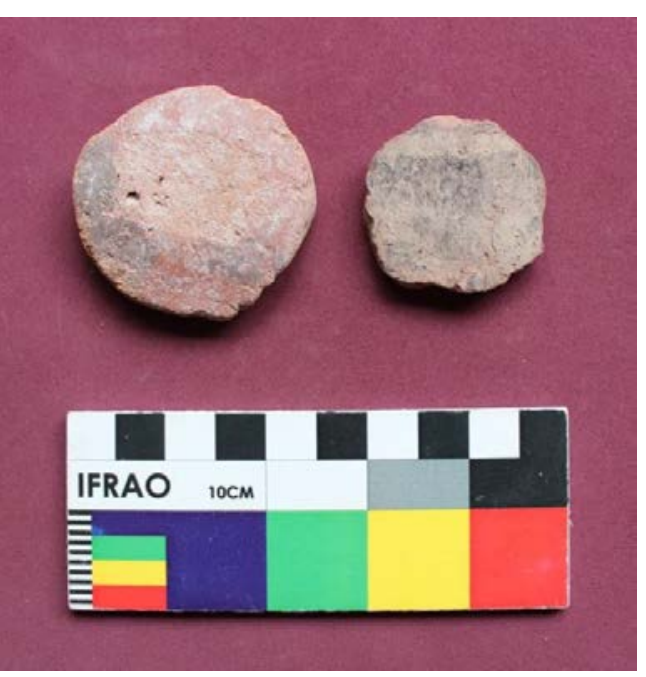

Figura 5.5. Posibles torteros en proceso de fabricación a partir de piezas Belén (izquierda) y Santamariana (derecha) 
Con relación a las formas cerámicas de estilo Inkaico (2\%), aquí también se observa un predominio de piezas cerradas (86\%), algunas identificadas como aríbalos o aribaloides (tabla 5.3). Sólo dos tiestos corresponden a segmentos de piezas abiertas $(9,5 \%)$, posiblemente platos y un fragmento pequeño de difícil determinación $(4,5 \%)$. En general, las piezas Inkas analizadas presentan caras externas con engobes monocromos rojos con un pulido intenso y otros con una marcada decoración geométrica formada por líneas muy delgadas $(>0,4 \mathrm{~cm})$. Entre los diseños se destacan las líneas simples y dobles, rombos y chevrones (Figura 5.6). Por otra parte, el fragmento de estilo Famabalasto Negro sobre Rojo es un segmento de borde de un $p^{\prime} u k u$ remarcado con pintura negra en el labio, presenta fractura regular y pasta compacta con núcleo de cocción. Se lo considera un estilo foráneo, oriundo de la región de Santiago del Estero, que presentó una amplia dispersión geográfica en el NOA durante el periodo Inkaico (Calderari y Williams 1999) (Figura 5.6).
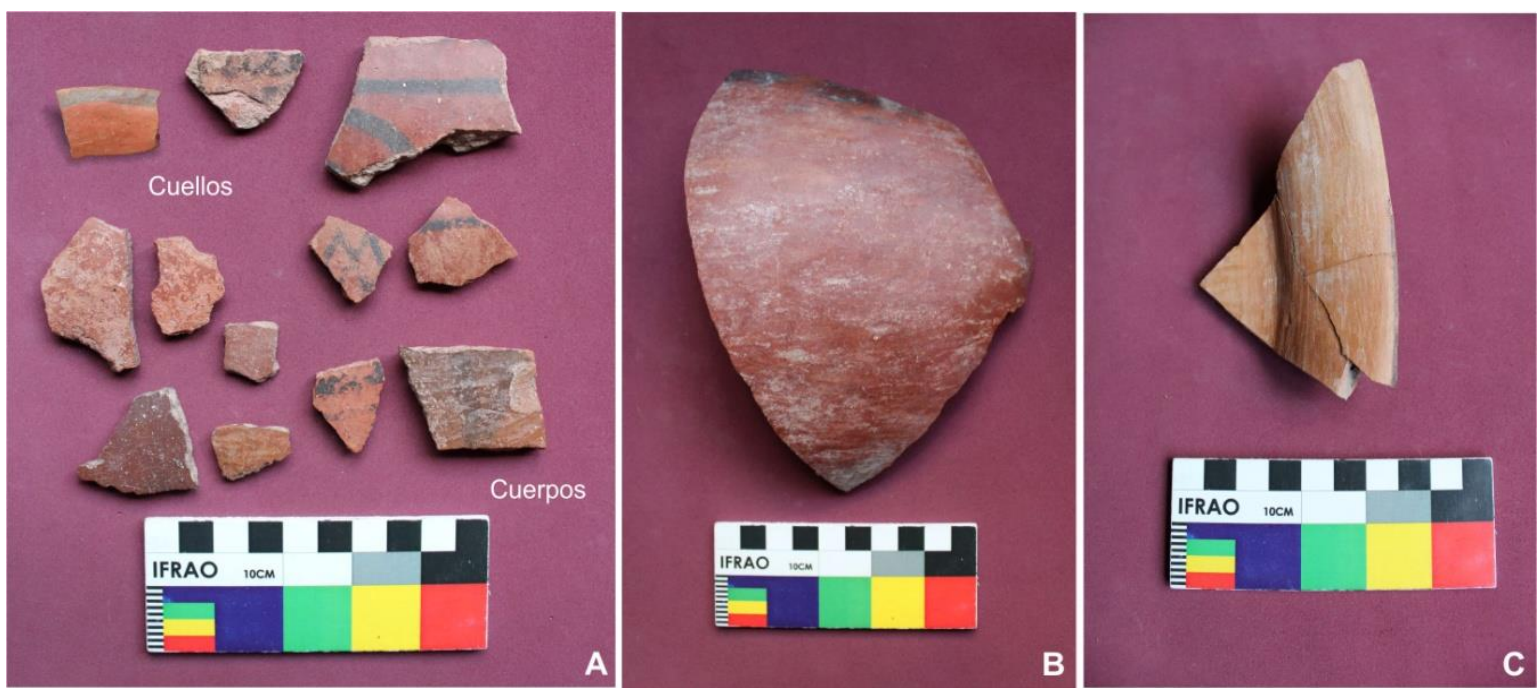

Figura 5.6. Fragmentos de Piezas Inkaicas. A. Segmentos de cuerpos y cuellos de aríbalos o aribaloides. B. Cuerpo globular de aríbalo o aribaloide, monócromo rojo. C. P'uku de estilo Famabalasto.

El conjunto de los tiestos pre-tardíos son principalmente fragmentos de formas cerradas y algunas abiertas correspondientes a los estilos Ciénaga y Aguada. De pastas grises de tipo reductora, fractura regular y superficies externas bruñidas, algunos con decoración geométrica y Figurativa formada por incisiones muy finas. También se 
identificaron algunos fragmentos de cerámica Aguada Pintada con cocción de tipo oxidante.

\begin{tabular}{|c|c|c|c|c|c|c|c|}
\hline \multirow{2}{*}{ ESTILOS } & \multicolumn{7}{|c|}{ MORFOLOGÍAS (n) } \\
\cline { 2 - 9 } & Abiertas & $P^{\prime} u k u$ & Cerradas & $\begin{array}{c}\text { Aribalos o } \\
\text { Aribaloides }\end{array}$ & Tinajas & iTorteros? & Indet \\
\hline Ciénaga & 2 & - & - & - & - & - & - \\
\hline $\begin{array}{c}\text { Ciénaga o } \\
\text { Aguada }\end{array}$ & 1 & - & 10 & - & - & - & - \\
\hline Aguada & 5 & - & 21 & - & - & - & 2 \\
\hline Belén & 17 & 51 & 107 & - & 106 & 1 & 13 \\
\hline Posible Belén & 23 & 6 & 99 & - & - & - & 27 \\
\hline Santamariano & 1 & 1 & 28 & - & 10 & 1 & 2 \\
\hline $\begin{array}{c}\text { Posible } \\
\text { Santamariano }\end{array}$ & - & 2 & 18 & - & - & - & - \\
\hline Sanagasta & - & - & 1 & - & - & - & - \\
\hline $\begin{array}{c}\text { Sanagasta o } \\
\text { Santamariano }\end{array}$ & - & - & 1 & - & - & - & - \\
\hline Hualfin & - & - & - & - & 1 & - & - \\
\hline Marrón Pulido & - & - & 1 & - & - & - & - \\
\hline Inka & 2 & - & 13 & 5 & - & - & 1 \\
\hline Posible Inka & - & - & 5 & - & - & - & 4 \\
\hline Famabalasto & - & 1 & - & - & - & - & - \\
\hline Belén o Inka & 16 & - & 52 & - & - & - & 13 \\
\hline Total & $\mathbf{6 7}$ & $\mathbf{6 1}$ & $\mathbf{3 5 6}$ & $\mathbf{5}$ & $\mathbf{1 1 7}$ & $\mathbf{2}$ & $\mathbf{6 2}$ \\
\hline
\end{tabular}

Tabla 5.3. Frecuencia en números absolutos de las formas de cerámicas decoradas

Por último, como ya se ha comentado las piezas denominadas "Toscos utilitarios" constituyen el segundo grupo más importante dentro del conjunto cerámico $(31 \%$, Gráfico 5.1). Son fragmentos alisados pero que aún conservan una textura rugosa, algunos con tratamientos superficiales de cepillado y otros con baño blanquecino. Sus pastas son semicompactas con abundantes inclusiones líticas de grano grueso. Se han reconocido diversas partes de piezas cerradas (69\%), de las cuales un $30 \%$ fueron reconocidas como ollas. Prevalecen los segmentos de cuerpos con perfiles globulares y algunos bordes, asas y bases. La gran mayoría posee espesores gruesos (entre 1 y $3 \mathrm{~cm}$ ) que pueden corresponder a ollas de gran tamaño y otros más delgados $(>1 \mathrm{~cm})$ 
asociados a piezas medianas a chicas ${ }^{1}$. Por otro lado, si bien es cierto que las piezas ordinarias presentan pocos atributos que permiten asociarlos a un periodo cronológico en particular, se han observado asas remachadas con forma de arco y orificios ovales características de momentos tardíos (Puente 2012; Iucci 2013) y dos segmentos de pie de compotera generalmente asociados a vasijas inkaicas (Bray 2004).

Con relación a los vestigios de uso, es importante remarcar que sólo un $8 \%$ $(\mathrm{n}=56)$ de las piezas con atributos decorativos presentaron marcas directas de utilización (desgaste, picados y/o hollín). En cambio, predominan en las piezas ordinarias, donde el $31 \%$ de los fragmentos toscos presentan marcas de haber sido expuestos al fuego. Estas consisten en restos de hollín o manchas de quemado en la superficie externa y un $14 \%$ también posee en la interna. Estos contenedores posiblemente estén asociados con la cocción de alimentos. Además, un $19 \%$ de fragmentos presenta en sus superficies internas un ennegrecido intenso y homogéneo que por sus características parecería responder a particulares prácticas de cocción de vasijas ordinarias y no tanto a huellas de uso.

\subsection{Materiales refractarios: tipos artefactuales y sus características}

Los materiales refractarios fueron hallados superficialmente en el sector de recintos y en un amplio espacio de hasta $200 \mathrm{~m}$ hacia el este de las unidades arquitectónicas. Cuatro de ellos, han sido recuperados en las recolecciones realizadas mediante transectas y otros 10 fueron identificados en las prospecciones del sector A, siendo registrada su localización mediante GPS. Por último, dos ejemplares -una cuchara y un tapón- se encontraron alojados en los depósitos del Museo de La Plata dado que han sido recuperados por otros investigadores (Raffino et al. 1996).

Como se adelantó previamente, los refractarios identificados en Quillay están fabricados de materiales arcillosos y contienen abundantes inclusiones, principalmente de cuarzo, micas (muscovita y biotitas) y litoclastos. Sus pastas son de coloración grisácea, muy compactas y con una alta porosidad, en especial en los bordes y sobre la superficie externa.

\footnotetext{
${ }^{1}$ El espesor de las paredes de las vasijas cerámicas es considerado un indicador indirecto del tamaño del contenedor, así como de su uso. En general se considerada que los grandes contenedores requieren paredes más gruesas que sirven de soporte estructural (Rice 2005 [1987])
} 
Fueron reconocidos fragmentos de piezas que corresponden a tres clases artefactuales y otros indeterminados: siete crisoles (44\%); cinco piezas intermediarias (31\%), de las cuales una es claramente una cuchara y las otras cuatro son fragmentos de tapones; un único fragmento de molde (6 \%) y por último tres fragmentos indeterminados (19\%) (Gráfico 5.4).
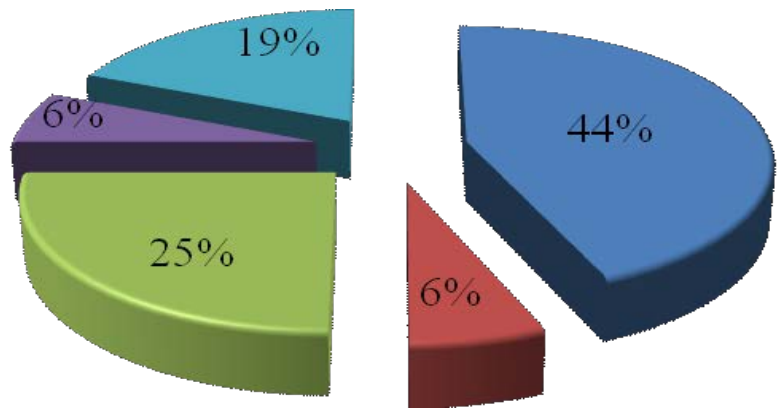

a Crisoles

a Cucharas

a Tapones

a Moldes

a Indet

Gráfico 5.4. Frecuencia porcentual de los artefactos refractarios

1- Crisoles: las muestras rotuladas como M3, M5, M6, M8, M9, M14 y M16 corresponden a partes de crisoles $^{2}$. Están conformados por segmentos de cuerpos cóncavos y bordes de labios convexos y rectos (Figura 5.7). Presentan gruesos espesores de entre $1,8 \mathrm{~cm}$ y $2,8 \mathrm{~cm}$. Los diámetros de boca calculados oscilan entre 8 y $16 \mathrm{~cm}$. Cuatro casos presentan mecanismos de sujeción, dos consisten en acanaladuras perimetrales externas que siguen la circunferencia del cuerpo, una de sección semicircular y la otra en "V". En ambos casos, se alojan a 3,5 cm de distancia calculado desde el borde de los fragmentos. Los otros dos ejemplares presentan rebordes abultados que servirían asimismo para sostener algún tipo de implemento (ej. ramas verdes) lo cual facilitaría su utilización (González y Gluzman 2009; Gluzman 2017).

Todos los crisoles presentan en su cara interna un recubrimiento blanquecino y en tres casos también se reconocieron vestigios de esta sustancia en la superficie externa. Para el caso de la M14, hacia el interior, se observó la superposición de al menos dos

\footnotetext{
${ }^{2}$ El grado de fragmentación de los materiales y la ausencia de sus bases no permite diferenciar entre aquellos cuencos que presentan perforación de aquellos en los que está ausente. Este rasgo posibilitaría distinguir entre crisoles y cucharas. Frente a esta situación, se los consideró dentro de la categoría más general de crisoles.
} 
capas de este recubrimiento, que señalaría la reutilización de estos implementos en sucesivos eventos metalúrgicos (González 2002; Angiorama 2004). En todos los casos, se observaron evidencias de termoalteración como sectores quemados, vitrificaciones y superficies de "aspecto burbujoso" (sensu Fraresso 2010: 360) con grandes vesículas de gas. Estas fueron detectadas principalmente hacia los bordes y en la superficie interna de los fragmentos. Dichas alteraciones señalan que los materiales estuvieron sometidos a elevadas temperaturas, las cuales es probable que hayan superado $\operatorname{los} 1000^{\circ} \mathrm{C}$. Del conjunto de crisoles, únicamente la M3 presenta adherencias metálicas de coloración verde esmeralda en el sector interno próximo al borde (Figura 5.7), las cuales fueron analizadas por EDS y cuyos resultados serán presentados más adelante.

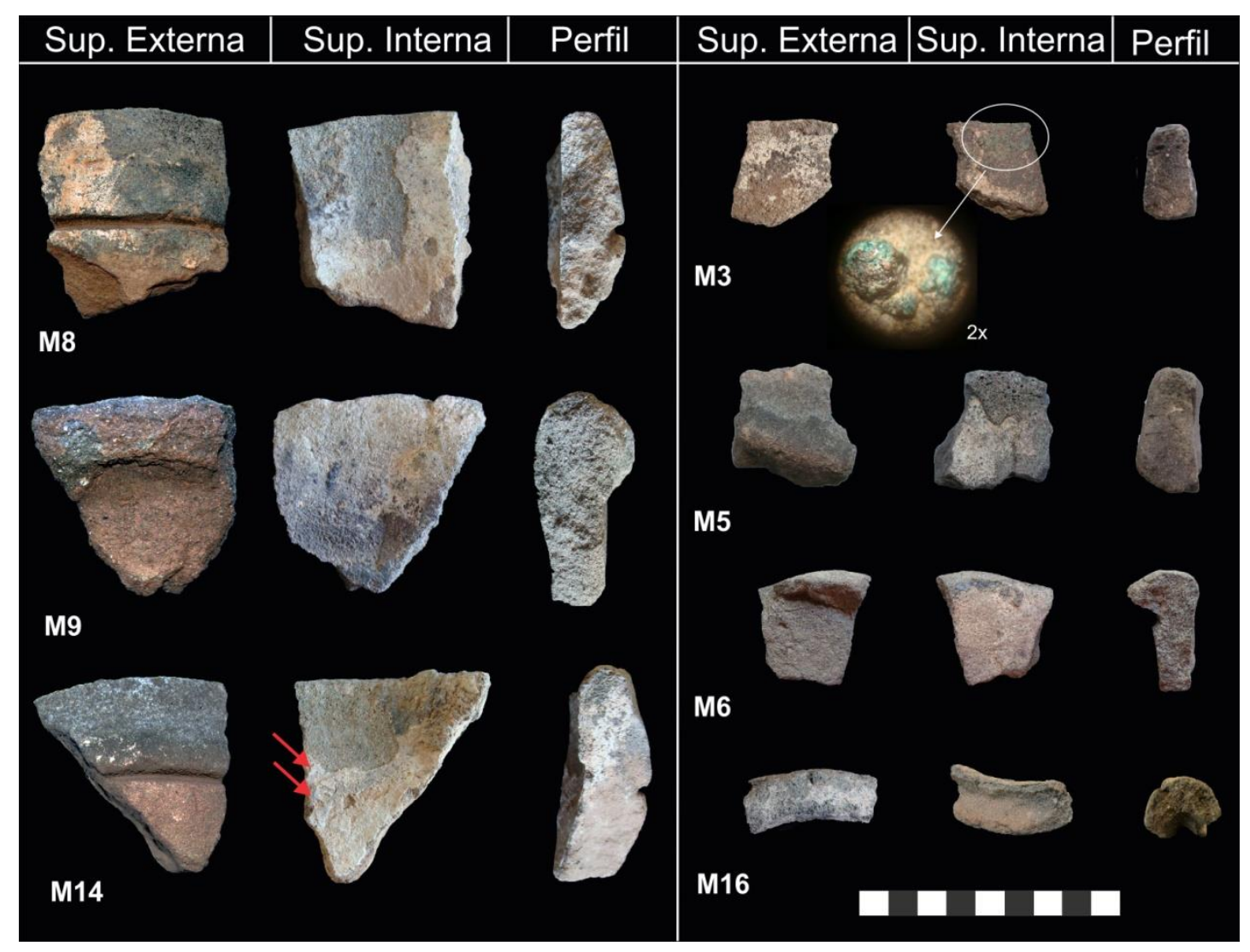

Figura 5.7. Fragmentos de crisoles. El círculo muestra las adherencias metálicas (M3) y las flechas rojas señalan las capas de recubrimiento blanco.

2- $\quad$ Piezas intermediarias: de este conjunto se han reconocido una cuchara (M11) y cuatro fragmentos de tapones. Estos últimos presentan una forma tubular de perfil curvo 
(M1) o algo curvado (M15), recto (M10) e indeterminado (M13). Sus secciones transversales son variables, presentando aspecto esférico, prismático y circular, pero de espesores estandarizados que rondan los $3 \mathrm{~cm}$ (Figura 5.8). Dos tapones - M10 y M15 están recubiertos con un sedimento blanquecino y el segundo de ellos presenta adherencias de metal de coloración verde que fueron analizados químicamente. La observación a lupa binocular permitió detectar que estas inclusiones metálicas se hallan distribuidas a lo largo de toda la circunferencia del cuerpo, junto a una pasta fuertemente vitrificada y de aspecto "burbujoso". La presencia de metal en el cuerpo del vástago, apoyaría la idea que la oclusión/apertura del orificio del cuenco se realizaría por el interior del recipiente en contacto con el fundido, tal como ha sido propuesto para ejemplares similares en Chile (Niemeyer 1981).

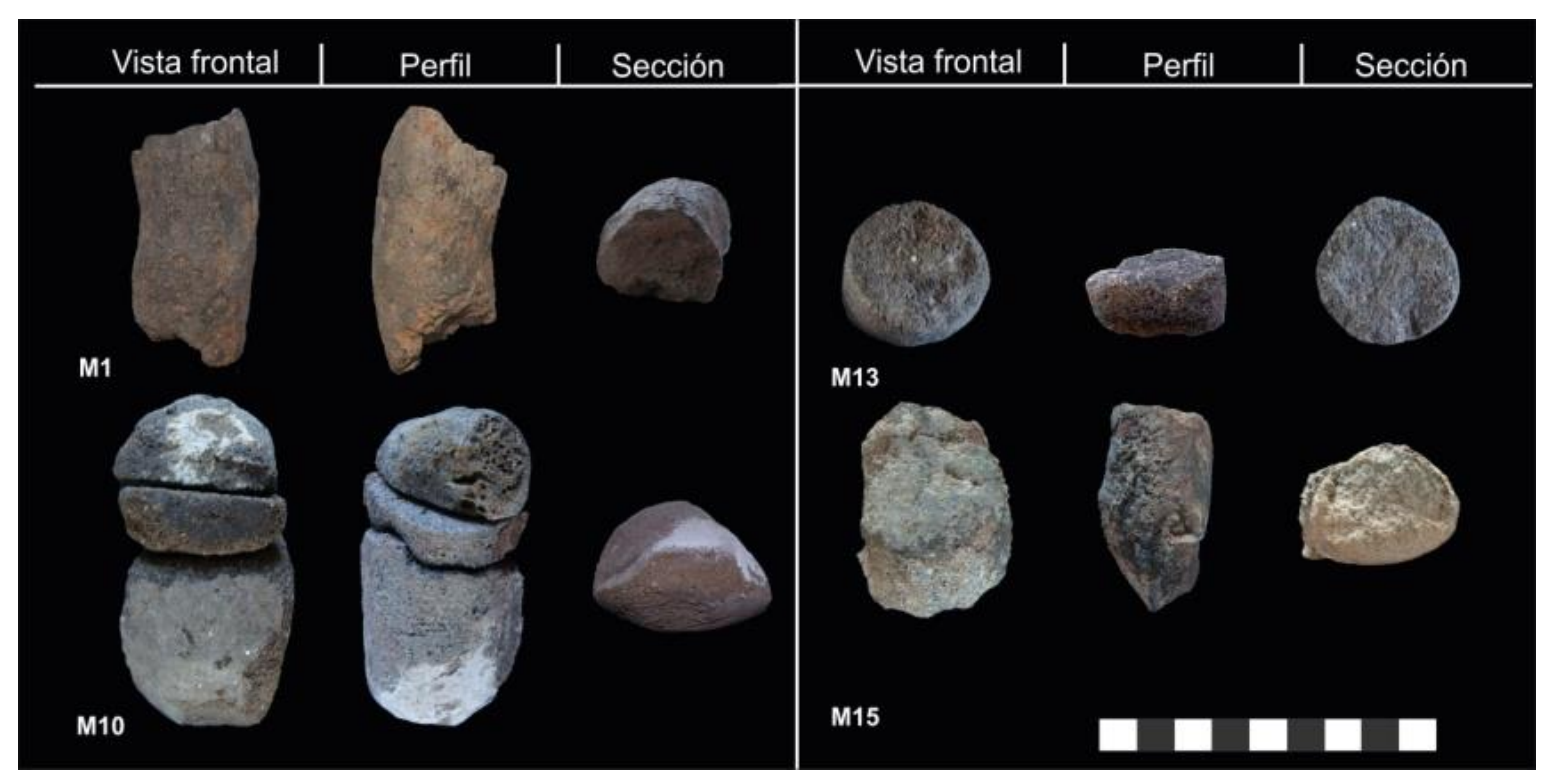

Figura 5.8. Fragmentos de tapones

Respecto a la única cuchara claramente identificada en Quillay es un cuenco de $12,5 \mathrm{~cm}$ de diámetro y alcanza una profundidad de $6,7 \mathrm{~cm}$. Su perfil es cónico, sin una base plana lo que dificulta su apoyo. Presenta el atributo diagnóstico para este tipo de artefactos, esto es, un orificio en la base de la escudilla, que en este caso adquiere forma circular con $0,7 \mathrm{~cm}$ de diámetro. Por otro lado, la cuchara, presenta una acanaladura de sección semi-circular alojada en el cuerpo a $1,7 \mathrm{~cm}$ desde el borde del cuenco. El recubrimiento blanquecino se halla en ambas superficies y hacia el interior fue posible 
reconocer dos capas superpuestas (Figura 5.9), señalando también en este caso instancias de reutilización del recipiente.

Estas observaciones morfométricas son coincidentes con las informadas por los investigadores previos para este mismo objeto (Raffino et al. 1996). Sin embargo, diferimos en la consideración de la materia prima utilizada. Anteriormente se planteó que "la pieza fue construida en una arenisca de grano fino segmentada con carbonato de calcio" (Raffino et al. 1996: 67). Sin embargo, un análisis minucioso con lupa binocular permitió reconocer que la materia prima empleada fue un material arcilloso fino con antiplásticos ricos en micas.

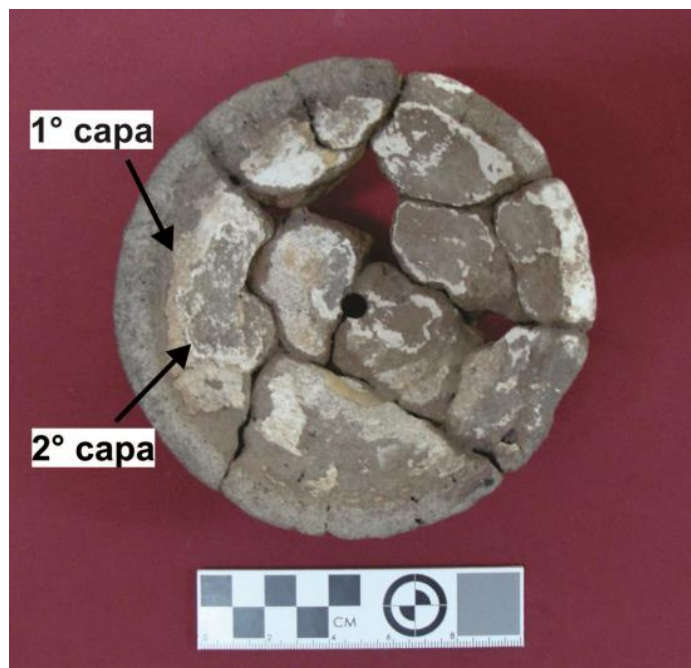

Figura 5.9. Cuchara con doble capara de apatita.

Respecto al sedimento blanquecino, los investigadores citados realizaron análisis químicos por DRX en muestras de este material. Los resultados obtenidos por ellos brindaron picos correspondientes a varios compuestos ricos en calcio como silicato de calcio, oxalato de calcio, hidroxi-apatita, parisita, ellestadita y larnita (Raffino et al. 1996: 68).

3- $\quad$ Fragmentos indeterminados: la M2, es un pequeño cuenco cóncavo de no más de $6 \mathrm{~cm}$ de diámetro y borde recto, cuyas características morfológicas no permiten discriminar a qué tipo artefactual pertenecería. Podría ser parte de una pequeña cuchara refractaria fracturada en su base. Únicamente hacia el interior, presenta dos capas de recubrimiento blanquecino y adherencias metálicas verdosas (Figura 5.10). La M4 es un segmento de cuerpo cóncavo con evidencias de vitrificado y gran

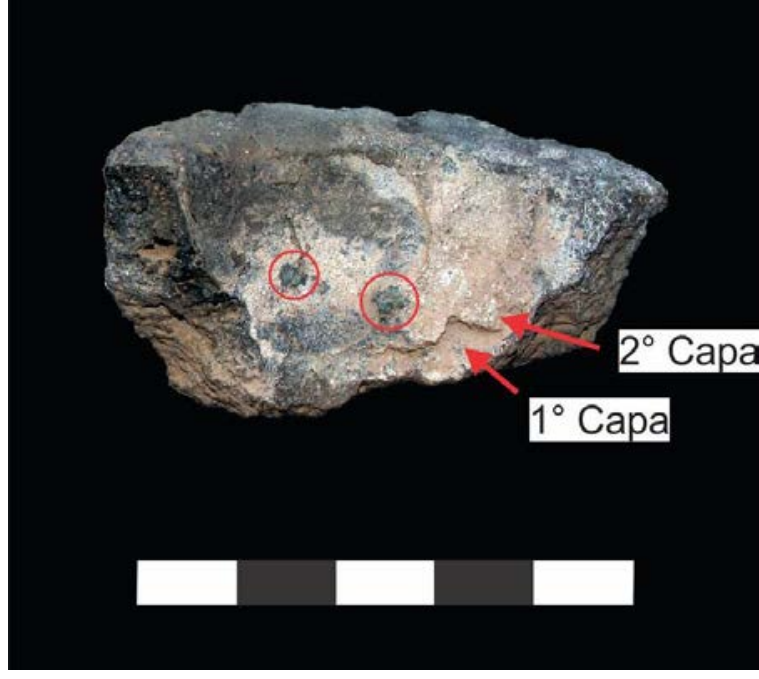

Figura 5.10. Fragmento cóncavo indeterminado con recubrimiento de apatita. 
porosidad. El tercer fragmento -M7- presenta una forma anómala de pequeño cuenco y base cóncava, con una superficie externa quemada y sin recubrimiento. Por el tipo de matriz cerámica macroscópica, se lo consideró como material refractario, sin embargo, su morfología se aleja de aquellas esperadas para esta tecnofactura. Como veremos más adelante, se le realizó un corte petrográfico con la finalidad de conocer las características de la pasta para corroborar su pertenencia a esta clasificación.

4- $\quad$ Molde: el único material refractario identificado dentro de esta categoría es un fragmento plano de forma rectangular, con un quiebre anguloso que se encuentra quemado -M12-. Es posible que el quiebre constituya parte de la cavidad para el vaciado de metal que daría forma al objeto, por lo cual, ha sido clasificado como un molde. La superficie interna está enlucida con el recubrimiento blanquecino con evidencias de quemado. Incluso se observaron vestigios de adherencias metálicas en estado altamente oxidado.

Por otro lado, en la superficie externa no se han observado restos del recubrimiento y la pasta presenta una coloración marrón, sin rastros de alteración térmica. Asimismo, en este sector se han identificado posibles marcas de cestería que podrían estar indicando procesos de manufactura para la confección del molde (Figura 5.11).

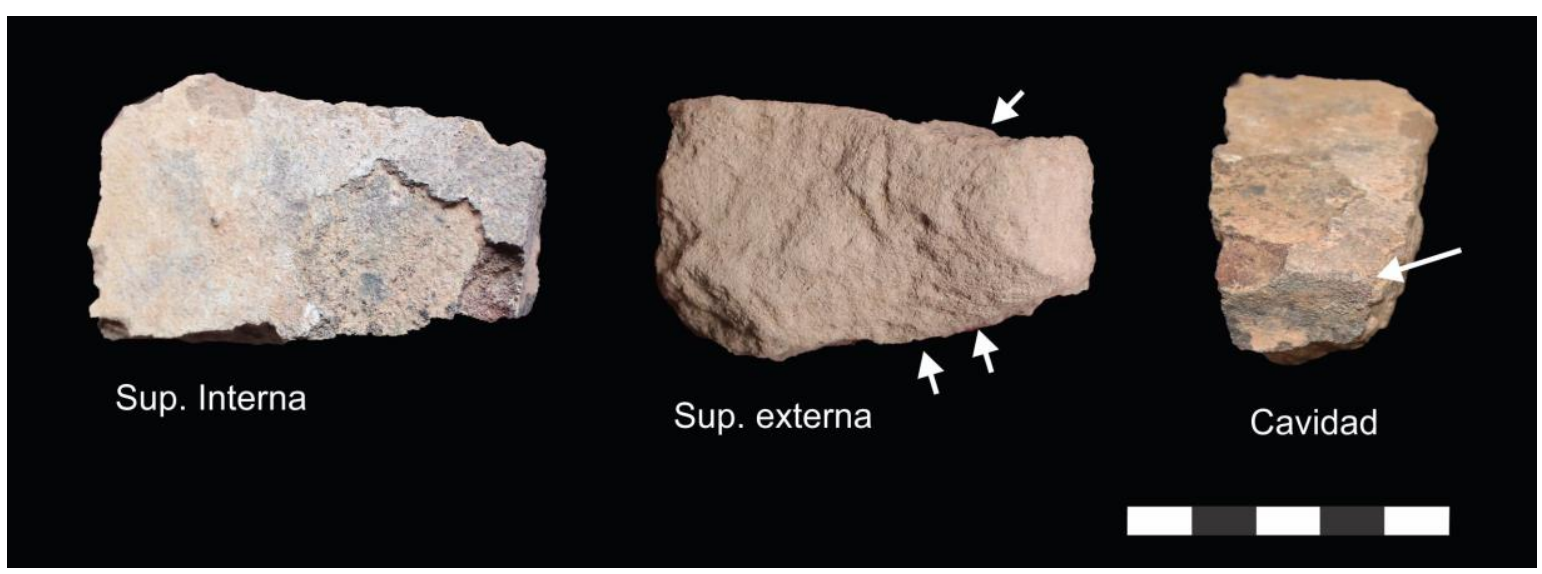

Figura 5.11. Muestra 12, posible molde. Las flechas señalan posibles marcas de cestería y la cavidad. 


\subsubsection{Primera aproximación para la caracterización de las pastas refractarias}

Como se ha planteado en la metodología, los análisis petrográficos fueron realizados sobre cuatro cortes de cerámicas metalúrgicas: dos crisoles -M8 y M9, un tapón -M10- y un fragmento indeterminado -M7-. Asimismo, se incorporaron dos muestras de cerámicas no refractarias con decoración para fines comparativos, dado que, si bien ambas clases de tecnofacturas son realizadas con arcillas y antiplásticos, se ha propuesto que las proporciones entre estos elementos y las cualidades de las inclusiones otorgarían propiedades distintas que suelen responder a sus diferentes usos y requerimientos -cocción y/o almacenaje de alimentos y líquidos vs. fundición, refinación o aleación de metales- (González 2004b). Respecto a las muestras de cerámicas decoradas, se seleccionó una correspondiente al estilo Belén y otra al estilo Santamariano que fueron registradas en la superficie del sector $A$.

Los resultados petrográficos obtenidos señalan semejanzas entre las pastas de las muestras refractarias identificadas como crisoles y tapones -M8, M9 y M10-, siendo diferente las características observadas en el fragmento indeterminado -M7-. Las primeras tres poseen una alta proporción de antiplásticos de entre 51 y $58 \%$, insertos en una matriz arcillosa escasa (20 y $25 \%$ ) con igual proporción de poros (entre 21 y $26 \%$ ). En estas muestras, se identificaron una gran variedad de inclusiones de gran tamaño que pueden diferenciarse en función de sus porcentajes en inclusiones principales $(\geq 1 \%)$ y secundarias $(<1 \%$ ) (tabla 5.4). Entre las primeras se destacan los granitos (alrededor del $15 \%$ ), cuarzos (entre $8 \%$ y $16 \%$ ), feldespatos (entre $7 \%$ y $17 \%$ ) y el vidrio volcánico (4\% a $12 \%$ ). Estos se hallaron junto a proporciones menores de clastos de rocas volcánicas y metamórficas (entre 2 y 4 \%) (Figura 5.12). Pese a la semejanza en la naturaleza de los minerales y rocas principales, se observaron algunas diferencias en las composiciones de las inclusiones secundarias que podrían estar señalando variaciones en la selección de fuentes de aprovisionamiento. Como puede observarse en el gráfíco 5.5, a diferencia de las restantes muestras, en la M8 no se han identificado ninguna clase de micas y la M9 contiene rocas sedimentarias tipo arcillitas, mientras que la M10 tiene micas frágiles, estilpnomelana y rocas metamórficas. 


\begin{tabular}{|c|c|c|c|c|c|c|c|c|c|c|c|c|c|c|c|c|c|c|c|c|c|c|c|c|c|}
\hline \multirow{4}{*}{ Muestra } & \multicolumn{22}{|c|}{ Inclusiones } & \multirow{4}{*}{1 Porosidad } & \multirow{4}{*}{$\begin{array}{l}\text { Matriz } \\
\text { Arcillos }\end{array}$} & \multirow{4}{*}{ Total } \\
\hline & \multicolumn{19}{|c|}{ Tipos de Minerales y Rocas } & \multicolumn{2}{|c|}{ Plásticas } & & & & \\
\hline & \multicolumn{9}{|c|}{ Primarios } & \multicolumn{10}{|c|}{ Secundarios } & \multirow{2}{*}{$\mathrm{GA}$} & & \multirow{2}{*}{ Total } & & & \\
\hline & $\mathrm{F}$ & $\mathrm{Q}$ & GR & $\mathrm{V}$ & $\mathrm{R}$ & $\mathrm{B}$ & RM & $\mathrm{Pl}$ & Ap & $\mathrm{RF}$ & \begin{tabular}{l|l}
$\mathrm{Au}$ & $\mathrm{I}$
\end{tabular} & $\mathrm{MO}$ & $\mathrm{H}$ & $\mathrm{C}$ & Mf & $\mathrm{Bi}$ & M & E & $\mathrm{RS}$ & & & & & & \\
\hline $\mathrm{M} 7$ & 4,7 & 3,8 & 3,8 & 5,3 & n.d. & 2,2 & 0,2 & 0,1 & n.d. & n.d. & 0,1 & 0,3 & 0,1 & 0,1 & 0,7 & 0,4 & 0,5 & n.d. & n.d. & 0,7 & 4,4 & 26,9 & & 64,6 & 100 \\
\hline M8 & 6,9 & 16,9 & 10,2 & 4,4 & 4,3 & 3 , & 2,0 & 0,9 & n.d. & n.d. & 0,3 & 0,7 & 0,9 & 0,5 & n.d. 1 & n.d. & n.d. & n.d. & n.d. & n.d. & n.d. & 51 & 36 & 9 & 100 \\
\hline M9 & 13,5 & 10,1 & 9,1 & 12,6 & 0,6 & 2,3 & n.d. & 1,0 & 1,9 & n.d. & 0,4 & 0,6 & 0,2 & n.d. & n.d. & 0,6 & 0,5 & 0,1 & 0,1 & n.d. & n.d. & 53 & 21,2 & 25,07 & 99 \\
\hline M10 & 17,6 & 8,0 & 12 & 9,6 & 1,2 & 0,2 & 0,9 & 2,4 & 1,5 & 1,0 & \begin{tabular}{l|l|}
0,0 & \\
\end{tabular} & 0,3 & 0,2 & 1,2 & \begin{tabular}{l|l}
0,8 & \\
\end{tabular} & 0,6 & 0,3 & 0,7 & n.d. & n.d. & n.d. & 59 & 21,69 & 20,01 & 100 \\
\hline
\end{tabular}

Tabla 5.4. Características petrográficas de las muestras refractarias e indetermnada. F: Feldespato; Q: cuarzo; GR: Granito; V: vidrio; R: riolita; B: basalto; RM: metamorfitas indet.; Pl: plagioclasa; Ap: aplita; RF: rocas con feldespatos; Au: augita; MO: minerales opacos; H: hornblenda; C: cuarcita; Mf: micas frágiles; Bi: biotita; M: muscovita; E: estilpnomelana; RS: rocas sedimentarias; GA: grumos de arcillas; T: tiesto molidos; n.d.: no detectado.

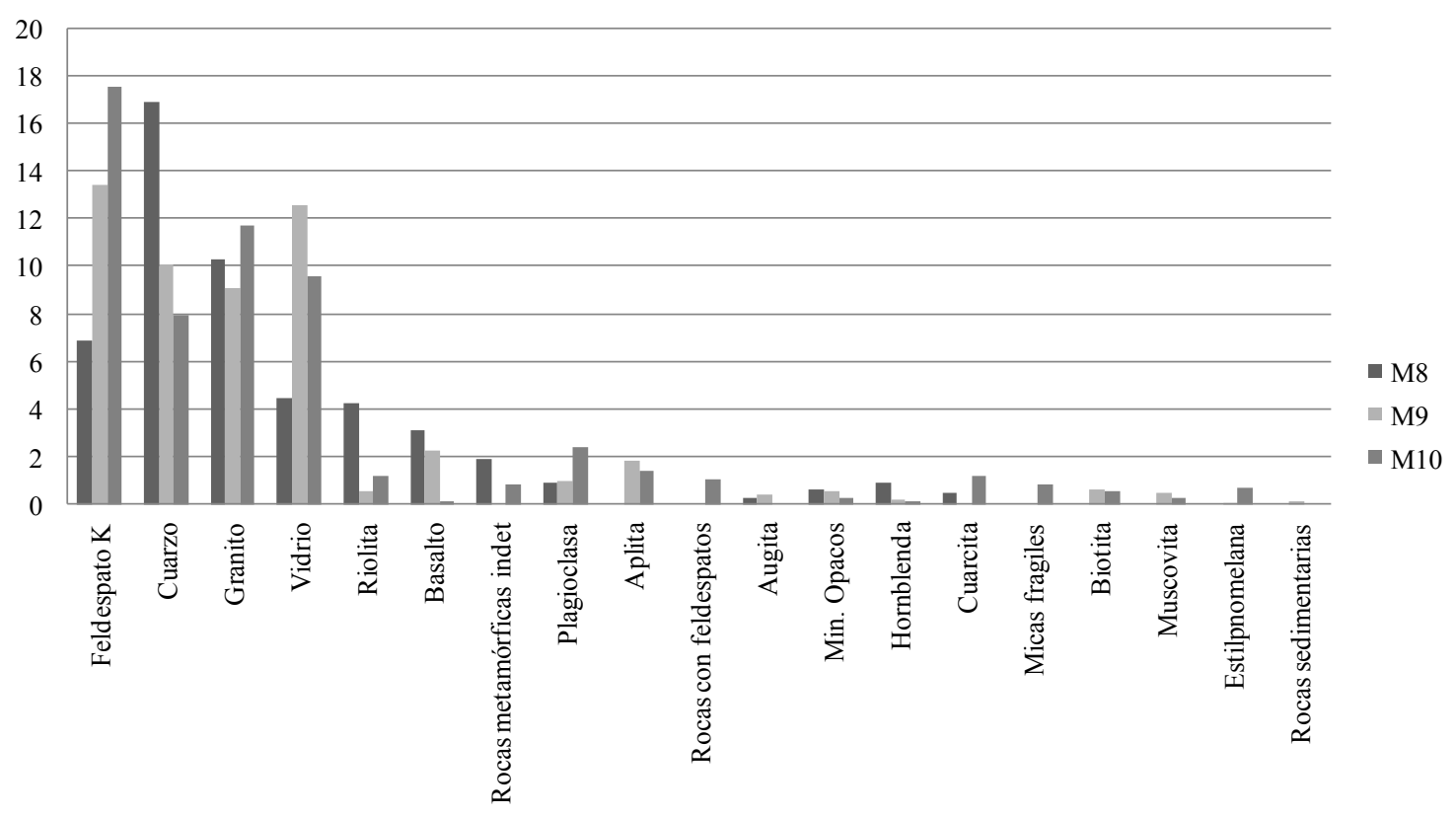

Gráfico 5.5. Tipos y proporción de inclusiones rocosas y minerales de las muestras refractarias. 


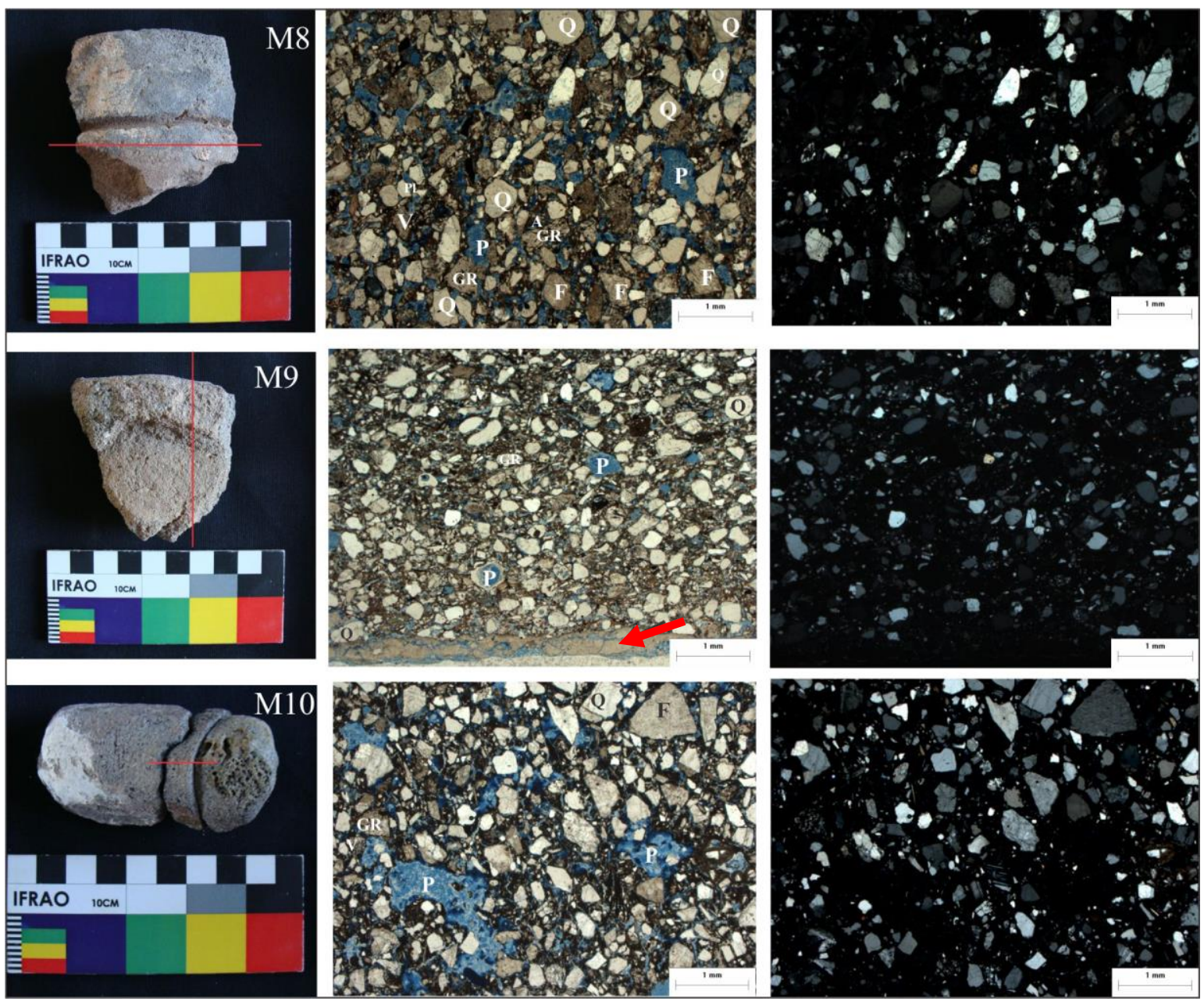

Figura 5.12. Petrografías de las cerámicas refractarias. Izquierda imágenes tomadas con luz plana. Derecha con luz cruzada. P: Poro; Q: cuarzo, F: feldespato; Pl: plagioclasa; GR: granito; $\mathrm{V}$ : vidrio; A: augita. La flecha roja señala la capa de apatita.

A diferencia de estas muestras, la pasta del fragmento indeterminado (M7) está compuesto principalmente por arcilla $(64,6 \%)$ con una moderada cantidad de antiplásticos $(26,9 \%)$ que contienen tamaños variables, lo que señala una pobre selección (tabla 5.4). Entre las inclusiones líticas predominan los feldespatos (4,7\%), vidrio volcánico $(5,3 \%)$, cuarzos (4\%) junto a otros clastos de naturaleza sedimentaria, volcánica y metamórfica. En este ejemplar se han reconocido inclusiones de tiesto molido (4,4 \%) y grumos de arcilla $(0,7 \%)$ que estuvieron ausentes en las muestras refractarias. La porosidad de la pasta de esta muestra es baja ( $8 \%$ ) y con cavidades de formas irregulares (Figura 5.13). Dada la baja proporción de antiplásticos, la presencia de inclusiones plásticas y la escasa porosidad, las características petrográficas de esta muestra se diferencian de aquellas observadas en los restantes materiales refractarios y como veremos la proporción de arcilla/antiplásticos se acerca a la presente en las 
cerámicas decoradas para el sitio (tabla 5.6). Esta situación, sumado a la ausencia de recubrimientos, pone en duda la funcionalidad de esta muestra como material refractario.

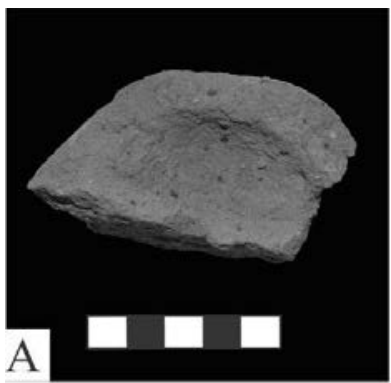

Figura 5.13. A.

Fragmento indeterminado (M7). B. Grumos de arcilla; C. Tiesto molido. A la izquierda imágenes tomadas con luz plana; derecha, con luz cruzada.
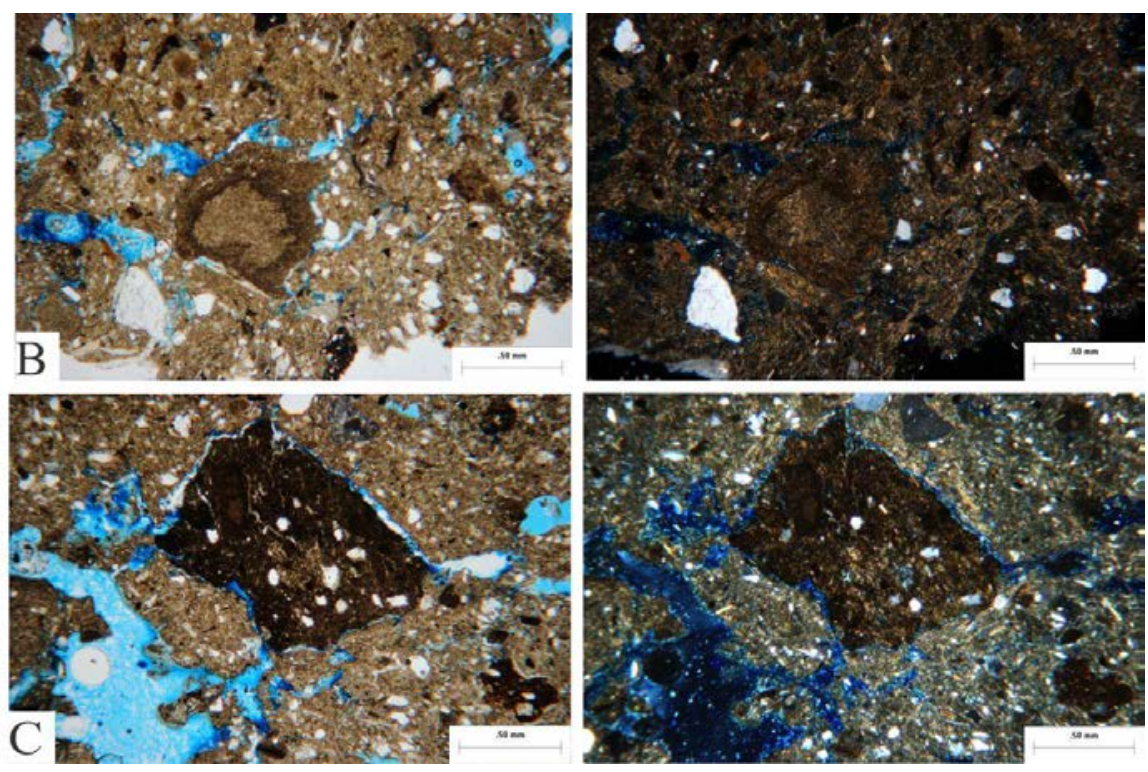

Respecto a las cerámicas con decoración (tabla 5.5 y Figura 5.14), la muestra de estilo Belén presenta una matriz muy rica en arcilla (79\%) con baja porosidad (5\%) y un contenido medio de antiplásticos (16\%) conformados por granos pequeños a medianos. Entre las inclusiones líticas se observó un predominio de vidrio, cuarzos y feldespatos con bajo contenido en micas y clastos metamórficos. Además, se identificaron grumos de arcilla de gran pureza. El fragmento Santamariano presentó una alta proporción de matriz de tipo arcillo-limosa (72\%) con una concentración media de antiplásticos (19\%) de tamaños variables, donde predominaron los granitos, cuarzos y vidrio asociados a una menor proporción de litoclastos de metamórficas y plutónicas. Entre las inclusiones plásticas se reconocieron tanto grumos de arcilla como tiestos molidos (2\%). Presenta una porosidad baja, cercana al $9 \%$.

\begin{tabular}{|c|c|c|c|c|c|c|c|c|c|c|c|c|c|c|c|c|c|c|c|c|}
\hline \multirow{4}{*}{ Muestra } & \multicolumn{17}{|c|}{ Inclusiones } & \multirow{4}{*}{ Porosidad } & \multirow{4}{*}{$\begin{array}{c}\text { Matriz } \\
\text { arcillosa }\end{array}$} & \multirow{4}{*}{ Total } \\
\hline & \multicolumn{14}{|c|}{ Tipos de Minerales y Rocas } & \multirow{3}{*}{$\begin{array}{c}\text { Grumos } \\
\text { de } \\
\text { Arcillas }\end{array}$} & \multirow{3}{*}{ Tiestos } & \multirow{3}{*}{ s | Total } & & & \\
\hline & \multicolumn{6}{|c|}{ Primarios } & \multicolumn{8}{|c|}{ Secundarios } & & & & & & \\
\hline & $\mathrm{F}$ & Q & GR & $\mathrm{V}$ & B & $\mathrm{Pl}$ & $\mathrm{RM}$ & $\mathrm{Au}$ & MO & $\mathrm{H}$ & $\mathrm{C}$ & $\mathrm{Bi}$ & $\mathrm{T}$ & $\mathrm{M}$ & & & & & & \\
\hline M11 & 3,02 & 3,63 & 5,8 & 3,01 & 0,56 & 0,95 & n.d. & n.d. & n.d. & 0,5 & n.d. & n.d. & \begin{tabular}{l|l|l}
0,06 & 1 \\
\end{tabular} & n.d. & 0,39 & 0,95 & 18,9 & 9,33 & 71,79 & 100 \\
\hline M12 & 2,05 & 2,7 & 1,29 & 5,18 & 0,43 & 1,08 & 0,11 & 0,22 & n.d. & 0,54 & n.d. & 0,86 & n.d. & 0,43 & 1,08 & n.d. & 16 & 4,85 & 79,18 & 100 \\
\hline
\end{tabular}

Tabla 5.5. Características petrográficas de las muestras cerámicas no refractarias. F: Feldespato; Q: cuarzo; GR: Granito; V: vidrio; B: basalto; Pl: plagioclasa; RM: rocas metamórficas indet; Au: augita; MO: minerales opacos; $\mathrm{H}$ : hornblenda; $\mathrm{C}$ : cuarcita; Bi: biotita; T: turmalina $; 5 \mathrm{~A}$ : muscovita; n.d.: no detectado. 

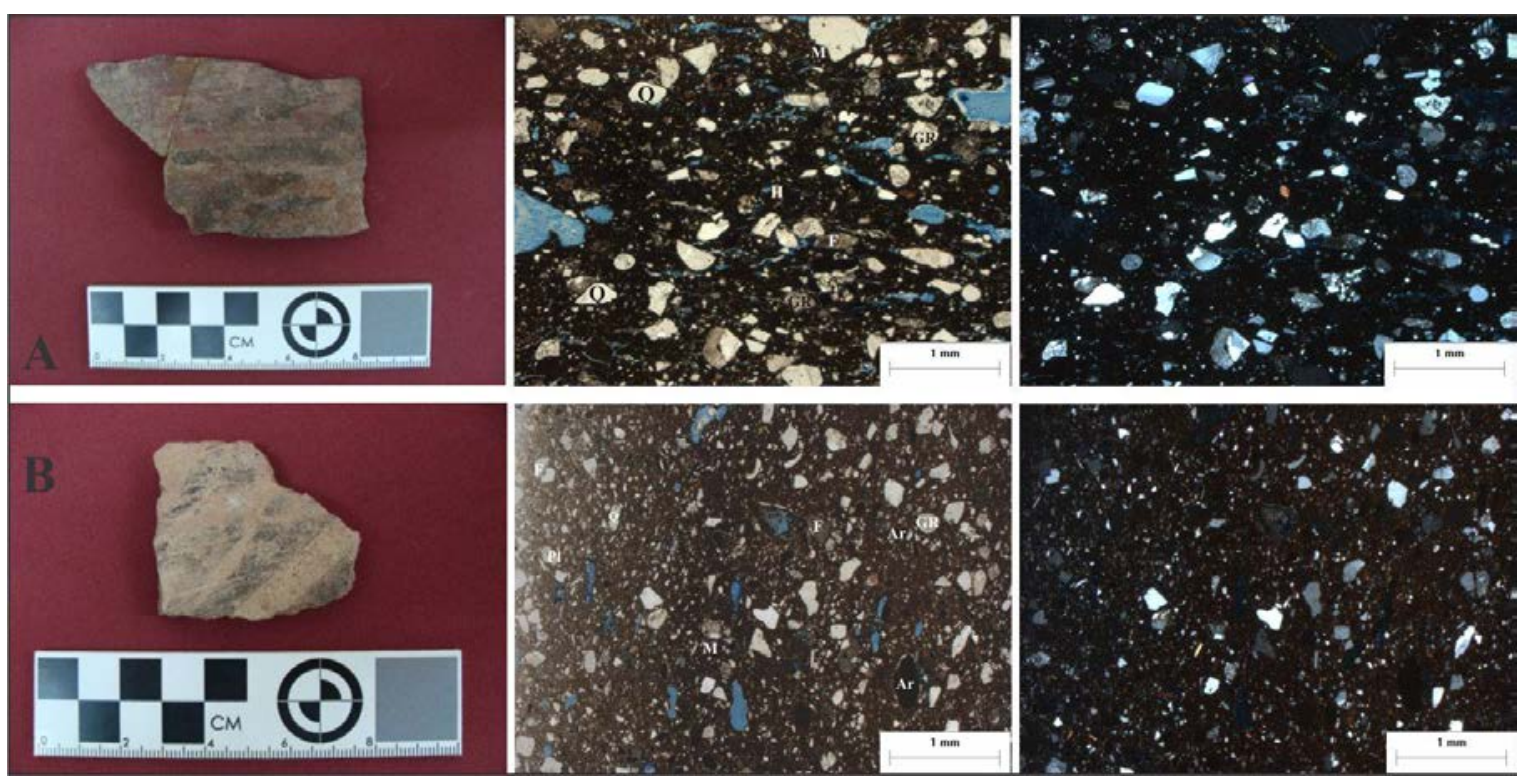

Figura 5.14. Cerámicas tradicionales. Al centro imágenes tomadas con luz plana, a la derecha con luz cruzada. Arriba Belén (A); abajo Santamariano (B). Q: cuarzo; Pl: plagioclasa; M: mica; F: feldespato; H: hornblenda; GR: granito; Ar: arcilla.

\begin{tabular}{|c|c|c|c|}
\hline \multirow{2}{*}{$\begin{array}{c}\text { CARACTERÍSTICAS } \\
\text { DE PASTAS }\end{array}$} & \multicolumn{3}{|c|}{ CERÁMICAS } \\
\hline & REFRACTARIAS & TRADICIONALES & INDET \\
\hline Matriz arcillosa & $20-25 \%$ & $71-79 \%$ & $64 \%$ \\
\hline Inclusiones & $51-59 \%$ & $16-19 \%$ & $27 \%$ \\
\hline Porosidad & $21-26 \%$ & $5-9 \%$ & $8 \%$ \\
\hline
\end{tabular}

Tabla 5.6. Comparación de los caracteres principales de las pastas cerámicas de Quillay.

\subsubsection{Análisis de los materiales adheridos a los refractarios}

En la descripción de los refractarios se comentó que en cuatro casos fueron observadas adherencias metálicas de coloración verde. Sólo se analizaron las inclusiones presentes en las muestras M2, M3 y M15 (Figura 5.15), al presentarse aquellas observadas en la M12 muy oxidadas.

Como se puede observar en la tabla 5.7, los análisis químicos realizadas sobre estas inclusiones permitieron reconocer tanto elementos metálicos como no metálicos. Entre los primeros se destaca el cobre $(\mathrm{Cu})$ que resalta por su alta proporción (e/23 y 52 wt \%) y por el otro se detectó hierro $(\mathrm{Fe})$ en menores cantidades $(<5 \mathrm{wt} \%)$. Entre los 
elementos no metálicos, se han identificado $\mathrm{O}, \mathrm{C}, \mathrm{Si}, \mathrm{Ca}, \mathrm{Cl}, \mathrm{Al}, \mathrm{Mg}, \mathrm{P}$ y $\mathrm{K}$ en rangos variables.

Un punto control tomado sobre un segmento de matriz arcillosa, sin recubrimiento observable, detectó picos de $\mathrm{Si}, \mathrm{P}$ y $\mathrm{Ca}$. En este sentido, es probable que la presencia de estos elementos en los espectros de las inclusiones metálicas, provenga de la excitación de la matriz y del sedimento blanco adyacente. La misma situación se propone para el $\mathrm{Al}, \mathrm{Mg}, \mathrm{K}$ y $\mathrm{Fe}$, que corresponderían a las inclusiones minerales reconocidos petrográficamente (como granitos, feldespatos, plagioclasas) o bien a vestigios de un metal impuro. En cambio, el $\mathrm{Cl}, \mathrm{O}$ y $\mathrm{C}$ indican compuestos oxidados de cobre que le otorgan a las adherencias metálicas el característico color verde esmeralda.

\begin{tabular}{|c|c|c|c|c|c|c|c|c|c|c|c|}
\hline \multirow{2}{*}{ Referencia } & \multicolumn{10}{|c|}{ Elementos Wt \% } \\
\cline { 2 - 14 } & $\mathbf{C u}$ & $\mathrm{Si}$ & $\mathrm{Ca}$ & $\mathrm{P}$ & $\mathrm{Al}$ & $\mathrm{Mg}$ & $\mathbf{F e}$ & $\mathrm{K}$ & $\mathrm{Cl}$ & $\mathrm{O}$ & $\mathrm{C}$ \\
\hline M2 (Indet) & 38,24 & - & - & - & - & - & 4,88 & 2,83 & 4,46 & 49,17 & - \\
\hline \multirow{2}{*}{ M3 (Crisol) } & 24,03 & 15,78 & 6,48 & 1,14 & 4,91 & 1,38 & 2,22 & 0,90 & - & 36,08 & 4,22 \\
\cline { 2 - 13 } & 52,53 & - & - & - & - & - & 1,28 & - & 12,54 & 33,65 & - \\
\hline M15 & 23,30 & 15,54 & 8,87 & - & 5,50 & 1,40 & 2,19 & 1,23 & 3,03 & 34,95 & 4 \\
\cline { 2 - 11 } (Tapón) & 25,85 & 11,84 & 11,94 & - & 4,09 & 1,45 & 1,60 & 0,80 & 0,44 & 35,32 & 6,71 \\
\hline
\end{tabular}

Tabla 5.7. Datos del análisis composicional obtenido de las adherencias metálicas de piezas refractarias. Porcentajes en peso $(\mathrm{Wt} \%)$ 

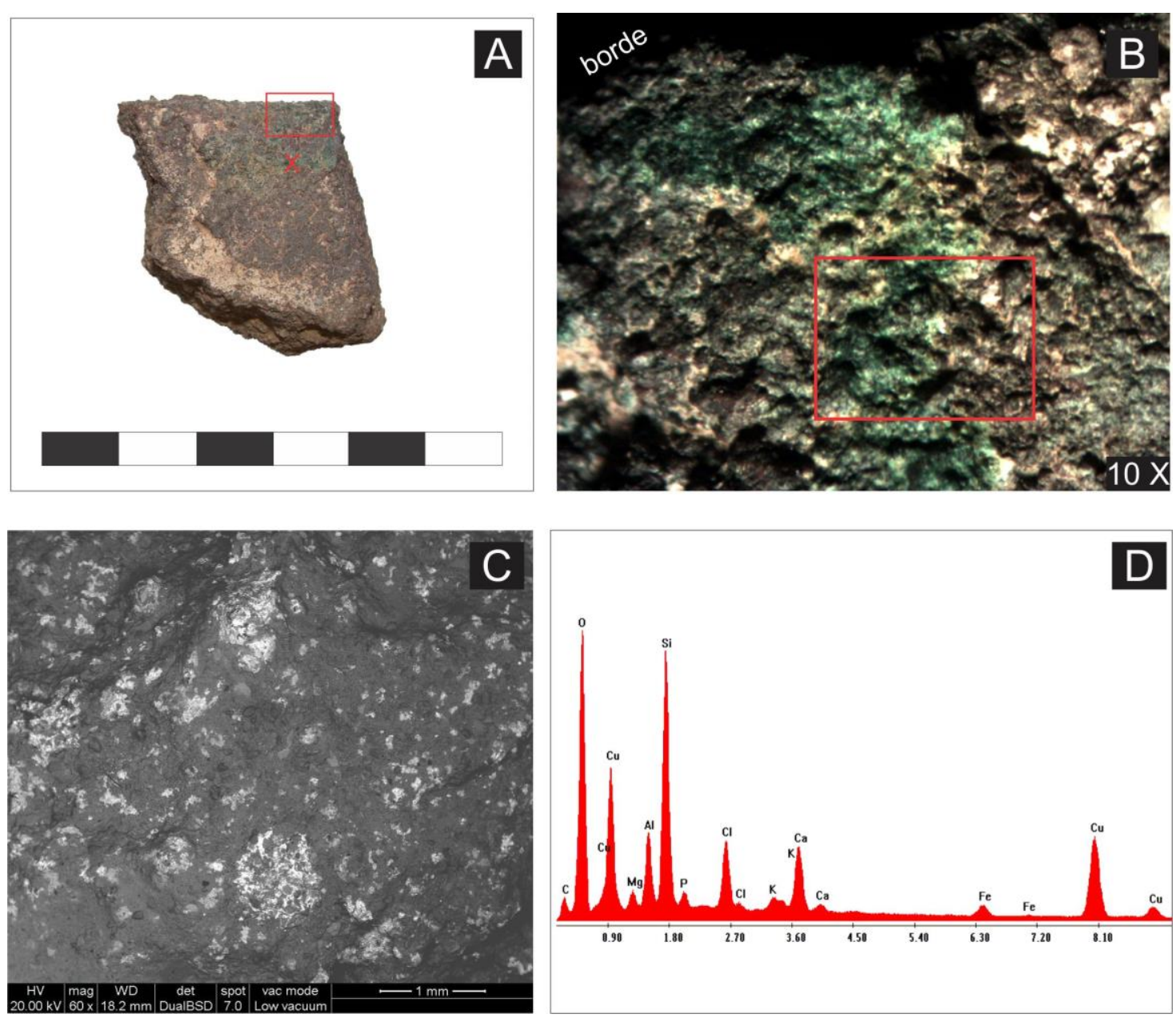

Figura 5.15. Análisis de adherencias metálicas de un fragmento de crisol (M3). A. Sectores analizados por espectrometría: el recuadro rojo señala análisis por ventana y la cruz roja análisis puntual. B. Detalle de las adherencias marcada con recuadro rojo en A. C. Microfotografía con electrones retrodispersados del sector señalado en B (los puntos blancos brillantes indican elementos con número atómico alto). D. Espectro de EDS de los sectores blancos donde se identificó cobre $(\mathrm{Cu})$.

En relación con la identificación composicional del recubrimiento blanquecino, observados en las superficies de las cerámicas refractarias, sólo la M10 -tapón- presentó las cantidades necesarias para el análisis por DRX, obteniendo como resultado el difractograma presentado en la Figura 5.16. Allí, se observa la presencia de varios compuestos cristalinos que pertenecen a la familia de las apatitas como hidroxi-apatita $\left(\mathrm{Ca}_{5}\left(\mathrm{PO}_{4}\right)_{3} \mathrm{OH}\right)$, fluorapatita $\left(\mathrm{Ca}_{5}\left(\mathrm{PO}_{4}\right)_{3} \mathrm{~F}\right)$, clorapatita $\left(\mathrm{Ca}_{5}\left(\mathrm{PO}_{4}\right)_{3} \mathrm{Cl}\right)$ y carbonato-apatita $\left(\mathrm{Ca}_{10}\left(\mathrm{PO}_{4}\right)_{6} \mathrm{CO}_{3}\right)$.

Estos compuestos pueden tener un origen biológico -siendo los constituyentes principales de huesos y dientes- o bien provenir de fuentes geológicas (Plaza y 
Martinón-Torres 2015). El análisis petrográfico brindó ciertos indicios para distinguir el material originario de estos compuestos. Al respecto, en la M9 se han identificado canales óseos denominados conductos de Havers, es decir vestigios de la estructura anatómica característicos de los huesos que señalaría que la apatita es de origen biológico (Figura 5.17).

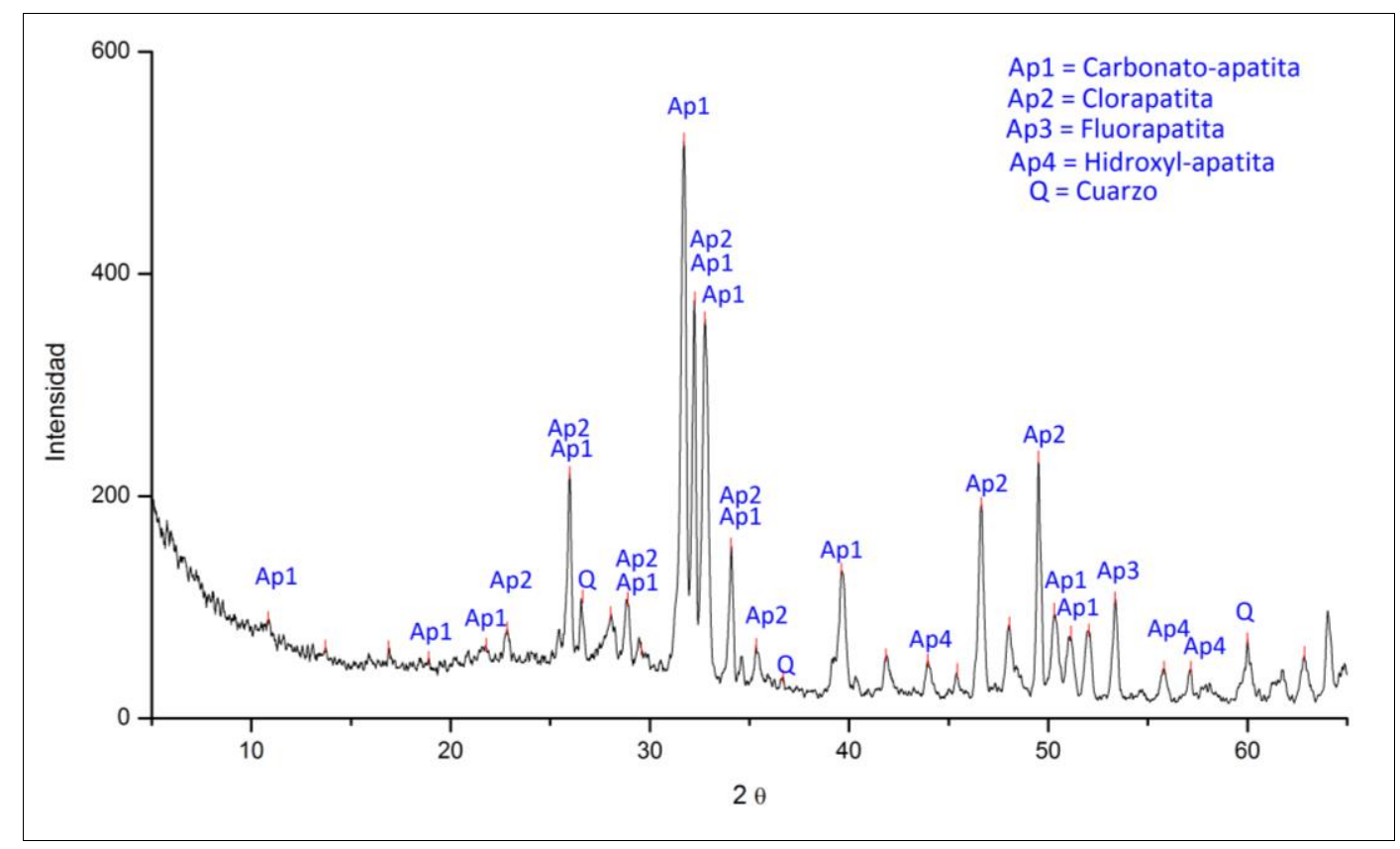

Figura 5.16. Difractograma del recubrimiento blanquecino de la M10. Se observan los picos correspondientes a distintos compuestos de apatitas y de cuarzo.

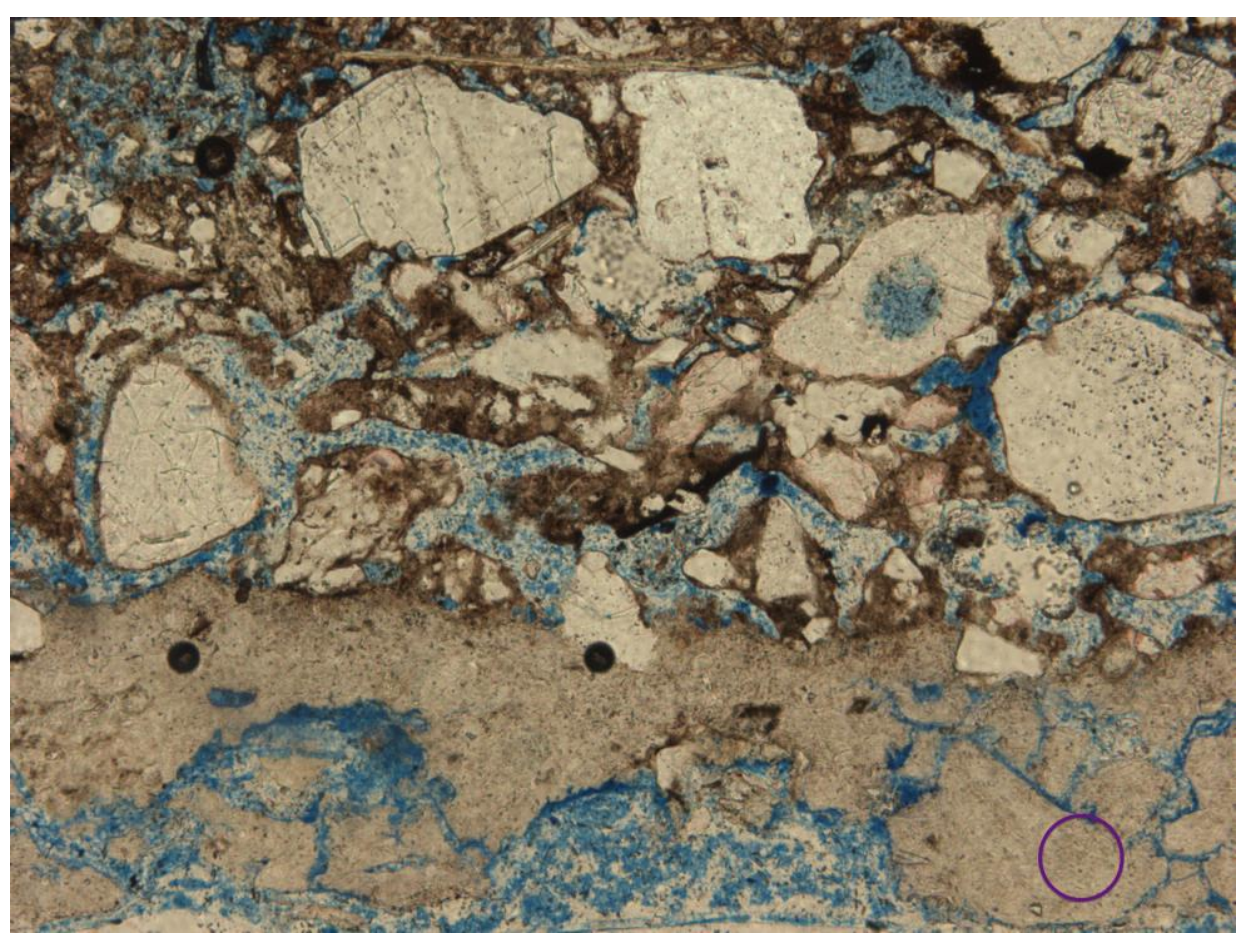

Figura 5.17. Fotografía de la sección delgada del sector con recubrimiento blanquecino de un crisol (M9). El círculo señala los conductos de Havers. (Aumento del lente 10x) 
En las restantes muestras refractarias con recubrimiento blanquecino, la identificación química elemental de este material fue realizada por espectrometría (EDS). Los espectros obtenidos señalan la presencia mayoritaria de calcio $(\mathrm{Ca}) \mathrm{y}$ fósforo $(\mathrm{P})$, en dos casos complementados con carbono $(\mathrm{C})$ y en uno con cloro $(\mathrm{Cl})$, concordantes con las composiciones fosfatadas obtenidas en la muestra difractada, principalmente en lo que refiere a la hidroxiapatita y en segundo lugar con clorapatita y carbonato-apatita (tabla 5.8).

\begin{tabular}{|c|c|c|c|c|c|c|c|c|c|c|c|c|}
\hline \multicolumn{2}{|c|}{ Referencia } & \multicolumn{10}{|c|}{ Elementos Wt \% } \\
\cline { 2 - 14 } & $\mathrm{Si}$ & $\mathbf{C a}$ & $\mathbf{P}$ & $\mathrm{Al}$ & $\mathrm{Mg}$ & $\mathrm{Fe}$ & $\mathrm{K}$ & $\mathrm{Na}$ & $\mathrm{Cl}$ & $\mathrm{O}$ & $\mathrm{C}$ \\
\hline \multirow{2}{*}{$\begin{array}{c}\mathrm{M} 2 \\
(\text { Indet })\end{array}$} & $\begin{array}{c}\mathrm{E} 1 \\
\left(1^{\circ} \mathrm{Capa}\right)\end{array}$ & 15,5 & 21,32 & 9,78 & 3,8 & 1,55 & 2,03 & 2,04 & 1,38 & - & 40,15 & 2,23 \\
\cline { 2 - 14 } & $\begin{array}{c}\mathrm{E} 2 \\
\left(2^{\circ} \mathrm{Capa}\right)\end{array}$ & 14,91 & 26,02 & 8,53 & 3,94 & 1,26 & 1,63 & 1,12 & 0,29 & - & 40,95 & - \\
\hline \multicolumn{2}{|c|}{$\mathrm{M} 3$ (Crisol) } & 10,86 & 26,81 & 9,43 & 3,8 & 1,33 & 2,77 & 0,87 & 1,05 & - & 39,36 & 3,71 \\
\hline \multicolumn{2}{|c|}{ M12 (Molde) } & 23,27 & 9,19 & 2,78 & 8,58 & 2,35 & 3,81 & 1,87 & 0,29 & 0,55 & 47,32 & - \\
\hline
\end{tabular}

Tabla 5.8. Datos del análisis composicional del recubrimiento blanquecino presente de muestras refractarias. Porcentajes en peso (Wt \%).

\subsubsection{Integración y evaluación de los resultados obtenidos en muestras refractarias.}

Los refractarios identificados en Quillay responden a las morfologías conocidas para esta clase de cerámicas en otras regiones del NOA, con similares formas, dimensiones, sistemas de sujeción y el empleo de un recubrimiento blanquecino en ambas superficies (González 1992, 2010; Earle 1994; Williams 1995; Angiorama 2004; Pifferetti 2004; Gluzman 2017). Aquí, se registraron principalmente las clásicas formas de crisoles con diámetros que no superan los $16 \mathrm{~cm}$, tapones de los tipos curvos y rectos, una cuchara con perforación circular y un solo fragmento clasificado como molde. La escasez de estos últimos puede responder a que la fabricación de objetos no fue realizada a nivel intrasitio. Como se tratará más adelante la mayor cantidad de evidencias señalan que en Quillay predominó otro tipo de actividad metalúrgica diferente de la anterior (ver capítulos 7 y 8 ).

Respecto al recubrimiento blanquecino, los análisis químicos indican que en todos los casos se trata de compuestos ricos en calcio $(\mathrm{Ca})$ y fósforo $(\mathrm{P})$ pertenecientes a la familia de las apatitas. Diversos estudios experimentales han demostrado que, la apatita 
empleada en materiales refractarios, fue obtenida a partir de tejido óseo calcinado y no de fuentes geológicas (Plaza y Martinón-Torres 2015). Para el caso de Quillay, en uno de los cortes se pudo observar que el material se corresponde con elementos de esa naturaleza dada la presencia de estructuras de Havers.

En lo que refiere a la funcionalidad de este material, la ausencia de elementos metálicos que hayan quedado atrapados en las pastas de los refractarios estudiados señala la función aislante de la apatita que, al minimizar el contacto entre el cuerpo cerámico y el material fundido, redujo el anclaje de metal líquido. Tal como fue sugerido para materiales con este recubrimiento en otros talleres metalúrgicos (González 1992, 1997; Angiorama 2005; Gluzman et al. 2009). En el caso de los moldes, es posible que además este material haya contribuido al acto de desmoldar (Pifferetti 2004).

A nivel composicional, se ha observado que en Quillay las pastas de cerámicas refractarias y decoradas presentan diferencias en la proporción de arcillas y antiplásticos. Mientras las primeras tienen una mayor cantidad de inclusiones y bajo contenido arcilloso, la situación contraria sucede en las cerámicas con decoración analizadas. Incluso también difieren en los tipos y tamaños de los antiplásticos siendo las inclusiones rocosas y minerales detectados en los materiales refractarios elementos de grandes tamaños.

En este sentido, la elevada fracción de inclusiones de grano grueso en los refractarios sumado a la porosidad y los gruesos espesores, posiblemente brindó a estas pastas resistencia al shock térmico, reduciendo la conductividad del calor que genera el contacto con el fundido (Gluzman 2017) aunque, seguramente, también contribuyó a la fragilidad estructural (González 2002). El tipo de inclusiones líticas predominantes en las muestras analizadas consisten en feldespatos, cuarzos y rocas magmáticas como vidrio volcánico y granito. El origen geológico de estas inclusiones posiblemente también haya contribuido a la elevada resistencia térmica de estas pastas, al ser minerales con elevados puntos de fusión. Razón por la cual se considera que su presencia mejora las propiedades refractarias del cuerpo cerámico (Rice 2005 [1987]; Hein et al. 2007). 
Por otro lado, aunque necesitaríamos incrementar el número de muestras, llama la atención la heterogeneidad observada entre los ejemplares refractarios en relación a la diversidad de inclusiones secundarias. Si bien éstas últimas representan porcentajes menores $(<1 \%)$ podrían estar dando cuenta o bien del uso de fuentes geológicas alternativas o de mezclas de fuentes. Esta diversidad composicional resultó interesante al compararlas con las pastas de refractarios de Rincón Chico, las cuales exhiben una gran homogeneidad en sus componentes con predominio del vidrio volcánico (Spina y Gluzman 2017). Sugerimos que las diferencias en la selección de antiplásticos entre los dos grupos podrían estar relacionadas tanto con los contextos históricos de ambos sitios como con las fuentes geológicas disponibles en cada región.

Por último, las adherencias metálicas halladas en crisoles y tapones brindaron información sobre los metales procesados con estos implementos. La presencia exclusiva de metal de cobre con bajo contenido en Fe y otros elementos no metálicos, señala que allí se habría refundido un cobre impuro relacionado a instancias de refinación o bien de fusión del metal para conformar masas de cobre, quizás en forma de lingotes. Se recuerda que estas piezas provienen de recolecciones superficiales, por lo tanto, la falta de asociaciones contextuales con otros desechos metalúrgicos imposibilita por el momento diferenciar entre una y otra actividad. Por otro lado, ninguno de los espectros obtenidos de las inclusiones metálicas ha brindado picos correspondientes a otros elementos metálicos (como $\mathrm{Au}, \mathrm{Ag}, \mathrm{Sn}$ o As) que podrían sugerir el procesamiento de otros metales o actividades de aleación.

\subsection{Lámina de metal}

Entre los materiales recolectados en superficie por el equipo de Raffino en la década de 1990, se identificó un pequeño fragmento metálico intensamente oxidado. Los datos registrados en su etiqueta señalan que el mismo fue recuperado del sector de recintos empleando un equipo de detección de metales, sin mayor información sobre el contexto de hallazgo.

Esta pieza es un delgado fragmento laminar de metal de unos pocos gramos $(3,12 \mathrm{gr})$ y presenta $4,3 \mathrm{~cm}$ de largo y $1,1 \mathrm{~cm}$ de ancho y espesor homogéneo. Los análisis químicos por EDS realizados sobre un segmento de superficie limpia, detectó que se trata de metal de cobre, con otros elementos en proporciones trazas que 
representan principalmente productos de oxidación (cloruros) (Figura 5.18). Es difícil inferir por el momento, si se trataría de restos de un objeto de cobre o desechos producto del vaciado de metal en un molde.
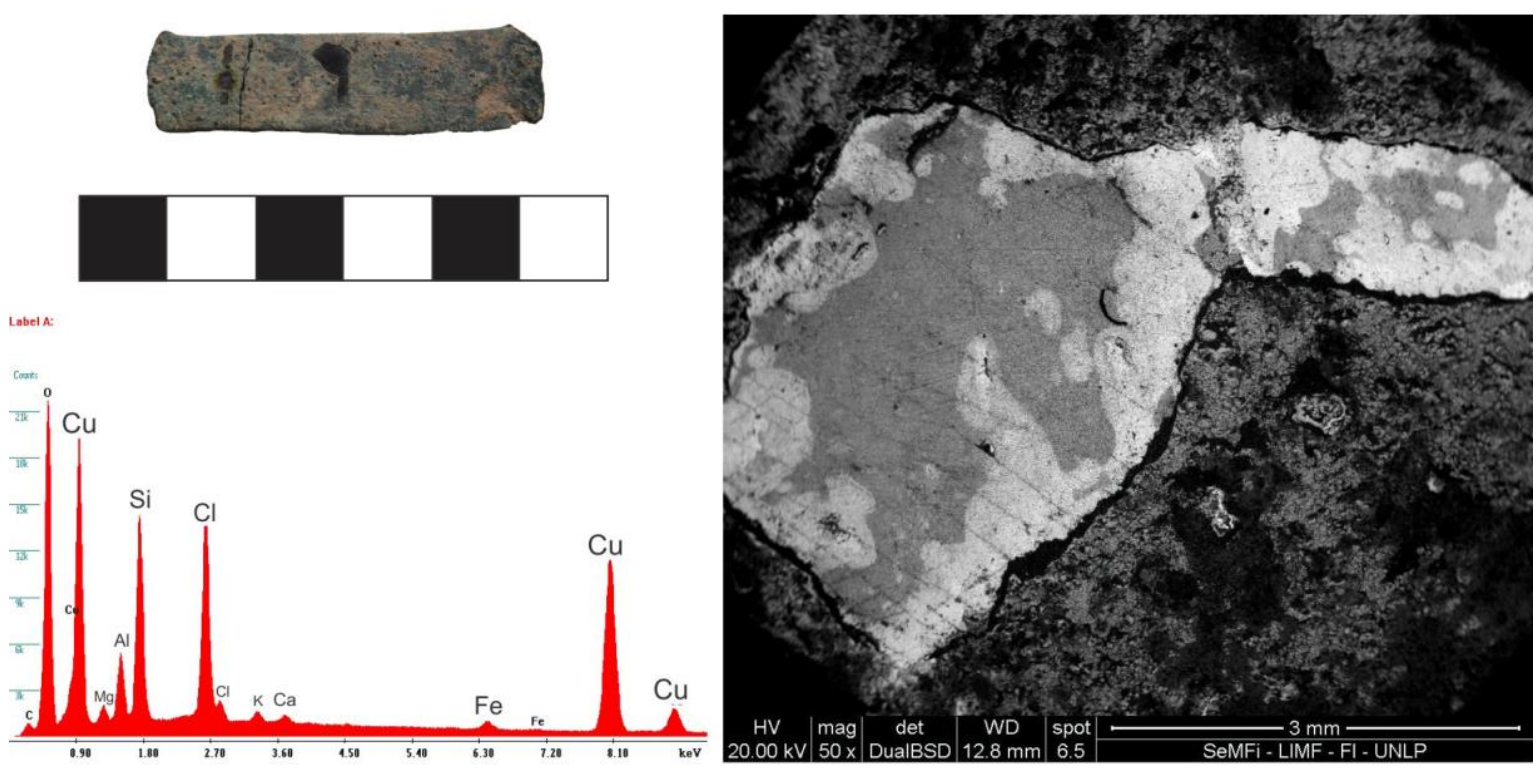

Figura 5.18. Fotografía del fragmento de metal, imagen al microscopio electrónico de barrido y espectro EDS.

\subsection{Materiales y contextos de excavación en las estructuras arquitectónicas}

\subsubsection{Recinto 3. Re- evaluación del material cerámico obtenido en 1952}

Como se ha comentado en los antecedentes (capítulo 2), el recinto de planta circular de mayor tamaño fue excavado en las campañas de 1952 por Alberto Rex González. Respecto a los materiales recuperados, la información publicada (González 1959) indica únicamente la coexistencia de estilos cerámicos Belén e Inkaicos, posiblemente debido a los objetivos de periodificación que perseguían los trabajos de campo del autor por aquellos años. A esta información se le sumaría algunos fragmentos óseos y carbones, según figura en las libretas de campo (Repositorio DILA, González, A. R. Cuaderno de campo, expediciones a Catamarca, 1951, 1952 y 1957), pero de los cuales no aportan mayores indicaciones que permitan contextualizarlos. Hemos podido tener acceso a los tiestos cerámicos registrados en este recinto que fueron re-analizados, según los parámetros previamente señalados, con la finalidad de explorar en mayor detalle las características de estos materiales. 
Los fragmentos registrados en este recinto consisten en 66 tiestos que pudieron ser remontados y agrupados en 48 piezas cerámicas. El mayor porcentaje de cerámicas corresponden a las piezas clasificadas como "toscos utilitarios" (34\%, n=16; Gráfico 5.6). Son fragmentos con superficies alisadas y cepilladas, de pasta de cocciones variables, pero siempre con inclusiones de grano grueso, ricos en cuarzos, micas, litoclastos variados y en menor medida tiestos molidos. En su mayoría son cuerpos de espesores gruesos (entre 0,8 y $1,5 \mathrm{~cm}$ ) que posiblemente correspondan a ollas de grandes tamaños (Figura 5.19). Respecto a las huellas de uso, en un $81 \%$ de los tiestos fueron observadas vestigios de hollín y manchas de quemado que estarían señalando su exposición al calor del fuego. Sin embargo, la falta de información contextual clara impide proponer situaciones concretas de cocción de alimentos.
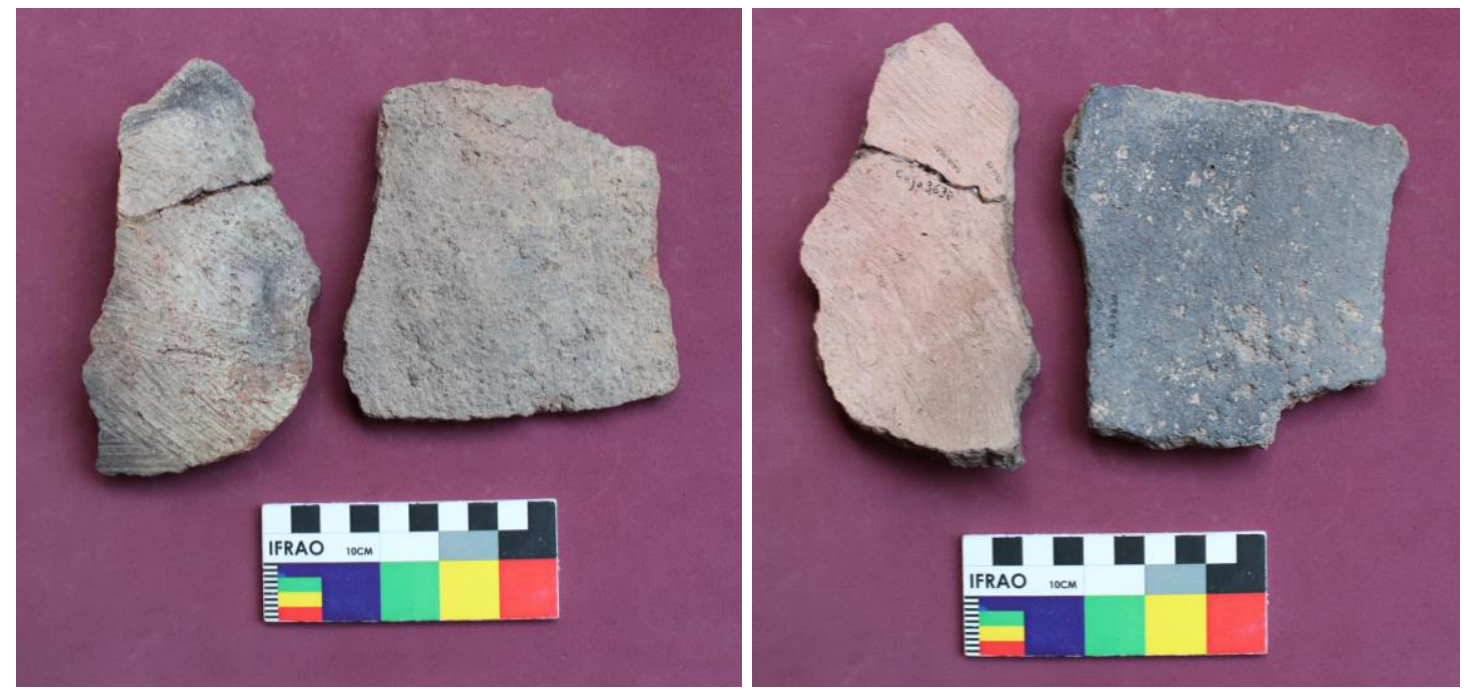

Figura 5.19. Cerámica "tosca utilitaria" del Recinto 3, superficie externa (izquierda) e interna (derecha)

Un dato muy interesante, que difiere con lo observado en el conjunto recolectado en superficie, es que, en este recinto, existe una alta frecuencia de piezas de estilo Inka Provincial $(27 \% ; n=13)$ los cuales se encontraron asociados con cerámicas de clara asignación a estilos tardíos $(25 \%, \mathrm{n}=12)$. De éstos últimos, predominan las piezas locales Belén $(17 \%, \mathrm{n}=8)$ y en menor frecuencia los estilos Santamariano $(2 \%, \mathrm{n}=1)$ y Sanagasta $(2 \%, n=1)$. El 4\% restante está conformado por fragmentos de estilos dudosos e indeterminados (Gráfico 5.6 y tabla 5.9). 


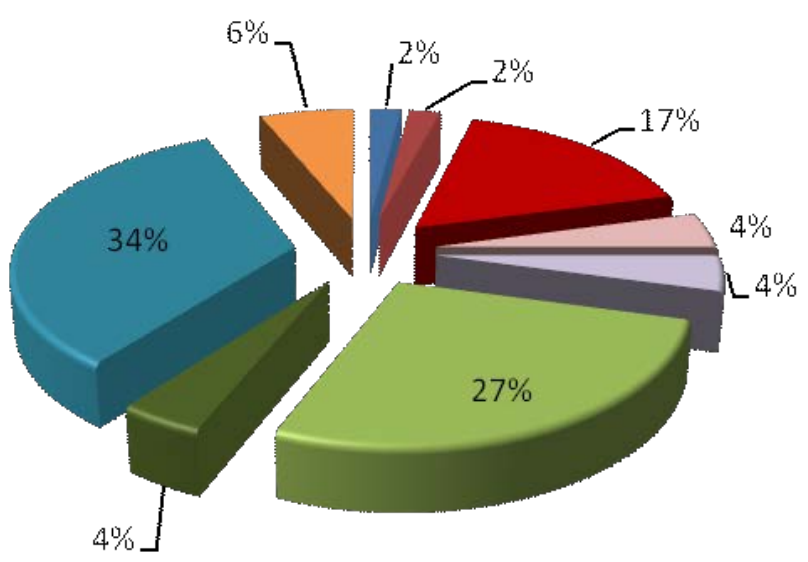

Garnagasta
Santamariano
Belér
a Posiblemente Belér
a Belér o lnka
a Inka
a Posible inka
Tosco utilitario
Indet

Gráfico 5.6. Frecuencia porcentual de estilos cerámicos del recinto 3.

Entre las piezas de estilo Inka Provincial, el $77 \%(n=10)$ fueron reconocidas como segmentos de cuerpos, cuellos y bordes de aríbalos o aribaloides; un 7,7\% a formas cerradas y otro $15,4 \%(n=2)$ corresponde a un borde de plato y a un segmento de cuerpo con inflexión al cuello que posiblemente corresponde a una jarrita (Tabla 5.9, Figura 5.20 y 5.21). De esta manera, se identificaron dos de las formas inkaicas más clásicas -aribalos y platos- consideradas como las más frecuentes en sitios provinciales del Tawantinsuyu (Bray 2004).

Respecto a los diseños decorativos de los aríbalos o aribaloides, se observaron patrones con líneas negras finas, triángulos invertidos y rombos, en especial en los segmentos externos de cuellos y cuerpos. Asimismo en los cuerpos, se reconoció la segmentación vertical con un patrón formado por líneas diagonales paralelas y triángulos rellenos con puntos (Figura 5.22) 3 $^{3}$ También se observó la clásica línea que circunscribe el perímetro interno de la boca de los aríbalos (Figura 5.19). Sin embargo, gran parte de los cuerpos presentan superficies lisas intensamente pulidas de colores rojos, naranjas y marrones (Figura 5.21). Incluso, en fragmentos que corresponden a la misma pieza se ha podido observar variaciones de coloración, que pueden ser efectos de cocción o producto de alteraciones postdepositacionales (Figura 5.22).

Si bien no se ha profundizado en la caracterización de las pastas, resultan interesantes las inclusiones observadas a lupa binocular en los fragmentos inkaicos,

\footnotetext{
${ }^{3}$ Estos diseños de líneas quebradas paralelas y espacios rellenos con puntos son comunes en los patrones iconográficos inkaicos. Ver por ejemplo Fernández Baca 1971: Figura 143 y Giovannetti et al. 2012: Figura 9.
} 
sobre todo en lo que refiere a aquellas de tipo piroclástico que resaltan en las pastas finas de tipo oxidante. Este tipo de material se ha observado en asociación con algunos litoclastos y cuarzos muy pequeños en las piezas de tipo cerrado, y en concreto en un $60 \%$ de los aríbalos o aribaloides. Esta observación es interesante dado que se ha propuesto que el agregado de inclusiones pumíceas fue una práctica manufacturera relacionada con la política estatal (Páez y Arnosio 2009). Desde un punto de vista funcional, su ventaja radicaría en que reducen el peso específico de las vasijas y otorgan mayor resistencia a quiebres y fracturas, beneficioso durante la movilización y transporte de los contenedores cerámicos (Páez y Giovannetti 2010). Esto es importante para vasijas como los aríbalos si pensamos su circulación en los espacios socio-políticos estatales para ser empleados en eventos relacionados a prácticas de comensalismo político (Bray 2004).
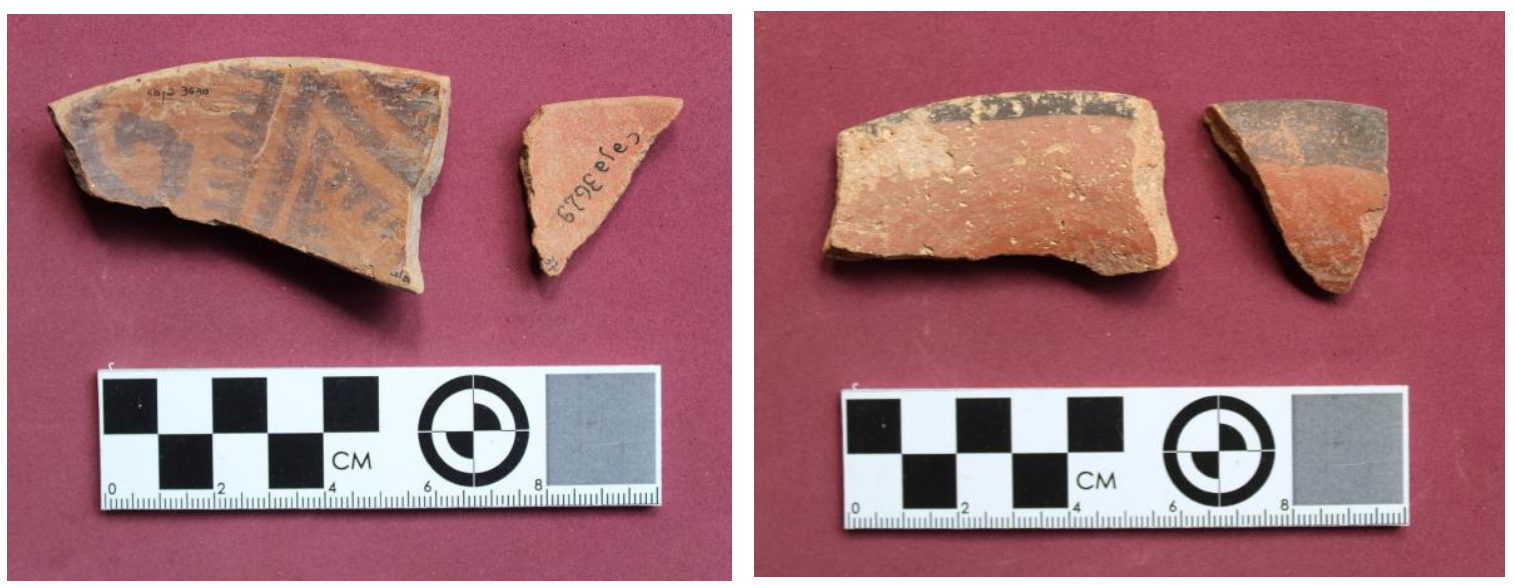

Figura 5.20. Cerámica Inka del Recinto 3. Bordes de aríbalos o aribaloides (izquierda) y platos (derecha).
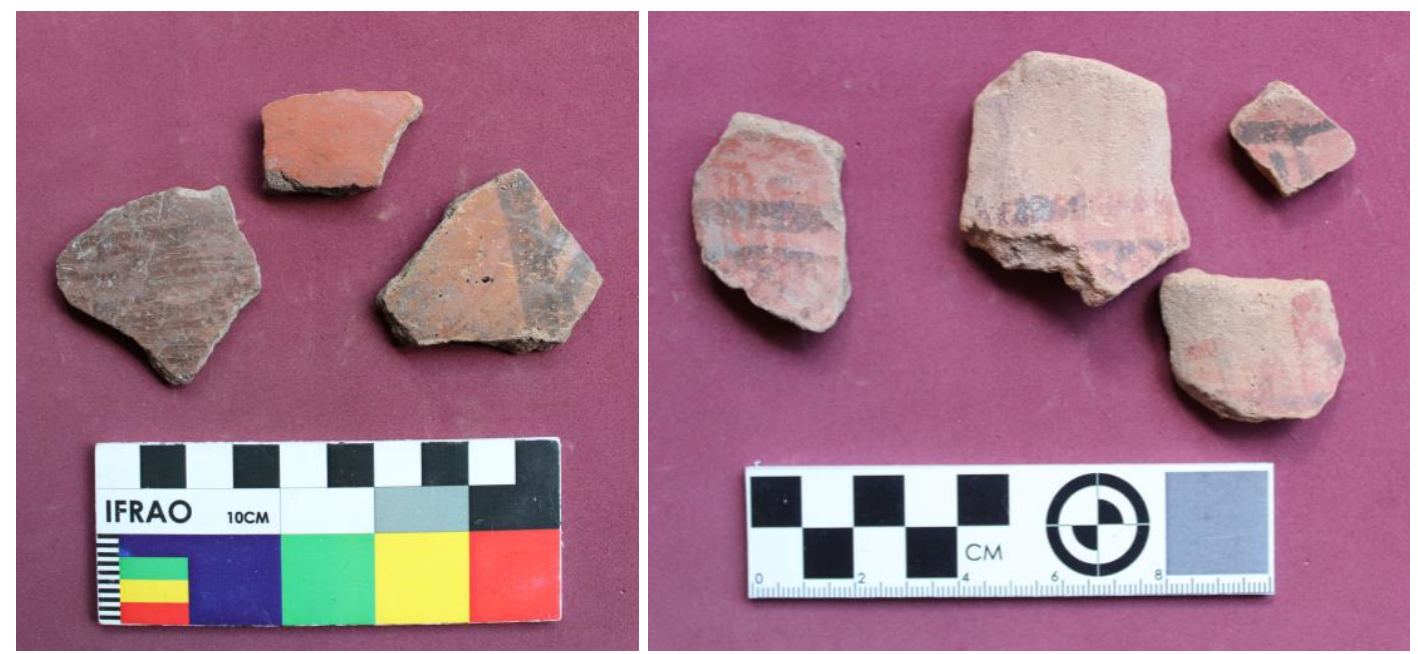

Figura 5.21. Fragmentos de cuerpos (izquierda) y cuellos (derecha) de aríbalos o aribaloides Inkas del Recinto 3. 

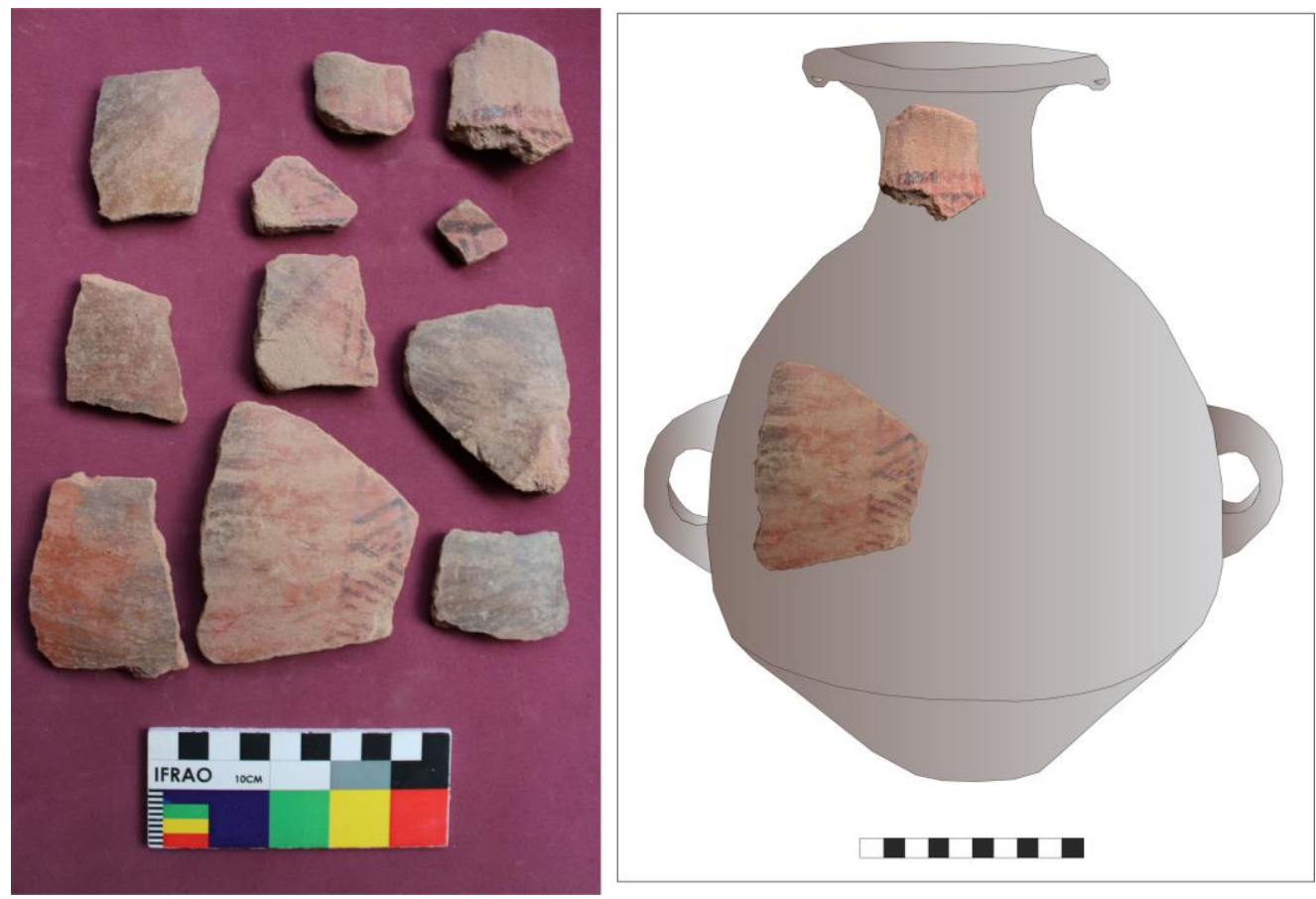

Figura 5.22. Fragmentos de un aríbalo o aribaloide y su reconstrucción gráfica.

Entre las piezas tardías, los fragmentos de estilo Belén están decorados con pintura negra sobre engobes rojos o morados (Figura 5.23). En su mayoría son segmentos de cuerpos de formas cerradas (75 \%), dentro las cuales el $50 \%$ corresponden a tinajas (Tabla 5.9). El $25 \%$ restante son fragmentos de piezas abiertas tipo $p^{\prime} u k u$.

Las tinajas Belén presentan patrones decorativos en la superficie externa con reticulados, diseños figurativos de rostros y "manos" así como campos amplios de pintura negra. En cambio, los $p^{\prime} u k u$ presentan un engobe rojo hacia el exterior $\mathrm{y}$, en el interior, decoración con pintura negra sobre fondo rojo o morado. Sólo en un caso, se pudo observar claramente el patrón decorativo interno compuesto por dos líneas diagonales con grecas estilizadas.

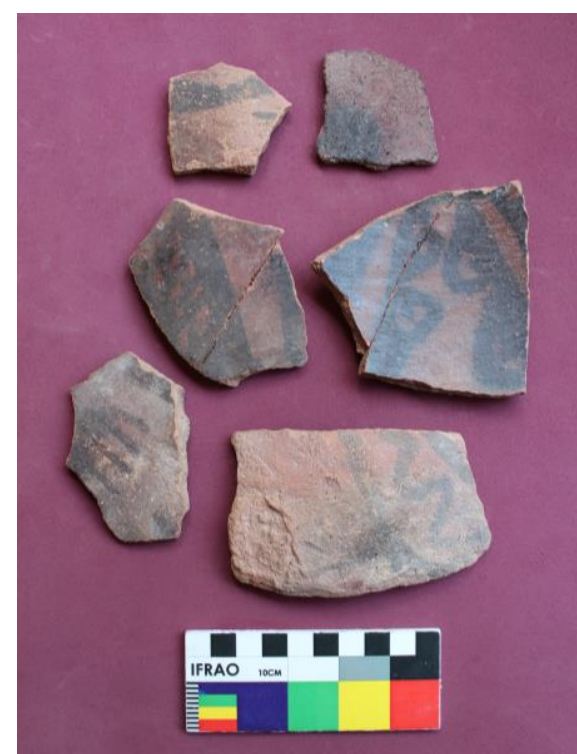

Figura 5.23. Cerámica Belén del R3

El fragmento Santamariano es un pequeño segmento del cuerpo de una tinaja con pintura negra sobre engobe blanco y el fragmento Sanagasta presenta decoración de pintura negra sobre una pasta alisada. 


\begin{tabular}{|c|c|c|c|c|c|c|c|c|c|c|c|c|c|c|c|c|c|c|c|c|c|c|}
\hline \multirow{3}{*}{$\begin{array}{c}\text { Asignación } \\
\text { Estilística }\end{array}$} & \multicolumn{20}{|c|}{ Morfologías Cerámicas } & \multicolumn{2}{|c|}{ Total } \\
\hline & \multicolumn{2}{|c|}{ Cerrada } & \multicolumn{2}{|c|}{ Tinaja } & \multicolumn{2}{|c|}{ Olla } & \multicolumn{2}{|c|}{ Ollita } & \multicolumn{2}{|c|}{$\begin{array}{l}\text { Aríbalos o } \\
\text { aribaloides }\end{array}$} & \multicolumn{2}{|c|}{ Jarrita } & \multicolumn{2}{|c|}{ Abierta } & \multicolumn{2}{|c|}{ P'uku } & \multicolumn{2}{|c|}{ Plato } & \multicolumn{2}{|c|}{ Indet } & \multirow[t]{2}{*}{$\mathbf{N}$} & \multirow[t]{2}{*}{$\%$} \\
\hline & $\mathrm{N}$ & $\begin{array}{c}\% \\
\text { estilo }\end{array}$ & $\mathrm{N}$ & $\begin{array}{c}\% \\
\text { estilo }\end{array}$ & $\mathrm{N}$ & $\begin{array}{c}\% \\
\text { estilo }\end{array}$ & $\mathrm{N}$ & $\begin{array}{c}\% \\
\text { estilo }\end{array}$ & $\mathrm{N}$ & $\begin{array}{c}\% \\
\text { estilo }\end{array}$ & $\mathrm{N}$ & \begin{tabular}{|c|}
$\%$ \\
estilo
\end{tabular} & $\mathrm{N}$ & $\begin{array}{c}\% \\
\text { estilo }\end{array}$ & $\mathrm{N}$ & $\begin{array}{c}\% \\
\text { estilo }\end{array}$ & $\mathrm{N}$ & $\begin{array}{c}\% \\
\text { estilo }\end{array}$ & $\mathrm{N}$ & $\begin{array}{c}\% \\
\text { estilo } \\
\end{array}$ & & \\
\hline Sanagasta & 1 & 100 & 0 & 0 & 0 & 0 & 0 & 0 & 0 & 0 & 0 & 0 & 0 & 0 & 0 & 0 & 0 & 0 & 0 & 0 & 1 & 2,1 \\
\hline Santamariano & 0 & 0 & 1 & 100 & 0 & 0 & 0 & 0 & 0 & 0 & 0 & 0 & 0 & 0 & 0 & 0 & 0 & 0 & 0 & 0 & 1 & 2,1 \\
\hline Belén & 2 & 25 & 4 & 50 & 0 & 0 & 0 & 0 & 0 & 0 & 0 & 0 & 0 & 0 & 2 & 25 & 0 & 0 & 0 & 0 & 8 & 17 \\
\hline $\begin{array}{l}\text { Posiblemente } \\
\text { Belén }\end{array}$ & 2 & 100 & 0 & 0 & 0 & 0 & 0 & 0 & 0 & 0 & 0 & 0 & 0 & 0 & 0 & 0 & 0 & 0 & 0 & 0 & 2 & 4,1 \\
\hline Belén o Inka & 2 & 100 & 0 & 0 & 0 & 0 & 0 & 0 & 0 & 0 & 0 & 0 & 0 & 0 & 0 & 0 & 0 & 0 & 0 & 0 & 2 & 4,1 \\
\hline Inka & 1 & 7,7 & 0 & 0 & 0 & 0 & 0 & 0 & 10 & 76,9 & 1 & 7,7 & 0 & 0 & 0 & 0 & 1 & 7,7 & 0 & 0 & 13 & 27 \\
\hline $\begin{array}{l}\text { Posiblemente } \\
\text { Inka }\end{array}$ & 2 & 100 & 0 & 0 & 0 & 0 & 0 & 0 & 0 & 0 & 0 & 0 & 0 & 0 & 0 & 0 & 0 & 0 & 0 & 0 & 2 & 4,1 \\
\hline $\begin{array}{l}\text { Tosco } \\
\text { Utilitario }\end{array}$ & 1 & 6,25 & 0 & 0 & 13 & 81,25 & 1 & 6,25 & 0 & 0 & 0 & 0 & 0 & 0 & 0 & 0 & 0 & 0 & 1 & 6,25 & 16 & 33,3 \\
\hline Indet & 1 & 33,3 & 0 & 0 & 0 & 0 & 0 & 0 & 0 & 0 & 0 & 0 & 1 & 33,3 & 0 & 0 & 0 & 0 & 1 & 33,3 & 3 & 6,2 \\
\hline $\begin{array}{l}\text { Total por } \\
\text { Categoria }\end{array}$ & 12 & - & 5 & - & 13 & - & 1 & - & 10 & - & 1 & - & 1 & - & 2 & - & 1 & - & 2 & - & 48 & 100 \\
\hline $\begin{array}{l}\text { \% del Total } \\
\text { de Piezas }\end{array}$ & & 25 & & 0,4 & & 7,1 & & 2,1 & & 0,8 & & 2,1 & & 2,1 & & 4,2 & & 2,1 & & 4,2 & & \\
\hline
\end{tabular}

Tabla 5.9. Frecuencia numérica y porcentual de formas de cada estilo cerámico del Recinto 3. 


\subsubsection{Recinto $\mathrm{n}^{0} 1$}

La cuadricula del R1 se constituyó con una medida de 3 m (eje N-S) x 2,77 m (eje E-O), abarcando la totalidad de la superficie interna de la unidad arquitectónica (Figura 5.24).

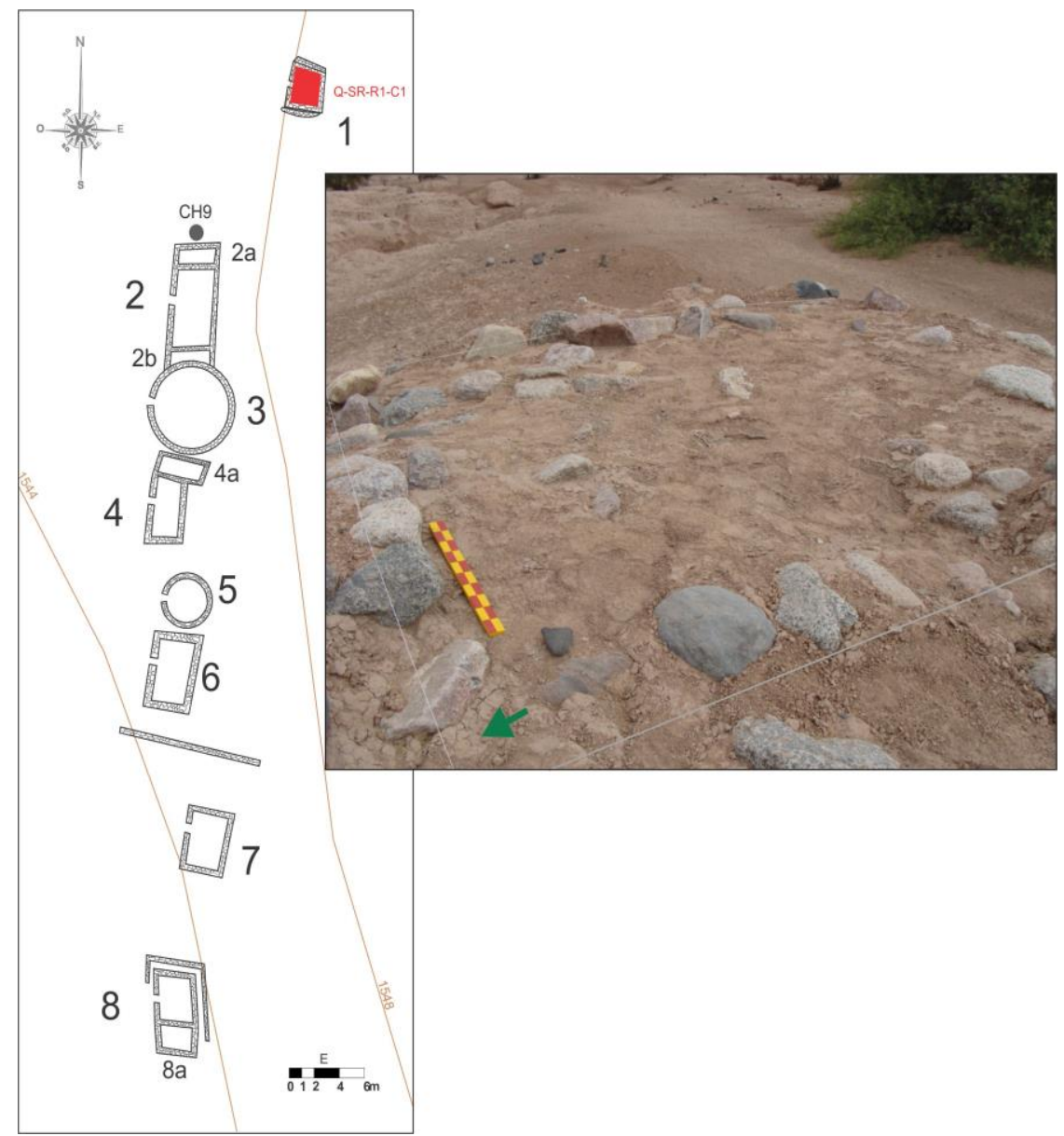

Figura 5.24. Cuadricula trazada en el Recinto 1

Metodológicamente, se utilizó la técnica de excavación por niveles artificiales de $10 \mathrm{~cm}$. Si bien esto es resultado de una división arbitraria, fue útil para un ordenamiento y registro provisorio de los hallazgos y sus contextos. Estos últimos fueron registrados con precisión a través de su posición tridimensional. El análisis posterior de gabinete pudo brindar un panorama más completo de las asociaciones contextuales inicialmente reconocidas en el campo. Los resultados obtenidos en este recinto, se presentarán según el ordenamiento por niveles seguidos en la excavación que serán finalmente integrados 
en función de los contextos culturales identificados. La excavación alcanzó una profundidad de $60 \mathrm{~cm}$ (desde el punto 0), estableciéndose 6 niveles artificiales:

- Nivel 1: de 0 a $10 \mathrm{~cm}$.

- Nivel 2: de 10 a $20 \mathrm{~cm}$.

- Nivel 3: de 20 a $30 \mathrm{~cm}$.

- Nivel 4: de 30 a $40 \mathrm{~cm}$.

- Nivel 5: de 40 a $50 \mathrm{~cm}$.

- Nivel 6: de 50 a $60 \mathrm{~cm}$.

\subsubsection{Niveles 1,2 y 3}

En este apartado se unen los tres primeros niveles de excavación dado que presentaron un sedimento con abundantes rocas de derrumbe, pero sin ningún otro hallazgo cultural (Figura 5.25). Dichas rocas se hallaron principalmente sobre el perfil E, sobre el ángulo NE y hacia el centro de la cuadricula. El sedimento natural identificado entre las rocas desmoronadas, es de tipo arenoso de coloración marrón claro y presentó una textura laminar producto de la absorción hídrica. Hacia el $\mathrm{O}$, se registraron restos de coprolitos húmedos que señalan niveles actuales de sedimentación, coincidentes con la inclinación observada en el terreno. En el muro O se observó un fragmento de mortero cupuliforme de granito. 


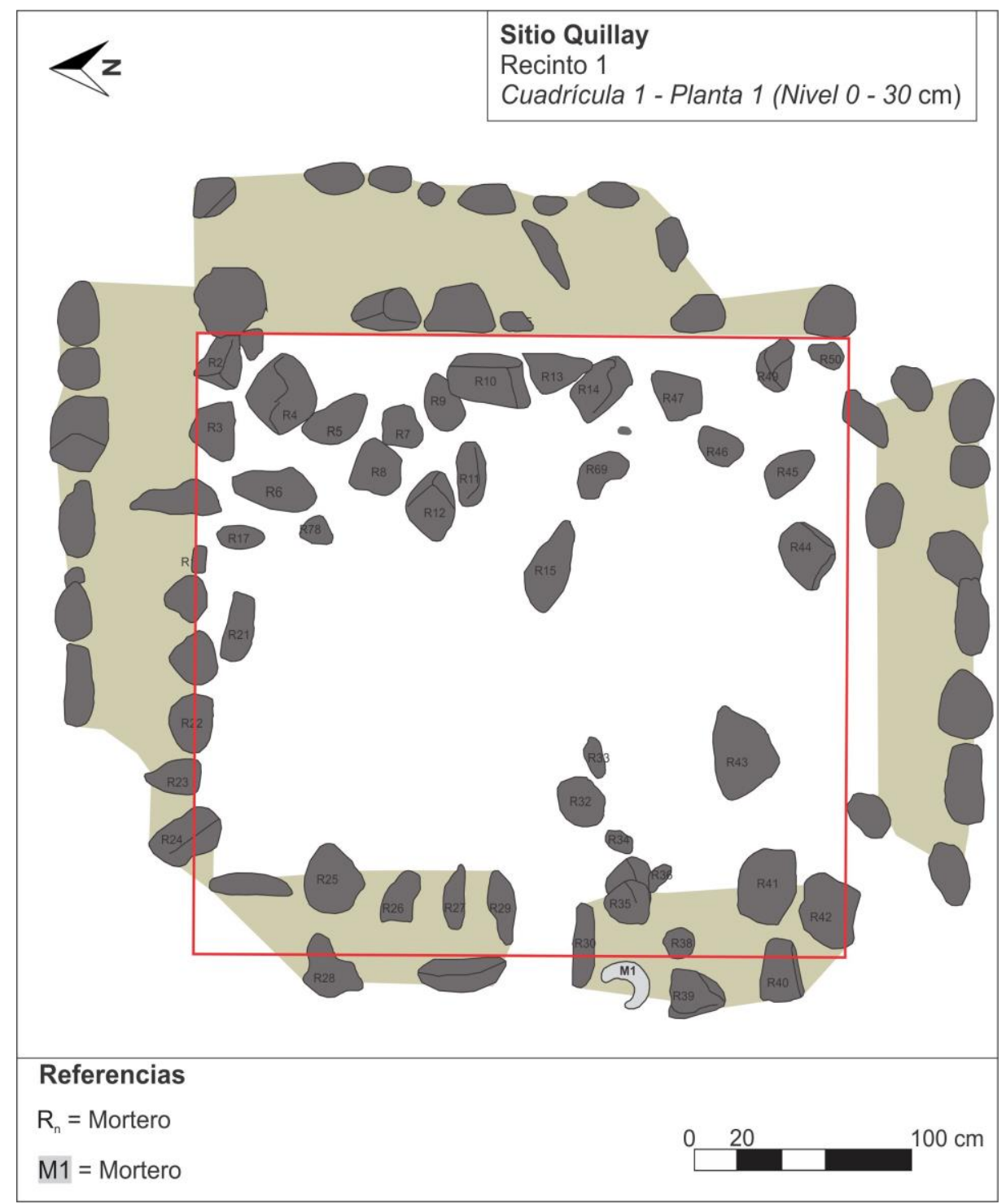

Figura 5.25. Planta del recinto 1 (Nivel 1-3). Se observan las rocas de derrumbe y el fragmento de mortero sobre muro.

\subsubsection{Nivel 4}

En este nivel, las rocas de derrumbe se mantuvieron únicamente en el extremo NE de la cuadricula. A partir de los $32 \mathrm{~cm}$ de profundidad comenzaron a registrarse hallazgos culturales (figura 25 en Anexo IV). Estos consistieron en 9 fragmentos cerámicos - dos de los cuales remontaron entre sí -, una microlasca de desecho de material cuarzoso y unos pocos restos faunísticos altamente fragmentados que imposibilitó el reconocimiento de taxones o partes anatómicas. Respecto a los 
materiales cerámicos, éstos corresponden a los estilos Belén $(n=4)$, Sunchituyoj $(n=1)$, Tosco utilitarios $(n=1)$ e indeterminados $(n=2)$.

A los $35 \mathrm{~cm}$ de profundidad hacia el extremo SO de la cuadrícula comenzó a delimitarse un lente de ceniza con fragmentos de carbón. El sector se encontró limitado por rocas, algunas de la cuales presentaron bordes redondeados, que las diferenciaría de las rocas de muro con laterales planos.

\subsubsection{Nivel 5}

En este nivel, el lente de carbones y cenizas del sector central se hizo más evidente y delimitó un fogón no formatizado (fogón 1) con pequeños leños, fragmentos de carbón, cenizas y sedimento termoalterado (Figura 5.26 y Figura 5.27). La potencia de este fogón fue de $10 \mathrm{~cm}(\lambda 35-45 \mathrm{~cm})$. Las rocas descriptas en el nivel previo continuaron delimitando la distribución del mismo. A los $45 \mathrm{~cm}$ se identificó una roca que atravesaba el extremo este del fogón, la misma presentó una cara superior plana y sectores laterales termoalterados. En el sector centro oeste de la cuadrícula - cercano al acceso del recinto -, comenzaron a visualizarse un conjunto de 5 manos de moler y en el vértice NE del recinto una roca plana.

Por otro lado, se recuperaron en este nivel varios tiestos cerámicos, restos arqueofaunísticos fragmentados y astillados, abundantes macrorestos botánicos y unos pocos fragmentos líticos que serán presentados siguiendo este orden de enumeración. 


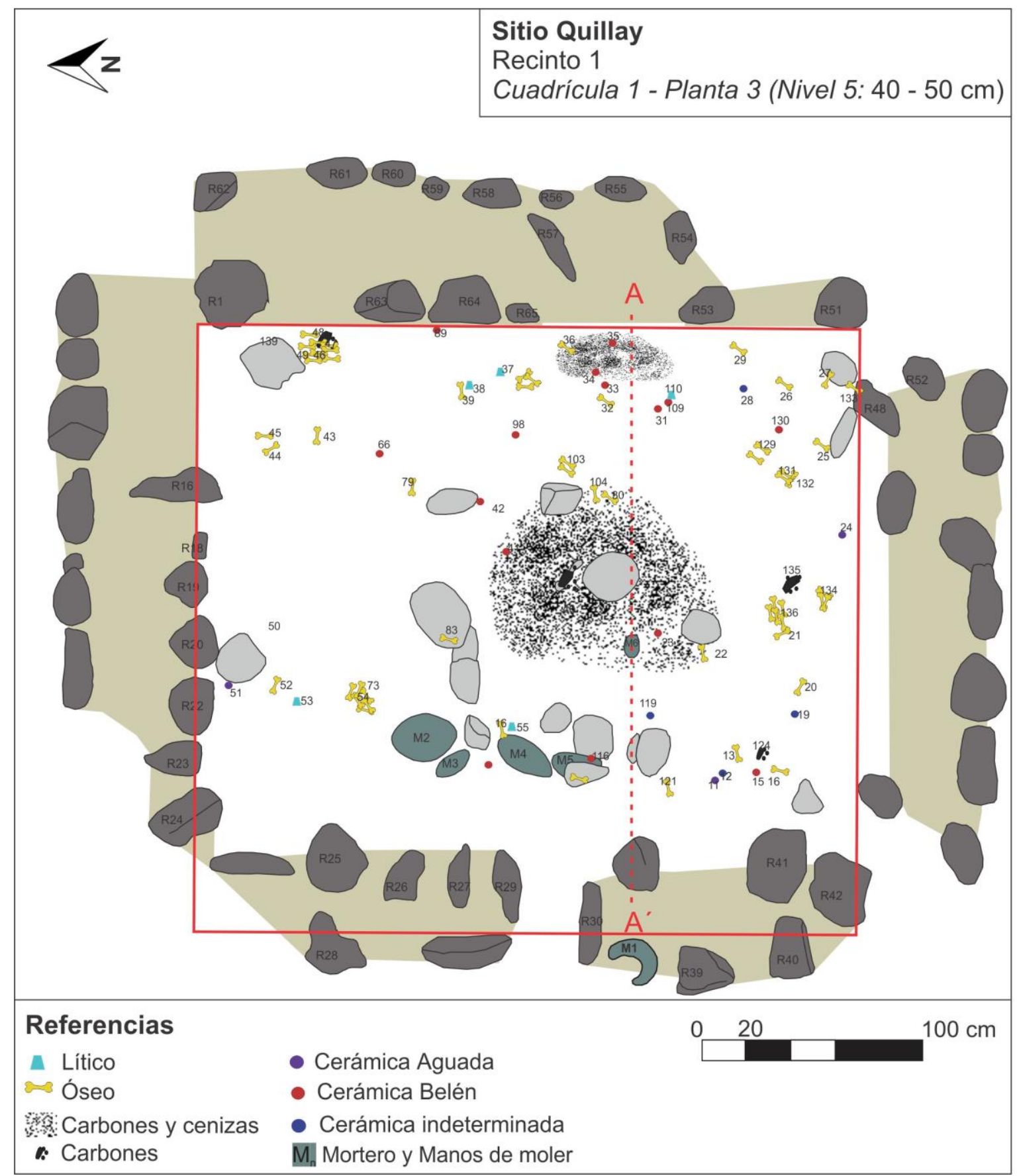

Figura 5.26. Planta del recinto 1 (Nivel 5). El eje A-A' señala el perfil estratigráfico levantado en este sector (ver figura 5.42). 


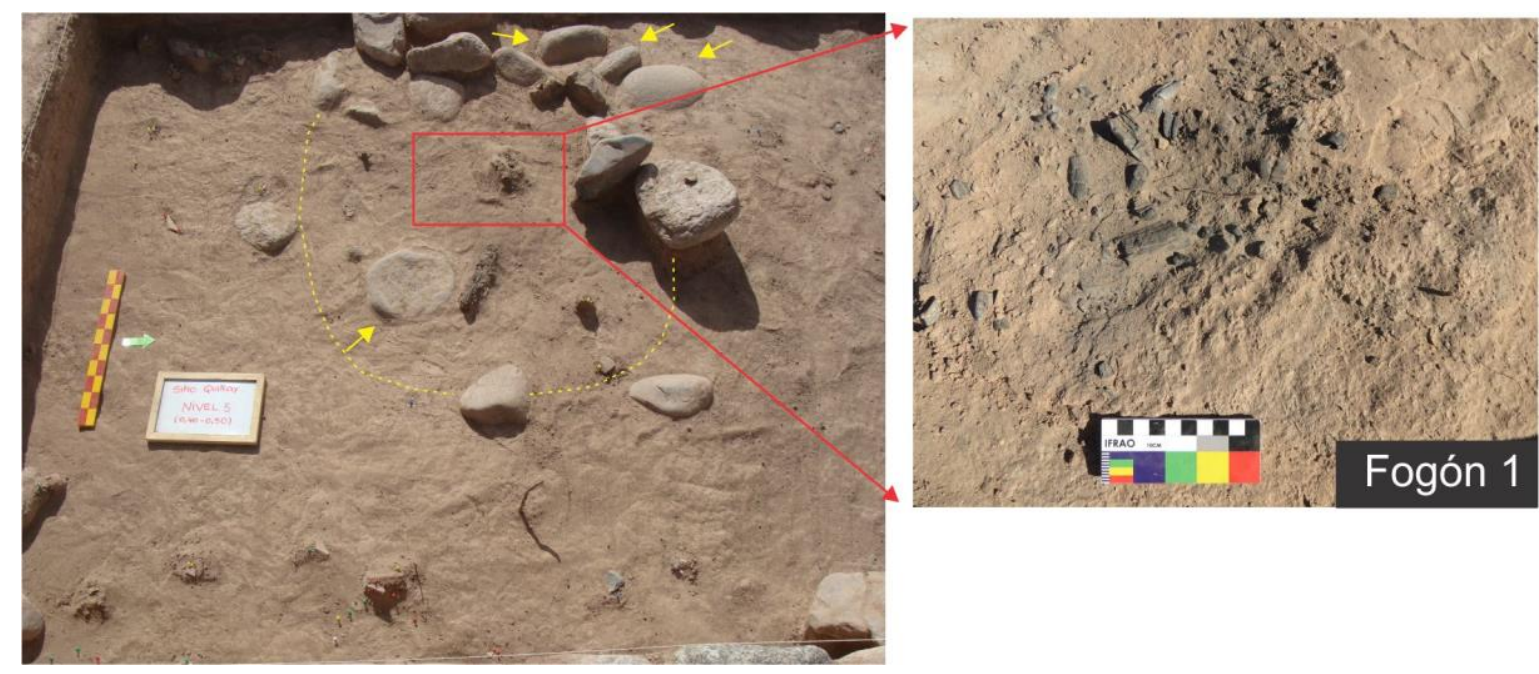

Figura 5.27. Fotografías del fogón central observado en el Recinto 1.

El conjunto cerámico de este nivel está representado por un total de 18 piezas $\left(\mathrm{n}_{\text {fragm }}=22\right)$. El Gráfico 5.8 exhibe los resultados de la identificación estilística, los cuales corresponden exclusivamente a tiestos con algún tipo de decoración. Como se puede observar, el 53\% son piezas de estilo Belén negro sobre rojo (Figura 5.28). El alto porcentaje de fragmentos indeterminados $(26 \%)$ responde a que son tiestos de pequeñas dimensiones con superficies erosionados que no permitieron reconocer atributos diagnósticos que posibiliten asignarlos a un estilo en particular. Por último, el 10\% restante corresponde a piezas tempranas del tipo Aguada Pintada $\left(\mathrm{n}_{\mathrm{fragm}}=4 ; 2\right.$ fragmentos de familia; Figura 5.29).

En cuanto a las morfologías cerámicas, se observa que la mayoría de las piezas son formas cerradas. Dentro del estilo Belén, siete fueron especificadas como tinajas y un solo fragmento corresponde a piezas abiertas. Ninguno de los tiestos presentó evidencias de quemado. 


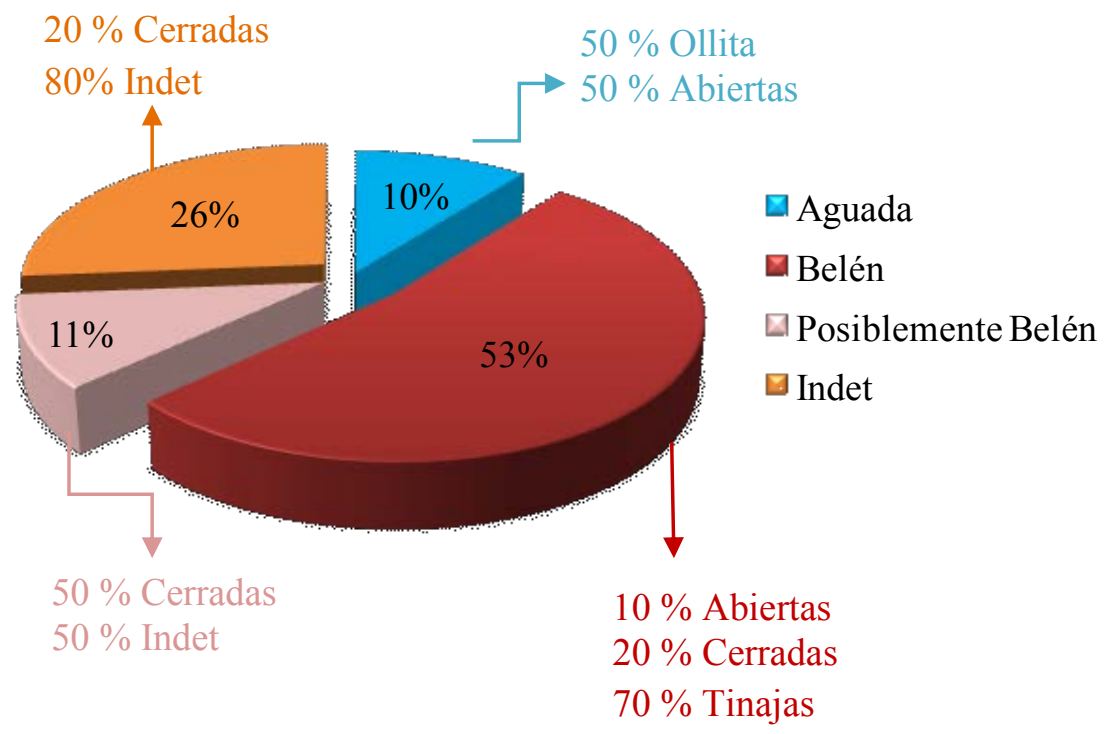

Gráfico 5.8. Frecuencia porcentual de estilos y morfologías cerámicas identificadas en el Nivel 5 del Recinto 1.

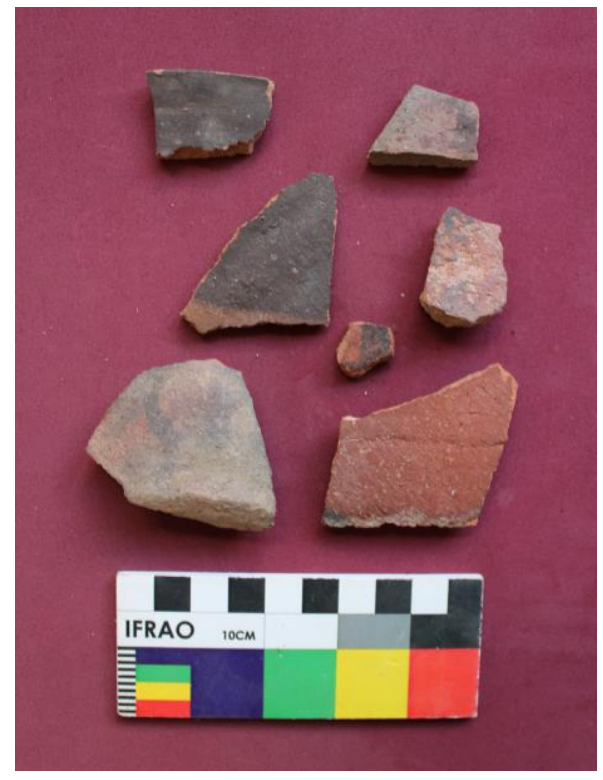

Figura 5.28. Cerámica Belén (R1-N5)

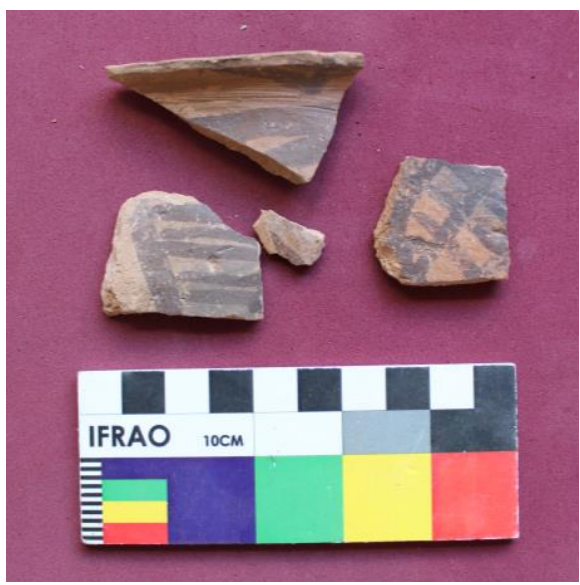

Figura 5.29. Cerámica Aguada (R1-N5)

Respecto a los macrorestos botánicos, se han contabilizado un total de 181 restos. La mayor representación está dada por semillas, endocarpos y vainas de algarrobo (Prosopis sp.) de los cuales un 30\% esta carbonizado (Gráfico 5.9 y Figura 5.30). En menor grado se identificaron semillas de chañar (Geoffroea decorticans), zapallo (Cucurbita sp.), ají (Capsicum sp.), granos de maíz (Zea Mays) y dos carozos de durazno (Prunus sp.). Estos últimos posiblemente sean parte de una intrusión. 


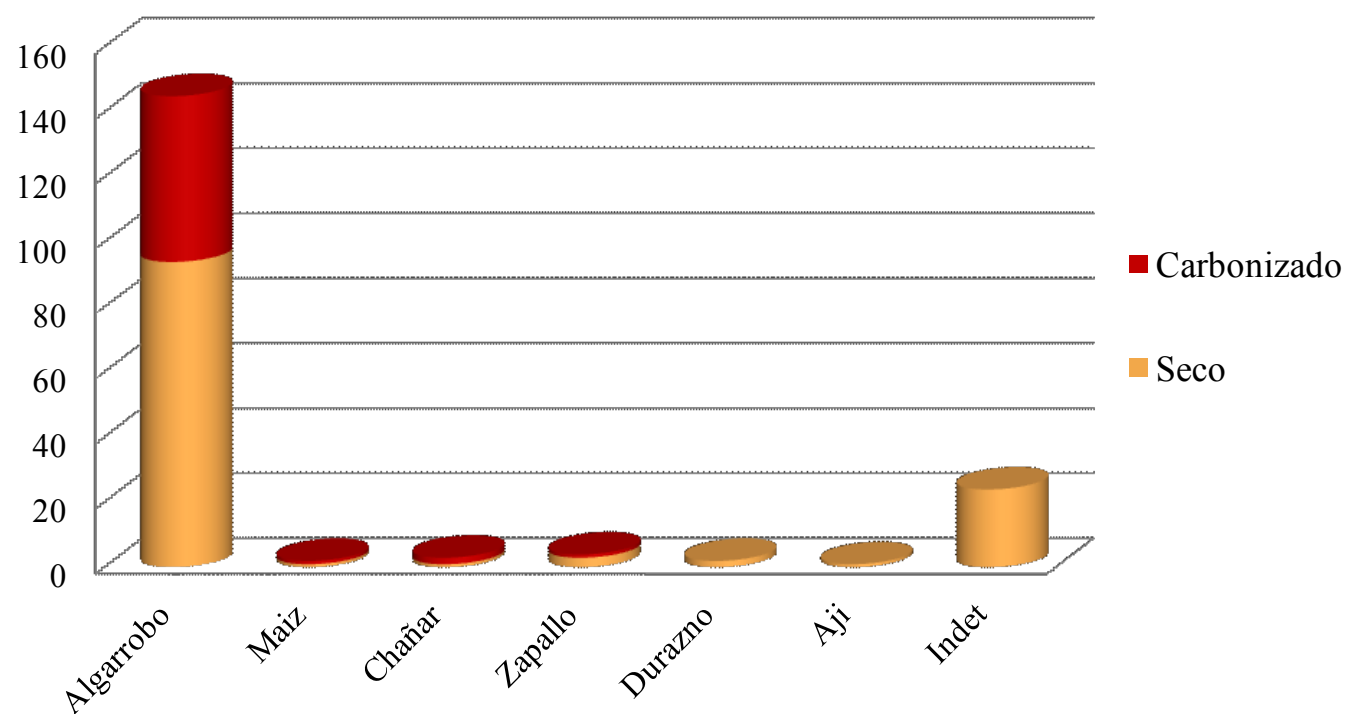

Gráfico 5.9. Frecuencia numérica y estado de los taxones vegetales identificados en el nivel 5 del R1.

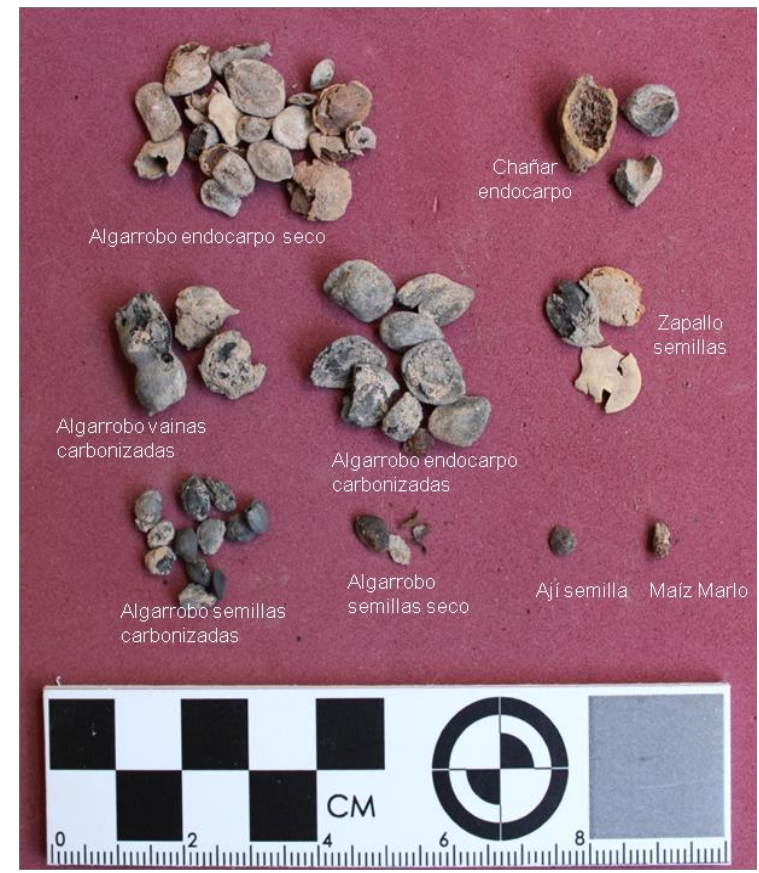

Figura 5.30. Fotografía de los restos botánicos identificados en el nivel 5 del R1

Los restos arqueofaunísticos recuperados en este nivel son 88 especímenes, siendo un $42 \%$ identificado en algún nivel taxonómico o anatómico. Aun así, se aclara que el conjunto presentó un altísimo grado de fragmentación lo que dificultó realizar en 
algunos casos determinaciones específicas ${ }^{4}$. En la tabla 5.10 se observa que dentro del conjunto se reconocieron varios mamíferos, con una mayor frecuencia de especímenes grandes (con pesos > a $50 \mathrm{~kg}$ ) y en un caso fue posible reconocer su pertenencia a la familia camelidae (Figura 5.31). También se reconocieron fragmentos óseos pertenecientes a la clase Reptilia con una frecuencia de $32 \%$ y a la especie Chaetophractus vellerosus en un $8 \%$. Entre las modificaciones culturales se han registrado marcas de corte y evidencias de termoalteración en un $27 \%$ de las muestras (Figura 5.32). Esta últimas principalmente fueron observadas en fragmentos tanto de huesos largos como planos de mamíferos

\begin{tabular}{|l|c|c|}
\hline R1- Nivel 5 & NISP & \%NISP \\
\hline Reptilia & 12 & 32,4 \\
\hline Mammalia indet & 4 & 10,8 \\
\hline Micromamífero indet & 2 & 5,4 \\
\hline Rodentia & 1 & 2,7 \\
\hline $\begin{array}{l}\text { Chaetophractus } \\
\text { vellerosus }\end{array}$ & 3 & 8,1 \\
\hline $\begin{array}{l}\text { Mammalia Grande } \\
\text { indet. }\end{array}$ & 14 & 37,8 \\
\hline Camelidae & 1 & 2,7 \\
\hline Total & $\mathbf{3 7}$ & $\mathbf{4 2}$ \\
\hline
\end{tabular}

* Placa de la armadura ósea

Tabla 5.10. Taxones faunísticos identificados en el Recinto 1

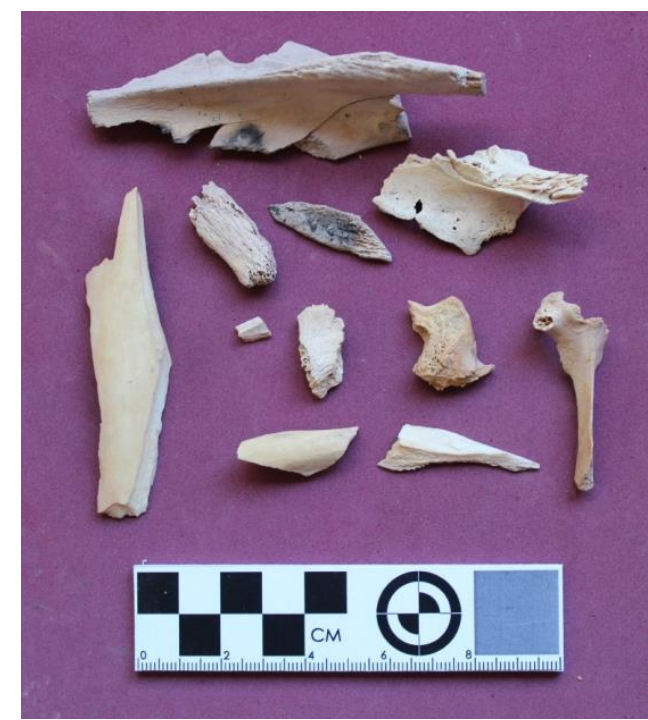

Figura 5.31. Restos faunísticos. Huesos largos y planos de mamíferos.

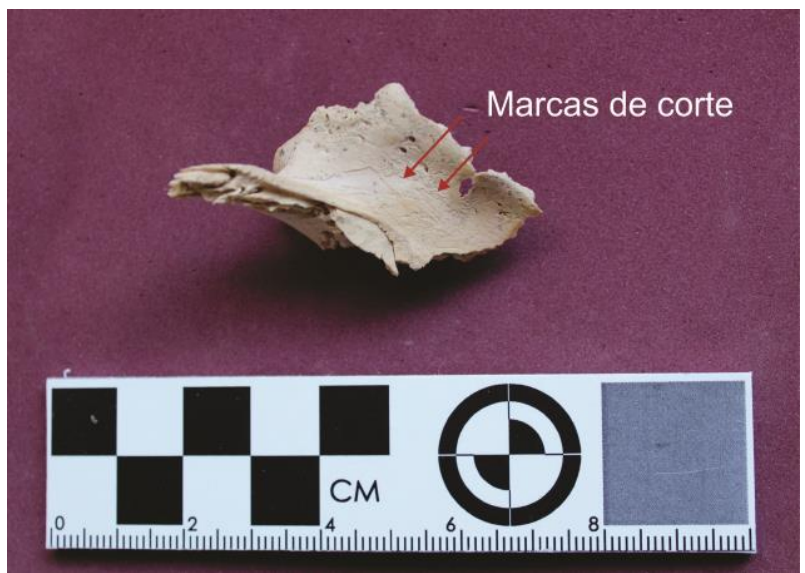

Figura 5.32. Las flechas señalan las marcas de corte en fragmento mandíbula de mamífero grande.

\footnotetext{
4 Se aclara que, dado la fragmentación del conjunto óseo de todo el recinto, para el análisis de especímenes reconocidos dentro de la clase Mammalia se emplearon para su clasificación categorías de peso relativo, diferenciando así entre mamíferos grandes, medianos, pequeños y micromamíferos.
} 
Por último, los materiales culturales menos frecuentes fueron los fragmentos líticos, siendo registrados cuatro especímenes para este nivel. Son dos fragmentos líticos de arenisca cuarzosa: una lasca de desecho y una lasca primaria con un extremo punzante. Los otros dos fragmentos son lascas de desecho de andesita y un fragmento de granito. La primera presenta evidencias de percusión antrópica (talón, bulbo, etc.), la segunda parece corresponder a los "desprendimientos" de manos de moler producto de un uso continuado.

\subsubsection{Nivel 6}

En este nivel, el fogón 1 ya no es visible (Figura 5.33). Aquí se identificaron los niveles basales de las cuatro manos de moler y se delimitó claramente el yunque dispuesto en el extremo NE de la cuadrícula (Figura 5.34). Asimismo, sobre el muro N y NO - hacia el $\mathrm{N}$ del vano de acceso - se identificaron abundantes vestigios de restos de vainas y endocarpos de algarroba que sufrieron un proceso de molienda, de color morado y sin evidencias de termoalteración (Figura 5.35). De forma continua y hacia el sur se delimitó una marca semicircular de $12 \mathrm{~cm}$ de diámetro, que posiblemente responda a la huella de la base de una tinaja.

Un punto a destacar es que apenas unos $2 \mathrm{~cm}$ por debajo de la cota de hallazgo de la algarroba molida comenzaron a delimitarse un lente de ceniza en dicho sector ( $\lambda 58$ $\mathrm{cm})$ que coincidió con otros cuatro focos de ceniza desplegados hacia los extremos del recinto. En el campo se pudo observar que estas zonas de mayor concentración de cenizas y carbones abarcaban sectores discretos del recinto con restos de ceniza esparcida en los alrededores.

Entre los hallazgos dispersos, fueron abundantes los restos botánicos, faunísticos y cerámicos. En menor medida se recuperaron fragmentos líticos y un único resto malacológico representado por una cuenta. Las frecuencias y especificidades de estos materiales serán presentas a continuación. 


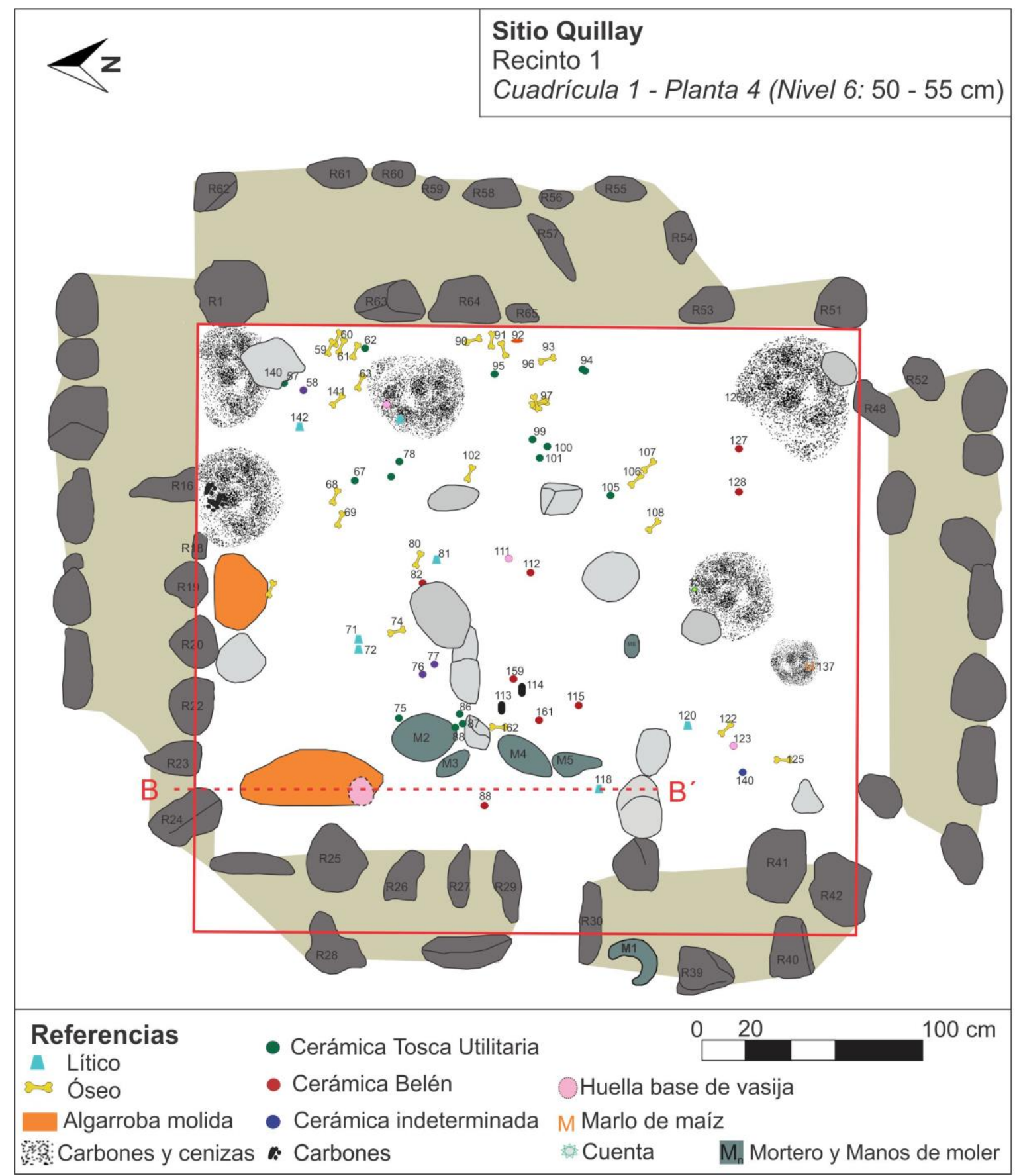

Figura 5.33. Planta del Recinto 1, nivel 6. El eje B-B' señala el perfil estratigráfico levantado en este sector (ver figura 5.43). 

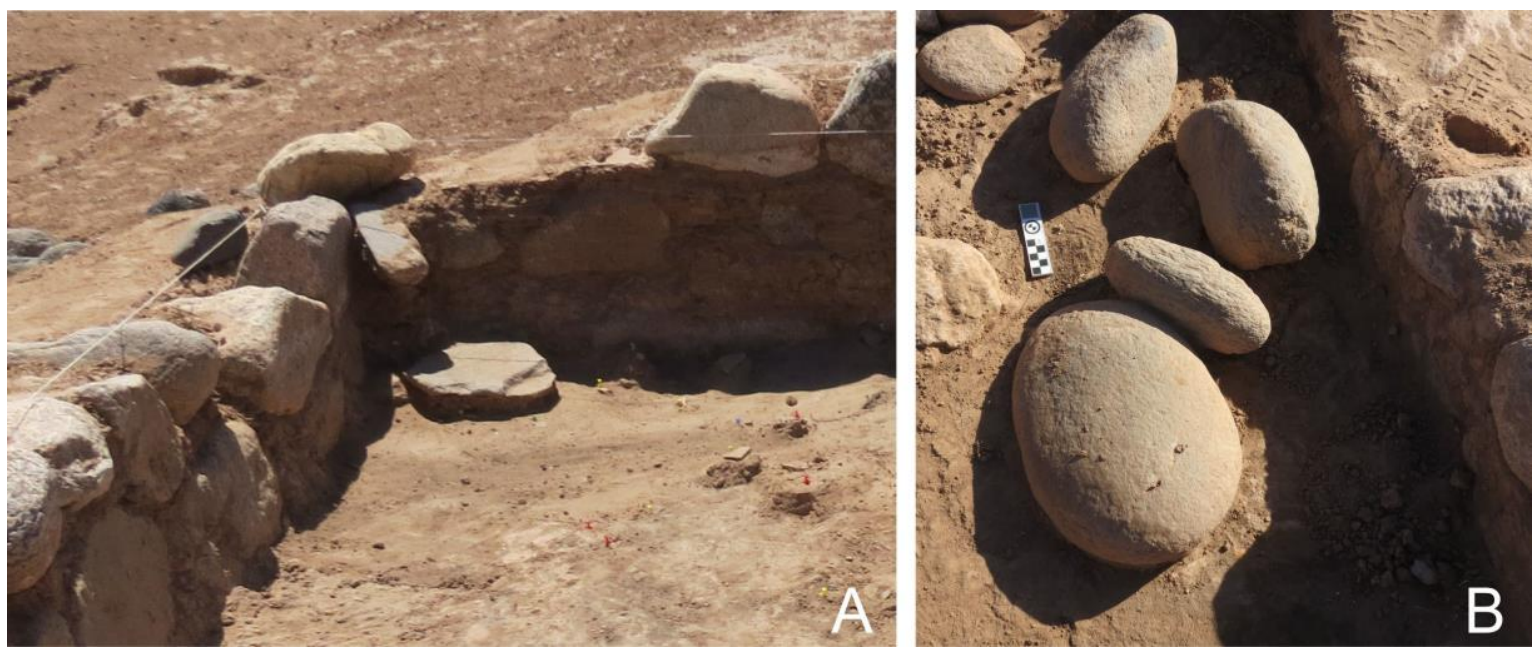

Figura 5.34. Fotografías del material lítico del R1. A. Yunque en el extremo NO; B. Manos de moler.

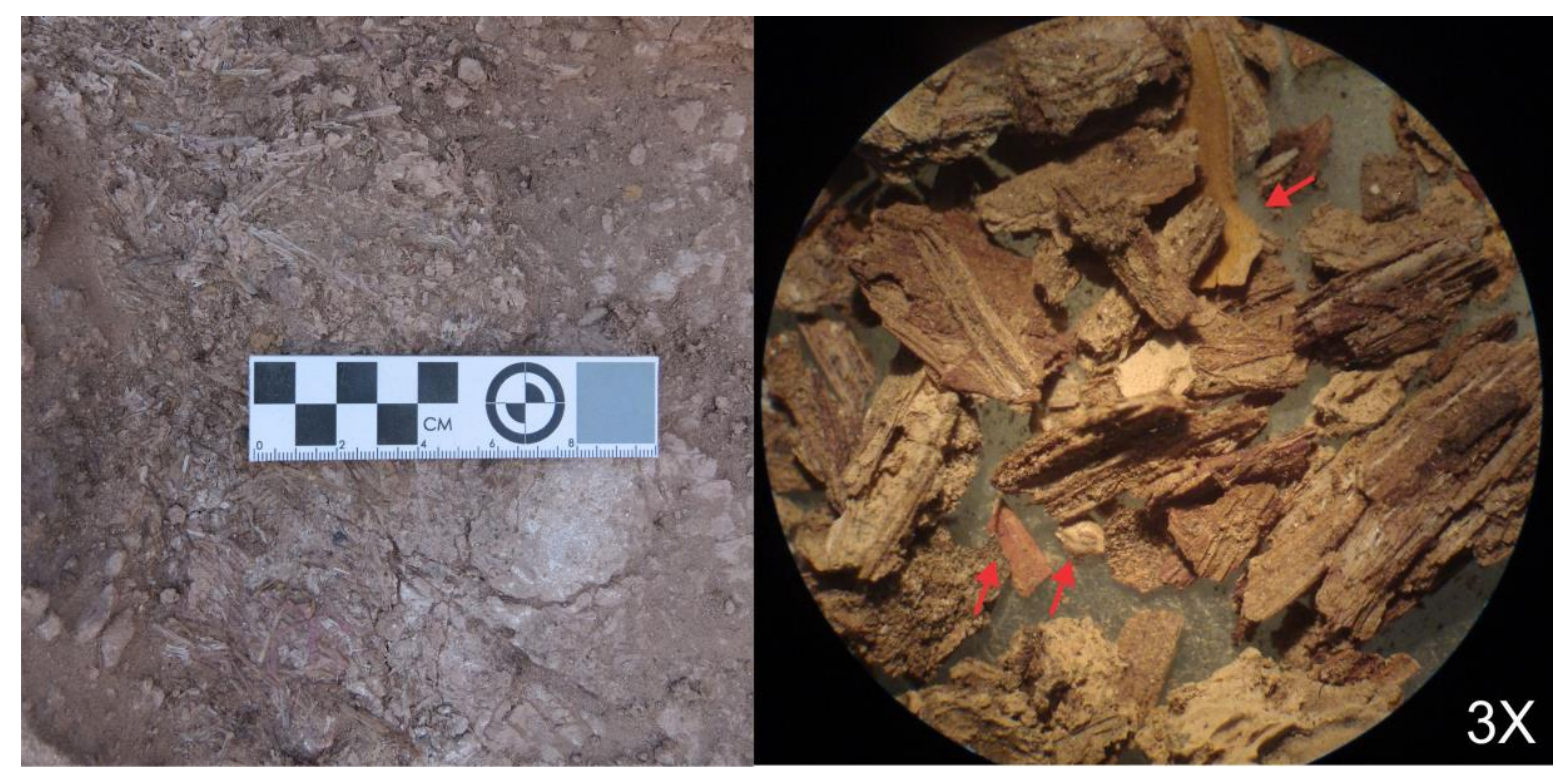

Figura 5.35. Fotografías de la algarroba molida identificada en el extremo SW del Recinto 1.

El material cerámico registrado en este nivel es de 30 piezas $\left(\mathrm{n}_{\text {fragm }}=38\right)$, siendo los toscos utilitarios los más frecuentes (53\%) (Gráfico 5.10). Consisten en segmentos de vasijas cerradas, principalmente ollas, de las cuales el $60 \%$ presenta evidencias de quemado y restos de hollín (Figura 5.36). Le siguen en frecuencia las piezas de estilo local Belén (17\%) y posiblemente Belén (17\%), por último, las Aguada $(6,5 \%)$ e indeterminadas $(6,5 \%)$, donde también predominan las formas cerradas. Dentro de los fragmentos Belén un $60 \%$ fueron reconocidas como partes de tinajas (Figura 5.36). Sólo un caso presentó manchas grisáceas producto del contacto con el fuego. 


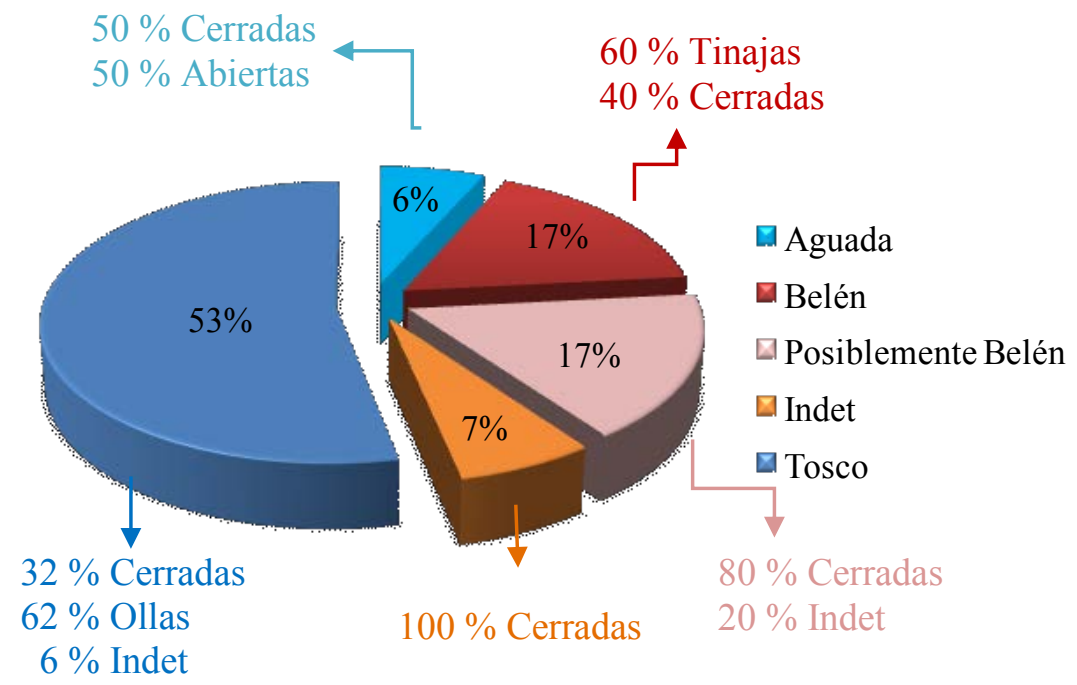

Gráfico 5.10. Frecuencia porcentual de estilos y morfologías cerámicas identificadas en el Nivel 6 del Recinto 1.
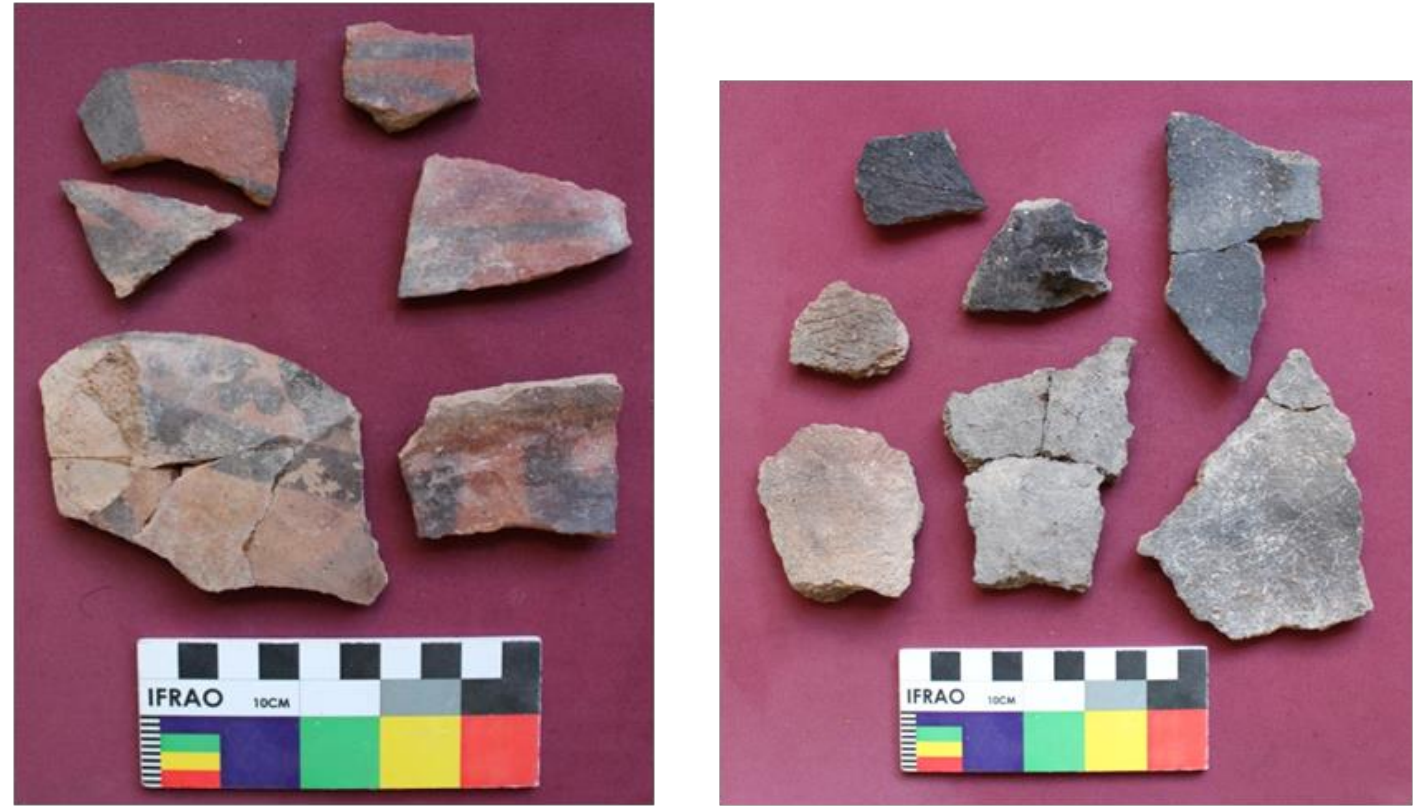

Figura 5.36. Fragmentos cerámicos registrados en el nivel 6 del R1. Estilo Belén (izquierda) y toscos utilitarios (derecha) 


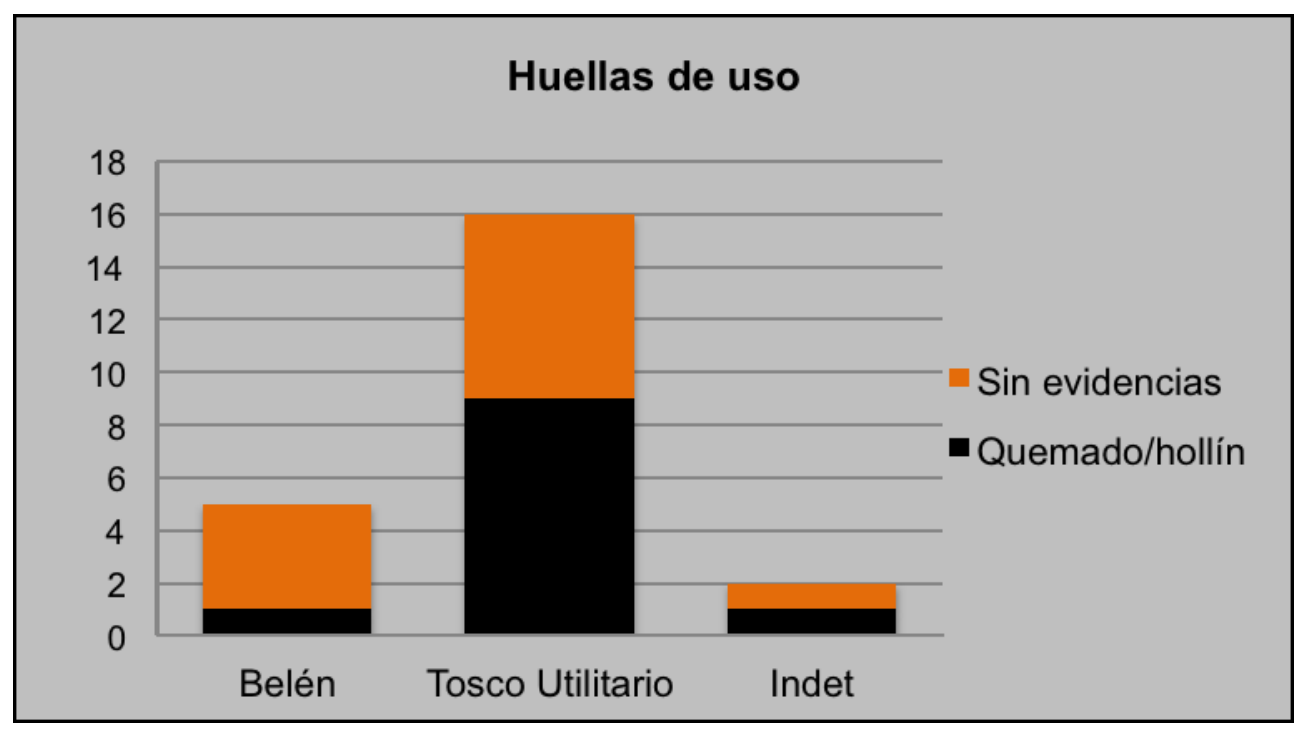

Gráfico 5.11. Marcas de uso discriminadas por estilos cerámicos

Los restos botánicos en este nivel fueron los que presentaron mayor frecuencia en toda la excavación $(\mathrm{N}=938)$ presentando una mayor diversidad de taxones (Gráfico 5.12). Aun así, al igual que en lo observado en el nivel precedente, aquí también predominan las vainas, endocarpos y semillas de algarrobo (Prosopis sp.) en un $70 \%$, de las cuales el $30 \%$ está carbonizado. Los restos de algarroba seca han sido recuperados principalmente en los sectores adyacentes al muro norte del recinto y al sector NO, es decir se corresponden con las zonas de molienda referenciadas en las figuras 5.33 y 5.35 .

El segundo lugar lo ocupan las semillas y partes de endocarpos del fruto de chañar (Geoffroea decorticans) (11\%), presentes en estado carbonizado y seco; granos y marlos de maíz (Zea Mays) en su mayoría carbonizados $(8,5 \%)$ y semillas de zapallo (Cucurbita sp.) (5\%). Con una menor frecuencia (>1\%) se han recuperado frutos de poroto (Phaseolus sp.), mistol (Zizipus sp.), tuna (Opuntia tuna) y un carozo de ciruela (Prunus sp.), todos ellos en estado seco (Figura 5.37). 
Capítulo 5

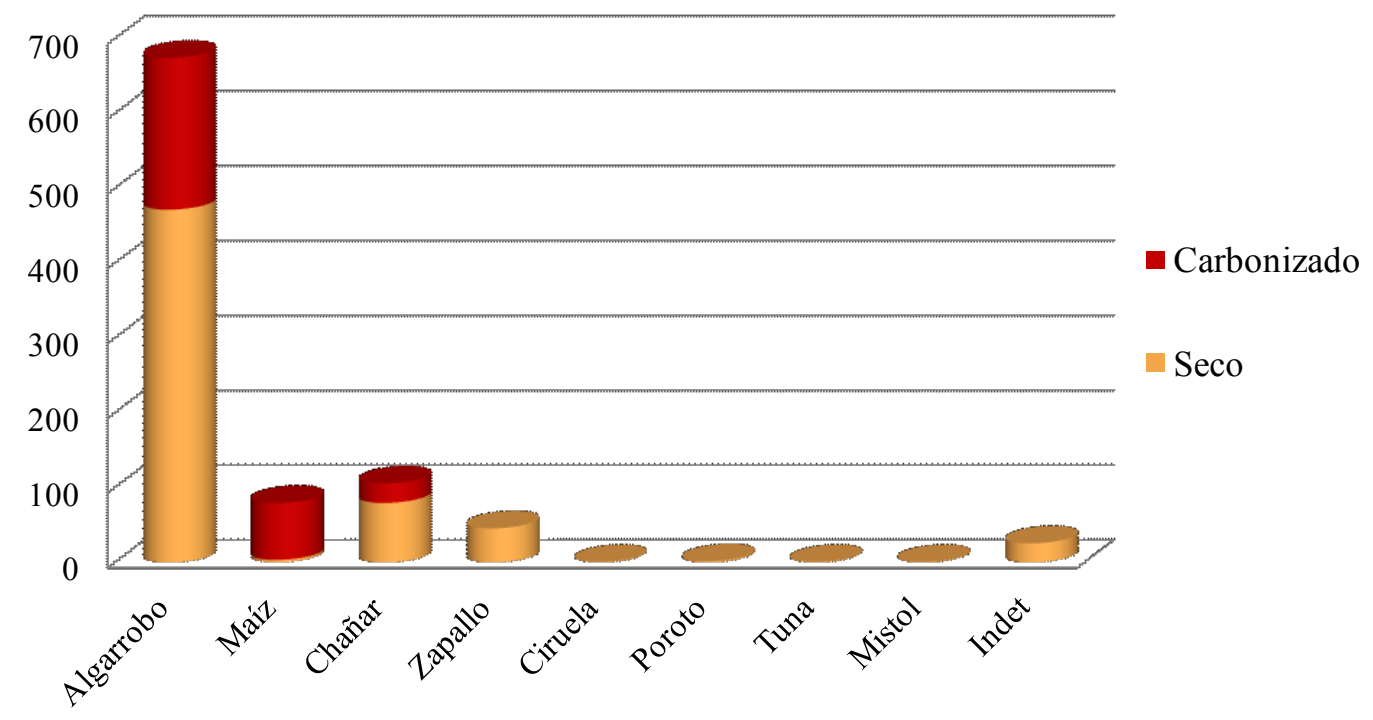

Gráfico 5.12. Frecuencia numérica y estado de los taxones vegetales identificados en el nivel 6 del R1.

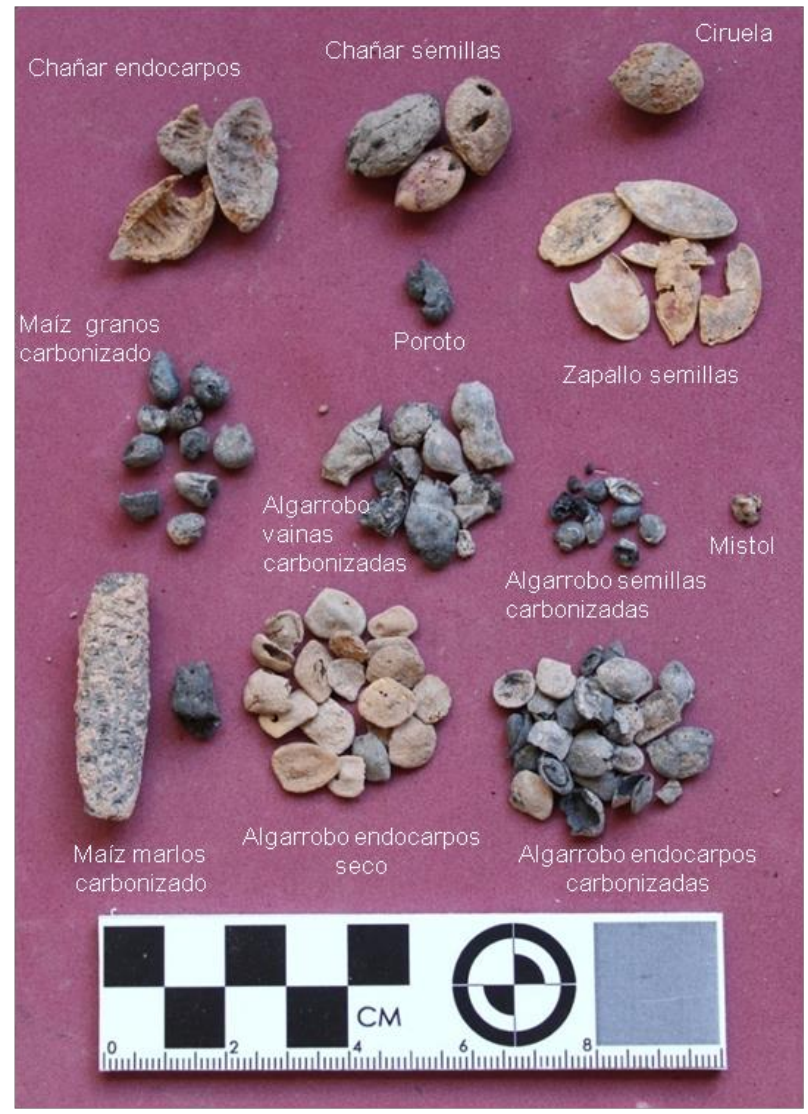

Figura 5.37. Fotografía de los restos botánicos registrados en el nivel 6 del Recinto 1. 
Los vestigios óseos también fueron abundantes en este nivel. Se han contabilizado un total de 198 restos, de los cuales el $40 \%$ ha podido ser identificado en algún nivel taxonómico o anatómico (Tabla 5.11). También aquí se observa un predominio de mamíferos que fueron incluidos en categorías generales como Mammalia indeterminado (38\%), mamíferos grandes (26\%) así como mamíferos pequeños y micromamíferos $(>2 \%)$. Aun así, se han podido identificar especímenes de camélidos a partir de molares y metapodios que representan el $5 \%$ del conjunto. Por otro lado, se registraron varias placas de armadura ósea de Chaetophractus vellerosus (piche) con grados variables de termoalteración y fragmentación (Figura 5.38), especímenes del orden Rodentia entre ellos el tucu - tucu (Ctenomys sp.) y restos pertenecientes al orden Artiodactyla.

\begin{tabular}{|l|l|l|}
\hline R1- Nivel 6 & NISP & $\%$ NISP \\
\hline Mammalia indet & 30 & 38,5 \\
\hline Micromamífero indet. & 1 & 1,3 \\
\hline Rodentia & 4 & 5,1 \\
\hline Ctenomys sp. & 1 & 1,3 \\
\hline Mammalia indet. Peq & 1 & 1,3 \\
\hline $\begin{array}{l}\text { Chaetophractus } \\
\text { vellerosus }\end{array}$ & 14 & 17,9 \\
\hline $\begin{array}{l}\text { Mammalia indet. } \\
\text { Mediano }\end{array}$ & 1 & 1,3 \\
\hline $\begin{array}{l}\text { Mammalia indet. } \\
\text { Grande }\end{array}$ & 21 & 26,9 \\
\hline Artiodactyla & 1 & 1,3 \\
\hline Camelidae & 4 & 5,1 \\
\hline TOTAL & $\mathbf{7 8}$ & $\mathbf{1 0 0}$ \\
\hline \multicolumn{2}{|l|}{ * Placa de la armadura ósea } & \\
\hline
\end{tabular}

Tabla 5.11. Taxones faunísticos identificados en el recinto 1 (N5)

En relación con este conjunto, resulta relevante que un 33\% de los especímenes óseos mostraron marcas de alteración cultural (Gráfico 5.34). La mayoría de ellas refieren a cambios en la coloración de los huesos que señalan su exposición al fuego. Así se han reconocido un $3 \%$ de especímenes quemados, un $28 \%$ carbonizados y un $68 \%$ calcinados indicando un grado creciente de termoalteración (Figura 5.39). Por otro lado, en cinco especímenes se identificaron huellas de corte y marcas de percusión observadas en segmentos de huesos largos y costillas correspondientes a mamíferos grandes que señalarían el procesamiento de recursos cárnicos (Figura 5.40). 


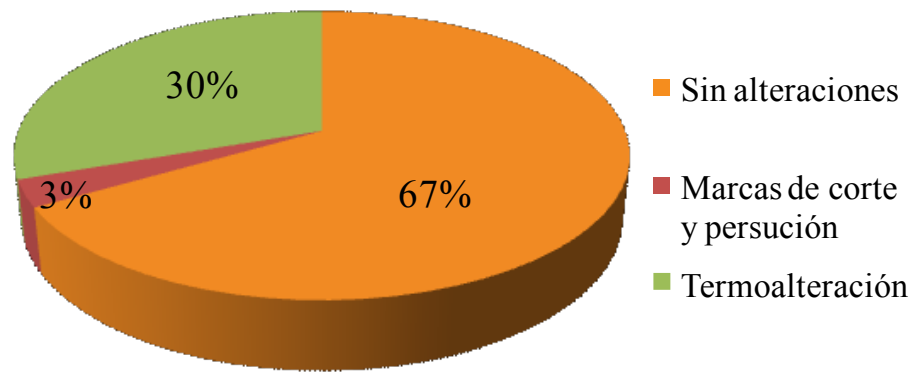

Grafico 5.14. Proporción de especímenes óseos con alteraciones culturales y sin ellas.

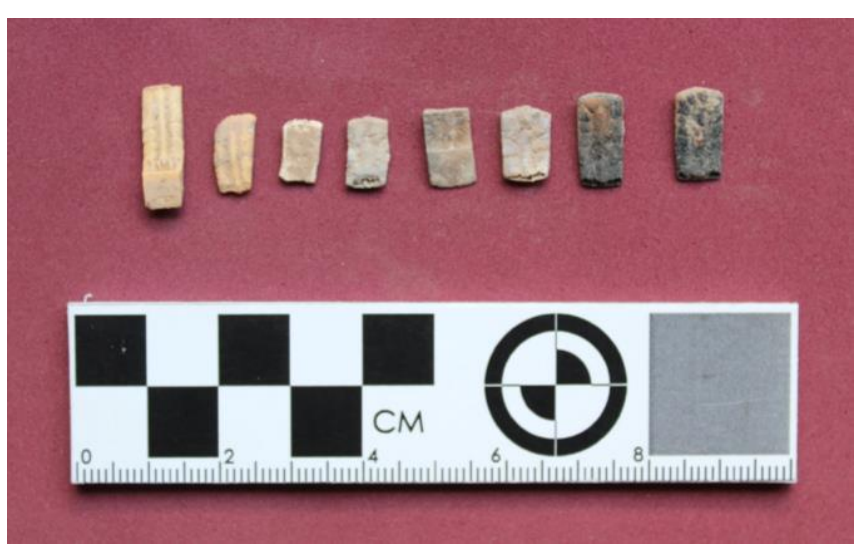

Figura 5.38. Placas de Chaetophractus vellerosus en estado natural, fragmentado y termoalterado

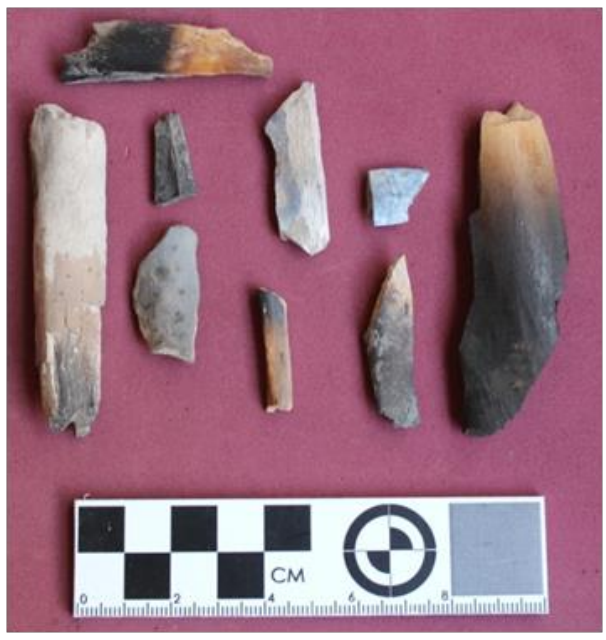

Figura 5.39. Restos de huesos largos con distintos grados de termoalteración

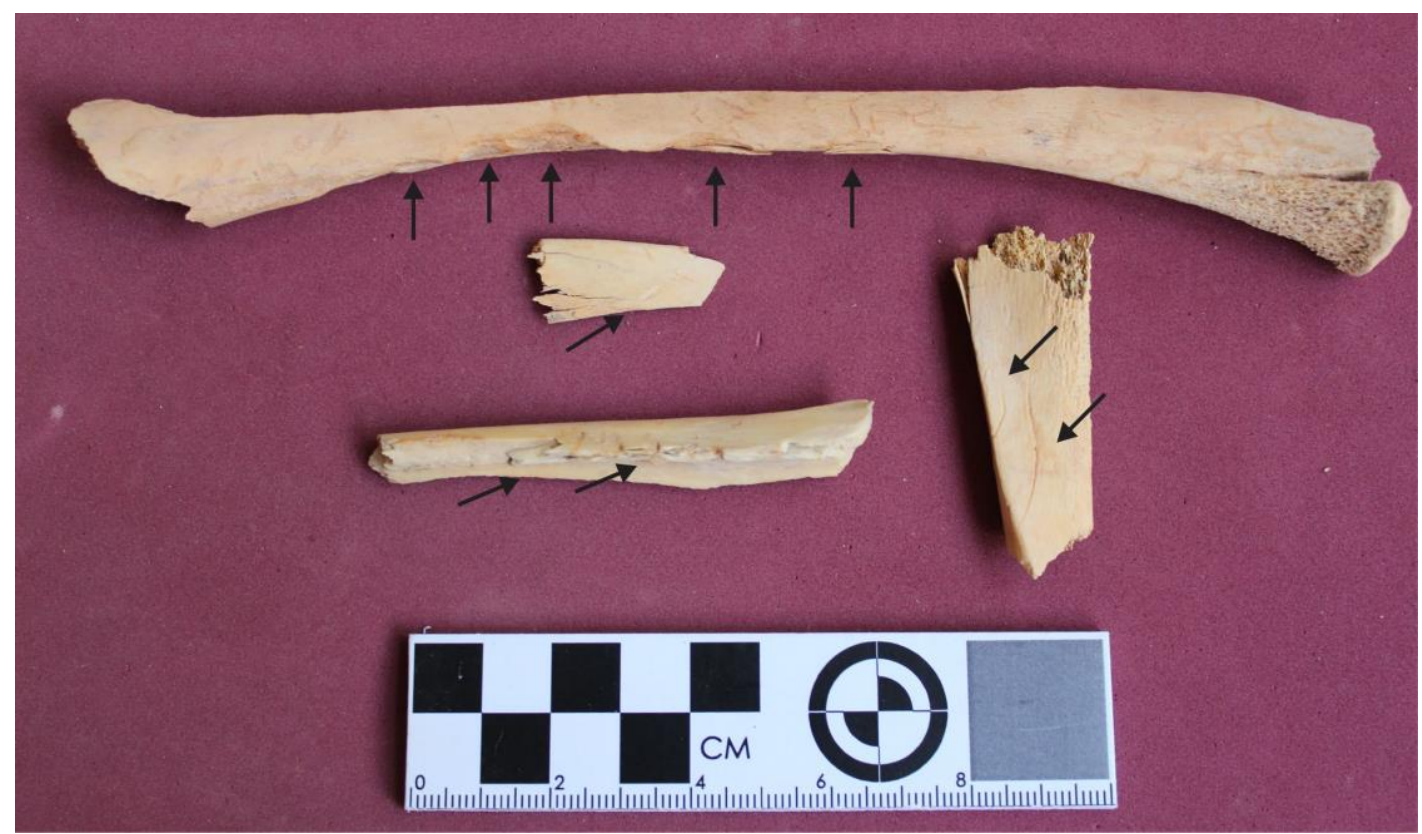

Figura 5.40. Huesos largos de mamíferos, las flechas señalan marcas de percusión y corte. 
Finalmente, los fragmentos líticos contabilizados ascienden a 14 en este nivel. En lo que se refiere a sus materias primas se observa un predominio de rocas ígneas de carácter volcánico, disponibles en la geología local (Gráfico 5.51). En concreto, el 57\% de la muestra está conformada por andesitas y consisten en lascas de desecho y lascas primarias, dos de las cuales presentan sectores aguzados con bordes filosos (Figura 5.41). En menor frecuencia se reconocieron lascas de basalto (22\%) algunas con filo natural cortante. Además, se detectaron lascas de desecho de material de cuarcita, un fragmento de granito (desprendimiento de mano) y una laja de pizarra que podría corresponder a un segmento de yunque. Pese a la presencia de lascas con filos naturales, que podrían servir como instrumentos cortantes, no se ha recuperado ningún instrumento formatizado.

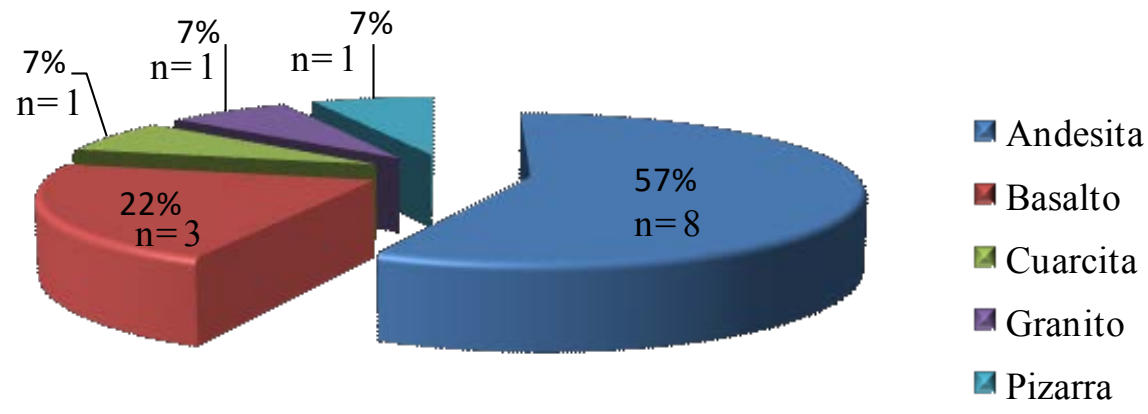

Gráfico 5.15. Frecuencia porcentual de materias primas líticas del recinto 1

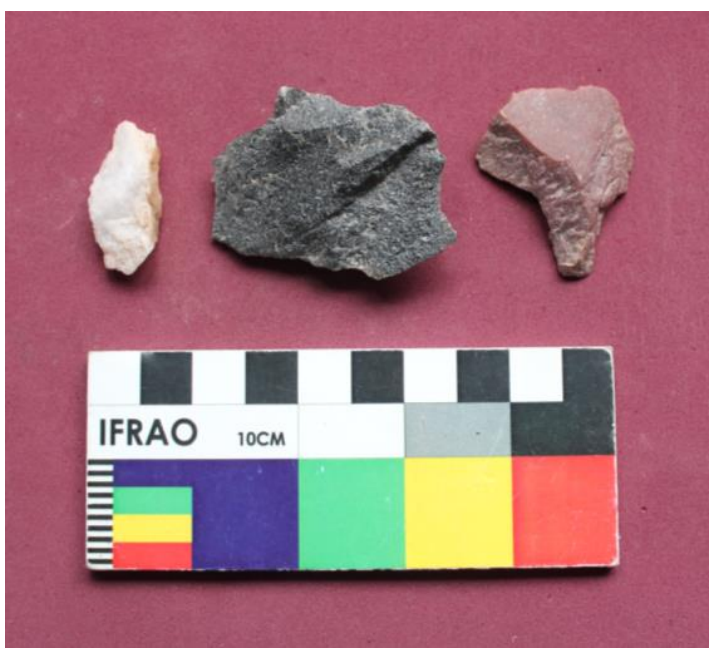

Figura 5.41. Lascas registradas en el R1 


\subsubsection{Perfiles del Recinto 1}

Se han levantado los perfiles de los cortes A-A' y B-B' señalados en las plantas de los niveles 5 (Figura 5.26) y 6 (Figura 5.33) respectivamente, con el fin de diagramar la secuencia estratigráfica en sectores específicos del recinto. También se relevaron los perfiles sur y este de la cuadrícula de excavación. El primero corresponde completamente a estratos sedimentarios mientras que el segundo incluye la pared interna del recinto 1 .

Perfil $\boldsymbol{A}-\boldsymbol{A}^{\prime}$ (Figura 5.42): se realizó este perfil en el sector donde fue identificado el fogón 1. Se observa un sedimento natural de relleno de tipo arenoso fino y color castaño por encima y por debajo de la estructura de combustión. Los primeros $30 \mathrm{~cm}$ no se observan vestigios culturales y se corresponden con los niveles 1,2 y 3 previamente descriptos. Luego se puede apreciar hacia el perfil este un lente de cenizas de $20 \mathrm{~cm}$ y hacia el centro el fogón 1, la roca de base (R95), la mano de moler y una de las rocas que delimita la estructura de combustión (R72). Por debajo del fogón 1 el sedimento natural adquiere coloración rojiza producto de la termoalteración y se registraron unos pocos fragmentos cerámicos por debajo.

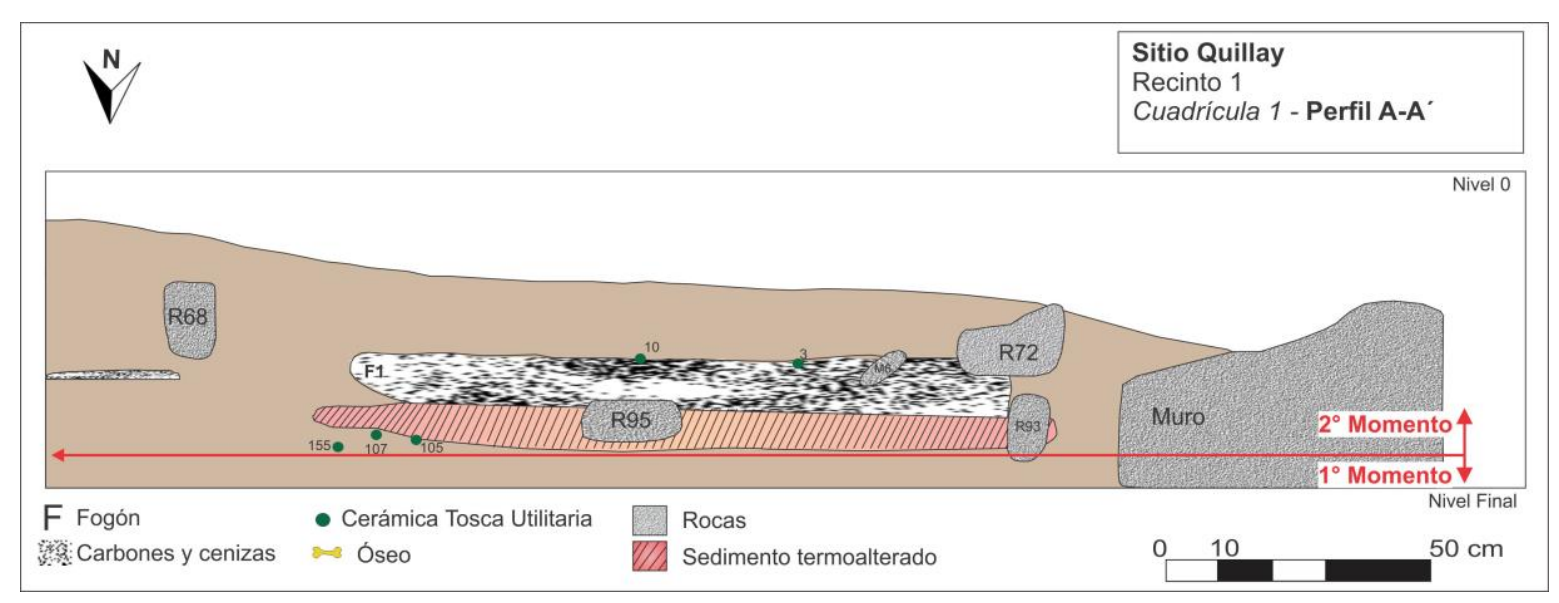

Figura 5.42. Perfil estratigráfico del eje A-A' del Recinto 1

- Perfil B-B' (Figura 5.43): en este corte también se observa un sedimento homogéneo natural de arena fina. Aquí lo que quiere señalar es la relación entre los vestigios de algarroba molida identificados en el extremo NE del recinto y la huella de la base de una vasija. En el perfil se observa que la extensión del estrato de algarroba 
está interrumpida. Inmediatamente por debajo se identificó una huella semicircular de 9 $\mathrm{cm}$ de diámetro que asociamos a la marca dejada por una vasija semienterrada. Luego, de identificó un sedimento natural sin vestigios culturales de $2 \mathrm{~cm}$ de espesor que señala un pequeño hiatus, seguido de un lente de cenizas que corresponde al nivel 6 previamente descripto.

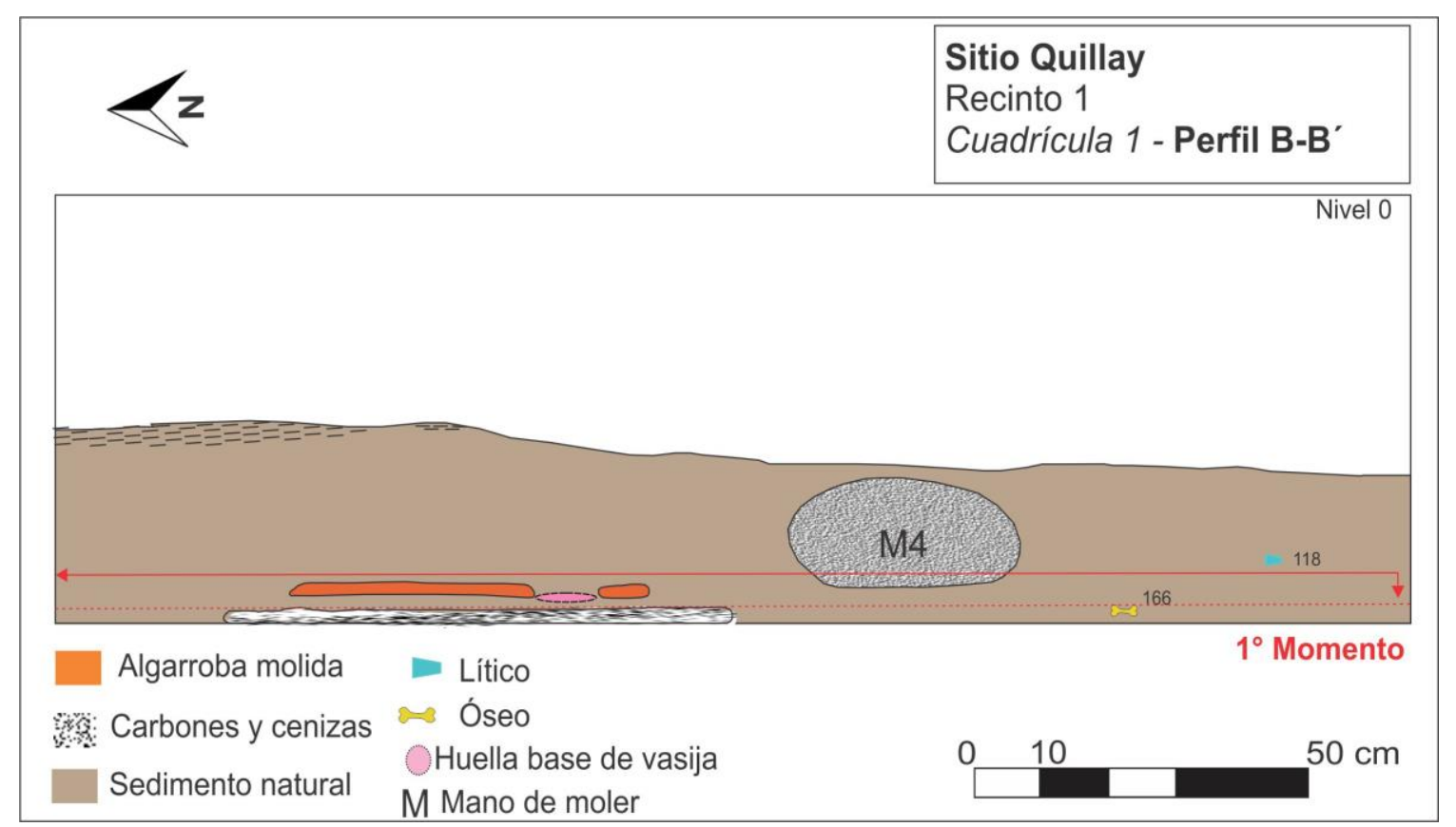

Figura 5.43. Perfil estratigráfico del eje B-B' del Recinto 1

- Perfil Sur (Figura 5.44): en general no se han observado variaciones sedimentarias significativas a lo largo de los perfiles naturales. El suelo está compuesto de un material arenoso fino homogéneo de color castaño compacto (estrato 1) que presentó sutiles variaciones en el grado de compactación y textura. Así, en función de estas se diferenció un estrato 2 de textura laminar friable característico de procesos de absorción y escurrimiento de agua de lluvia. El estrato 3 que señala, en ambos perfiles, lentes de cenizas y carbones de no más de $3 \mathrm{~cm}$ de potencia producto de la acción antrópica, que se corresponden con los focos de combustión observados en el nivel 6 (50-60 cm) de la excavación.

- Perfil Este (Figura 5.44): el estrato 4 señala la argamasa de barro compacta que une las rocas de la pared interna del muro y el estrato 5 indica un cambio de coloración 
grisáceo asociado con la alteración antrópica observada en los primeros niveles de excavación. Asimismo, este perfil permite observar las características constructivas del recinto. Al igual que lo visualizado en superficie (capítulo 5) las rocas de muro son rodados granitoides sin evidencia de canteado. Sin embargo, se aprecia que las rocas fueron dispuestas de una manera particular, utilizando sus superficies más planas hacia el interior del recinto (Figura 5.45). Por otro lado, el eje de mayor longitud de las rocas se colocó en sentido horizontal y fueron unidos con mortero de barro.

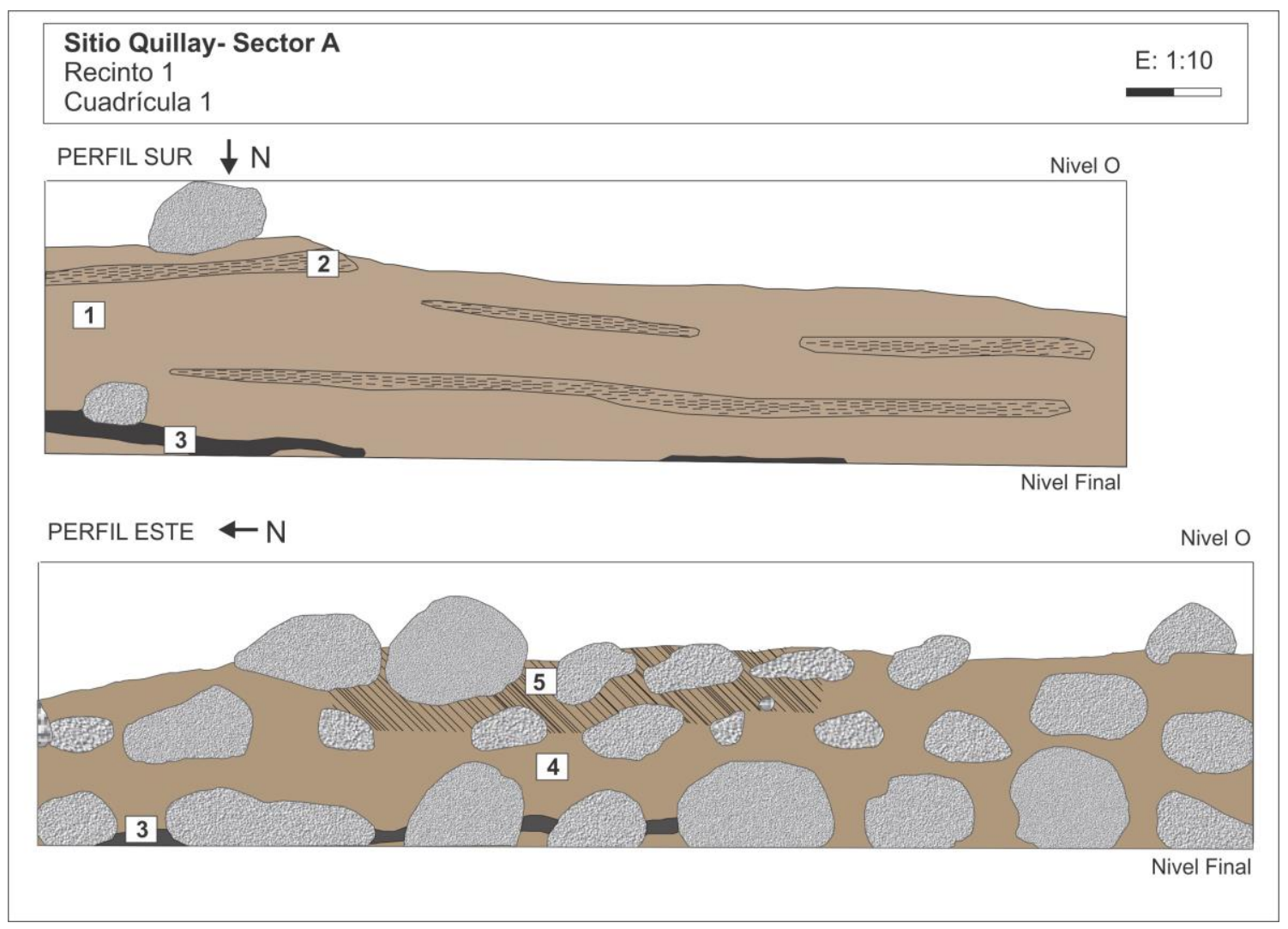

Figura 5.44. Perfiles Sur y Este de la cuadrícula de excavación del Recinto 1. 


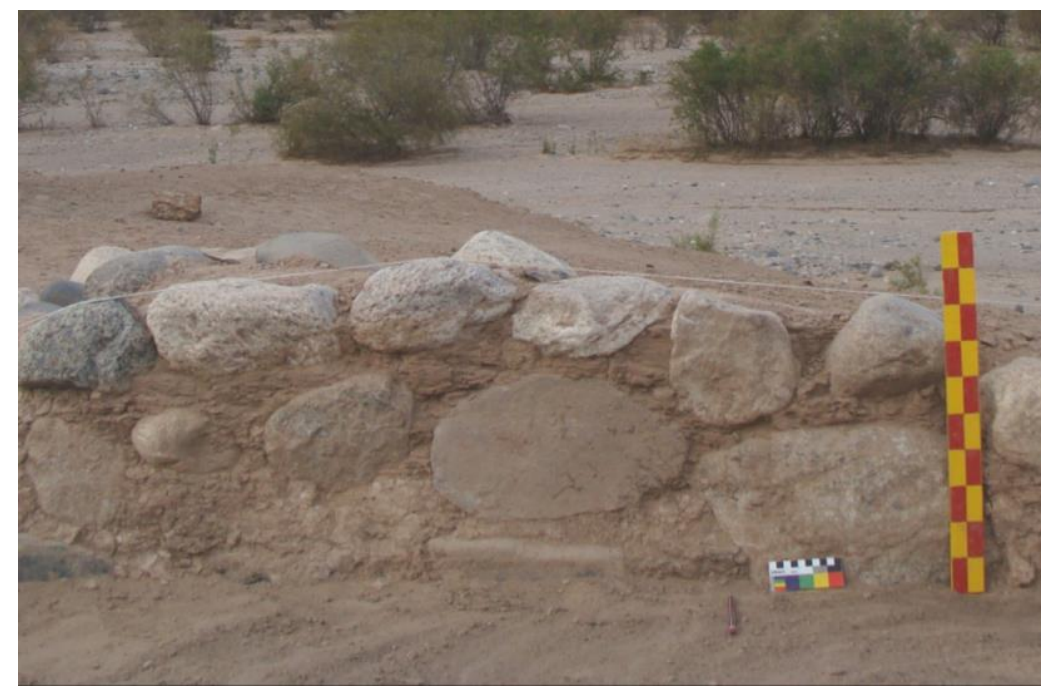

Figura 5.45. Detalles constructivos del muro norte del Recinto 1.

\subsubsection{Recinto 4}

Como se ha comentado al inicio del capítulo, la excavación de este recinto estuvo concentrada en el parte sur del mismo, dado que la hipótesis inicial era que el alineamiento de rocas observado en superficie podría ser una segmentación estructural que delimitaría un espacio pequeño adherido al recinto, denominado anexo ${ }^{5}$. Si bien en superficie se observó una única hilera de rocas enclavadas en el terreno, y no un muro doble - tal como sucedía en las restantes estructuras-, era posible que el muro se hallase destruido. Sin embargo, como se indicará más adelante en el perfil, el alineamiento no presentó continuidad vertical alguna.

Con el objetivo inicial de visualizar mejor este espacio y conocer los materiales asociados al mismo, se delimitó allí una única cuadrícula de 2,20 m (eje N-S) x 1,80 m (eje E-O) y se descendió por niveles artificiales de $10 \mathrm{~cm}$ alcanzando una profundidad de $70 \mathrm{~cm}$. A su vez, en el sector centro sur de la cuadrícula, a partir de la identificación de un rasgo particular, se avanzó un nivel más, alcanzando los $80 \mathrm{~cm}$ de profundidad. Así, se establecieron 8 niveles artificiales:

- Nivel 1: de 0 a $10 \mathrm{~cm}$.

- Nivel 2: de 10 a $20 \mathrm{~cm}$.

\footnotetext{
${ }^{5}$ En publicaciones anteriores a esta excavación, el mapa del sitio fue presentado con esta segmentación como anexo 4b (Spina y Giovannetti 2014).
} 
- Nivel 3: de 20 a $30 \mathrm{~cm}$.

- Nivel 4: de 30 a $40 \mathrm{~cm}$.

- $\quad$ Nivel 5: de 40 a $50 \mathrm{~cm}$.

- Nivel 6: de 50 a $60 \mathrm{~cm}$.

- Nivel 7: de 60 a $70 \mathrm{~cm}$.

- Nivel 8: de 70 a $80 \mathrm{~cm}$.

\subsubsection{Nivel 1 y 2}

Los dos primeros niveles de excavación presentaron un sedimento con rocas de derrumbe con sedimento natural de relleno sin otras evidencias de materiales de origen antrópico (Figura 32 - Anexo IV). Las rocas de derrumbe se distribuían sobre el perfil sur y este de la cuadrícula. Sobre el perfil oeste y a $40 \mathrm{~cm}$ del sur se alojaba parte de una raíz principal de un árbol de algarrobo (Figura 5.46), cuyo crecimiento fue uno de los factores de alteración postdepositacional del recinto, generando el desmoronamiento de muros entre otros efectos.

\subsubsection{Nivel 3}

En este nivel, gran parte de las rocas de derrumbe se mantuvieron hacia el perfil sur de la cuadricula (Figura 5.46). Una vez removidas las rocas alojadas en el extremo NE de la cuadrícula, hacia los $30 \mathrm{~cm}$ de profundidad se registraron seis fragmentos cerámicos que remontaron de a pares dando cuenta de tres tinajas de estilo Belén. Las piezas presentaban diseños de pintura negra sobre engobe rojo con decoración de reticulados, líneas perpendiculares al asa y salpicado de pintura negra en la superficie interior. Los tiestos se alojaron entre las rocas de derrumbe, una de las cuales parecería corresponder a una mano de moler de material granitoide (Figura 5.47).

Por otro lado, hacia el centro-sur de la cuadrícula (cota: $30 \mathrm{~cm}$ ), se recuperaron un conjunto de fragmentos óseos agrupados que corresponden al orden Rodentia (hallazgo 7). Son fragmentos de mandíbulas con incisivos y molares, varias vértebras y distintos huesos del esqueleto apendicular de ambas lateralidades, lo que parecería indicar que pertenecerían a un mismo individuo. Dada la ausencia de marcas de alteración antrópica y el nivel de representación de partes óseas se considera que corresponden a restos postdepositacionales de un roedor originados por muerte natural. 
Además, se identificaron otros especímenes óseos de categorías generales como Mammalia indeterminado y micromamíferos registrados en zaranda (tabla 5.12)

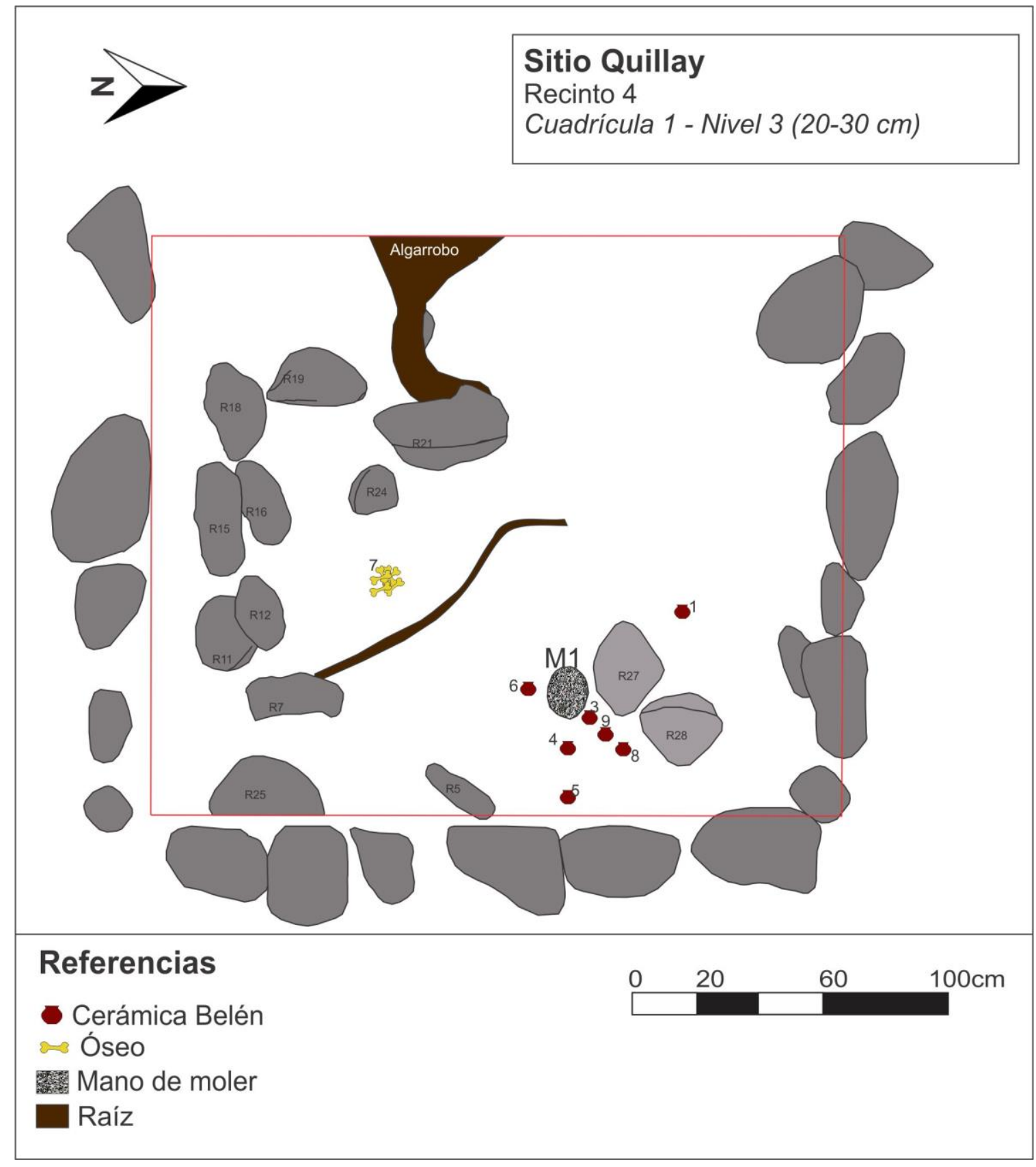

Figura 5.46. Planta del recinto 4, Nivel 3. 


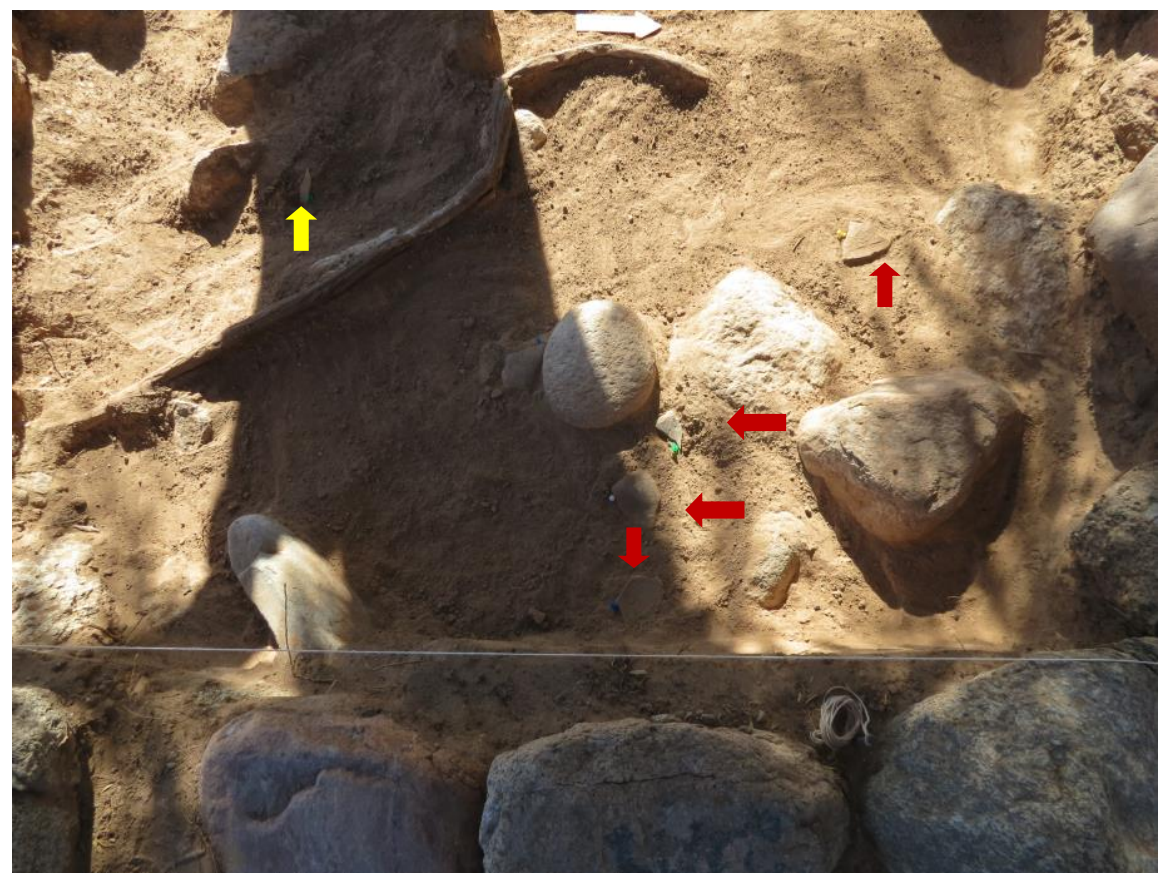

Figura 5.47. Cerámicas Belén (flechas rojas) halladas entre rocas de derrumbe del nivel 3 y restos óseos (flecha amarilla) del recinto 4.

\begin{tabular}{|l|r|r|}
\hline Quillay - NIVEL 3 & NISP & \%NISP \\
\hline Micromamífero indet & 2 & 8,7 \\
\hline Rodentia & 18 & 78,3 \\
\hline Mammalia indet. Grande & 1 & 4,3 \\
\hline Indet & 2 & 8,7 \\
\hline TOTAL & 23 & 100 \\
\hline
\end{tabular}

Tabla 5.12. Taxones faunísticos identificados en el recinto 4 , nivel 3.

\subsubsection{Nivel $4(30-40 \mathrm{~cm})$}

Este nivel presentó la mayor frecuencia de materiales arqueológicos. Aún entre rocas de derrumbe se recuperaron 17 fragmentos cerámicos (Figura 5.48). Luego del remontaje y agrupamiento por familias, se obtuvieron siete piezas cerradas de estilo Belén (tinajas), un tiesto muy erosionado que fue clasificado como posible Belén, una olla tosca utilitaria y una pieza cerrada monocromo rojo de estilo inkaico con inclusiones piroclásticas (Gráfico 5.16). Cabe aclara que la pieza Inkaica estaba compuesta por un grupo de familia compuesta de fragmentos remontados, cuyos segmentos se hallaron en lados opuestos de la cuadrícula e incluso un segmento que 
remontó se halló en el nivel siguiente. Esta situación estaría señalando movimientos y alteraciones posdepositacionales, posiblemente generadas por el crecimiento de raíces. Respecto a las piezas Belén, presentaron diseños de grecas, reticulados y figurativos semejantes a los observados el material superficial. Las superficies externas de los tiestos presentaron carbonato y segmentos picados como evidencia de desplazamiento. Por otro lado, se hallaron dos huesos largos fragmentados de mamíferos grandes con marcas de alteración por raíces e indeterminados.

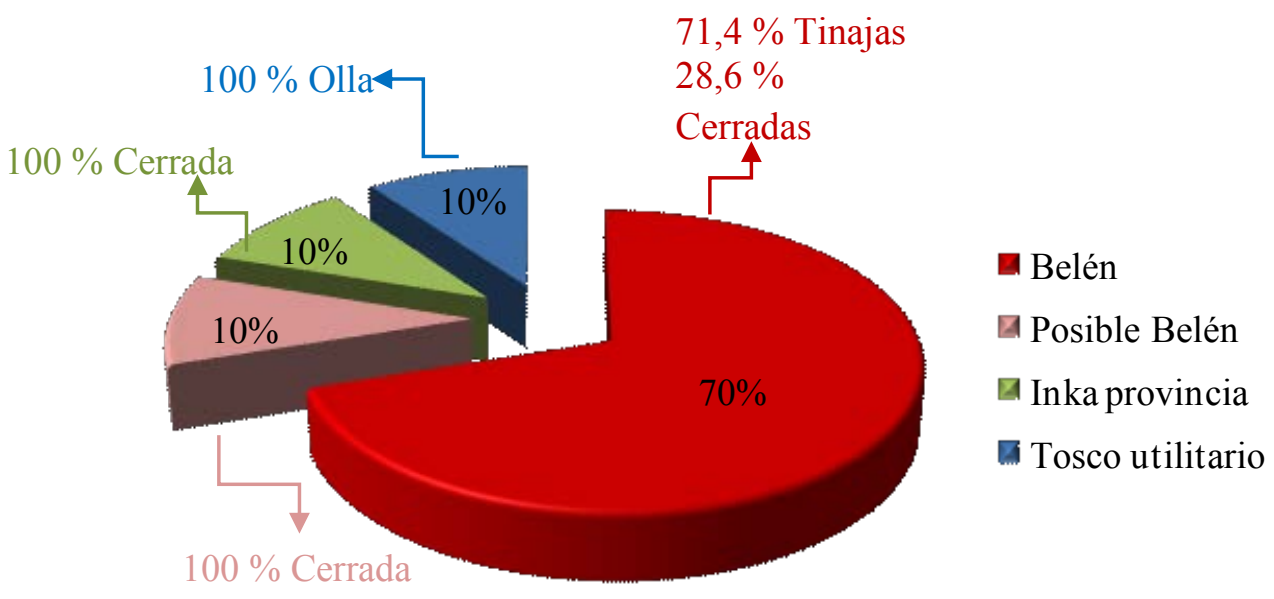

Gráfico 5.16. Frecuencia porcentual de estilos y morfologías cerámicas identificadas en el Nivel 3 del Recinto 4.

\subsubsection{Nivel $5(40-50 \mathrm{~cm})$}

Sobre el perfil sur se identificaron nuevas rocas de derrumbe (Figura 5.45). En el ángulo $\mathrm{NE}$, hacia los $40 \mathrm{~cm}$ pudieron removerse las rocas de este sector y el sedimento natural se presentó suelto y friable. El material cultural recuperado fue escaso, siendo representado por tres fragmentos cerámicos pertenecientes a dos ollas toscas con evidencias de quemado y a una tinaja Belén. También se hallaron 4 especímenes de mamíferos grandes indeterminados junto a varias astillas y minúsculos fragmentos óseos recuperados en zaranda, los cuales por su nivel de fragmentación no pudieron ser identificados taxonómicamente. Por último, se hallaron cuatro fragmentos líticos que por sus características y materias primas parecen corresponder a desprendimientos de las rocas de derrumbe y no a materiales de origen antrópico por lo cual no se profundizará en estos materiales. 


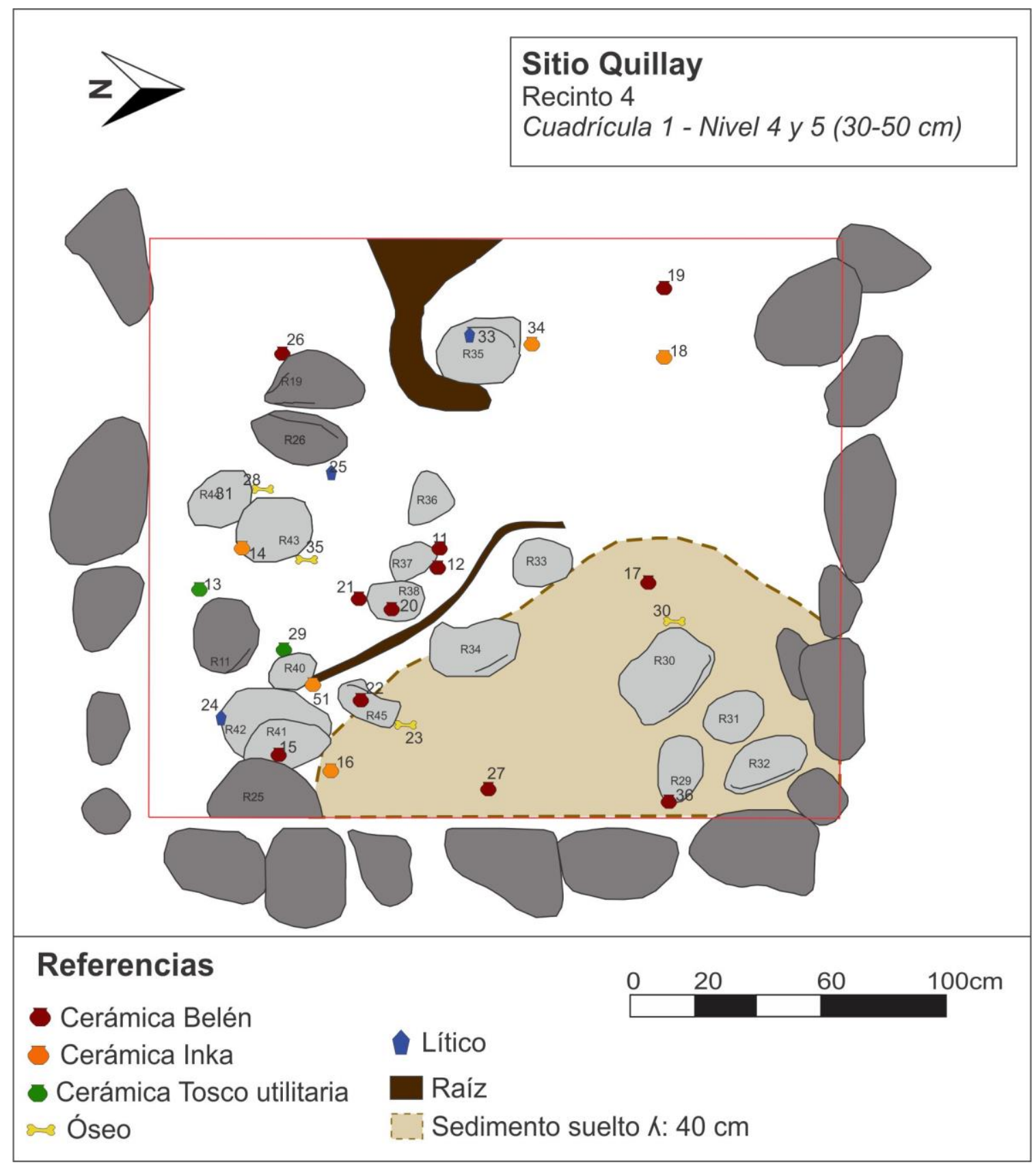

Figura 5.48. Planta del recinto 4, niveles 4 y 5.

\subsubsection{Nivel 6}

Hacia el perfil centro-oeste quedaron expuestas varias de las raíces del árbol de algarrobo y comenzaron a delimitarse nuevas rocas de derrumbe sobre el muro $\mathrm{O}$. Incluso otra raíz atravesó la cuadrícula en sentido E-O hacia el sector N. Los hallazgos se concentraron hacia el extremo NO y consistieron en fragmentos cerámicos junto a restos óseos y botánicos. Se recuperaron sobre un lente de cenizas con bajo contenido 
leñoso, de $1 \mathrm{~cm}$ de potencia, que se desplegó por todo el perfil $\mathrm{N}$ de la cuadrícula y hasta el centro de la misma (Figura 5.49).

Los tiestos cerámicos $\left(\mathrm{N}_{\text {fragm }}=10\right)$ pertenecen a segmentos de seis ollas Toscas utilitarias, a una tinaja Belén con pintura negra sobre engobe rojo y a un fragmento pequeño de estilo Inkaico (Gráfico 5.17; Figura 5.50 y Figura 5.51). Este último presenta una superficie externa pulida con pintura negra y un blanco intenso y espeso sobre un engobe rojo. Representa, posiblemente, un segmento del aplique realizado a los bordes de platos (Figura 5.50). Las piezas toscas presentaron superficies alisadas y pastas oxidantes con inclusiones minerales de gran tamaño. Representan ollas de espesores medios $(0,6 \mathrm{~cm})$ y gruesos $(>0,8 \mathrm{~cm})$ y dos de ellas presentaron evidencias de exposición al fuego en su superficie externa (hollín y quemado).

Los restos arqueofaunísticos identificados en este nivel fueron cinco especímenes óseos de mamíferos indeterminados, un artiodactyla y dos indeterminados. En cuanto a las evidencias botánicas halladas $(\mathrm{N}=63)$, los restos consistieron principalmente en carporestos (semillas, endocarpos y vainas) de algarrobo (Prosopis sp.) (48 \%) en su mayoría en estado carbonizado; granos de maíz (Zea Mays) carbonizados (19\%), un $6 \%$ de semillas de chañar (Geoffroea decorticans) y con frecuencias del $2 \%$ restos de ají (Capsicum annuum), zapallo (Cucurbita sp.) y un posible poroto (Phaseolus sp.) (Gráfico 5.18 y Figura 5.52). El $22 \%$ restante no ha podido ser identificado taxonómicamente. Estos restos fueron recuperados producto del tamizado del lente de cenizas previamente comentado, a una profundidad de entre $53 \mathrm{y}$ $60 \mathrm{~cm}$ junto a pequeños fragmentos de leños. 


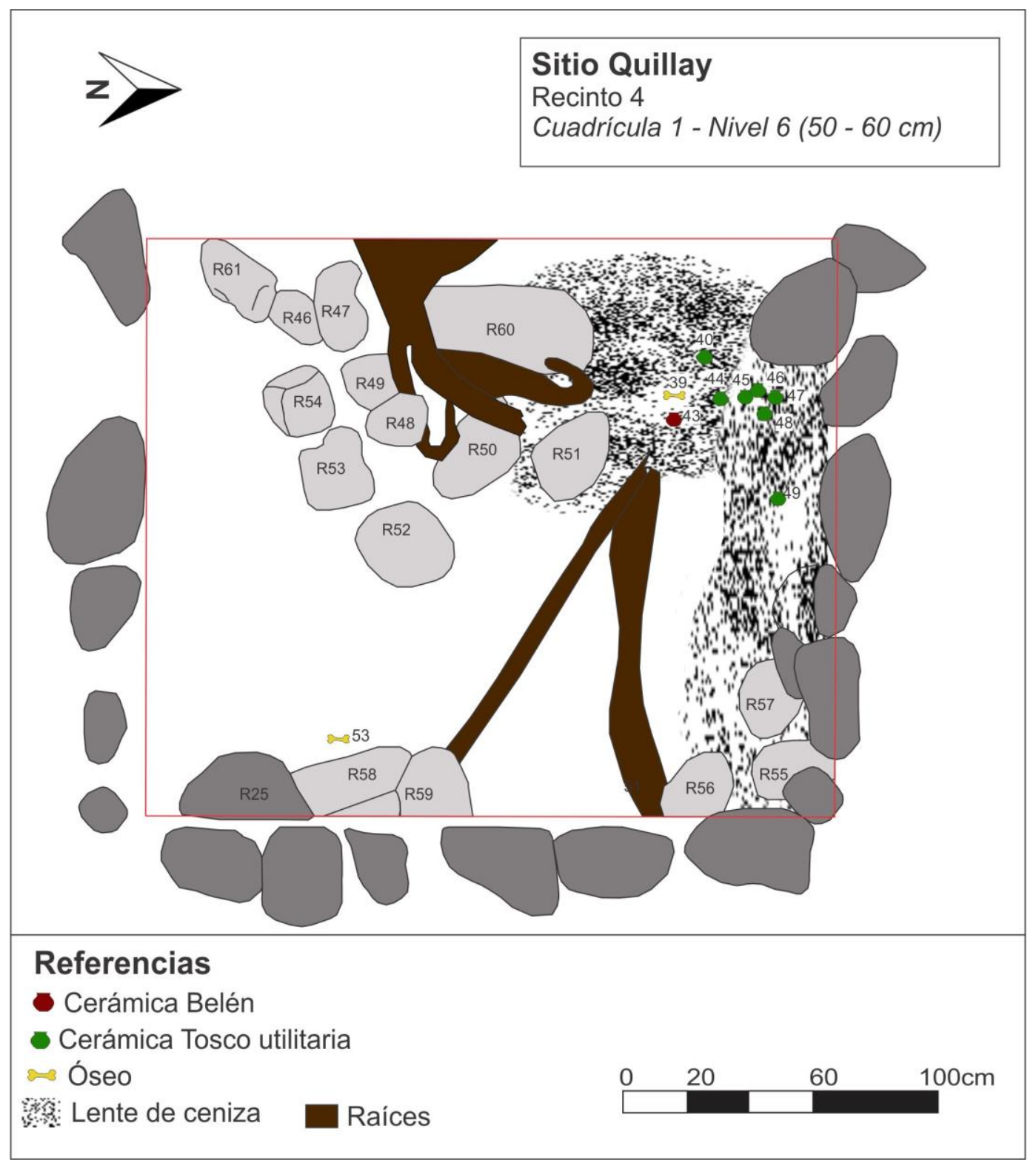

Figura 5.49. Planta del recinto 4, nivel 6.

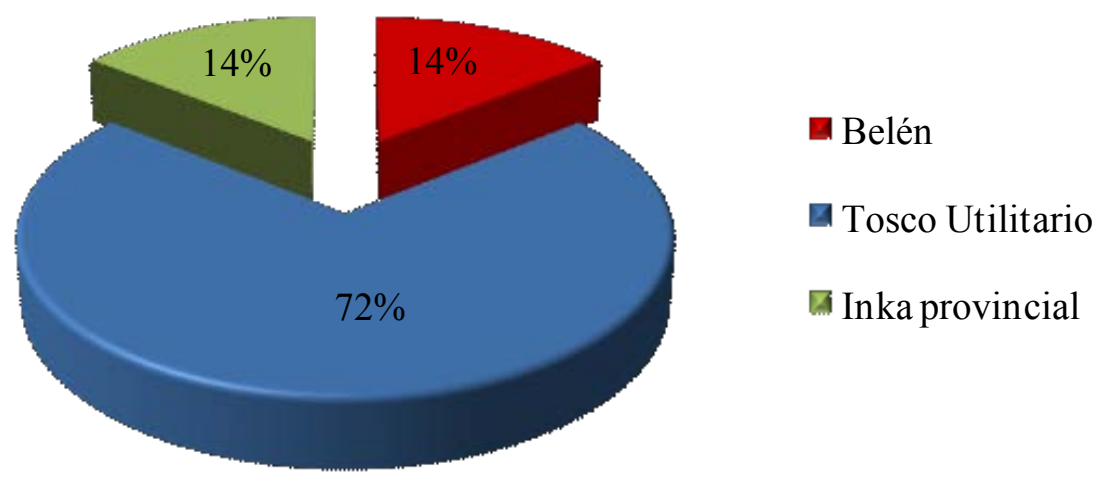

Gráfico 5.17. Frecuencia porcentual de estilos cerámicos identificados en el Nivel 6 del Recinto 4. 

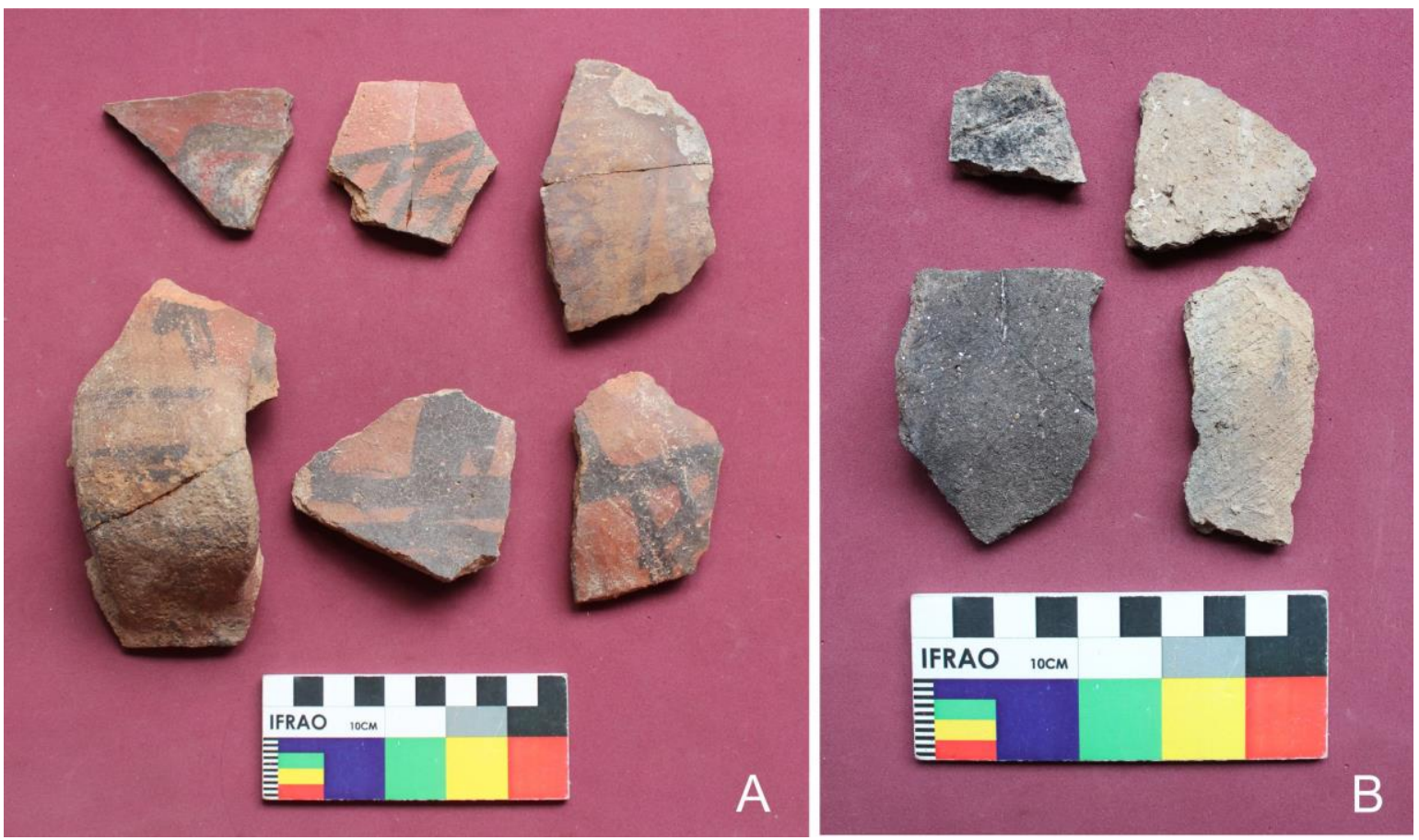

Figura 5.50. Cerámica del recinto 4. A. Estilo Belén. B. Tosco Utilitario
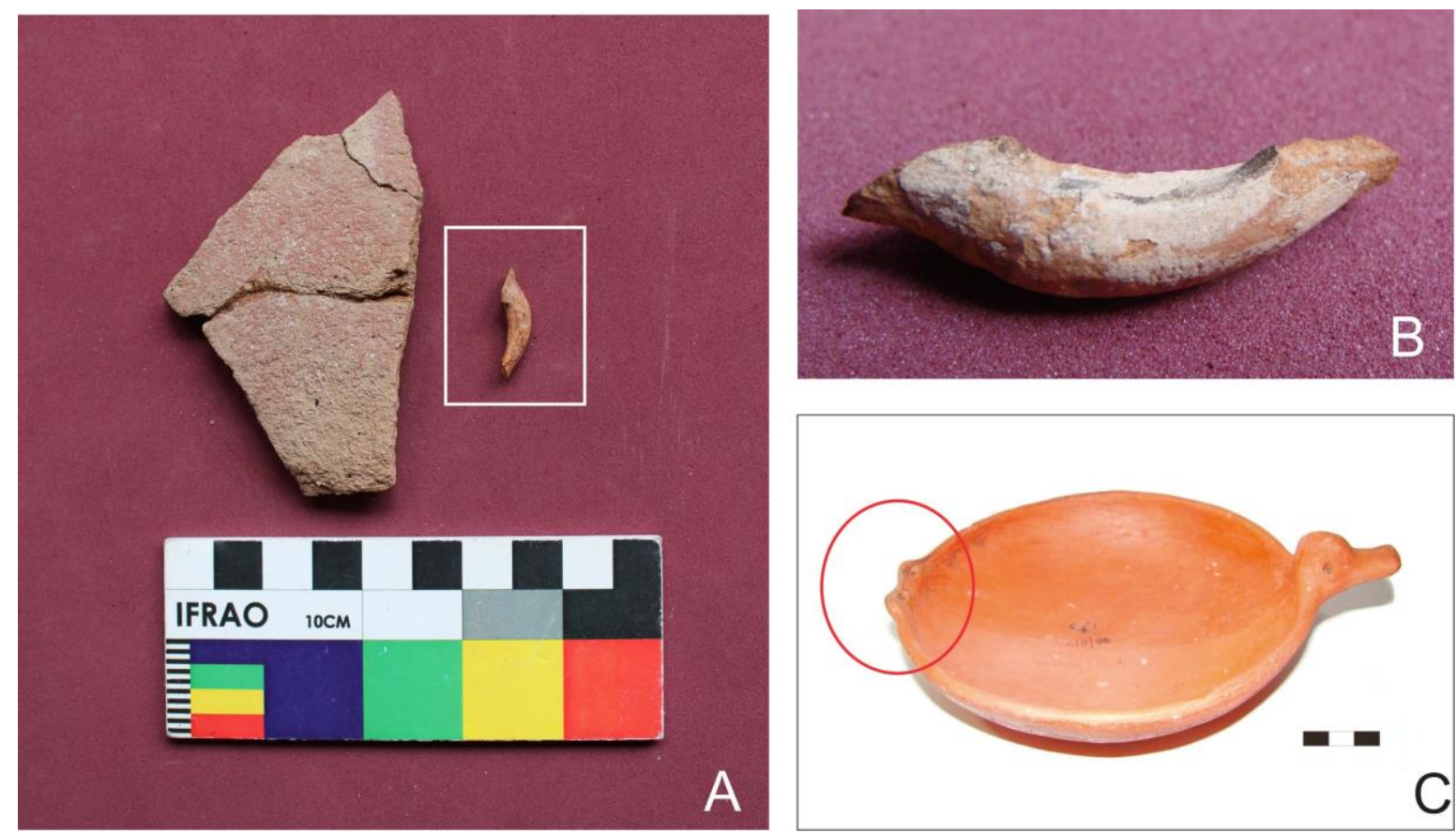

Figura 5.51. A. Fragmentos Inkas del recinto 4: monocromo rojo erosionado y apéndice de plato B. Detalle del apéndice de la foto A. C. Plato ornitomorfo con apéndices estilo Inca YaviChicha (MEJBA 3373), foto tomada de Otero 2015: 10. 


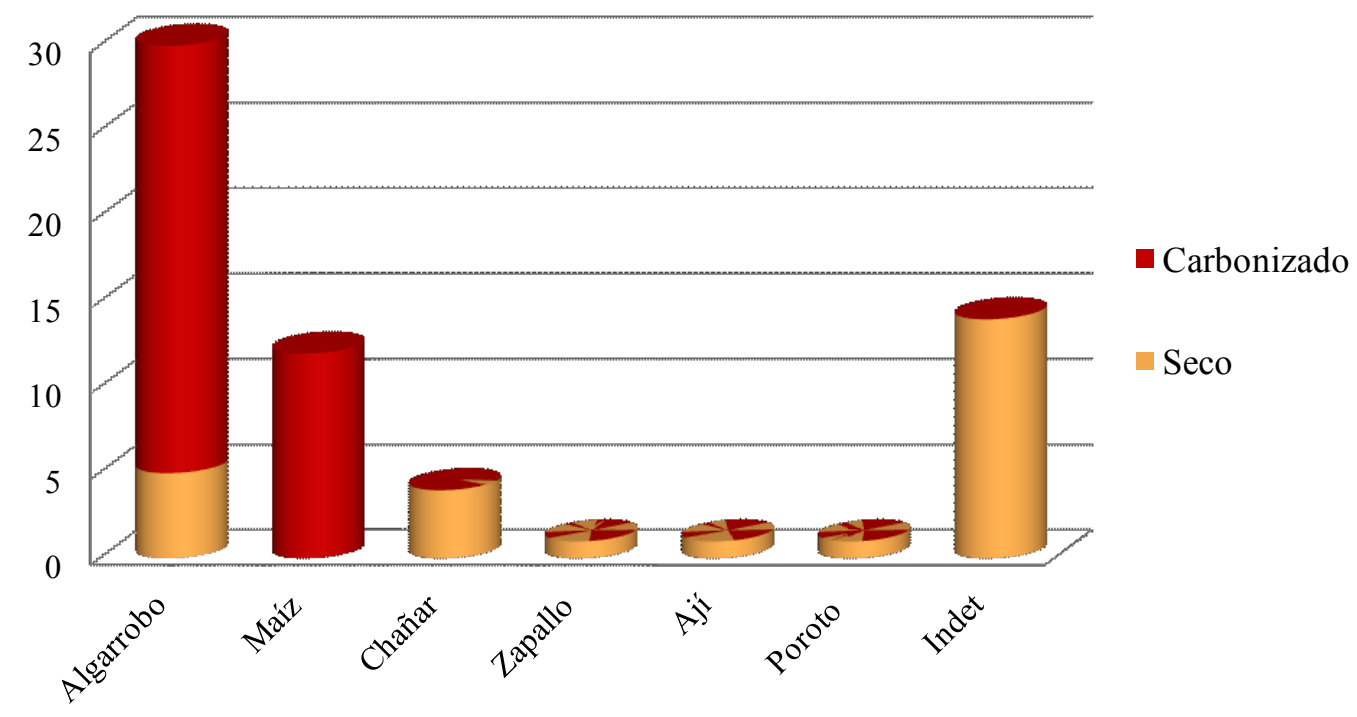

Gráfico 5.18. Frecuencia numérica y estado de los taxones vegetales identificados en el recinto 4.

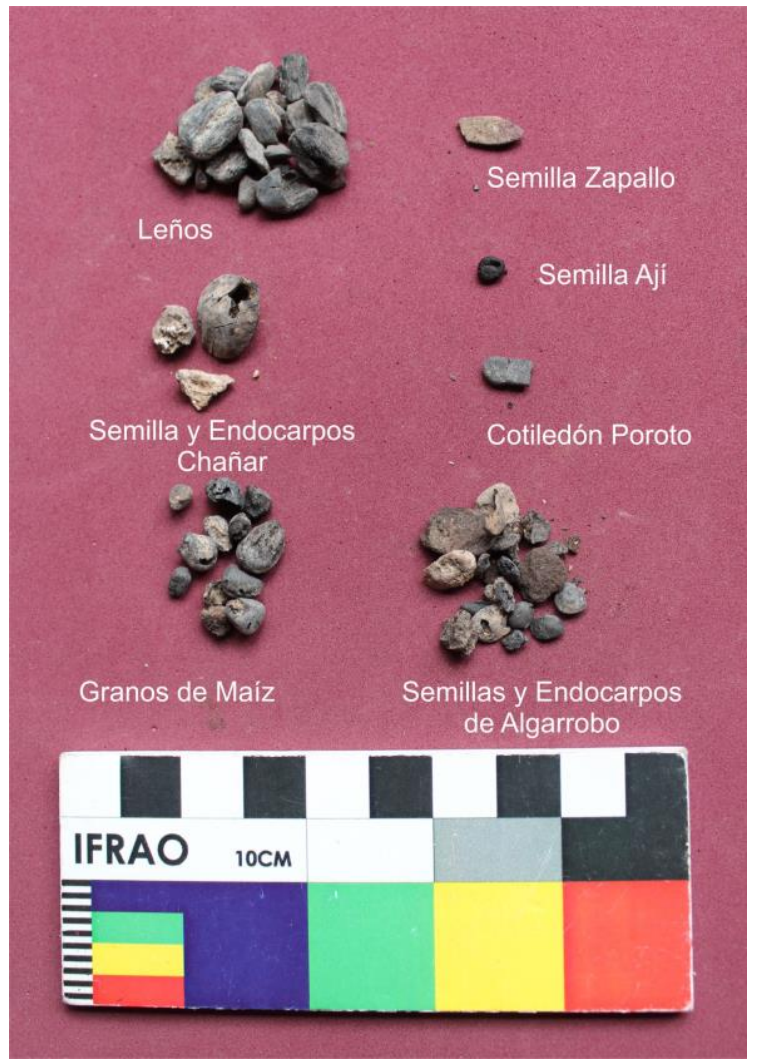

Figura 5.52. Fotografía de los restos botánicos registrados en el Recinto 4. 


\subsubsection{Nivel 7}

Hacia el sur de la raíz, se demarcó un segmento compacto y alargado de arcilla cocida de coloración rojiza de $6 \mathrm{~cm}$ de espesor y con laterales quemados (Figura $5.53 \mathrm{y}$ Figura 5.54, figura 34 en Anexo IV). Este rasgo parecía delimitar hacia el sur un sector con sedimento ceniciento, minúsculos fragmentos de carbón y números escorias de combustión de pequeñas dimensiones. Por otro lado, hacia el $\mathrm{N}$ de la cuadrícula el sedimento natural se presentó compacto y fue culturalmente estéril, indicando un posible piso de ocupación (Figura 5.54).

\subsubsection{Nivel 8}

Este último nivel fue alcanzado sólo en el espacio hacia el sur del segmento de arcilla cocida (Figura 5.55). El sedimento inmediato al mismo se compactó y adquirió una coloración gris-blancuzca posiblemente producto de la termoalteración y segmentación de la calcita del sedimento. Hacia el $\mathrm{O}$, entre las raíces de árbol de algarrobo, se visualizó un tronco quemado atrapado por las raíces - razón por la cual fue imposible extraerlo - y dos fragmentos cerámicos: un segmento de una pieza abierta de posible asignación Belén y un tosco utilitario, sin evidencias de exposición al fuego. 


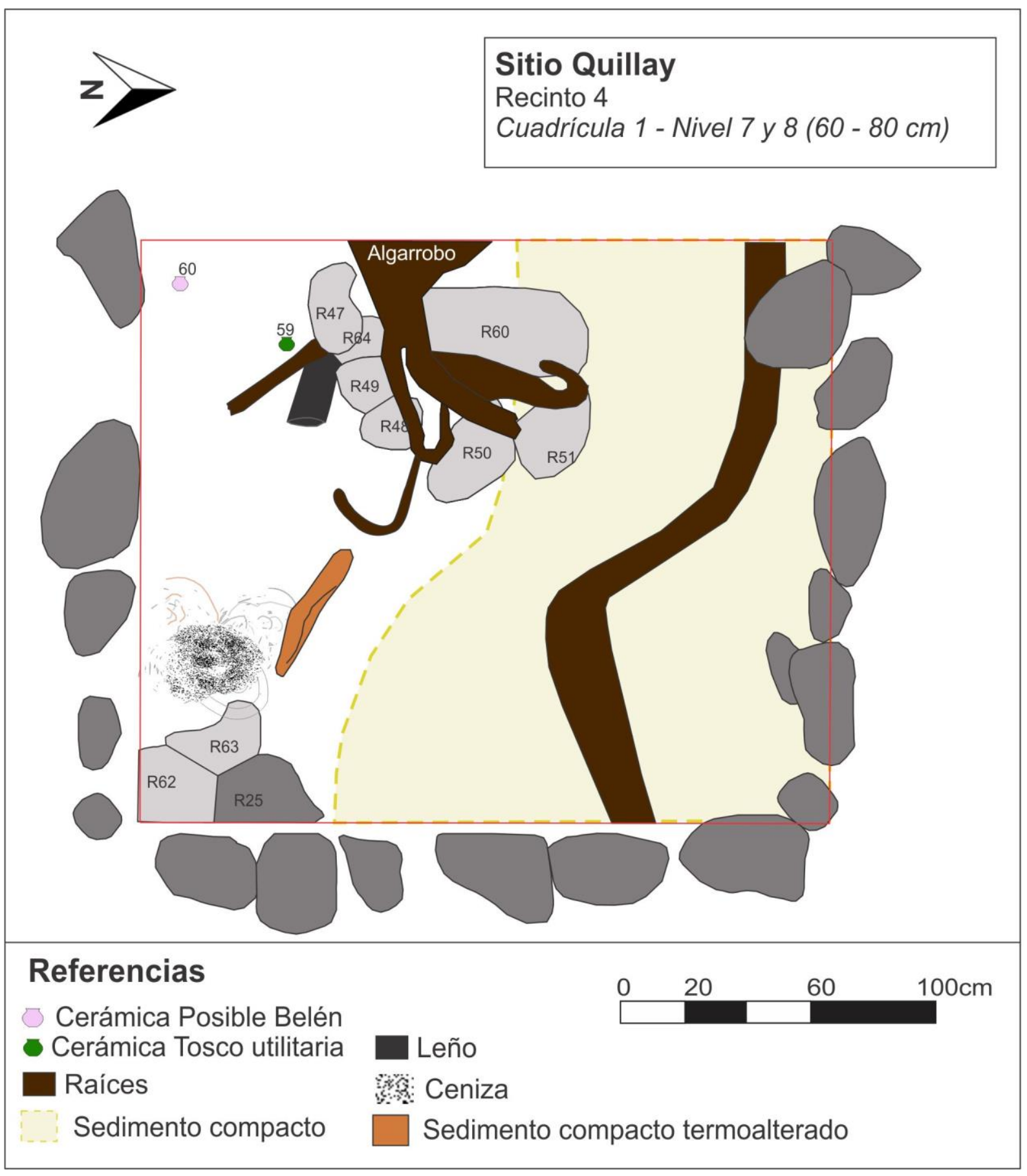

Figura 5.53. Planta del recinto 4, niveles 7 y 8. 


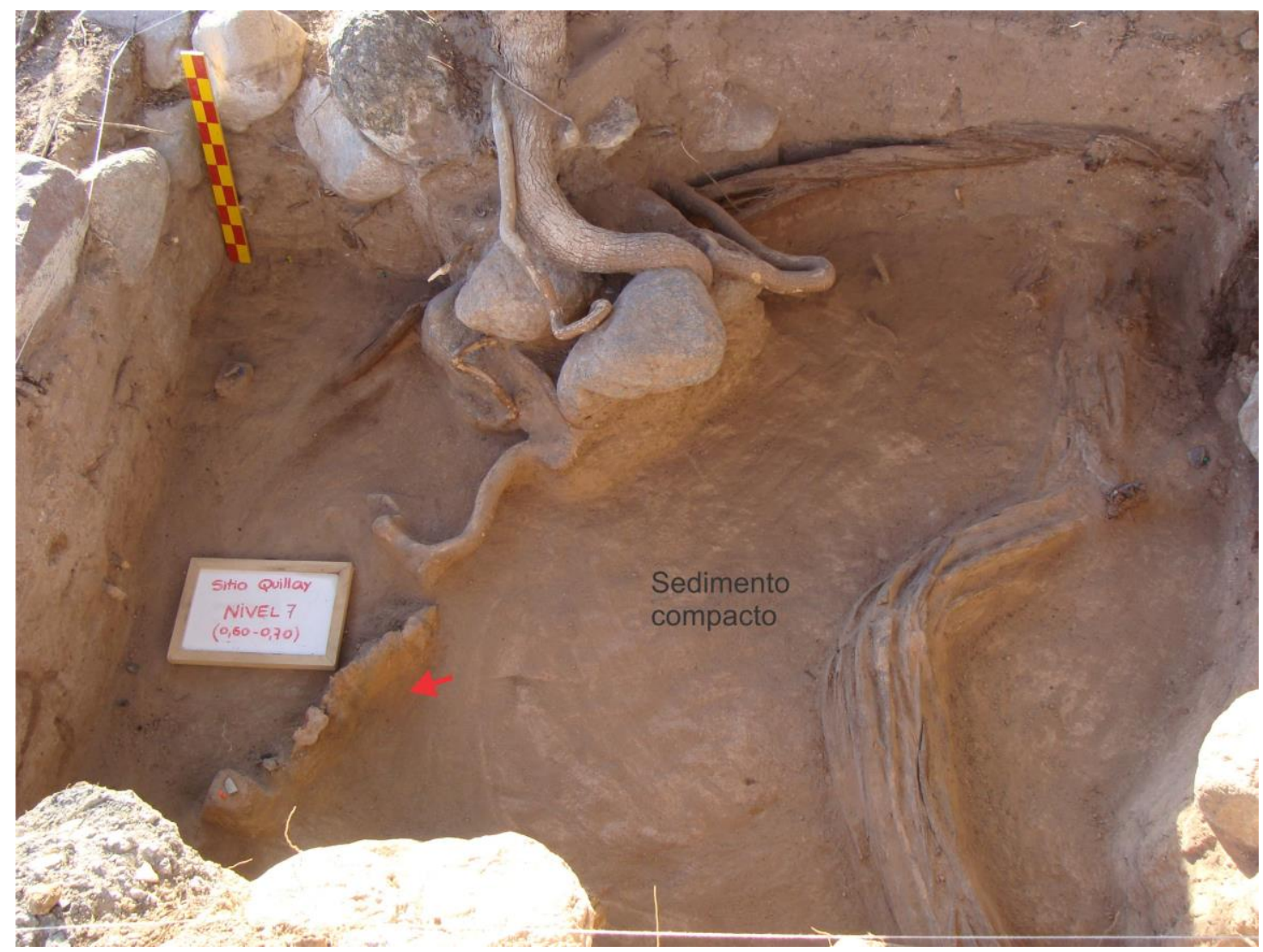

Figura 5.54. Planta del recinto 4, nivel 7. La flecha señala el segmento de arcilla cocida.

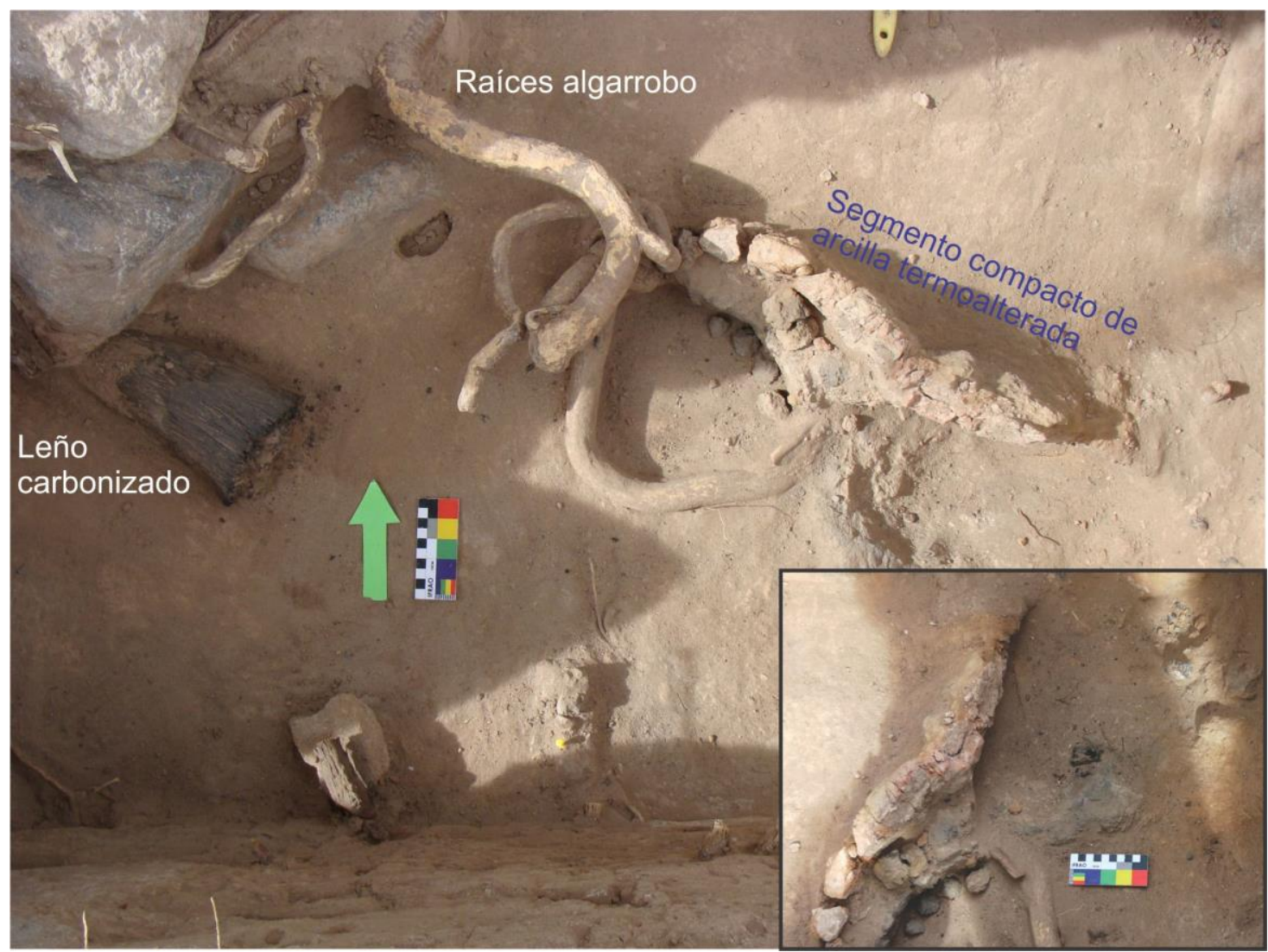

Figura 5.55. Planta del recinto 4, nivel 8. Se observa el leño; el segmento de arcilla cocida y el sedimento termoalterado con cenizas hacia el sur (ampliados en el recuadro). 


\subsubsection{Perfiles del Recinto 4}

En concordancia con lo observado en el otro recinto y en la sedimentología natural del sitio, aquí también el perfil del suelo observado es uniforme. Se han levantado los perfiles norte (Figura 5.56) y este (ver figura 34- Anexo IV) de la cuadrícula, los cuales no presentaron diferencias significativas entre sí. Siguiendo la Figura 5.56, podemos ver que se observó un sedimento arenoso suelto de color castaño (estrato 1). A partir de los $10 \mathrm{~cm}$ de profundidad, este sedimento comienza a ser rico en carbonato de calcio, concentrándose en los alrededores de las rocas (estrato 2). Entre las rocas de derrumbe hacia el NE, el sedimento se presentó suelto y friable (estrato 3) producto del impacto producido por el desmoronamiento del muro. Allí, fueron reconocidos fragmentos de piezas cerámicas, varias de las cuales remontaron entre sí, tal como fue presentado en los niveles 3 y 4 . El estrato 4, exhibe un sedimento que comienza a compactarse y endurecerse. El estrato 5 señala la zona en la cual el sedimento presentó una textura muy compacta pero laminar, que se distribuye entre las capas de ceniza (estrato 6).

Por otro lado, hemos seleccionado este perfil, por ser el sector donde se observó el alineamiento de rocas en superficie que fuera inicialmente propuesto como una segmentación del recinto mayor que delimitaría un anexo. Sin embargo, como puede observarse en la imagen, la hilera de rocas observada en superficie no presenta continuidad en sentido vertical como para sostener dicha segmentación. Es más probable que estas rocas formen parte del derrumbe de los muros laterales y que el alineamiento horizontal observado en superficie se deba a modificaciones culturales relativamente actuales, como pudo observarse en otros sectores por fuera de los recintos. 


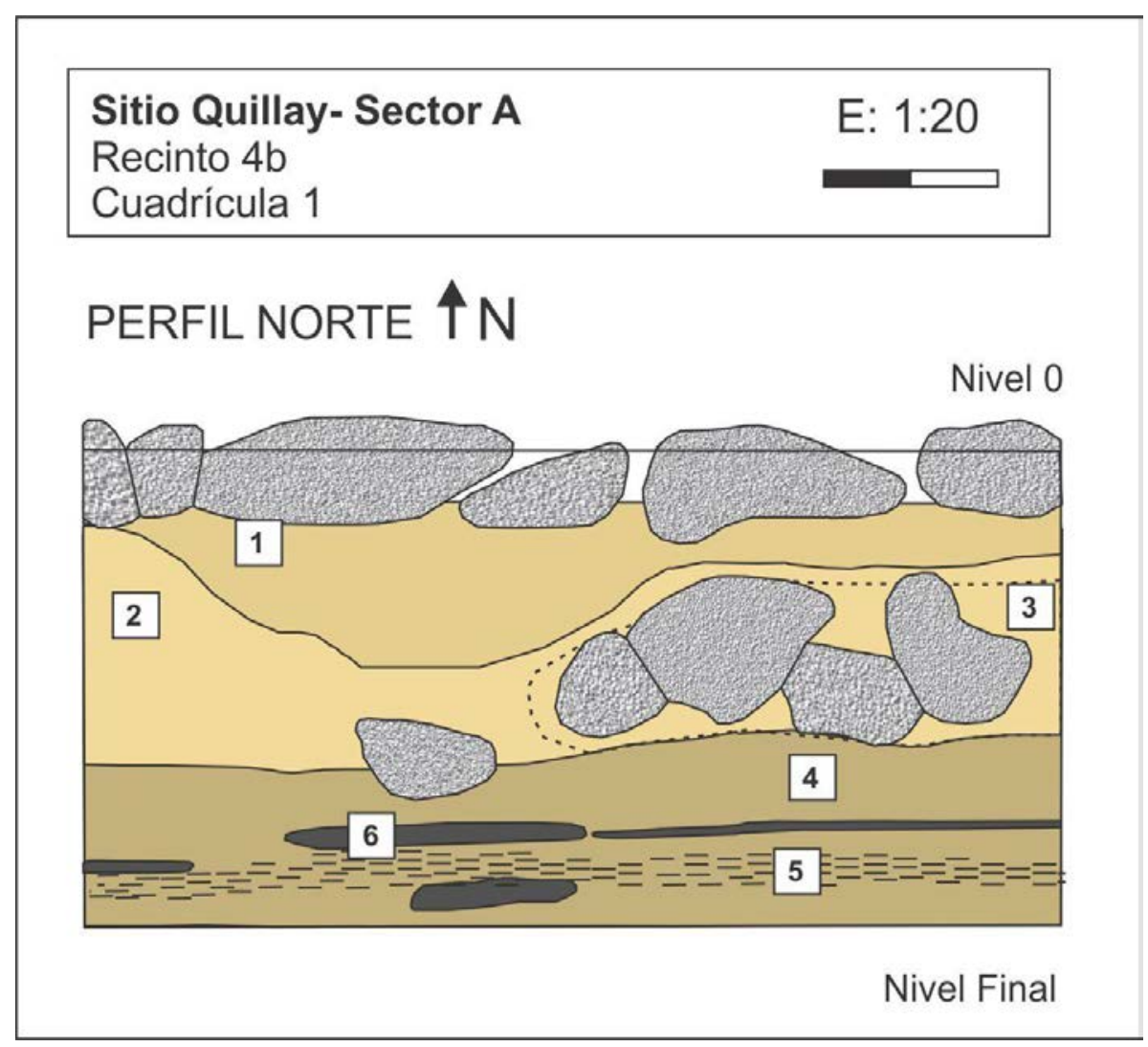

Figura 5.56. Perfil norte de la cuadrícula de excavación del recinto 4.

\subsubsection{Integración y discusión de resultados obtenidos en los recintos}

En las excavaciones de los recintos del sector $A$ se han recuperado diversos materiales y contextos arqueológicos cuya integración y contrastación permite interpretar algunas prácticas sociales efectuadas en estos espacios. Asimismo, respecto al diseño arquitectónico de los recintos, en el capítulo precedente se comentó sobre las modalidades arquitectónicas y el patrón de asentamiento con una disposición de tipo lineal íntimamente asociado a los puntos cardinales. En este capítulo, presentamos los resultados obtenidos de la excavación de tres recintos R1, R3 (excavado por González) y R4, los cuales poseen plantas arquitectónicas disímiles: el primero es cuadrangular, el segundo circular y el último rectangular. De esta forma, se ha podido corroborar- al menos para los dos excavados durante nuestros trabajos de campo- que presentan patrones de construcción similares basados en la utilización de muros dobles construidos con rodados graníticos de materiales locales unidos con mortero de barro. Si bien no se han registrado los clásicos muros canteados para sitios inkaicos (ver Raffino 1981, 2004), es significativo que la técnica constructiva y las materias primas 
empleadas en Quillay se asemejen a aquellas utilizadas en otros sitios estatales del valle como Hualfín Inka (Lynch 2013) ubicado unos $26 \mathrm{~km}$ al norte del sitio. Por otro lado, la estratigrafía del R4 refutó la hipótesis sobre la existencia de un muro de segmentación interno dentro de esta unidad arquitectónica, que fuera inicialmente propuesta como un anexo en el momento que se realizó el levantamiento planimétrico del sitio.

Finalmente, en el capítulo anterior se ha hecho referencia a la construcción de recintos sobre montículos artificiales. Esta situación podría explicar la presencia de los fragmentos tempranos de estilo Aguada registrados en las excavaciones como producto de la remoción de tierra de otros sectores, su posterior transporte y adición para elevar el terreno y construir las estructuras habitacionales de este sector.

Respecto a las evidencias materiales, los hallazgos de los tres recintos corresponden mayoritariamente a tiestos cerámicos, restos óseos y botánicos. Sin embargo, el R1 fue la estructura que presentó mayor cantidad de estos materiales por unidad de superficie. Además, se identificaron otras ergologías como restos líticos y malacológicos, así como asociaciones contextuales mejor definidas. A continuación, se realizarán algunas reflexiones finales con relación a las evidencias registradas en cada recinto.

- $\quad$ Recinto 1: esta estructura presentó un conjunto de materiales y contextos que aportan varias líneas de evidencias que permiten recuperar prácticas sociales concretas referidas a actividades comunales de preparación y cocción de alimentos. En primer lugar, se sistematizan los indicios arqueológicos previamente presentados que nos remiten a prácticas culinarias para luego examinar con mayor detenimiento las distintas evidencias enumeradas. De esta manera, la información general obtenida del recinto subraya:

Una alta frecuencia de vestigios de tipo alimenticos. Entre ellos prevalecen los macro restos botánicos de especies silvestres y en menor grado las domesticadas. Siendo en el primer caso abundantes los restos de algarroba molida. Además, se encontraron restos faunísticos con marcas de utilización antrópica.

Presencia de instrumentos de molienda: yunque, mortero y manos de moler de materiales granitoideos. 
Espacios de combustión en sectores definidos y asociados a vestigios alimenticios.

Predominio de vasijas de tipo cerradas que sirven como contenedores de alimentos y líquidos.

Respecto a los vestigios alimenticios, el $80 \%$ de los macro restos botánicos corresponden a frutos de recolección (principalmente de algarroba y chañar), el 15\% son cultivos agrícolas (maíz, zapallo, poroto) y el 5\% restante son frutos que no han podido ser determinados. Los vestigios de algarrobo (Prosopis sp.) pertenecen a diversas estructuras botánicas de su fruto: $6 \%$ de vainas, $87 \%$ de endocarpos y $7 \%$ de semillas, estando una alta fracción en estado carbonizado (32\%).

Las partes del fruto de Prosopis sp. representadas en el R1, suelen estar asociadas a procesos de molienda de la algarroba para la producción de dos clases de alimentos frecuentes en las dietas de las poblaciones del NOA. Por un lado, un pan realizado con la harina de la vaina denominado "patay", por el otro, una serie de bebidas dulces como la "añapa" y el "arrope", o bien una bebida alcohólica llamada "aloja" lograda a partir de la fermentación de las primeras (Babot 1999; Biurrum et al. 2007; Capparelli 2007, 2008). Según las observaciones etnográficas realizadas por Capparelli (2007) en el valle de Hualfín, la molienda de la harina para la producción de alimentos como el patay y la añapa puede generar residuos constituidos por partes de endocarpos y semillas del fruto. ${ }^{6}$ Estos macro restos botánicos desechados podrían constituir parte del registro arqueológico, tal lo observado en el R1. Incluso se han reconocido espacios discretos en el recinto con acumulaciones de fragmentos secos de algarroba triturada (sector $\mathrm{N}$ y NO). Como hemos señalado, en uno de los sectores estaba asociada inmediatamente a una huella semicircular que podría corresponder a la marca de la base de una vasija semienterrada, la cual podría haber contenido la algarroba recolectada. Dado este hallazgo y la alta frecuencia de segmentos de tinajas y ollas que sirven como contenedores, es probable que se hayan utilizado grandes vasijas cerámicas para el almacenamiento de la algarroba recolectada. Así como también para las etapas de remojo y cocción durante la producción del alimento.

\footnotetext{
6 Para poder diferenciar entre uno u otro producto alimenticio sería necesario realizar estudios pormenorizados sobre la morfometría de estos desechos (Capparelli 2008)
} 
Por otro lado, en vinculación con estos vestigios triturados de algarroba se han identificado en el recinto varios de los implementos útiles para la molienda. De estos últimos, se destacan las cuatro manos de moler con marcas de uso y el mortero cupuliforme actualmente fragmentado. En este punto, hay que considerar que es posible que otros morteros móviles hayan estado disponibles, dado que los lugareños poseen un amplio repertorio de estos instrumentos que, según han indicado, fueron recuperados del sector de recintos para su uso en la actualidad (ver capítulo 4).

Por otro lado, también en el recinto se han recuperado otros frutos de recolección. Por ejemplo, el chañar presentó una buena representación (12\%) siendo reconocidas semillas y endocarpos fragmentados en estado seco. En menor frecuencia $(<1 \%)$ se recuperaron semillas de especies de tuna y mistol. Los estudios etnográficos siguieren que estos frutos también han participado de la alimentación cotidiana de los pobladores del NOA. En general suelen ser consumidos frescos, como podría ser el caso del fruto de la tuna y el mistol, o empleados para la producción de harinas, bebidas o bien como ingredientes de los guisos y demás recetas (Babot 1999; Figueroa y Dantas 2006; Biurrun et al. 2007;). Respecto a los cultivos agrícolas también han participado en estas recetas, aunque tuvieron una menor representación dentro del conjunto identificado en este recinto. En suma, se reconocieron fragmentos de marlos y granos de maíz (9 \%), también semillas de zapallo $(6 \%)$ y en menor frecuencia $(<1 \%)$ semillas de ají y cotiledones de poroto. Los productos cultivados, debieron ser necesariamente abastecidos desde otras regiones, dado la ausencia en el sitio de estructuras de producción agrícola.

Por último, se ha comentado la identificación de unas pocas semillas de frutas de procedencia europea: dos carozos de durazno y uno de ciruela. Estos hallazgos son llamativos dado que no están acompañados de ningún otro indicio de contacto hispanoindígena a nivel intrasitio. En este sentido, es probable que su presencia se deba a alteraciones postdepositacionales más recientes. En el campo se ha observado como práctica habitual de los pobladores actuales, el acto de desechar carozos de fruta fresca en el momento de consumo, transformándose así en objeto de movimientos activados por agentes naturales. 
Otro tipo de vestigio alimenticio identificados son los restos faunísticos. Si bien presentaron un estado altamente fragmentado, el $40 \%$ del conjunto pudo ser identificado taxonómicamente. En su mayoría corresponden a partes óseas de mamíferos grandes, siendo algunos restos reconocidos como partes del esqueleto apendicular de camélidos. El segundo lugar, lo ocupan las placas óseas del caparazón de armadillos como el piche llorón y diversas partes del esqueleto de reptiles y roedores pequeños. Respecto a estos últimos, es difícil distinguir si corresponden a restos naturales o a vestigios de consumo humano. Esto se debe a que no fueron reconocidos indicadores que permitiesen diferenciar entre una u otra acción como podría ser el reconocimiento de cuevas durante la excavación o la identificación de marcas antrópicas en dichos restos.

Los restantes especímenes sí poseen marcas de alteración cultural que señalan el procesamiento de estos animales. Entre ellas prevalecen las evidencias de exposición al fuego, las huellas de corte y las marcas de percusión. Estas últimas principalmente aparecen en restos del esqueleto apendicular de mamíferos grandes. El alto índice de fragmentación y de astillas del conjunto óseo, estaría señalando instancias de procesamiento como troceado y descarne dentro de este contexto de prácticas culinarias. Pero también este nivel de alteración no posibilita reconocer si allí mismo eran consumidos estos restos o si sólo se realizarían acciones de preparación de alimentos, descarte de desechos y posterior limpieza.

Al hablar de marcas de procesamiento, surge la pregunta sobre cuáles serían los instrumentos empleados para dichas acciones. En este sentido, es posible que se hayan utilizado algunos de los fragmentos líticos detectados en el recinto. Si bien se ha dado cuenta de la baja representación de estos materiales, alguno de ellos podría haber cumplido alguna función durante la preparación de alimentos. El yunque podría haber sido utilizado como elemento pasivo para el troceado y las lascas de descortezamiento de basalto y andesita presentaron filos naturales aptos para el procesamiento cárnico.

Las vasijas cerámicas recuperadas indican un fuerte predominio de formas cerradas que podrían haber servido como contenedores. Como hemos demostrado abundan los fragmentos de tinajas Belén posiblemente empleadas para el almacenaje de frutos y líquidos, así como para el remojo de la harina de la algarroba tal como fue observado en los estudios etnográficos realizados en el mismo valle (Capparelli 2007). 
Por otro lado, numerosas ollas toscas presentan evidencias de exposición al fuego indicando su uso en actividades de cocción de alimentos.

Finalmente, se han observado estructuras de combustión no formatizadas. Sin embargo, el fogón 1 presenta una extensión y profundidad bien delimitada con algunas rocas en su perímetro con evidencias de termoalteración. El sedimento interior presentó cenizas, leños carbonizados, restos faunísticos quemados, unos pocos fragmentos cerámicos y en zaranda se recuperaron abundantes restos botánicos. Asimismo, se ha hecho referencia al hallazgo de una roca plana, ubicada hacia un lateral del fogón, que podría haber servido como soporte de vasijas empleadas durante la cocción de alimentos. Los restantes focos de combustión hallados en el último nivel, son cuerpos lenticulares de cenizas y fragmentos de leños carbonizados, en algunos casos con vestigios vegetales.

En este momento, es importante recuperar lo expuesto con anterioridad respecto a los perfiles A-A' y B-B'. Del análisis de la distribución y profundidad de las estructuras de combustión y los pequeños hiatus sedimentarios observados entre ellos, se puede inferir cambios en el uso del espacio. Al relacionar estos datos con los registros materiales y sus asociaciones contextuales previamente presentadas, se pueden proponer al menos dos momentos de ocupación del recinto donde las actividades culinarias sucedieron a diferentes intensidades. Para ilustrar esto será preciso ordenar las evidencias que sustentan esta hipótesis.

Avanzando en este razonamiento, se plantea un primer momento de actividad coincidente con el nivel 6 (remitimos a la Figura 5.30). El mismo está marcado por varios focos de combustión distribuidos en varios puntos, en especial hacia los extremos del recinto. Sin embargo, esto no significa que hayan sido utilizados simultáneamente. Aquí, fueron muy abundantes los restos alimenticios de origen vegetal y animal. Respecto a los primeros, gran parte de los vestigios se distribuyen en dos sectores discretos con algarroba molida. Por otro lado, sobre la esquina NE en los alrededores del yunque, se concentraron otros restos botánicos con predominio de zapallo, maíz, chañar y fragmentos faunísticos. Estos últimos presentan en general una distribución irregular y diversas marcas de alteración antrópica. Respecto a las vasijas cerámicas se 
observó un predominio de formas contenedoras como ollas ordinarias con evidencias de exposición al fuego y en menor proporción tinajas de estilo Belén.

Otro dato interesante proviene del extremo NO del recinto. En el perfil B-B' (ver Figura 5.40 más arriba) se mostró la relación entre la algarroba molida con la huella basal de un contenedor cerámico que remite a un contexto de molienda para la preparación de alimentos, identificado sobre restos de cenizas del nivel 6. Ambos materiales estaban separados de un lente de carbón por un hiatus de sedimento natural que podría indicar al mismo tiempo un lapsus temporal corto entre una y otra actividad.

En cuanto al segundo momento de actividad, el mismo se halló concentrado en torno al fogón 1 del recinto. Esta estructura de combustión posee una ubicación central hacia la entrada del recinto, lo cual condicionaría la circulación de las personas y las actividades de preparación de alimentos hacia los laterales y extremos de la habitación, de forma similar a lo que se puede observar en la cocina actual de los habitantes del sitio. A este momento le corresponderían los niveles 1, 2, 3, 4 y 5. Incluso como pudo observar en la Figura 5.23, los materiales recuperados se hallaron distribuidos en los extremos del recinto, que podría asociarse asimismo con eventos de limpieza. Por otro lado, se evidencia una disminución en la frecuencia de los diversos vestigios materiales con respecto al momento previo, que contribuyen a la propuesta relativa a una actividad más concentrada y de menor intensidad.

Finalmente, es preciso remarcar que los momentos de actividades de preparación y cocción de alimentos señaladas pueden corresponderse con sucesivas jornadas laborales en el taller metalúrgico, quizás a intervalos semestrales, anuales o de una mayor temporalidad. En este marco, las evidencias presentadas señalan que las prácticas culinarias de los trabajadores estuvieron concentradas en torno a las plantas silvestres y en menor medida a recursos faunísticos. Estas ideas serán retomadas en las conclusiones generales al poner en relación las prácticas inferidas en estos espacios con aquellas observadas en el sector $B$ del sitio (capítulo 8).

- $\quad$ Recinto 3: es la estructura circular de mayores dimensiones dentro de las unidades desplegadas en el sector $A$. La reevaluación del material cerámico obtenido por González (1959) permitió evidenciar una alta representatividad de piezas de estilo Inka provincial (27\%) junto a vasijas correspondientes al estilo local Belén (17\%), siendo la 
única estructura donde la proporción de estilos locales respecto a los estatales se invierte. En este sentido, la alta concentración de cerámica inka marca una diferencia significativa en relación con los otros recintos del sitio, aunque no es exclusivo en tanto que en otros espacios se registraron restos de vasijas inka. Dentro de las piezas inkaicas, se identificaron las clásicas formas de aríbalos o aribaloides y platos, que es considerado como el "conjunto mínimo para cualquier individuo o grupo afiliado al estado inka" (Bray 2004:366), señalando de esta manera la circulación y apropiación de estos enseres por un conjunto pequeño de actores en las prácticas acontecidas en el sitio. Es posible que estos implementos culinarios pudieran haberse empleado en particulares instancias de comensalismo político en el marco de las actividades productivas realizadas en el sitio. Justamente, dada las características arquitectónicas distintivas de este recinto -en cuanto a su planta, tamaño, ubicación y vista a los cerros de mayor altura- y la presencia del repertorio cerámico estatal, prácticamente ausente en otros espacios de habitación, se infiere que este recinto debió cumplir funciones especiales en la dinámica social del sector posiblemente asociado a los líderes locales, como será retomado en el capítulo 8.

Sin embargo, en los estudios previos se ha considerado a este recinto como un espacio para el almacenamiento de alimentos (González 1980) dado que tradicionalmente se asoció a las plantas circulares a este tipo de estructuras. En relación a este tema, los sitios inkaicos del valle ofrecen un escenario comparativo para contextualizar los hallazgos. En el sitio El Shincal se identificaron qollqas de plantas circulares y cimientos de rocas ubicadas en el Cerro Aterrazado Este y que podrían alcanzar un número cercano a 80 ejemplares (Giovannetti 2015b). Por su parte, en Hualfín Inka se reconocieron cerca de 37 qollcas de planta circular con diámetros de entre 3 y $5 \mathrm{~m}$ y con vanos orientados hacia el este. Se diferenciaron de otros recintos circulares del sitio por sus menores dimensiones, su localización y topografía, estando los almacenes agrupados en la periferia del sitio y en las zonas más altas del terreno que favorecería la conservación de alimentos (Lynch 2013). En cambio, otros recintos circulares muestran evidencias que sugieren su empleo para la habitación. En el caso de Hualfín Inka esto sucedió en el recinto circular ubicado en el lado NE de la plaza central. Es un recinto de grandes dimensiones (9,5 $\mathrm{m}$ de diámetro) con evidencias materiales y contextuales que sustentan su uso en actividades domésticas relacionadas a los pobladores permanentes o a grupos de elite (Lynch 2013). De esta manera, 
contextualizando la estructura y a la luz de los hallazgos cabe la posibilidad de asignarle funciones de habitación al recinto 3 de Quillay.

- $\quad$ Recinto 4: esta estructura estaba fuertemente alterada debido a procesos tafonómicos de floraturbación (Schiffer 2010). Si bien las alteraciones no permitieron delimitar claros contextos arqueológicos, es posible avanzar en algunas interpretaciones según las evidencias disponibles. Por un lado, a diferencia del recinto 1, es probable que este espacio responda a una sola fase de ocupación estando hacia los $75 \mathrm{~cm}$ el piso dada la presencia de un sedimento homogéneo, consolidado y sin vestigios de material cultural. Por otro lado, la presencia de algunos restos botánicos y óseos permite proponer que fue utilizado como espacio habitacional. Además, el estrato de cenizas, el leño carbonizado, la termoalteración del sedimento, las microescorias de combustión y el segmento de arcilla cocido indican que el recinto estuvo sujeto a altas termperaturas. Por la alteración no es claro si pueden haber sido producto de actividades domésticas en el recinto o producto de un incendio. Aunque esto último es menos probable dado que suelen dejar gruesos estratos de cenizas y abudantes materiales quemados. En este recinto sólo parte de los restos comestibles se identificaron quemados y en general el material cerámico no presentó marcas de exposición al fuego, excepto en las superficies de unas dos fragmentos de ollas toscas, posiblemente mas relacionado a actividades de cocción.

Para cerrar, un aspecto a remarcar de este recinto es el predominio de cerámicas de estilo Belén (48 \%) y su asociación con material inkaico ( $8 \%$ ). Si bien este último fue fragmentario y estuvo presente en muy bajas frecuencias, desde un punto de vista cronológico señalaría el uso de este espacio durante momentos inkaicos, en concordancia con la presencia de cerámica inka en el recinto circular y en las recolecciones superficiales del sector $A$. 


\section{EL SECTOR PRODUCTIVO. LOS HORNOS METALÚRGICOS}

\subsection{Presentación del capítulo}

En el capítulo 4 se han mostrado las características generales de los hornos y su distribución espacial en el sector $B$. La evaluación del estado de conservación permitió reconocer los ejemplares mejor preservados sirviendo como criterio para la selección de las unidades a excavar. En este capítulo se presentarán los estudios realizados en los hornos metalúrgicos y de los materiales recuperados tanto en contextos de excavación como en recolecciones superficiales, con el fin de conocer en detalle la morfología de las estructuras de combustión, identificar para qué tipo de operación metalúrgica fueron utilizados y abordar algunos parámetros tecnológicos que permitan evaluar su funcionamiento.

En primer lugar, se mostrarán los materiales recuperados de la recolección superficial realizada en el conjunto de hornos 2 dentro de un radio de $30 \mathrm{~m}$ desde el horno 14. Allí se registraron principalmente materiales cerámicos, líticos y escorias. Los primeros fueron analizados con los procedimientos metodológicos explicitados en el capítulo precedente por lo cual se avanzará directamente sobre los resultados obtenidos.

En segundo lugar, se detallará la metodología de excavación utilizada en los hornos y los materiales y contextos identificados en cada uno de los ejemplares. Los hallazgos consisten en escorias, carbones, sedimentos, paredes de hornos y un fragmento textil. Se presentarán de manera consecutiva las metodologías de análisis, los resultados obtenidos y una discusión para cada clase de material, con el fin de facilitar la lectura y comprender los parámetros tecnológicos que estos permitieron inferir. Finalmente, se integrarán y discutirán los resultados y se pondrán en relación los datos tecnológicos obtenidos en los hornos de Quillay con aquellos conocidos para otras regiones Andinas. 


\subsection{Los materiales de recolección superficial}

\subsubsection{Cerámica}

En las inmediaciones de los hornos que conforman el conjunto $\mathrm{n}^{\circ} 2$ se han recolectado abundantes fragmentos cerámicos (tabla 11- Anexo I). Las tareas de remontaje fueron realmente fructíferas logrando distinguir 192 vasijas cerámicas entre un conjunto numeroso de tiestos individuales $\left(\mathrm{N}_{\text {fragm }}=371\right)$. El análisis estilístico permitió reconocer principalmente cerámicas que responden a estilos tardíos (gráfico 6.1). Al igual que lo observado en el sector $A$, en las inmediaciones de estos hornos también predomina la cerámica Belén con un $51 \%$ de representatividad, teniendo en cuenta fragmentos que si bien no pudieron ser identificados con absoluta seguridad, tienen altas probabilidades de corresponderse con este estilo. El segundo lugar lo ocupan las piezas Toscos utilitarias que conforman un 35,4 \% de la muestra. En menor frecuencia, se identificaron piezas de tipo Santamariano (3,6 \%), Sanagasta $(1,5 \%)$, Inka Mixto (1\%) y un único fragmento del periodo temprano de estilo Ciénaga. El 6,8 $\%$ restante son fragmentos de difícil asignación estilística al presentar superficies pequeñas y/o muy erosionadas.
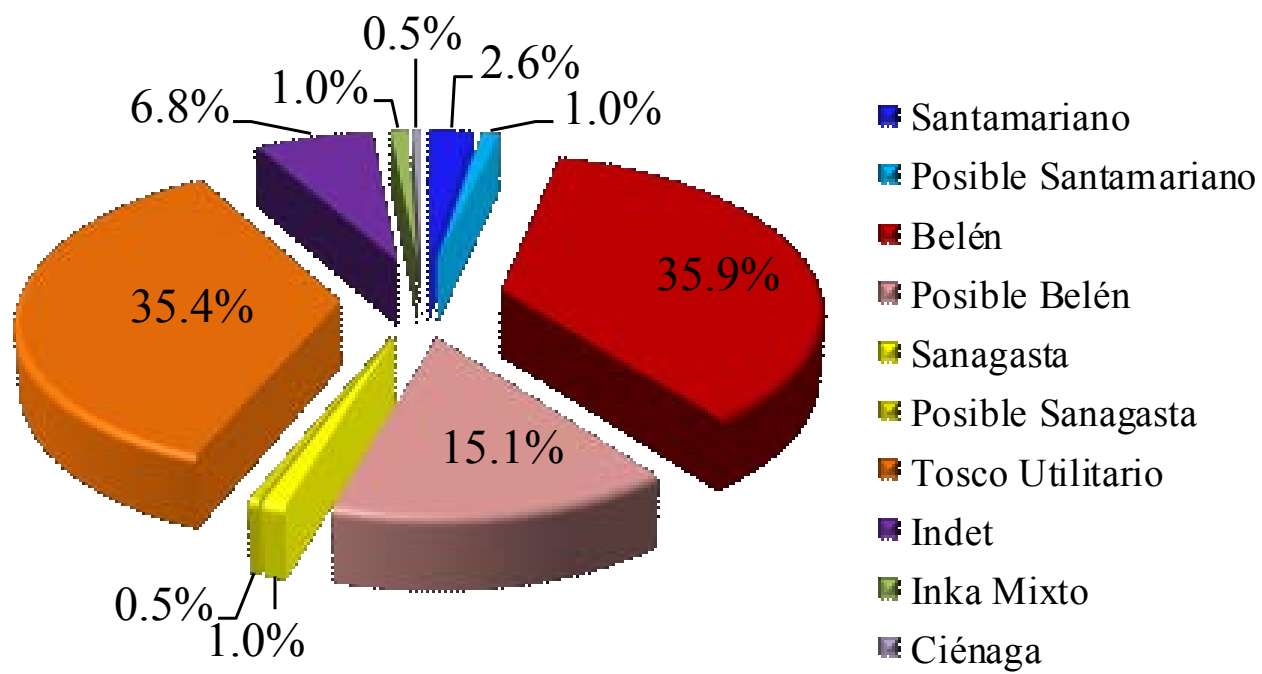

Gráfico 6.1. Frecuencia de estilos cerámicos registrados en el conjunto de hornos 2.

Respecto a las formas cerámicas, en el gráfico 6.2 se observa que el $76 \%$ de la muestra son vasijas de tipo cerrado, de las cuales el $18 \%$ fueron identificadas como partes de tinajas que en su mayoría corresponden a segmentos de piezas de estilo Belén. 
Por otro lado, las identificadas como ollas $(20 \%)$ son principalmente del tipo toscas cuyos espesores (entre 0,6 y 2,7 cm) indican que fueron contenedores de grandes tamaños. A diferencia de otros sectores del sitio, aquí las vasijas abiertas son numerosas alcanzando el $17 \%$ de la muestra, siendo un $13 \%$ de éstas reconocidas como partes de cuencos tipo $p^{\prime} u k u$ (Tabla 6.1).

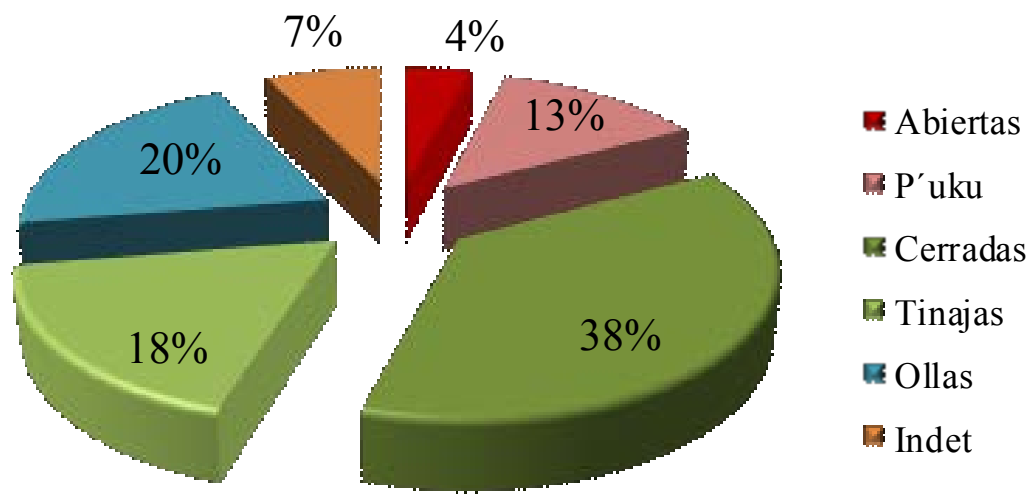

Gráfico 6.2. Frecuencia de formas cerámicas tardías de la superficie del conjunto de hornos 2.

\begin{tabular}{|c|c|c|c|c|c|c|c|}
\hline \multirow{2}{*}{ ESTILO } & \multicolumn{6}{|c|}{ MORFOLOGÍA } & \multirow{2}{*}{ TOTAL } \\
\hline & Abierta & $P^{\prime} u k u$ & Cerrada & Tinaja & Olla & Indet & \\
\hline Santamariano & - & - & 4 & 1 & - & - & 5 \\
\hline Posible Santamariano & - & - & 1 & 1 & - & - & 2 \\
\hline Belén & 4 & 22 & 13 & 29 & - & 1 & 69 \\
\hline Posiblemente Belén & 3 & 3 & 13 & 3 & - & 7 & 29 \\
\hline Sanagasta & - & - & 2 & - & - & - & 2 \\
\hline Posiblemente Sanagasta & - & - & 1 & - & - & - & 1 \\
\hline Tosco Utilitario & - & - & 25 & - & 39 & 4 & 68 \\
\hline Indet & 1 & - & 10 & - & - & 2 & 13 \\
\hline Inka Mixto & - & - & 2 & - & - & - & 2 \\
\hline Ciénaga & - & - & 1 & - & - & - & 1 \\
\hline TOTAL & 8 & 25 & 72 & 34 & 39 & 14 & 192 \\
\hline
\end{tabular}

Tabla 6.1. Frecuencia numérica de tipos morfológicos discriminados para cada estilo cerámico.

Los diseños decorativos de las tinajas Belén recolectadas, presentan patrones geométricos similares a los observados en los otros sectores del sitio, con diseños que siguen la segmentación tripartita clásica de la cerámica Belén para este valle (ver Wynveldt et al. 2005; Wynveldt 2007). Respecto a los p'uku de estilo Belén presentan superficies externas que exhiben mayormente diseños conformados por dos líneas 
paralelas de contornos sinuosos. En cambio, las superficies internas muestran patrones decorativos más complejos, conformados por grecas, cuadriculados, escalonados, líneas paralelas oblicuas y diseños figurativos de armadillos (Figura 6.1).

Las piezas Santamarianas analizadas son vasijas del tipo bicolor y tricolor. Sus diseños no pudieron ser identificados dado que los tiestos presentaron superficies relativamente pequeñas. Sólo se pudieron observar segmentos iconográficos de líneas y puntos. Los escasos fragmentos Sanagasta, ostentan diseños de triángulos y festoneados realizados con pintura negra sobre una pasta finamente alisada (ver figura 37 en Anexo IV).

Los fragmentos distintivos clasificados bajo la categoría de "Inka Mixto" representan a piezas cerámicas que combinan elementos decorativos, tecnológicos y/o morfológicos de estilos locales e inkaicos (Calderari y Williams 1991). Por ejemplo, desde un punto de vista morfológico uno de los ejemplares identificados en el sector de hornos podría corresponder por su cuello corto a una ollita de tipo Belén. Sin embargo, presenta un patrón decorativo que incluye una serie de triángulos que evoca los clásicos diseños inkaicos. El otro fragmento, es un segmento de cuerpo de una vasija cerrada globular con un diseño decorativo en banda de disposición diagonal y rellena con pinceladas cortas (Figura 6.2). Ambos fragmentos recuerdan a algunos ejemplares reconocidos en El Shincal de Quimivil (Giovannetti et al. 2012), incluso el primero presenta semejanzas en el diseño con la tinaja $\mathrm{N}^{\circ} 11934-625$ de la colección Muñiz Barreto de influencia inkaica (Sempé 1986: Lámina 1; Wynveldt 2008: Figura 13).
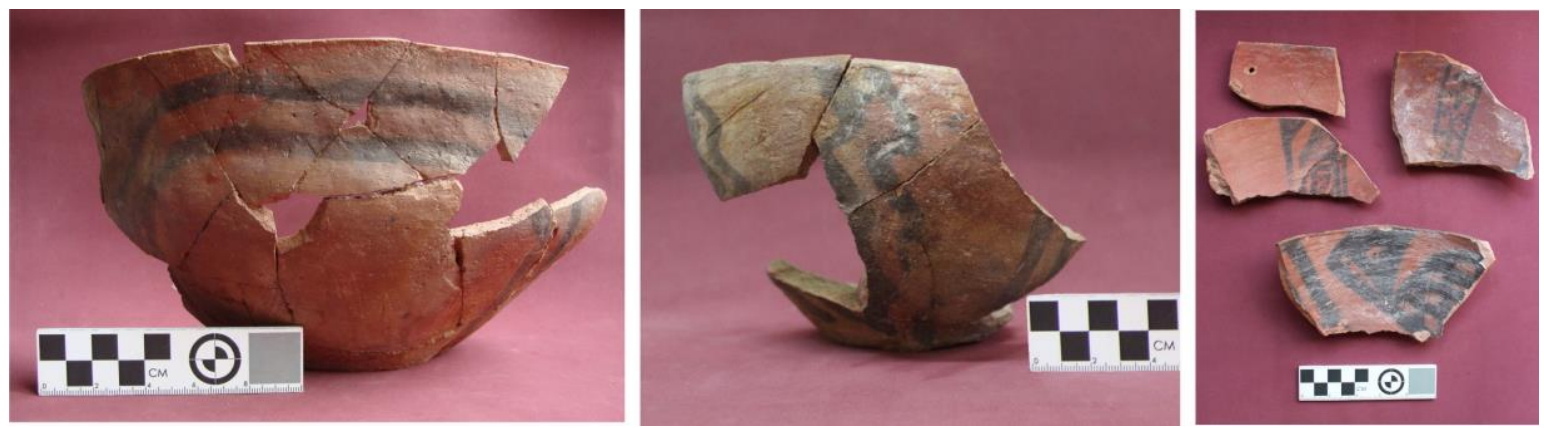

Figura 6.1. Piezas abiertas tipo p'uku de estilo Belén negro sobre rojo. Se observan los patrones decorativos externos e internos. 

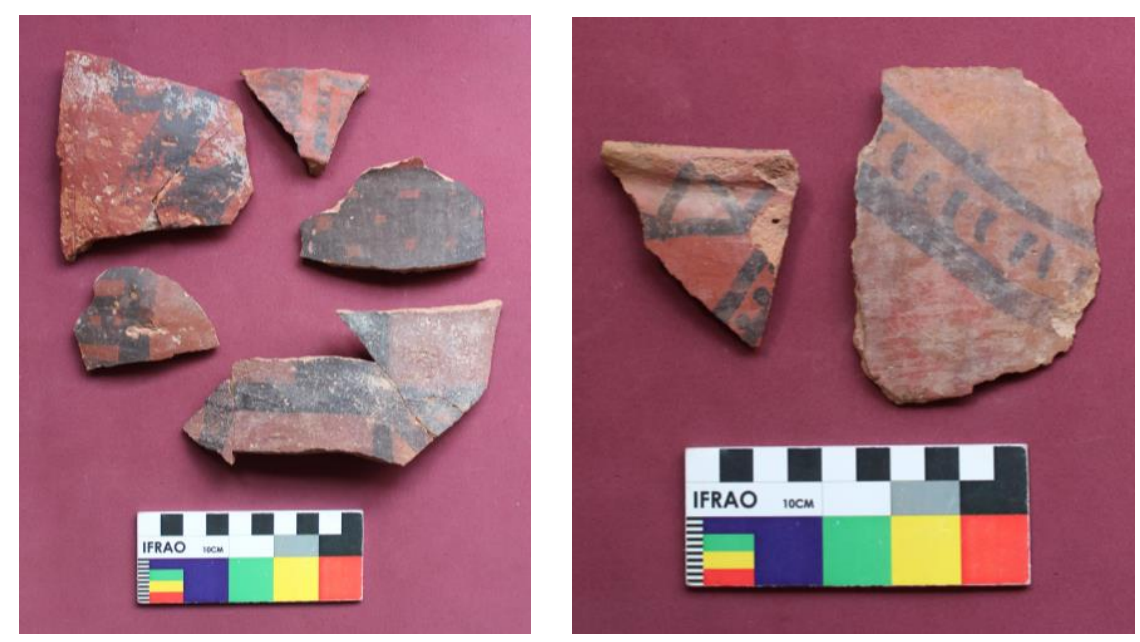

Figura 6.2. A la izquierda se observan fragmentos de tinajas Belén. A la derecha aquellos identificados como Inka Mixto.

En cuanto a las marcas de uso, resulta interesante el gran porcentaje de piezas que exhibieron rastros de alteraciones antrópicas, las cuales alcanzan el $48 \%$ de la muestra total. Para caracterizar este conjunto cerámico se diferenciaron las huellas de uso en función de los tratamientos superficiales de las piezas. Así, en el gráfico 6.3 se puede observar que las piezas toscas presentaron una mayor frecuencia de superficies quemadas $(21 \%)$ frente a aquellas decoradas (4\%), posiblemente asociadas con la exposición al fuego, en general relacionado con acciones de cocción. Por otro lado, dentro de las vasijas con superficies decoradas, un $28 \%$ exhibió alteración por uso, manifestado a partir de bases desgastadas, picados en los cuerpos cerámicos y segmentos perforados con el fin de unir piezas fragmentadas. Estas marcas estarían señalando que han sufrido diversas alteraciones por desplazamientos, roces y quiebres.

Un dato interesante es la identificación de superficies externas con escorificaciones, detectadas principalmente en los fragmentos de tinajas Belén. Asimismo, la observación a lupa binocular permitió detectar minúsculos poros vitrificados de aspecto "burbujoso" presentes en tanto en las superficies internas como enternas (Figura 6.3). Tienen un aspecto similar a lo observado en materiales refractarios, aunque son de menor tamaño y cantidad por superficie (ver capítulo 5). Dado que los tiestos con alteraciones en las pastas fueron registrados en el contexto inmediato de los hornos, es factible que las alteraciones térmicas observadas en las vasijas y las escorificaciones adheridas se deban a la cercanía con las actividades productivas. Los procesos metalúrgicos emanan gases y partículas calientes que al 
entrar en contacto con el material arcilloso suelen generar las termoalteraciones observadas. Con esto, no se sugiere su utilización en actividades metalúrgicas propiamente dichas, sino como implementos utilizados posiblemente para el abastecimiento de los trabajadores. La alta frecuencia de tinajas y pucos profundos puede estar relacionada al almacenamiento y consumo de líquidos indispensable para la salud de los trabajados en un contexto laboral caracterizado por altas temperaturas.

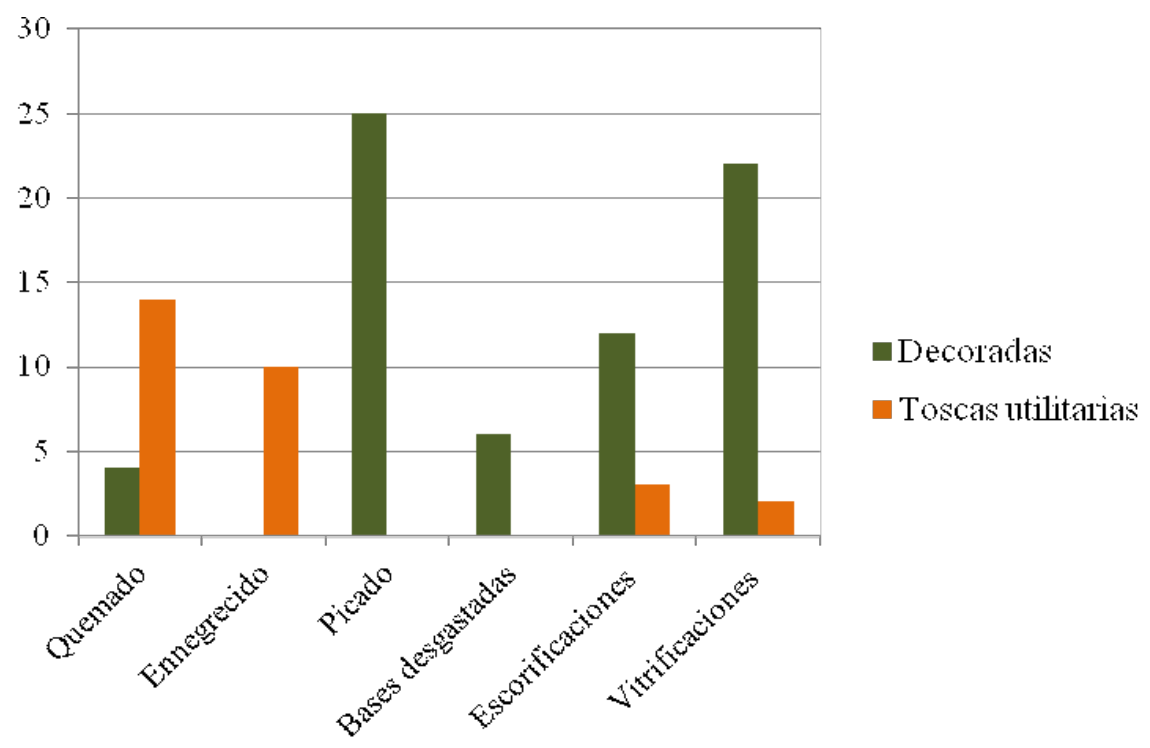

Gráfico 6.3. Proporción de marcas de uso en distintas vasijas cerámicas.
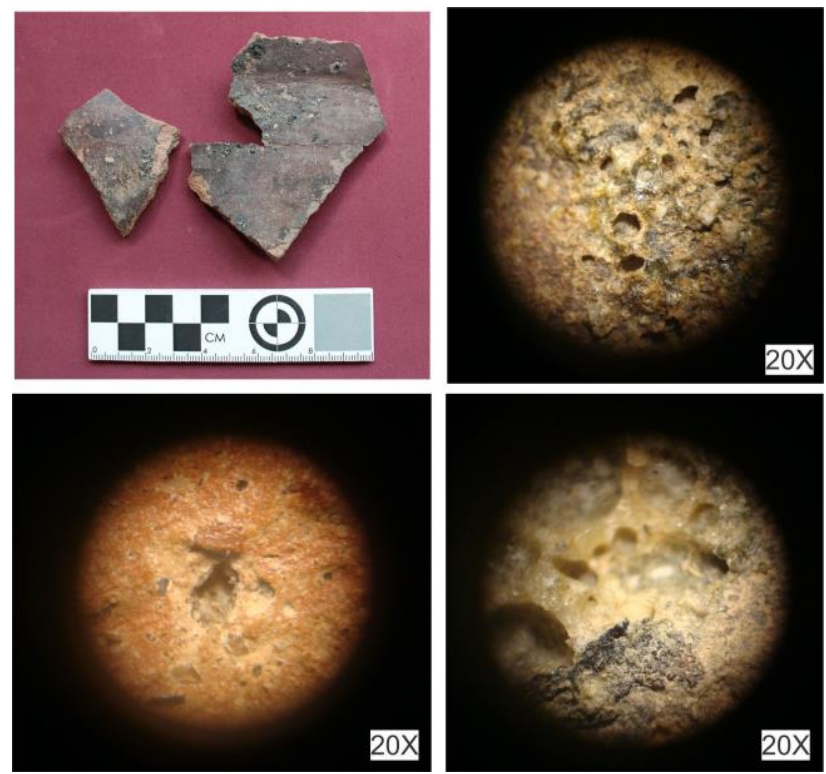

Figura 6.3. Fragmentos de tinaja Belén con escorificaciones y vitrificaciones en la superficie externa. 


\subsubsection{Lítico}

Respecto a los materiales líticos se han recuperado en la superficie del conjunto de hornos 2 un total de 54 piezas (tabla 12- Anexo I). La naturaleza petrográfica de los mismos responde principalmente a rocas de origen volcánico destacándose las andesitas (62\%), la obsidiana (11\%) y el basalto (10\%) así como minerales de cuarzo (9\%). En bajas frecuencias se detectaron fragmentos líticos de cuarcitas, pumita y un material indeterminado de tipo sedimentario (gráfico 6.4). Estas rocas están ampliamente disponibles en el ambiente natural del sitio, tal como fue comentado en la caracterización geológica de la zona (capítulo 4). La excepción lo constituye la obsidiana que es un material de carácter alóctono, dado que las fuentes geológicas más cercanas se hallan en la puna catamarqueña, distante cientos de kilómetros hacia el NO de esta región (Flores y Balesta 2011).

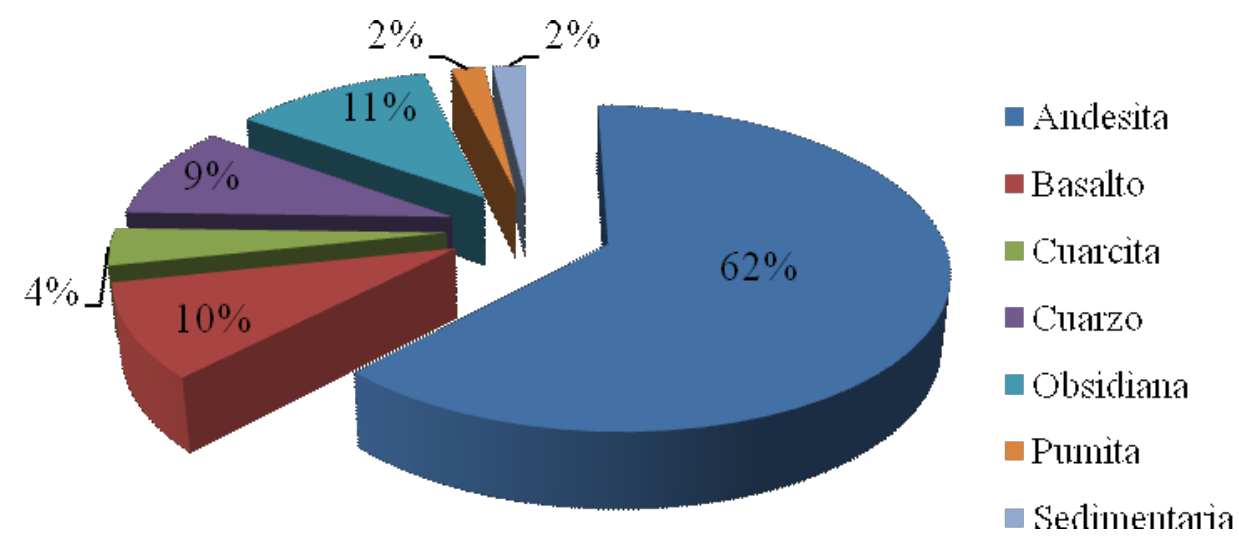

Gráfico 6.4. Frecuencia porcentual de materias primas líticas.

En el gráfico 6.5 se discriminan las categorías morfo-tecnológicas identificadas para cada materia prima. Allí se observa que el conjunto está compuesto por núcleos y lascas de distinto tipos de materiales: andesita, basalto, cuarzo y obsidiana. También se registraron unos pocos instrumentos formatizados realizados en andesita, basalto, cuarcita y pumita. 


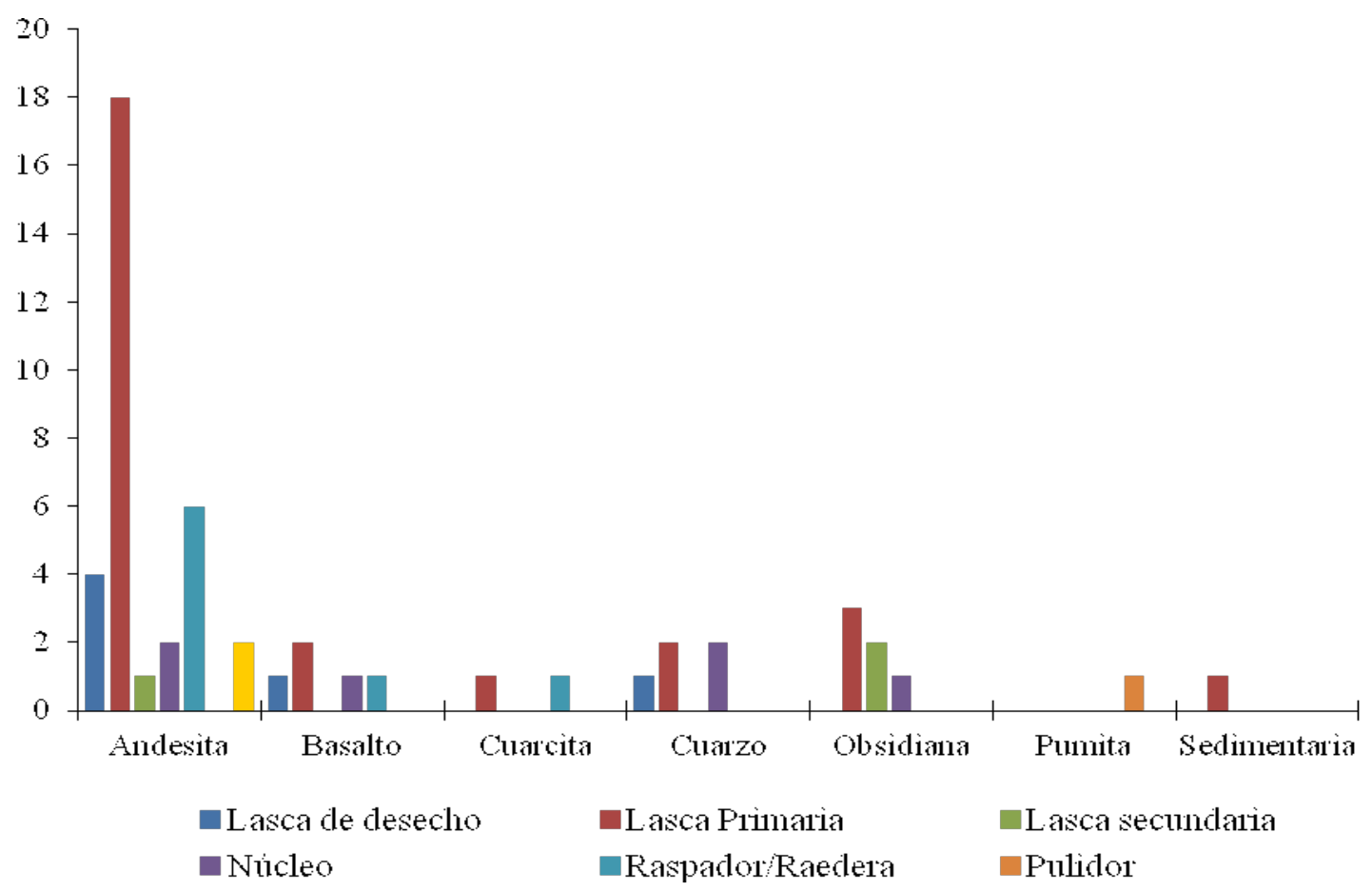

Gráfico 6.5. Frecuencia numérica de las categorías líticas para cada materia prima.

Los núcleos se han registrado en materiales de cuarzo blanquecino $(n=2)$, andesitas $(n=2)$ y basalto $(n=1)$, presentan en todos los casos vestigios de corteza. En las dos últimas materias primas fue posible observar los negativos de las lascas obtenidas por talla que condujeron en un caso al agotamiento del nódulo. Para el caso de la obsidiana, también se han registrado núcleos y productos de talla (Figura 6.4.A y B) estando ausentes los artefactos formatizados. Estos vestigios estarían señalando instancias iniciales de talla lítica. Sin embargo, como se comentó previamente, al ser un material exótico requirió del desarrollo de lógicas de abastecimiento macroregionales. A nivel regional, en varios sitios del valle de Hualfín fueron hallados núcleos, lascas y puntas de proyectil realizadas en obsidiana (Flores y Balesta 2011; Lynch 2014). Los estudios de procedencia efectuados sobre el material proveniente de sitios locales de periodos tardíos, indican que las fuentes de aprovisionamiento se localizan en yacimientos de Antofagasta de la Sierra y se sugiere que habrían sido obtenidos por diversos mecanismos de intercambio (Flores y Morosi 2009; Flores y Balesta 2011).

Finalmente, en lo que respecta a los instrumentos formatizados se han contabilizado un total de 11 objetos que responden a los siguientes tipos artefactuales: 
A) Raspadores o raederas realizados sobre preformas de andesita $(n=6)$, basalto $(n=1)$ y cuarcita $(n=1)$. Sólo en un caso se observaron pequeños retoques laterales sobre uno de los bordes con la intensión de conformar un filo. Este objeto fue realizado sobre una lasca de basalto de gran dimensiones, cuyas medidas calculadas son de 12,3 $\mathrm{cm}$ de largo, $8 \mathrm{~cm}$ de ancho y un espesor máximo de 2,8 $\mathrm{cm}$ (Figura 6.5.A).

B) Un pequeño pulidor bifacial de forma subcuadrangular y laterales redondeados realizado sobre material pumítico (piedra pómez) (Figura 6.4.B).

C) Dos percutores líticos o martillos realizados en andesita y basalto. Presentan formas trapezoidales con bordes redondeados. Sus extremos exhiben marcas de fracturas, lascados y picados por uso (Figura 6.5.B). Sus características morfológicas son similares a las observadas en los martillos registrados en las áreas de molienda cercanas al conjunto de hornos que fueron presentadas en el capítulo 5.

A excepción de la obsidiana, se observa un predominio de materias primas de carácter local que, junto a la alta frecuencia de núcleos y productos de talla con corteza sugieren que se utilizaron materiales originarios de los ríos cercanos. Estos datos sumados a la baja frecuencia de instrumentos formatizados, señalan el carácter expeditivo de la talla lítica en la búsqueda de filos y percutores que podrían ser necesarios para las actividades complementarias efectuadas alrededor de los hornos.
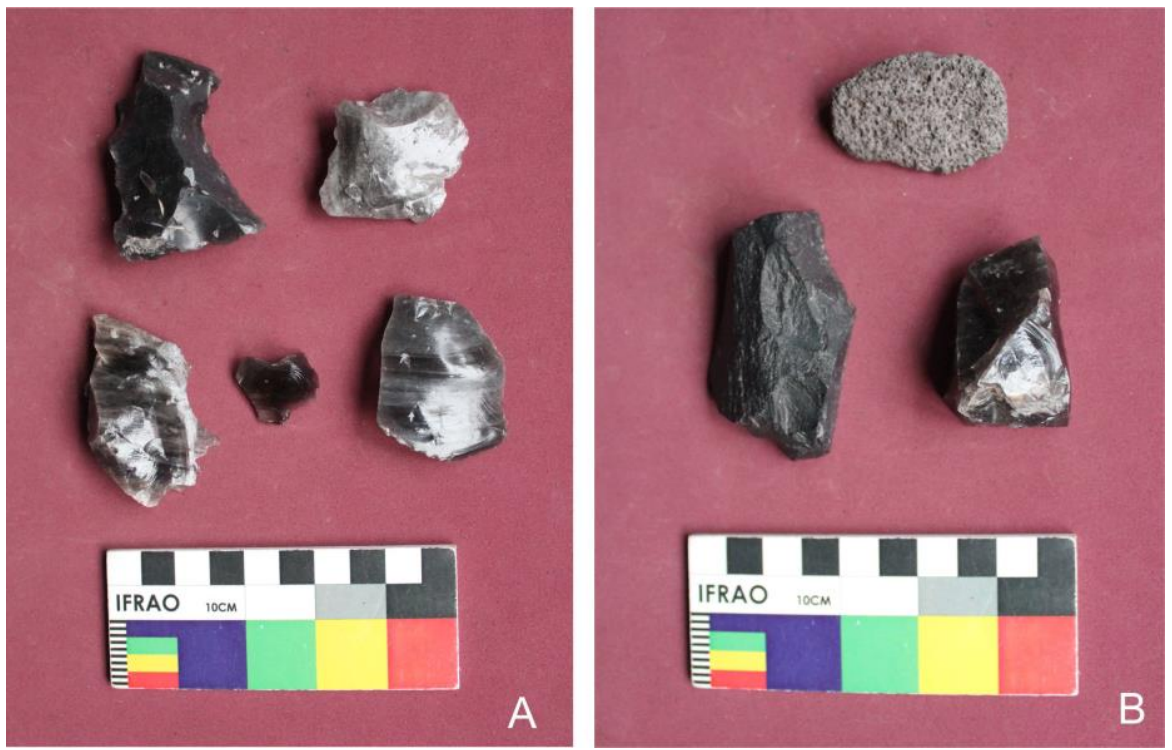

Figura 6.4. A. Lascas de obsidiana; B. Núcleos de basalto, obsidiana y pulidor de pumita- 

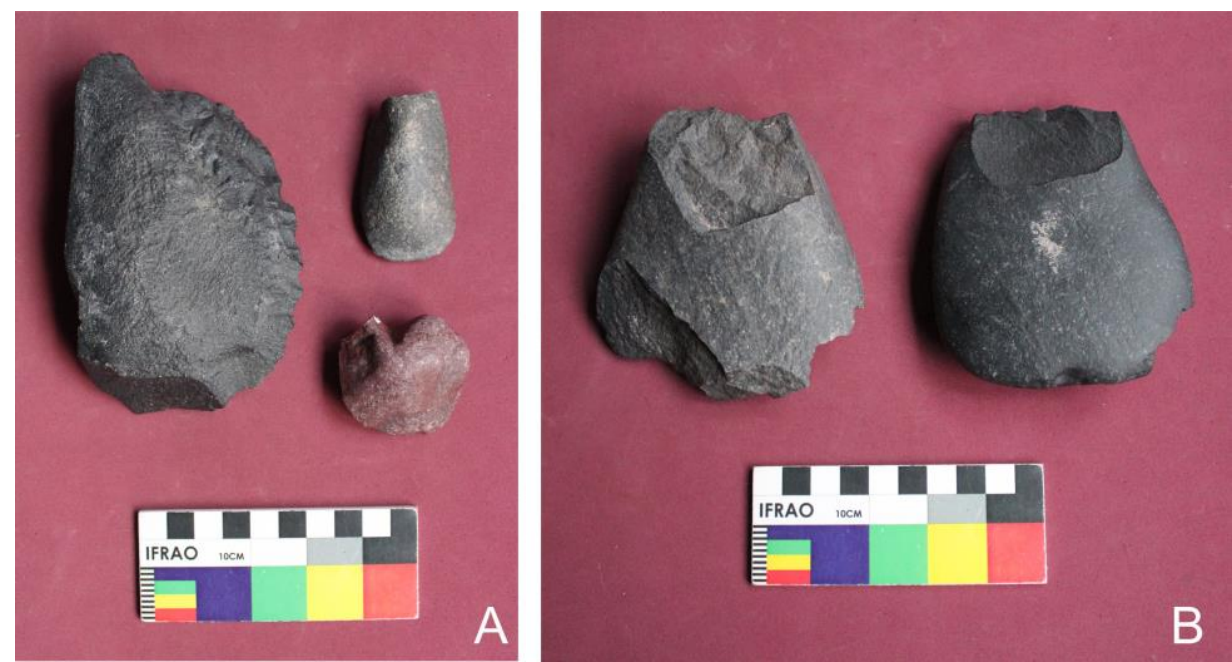

Figura 6.5. Artefactos líticos A. Raederas y raspadores; B. Martillos o percutores.

\subsection{Hornos: excavación, materiales y morfología}

\subsubsection{Metodología de excavación}

Durante los trabajos de campo se excavaron tres hornos metalúrgicos (Figura 6.6). El horno 14 (H14) y el horno 17 (H17) pertenecen al conjunto de hornos $n^{\circ} 2(\mathrm{CH} 2)$ y fueron seleccionados al ser estructuras que presentaron un buen estado de conservación. En cambio, el tercer horno -H7- forma parte del conjunto $\mathrm{n}^{\circ} 1(\mathrm{CH} 1)$ y se encuentra muy erosionado dada su ubicación en el perfil de una cárcava. Su intervención se efectuó con el objetivo de registrar sistemáticamente el segmento de horno aún preservado antes que el avance de la cárcava produzca su destrucción total.

Los tres ejemplares presentaron complejidades distintas durante su excavación, por lo cual los procedimientos empleados fueron adaptados a cada circunstancia. En el caso de los $\mathrm{H} 17$ y $\mathrm{H} 7$ se empleó la técnica de decapage siguiendo niveles artificiales de $10 \mathrm{~cm}$. Las excavaciones en ambos casos, fueron realizadas hacia el interior de las estructuras y permitieron registrar sus morfologías y los materiales asociados. En el caso del H17, se definió una única cuadrícula de excavación de $2 \mathrm{~m}$ x $2 \mathrm{~m}$, ubicándose el horno en el sector central de la misma (figura 6.7). Para la intervención del H7 se definieron dos cuadrículas. La primera $(\mathrm{C} 1)$ de 1,20 x $1 \mathrm{~m}$ se trazó sobre el frente de la cárcava dónde se observó el segmento de horno inferior. La cuadrícula 2 (C2) de 1,50 m x $1 \mathrm{~m}$ se dispuso sobre el terreno alojando la estructura superior del ejemplar (Figura $6.8)$. 
En el caso del H14, su excavación fue realizada en dos campañas consecutivas. En la primera, se empleó el mismo procedimiento que en los otros ejemplares para la intervención de la cámara superior mediante la delimitación de una cuadrícula $(\mathrm{C} 1)$ de $1,70 \mathrm{~m}$ x $2 \mathrm{~m}$. En la segunda campaña, se amplió la superficie de excavación mediante la apertura de una nueva cuadrícula (C2) adyacente al horno que se fue extendiendo paulatinamente hasta alcanzar 2,5 m x 2,7 m de cada lado (Figura 6.9). En este caso, a pocos centímetros de iniciado el descenso se detectaron varios cúmulos de materiales que plantearon la necesidad de cambiar el método de excavación hacia uno de tipo estratigráfico (Harris 1991; Carandini 1997). De esta manera, durante la excavación se definieron unidades estratigráficas arqueológicas (UEA) en función de su composición, compactación y color, se delimitó la extensión de cada depósito mediante el cálculo tridimensional de contornos, espesores y profundidades y se observaron sus posiciones estratigráficas relativas (Carandini 1997). Para su relevamiento, se levantaron plantas tridimensionales de depósitos y estructuras, siempre acompañadas de fotografías y anotaciones de campo. Asimismo, se tomaron muestras de los diversos materiales para su posterior análisis. De esta manera, se delimitaron las siguientes unidades estratigráficas en cada cuadrícula del H14:

Cuadrícula 1 (interior H14): UEA 6 y 7.

Cuadrícula 2 (exterior): UEA 1; UEA 2; UEA 3; UEA 4; UEA 5

Como resultado, las excavaciones permitieron conocer las estructuras de los hornos, la estratigrafía interior, así como la presencia de desechos metalúrgicos en especial en los sectores externos de las estructuras pirometalúrgica, que serán detalladas a continuación. 


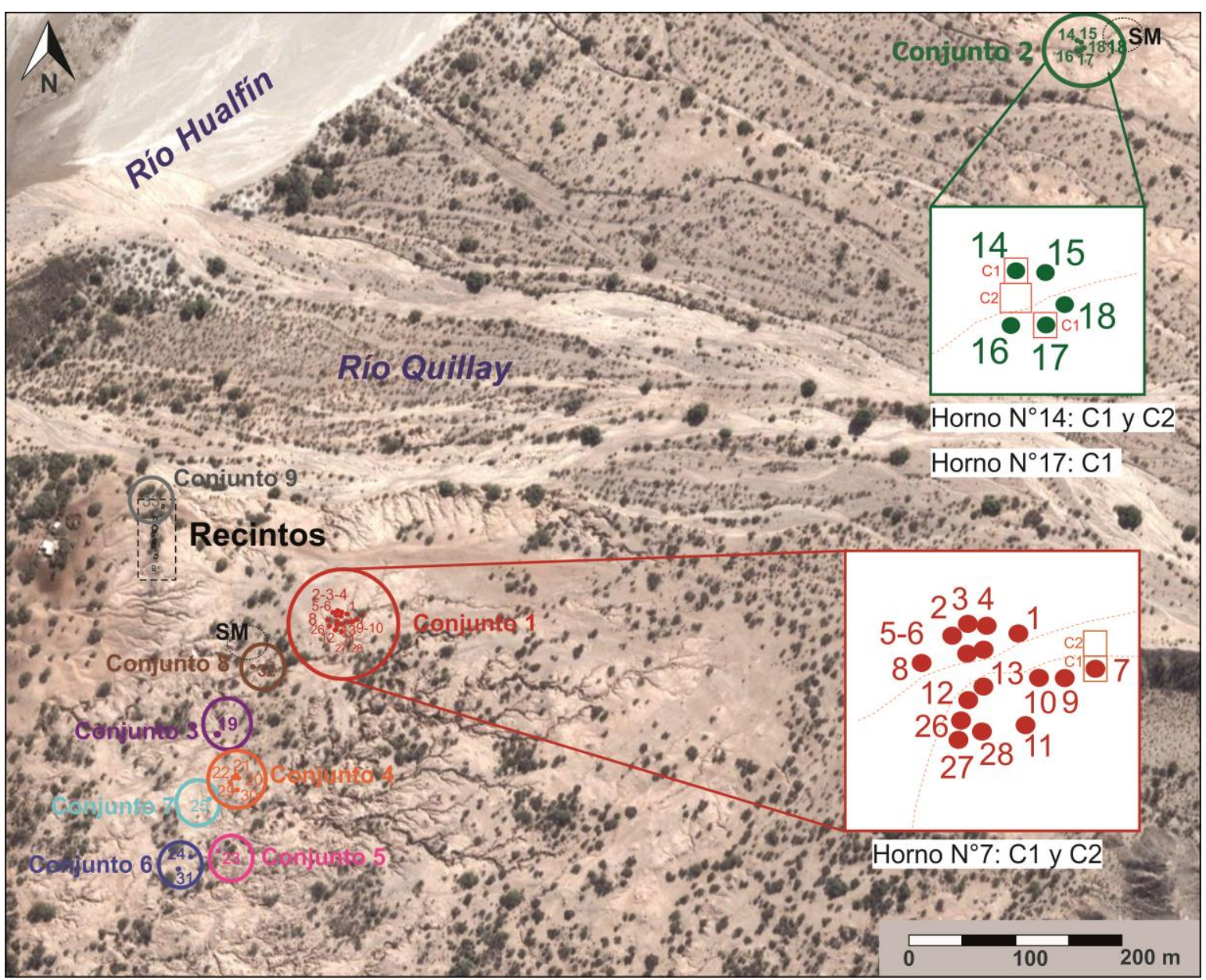

Figura 6.6. Mapa del sitio con ampliación de los hornos excavados por conjunto. Los cuadrados indican las cuadrículas de excavación.

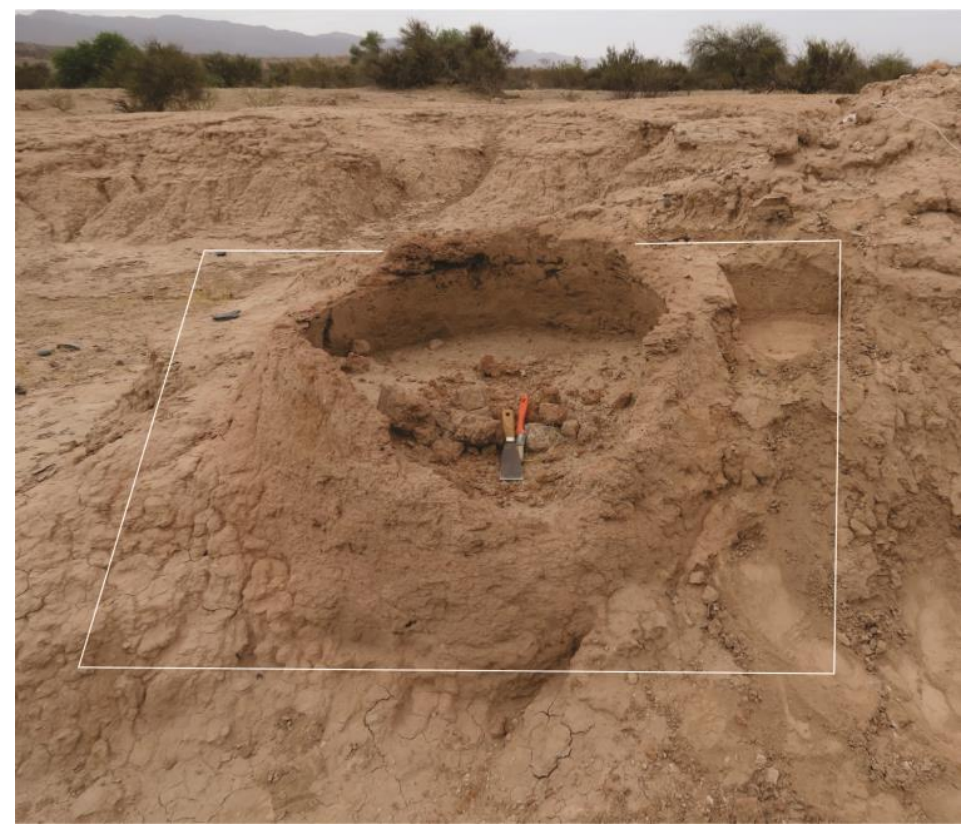

Figura 6.7. Cuadrícula 1 del horno 17. 

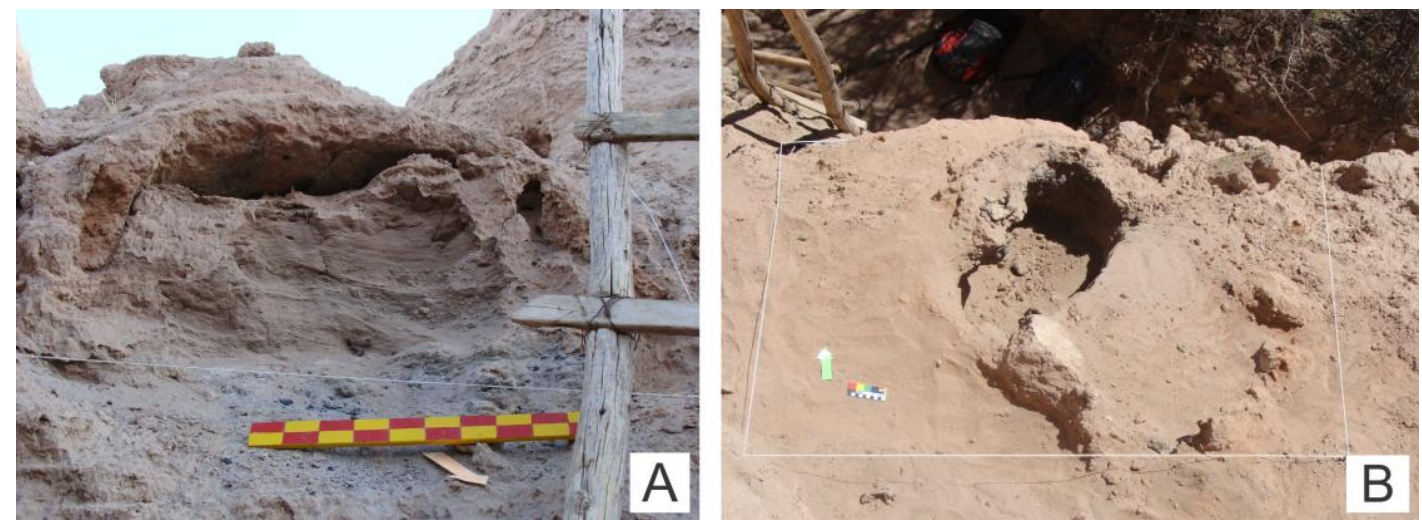

Figura 6.8.A. Cuadricula 1 del horno 7; B. Cuadrícula 2 del mismo ejemplar.

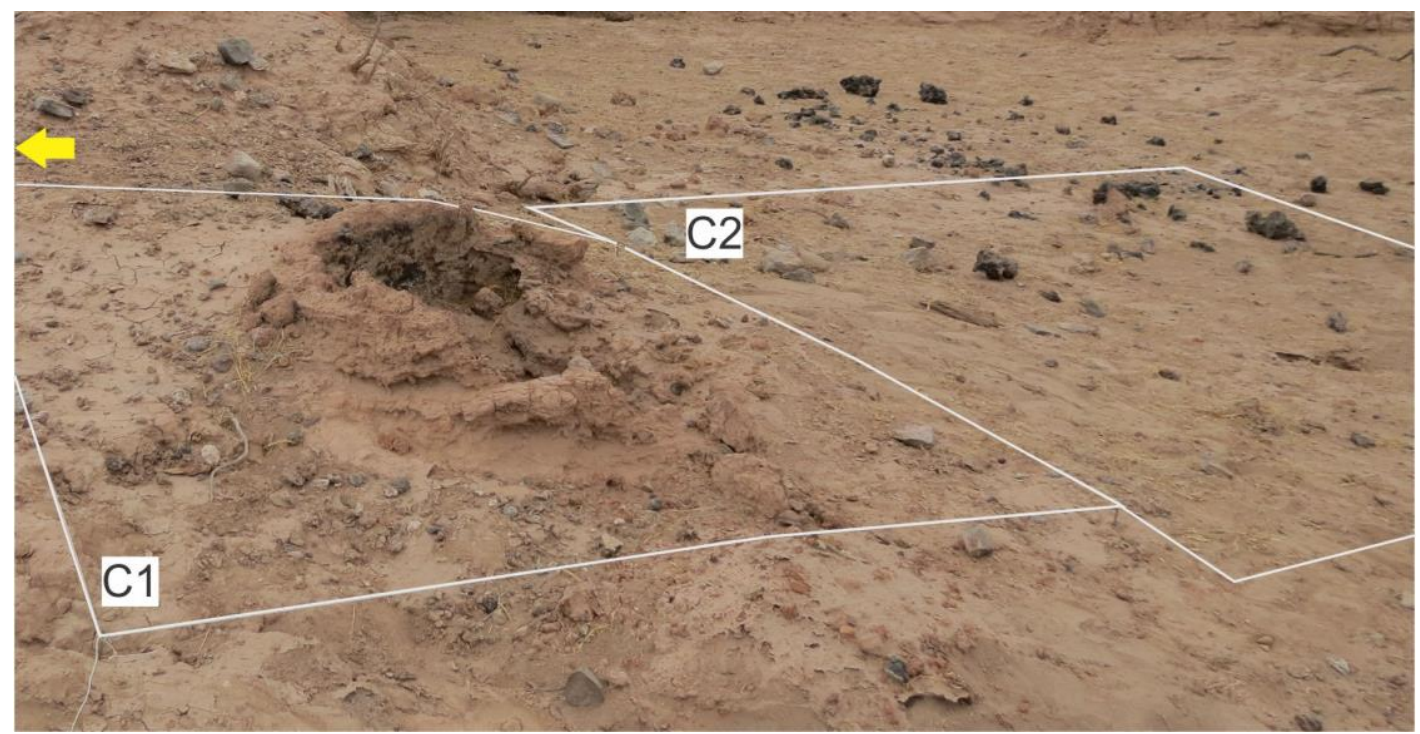

Figura 6.9. Cuadrículas 1 y 2 del horno 14.

\subsubsection{Horno 14}

La excavación de la $\mathrm{C} 1$ de este ejemplar se realizó principalmente hacia el interior del horno, dado que el sedimento exterior presentó un estado altamente compacto y su descenso podía dañar la estructura original. Hacia el interior del horno, en los primeros $70 \mathrm{~cm}$ se identificó un sedimento natural de relleno de tipo arenoso suelto, con algunos restos aislados de fragmentos de pared y desechos metalúrgicos. Luego, el descenso fue interrumpido por la propia estructura del horno. Sin embargo, la apertura de la C2 brindó un nuevo acceso al segmento de horno enterrado. En primer lugar, se detallarán las unidades estratigráficas registradas en la C2 para luego adentrarnos en aquellas identificadas hacia el interior del horno en la C1. Entonces, la C2 mostró las siguientes unidades estratigráficas arqueológicas (UEA) (figura 6.10): 
- UEA 1: estaba conformada por una capa homogénea y muy compacta de sedimento blanco de textura fina y aspecto pulverulento. Este estrato, apareció a los $60 \mathrm{~cm}$ desde el nivel de inicio de la excavación y se extendió abarcando todo el sector centro-norte de la cuadrícula. Su espesor varió entre 8 y $12 \mathrm{~cm}$ y presentó una inclinación hacia el sur siguiendo la pendiente natural del terreno. En el límite norte se registró un pequeño fragmento cerámico de estilo Belén.

- UEA 2: este depósito estaba ubicado en la esquina $\mathrm{NO}$ de la $\mathrm{C} 2$, presentó una matriz de sedimento arenoso suelto con desechos de concreciones calcáreas y restos de materiales de aspecto tubular. Este montículo, inició a los $62 \mathrm{~cm}$ y se extendió hasta los $78 \mathrm{~cm}$ de profundidad, sus límites perimetrales coincidieron con los laterales de las UEA 1 y UEA 3-A.

- UEA 3: son desechos metalúrgicos que adquirieron una estructura monticular. Estaban compuestos de fragmentos de leños carbonizados de dimensiones variables, unos pocos restos de escorias y desechos no vitrificados sobre una matriz de ceniza. Esta clase de depósito fue registrada en dos zonas -A y B-. El primero, se proyectó por el perfil $\mathrm{O}$ de la cuadrícula, apareció a una profundidad de $50 \mathrm{~cm}$ y presentó una longitud máxima de $165 \mathrm{~cm}$ siguiendo el límite de la cuadrícula y un ancho variable en función del contacto con las otras unidades. En sección mostró un espesor máximo de $27 \mathrm{~cm}$ que se fue adelgazando hacia los extremos, adquiriendo así un aspecto lenticular (ver figura 47 en Anexo IV). El montículo de la zona B, se halló en el ángulo SE de la cuadrícula y se extendió por el perfil sur unos $20 \mathrm{~cm}$ y por el este unos $140 \mathrm{~cm}$, con un espesor de $30 \mathrm{~cm}$ en promedio.

Relacionado a este depósito hay dos puntos interesantes a considerar. Por un lado, en el capítulo 4, se ha señalado la presencia superficial de montículos de carbón a una distancia regular de los hornos. En el caso del H14, a 3,3 m hacia el SO, se observó uno de estos montículos, lo que conduce a hipotetizar que lo observado en la zona A son los extremos del mismo, posiblemente producto de limpiezas sucesivas del horno. Por otro lado, la base de estos montículos coincide con el inicio de la cámara inferior del horno lo que estaría señalando que el horno estaba semienterrado. 


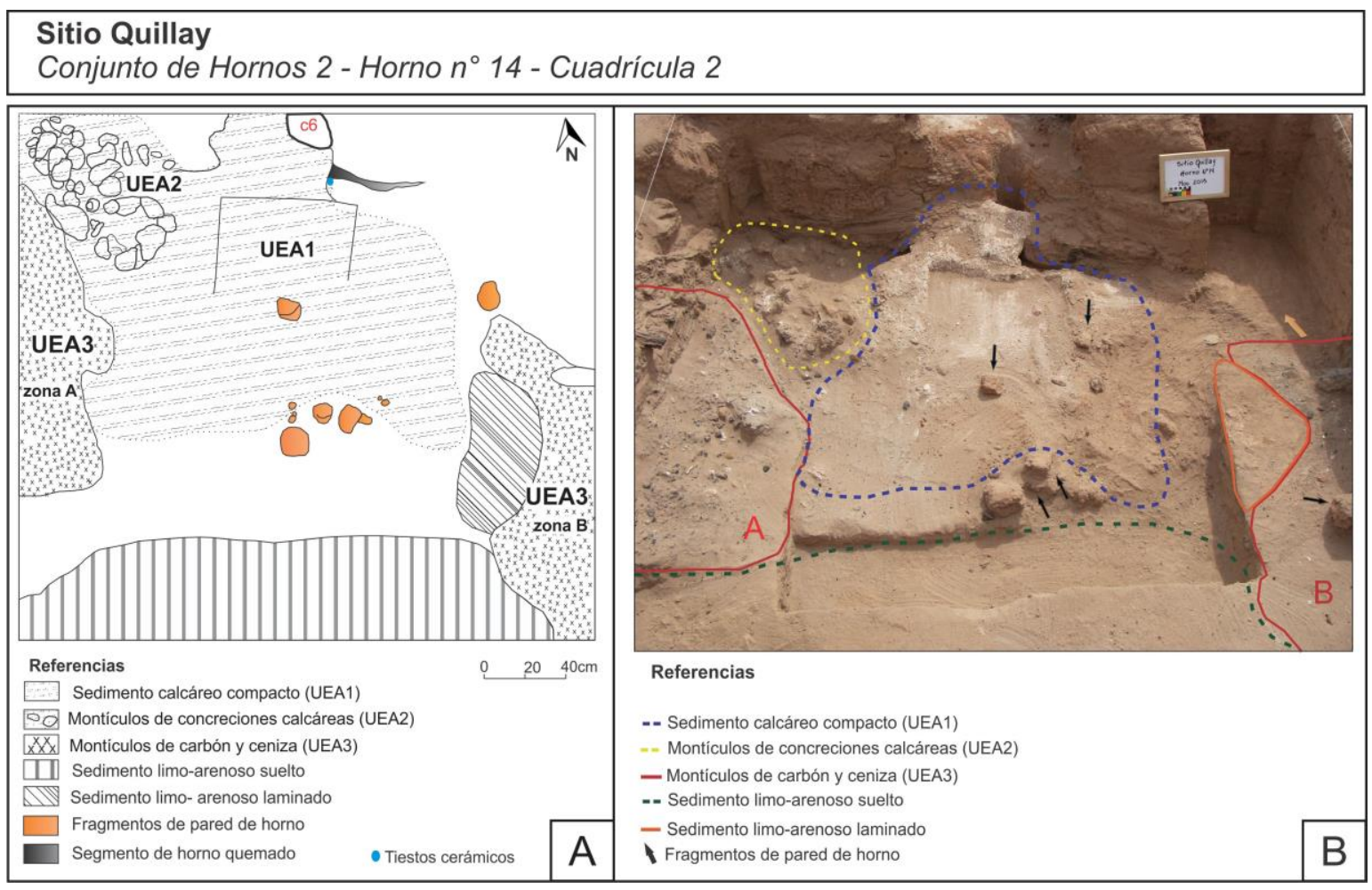

Figura 6.10. A. Planta donde se exhiben las asociaciones contextuales entre las tres primeras unidades estratigráficas arqueológicas. B. Fotografía de la planta.

- UEA 4: estratigráficamente se encontró por debajo de la UEA 1 comprendiendo una extensión similar. Estaba conformada por una matriz de sedimento arenoso color castaño que contenía fragmentos terrosos cocidos con evidencias de quemado en su cara inferior. Asimismo, se encontró atravesada por un rasgo estructural del horno representado por un segmento de una pared lateral que se proyectó desde la cámara inferior del ejemplar. Dada la presencia de termoalteración y la ubicación estratigráfica, los fragmentos terrosos son interpretados como evidencia de una antecámara destruida. Entre los vestigios culturales se recuperaron dos pequeños fragmentos cerámicos de estilo local (Belén) y el llamativo hallazgo de una pieza textil de tonalidades rojizas en el sector de acceso a la cámara inferior del horno (Figura 6.11).
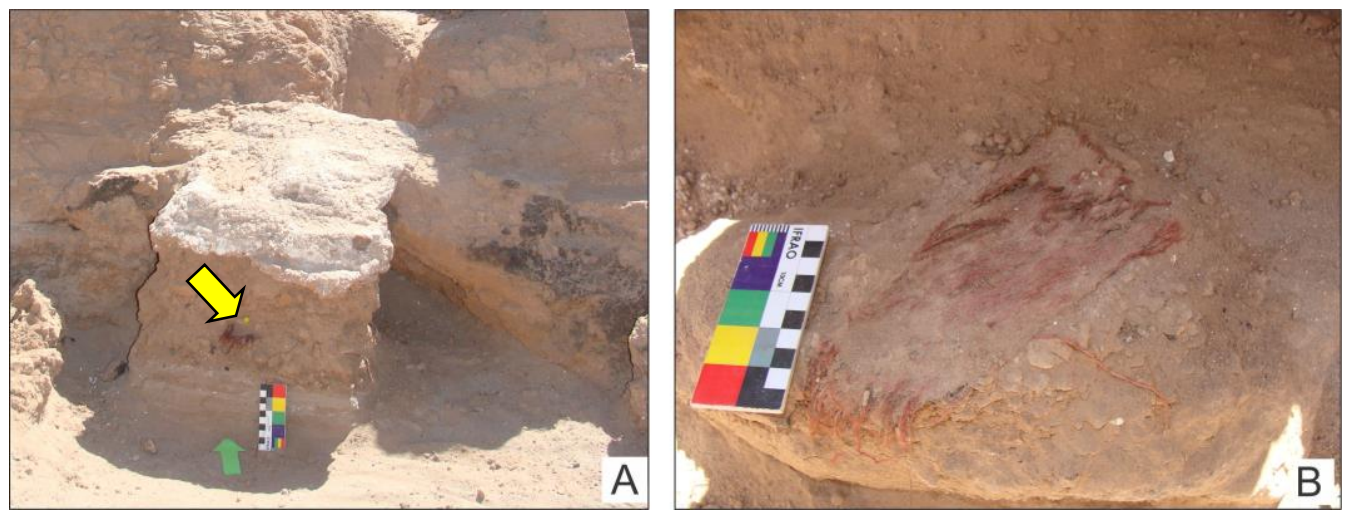

Figura 6.11. A. contexto de hallazgo del fragmento textil, se localizó en el acceso a la cámara inferior y por debajo del sedimento blando (flecha); B. Posición horizontal. 
- UEA 5: una vez removido el depósito anterior y a una profundidad de 90- $95 \mathrm{~cm}$, se hallaron distribuidos hacia el centro norte de la cuadrícula y en el espacio delimitado por la boca del horno, una gruesa capa de carbón y cenizas que se corresponden con la estratigrafía del interior del horno (C1), la cual será comentada a continuación. Los fragmentos de carbón de esta unidad son vestigios de grandes tamaños de los cuales se aprecian el núcleo y los anillos de crecimiento con diámetros cercanos a los $12 \mathrm{~cm}$ (ver figura 44 en Anexo IV). Asimismo se halló un tronco de madera carbonizada de $19 \mathrm{~cm}$ de largo y $12 \mathrm{~cm}$ de ancho cuyo análisis taxonómico indicó que se trata de Prosopis sp. (ver apartado 6.5 más abajo).

- UEA 6: esta unidad de identificó en la $\mathrm{C} 1$ en el segmento inferior del horno a una profundidad de $140 \mathrm{~cm}$. Está compuesta por el mismo sedimento blanco y de igual compactación identificado en la $U E A$ 1. Posee un espesor de entre 8 y $10 \mathrm{~cm}$, adquiere un aspecto monticular con presencia de depresiones o concavidades y una inclinación abrupta hacia el sector izquierdo, para desde allí continuar hacia el exterior de la cámara (Figura 6.12.A). Es importante señalan a los fines interpretativos, la precisa extensión de este depósito y su relación con la estructura del horno la cual será detallada en el siguiente apartado. Por ahora, diremos que, visto en planta, el sedimento blanco comienza a aparecer hacia la mitad de la cámara inferior del horno, por debajo de uno de los conductos que más adelante denominarémos como $\mathrm{Cd} 5$ y desde allí se expande hacia el fondo de la cámara (ver más adelante figura 6.13 B). Otro punto importante es que sobre este estrato y en una ubicación que coincide con otro de los conductos -el $\mathrm{Cd} 2-$, se halló una escoria de grandes dimensiones y aspecto fluido que habría mantenido conexiones físicas con dicho conducto (Figura $6.12 \mathrm{~B} \mathrm{y} \mathrm{C).}$

- UEA 7: por debajo de la unidad previa se identificó una gruesa capa de sedimento suelto, carbones y cenizas con algo de calcita, todo mezclado irregularmente, que alcanza un espesor de $35 \mathrm{~cm}$ y entra en contacto con la base del horno (Figura 6.12.A). Aunque los carbones se distribuyen en toda la extensión de la cámara hasta el exterior de la misma, donde se unen con la UEA 5 de la C2, ni la extensión ni las cualidades de los fragmentos fueron uniformes. Aquellos por debajo del sedimento calcáreo eran mucho más pequeños. Por otro lado, los carbones de mayor tamaño se encontraron acumulados en el sector derecho de la cámara, cercano a la boca de acceso, así como también por fuera de la misma. 

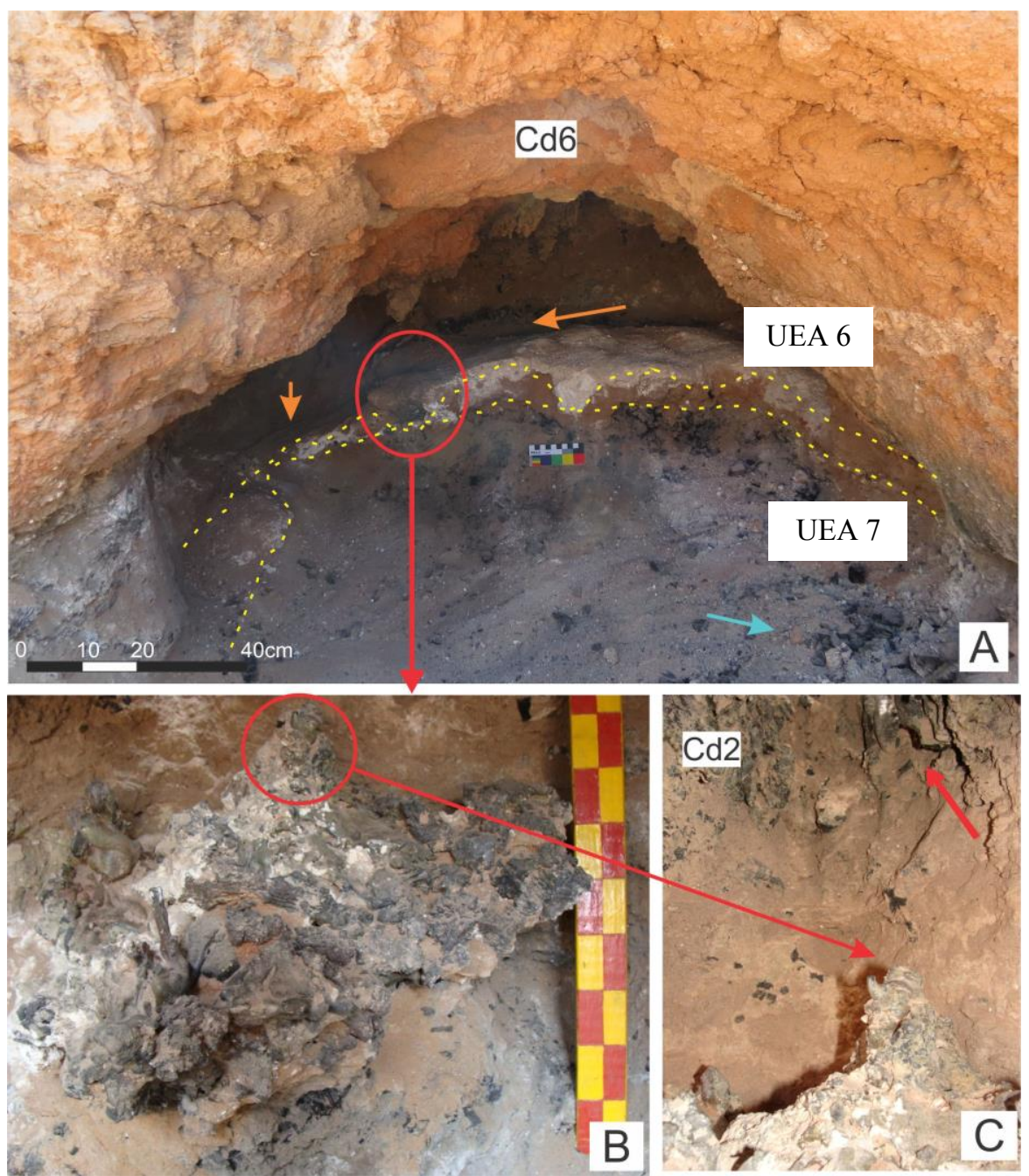

Figura 6.12. Estratigrafía de la cuadrícula 1 en el segmento inferior del horno. A. Se observa el estrato calcáreo inclinado hacia la izquierda y con concavidades; B. Detalle de la escoria remarcada en A; C. Posible conexión entre la escoria drenada y las "estalactitas" del conducto.

\section{- $\quad$ Morfología H14}

Al finalizar la excavación de ambas cuadrículas, se obtuvo una imagen completa del horno 14. Para su descripción se ha dividido su estructura en cuatro componentes: una antecámara inferior, dos cámaras -superior e inferior- y un sector intermedio que se interpone entre las últimas (Figura 6.13 y Figura 6.14). Este último sector es perforado por conductos cilíndricos verticales. A continuación se detallarán las características morfométricas de cada uno de los componentes estructurales observados en el H14 (Tabla 6.2): 
Cámara superior. Este componente presenta en su base un diámetro de $110 \mathrm{~cm}$. Sus paredes laterales se elevan y curvan inclinándose hacia el interior, finalizando en una gran abertura horizontal (Figura 6.13.C y Figura 6.14). En la actualidad, las paredes alcanzan una altura de $71 \mathrm{~cm}$ y su espesor se mantiene cercano a los $10 \mathrm{~cm}$. La cara interna de las mismas presenta un enlucido blanco, con sectores termoalterados bien delimitados. Estas zonas quemadas y vitrificadas por el fuego se distribuyen por encima de aquellos conductos que comunican ambas cámaras. La base de esta cámara, es una superficie plana con una capa de sedimento blanco fino y compacto que apoya sobre el sector intermedio.

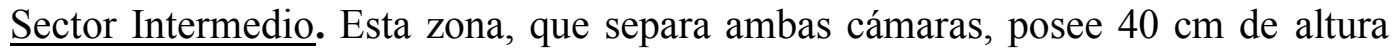
siendo atravesado por seis conductos dispuestos de manera radial: uno central y otros cinco casi equidistantes y adyacentes a la pared del horno (Figura 6.13.A). Poseen en el segmento más superficial -en la base de la cámara superior- diámetros de entre 17 y 26 $\mathrm{cm}$ que van disminuyendo en profundidad. De los seis conductos, cinco presentan lados vitrificados y recubiertos por escoria negras con tonalidades verdes y rojas (Figura 6.15). El Cd6 no presenta ningún tipo de alteración que pueda atribuirse a actividades de fundición. A partir de este conducto se pudo calcular la altura del sector intermedio.

$>\quad$ Cámara inferior. Tanto en corte transversal como en el longitudinal, esta cámara adquiere forma de elipse con un diámetro mayor de $130 \mathrm{~cm}$ (Figura 6.13.B y C). Sus paredes presentan una altura máxima de $75-80 \mathrm{~cm}$ y se encuentran alisadas y fuertemente tiznadas de hollín. El techo de la cámara muestra sectores quemados, zonas fuertemente vitrificadas y escoria sólo en los alrededores de los conductos. Este material vítreo adquiere aspecto de "estalactitas" que fluyó y solidificó en su camino hacia abajo.

Antecámara Inferior. Se infiere la existencia de este componente a partir del hallazgo de un segmento de pared de horno que se conecta con la abertura frontal de la cámara inferior (Figura 6.14). Los fragmentos de horno con evidencias de quemado en su cara inferior - que fueron referenciados en la descripción de UEA 4 - serían parte de este componente dado que se registraron en la estratigrafía por encima de la abertura de la cámara inferior. Es probable que la antecámara haya colapsado por procesos posdepositacionales. 
Capítulo 6

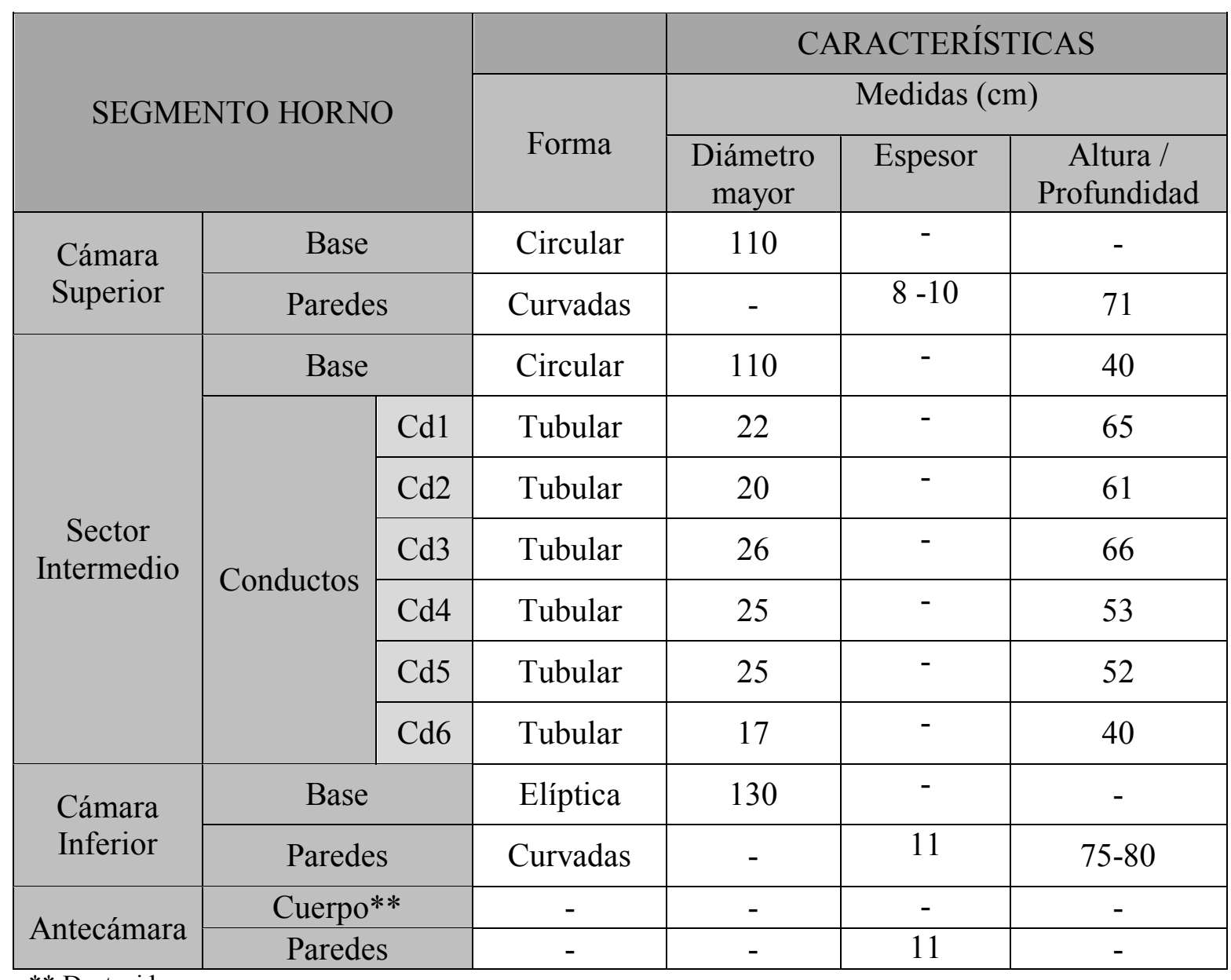

** Destruida

Tabla 6.2 Características morfométricas del Horno 14. 


\section{Sitio Quillay}

Conjunto de Hornos 2 - Horno $n^{\circ} 14$ - Cuadrícula 1

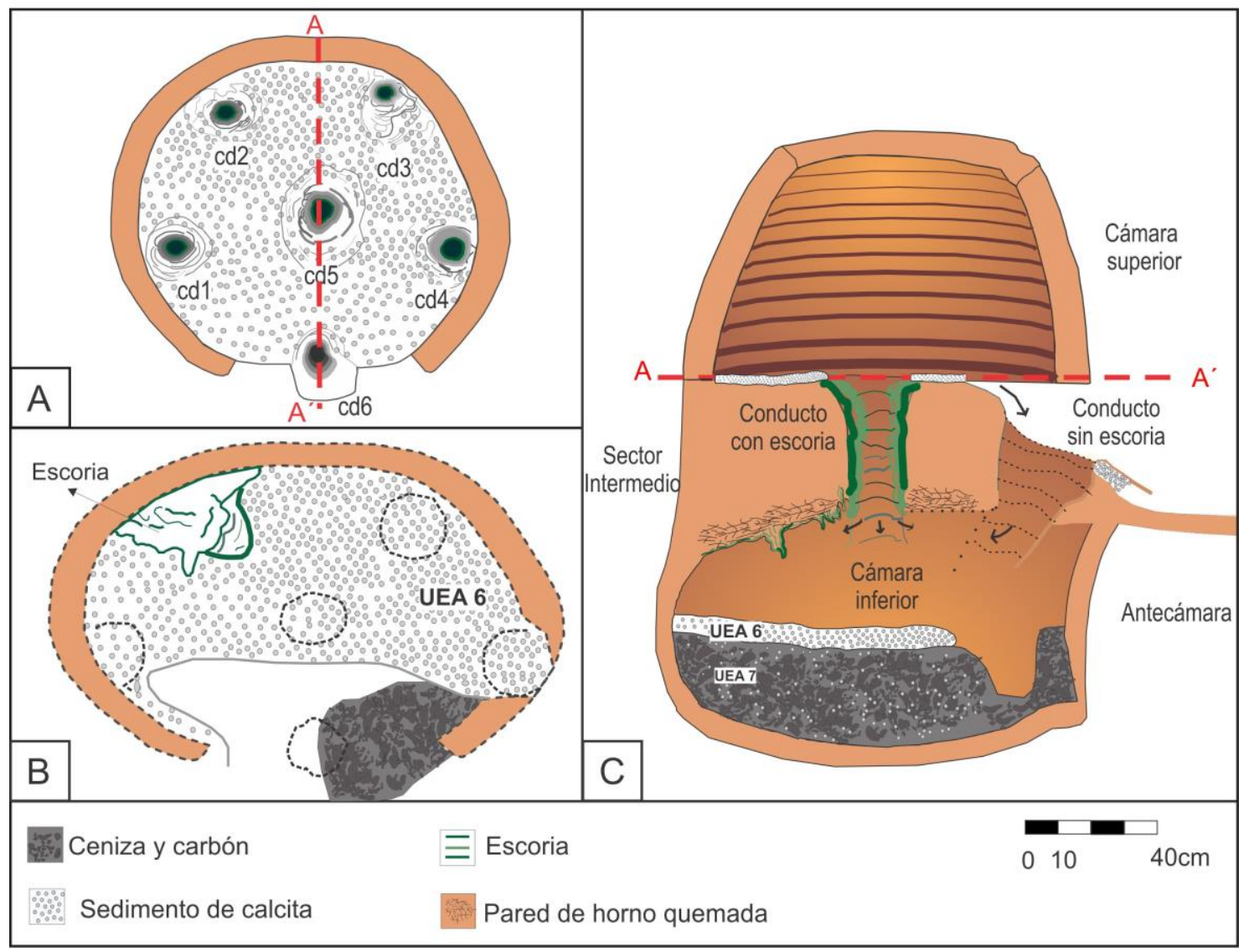

Figura 6.13. Croquis del Horno 14: A Planta de la cámara superior; B. Planta de la cámara inferior, las líneas puntuadas remiten a una proyección virtual hacia debajo de los conductos superiores; C. Corte longitudinal de la estructura completa. 
Capítulo 6

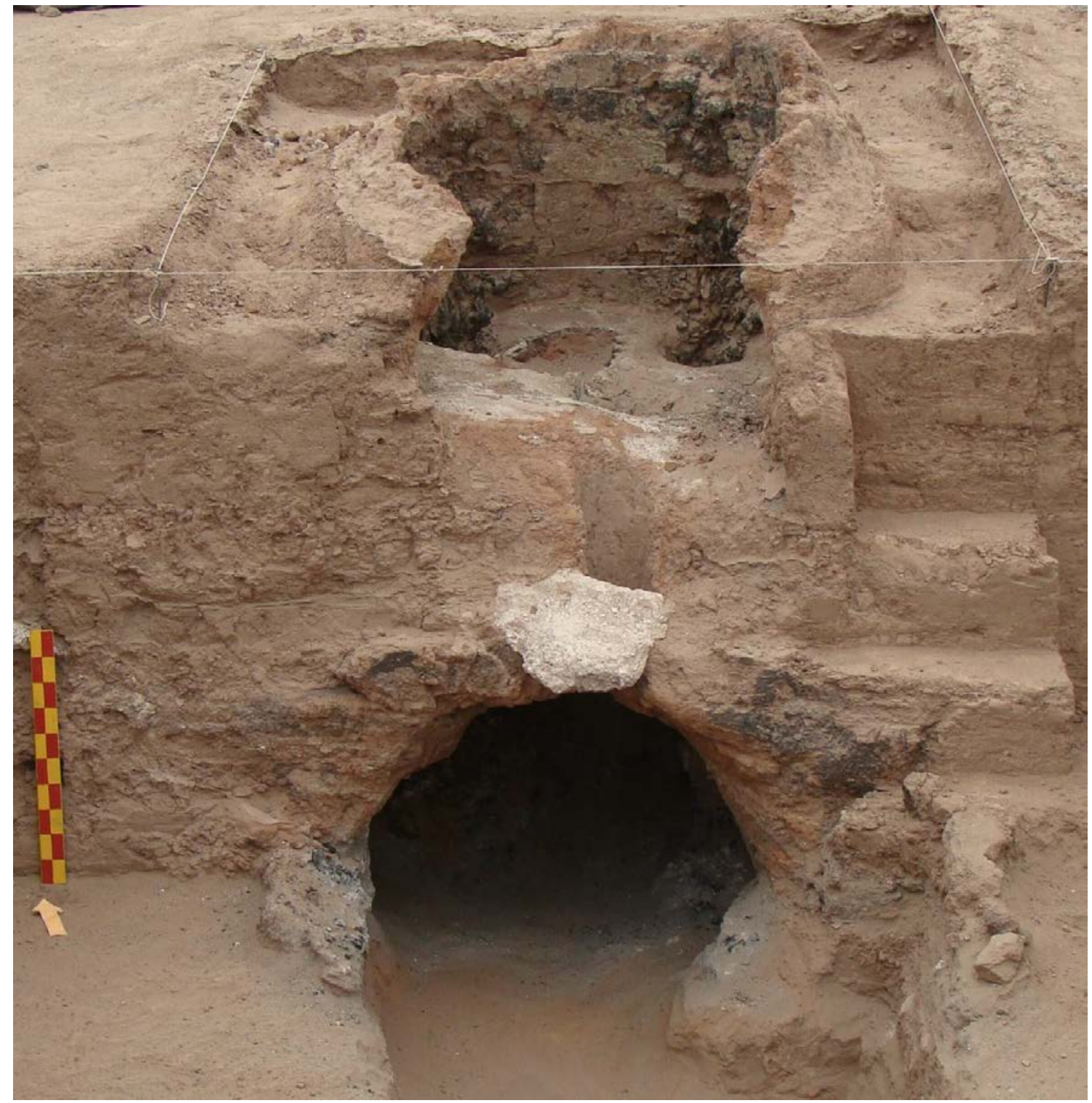

Figura 6.14. Fotografía del horno 14 totalmente excavado. 


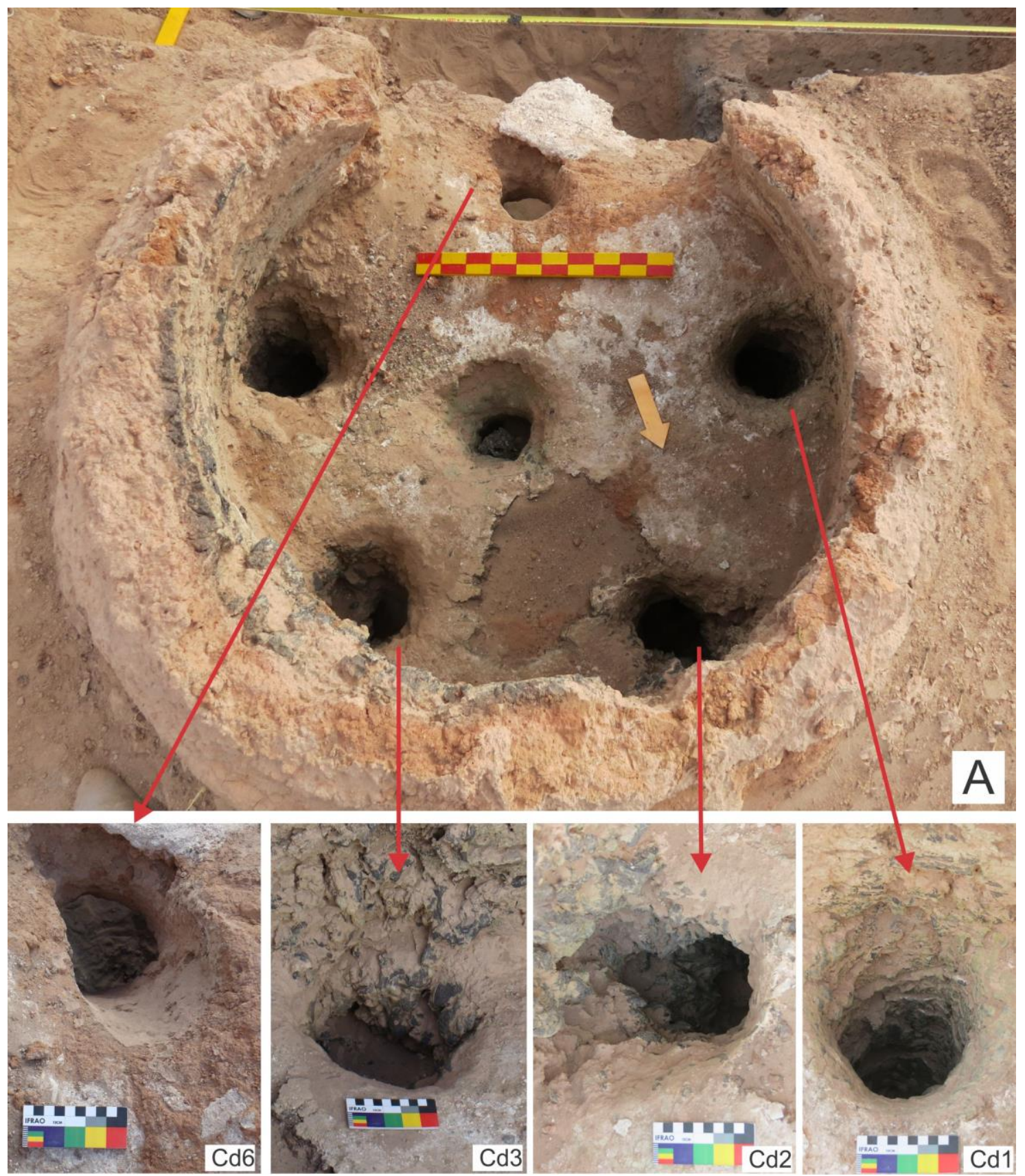

Figura 6.15. Detalles de la cámara superior y conductos del Horno 14.

\subsubsection{Horno 17}

Como se ha indicado previamente, para la excavación de este ejemplar se definió una única cuadrícula de excavación y se descendió por niveles artificiales de $10 \mathrm{~cm}$ hacia el interior de la estructura. El punto cero fue establecido en el lugar más alto del terreno adyacente al ejemplar. Hacia el interior se halló un sedimento de color marrón claro y de textura arenosa producto del relleno posdepositacional. Se registraron dos 
ecofactos líticos que remontaron en un rodado de granito. No se han recuperados vestigios culturales sueltos en el sedimento.

Hacia los $128 \mathrm{~cm}$ de profundidad desde el punto cero, se alcanzó la base de esta cámara. Allí se delimitaron una serie de conductos $\left(\mathrm{Cd} n^{\circ}\right): 4$ cilíndricos y un par de circunferencias cóncavas que insinuaban otros dos conductos. Los laterales de $\operatorname{los} \mathrm{Cd} 2$, $\mathrm{Cd} 3$ y $\mathrm{Cd} 4$ se encontraron derrumbados y atravesados por una raíz. Una vez removida, se continuó extrayendo el sedimento del interior de los conductos. Allí se registraron otras dos rocas fragmentadas, y del Cd1 se recuperaron varios carbones y dos hebras de lana color azul reconocidas en zaranda.

\section{- Morfología H17:}

En este horno se pudieron obtener datos de los siguientes componentes estructurales (ver Tabla 6.3 y Figura 6.16):

Cámara superior. También aquí se observa una base circular con un diámetro de $105 \mathrm{~cm}$, recubierta por un sedimento blanco compacto. Respecto a las paredes, la altura máxima observada fue de $74 \mathrm{~cm}$, son levemente curvas hacia el interior, presentan una superficie interna alisada y espesores de $9 \mathrm{~cm}$ que se ensanchan hacia la base.

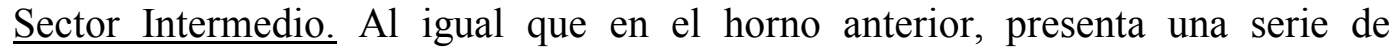
conductos que exhiben un perímetro circular y recubrimientos vítreos en sus paredes. Sus diámetros varían entre 15 y $35 \mathrm{~cm}$. Sólo en el caso de los $\mathrm{Cd} 1$ y Cd 2 se han podido calcular sus profundidades que rondan los $90 \mathrm{~cm}$, dado que los restantes se encontraron colapsados. También se pudo observar que los conductos se conectaban en un espacio abierto inferior. Incluso el Cd2 se abría hacia el N por fuera del límite de la cuadrícula. Es probable que estos espacios estén señalando la existencia de los restantes compartimientos -cámara inferior y antecámara- tal como fue observado en el H14. A diferencia de este ejemplar, dos conductos estaban sólo insinuados, la observación de restos vítreos en uno de ellos sugiere que se encontraban bloqueados (Figura 6.17). 
Capítulo 6

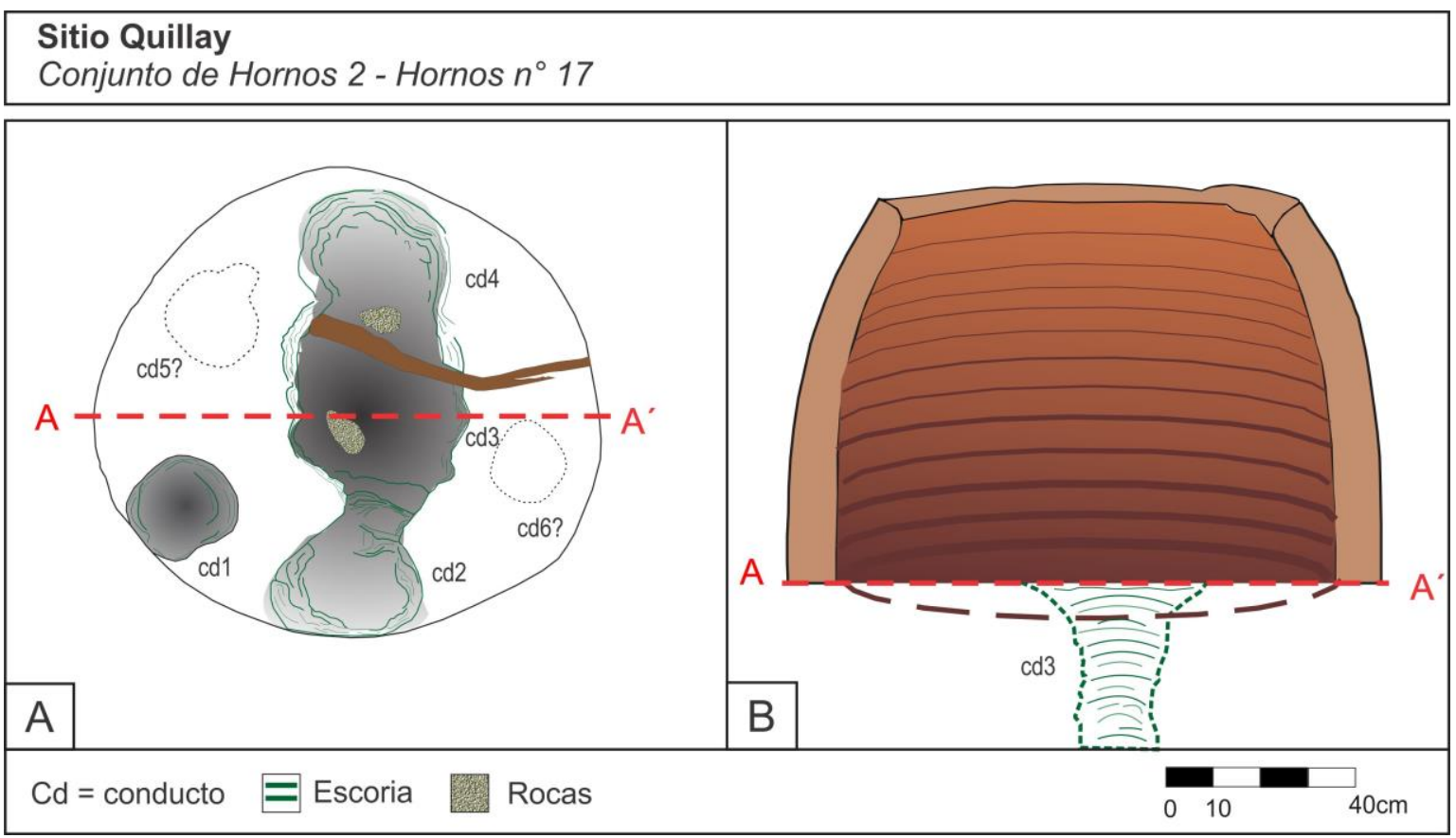

Figura 6.16. Croquis del Horno 17: A. Planta de la cámara superior; B. Corte Longitudinal de la misma cámara.

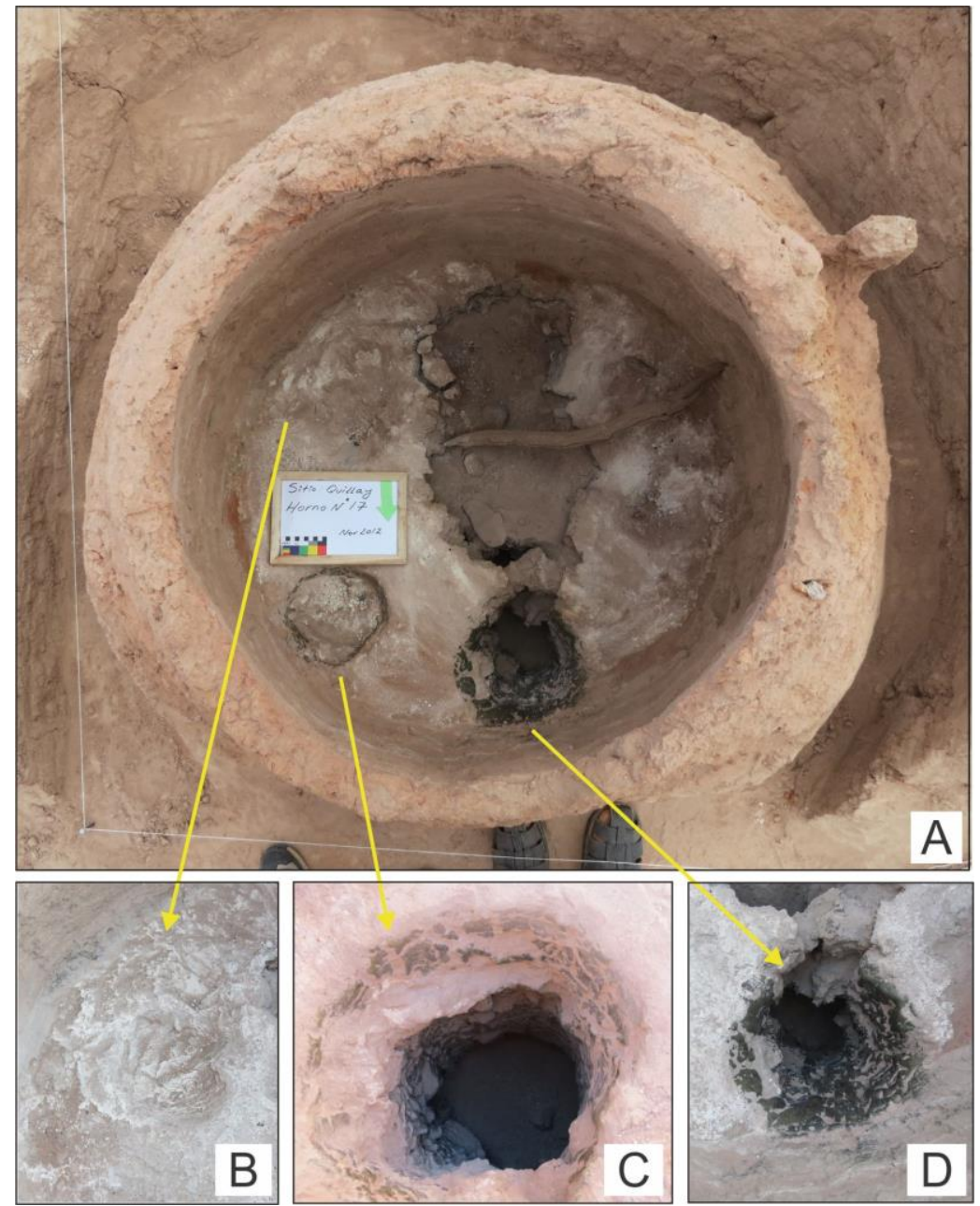

Figura 6.17. A. Cámara superior del horno 17; B. Conducto 5; C. conducto 1 ; D. conducto 2 . 


\begin{tabular}{|c|c|c|c|c|c|c|}
\hline & & & \multicolumn{4}{|c|}{ CARACTERÍSTICAS } \\
\hline \multirow{2}{*}{\multicolumn{3}{|c|}{$\begin{array}{c}\text { SEGMENTO } \\
\text { HORNO }\end{array}$}} & \multirow{3}{*}{$\begin{array}{l}\text { Forma } \\
\text { Circular }\end{array}$} & \multicolumn{3}{|c|}{ Medidas $(\mathrm{cm})$} \\
\hline & & & & \multirow{2}{*}{$\begin{array}{c}\begin{array}{c}\text { Diámetro } \\
\text { mayor }\end{array} \\
105\end{array}$} & \multirow{2}{*}{$\begin{array}{c}\text { Espesor } \\
-\end{array}$} & \multirow{2}{*}{$\begin{array}{c}\text { Altura/ } \\
\text { Profundidad } \\
-\end{array}$} \\
\hline \multirow{2}{*}{\multicolumn{2}{|c|}{ Cámara Superior }} & Base & & & & \\
\hline & & Paredes & Curvada & - & 9 & 74 \\
\hline \multirow{6}{*}{ 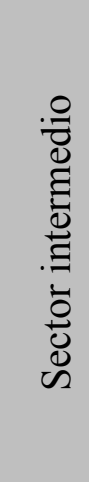 } & \multirow{6}{*}{ Conductos } & $\mathrm{Cd} 1$ & Tubular & 22 & - & 90 \\
\hline & & $\mathrm{Cd} 2$ & Tubular & 30 & - & 76 \\
\hline & & $\mathrm{Cd} 3$ & ¿Tubular? & 35 & - & $30 * *$ \\
\hline & & $\mathrm{Cd} 4$ & ¿Tubular? & 30 & - & $50 * *$ \\
\hline & & $\mathrm{Cd} 5 ?$ & $\begin{array}{l}\text { Circular- } \\
\text { cóncavo }\end{array}$ & 20 & - & 8 \\
\hline & & Cd6? & $\begin{array}{l}\text { Circular- } \\
\text { cóncavo }\end{array}$ & 15 & - & 10 \\
\hline
\end{tabular}

**indica la profundad hasta la que se pudieron extraer los derrumbes y el sedimento de relleno

Tabla 6.3. Características morfométricas del Horno 17.

\subsubsection{Horno 7}

Este horno se halló sobre el perfil de una cárcava y con un grado de destrucción avanzado (G3). Por esta razón la excavación se realizó con especial recaudo evitando el colapso de la estructura. En la cuadrícula 1 (C1), se identificó un sedimento arenoso de relleno color marrón claro y de textura laminar con unos pocos carbones aislados. Recién hacia los $60 \mathrm{~cm}$ de profundidad - desde el techo de la antecámara - se registró un estrato de sedimento blanco inclinado hacia la izquierda y de aproximadamente 10 cm de espesor (similar al observado en el H14), algunos carbones y vestigios de pared de horno (Figura 6.18.A). Este estrato comenzó a desplegarse hacia los $30 \mathrm{~cm}$, calculado desde el exterior de la antecámara. Por debajo del mismo, se registró una acumulación de cenizas y carbones que no fueron extraídos para evitar el derrumbe de la estructura. Por otro lado, en el ángulo SE de la antecámara, se identificaron vestigios de escoria adherida al techo del horno. La misma se encontraba a $60 \mathrm{~cm}$ de profundidad desde el exterior del horno (Figura 6.18.A y Figura 6.19).

En la cuadrícula 2 (C2), las paredes del horno se encontraron muy frágiles y altamente fragmentadas. Luego de removidos los bloques fraccionados de pared, el descenso de la cámara fue impedido dada la presencia de abundantes concreciones 
blanquecinas cuya remoción debilitaba aún más la estructura. Aún así, se pudieron delimitar las paredes del horno y sectores laterales que insinuaban la presencia de conductos como lo observado en los otros hornos, en este caso totalmente colapsados. Además se pudo corroborar que la escoria observada en la C1 guardó conexión con uno de estos sectores que insinuaban conductos.

- $\quad$ Morfolofía del H7:

A partir de la excavación, en este ejemplar se pudieron extraer sólo unos pocos datos morfométricos (Tabla 6.4), pero complementarios a los obtenidos en los restantes hornos excavados. En primer lugar, se subraya la existencia de una antecámara y la cámara superior con el sector intermedio, ya observada en los otros ejemplares:

Cámara superior (¿0 inicio sector intermedio?). Presenta una forma semicircular en torno a los $85 \mathrm{~cm}$ de diámetro. En base a las tres circunferencias que insinúan las paredes laterales, es probable que lo que observado sea la base de la cámara superior, la cual estaría perforada por conductos similares a los identificados en los H14 y H17 que conforman el sector intermedio. Las paredes presentan un interior quemado, vitrificado y con sectores de escoria adherida. Sus espesores varían entre 10 y $13 \mathrm{~cm}$ (Figura 6.18).

Antecámara. En vista frontal luce una forma semi-rectangular con ángulos redondeados, cuyas medidas son $62 \mathrm{~cm}$ de alto por $80 \mathrm{~cm}$ de ancho, en promedio, dado que el tamaño de la abertura aumentaba a medida que se introduce en la cámara del horno. El espesor de las paredes laterales varía entre 9 y $11 \mathrm{~cm}$ (Figura 6.17). 


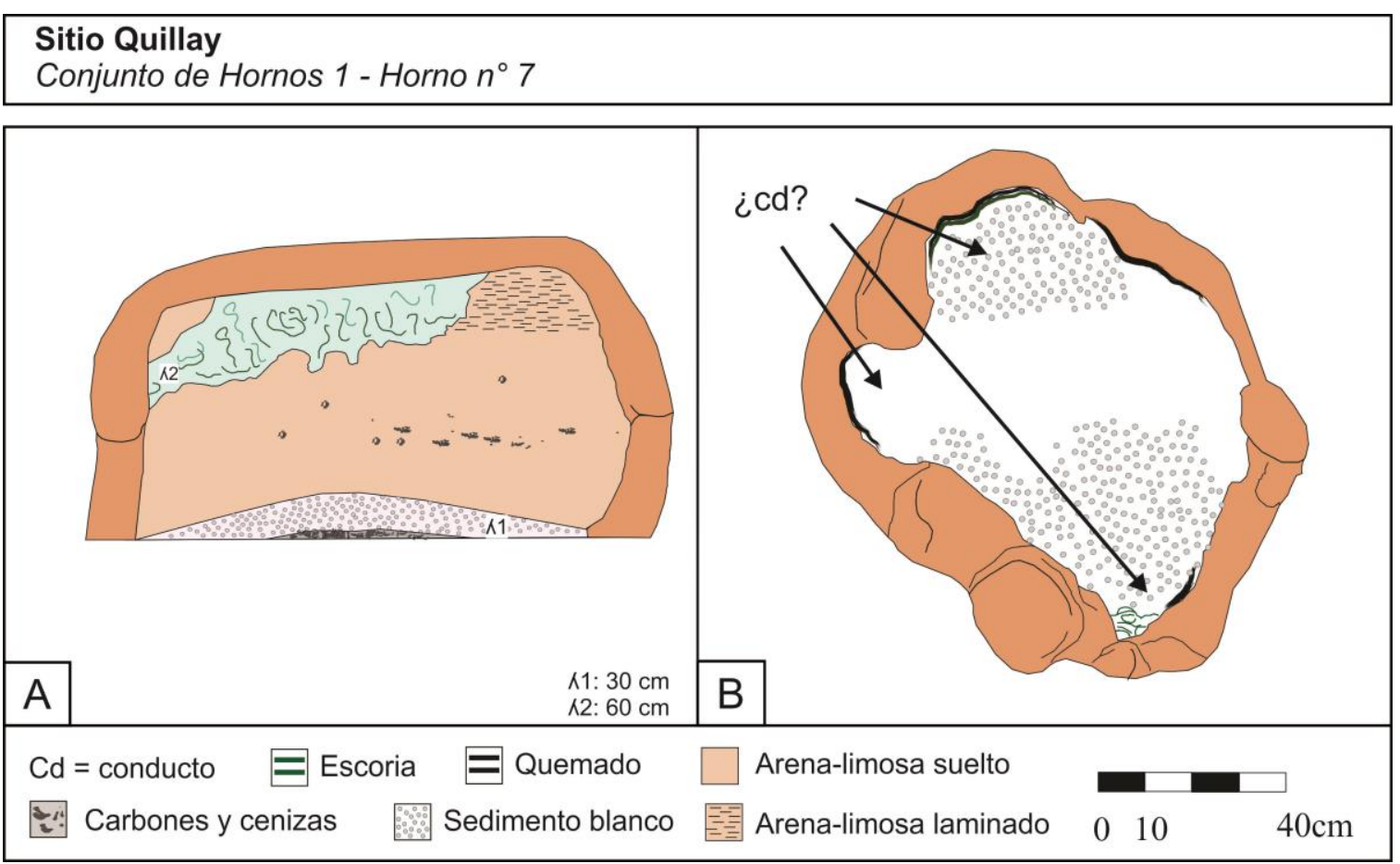

Figura 6.18. Croquis del horno 7. A. Corte longitudinal de la antecámara. B. vista en planta de la cámara superior.
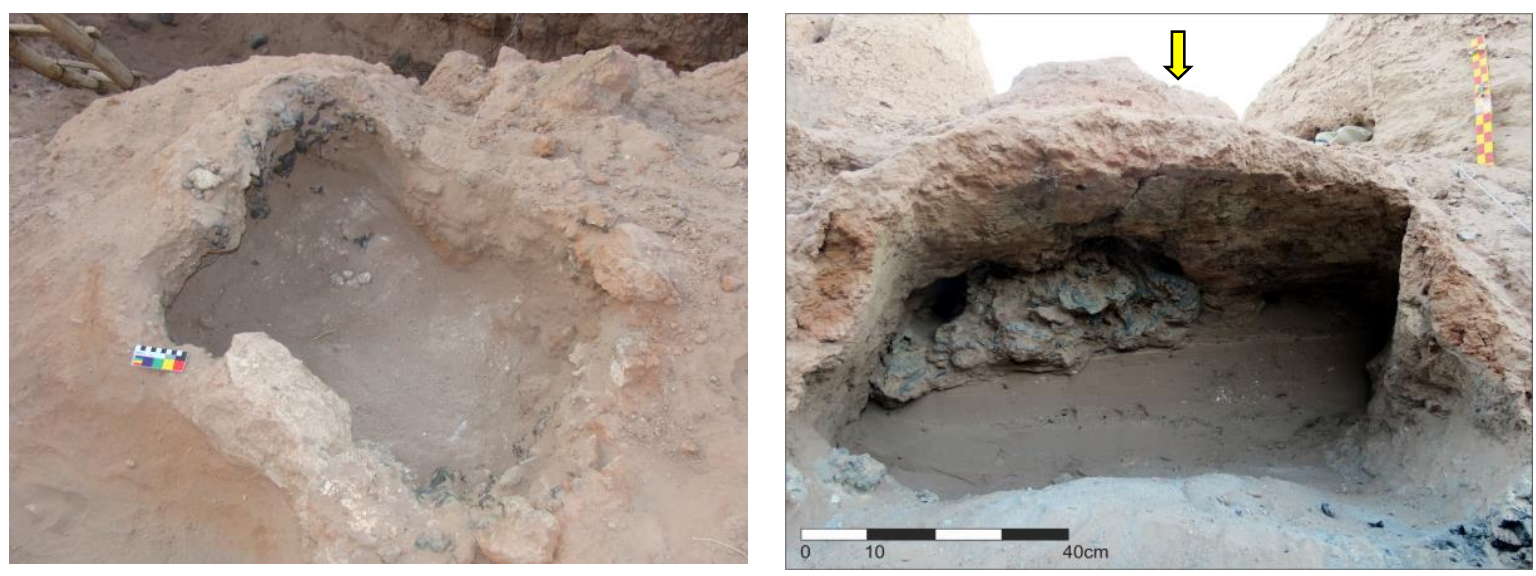

Figura 6.19. Cámara superior del Horno 17 (izquierda), antecámara (derecha) y cámara inferior al fondo (flecha).

\begin{tabular}{|c|c|c|c|c|c|}
\hline \multirow{2}{*}{$\begin{array}{c}\text { SEGMENTO } \\
\text { HORNO }\end{array}$} & \multicolumn{4}{c|}{ CARACTERÍSTICAS } \\
\cline { 3 - 6 } & Forma & \multicolumn{3}{c|}{ Medidas (cm) } \\
\cline { 3 - 6 } & & $\begin{array}{c}\text { Diámetro } \\
\text { mayor }\end{array}$ & Espesor & $\begin{array}{c}\text { Altura / } \\
\text { Profundidad }\end{array}$ \\
\hline \multirow{3}{*}{$\begin{array}{c}\text { Cámara } \\
\text { Superior }\end{array}$} & Base & Semicircular & 85 & - & - \\
\cline { 2 - 6 } & Paredes & - & - & $10-13$ & - \\
\hline \multirow{3}{*}{$\begin{array}{c}\text { Conductos } \\
\text { Antecámara }\end{array}$} & Forma & Semicirculares & $20-30$ & - & - \\
\cline { 2 - 6 } & Paredes & Curvadas & - & $9-11$ & 62 \\
\hline
\end{tabular}

Tabla 6.4. Características morfométricas del horno 7. 


\subsection{Análisis de Laboratorio}

\subsubsection{Las escorias como categoría analítica}

El término escoria se utiliza genéricamente para designar residuos que resultan de actividades pirotécnicas. En primer lugar, se pueden distinguir las escorias no metalúrgicas de las metalúrgicas según las acciones que les dan origen (Bachmann 1982). Las primeras consisten en sedimentos vitrificados producidos en diversos contextos de combustión intensificada (Mohen 1992; González 2004b). Mientras que las segundas, son desechos que resultan de múltiples y distintivas operaciones metalúrgicas (Miller y Killick 2004). Desde un punto de vista composicional, las escorias metalúrgicas son compuestos formados por silicatos complejos, óxidos de metales que suelen contener vestigios de elementos metálicos y/o inclusiones minerales (Bachmann 1982; Mohen 1992; Hauptmann 2007).

Bachmann destaca que "la formación de escorias es una parte esencial de los procesos pirometalúrgicos. Por esta razón, las escorias metalúrgicas sirven como indicadores de estos procesos" (Bachmann 1982: 3). Su formación es útil a los efectos de separar las impurezas contenidas en la materia prima procesada (ya sea mena o metal impuro) del elemento metálico deseado mediante el empleo de fundentes (González 2004b). Estos últimos, suelen ser óxidos de hierro o sílice que reaccionan con los elementos no deseados y actúan como agentes disgregantes al disminuir el punto de fusión de las impurezas. Los elementos fundentes pueden estar contenidos en la mena de origen o ser agregados intencionales durante los procesos metalúrgicos (González 2004b). Luego, bajo un modelo teórico ideal, las impurezas y fundentes - que constituyen la escoria - por su menor densidad se suspenden sobre el metal y solidifican generalmente en masas vítreas las cuales son desechadas (Hauptmann 2007).

Existen dos aspectos importantes por los cuales las escorias son de gran utilidad para el estudio de las tecnologías metalúrgicas antiguas. Por un lado, al ser productos de desecho suelen ser abundantes en el registro material de sitios arqueológicos con contextos de producción metalúrgica. Por el otro, al ser materiales que resultan de las reacciones químicas y físicas entre todos los elementos involucrados en los procedimientos técnicos, presentan en su estructura cristalina indicadores sobre la

\footnotetext{
1 “...slagging was an essential part of the pyrometallurgical process. This is the reason why metal slag serves as process indicators" (Bachmann 1982: 3)
} 
historia de su formación factibles de ser abordados por diversas técnicas arqueométricas (p. ej. análisis texturales, mineralógicos, químicos) (Bachmann 1982; González 2004; Hauptmann 2007). Mediante dichas técnicas es posible obtener información sobre los siguientes parámetros tecnológicos (Hauptmann 2007: 20):

1. Las composición de la carga (mineral/metal y fundentes);

2. Las temperaturas alcanzadas;

3. Las condiciones de óxido-reducción, relacionadas con los tipos de atmósferas;

4. Las reacciones entre los componentes de la carga.

A partir de la integración de estos datos es posible evaluar la eficacia de los procedimientos técnicos utilizados por los artesanos (Mohen 1992). En este sentido, la formación de una escoria libre del metal deseado, requiere de variados conocimientos y una gran experiencia para poder controlar aspectos como: el tipo y la proporción indicada de fundentes para lograr bajos puntos de fusión y de viscosidad; alcanzar y mantener las temperaturas de fusión necesarias; conseguir una ventilación adecuada y controlar el modo de operación a lo largo de todo el proceso (González 2004b).

El potencial informativo contenido en las escorias puede notarse en varios trabajos realizados en sitios arqueológicos del "viejo mundo" para distintos periodos temporales (p. ej. Tylecote 1979; Sáez et al. 2001; Hauptmann et al. 2003; Sáez et al. 2003; Miller y Killick 2004; Mei y Rehen 2005; Rovira 2005; Hauptmann 2007; Bourgarit et al. 2008; Moreno Onorato et al. 2010; Geogakopoulou et al. 2011). Para la región Andina, se cuenta por ejemplo con los estudios realizados por Merkel y Shimada (1988) en Perú; Cohen et al. (2008) y Lechtman et al. (2010) en Bolivia.

En Argentina, el análisis específico de escorias estuvo orientado principalmente sobre contextos coloniales. Entre ellos se encuentran los trabajos de Cabanillas et al. (1996) y Gluzman y González (2005) para escorias de cobre halladas en sitios de Catamarca. En las últimas décadas resaltan los intensos trabajos de Becerra (Becerra 2014; Becerra et al. 2011; Becerra et al. 2014a y b, entre otros) quien desarrolló un plan de trabajo continuo y sistemático para abordar el estudio de la tecnología metalúrgica de minerales de plata, incorporando el análisis de los desechos metalúrgicos registrados en 
hornos de reverbero localizados en la actual provincia de Jujuy. Sin embargo, para épocas prehispánicas, los análisis de escorias metalúgicas son escasos y en la actualidad se cuenta con datos obtenidos de análisis químicos realizados en desechos de fundición identificados en los sitios Potrero Chaquiaco en Andalgalá (Williams 1995) y en Campo de Carrizal en el valle de Hualfín (Zagorodny et al. 2015).

\subsubsection{Clasificación de las escorias metalúrgicas}

En el capítulo 3, se ha comentado sobre las distintas etapas y tareas involucradas en el proceso de producción de metales: minería, metalurgia extractiva y trabajo del metal. La metalurgia extractiva involucra una serie de operaciones que permiten obtener un metal puro factible de utilización y varios materiales de desecho, entre ellos las escorias. González (2004b) sistematizó la información disponible sobre estos desechos, distinguiendo tres tipos de escorias en función del procedimiento que le dan origen. Conjugando esta propuesta con los datos brindados previamente, se obtiene el siguiente esquema:

\section{Escorias Metalúrgicas}

\subsection{Escorias de fundición}

1.2. Escorias de refinación en crisoles

\section{Escorias no metalúrgicas o de combustión}

Este modelo clasificatorio propone una serie de características morfológicas y composicionales distintivas para cada tipo de escorias. Es por esta razón que, a partir de su análisis, es posible inferir el procedimiento tecnológico que les dieron origen. Bajo un modelo teórico general, los distintos tipos de escorias presentan las siguientes características:

Las escorias de fundición son silicatos ricos en hierro, calcio o manganeso y bajo contenido en alcalinos y fósforo (Bachmann 1982). En su estructura suelen presentar inclusiones metálicas que no tienden a superar el 4\% (Tylecote 1979) también suelen contener vestigios de los minerales procesados (Bachmann 1982). Desde un punto de vista morfológico, exhiben colores dentro de las tonalidades del negro, una porosidad moderada y mayor densidad. En función de su aspecto macroscópico, también se puede distinguir si fue una escoria drenada o solidificada in situ. En el primer caso, suelen 
presentar ondas de fluencia; en el segundo será una masa compacta cuya forma basal adquiriría aquella presente en el contenedor (González 2004b).

Las escorias de refinación son producidas por actividades de fundición secundaria de metales aún impuros, generalmente llevadas a cabo en crisoles. Consisten en materiales más livianos dado que poseen una gran porosidad y composiciones heterogéneas con mayor contenido metálico respecto a las de fundición, debido a las condiciones oxidantes (González 2004b). Composicionalmente, son escorias con bajo contenido en hierro y ricas en silicatos de aluminio y alcalinos ( $\mathrm{Na}, \mathrm{K}$, etc.) que se deben a la interacción del material líquido caliente con las arcillas del crisol y el combustible (González 2004b; Hauptmann 2007).

Las escorias de combustión son la resultante de las reacciones físico-químicas entre las cenizas del combustible y los álcalis de los sedimentos. Durante los procedimientos pirometalúrgicos, las altas temperaturas favorecen estas reacciones generando la vitrificación de materiales limo-arenosos que adquieren un color gris claro con algunas tonalidades verdosas (González 2004b).

\subsubsection{Muestreo y metodología para el estudio de escorias}

En Quillay se han detectado escorias distribuidas superficialmente en los alrededores de los hornos. Se han seleccionado muestras representativas de los conjuntos de hornos 1 y 2 por ser los más numerosos $\left(\mathrm{N}_{\mathrm{esc}}=11\right)$. Asimismo, se seleccionaron muestras registradas en la excavación de los distintos componentes estructurales de los hornos - cámara superior, inferior y conductos- y otras recuperadas en los cúmulos de desechos identificados en la cuadricula 2 del horno $n^{\circ} 14\left(\mathrm{~N}_{\mathrm{esc}}=28\right)$.

Las escorias fueron estudiadas siguiendo los lineamientos metodológicos desarrollados por Bachmann (1982), Hauptmann (2007) y Becerra et al.(2011, 2014). De esta manera, se emplearon dos escalas de abordaje:

1. Observaciones macroscópicas: con el objetivo de realizar una clasificación preliminar de todas las escorias muestreadas $\left(\mathrm{N}_{\mathrm{esc}}=39\right)$ se observó el aspecto general de cada pieza. La identificación se realizó en base a criterios morfológicos que fueron volcados en una tabla diseñada a tal fin (Tabla 13 - Anexo I). La misma posee un conjunto de variables cualitativas: forma, textura, color y magnetismo; y cuantitativas: largo, ancho, espesor (medidas máximas) y peso. Luego se determinó preliminarmente, 
el tipo de escoria a la que pertenecerían en función de las características previamente definidas.

2. Análisis microscópicos: para alcanzar una correcta identificación de las escorias se requiere conocer sus composiciones químicas y mineralógicas. Para ello se conjugaron una serie de técnicas arqueométricas:

2.1. Análisis de la estructura cristalina por microscopía óptica y electrónica. Para ello se seleccionaron 7 muestras pertenecientes al horno 14. Se priorizó analizar los desechos identificados en este ejemplar dado que se poseen datos morfológicos completos del horno y éste es un parámetro importante a la hora de evaluar la eficacia de los procesos pirometalúrgicos (Mohen 1992). Las muestras 1 y 2 (M1 y M2) fueron tomadas de los montículos de desecho de las UEA3A y B respectivamente; las M3 y M4 se recuperaron dentro de la cámara inferior del horno; la M5 de los alrededores del horno; la M6 de la cámara superior y finalmente la M7 fue extraída del interior del conducto 3 .

Las muestras fueron preparadas siguiendo los procedimientos estándares para análisis metalográfico (Scott 1991). En primer lugar, se cortaron con una máquina de disco de diamante de velocidad regulable, luego fueron desbastadas manualmente con lijas al agua de granulometría variable $(100,150,250,360,400,600,1000$ y 1200). Por último, se realizó un pulido mecánico con alúmina de 0,$5 ; 0,3 ; 0,1$ micrones.

El reconocimiento de fases cristalinas se realizó utilizando un microscopio metalográfico invertido marca Arcano a diferentes aumentos. Se observaron y registraron los distintos microconstituyentes por su forma, color y brillo, acompañados de fotografías y dibujos. Luego, las distintas fases reconocidas previamente, fueron identificadas al microscopio electrónico de barrido ambiental (ESEM) y se semicuantificaron los elementos presentes en cada fase por microanálisis de energía dispersiva de rayos $\mathrm{X}$ (EDS) y mediante mappings composicionales. Se utilizó el equipo marca FEI, modelo Quanta 200 disponible en el Laboratorio de Investigaciones de Metalurgia Física de la UNLP. Se empleó la modalidad bajo vacío y se priorizó el uso de detectores retrodispersados (BSED) $)^{2}$.

\footnotetext{
${ }^{2}$ Se priorizó la observación bajo esta modalidad (BSED) porque el detector es sensible a la presencia de elementos y mediante cambios en la coloración se revelan diferencias en las composiciones químicas de las fases.
} 
La correspondencia entre caracteres morfológicos, colorimétricos y elementos químicos es importante para la identificación de las fases, dado que existe una correlación cristalina entre estos caracteres (Hauptmann 2007). Los resultados obtenidos se compararon con las fases cristalinas reconocidas en las publicaciones científicas (Bachmann 1982; Merkel y Shimada 1988; Sáez et al. 2003; Rovira 2005; Hauptmann 2007; Moreno et al. 2010; Zori et al. 2010, entre otros) sobre escorias metalúrgicas originarias de contextos arqueológicos.

2.2. Análisis por Difracción de Rayos X por método en polvo, se efectuó con el objetivo de identificar los compuestos químicos que complementan los análisis previos. Los estudios fueron realizados en los servicios del Museo de la Plata y en el Centro de Investigaciones Geológicas (CIG-CONICET) sobre un total de tres muestras. La identificación de los compuestos se realizó utilizando programas como Pc Identify y PANalitical X'Pert High Score 2.0, e identificación manual siguiendo las características y posición (grados 20) de los picos otorgados por el diagrama y utilizando la información disponible en bases de datos de acceso on line l $^{3}$.

2.3. Análisis por Fluorescencia de Rayos X para el reconocimiento de los elementos químicos que componen la totalidad de la muestra. La misma fue realizada en el Laboratorio de Especies Cristalinas del área de Química del INTI sobre las superficies pulidas de 5 muestras. Los resultados obtenidos se volcaron en un diagrama de fases para evaluar las temperaturas alcanzadas (Bachmann 1982).

\subsubsection{El reconocimiento macroscópico de las escorias: hacia una primera clasificación}

Las escorias recuperadas en Quillay presentan un aspecto macroscópico general bastante homogéneo. Se pueden distinguir dos conjuntos en base a las observaciones realizadas (Tabla 13 - Anexo I). El primero son masas compactas y vítreas de coloración negra con tonalidades verdes y rojizas. Contienen inclusiones de sedimento calcáreo y granos de cuarzo termoalterado. El segundo grupo, son cuerpos grisáceos con cenizas y sedimento blanco. Son resistentes a la compresión y tienen una alta porosidad que le otorga al cuerpo un aspecto espumoso.

\footnotetext{
${ }^{3}$ www.mindat.org; www.webmineral.com; www.mincryst.com
} 
Respecto a las dimensiones y formas. Dentro del primer conjunto se cuenta con escorias de masas de grandes volúmenes y textura fluida. Poseen dimensiones variables que van de 10 a $30 \mathrm{~cm}$ de largo y 7 a $18 \mathrm{~cm}$ de ancho, con pesos que oscilan entre $250 \mathrm{y}$ 2700 gr. Otro conjunto presenta tamaños menores de entre 5 y $10 \mathrm{~cm}$ de largo y 4 a 7 de ancho, con pesos que varían entre 100 y 300 gr.

Respecto a su forma, sólo una muestra posee un aspecto plano-cóncavo con poros alargados en sentido longitudinal. Esta masa está adherida a un segmento de pared de horno, lo que conduce a hipotetizar que formó parte de uno de sus componentes, posiblemente un conducto dada su curvatura (Figura 6.20). Segmentos similares han sido observados en las inmediaciones de los hornos, presentan curvaturas y paredes con cambios graduales en la coloración que indican gradientes térmicos, vitrificaciones y adherencias de escorias con aspecto fluido (Figura 6.21).

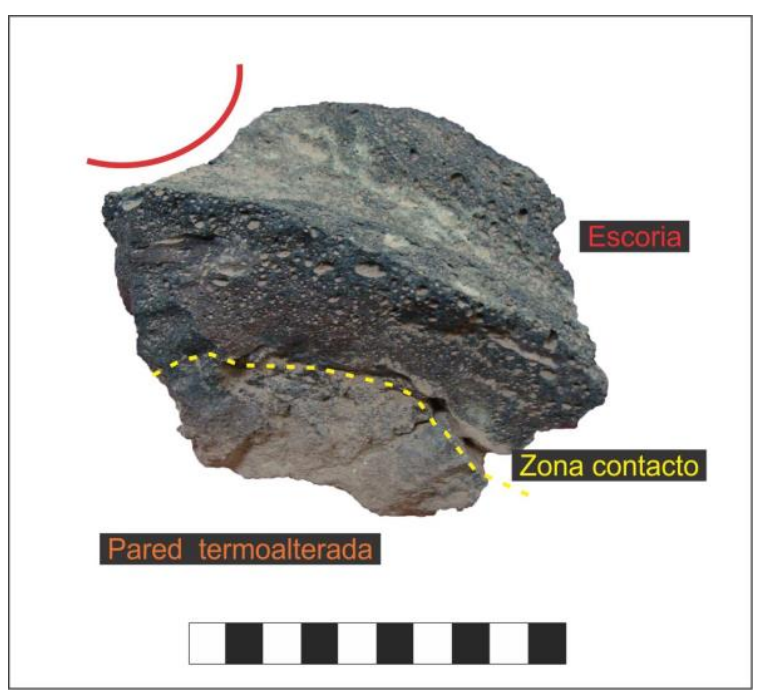

Figura 6.20. Escoria fluida adherida a pared de horno del conjunto 2 .

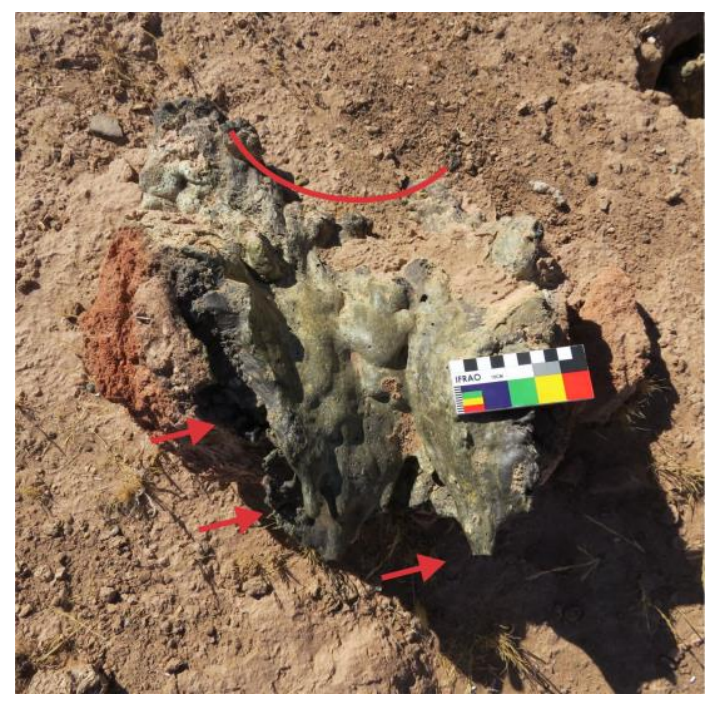

Figura 6.21. Escoria fluida adherida a pared de horno, hallada adyacente al H7. $\mathrm{Su}$ curvatura señala su posible correspondencia con un conducto.

Las restantes escorias son masas con aspecto irregular de textura fluida (Figura 6.22). En ellas se observan ondas cuyos pliegues que señalan el deslizamiento de la materia. Las ondas inferiores presentan algunos poros y adherencias de sedimentos quemados. En las ondas superiores, la coloración de los óxidos evidencia el sentido de flujo y en sus fracturas se observa mayor proporción de poros, compatible con la eliminación de gases. También se ha observado que las masas de volúmenes menores 
son las que presentan forma de estalactita y una mayor porosidad en los segmentos más externos.

Teniendo en cuenta estas características (ver detalles en tabla 13- Anexo I), en la tabla 6.5 se sintetiza la clasificación de las escorias muestreadas en el sitio, donde un $84,6 \%$ han sido reconocidas como escorias de metalúrgicas $(84,6 \%)$ y un $15,4 \%$ como escorias de combustión.

\begin{tabular}{|c|c|c|c|c|c|c|}
\hline \multicolumn{2}{|c|}{ CLASIFICACIÓN } & \multicolumn{2}{c|}{ CH1 } & \multicolumn{2}{c|}{ CH2 } & \multirow{2}{*}{ TOTAL } \\
\cline { 3 - 7 } \multicolumn{2}{|c|}{} & Sup. & Exc. (H7) & Sup. & Exc. (H14) & \\
\hline \multirow{2}{*}{ Escorias de metalúrgicas } & Drenada & 3 & 3 & 5 & 19 & $\mathbf{3 0}$ \\
\cline { 2 - 7 } & Plana & 0 & 0 & 1 & 2 & $\mathbf{3}$ \\
\hline \multicolumn{2}{|c|}{ Escorias de combustión } & 0 & 2 & 1 & 3 & $\mathbf{6}$ \\
\hline \multicolumn{2}{|c|}{ Total } & $\mathbf{3}$ & $\mathbf{5}$ & $\mathbf{7}$ & $\mathbf{2 4}$ & $\mathbf{3 9}$ \\
\hline
\end{tabular}

Tabla 6.5. Caracterización macroscópica de escorias

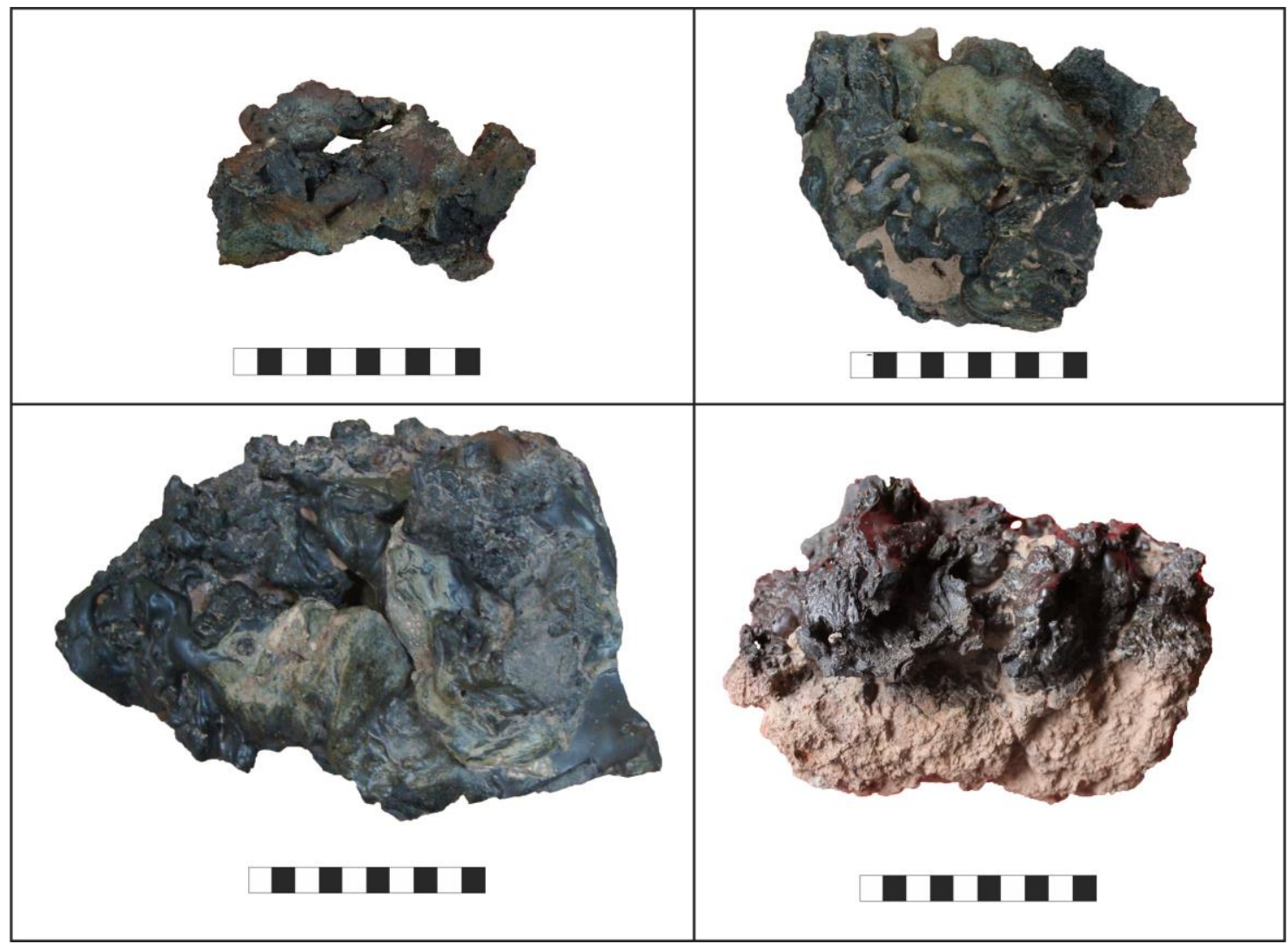

Figura 6.22. Escorias metalúrgicas de diversos tamaños, fluidas y adherida a pared (inferiorderecha). La escala representa $10 \mathrm{~cm}$ total (1:1). 
Por ultimo, quisiéramos hacer mención sobre otro tipo material identificado que, si bien no se ajusta a la definición estricta de escoria metalúrgica, son desechos producto de las actividades metalúrgicas. Consisten en masas no vítreas que presentan un conglomerado de material calcáreo de forma tubular y zonas aplanadas con pliegues, similar a una toba caliza, con signos de termoalteración (Figura 6.23). Han sido recuperadas en abundancia durante la excavación del horno 14, tanto en el interior del ejemplar, como por fuera del mismo formando parte de los depósitos de la UEA2 y de la UEA3A y B.

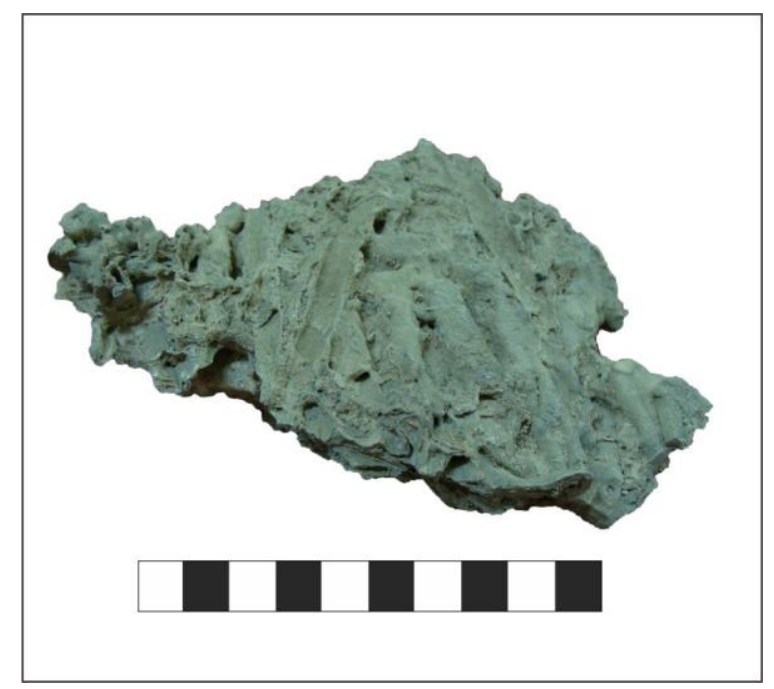

Figura 6.23. Desecho de material calcáreo.

\subsubsection{Características químicas y microestructurales de las escorias metalúrgicas}

\subsection{Limitantes en la identificación de fases y criterios adoptados}

Las escorias metalúrgicas registradas en el sitio son masas de grandes dimensiones. Esta característica dificultó su estudio dado que los equipos de análisis utilizados tienen límites en el tamaño de la muestra, la cual no debe superar los $5 \mathrm{~cm}$ en diámetro o altura. Por lo tanto, para muestras externamente homogéneas, se seleccionaron para el corte sectores que presentaron coloraciones rojizas y verdes, dado que tradicionalmente se consideran estos reflejos como indicadores de la oxidación del cobre (Bachmann 1982, Hauptmann 2007). Otro punto crítico fue la observación al microscopio de luz reflejada, cuyos aumentos máximos (1000X) no permitieron 
reconocer fácilmente fases metálicas. Éstas sólo fueron reconocidas al MEB a aumentos mayores a 5000X y durante el proceso fue dificultoso distinguirlas de aquellas con titanio o calcio, volviendo costoso su estudio.

Otra dificultad se registró en la identificación de las composiciones de las fases cristalinas. Sucedió que los espectros EDS, siempre detectaron las matrices ricas en silicatos y aluminios. Esto se debe a que los rayos $\mathrm{X}$ que excitan el material para la emisión y lectura de los electrones, tienen una gran capacidad de penetración y suelen afectar zonas próximas no buscadas, referidas tanto a fases adyacentes como inferiores (Becerra et al. 2011). Se buscó limpiar el ruido en ventanas con aumentos de hasta 20000 X, luego de lo cual las muestras se cargaban imposibilitando la observación. Incluso, para volver las muestras conductoras, se probó metalizando con carbono las superficies, pero el material de grafito reaccionó fracturándose impidiendo también la observación.

En este sentido, se aclara que la presencia constante de $\mathrm{Si}, \mathrm{Al}, \mathrm{K}, \mathrm{Na}$ y $\mathrm{Ca}$ en las fases cristalinas puede estar indicando la excitación de la matriz, rica en estos componentes. Por lo tanto, para la identificación de fases se priorizaron las formas que adquirían las estructuras cristalinas, sus colores y las composiciones elementales mayoritarias, así como los elementos detectados únicamente en ciertas fases. Estos datos en conjunto fueron comparados con las fases reconocidas por otros autores (Bachmann 1982; Sáez et al. 2003; Hauptmann 2007; entre otros) según los mismos parámetros para, finalmente, cotejar su correspondencia composicional con los datos obtenidos por DRX.

\subsection{Resultados del análisis por microscopía óptica y electrónica}

Las observaciones por microscopía óptica permitieron reconocer un conjunto de fases cristalinas insertas en una matriz vítrea. Se diferenciaron siete fases principales, cuyas características se detallan en la tabla 6.6. Presentan formas variables que van desde los nódulos y glóbulos hasta granos hexagonales, placas alargadas y aciculares. Las coloraciones fluctuaron desde el blanco mate a brillante y otras en distintos tonos de grises (Figura 6.24). 


\begin{tabular}{|c|c|c|}
\hline Fases & Características microestructurales & Muestra \\
\hline Fase 1 & Placas aciculares de color gris claro & M1 a M7 \\
\hline Fase 2 & $\begin{array}{l}\text { Placas tubulares largas, cuadrangulares o romboidales } \\
\text { de color gris claro y medio }\end{array}$ & M1 a M7 \\
\hline Fase 3 & $\begin{array}{l}\text { Pequeños glóbulos blancos brillantes diseminados por la } \\
\text { matriz }\end{array}$ & $\begin{array}{l}\text { M1, } \\
\text { M7 }\end{array}$ \\
\hline Fase 4 & $\begin{array}{l}\text { Granos blancos de formas irregulares: hexagonales, } \\
\text { cuadrangulares o tubulares }\end{array}$ & M1 a M6 \\
\hline Fase 5 & $\begin{array}{l}\text { Granos blancos brillantes agrupados con aspecto } \\
\text { "grumoso" }\end{array}$ & M1 a M7 \\
\hline Fase 6 & $\begin{array}{l}\text { Granos blancos de formas irregulares con brillo } \\
\text { metálico y hábito planar }\end{array}$ & $\begin{array}{l}\text { M3 } \\
\text { M5 }\end{array}$ \\
\hline Fase 7 & $\begin{array}{l}\text { Granos grandes irregulares color gris oscuro a negro. } \\
\text { Presentan bordes redondeados }\end{array}$ & M1 a M7 \\
\hline
\end{tabular}

Tabla 6.6. Características de las estructuras cristalinas identificadas en las escorias.

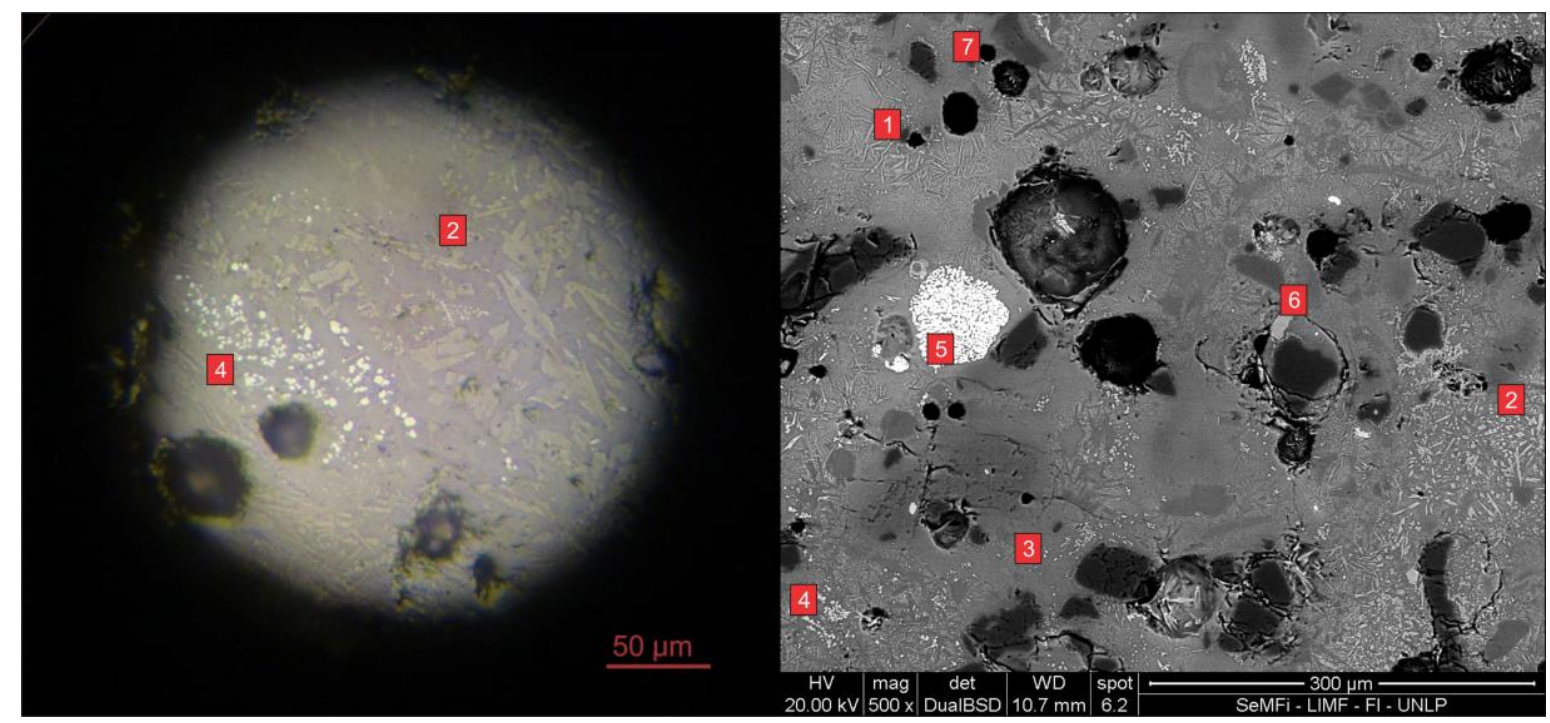

Figura 6.24. Fotografías de las Fases reconocidas ópticamente (en rojo). A la izquierda fotografía obtenida del microscopio metalográfico. A la derecha imagen MEB. Ambas corresponden a la M1

Respecto a las matrices de las escorias, en todas las muestras se detectaron composiciones similares (ver tabla 14 -Anexo I). Presentan alto contenido en Si (entre 32 y $55 \%$ w), $\mathrm{Al}($ entre 9 y $18 \%$ w) y Fe (entre 4 y $19 \%$ w) y bajo en $\mathrm{Mg}, \mathrm{Na}, \mathrm{K}$ y $\mathrm{Ca}$ $(>4 \% \mathrm{w})$. Las fases distinguidas ópticamente, presentaron los siguientes elementos espectrales:

$>$ Fase 1. Corresponde a los microconstituyentes de formas aciculares y de color gris claro. Sus espectros indicaron un alto contenido Si (entre 30 y $54 \% w$ ), Al (entre 7 
y $11 \%$ w) y Fe (entre 4 y $20 \%$ w) junto a proporciones menores de $\mathrm{Mg}, \mathrm{Ca}, \mathrm{K}, \mathrm{y} \mathrm{Na}(<5$ \%w) (Figura 6.25). En algunos espectros obtenidos en las muestras M4, M5 y M7, los valores de $\mathrm{Mg}$ fueron mayores (entre $7 \% \mathrm{w}$ y $10 \% \mathrm{w}$ ) y en otras dos -M1 y M7- el Ca superó el 6 \%w. En ambas situaciones alcanzaron valores equiparables a los de Fe y Al.

Teniendo en cuenta las investigaciones consultadas de estudios de antiguas escorias metalúrgicas, las formaciones cristalinas de placas alargadas o aciculares grises han sido identificadas como clinopiroxenos y plagioclasas (Sáez et al. 2003: 632; Bourgarit et al. 2008: 6) En el primer caso, estos compuestos pertenecen a la familia de los piroxenos bajo la fórmula general de $\left(\mathrm{Si}_{2} \mathrm{O}_{6}\right) \mathrm{XY}$, dónde los cationes " $\mathrm{X}$ ” pueden ser Ca o Na y los "Y" Fe, Mg, Al o Ti (Klein y Hulrbut 1996). Las plagioclasas pertenecen al grupo de los feldespatos, es decir silicatos de $\mathrm{Al}$ con $\mathrm{K}$, Na y Ca. Como se verá más adelante, los análisis por DRX han permitido reconocer estos compuestos.
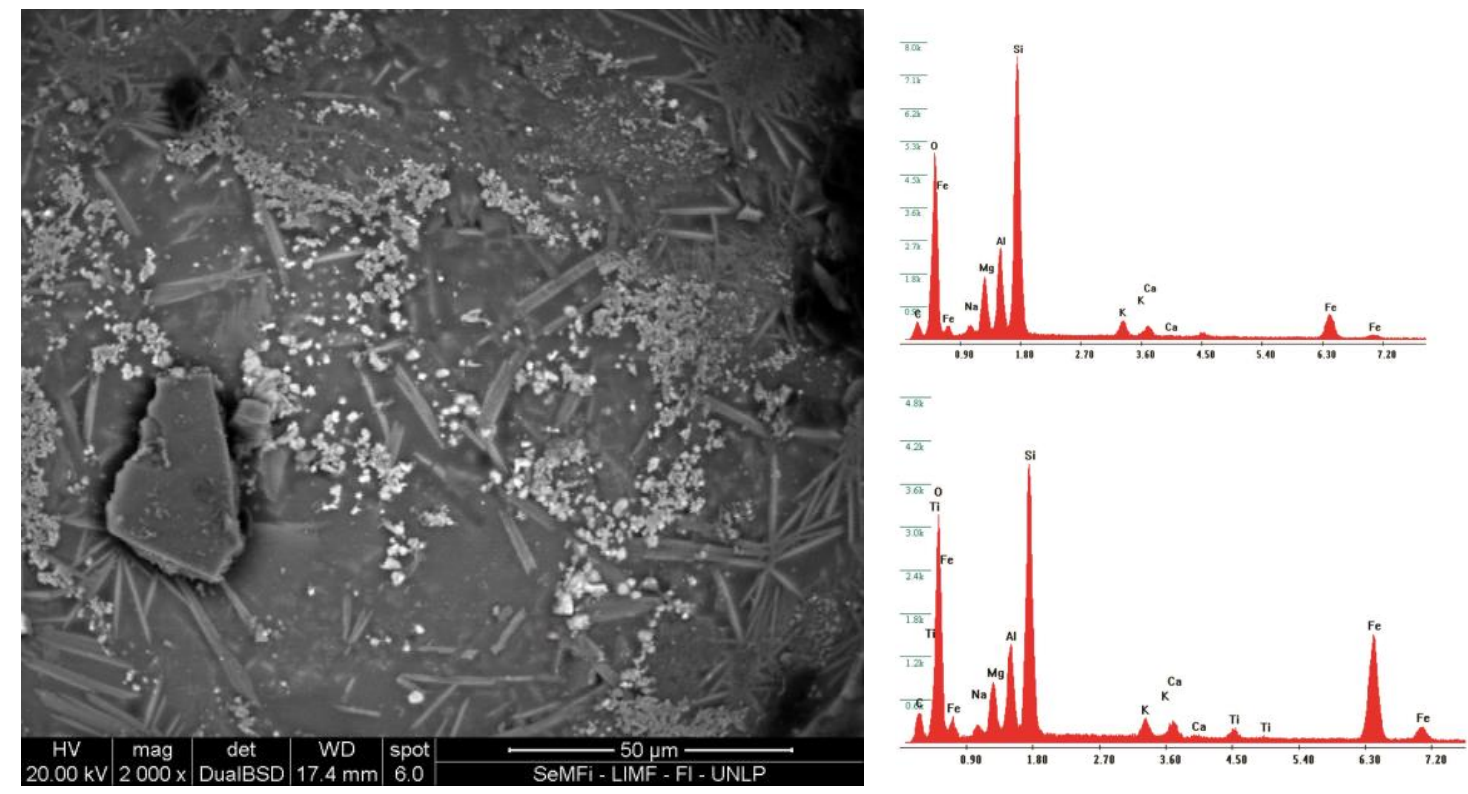

Figura 6.25. Imagen MEB de la Fase 1 (placas aciculares alargadas) y espectros obtenidos en ellas. Corresponden a la M2

Fase 2. Estas inclusiones cristalinas presentan formas variadas: cuadrangulares, tubulares o hexagonales, lo que condujo a separarla de la anterior. Sin embargo, en la mayoría de los casos, los espectros presentaron los mismos elementos constituyentes, aunque con mayores proporciones de magnesio. Los análisis semicuantitativos mostraron contenidos elevados de Si (e/30 y 68 \%w), Fe (10 y $20 \%)$, Al (e/6 y $11 \%$ w) 
y $\mathrm{Mg}(\mathrm{e} / 1$ y $10 \%$ ) (Figura 6.26). De esta manera también constituyen ferrosilicatos complejos de la serie de piroxenos. Sin embargo, algunas de las estructuras cristalinas de este tipo, exhibieron espectros con una significativa variación en la proporción de titanio. Así, en los microconstituyentes de la M1 y M7, el Ti alcanzo composiciones entre un 22 y $33 \% \mathrm{w}$, es decir posiblemente correspondan a compuestos de ferrosilicatos de titanio.

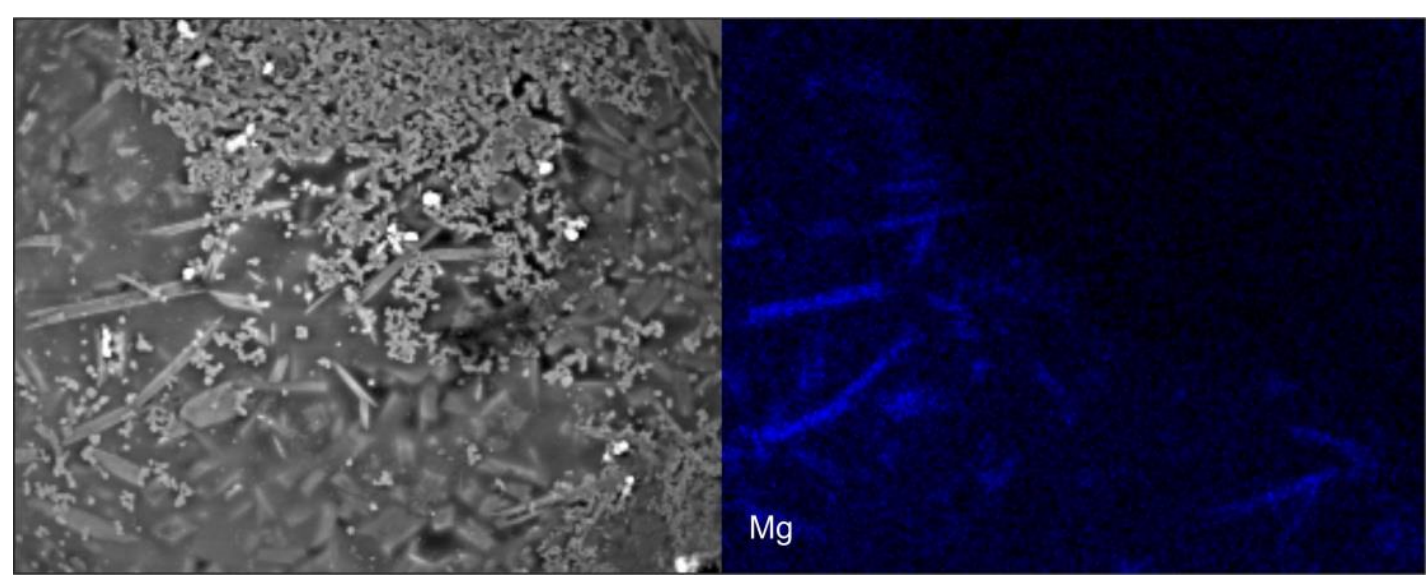

Figura 6.26. Imagen MEB (4000X) y mapping composicional de Mg. En azul se observa sectores donde hay mayor contenido de este elemento. Se observa que coincide con formas aciculares (fase 1) y cuadrangulares (fase 2).

$>$ Fase 3. Las inclusiones blancas globulares se observaron diseminadas por las matrices de las escorias de la M1, M3 y M7. Como consistían en fases de muy pequeñas dimensiones se analizaron por EDS utilizando ventanas de hasta $20.000 \mathrm{X}$. Es importante destacar que las inclusiones de este tipo fueron las únicas que presentaron elementos de cobre $(\mathrm{Cu})$. Sobre la base de los otros elementos asociados, se pudieron distinguir tres grupos composicionales de inclusiones metálicas:

3. A. Glóbulos con composiciones mayoritarias de Fe (entre 8 y $26 \%$ w) y Cu (entre 5 y $26 \% \mathrm{w}$ ), junto a elementos minoritarios de las matrices. Inclusiones de este tipo fueron reconocidas en la M3. Indican la presencia de óxidos de cobre y hierro, posiblemente delafosita.

3. B. Sulfuros de cobre con contenidos mayoritarios de $\mathrm{Cu}$ (entre 8 y $34 \% \mathrm{w}$ ), Fe (entre 12 y $29 \% \mathrm{w})$ y S (entre 3 y $15 \% \mathrm{w})$, junto a Si (18\%w en promedio) y Al (6\%w en promedio). Estas fases globulares o poliédricas fueron identificadas en la M1 y M3, pero en ésta última fueron más abundantes. Además, en la M3 se observó que algunos 
de los glóbulos blancos se encontraban distribuidos en sectores específicos y agrupados en especies de "burbujas" (Figura 6.27 y 6.28).
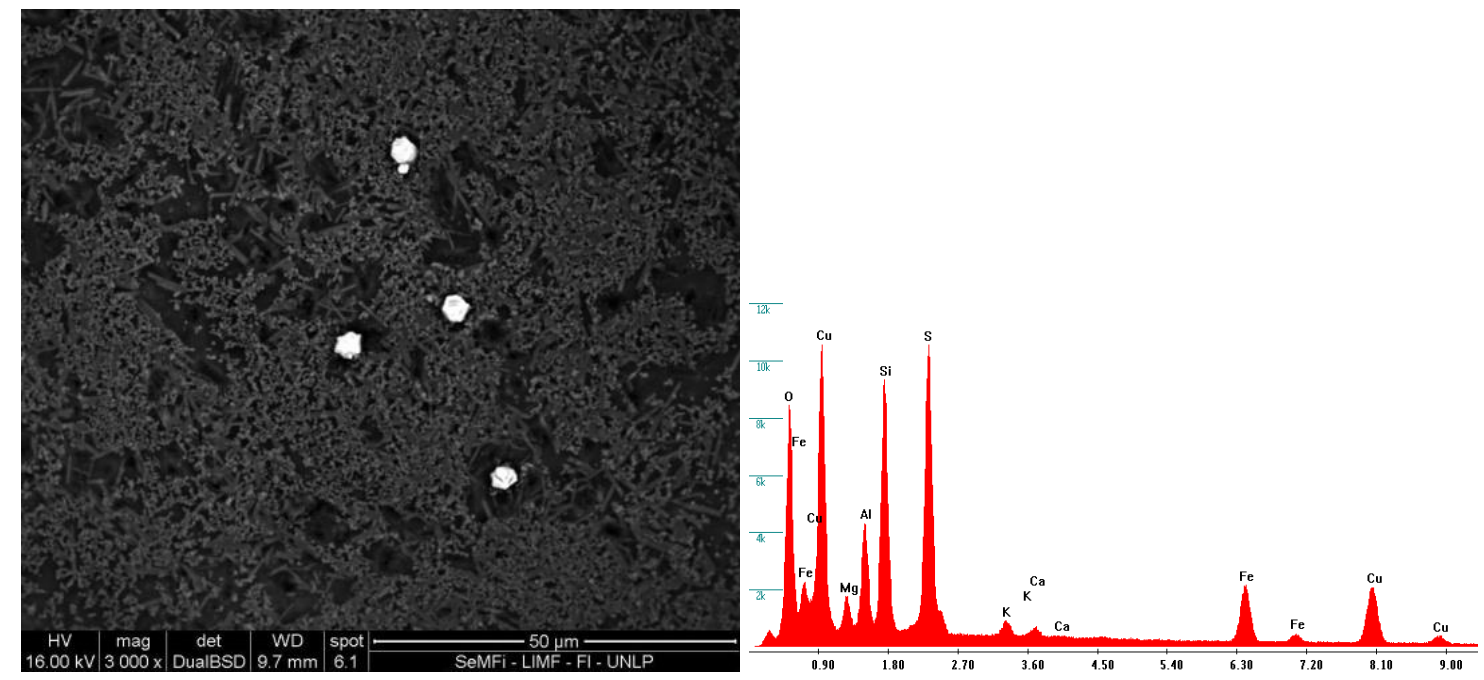

Figura 6.27. A la izquierda se observa imagen MEB con detalle de la fase 3B. A la derecha el espectro correspondiente que indica la presencia de cobre y azufre. Corresponden a la M1.

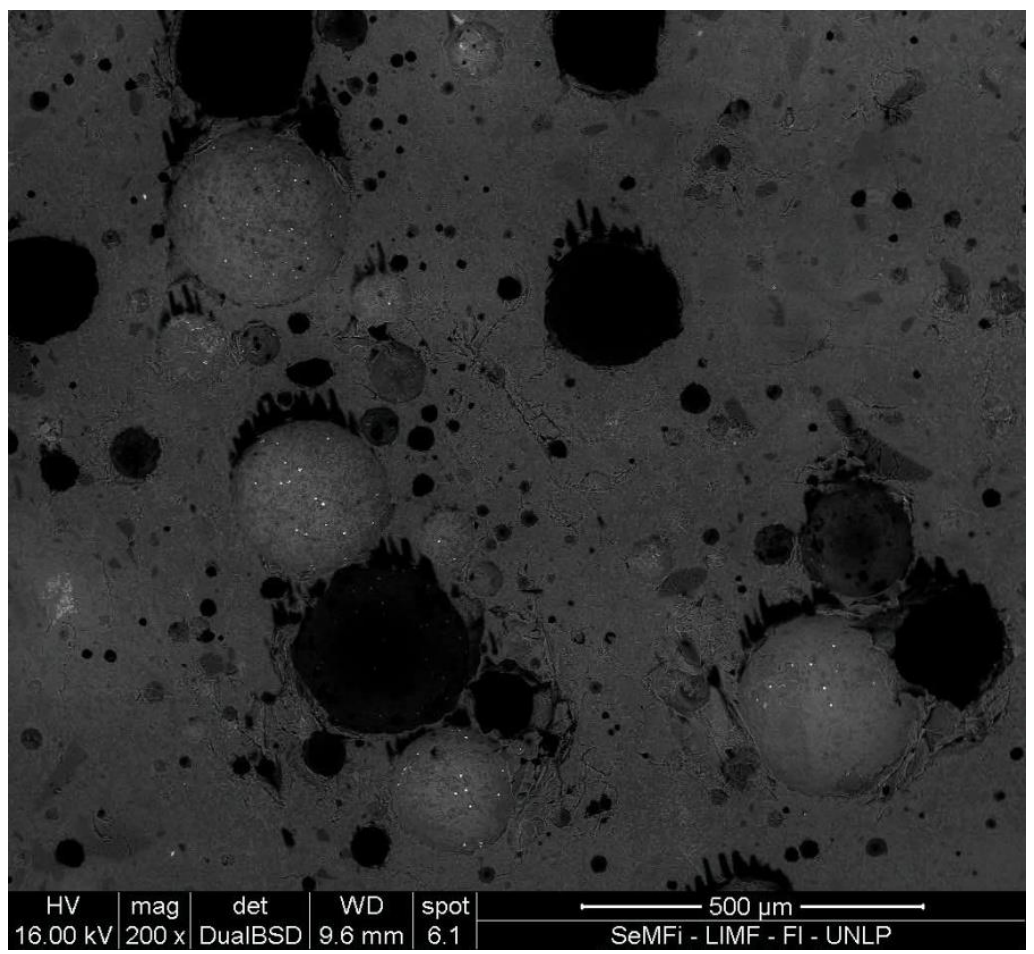

Figura 6.28. Imagen MEB a bajos aumentos (200X). Se observan fases globulares blancas contenidas en especies de "burbujas". Corresponden a la M3. 
Para evaluar la asociación del cobre $(\mathrm{Cu})$ con el azufre $(\mathrm{S})$ y el hierro $(\mathrm{Fe})$, así como su distribución en la superficie de la muestra, se empleó la técnica de mappings composicionales. Para ello se marcaron ventanas con aumentos de $4000 \mathrm{X}$ en dos sectores: 1) dentro de una de las "burbujas"; 2) en la zona por fuera de ellas. Esta técnica asigna un color diferente a cada elemento e identifica su distribución y concentración mediante cambios en la intensidad del color (Kang et al. 2013). Así, se obtiene una imagen que muestra varios puntos EDS, cuando éstos son más brillantes indican que el elemento se encuentra con una alta concentración en ese sector.

La figura 6.29 muestra el mapa de espectros obtenido en el sector 1. Allí se observa la asociación estrecha entre el $\mathrm{Cu}-\mathrm{Fe}-\mathrm{S}$ en las fases globulares blancas y su distribución por dentro de la esfera, detectando también la asociación en otras inclusiones por fuera de la misma. La figura 6.30 muestra el mapa composicional del segundo sector. Allí se pueden distinguir fases globulares con $\mathrm{Cu}-\mathrm{S}-\mathrm{Fe}$ y otros que presentan únicamente elementos de $\mathrm{Cu}-\mathrm{Fe}$ (fase 3.A).

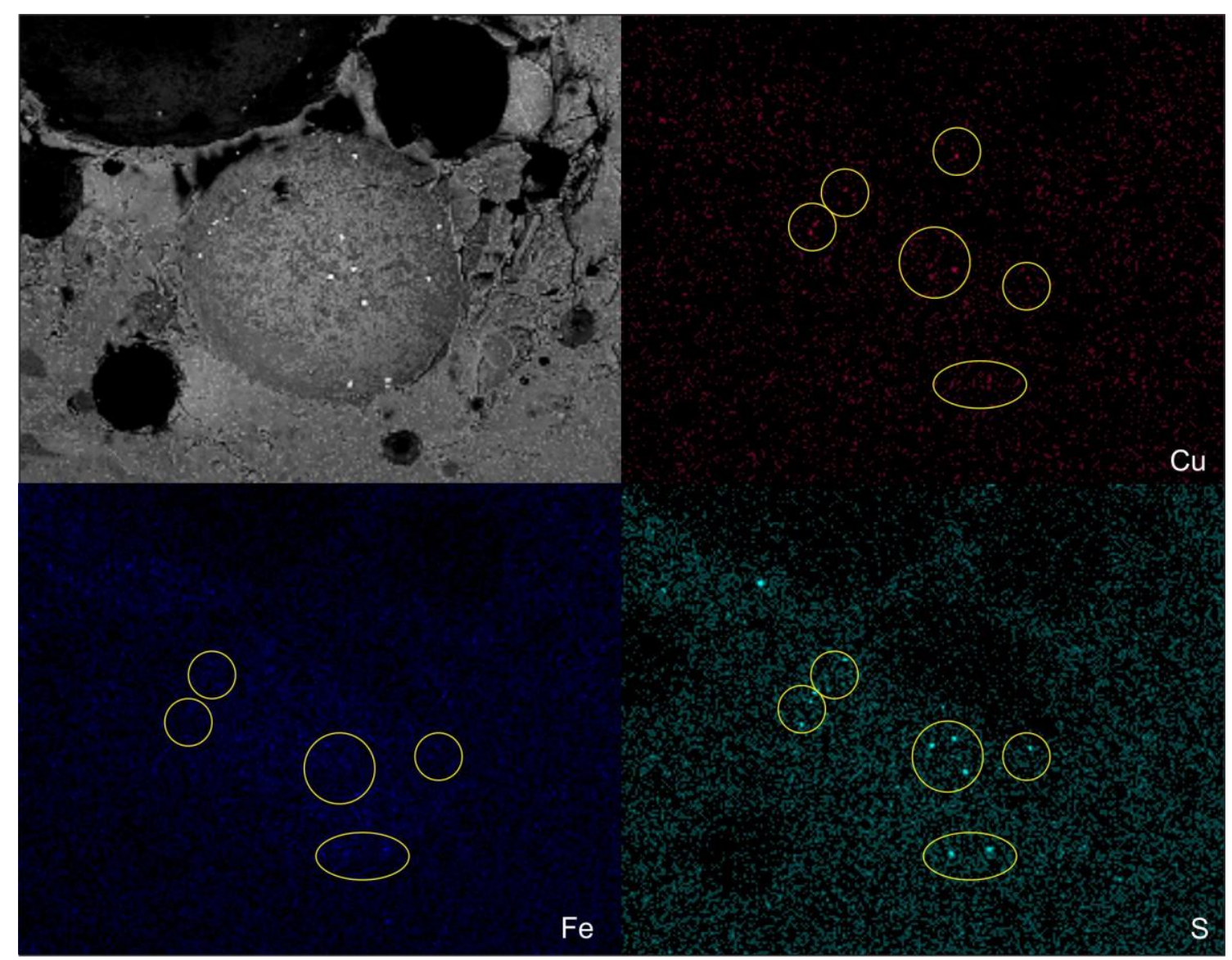

Figura 6.29. Mapping composicional para elementos de cobre (Cu-rojo); azufre (S-celeste) y hierro (Fe-azul). Se observa la correspondencia entre los tres elementos para las fases globulares en los puntos más brillantes para cada color (señalados con círculos) 


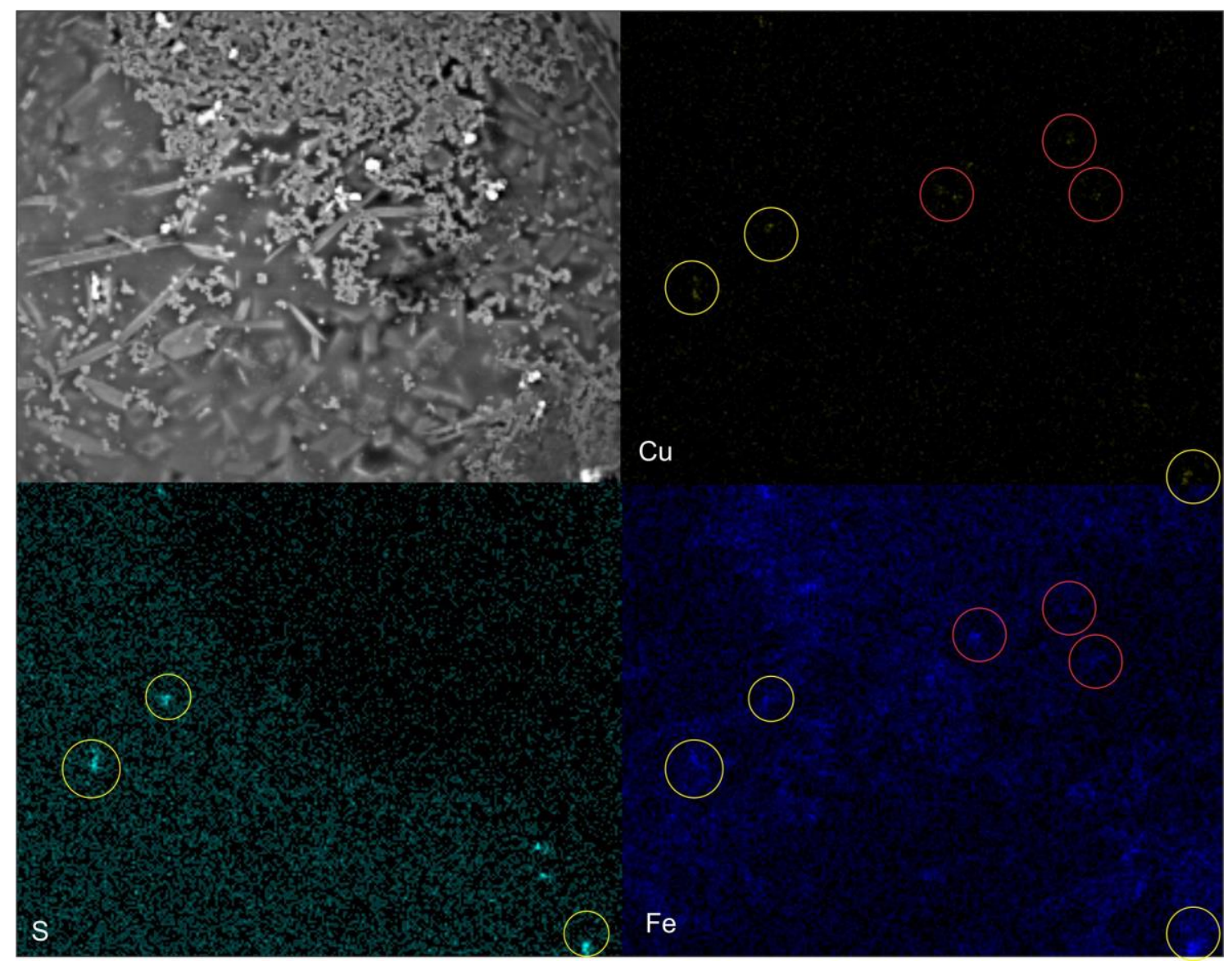

Figura 6.30. Mapping composicional para elementos de cobre (Cu-rojo); azufre (S-celeste) y hierro (Fe-azul). Se observa la correspondencia entre los tres elementos para las fases globulares blancas (círculos amarillos) y en otros la asociación $\mathrm{Cu}-\mathrm{Fe}$ (círculos rojos)

3. C. Glóbulos plúmbicos (e/15 y $17 \%$ w) con muy bajos contenidos de $\mathrm{Cu}(0,2-0,4$ $\% \mathrm{w})$, estos elementos se presentan junto a $\mathrm{Si}(\mathrm{e} / 25$ y $32 \% \mathrm{w}), \mathrm{Al}(\mathrm{ca} .9 \% \mathrm{w}$ ) y Fe (ca. 4 $\%$ w). Fases de este tipo fueron identificados únicamente en la M7.

$>\quad$ Fase 4. Está conformada por un conjunto de granos de color blanco y de formas irregulares: hexagonales, cuadrangulares o prismáticos (Figura 6.31). Generalmente se encuentran agrupados entre sí y distribuidos en amplios sectores de las matrices. A diferencia de las restantes fases, aquí los espectros obtenidos indican que el elemento mayoritario es el Fe (entre un 23 y $45 \% \mathrm{w}$ ) junto al Si (21\%w en promedio). Como elementos minoritarios se registraron $\mathrm{Al}, \mathrm{Ca}, \mathrm{Mg}, \mathrm{K}, \mathrm{Na}$ y $\mathrm{Ti}$ (correspondientes a las matrices). Sólo en dos espectros tomados de las M3 y M5, el porcentaje de Ti alcanzó un valor cercano el $14 \% \mathrm{~W}$. 
Se pueden seguir dos razonamientos para identificar estos compuestos. Por un lado, la presencia de Fe junto a Si conduciría a reconocer estas fases dentro del grupo de los olivinos, por ejemplo, fayalita. Compuesto considerado como uno de los más representados en las escorias de fundición (Bachmann 1982). Sin embargo, en las escorias de cobre este silicato de hierro suele presentarse en formas cristalinas de placas alargadas de color gris claro (Bachmann 1982: Placa IIIb; Sáez et al. 2001: Figura 6; Moreno et al. 2010: Figura 10) y sólo en algunos casos arqueológicos se han detectado como granos irregulares (Sáez et al. 2003: Figura 3D; Bourgarit et al. 2008: Figura 9a). Las muestras aquí presentadas si bien de morfologías similares, presentan coloración blanca, por lo tanto, no es claro que este sea el caso. Otra posibilidad es que la abundancia de Si se deba a que las lecturas hayan detectado las matrices y que en realidad estemos ante la presencia de óxidos de hierro ${ }^{4}$ como la magnetita.

En la bibliografía consultada, la magnetita suele adquirir formas poliédricas o esqueletales con coloraciones blancas como las observadas en las muestras de Quillay (ver Sáez et al. 2003: Figura 3C y 3D; Rovira 2005: Figura 6; Hauptmann 2007: Figura 6.9; Moreno et al. 2010: Figura 12). La semejanzas morfológicas, colorimétricas y composicionales conducen a pensar que es más probable que correspondan a magnetitas, pero es necesario complementar estos análisis con otras técnicas que permitan discriminar entre estos compuestos ya que indican condiciones redox opuestas. Como veremos más adelante fue posible diferenciarlos gracias a la técnica de difractometría.

\footnotetext{
${ }^{4}$ El oxigeno fue detectado en los espectros de todas las fases al ser uno de los elementos constituyente tanto de óxidos como de silicatos
} 
Capítulo 6

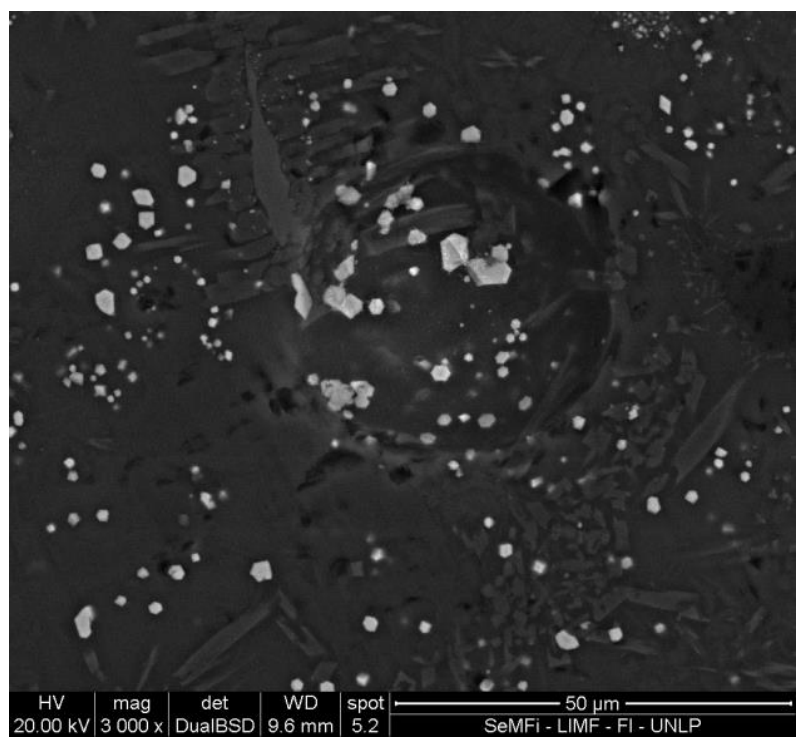

Figura 6.31. Imagen MEB de la fase 4 (posible magnetita)

$>$ Fase 5. Son granos blancos brillantes agrupados con aspecto "grumoso". Su composición presentó elevados contenidos de Ti (e/17 y $24 \% w)$ junto a Si (e/13 y 22 $\% w)$ y $\mathrm{Fe}(\mathrm{e} / 23$ y $33 \% \mathrm{w}$ ) (Figura 6.32). Posiblemente sea una titanita o ulvoespinela (ferrosilicatos ricos en titanio), que también han sido identificadas en otras escorias metalúrgicas de cobre (Sáez et al. 2003: Figura 3E).
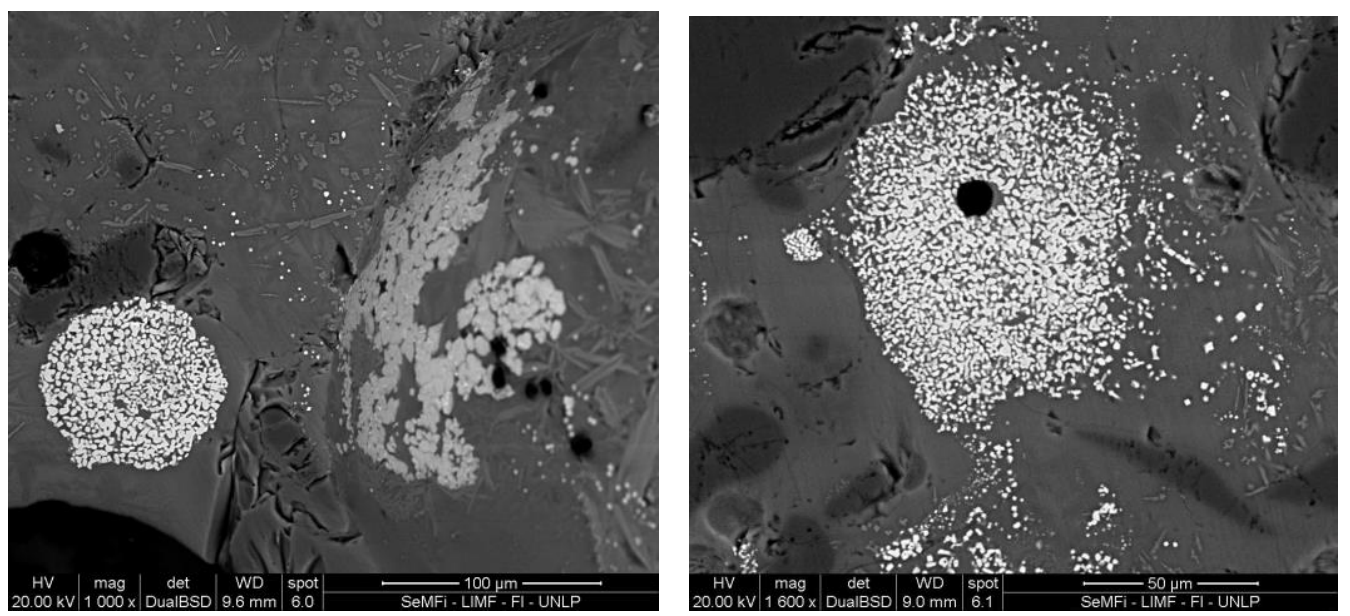

Figura 6.32. Imagenes MEB de la fase rica en Ti (granos blancos brillantes).

$>\quad$ Fase 6. Son inclusiones granulares de color blanco brillante y aspecto metálico, identificadas en las M3, M4 y M5 y cuyo componente mayoritario es el platino ( $>40$ \%w) (Figura 6.33). El Si, Fe, Al, Mg, K, Ca, y Na aparecen en cantidades minoritarias. Es un elemento atípico, no identificado en otras escorias. 


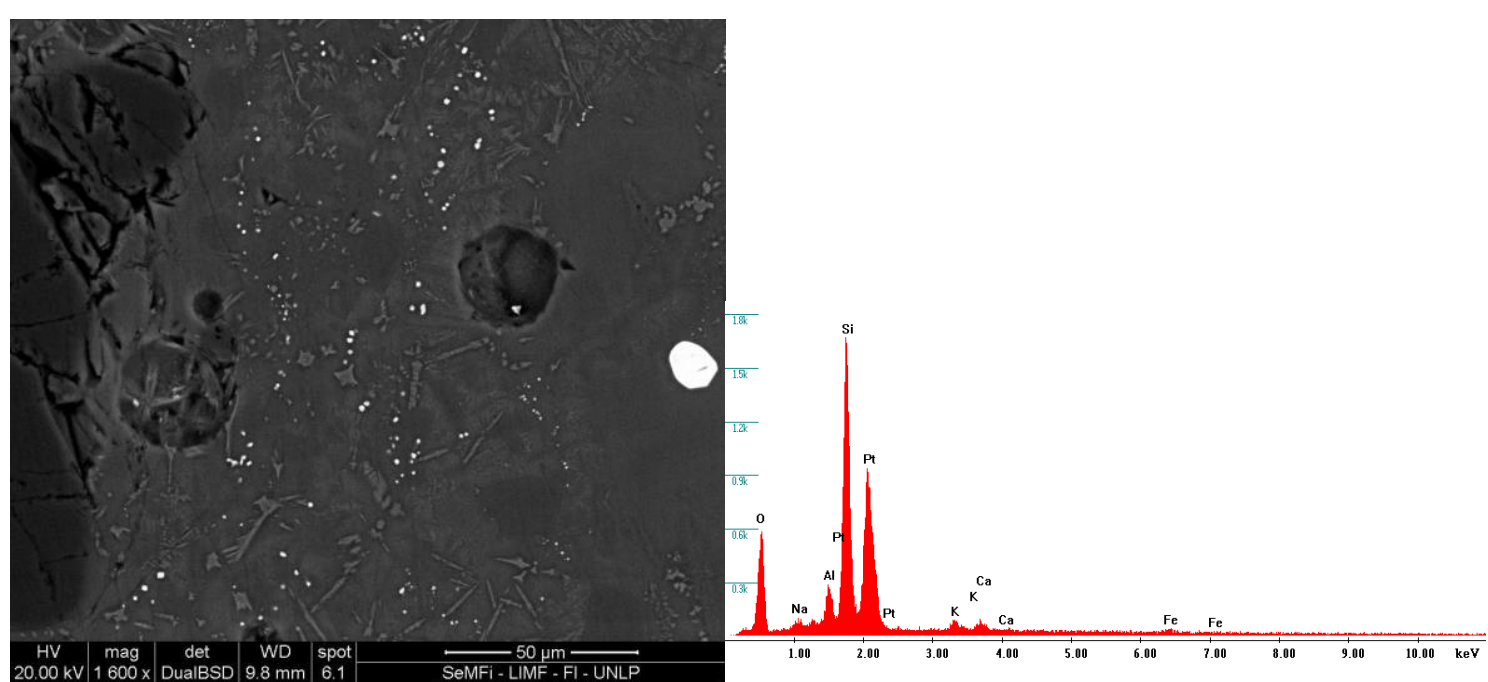

Figura 6.33. Imagen MEB con fase granular blanco brillante de platino (centro-derecha) y espectro EDS obtenido. Corresponde a la M5.

Fase 7. Son granos de color gris oscuro, están compuestas por sílice, en algunos casos con pequeñas cantidades de aluminio, correspondientes a cuarzos. Fueron observados en todas las muestras y siempre presentaron bordes redondeados (ver figura 6.24). Esto indica que han reaccionado con la matriz vítrea de la escoria siendo reabsorbidas por el fundido (Sáez et al. 2001).

\subsection{Resultados del análisis por Difractometria de Rayos $X$}

Estos análisis fueron realizados en las M1, M3 y M7. Los diagramas espectrales obtenidos en las tres muestras exhibieron picos de gran intensidad correspondientes al cuarzo $\left(\mathrm{SiO}_{2}\right)$, plagioclasas de tipo anortita $\left(\mathrm{CaAl}_{2} \mathrm{Si}_{2} \mathrm{O}_{8}\right)$, magnetita $\left(\mathrm{Fe}_{3} \mathrm{O}_{4}\right)$ y bornita $\left(\mathrm{Cu}_{5} \mathrm{FeS}_{4}\right)$, los cuales fueron fácilmente identificados por los softwares utilizados para el reconocimiento de compuestos químicos. En la M1 además se identificaron picos intensos de cuprita $\left(\mathrm{CuO}_{2}\right)$. Sin embargo, las muestras presentaron difractogramas con varios picos de menores intensidades, característicos de muestras con gran cantidad de minerales en bajas concentraciones (Melgarejo et al. 2010). Por lo tanto, al disponer de la información brindada por el MEB-EDS que indicó la presencia de inclusiones globulares con cobre, se realizó una búsqueda manual de sulfuros y óxidos de este metal siguiendo la posición e intensidad de los picos menores. A partir de lo cual, se obtuvieron los siguientes datos: 
- La M1 (Figura 6.34) presentó los picos de reflexión máxima de la bornita (1.93/4) y los picos máximos $(2.48)$, medios $(1.50 ; 2.13)$ y bajos $(3.02)$ de la cuprita.

- En la M3 (Figura 6.35), también se identificaron los picos de máxima reflexión de la bornita $(1.96,2.74)$ así como de la delafosita $(2.50,2.23)$ que es un óxido de $\mathrm{Cu}-$ Fe. Para el caso de la cuprita sólo se registró uno de los picos de reflexión media (1.28) por lo tanto su presencia es dudosa.

- La M7 (Figura 6.36) presentó el pico de máxima reflexión de la delafosita (2.50) el cual comparte el valor con la magnetita, sin embargo, la identificación de los picos de reflexión media y baja permite aceptar su presencia. También aquí se han registrado los picos máximos de la bornita $(1.94,2.74)$. En este caso, sí se ha podido detectar todo el espectro correspondiente a la cuprita $(\mathrm{CuO} 2)(2.46,1.50,1.28,2.13,3.01)$. En esta muestra se buscaron intencionalmente compuestos sulfurados de plomo, como la galena, pero no fueron reconocidos. Es posible que los espectros EDS realizados sobre inclusiones globulares blancas que brindaron picos de $\mathrm{Pb}$ junto a los de $\mathrm{Cu}$, correspondan en el primer caso a azufre dado que los valores alfa para estos elementos se superponen (Becerra et al. 2011).

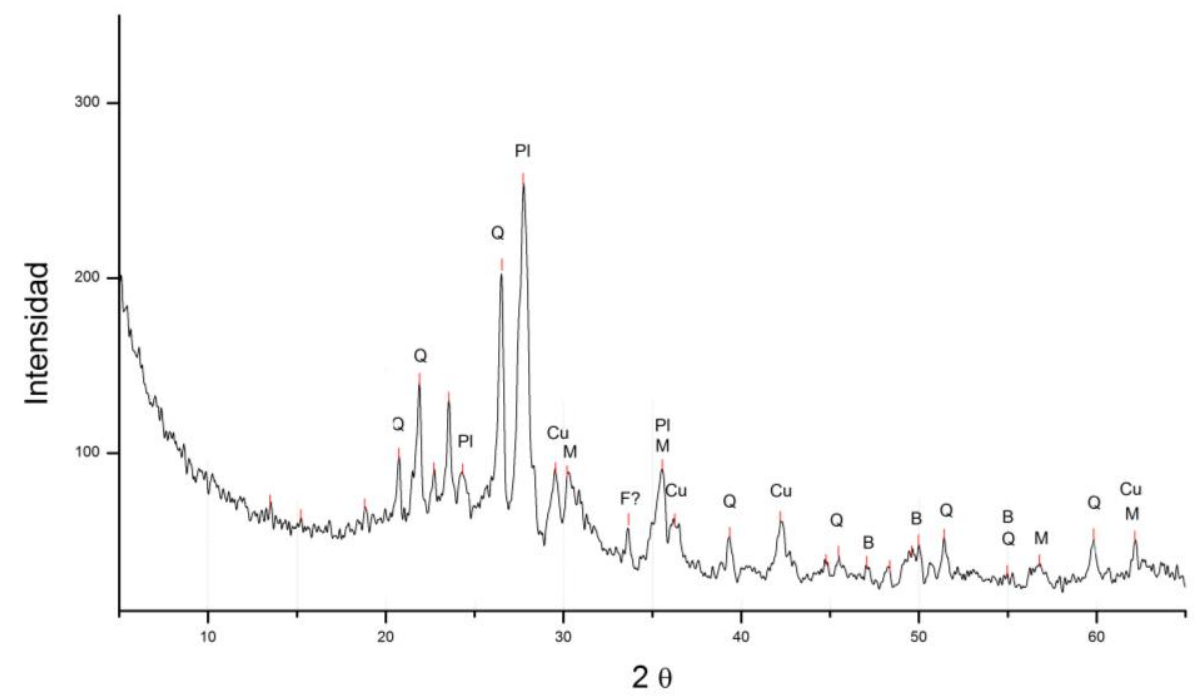

Figura 6.34. Difractograma de la M1. Se observa la presencia de cuarzo (Q); plagioclasas $(\mathrm{Pl})$, magnetita $(\mathrm{M})$, bornita $(\mathrm{B})$ y cuprita $(\mathrm{Cu})$. 


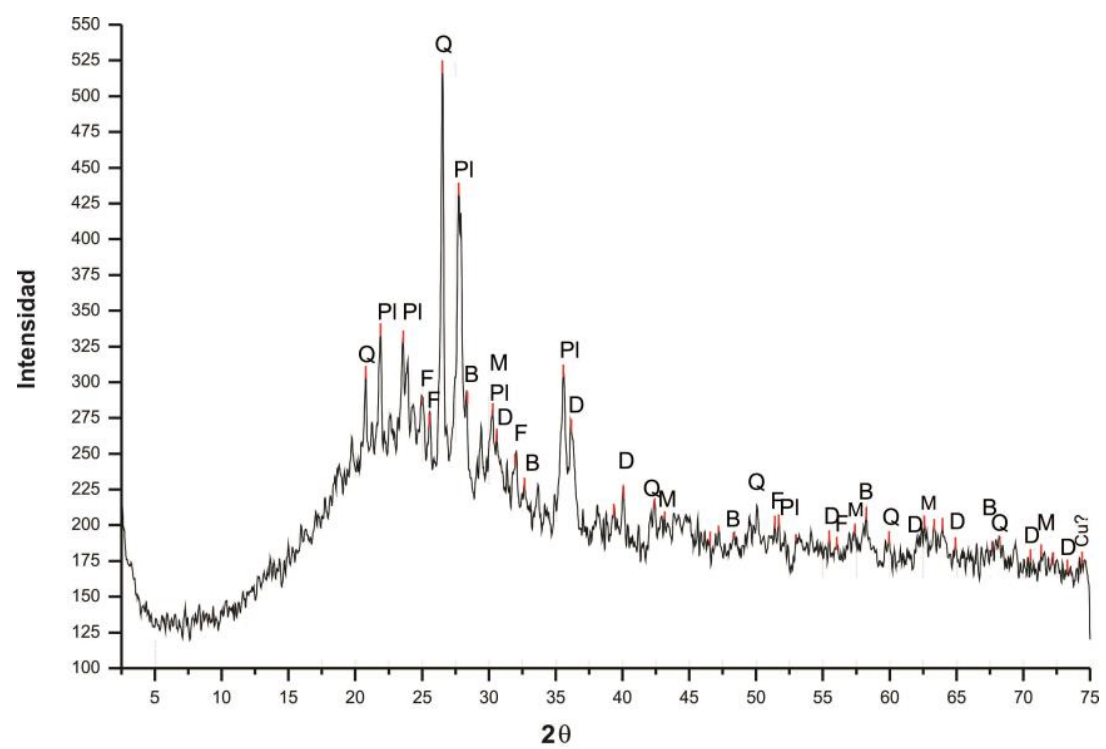

Figura 6.35. Difractograma de la M3. Se observa la presencia de cuarzo (Q); plagioclasas (Pl), fayalita (F), magnetita (M), bornita (B) y delafosita (D).

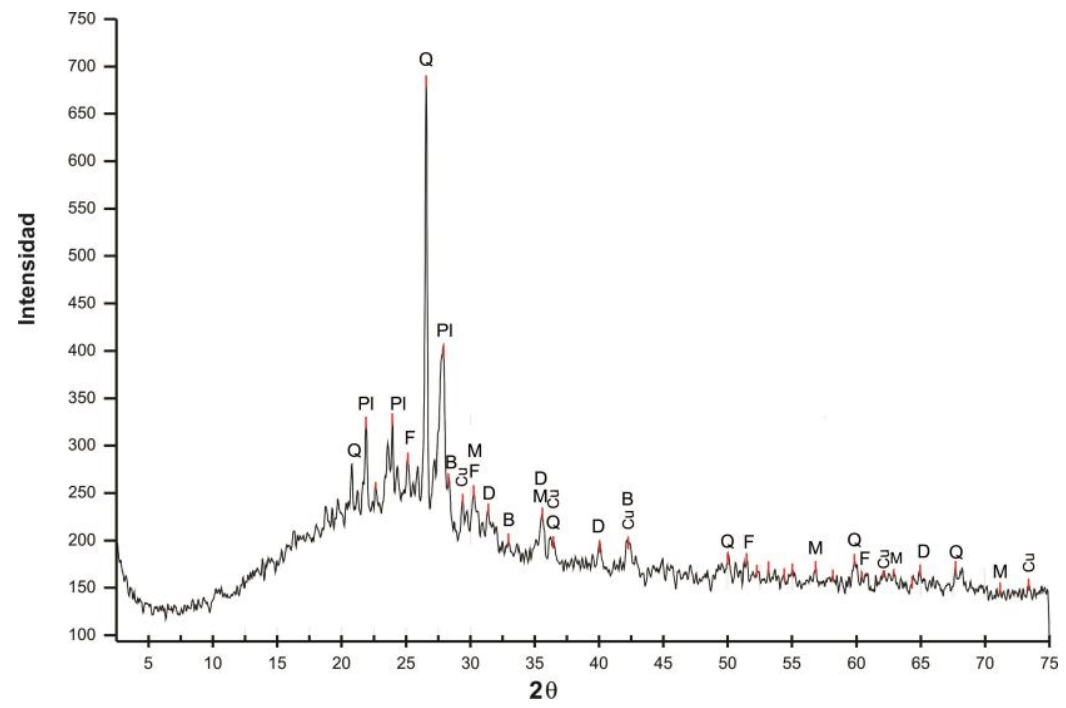

Figura 6.36. Difractograma de la M7. Se observa la presencia de cuarzo (Q); plagioclasas (Pl), fayalita (F), magnetita (M), bornita (B), delafosita (D) y cuprita $(\mathrm{Cu})$.

\subsection{Resultados del análisis por Fluorescencia de rayos $X$}

En la tabla 6.7 se exhiben los resultados del análisis por fluorescencia realizada sobre las superficies pulidas de cinco muestras de escorias. Se consideraron los trece elementos mayoritarios identificados que alcanzan valores porcentuales. Como se puede observar, las escorias son ricas en contenidos de sílice $\left(\mathrm{SiO}_{2}\right)$, aluminio $\left(\mathrm{Al}_{2} \mathrm{O}_{3}\right)$ y hierro $\left(\mathrm{Fe}_{2} \mathrm{O}_{3}\right)$ y en segundo lugar se hallan los elementos alcalinos $(\mathrm{CaO} ; \mathrm{K} 2 \mathrm{O} ; \mathrm{MgO} ; \mathrm{Na} 2 \mathrm{O})$. Finalmente presenta concentraciones menores de $\mathrm{TiO}, \mathrm{MnO}, \mathrm{CuO}, \mathrm{SO}, \mathrm{SrO}$ y $\mathrm{ZrO}$. Es interesante destacar la presencia de cobre en todas las muestras, aunque en bajos 
contenidos, en especial en aquellas donde no se han podido identificar fases con estas composiciones por microscopía electrónica (M4, M5).

Teniendo en cuanta las composiciones mayoritarias, se volcaron sus valores en el diagrama ternario de fases $\mathrm{FeO}-\mathrm{SiO}_{2}$-Anortita $\left(\mathrm{CaAl}_{2} \mathrm{Si}_{2} \mathrm{O}_{6}\right)$. En el triplot obtenido (Figura 6.37) las muestras se encuentran ubicadas en la región de la cristobalita debido al elevado porcentaje de sílice y esto señala que las temperaturas de fusión de estos materiales estuvieron alrededor de $\operatorname{los} 1500^{\circ} \mathrm{C}$. Como veremos más adelante, es necesario integrar esta información con aquella brindada por los análisis macroscópicos y microestructurales para aproximarnos a las temperaturas reales a la que estuvo sometido el fundido.

\begin{tabular}{|c|c|c|c|c|c|c|}
\hline \multicolumn{2}{|c|}{ Elementos } & \multicolumn{5}{c|}{ Id. Muestra } \\
\cline { 3 - 7 } \multicolumn{2}{|c|}{} & M1 & M2 & M14 & M4 & M5 \\
\hline Silicio & $\mathrm{SiO}_{2}$ & 68 & 64 & 67 & 70 & 67 \\
\hline Aluminio & $\mathrm{Al}_{2} \mathrm{O}_{3}$ & 17 & 17 & 16 & 14 & 18 \\
\hline Hierro & $\mathrm{Fe}_{2} \mathrm{O}_{3}$ & 5 & 6,2 & 5,8 & 4,9 & 4 \\
\hline Calcio & $\mathrm{CaO}$ & 3,2 & 4 & 3,4 & 3,3 & 3,6 \\
\hline Potasio & $\mathrm{K}_{2} \mathrm{O}$ & 2,9 & 3,4 & 2,7 & 3,4 & 2,9 \\
\hline Magnesio & $\mathrm{MgO}$ & 2,2 & 2,3 & 2,2 & 1,8 & 1,8 \\
\hline Sodio & $\mathrm{Na}_{2} \mathrm{O}$ & 2,6 & 2,6 & 2,6 & 2,4 & 2,5 \\
\hline Titanio & $\mathrm{TiO}_{2}$ & 0,48 & 0,56 & 0,52 & 0,47 & 0,37 \\
\hline Manganeso & $\mathrm{MnO}_{2}$ & 0,10 & 0,12 & 0,13 & 0,10 & 0,01 \\
\hline Cobre & $\mathrm{CuO}_{2 n y y y}$ & 0,02 & 0,01 & 0,04 & 0,03 & 0,01 \\
\hline Estroncio & $\mathrm{SrO}^{2}$ & 0,01 & 0,02 & 0,02 & 0,01 & 0,01 \\
\hline Circonio & $\mathrm{ZrO}_{2}$ & 0,01 & 0,01 & 0,01 & 0,02 & 0,01 \\
\hline Azufre & $\mathrm{SO}_{3}$ & 0,01 & 0,01 & 0,01 & 0,01 & 0,04 \\
\hline
\end{tabular}

Tabla 6.7. Composiciones generales de las escorias. Los datos se presentan como óxidos y los valores con porcentuales (\%). 


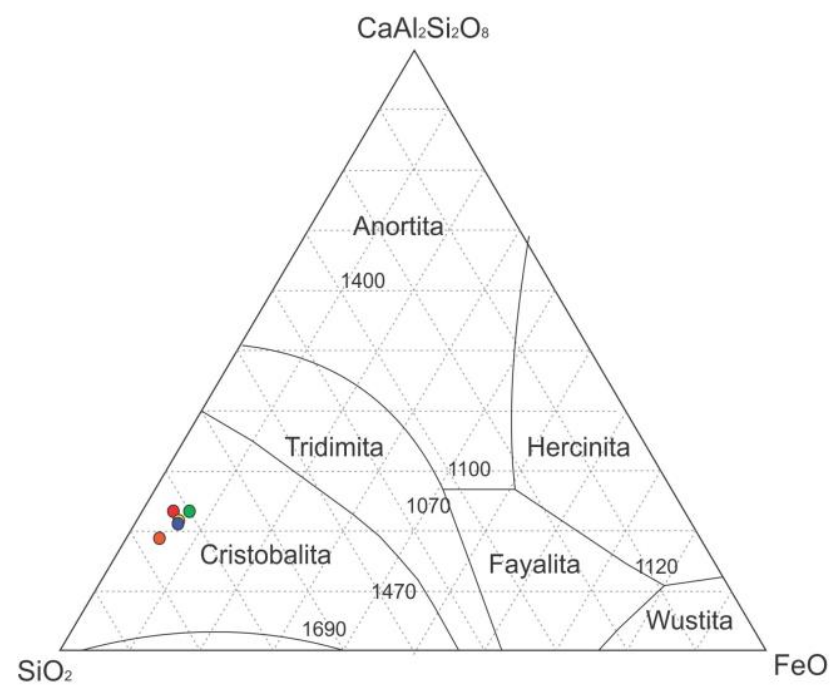

Figura 6.37. Sistema ternario de $\mathrm{FeO}-\mathrm{SiO}_{2}$-Anortita $\left(\mathrm{CaAl}_{2} \mathrm{Si}_{2} \mathrm{O}_{6}\right)$ basado en Sáez et al. 2003. Las muestras de escorias (círculos) se sitúan en la zona de la cristobalita.

\subsubsection{La información que nos brindan las escorias. Integración y discusión de resultados.}

Los caracteres morfológicos observados macroscópicamente indican que las escorias registradas en los alrededores del horno consisten en grandes masas con textura fluida y porosidad moderada a alta, concordantes con las descripciones de escorias metalúrgicas. Por otro lado, otro conjunto de muestras, son más porosas con vitrificados e inclusiones de carbones, cenizas y sedimento blanco propios de escorias de combustión.

Los datos mineralógicos y composicionales señalan que las escorias metalúrgicas presentan matrices vítreas ricas en alumino-silicatos y elementos alcalinos ( $\mathrm{Na}, \mathrm{Ca}, \mathrm{K})$ con abundante sílice libre y un conjunto de fases cristalinas heterogéneas. Entre estas últimas predominan feldespatos del tipo plagioclasas, piroxenos y en menor proporción olivinos como la fayalita y ferrosilicatos ricos en $\mathrm{Ti}$, como la titanita o ulvoespinela. Entre los óxidos se destaca la magnetita $\left(\mathrm{Fe}_{3} \mathrm{O}_{4}\right)$, la delafosita $\left(\mathrm{CuFeO}_{2}\right)$ y la cuprita $\left(\mathrm{CuO}_{2}\right)$. Finalmente, se detectaron glóbulos blancos de fases metálicas de cobre sulfuradas identificadas como bornita $\left(\mathrm{Cu}_{5} \mathrm{FeS}_{4}\right)$ y metales nobles como el platino.

En este punto, es necesario realizar algunas reflexiones en torno a las clasificaciones teóricas sobre escorias metalúrgicas en función de los resultados obtenidos en las muestras aquí analizadas. Inicialmente se han distinguido dos tipos de 
escorias metalúrgicas según las operaciones técnicas que las originaron, es decir, procedimientos de fundición primaria tendientes a reducir el mineral a metal o de refinación para purificar el metal (Miller y Killick 2004). Teniendo en cuenta las fases cristalinas identificadas, la presencia de bornita es considerada un indicador del procesamiento primario de menas sulfuradas de cobre (Bachmann 1982; Hauptmann 2007) que señala etapas de reducción del mineral.

Diversos estudios técnicos dan cuenta que en las escorias de fundición de minerales de esta clase es frecuente hallar prills sulfurosos, llamados mata, compuestos por $\mathrm{CuFeS}, \mathrm{CuS}$ o FeS, que quedan incluidas en la matriz debido a su baja solubilidad en silicatos (Bachmann 1982: Placa IXf, Xd; Merkel y Shimada 1988:6; Mei y Rehen 2005: Tabla 4; Zori et al. 2010: Figura 8), como parece ser el caso de las inclusiones sulfurosas observadas en las muestras de Quillay. Estas fases globulares blancas serían precipitados secundarios, producto de una etapa de tostación del sulfuro para su conversión a óxido metálico, de acuerdo con los procedimientos descriptos por Bachmann (1982). Dicho procedimiento requiere un ambiente rico en oxígeno y ante la presencia de hierro libre, suelen cristalizar asimismo óxidos de $\mathrm{Cu}$ y $\mathrm{Fe}$, como la delafosita, y óxidos de hierro como la magnetita (Hauptmann 2007; Onorato et al. 2010), compuestos que abundan en las muestras aquí analizadas.

Sin embargo, si se consideran las composiciones químicas generales de las muestras, se observa que las escorias son ricas en silicatos con bajo contenido en hierro, alejándose de las clásicas composiciones fayalíticas características de las escorias de fundición detalladas por Bachmann (1982) y acercándose a las composiciones clásicas de escorias de refinación, ricas en sílice y aluminio. En este punto, se vuelve fundamental vincular las muestras al contexto de hallazgo caracterizado por su íntima asociación a los hornos y evaluarlas teniendo en cuenta las restantes fases cristalinas reconocidas. Así, el alto contenido en sílice identificado puede deberse en realidad, a algunos de los siguientes factores que, según detalla Hauptmann (2007) generan un fundido heterogéneo:

- una ganga rica en cuarzo (mena autofundente);

- el agregado de fundentes silíceos; 
- al aporte de estos materiales por parte de las paredes del horno al reaccionar con los líquidos fundidos.

Incluso, varios estudios realizados en escorias de fundición de minerales de cobre asociadas a hornos metalúrgicos, han presentado ejemplos donde las composiciones son similares a las observadas en las muestras de Quillay, es decir, con altos contenidos en sílice que caen en la región de tridimita o cristobalita en los diagramas de fases ternarios (Petersen 1970; Sáez et al. 2003; Mei y Rehren 2005; Georgakopoulou et al. 2011). Dichos estudios sostienen que, en general, esto sucede porque las escorias contienen inclusiones de cuarzo parcialmente alterados que incrementan los contenidos de sílice en los análisis químicos. Por lo tanto, es imprescindible considerar estos resultados en conjunto a las observaciones microscópicas. En las muestras aquí presentadas, se han identificados inclusiones de cuarzo termoalterado tanto a nivel macroscópico como microscópico, por lo tanto, es factible que esto haya incrementado el contenido silíceo en las escorias.

Por otro lado, regresando a las inclusiones de sulfuro de cobre, su presencia nos indica las menas que fueron utilizadas en los procesos de fundición. Al respecto, Bachmann (1982: 22) muestra las reacciones químicas del proceso de fundición de menas sulfuradas de cobre a partir de la calcopirita, que pueden sintetizarse en la siguiente ecuación general:

REACCIÓN QUÍMICA PROCESO

I) $\mathrm{CuFeS2}+3 \mathrm{O} 2 \rightarrow \mathrm{FeO}+\mathrm{CuO}+2 \mathrm{SO} 2 \uparrow \quad$ Tostación completa en atmósfera oxidante con formación de óxidos metálicos y volatilización de azufre (gases)

II) $\mathrm{CuO}+\mathrm{CO} \rightarrow \mathrm{Cu}+\mathrm{CO} 2 \uparrow$

Reducción de óxidos a metales

III) $2 \mathrm{FeO}+\mathrm{SiO} 2 \rightarrow 2 \mathrm{FeO} . \mathrm{SiO} 2$

Formación de escoria

En la industria moderna, se realiza un paso intermedio que consiste, por un lado, en la formación de una mata rica en sulfuros cuprosos y de hierro y, por el otro, de escorias de fundición (Biswas y Davenport 1994). Por otro lado, Barba 1817 [1640] registró durante la colonia que también se pueden realizar ambos procedimientos al unísono regulando las condiciones atmosféricas. La presencia de inclusiones globulares y nodulares de metales sulfurados contenidos en especies de "burbujas" en las escorias, 
pueden deberse a procesos de retención de estos precipitados minerales fundidos durante el flujo de la escoria.

En cuanto a las condiciones atmosféricas, la presencia de magnetita, junto a minerales de fayalita, indica condiciones de ventilación fluctuantes. Mientras el primero se forma en un ambiente rico en oxígeno, el segundo requiere condiciones reductoras, es decir con monóxido de carbono libre (Rovira 2005). Controlar ambos tipos de atmósferas es indispensable para las transformaciones químicas que conducen a obtener el producto metálico deseado. Un viento errático puede cambiar las condiciones gaseosas al interior del horno, enfriar la muestra, mantener los óxidos de cobre sin reducir y retener las inclusiones metálicas disponibles en el fluido (tanto como prills de mata o como prills de $\mathrm{Cu}$ ). Si el objetivo fue liberar el contenido metálico durante el mismo proceso, la presencia de óxidos de cobre -identificadas por DRX- en las muestras de escorias sugiere una ineficacia en los procedimientos tecnológicos, tal como ha sido indicado por Sáez et al. (2003) para otras muestras.

Quizás esa sea la causa de la ausencia de prills de cobre en las muestras aquí analizadas. O bien, dado que las escorias presentan grandes dimensiones, es posible que los segmentos seleccionados para el corte no alojasen estos elementos metálicos al ser fundidos heterogéneos dónde en ciertos sectores se dieron las condiciones de reducción adecuadas $y$ en otros no. Esta irregularidad en las reacciones puede haber sido consecuencia de un ineficaz control de los gases en un horno de grandes dimensiones, como son los de Quillay. Se considera que esta posibilidad es más factible dada la baja proporción de cobre retenido en la masa según los datos obtenidos por FRX.

Por otro lado, ya se han comentado los recaudos que se deben tener a la hora de evaluar las composiciones generales de las escorias obtenidas por fluorescencia. Esta misma precaución se debe tomar cuando se calculan las temperaturas de fusión alcanzadas por el fundido. Se ha expresado que las muestras al poseer composiciones ricas en silicatos señalan una temperatura de fusión teórica cercana a los $1500^{\circ} \mathrm{C}$ (ver figura 6.37). La identificación de granos de cuarzo termoalterado demuestra que no todos los constituyentes de las escorias se encontraron totalmente fundidos, lo cual genera un sistema en desequilibrio que difiere de los modelos teóricos (Sáez et al. 2003; Kierczak y Pietranik 2011). De esta manera, los materiales de cuarzo parcialmente alterados aumentan los contenidos de $\mathrm{SiO}_{2}$ que generan una sobrevaluación de los 
rangos térmicos alcanzados, señalando varios grados más de los realmente conseguidos por el horno (Sáez et al. 2003; Mei y Rehren 2005; Hauptmann 2007; Georgakopoulou 2011). Asimismo, algunos investigadores sostienen que otros óxidos, aunque estén presentes en proporciones minoritarias $\left(\mathrm{CaO}, \mathrm{K}_{2} \mathrm{O}, \mathrm{Na}_{2} \mathrm{O}\right)$, contribuyen a reducir las temperaturas de fusión entre unos 100 a $200^{\circ} \mathrm{C}$ (Mei y Rehen 2005; Kierczak y Pietranik 2011). Esta propuesta, es concordante con la información sobre las temperaturas de fusión que brindan las restantes fases cristalinas identificadas en las muestras de Quillay. Los óxidos como la cuprita, la delafosita y la magnetita presentan puntos de fusión de entre $1100^{\circ} \mathrm{C}$ y $1300^{\circ} \mathrm{C}$, lo que indica que el fundido alcanzó esos rangos térmicos en un ambiente oxidante.

Por último, las escorias analizadas nos brindan información sobre la composición inicial de la carga mineral. La presencia de bornita nos señala la utilización, al menos, de minerales sulfurados de cobre. La abundancia de cuarzo detectado en las escorias puede deberse a que la mena estuvo acompañada de gangas ricas en este mineral y por lo tanto que haya sido autofundente. Minerales sulfurosos de cobre abundan en los yacimientos vetiformes de Farallón Negro, Capillitas y Cerro Atajo (Marquez Zavalía 1999; Putz et al. 2009) y dependiendo del estadio de mineralización cuentan con gangas de cuarzo o rodocrosita (Marquez Zavalía 2002). Incluso la presencia de platino en las escorias también conduce a estos yacimientos, dado que es un metal noble que abunda en los telurios disponibles en los yacimientos de Capillitas (Márquez Zavalía y Craig 2004).

\subsubsection{La identificación del sedimento blanco}

Anteriormente se ha hecho referencia al hallazgo de capas de sedimento blanco de textura compacta en los componentes estructurales de los hornos excavados. Con el objetivo de identificar la composición de este material, se seleccionaron dos muestras pertenecientes a la UEA1 y UEA6 del H14 para análisis por Difracción de Rayos X. La figura 6.38 muestra el espectro obtenido en ambas muestras, cuyos picos corresponden a un carbonato de calcio identificado como calcita, junto a minerales de cuarzo y feldespato en menor intensidad.

A partir de estos resultados, se testearon mediante la prueba de ácido otro conjunto de muestras tomadas de las mismas dos unidades arqueológicas, junto a un 
segundo grupo muestreado de la base de la cámara superior del H14 y de la antecámara del H7. Para ello se utilizó como reactivo ácido clorhídrico (HCL) diluido al 10\%. Como resultado se observó que todas las muestras produjeron efervescencias, que resultan de la disolución del carbonato corroborando su pertenencia a esta clase de mineral. Seguramente también a un carbonato de calcio, dada su asociación contextual y semejanzas en coloración y textura con las muestras analizadas por DRX.
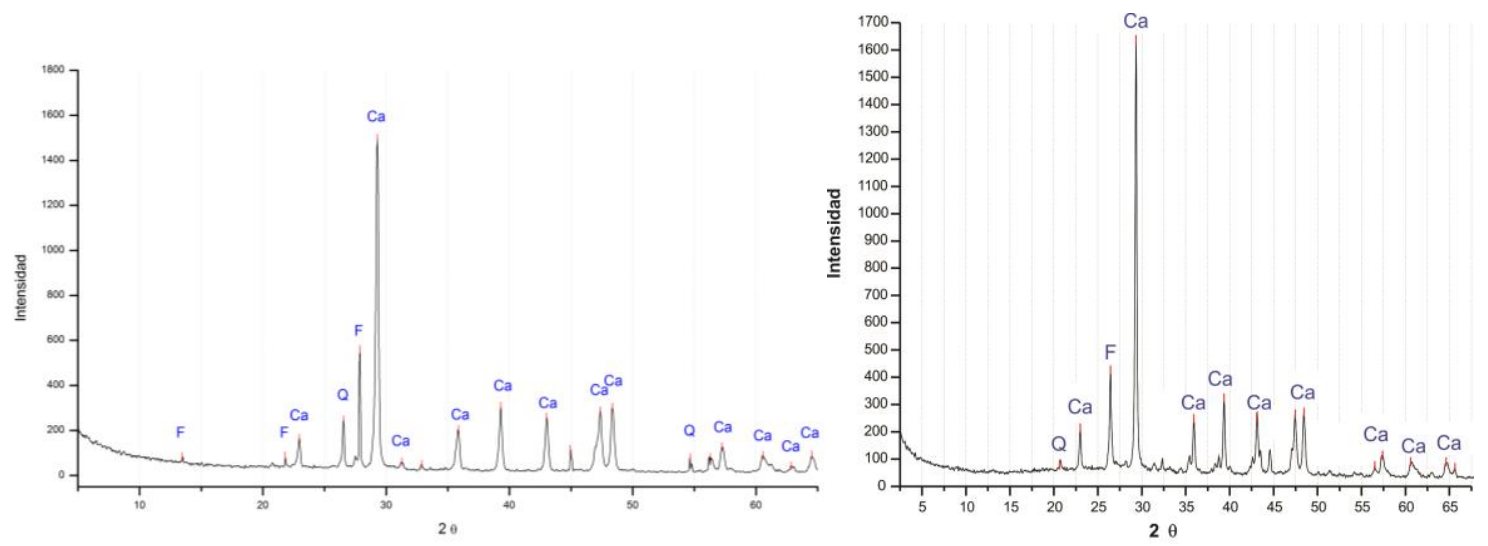

Figura 6.38. Difractogramas del sedimento blanco extraído de la UEA1 (izquierda) y UEA6 (derecha). El compuesto identificado corresponde a la calcita.

La presencia de este material en la cámara inferior del horno 14 por sobre un estrato de carbón, conduce a pensar que estuvo necesariamente en contacto con el combustible y por ello se indagó sobre las transformaciones de este material a altas temperaturas. La calcita $\left(\mathrm{CaCo}_{3}\right)$ es el compuesto principal de rocas sedimentarias como la caliza. Según informes técnicos, este material a temperaturas mayores a $800^{\circ} \mathrm{C}$ comienza una serie de reacciones químicas que liberan el dióxido de carbono contenido y forman cal viva $(\mathrm{CaO})$ (Segemar 2008). Sin embargo, estas transformaciones dependen de la presión parcial del dióxido de carbono $\left(\mathrm{pCO}_{2}\right)$ en la atmósfera y son totalmente reversibles. El ciclo de transformaciones señala que si la $\mathrm{pCO}_{2}$ es menor que la del equilibrio de este gas para una determinada temperatura, el carbonato cede el dióxido de carbono y se descompondrá. En cambio si la $\mathrm{pCO}_{2}$ es mayor se combinará con él, restaurando el carbonato (fuente consultada: https://www.textoscientificos.com/quimica/cales- Enero 2017).

Teniendo en cuenta estas reacciones, es viable detectar en un contexto de combustión carbonato de calcio en vez de óxido de calcio, ya sea por las presiones de los gases cambiantes durante los procedimientos técnicos o bien por un proceso de carbonatación paulatino del material en contacto con la atmósfera (Magaña 2013). Los 
datos obtenidos en los hornos aquí analizados aún no permiten reconstruir acabadamente sus atmósferas dado que los análisis de escorias indican fluctuaciones en la oxigenación.

Por otro lado, también se indagó sobre las funciones de este material. En la bibliografía especializada son múltiples los usos del carbonato de calcio en las industrias modernas. Circunscribiendo la información disponible a los procesos metalúrgicos, actualmente se utilizan como material fundente para la reducción de minerales de oro, plata, cobre, plomo y en la siderurgia (Guerrero Hernández 2001; Segemar 2008). También como recubrimiento de hornos actuando como material refractario (Guerrero Hernández 2001).

En el caso de los hornos de Quillay, consideramos factible brindarle una posible función refractaria similar a aquellas otorgadas para el recubrimiento de fosfato de calcio en cerámicas refractarias. Fundamentalmente dada su presencia en las bases de los hornos, la identificación de escorias por sobre estos estratos, su capacidad como impermeabilizante y además, porque consideramos que de haber sido utilizado como fundente, las muestras de escorias deberían posee un altísimo contenido de calcio como se plasman en las escorias de acería actuales. Por lo tanto, dado las propiedades del material es posible que sus funciones hayan sido múltiples actuando como antiadherente e impermeabilizante.

Un dato interesante refiere a la disponibilidad de fuentes de carbonato de calcio a nivel regional. La abundancia de este material en los hornos sugiere que fueron requeridos grandes cantidades de esta materia prima. Es significativo que en el valle de Hualfín, los afloramientos de caliza más cercanos se encuentran en la localidad de Azampay y consisten en lentes casi puros de origen metamórfico (Fuentes et al. 1998). Esta región se localiza a menos de $13 \mathrm{~km}$ al SO del sitio, atravesando el río Hualfín, señalando la existencia de fuentes de aprovisionamiento locales para este insumo.

\subsubsection{Análisis de paredes de hornos. El material constructivo de las estructuras de combustión.}

Previamente se han presentaron las características morfológicas y dimensionales de los hornos metalúrgicos, los cuales fueron construidos con un material de origen sedimentario de coloración rojo amarillento (Munsell 5 YR 5/6). Con el objetivo de 
reconocer las características del material constructivo de los hornos se realizaron análisis por petrología y difracción de rayos X. Por otro lado, a partir de las composiciones mineralógicas de los materiales es posible analizar las temperaturas alcanzadas por los hornos metalúrgicos.

Para ello, se estudiaron cuatro fragmentos de pared de horno que fueron seleccionados de los hornos H7 y H14 -para este último se tomó una muestra de la cámara superior (H14-1) y otra de la inferior (H14-2)- y la cuarta muestra fue recolectada de la superficie del sector del conjunto de hornos $2(\mathrm{CH} 2)$. El análisis de la composición mineralógica fue realizado por observaciones al microscopio óptico de segmentos tamizados de pared y mediante cortes de sección delgada observados bajo microscopio de luz polarizada (marca Leica DM750P) con aumento de hasta $100 \mathrm{X}$. Estos análisis fueron complementados con estudios químicos por difractometría en polvo, efectuados sobre las dos muestras del horno 14.

Las muestras $\mathrm{H} 7$ y H14 presentan semejanzas en la composición material (tabla 6.8). Estan conformadas principalmente por materiales arcillosos en un $80 \%$ y con un $20 \%$ de arena. Dentro del material grueso, se identificaron mayoritariamente minerales de cuarzo - rosado, blanco y traslúcido-, plagioclasas, feldespatos potásicos, litoclastos (ortosa), epídoto, micas del tipo biotita, muscovita y grupos desferrizados y minerales opacos. Para ambas muestras, la granulometría de la fracción arena es de fina a muy fina $(90 \%)$ y presenta sectores oscuros que se identifican como materia orgánica. Asimismo, las muestras poseen abundantes vacíos en forma de canales. Algunos contienen, a manera de revestimiento, un material de neoformación precipitado, probablemente un evento posterior, de tipo microcistalino, con moderada birrefringencia, relieve medio-bajo, anisótropo, pero del que no es posible distinguir su naturaleza mineral.

Por otro lado, al microscopio óptico se observaron conglomerados de sedimentos carbonatados y una alta presencia de sedimentarios termoalterados y vitrificados que pueden ser relacionadas con las actividades pirometalúrgicas desarrollados en el horno (Figura 6.38).

La muestra de superficie $(\mathrm{CH} 2)$ difiere composicionalmente respecto a las anteriores. Esto se debe a que el fragmento está conformado por arenas de tamaño medio a grueso en un $95 \%$ y un $5 \%$ de arena fina, sin material fino de tamaño arcilla. 
Respecto a la fracción arena, al igual que las otras muestras, está compuesta por minerales de origen ígneo como cuarzos, plagioclasas, feldespatos potásicos junto a litoclastos y opacos (Tabla 6.7). Asimismo, se observaron poros rellenos con el mismo material fino de neoformación.

\begin{tabular}{|c|c|c|c|c|c|c|c|c|c|}
\hline \multirow{2}{*}{ Muestra } & \multirow{2}{*}{ \% Arcilla } & \multirow{2}{*}{$\%$ Arena } & \multicolumn{6}{|c|}{ Minerales } \\
\cline { 4 - 9 } & & & Qz & FK & P1 & M & Op & Lit & E \\
\hline H14 & 80 & 20 & + & + & + & + & + & n.d & + \\
\hline H7 & 80 & 20 & + & + & + & + & + & + & n.d \\
\hline CH2 & 0 & 100 & + & + & + & & + & + & n.d \\
\hline
\end{tabular}

Tabla 6.8. Características petrográficas de las paredes de hornos; +: presente; n.d: no detectado.

El análisis por DRX de las muestras de pared de ambas cámaras del horno 14, permitió reconocer los picos de máxima reflexión del cuarzo, cristobalita, magnetita, feldespatos y plagioclasas, en concordancia con lo observado ópticamente (Figura 6.39). En la búsqueda de otros constituyentes solapados por la abundancia del cuarzo, se realizó un barrido de baja intensidad en intervalos $2^{\varphi}$ de 30 a 75 en la muestra H14-1 (Figura 6.40). Allí, además del cuarzo, se pudieron identificar los picos de mayor reflexión de la hematita y los picos de reflexión media y baja de las micas (biotita y muscovita), magnetita, anortita, alúmina, mullita y wollastonita. Para los cuatro primeros casos, se considera factible la presencia de estos compuestos al ser reconocidos ópticamente. Con respecto a la fracción arcilla el difractograma brindó los picos más fuertes de la hidrobiotita, illita y caolinita/clorita (Figura 6.41). 

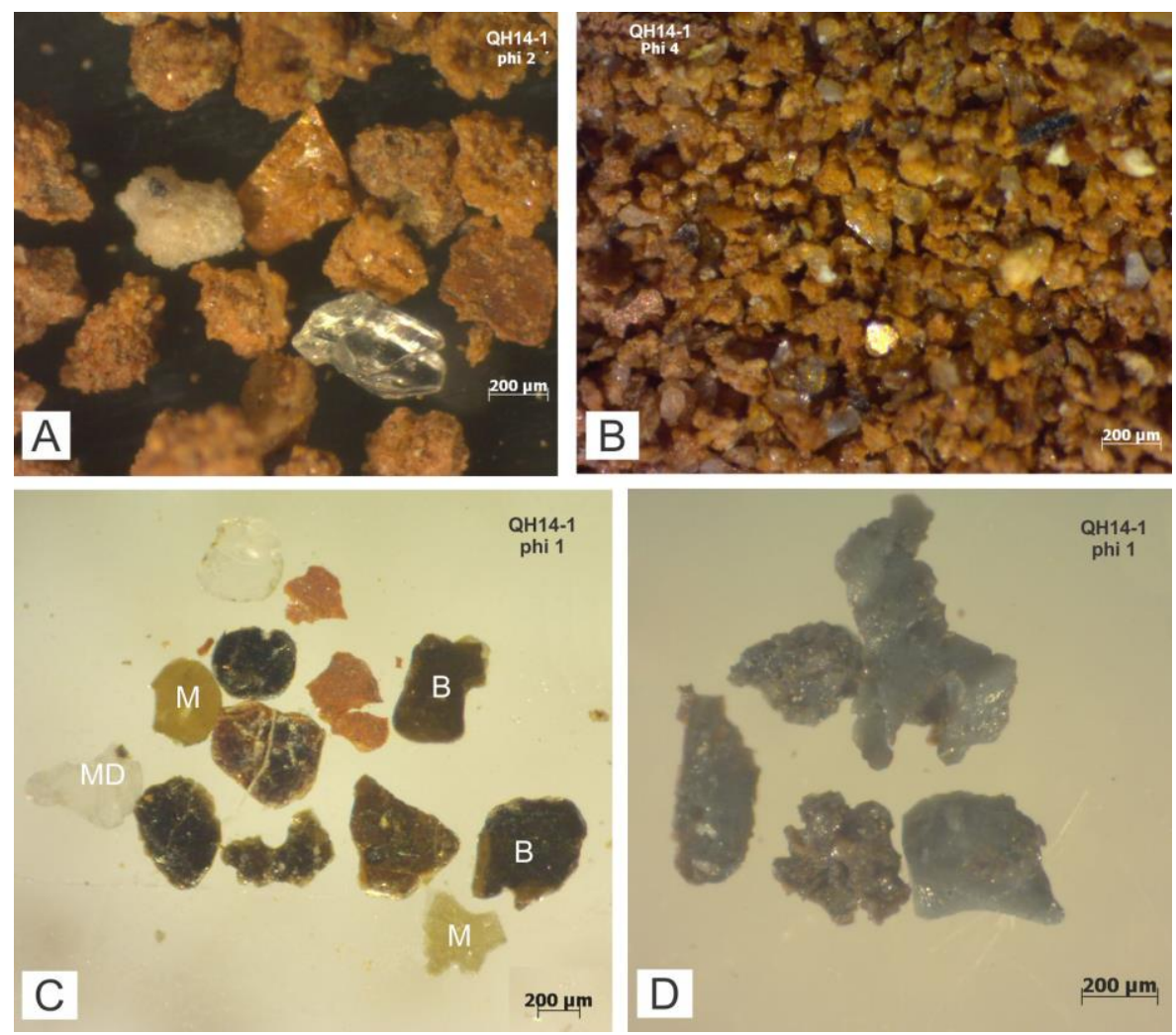

Figura 6.38. Minerales reconocidos en el microscopio óptico. A. cuarzo y grumos sedimentarios y cacáreos; B. cuarzos, micas, feldespatos; C. variedad de micas: biotita (B), muscovita (M) y micas desferrizadas (MD); D. material vitrificado.

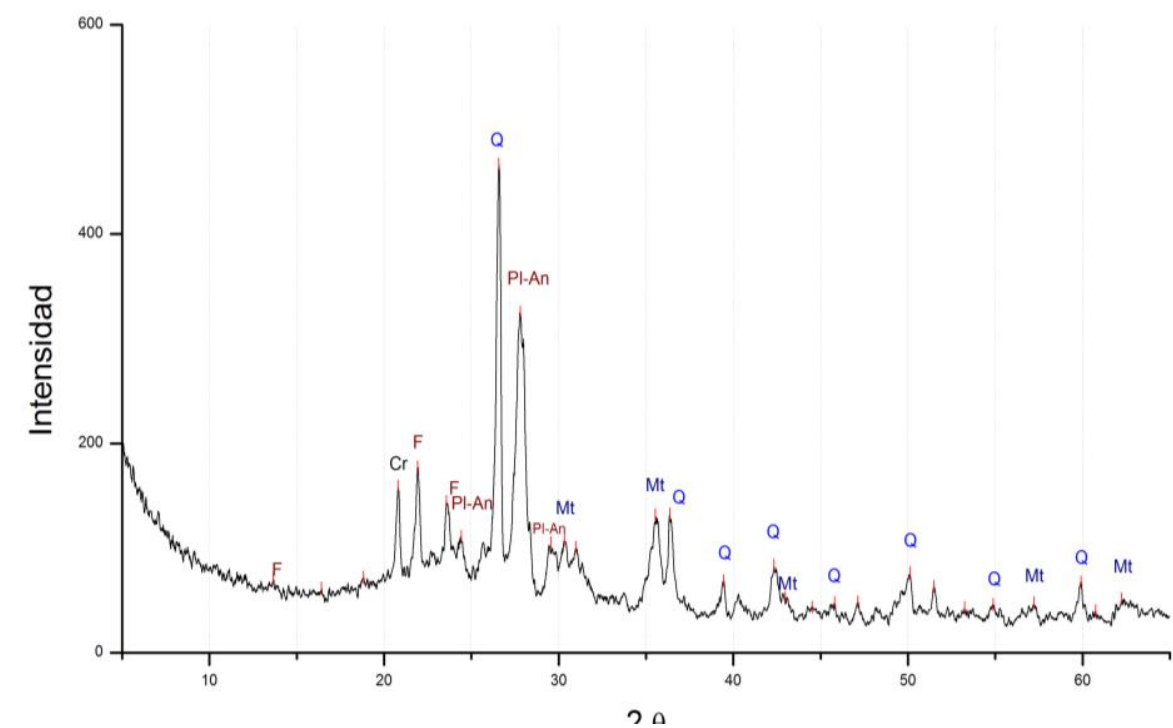

Figura 6.39. Difractograma de pared de horno (QH14_1). Se identificaron principalmente minerales de cuarzo $(\mathrm{Q})$; magnetita $(\mathrm{Mt})$, cristobalita $(\mathrm{Cr})$, feldespato (F) y plagioclasas de tipo anortita (Pl-An). 


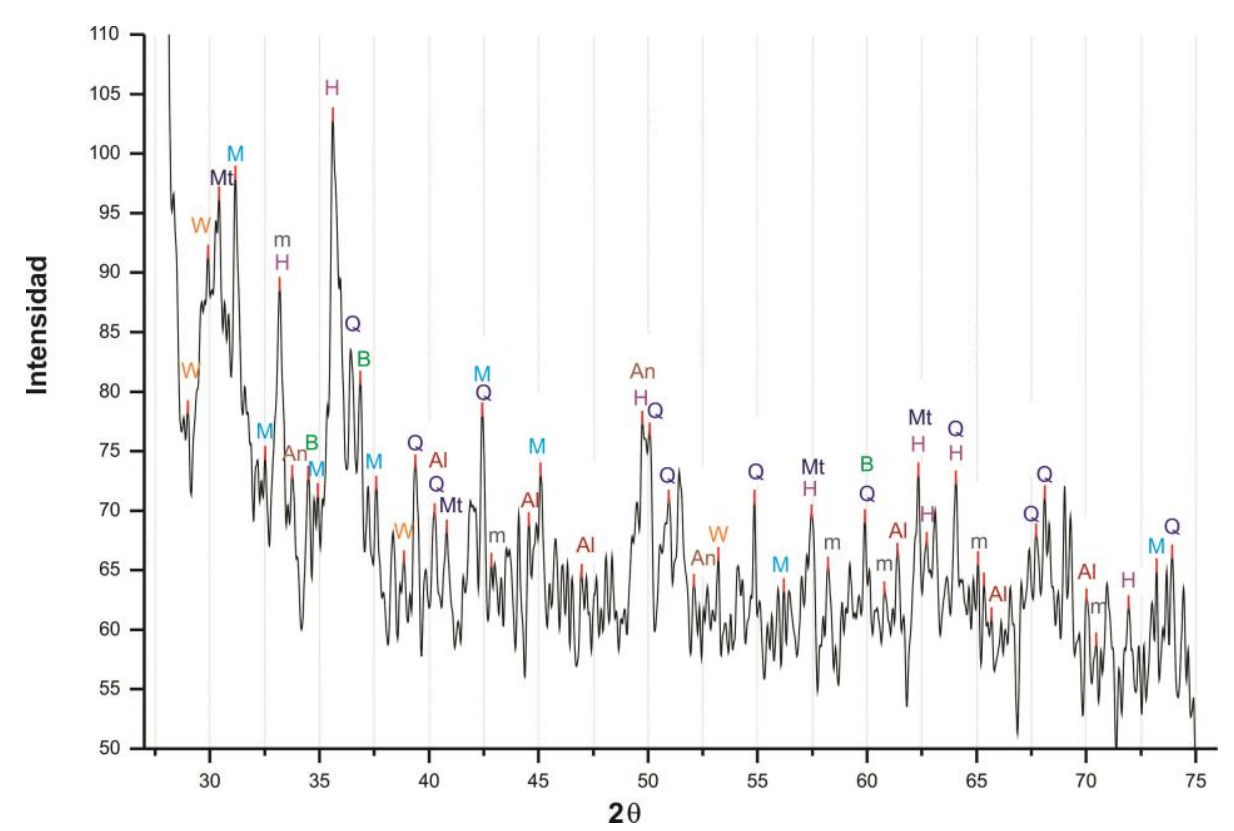

Figura 6.40. Difractograma de intervalos de baja intensidad. Se identificaron compuesto de cuarzo $(\mathrm{Q})$; muscovita $(\mathrm{M})$; biotita $(\mathrm{B})$; hematita $(\mathrm{H})$ o magnetita (Mt); mullita (m); alumina (Al); anortita (Pl-An) y wollastonita (W).

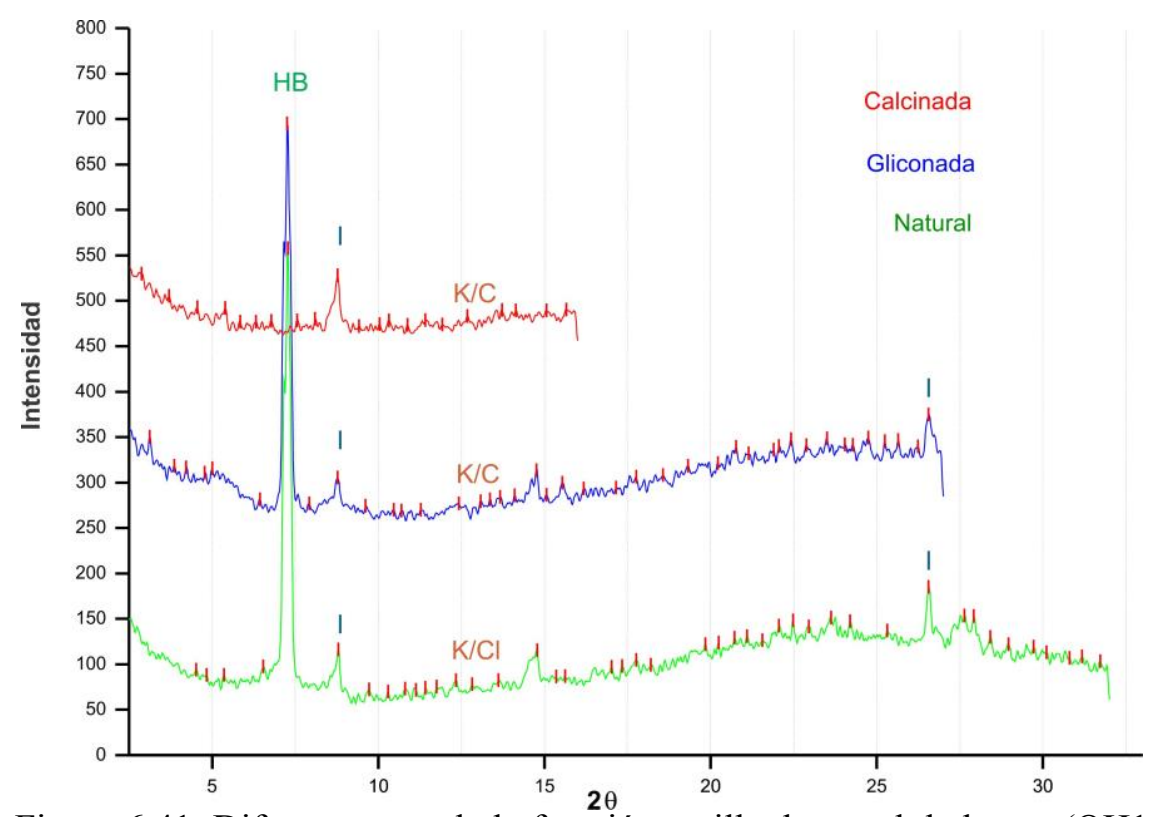

Figura 6.41. Difractograma de la fracción arcilla de pared de horno (QH14_1). Se observan los picos correspondientes a hidrobiotita (HB); illita (I) y Caolinita/Clorita (K-Cl).

Los compuestos cristalinos identificados en las difractometrías otorgan información interesante respecto a las temperaturas alcanzadas, gracias al conocimiento que se dispone sobre las tempraturas de cristalización y de fusión de minerales. Como se ha comentado en el capítulo anterior (capítulo 5) para el caso de los materiales 
refractarios, los minerales de cuarzo y feldespatos presentan una gran estabilidad térmica. El primero tiene puntos de fusión cercanos a los $1700^{\circ} \mathrm{C}$ y para los feldespatos varían en un rango entre $1100^{\circ} \mathrm{C}$ y $1550^{\circ} \mathrm{C}$ en función de su estructura atómica (Rice 2005 [1987]). La presencia de óxidos de hierro como la magnetita y hematita, sugieren temperaturas que superaron $\operatorname{los} 900^{\circ} \mathrm{C}$, al ser ésta su temperatura de formación a partir de la transformación de los filosilicatos, abundantes en la muestra (Linares et al. 1983; Cultrone et al. 2001). Por su parte, las micas presentan picos de reflexión factibles de ser detectados hasta los $1050{ }^{\circ} \mathrm{C}$ (Linares et al. 1983). Respecto a la mullita, es una fase mineral que suele derivar de la transformación gradual de los argilominerales en torno a temperaturas de cocción de $1000^{\circ} \mathrm{C}$ (Linares et al.1983; Rice 2005 [1987]), coincidente en la muestra del H14 con la ausencia de esmectita. Respecto a la wollastonita, es interesante señalar que su formación requiere de un ambiente con contenido de carbonato de calcio que reacciona con el cuarzo a temperaturas entre $800 / 1000^{\circ} \mathrm{C}$ (Kostov 1968; Cultrone et al. 2001). En este sentido, la presencia de calcita en la muestra quedo manifestada a partir de la observación macroscópica de grumos blanquecinos. Incluso, como se comentó más arriba, es un material presente en el interior de las cámaras del horno.

Este conjunto de datos mineralógicos indica que las muestras de pared de horno alcanzaron temperaturas que superaron $\operatorname{los} 1000^{\circ} \mathrm{C}$. Incluso, desde un punto de vista macroscópico, las variaciones de coloración observadas en las paredes permitieron establecer un gradiente térmico creciente. El mismo varía desde coloraciones naranjas y rojizas en el sector más externo que gradualmente se transforman en negro hacia los segmentos internos. Esto fue cotejado petrográficamente, dado que el corte transversal de la pared exhibe una vitrificación creciente hacia el interior del horno. La presencia de vitrificaciones en las superficies internas indica que allí la temperatura superó los $1100^{\circ} \mathrm{C}$ dado que, este es el rango por encima del cual varios de los minerales previamente nombrados se transforman en vidrio. Incluso la fusión del cuarzo supera ampliamente este rango térmico. 


\subsubsection{Análisis de macrorestos botánicos: el combustible de los hornos}

Con el objetivo de reconocer las maderas empleadas como combustible en los procesos metalúrgicos locales, durante el trabajo de campo se tomaron muestras del carbón registrado en los siguientes cuatro sectores de la excavación del horno 14 (ver apartado 6.3.2 en este mismo capítulo):

1) UEA 7 ubicada hacia el interior de la cámara inferior del horno,

2) UEA 5 distribuida en el sector adyacente a la boca de la estructura metalúrgica;

3) UEA 3A y B, es decir los montículos de desecho identificados hacia el oeste y este de la cuadrícula 2.

Una vez en el laboratorio, se seleccionaron 8 carbones de cada uno de los sectores, conformando una muestra representativa de 32 leños para su estudio. Se siguieron los procedimientos estándares para análisis antracológico (Tortorelli 2009 [1956]). En primer lugar, mediante fractura manual se obtuvieron los tres cortes diagnósticos utilizados para la determinación de maderas: corte transversal (CT); corte longitudinal tangencial (CLT) y corte longitudinal radial (CLR). Los mismos fueron observados a lupa binocular a aumentos de entre $10 \mathrm{X}$ y $30 \mathrm{X}$ y se sistematizaron los caracteres anatómicos identificados en cada plano siguiendo las propuestas de IAWA (1989) y Tortorelli (2009 [1956]). En base a dichos caracteres, se efectuó la identificación preliminar de maderas mediante claves dicotómicas, siguiendo como referencia la información disponible en Giménez et al. (2000); Demaio et al. (2002) y Tortorelli (2009 [1956]) y en bases de acceso online como Insedewood (2004)

Este análisis fue complementado con observaciones por microcopía electrónica de barrido (ESEM). Para ello se seleccionaron dos ejemplares de cada taxón identificado preliminarmente, que recibieron tratamientos de metalizado con oro. Mediante esta técnica se pudieron: corroborar los caracteres diagnósticos observados por microcopia óptica, identificar aquellos que requieren de mayores aumentos (como tabiques de elementos vasculares, tipo de punteaduras, tipo de fibras, contenidos, etc.) y calcular las dimensiones métricas de los elementos de los distintos tejidos.

\footnotetext{
${ }^{5}$ http://insidewood.lib.ncsu.edu
} 
El análisis realizado permitió identificar taxones botánicos en un $94 \%$ de la muestra (Tabla 6.9). Sólo en dos casos, no ha sido posible alcanzar una identificación precisa dado que la estructura atómica de la madera se encontraba fuertemente alterada por la temperatura. Como resultado, se han reconocido cuatro géneros de maderas sobre la base de los siguientes caracteres anatómicos:

1. Prosopis sp. (Fabaceae) - Nombre vulgar: algarrobo (Figura 6.42)

$>$ CT: se observaron anillos de crecimiento poco demarcados. La porosidad es difusa a semicircular con predominio de poros solitarios y múltiples cortos y algunos agrupados. El diámetro de los poros es mediano $(91-120 \mu \mathrm{m})$ y algunos casos pequeños $(57 \mu \mathrm{m})$. El parénquima es de tipo paratraqueal confluente en bandas anchas interrumpidas.

> CLT: se observó un diseño floreado originado por el abundante parénquima. Los elementos del vaso exhibieron tabiques horizontales a oblicuos. Se observaron critales alojados en el parénquima leñoso. Los radios son multiseriados fusiformes.

$>$ CLR: presentan radios homogéneos y puntuaciones intervasculares alternas. 

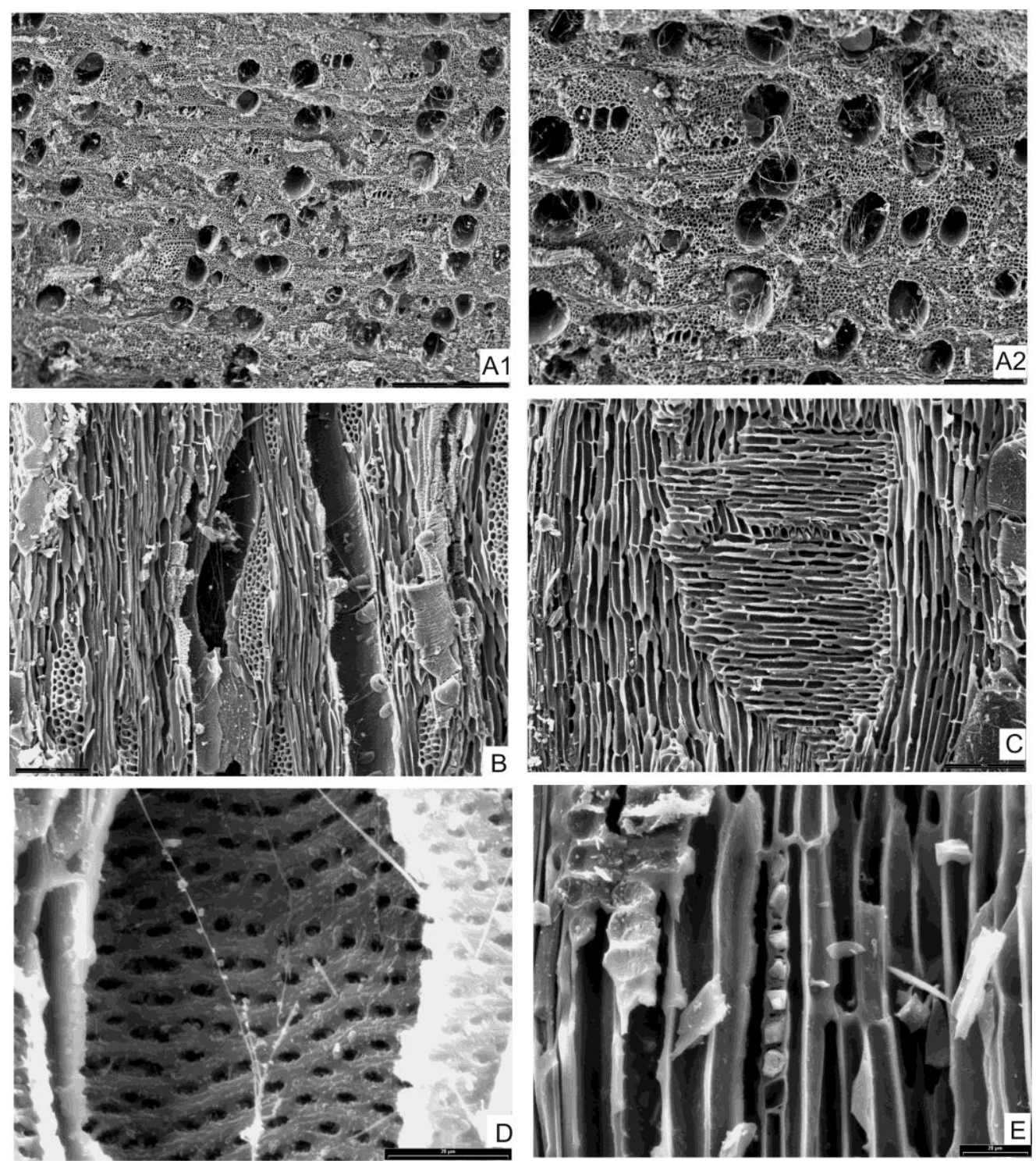

Figura 6.42. Cortes diagnósticos del género Prosopis sp. A1 y A2: Corte transversal (CT); B. Corte longitudinal tangencial (CLT); C. Corte longitudinal radial (CLR); D. Puntuaciones intervasculares alternas; E. Cristales en parénquima leñoso.

2. Bulnesia sp. (Zigophyllaceae) - Nombre vulgar: retama (Figura 6.43)

$>$ CT: presenta poros en su mayoría solitarios y escasos múltiples cortos, de forma elíptica y oval, algunos se encuentran agrupados y con contenidos. El diámetro de los poros es variable, detectando en algunos ejemplares elementos pequeños $(49,59 \mu \mathrm{m})$ y grandes $(182,75 \mu \mathrm{m})$ (Figura 6.43-A2) y en otros, los poros son medianos con valores de entre 126,61 y 143,26 $\mu$ m (Figura 6.43-A1). La porosidad es difusa y circular. Los anillos están levemente demarcados por achatamiento de fibras, las cuales presentan una pared delgada. El parénquima es vasicéntrico abundante y confluente en bandas cortas. 
$>$ CLT: se observaron elementos del vaso estratificados y radios no estratificados $^{6}$. Los radios en su mayoría son triseriados y en menor frecuencia tetraseriados. Se observaron cristales en células parenquimáticas, presencia de fibrotraqueidas y punteaduras alternas.

$>$ CLR: presentan un jaspeado pronunciado y radios homogéneos
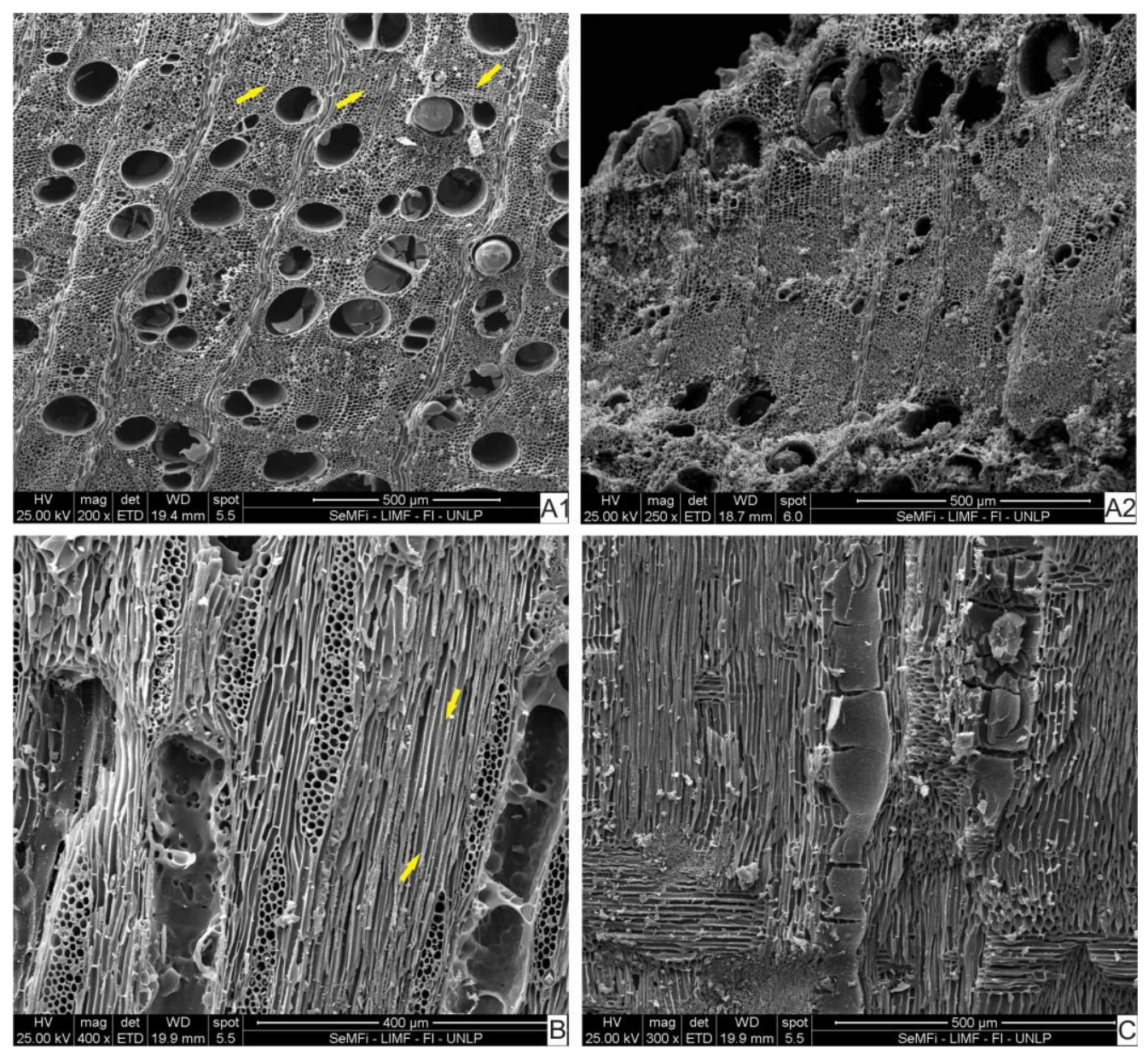

Figura 6.43. Cortes diagnósticos del género Bulnesia sp. A. Corte transversal (CT): porosidad difusa, las flechas señalan el achatamiento de fibras que demarca el anillo (A1); variante con porosidad circular (A2). B: Corte longitudinal tangencial, las flechas señalan una fibrotraqueida (CLT); C. Corte longitudinal radial (CLR).

3. Parkinsonia sp. (Fabaceae), también llamada Cercidium sp. - Nombre popular: brea (Figura 6.44):

$>\quad$ CT: se han observado principalmente poros solitarios y algunos agrupados. Los poros son de diámetros medianos en torno a los 187,57 $\mu \mathrm{m}$. La porosidad es

\footnotetext{
${ }^{6}$ Respecto a estos caracteres Tortorelli aclara que este género "presenta estratificación parcial ya que de ella participan el parénquima leñoso y la mayor parte de los elementos vasculares, no así los radios leñosos que abarcan varios estratos" (2009 [1956]: 475, Tomo I)
} 
circular a semicircular. Presenta fibras de pared gruesa. Los anillos están demarcados por parénquima marginal y por achatamiento de fibras. Presentan un tipo de parénquima aliforme confluente en bandas anchas y radios numerosos, estos últimos fueron asimismo visibles a lupa.

$>$ CLT: los radios en su mayoría son multiseriados con presencia de triseriados. El parénquima es fusiforme en series cortas ( 2 a 4 células). No presenta estructura estratificada. Se han observado cristales prismáticos alojados en el parénquima. Los elementos del vaso presentan tabiques oblicuos y punteaduras alternas.

$>\quad$ CLR: los radios son mayormente homogéneos con células procumbentes y jaspeado notorio.
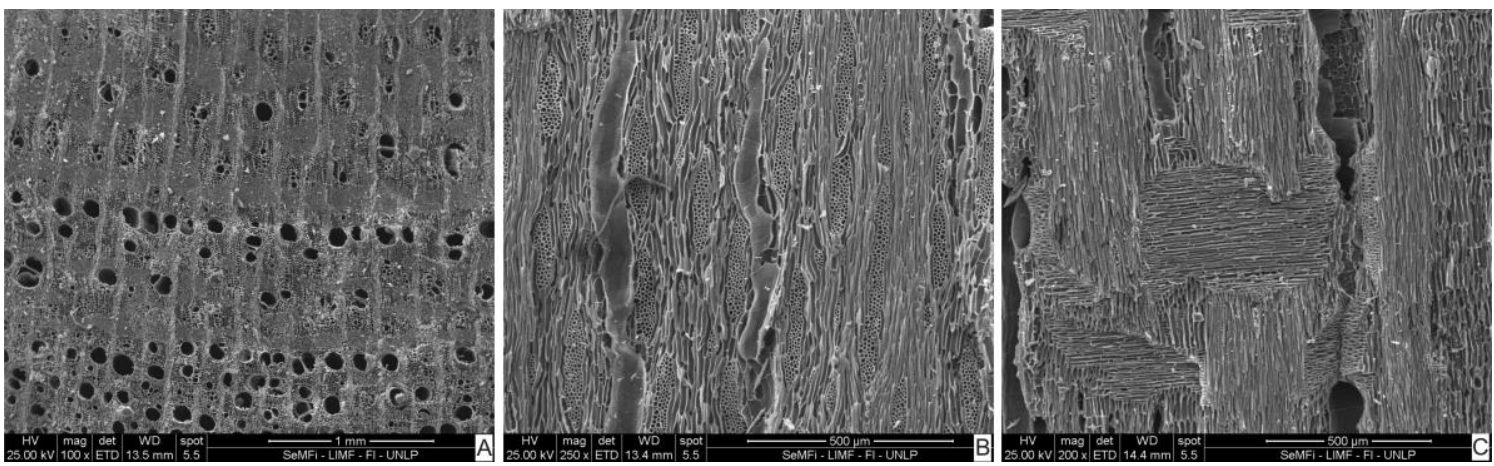

Figura 6.44. Cortes diagnósticos del género Parkinsonia sp. A. Corte transversal (CT); B: Corte longitudinal tangencial (CLT); C. Corte longitudinal radial (CLR).

4. Geoffroea sp. (Fabaceae) - Nombre popular: chañar (Figura 6.45):

$>\quad$ CT: presentan poros abundantes, en su mayoría solitarios y de contorno oval. Los poros son de diámetros medianos en torno a los 187,57 $\mu \mathrm{m}$. Algunas muestras presentan poros sin disposición y en otras se observó porosidad difusa tendiente a semicircular. Presentan parénquima vasicéntrico abundante y confluente en bandas. Los anillos se encuentran demarcados por parénquima marginal (Figura $6.46)$.

$>\quad$ CLT: Los radios en su mayoría son tetraseriados de $226,31 \mu \mathrm{m}$ de alto y 39,45 $\mu \mathrm{m}$ de ancho, son raros los biseriados. Algunos radios presentan células agregadas. El parénquima es fusiforme en series cortas. 
$>\quad$ CLR: se observó un jaspeado muy leve. Las punteaduras de los vasos son alternas. Los radios son homogéneos constituidos por células procumbentes.
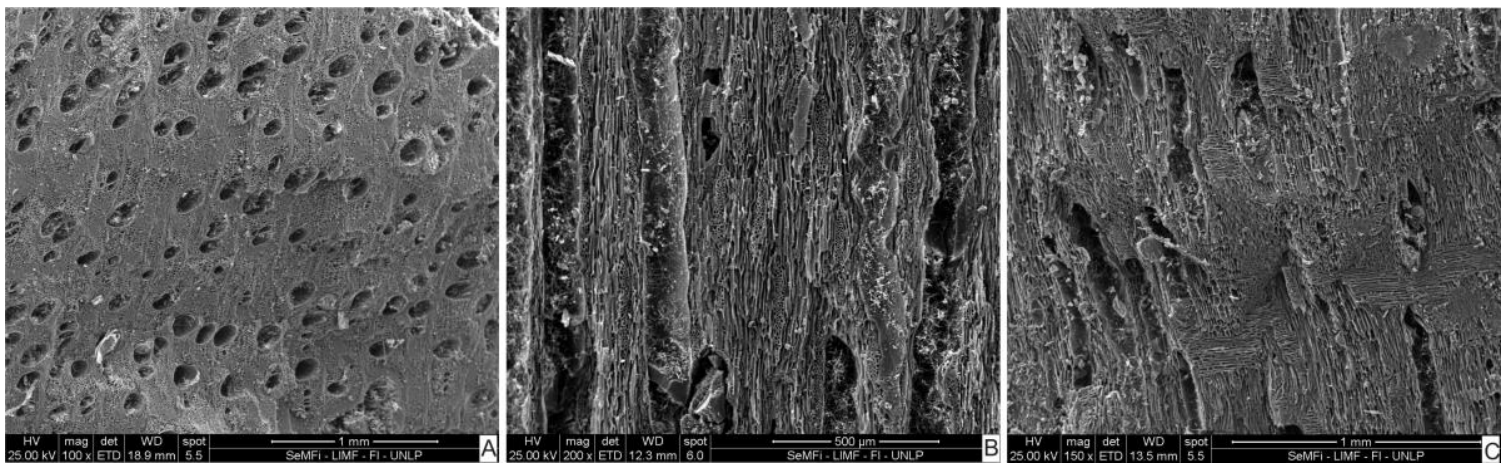

Figura 6.45. Cortes diagnósticos del género Geoffroea sp. A. Corte transversal (CT); B: Corte longitudinal tangencial (CLT); C. Corte longitudinal radial (CLR).
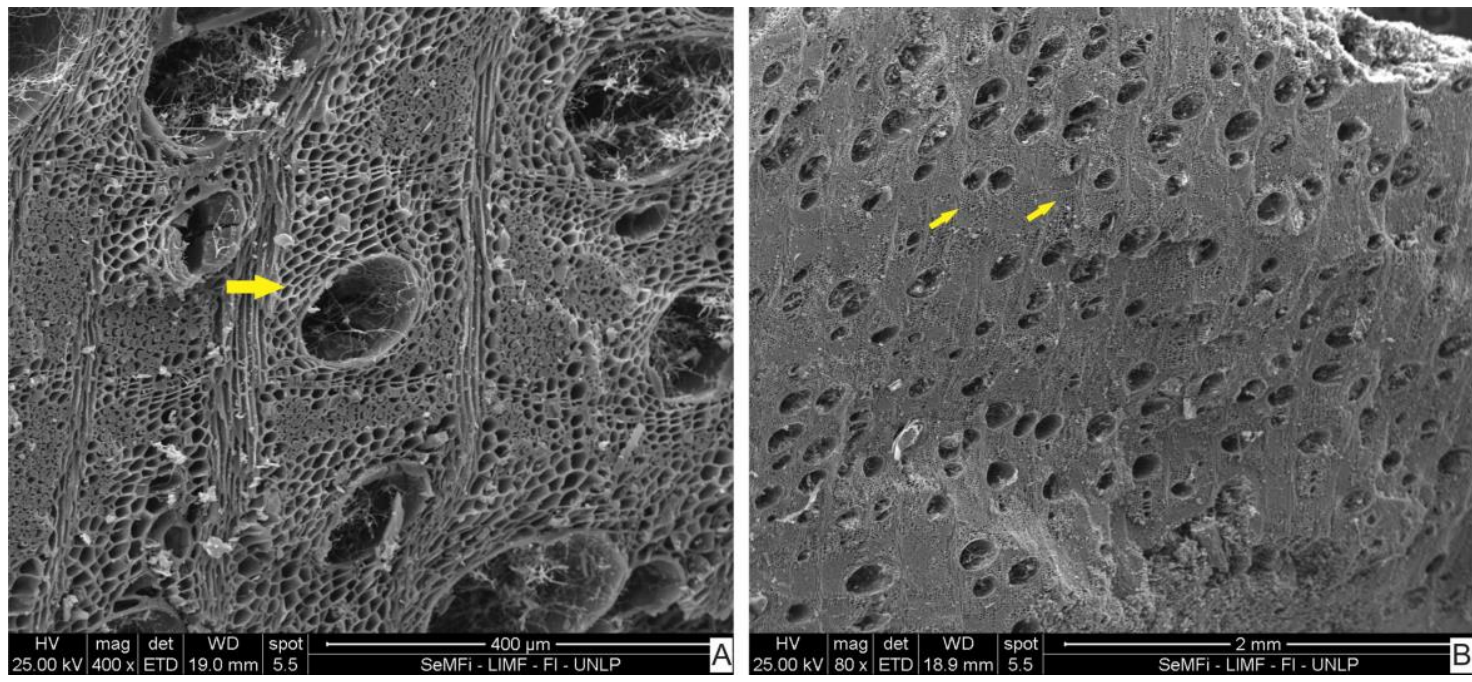

Figura 6.46. Detalles del corte transverdal del taxón Geoffroea sp. A. parénquima marginal; B. Las flechas indican el parénquima marginal que demarca el anillo.

\begin{tabular}{|c|c|c|c|c|c|}
\hline \multirow[b]{2}{*}{ GÉNERO } & \multicolumn{4}{|c|}{ CANTIDAD DE TAXONES POR SECTOR } & \multirow[b]{2}{*}{ TOTAL } \\
\hline & $\begin{array}{l}\text { Cámara } \\
\text { Inferior } \\
\text { (UEA7) }\end{array}$ & $\begin{array}{c}\text { Exterior } \\
\text { Horno } \\
\text { (UEA5) }\end{array}$ & $\begin{array}{l}\text { Monticulo } \\
\text { Este } \\
\text { (UEA3A) }\end{array}$ & $\begin{array}{l}\text { Montículo } \\
\text { Oeste } \\
\text { (UEA3B) }\end{array}$ & \\
\hline Prosopis sp. & 7 & 5 & 4 & 1 & 17 \\
\hline Bulnesia sp. & - & 1 & 1 & 4 & 6 \\
\hline Parkinsonia sp. & 1 & - & 2 & 1 & 4 \\
\hline Geoffroea sp. & - & 1 & - & 2 & 3 \\
\hline Indeterminadas & - & 1 & 1 & - & 2 \\
\hline
\end{tabular}

Tabla 6.9. Frecuencia numérica de los taxones identificados por sector muestreado. 
Los resultados obtenidos indican que los desechos de combustión analizados estan conformados mayormente por maderas de árboles de algarrobo, seguida de retama, brea y chañar (Gráfico 6.6), que son géneros nativos caracteristicos de la vegetación del clima semiárido de la región fitogeográfica del monte, a la cual pertenece la zona de estudio.
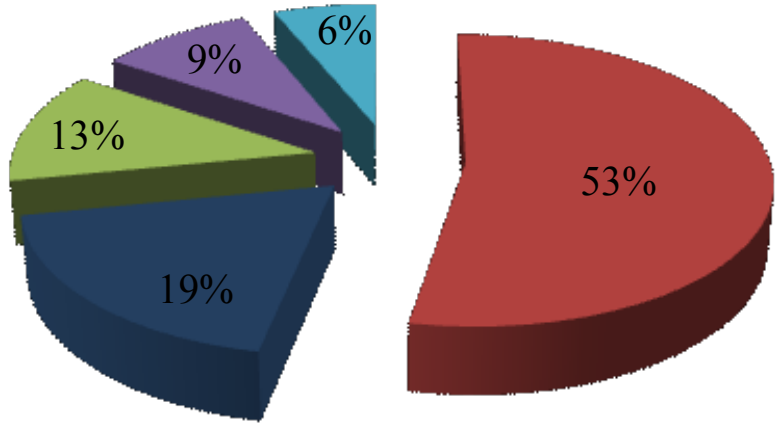

- Prosopis sp.

- Bulnesia sp.

Parkinsonia sp.

- Geoffroea sp.

- Indeterminadas

Gráfico 6.6. Frecuencia porcentual de taxones de maderas del horno 14.

Todos los géneros identificados corresponden a maderas semiduras, duras y de densidad moderada a alta (con valores entre 0,585 y 0,900 ), por lo cual tienen un gran poder calofíco que las posicionan dentro de los combustibles de mejor calidad (Tortorelli 2009 [1956]). La gran eficacia y rendimiento calórico radica en que las maderas duras presentan una combustión lenta y por lo tando permanecen más tiempo encendidas, liberando energía que alcanza temperaturas muy elevadas. Además, las maderas de Bulnesia sp. y Parkinsonia sp. poseen contenidos cerosos y resinas que favorecen la generación rápida de llama. Por lo tanto, se puede inferir que, en los distintos momentos de la fundición, los artesanos combinaron maderas de acuerdo a las necesidades de las operaciones, por ejemplo, incorporando aquellas que generen llama en momentos claves del proceso como ser el calentamiento de los hornos y del material a procesar. Por el otro, alcanzaron y mantuvieron altas temperaturas con maderas duras como el Prosopis sp., necesario para las transformaciones químicas y físicas de los minerales. La carbonización de la leña ofrece, además, el ambiente reductor requerido para las operaciones de fundición.

En este sentido, los artesanos habrían seleccionado las maderas más óptimas para las actividades de producción. Para ello se valieron de sus conocimientos sobre las 
cualidades físico-químicas de cada tipo de madera en relación con tipo de combustión requerida para las actividades metalúrgicas. Así, la mayor frecuencia de Prosopis sp. entre las muestras de carbón señala la selección del mejor combustible para estas operaciones (González 2002). Las restantes maderas identificadas indican que hicieron un uso más amplio de recursos madereros, pero siempre seleccionando aquellos de buena calidad para generar fuegos resistentes entre la diversidad de recursos forestales disponibles en la zona (ver capítulo 5).

\subsubsection{Dataciones Radiocarbónicas}

Se han seleccionado dos muestras de carbones recuperados del H14 del conjunto de hornos 2 para realizar fechados radiocarbónicos. Una de ellas fue obtenida de la cámara inferior (CH2-H14-CI) y la segunda del montículo de carbón de la UEA3-A del mismo horno (CH2-H14-UEA3A). Las muestras corresponden a ramas pequeñas de maderas del género Prosopis sp. Se buscó seleccionar aquellos leños más jóvenes con el fin de reducir el efecto de "madera vieja" que sucede principalmente al analizar taxones longevos y de alta durabilidad (Marconetto 2007), como este género, cuyas dataciones pueden indicar fechas que no necesariamente se corresponden con el momento de su quema, sino con eventos anteriores. Esto puede ocurrir si se emplea para la combustión troncos que fueron previamente utilizados en la construcción de recintos dónde formaron parte de vigas y pilares (Marconetto 2007). Sin embargo, al considerar la escala de producción metalúrgica del sitio, incluso a nivel de cada horno individual, se observa que la demanda de combustibles fue muy alta señalando un sistema de abastecimiento que posiblemente implicaba actividades de corte y tala de los árboles que estaban disponibles en el bosque local.

Los fechados fueron realizados en el laboratorio de Tritio y Radiocarbono (LATYR) de la Facultad de Ciencias Naturales y Museo de la Universidad Nacional de La Plata, CIG, CONICET, siendo calibrados para el Hemisferio Sur SHCal13.14c (Stuiver and Reimer 1993 y Hogg et al. 2013) (Figura 6.47 y Tabla 6.10).

Además de este par de fechados realizados en el marco de la presente investigación, se disponen de aquellos efectuados por los investigadores previos. El primer fechado obtenido del sitio fue realizado sobre muestras de carbón recuperadas en el sector de recintos (González y Lagiglia 1973) y los segundos, sobre carbones seleccionados de dos hornos del conjunto 1 (Raffino et al. 1996). Dado que ambos 
conjuntos de datos fueron obtenidos durante las fases iniciales de desarrollo de esta técnica, sus edades convencionales no solían ser calibradas para el hemisferio sur. Por lo tanto, para poder evaluarlos en conjunto a los nuevos datos, se procedió a su calibración con el programa CALIB 7.0.4 y Stuiver y Reimer (1993) y se presentan junto a los fechados recientes en la tabla 6.10 .

\begin{tabular}{|c|c|c|c|c|c|}
\hline \multirow{2}{*}{$\begin{array}{c}\text { Id } \\
\text { Quillay/ } \\
\text { Referencia }\end{array}$} & \multirow{2}{*}{$\begin{array}{c}\text { Id } \\
\text { Muestra }\end{array}$} & \multirow[t]{2}{*}{ Laboratorio } & \multirow{2}{*}{$\begin{array}{c}\text { Edad } \\
\text { convencional } \\
(\text { años AP) }\end{array}$} & \multicolumn{2}{|c|}{ Calibrado por Latyr - AD } \\
\hline & & & & $1 \sigma$ & $2 \sigma$ \\
\hline $\begin{array}{l}\text { CH2-H14- } \\
\text { CI }\end{array}$ & LP- 3198 & Latyr & $560 \pm 50$ & $\begin{array}{l}\text { cal AD 1317 - } \\
\text { cal AD 1354] } \\
\text { Area relativa } 1\end{array}$ & $\begin{array}{l}\text { [cal AD 1382 } \\
\text { cal AD 1458] } \\
\text { Area relativa } \\
0,862018 \\
\\
\text { [cal AD 1317 - } \\
\text { cal AD 1354] } \\
\text { Area relativa: } \\
0,137982\end{array}$ \\
\hline $\begin{array}{l}\text { CH2-H14- } \\
\text { UEA3A }\end{array}$ & LP- 3216 & Latyr & $510 \pm 50$ & $\begin{array}{l}{[\mathrm{cal} \text { AD 1411- }} \\
\text { cal AD 1456] } \\
\text { Area relativa } 1\end{array}$ & 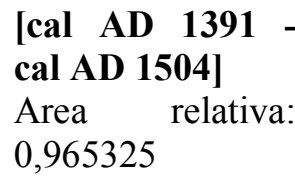 \\
\hline & & & & & 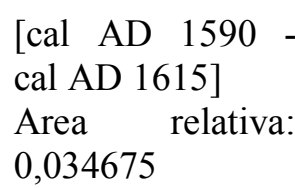 \\
\hline $\begin{array}{l}\text { González y } \\
\text { Lagiglia }\end{array}$ & $\begin{array}{l}\text { UCLA } \\
785-B\end{array}$ & $\begin{array}{l}\text { University of } \\
\text { California, }\end{array}$ & $935 \pm 80$ & $\begin{array}{l}\text { [cal AD 1127: } \\
\text { cal AD 1217] }\end{array}$ & $\begin{array}{l}\text { [cal AD 1017: cal } \\
\text { AD 1276] }\end{array}$ \\
\hline 1973 & & Los Angeles & & $\begin{array}{l}\text { Area relativa } \\
0,60\end{array}$ & Area relativa 1 \\
\hline $\begin{array}{l}\text { Raffino et } \\
\text { al. } 1996\end{array}$ & AC-0553 & INGEIS & $390 \pm 100$ & $\begin{array}{l}\text { [cal AD 1457: } \\
\text { cal AD 1630] } \\
\text { Area relativa } 1\end{array}$ & $\begin{array}{l}\text { [cal AD 1397: cal } \\
\text { AD 1696] } \\
\text { Area relativa } 0,92\end{array}$ \\
\hline $\begin{array}{l}\text { Raffino et } \\
\text { al. } 1996\end{array}$ & AC-0552 & INGEIS & $460 \pm 100$ & 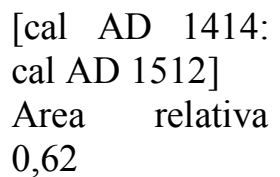 & $\begin{array}{l}\text { [cal AD 1380: cal } \\
\text { AD 1668] } \\
\text { Area relativa } 0,96\end{array}$ \\
\hline
\end{tabular}

Tabla 6.10. Fechados radiocarbónicos calibrados del sitio Quillay 

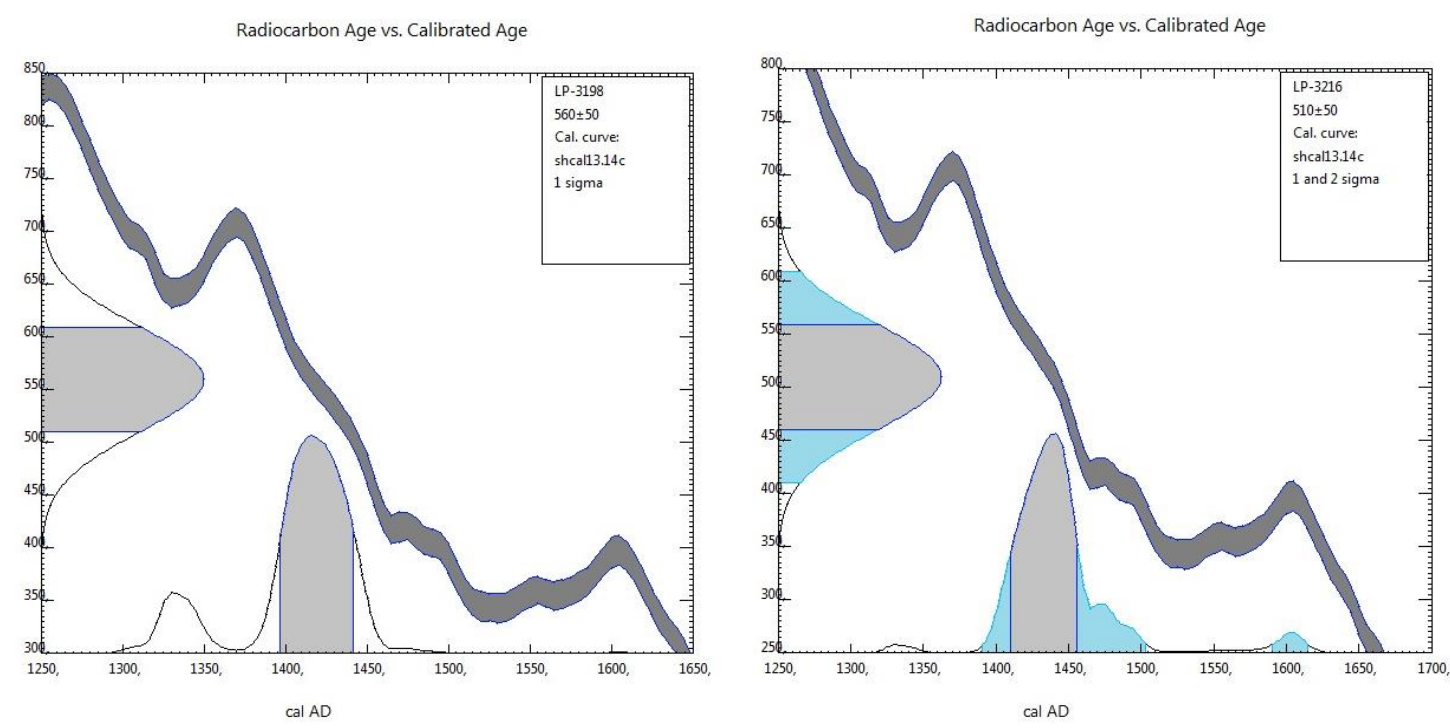

Figura 6.47. Fechados radiocarbónicos de hornos del conjunto 2 y curvas de calibración.

A partir de los resultados presentados en la tabla, se observa que el mayor número de fechados otorgan edades radiocarbónicas posteriores al siglo XIV. Únicamente el fechado realizado González y Lagiglia (1973) sobre muestras de los recintos otorga rangos más tempranos. Es importa señalar que no se poseen datos concretos de dónde fue seleccionada esta muestra, sin embargo, es probable que haya sido extraída de la excavación del recinto circular ya que en las anotaciones de campo señala la identificación de carbones. En este sentido, dado que los recintos se emplazaban sobre montículos artificiales es posibile una contaminación mediante el traslado de tierra de otras zonas.

Respecto al otro conjunto de fechados, para el intervalo de $2 \sigma$ se observa que aquellos con mayor grado de probabilidad indican rangos temporales que van desde fines del siglo XIV hasta inicios del siglo XVI. Dentro del conjunto de $1 \sigma$, los datos otorgan fechas de inicios hasta mediados del siglo XV, señalando fechas que caen dentro del período de ocupación Inka contemplado para el valle. 


\subsection{8. ¿Qué nos dice el fragmento textil registrado en el horno 14?}

Anteriormente se ha hecho referencia al hallazgo de una pieza textil en la boca de acceso a la cámara inferior del H14. El mismo se encontró en una posición horizontal por debajo del estrato calcáreo (UEA1). Se habla del carácter distintivo de este hallazgo, dado que su preservación no es frecuente en ambientes caracterizados por lluvias intensas que, aunque circunscriptas a los meses de verano, contribuyen a aumentar la humedad relativa de los suelos favoreciendo el deterioro de los textiles debido a su naturaleza orgánica. En este sentido, se considera que el sedimento calcáreo inmediato actuó impermeabilizando el entorno del tejido al frenar la lixiviación hídrica. Indicios de esto último fue la textura laminada del sedimento natural, detectado únicamente en los niveles superiores al estrato de calcita.

Al fragmento textil se le efectuaron tratamientos de limpieza y conservación que han posibilitado resguardarlo y emprender su estudio técnico. Ambas tareas fueron realizadas por las especialistas Mg. Silvana Di Lorenzo y la Dr. Cecilia Pérez de Micou (ver informes correspondientes en Anexo II). A partir de estos tratamiento se observó que si bien el sedimento calcáreo contribuyó a su preservación en el contexto arqueológico, estas partículas se adhirieron fuertemente a las fibras del textil imposibilitando su extracción profunda que hubiera contribuido a la ruptura de la pieza (Di Lorenzo et al. 2016).

Aún así, el trabajo de conservación aplicado al textil permitió reducir el potencial de fragilidad, eliminar pliegues, registrar la técnica de manufactura y los colores utilizados e incluso reconocer sus motivos decorativos. En términos morfológicos, el fragmento es una pieza con dimensiones de 20 por $15 \mathrm{~cm}$, no se observaron bordes ni orillos, pero si terminaciones de refuerzo que contribuyó a su orientación morfológica. Fue conformado con fibras de camélidos, posiblemente de vicuña dado su textura fina.

Los datos del informe señalan que el textil está conformado por un tejido llano balanceado $1 / 1$ con decoración estructural producida por urdimbres flotantes. Las tramas y urdimbres están compuestas por dos cordeles cada una. Las urdimbres presentan alternancia de colores rojo-morado y castaño, siendo las tramas monocromas castañas. Se observó que los hilos poseen un alto grado de torsión en "S" y un patrón de hilado en "Z" (para mayores detalles técnicos ver el informe correspondiente). 
Respecto a los motivos decorativos, se observaron patrones geométricos conformados con las urdimbres rojo/moradas. Se pudieron distinguir escalonados, líneas paralelas, grecas, motivos diagonales y puntos (Figura 6.48). Estos patrones decorativos rememoran los diseños observados en otras piezas textiles de periodos tardíos registradas en Catamarca, como el fragmento de Loro Huasi, recuperado de un ajuar funerario junto a piezas cerámicas Belén (Renard 1997). Incluso, los diseños de grecas y escalonados son frecuentes en las piezas cerámicas de carácter local. También dentro de los grupos tardíos, pueden relacionarse con diseños Sanagasta o Angualasto de las regiones hacia el sur del valle de Hualfín. Tal como sugiere Pérez de Micou, motivos similares han sido reconocidos en textiles de San Juan (Michelli 2012).

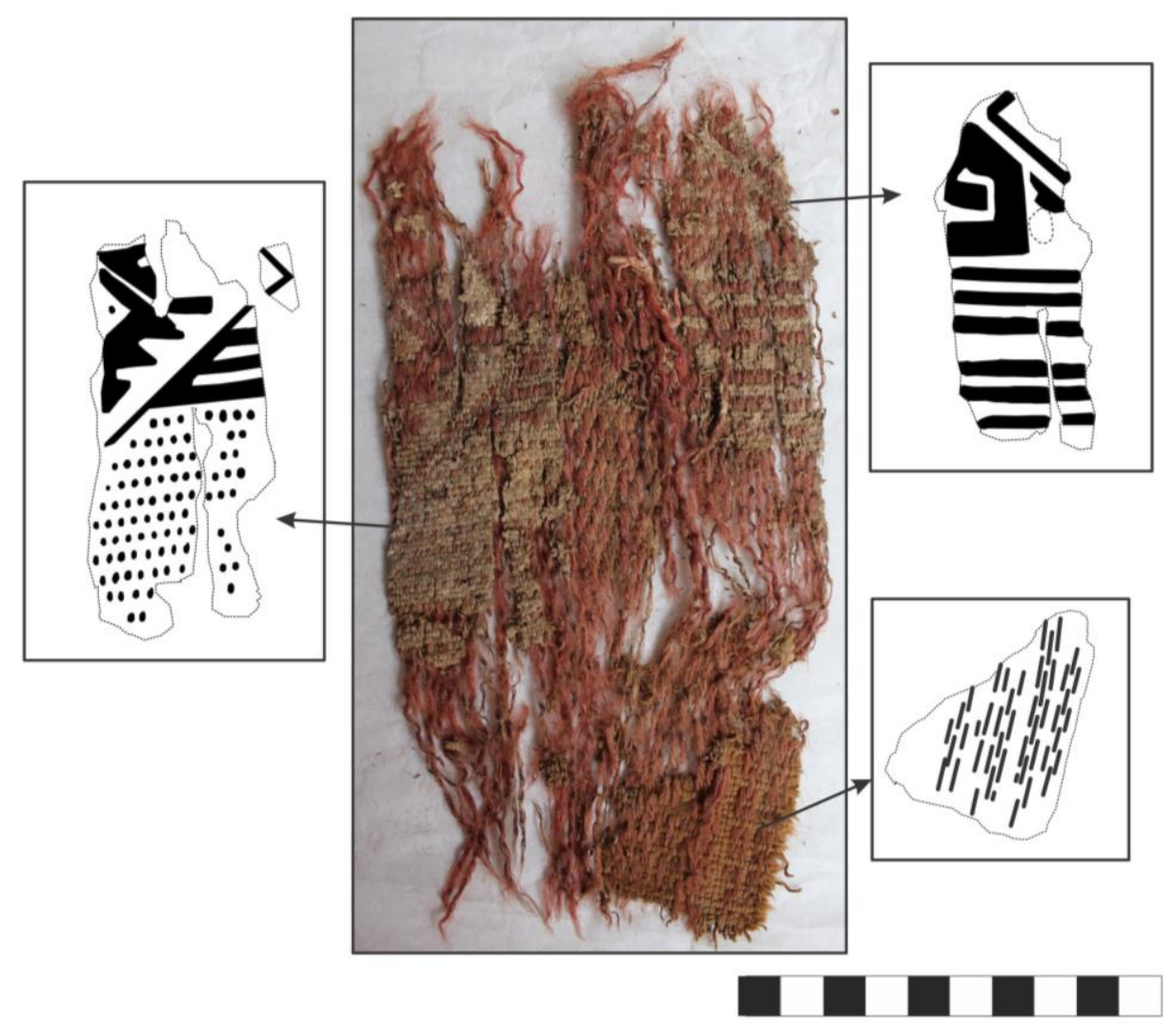

Figura 6.48. Diseños del fragmento textil recuperado en el H14.

Una mención especial requiere el patrón de hilado del tejido. El hilado en " $Z$ " o llok'e (es decir aquel que se teje hacia la izquierda) no es un patrón de uso cotidiano, sino que se lo asocia a tejidos especialmente fabricados con fines ceremoniales y para su empleo en ritos asociados a prácticas curativas, funerarias y fundamentalmente a rituales relacionados con la Pachamama (Rolandi de Perrot y Jiménez de Puparelli 1983-1985). En los pueblos actuales del NOA, se concibe que este tipo de tejidos 
"actúan como intermediarios entre esta deidad y los seres humanos, aplacando a veces su acción maligna y otras permitiendo su efecto benéfico" (Rolandi de Perrot y Jiménez de Puparelli 1983-1985: 285).

En el capítulo 2, se ha hecho referencia de la estrecha relación entre las prácticas metalúrgicas y las entidades no humanas, en especial con la madre tierra, dado los complejos procedimientos que implican las transformaciones del mineral y del metal (González 2004a). Todas las operaciones involucradas en la metalurgia, desde la minería hasta la producción y uso de los objetos, están imbuidas de una alta sacralidad y existen numerosos ritos vinculados a los procesos productivos (Lechtman 1999). En este marco, dado las cualidades técnicas distintivas del textil y el contexto de hallazgo, es decir su ubicación y disposición horizontal, así como la extensión del estrato calcáreo que señalaría un bloqueo en el acceso a la cámara inferior del horno, se considera posible enmárcalo en una acción ritual de cierre de la actividad metalúrgica. Además, se debe considerar que los textiles al romperse, no suelen ser desechados, sino que suelen repararse mediante la costura de sus fragmentos. Una situación similar, se observa en otras tecnofacturas como ser la fusión de metales fracturados o la unión de cerámicas fragmentadas. Por lo tanto, se considera que su recuperación en el horno señala que en el pasado existió una acción deliberada de depósito, seguramente como parte una ofrenda ritual. Incluso, también en el horno 17 - que fue parcialmente excavado- se han recuperado hilos sueltos de lana de camélido de color azul y un alto grado de torsión en "S", que sugieren la posibilidad de encontrar nuevos textiles en estos contextos.

Como se ha explicitado en los antecedentes, existen algunos contextos arqueológicos con ofrendas de distinto tipo asociado a hornos metalúrgicos, que sirven como referentes arqueológicos de las numerosas prácticas de carácter ritual observadas en los trabajos etnográficos actuales (pe. Valencia 1978; Absi 2005; Van Buren y Mills 2005). En Perú, las ofrendas fueron de tipo fundacional y consistían en neonatos de llamas y materia orgánica (Shimada 1987). Para el NOA, se cuenta con las evidencias registradas en el Sitio 15 de Rincón Chico (Catamarca) dónde, asociado a las wayras, se hallaron valvas de moluscos marinos, un diente de un mamífero extinto y restos óseos faunísticos interpretados como ofrendas rituales relacionadas a la práctica de fundición (González 2004a). Los restos de textiles registrados en Quillay dado su asociación con los hornos son factibles de ser interpretados en el mismo sentido. 


\subsection{Sintetizando las características estructurales de los hornos metalúrgicos}

En el capítulo 5 se expuso que las características morfométricas de los hornos en Quillay son similares, incluso la evaluación estadística indica que no existen diferencias significativas entre los ejemplares mejor conservados. A partir de esto, podemos proponer que los hornos fueron construidos en serie. Los datos obtenidos a partir de las excavaciones de tres hornos, señalan que su estructura es semejante estando conformada por cuatro componentes conectados en sentido vertical: una cámara superior, un sector intermedio con seis conductos, una cámara inferior y una corta antecámara inferior.

Más allá de las diferencias generadas por procesos postdepositacionales, se observaron ciertas variaciones en el sector intermedio y en la cámara superior. Nos referimos específicamente a diferencias en el grado de termoalteración de los conductos y paredes, que pueden deberse tanto a variaciones en la intensidad de su uso como a requerimientos específicos durante los procedimientos metalúrgicos. Este sería el caso para el H14, donde se destinó un conducto a los fines de ventilación y para el H17 donde se observan conductos colapsados y bloqueados.

Las asociaciones contextuales de estructuras y materiales obtenidos de la excavación del H14 señalan que los hornos fueron estructuras semienterradas. Las bases de los montículos de desechos observados en la $\mathrm{C} 2$, se hallaron al nivel de inicio de la cámara inferior, indicando el nivel del suelo. Es posible que para su construcción se haya excavado el terreno aprovechando la pendiente natural. A partir de allí, se daría forma al horno que quedaría enclavado en el terreno, quedando la cámara inferior y la antecámara a nivel del subsuelo conseguido y elevándose la cámara superior por sobre el piso. La tendencia actual de fragmentación de las paredes de esta última, señala una construcción con panes o especie de "ladrillos" de arcilla, que se irían superponiendo siguiendo la circunferencia de la base del horno. Finalmente, requerirían de un paulatino calentamiento para eliminar la humedad y alcanzar la fortaleza estructural necesaria para soportar la carga de mineral durante los procedimientos pirometalúrgicos.

\subsection{Algunas propuestas sobre dinámica de funcionamiento de hornos}

En este apartado se proponen algunas hipótesis sobre el funcionamiento a nivel estructural de los hornos. Para ello nos basamos en la evidencia otorgada por los materiales de desecho y su evaluación, teniendo en cuenta el conocimiento sobre el 
funcionamiento de hornos andinos y los procedimientos tecnológicos disponibles en el tratado metalúrgico de Barba (1817 [1640]).

En primer lugar, proponemos que las dos cámaras principales cumplirían, cada una, un rol diferente en esta primera etapa de fundición. Las funciones de la cámara superior incluirían la carga del mineral y el fundente así como el control de la ventilación durante los procedimientos iniciales. La cámara inferior cumpliría tareas de combustión y de vaciado de los productos y desechos metalúrgicos.

Entonces por la cámara superior se realizaría la carga de la mena triturada. En base a las evidencias de las escorias y vestigios de mineral en las manos de moler (capitulo 4) es probable que se hayan empleado menas mixtas compuesta de sulfuros y óxidos de cobre. Estas se colocarían en trozos por sobre los conductos utilizando algún implemento para su sostenimiento momentáneo, quizás alguna especie de enramada vegetal, la cual no dejaría macro vestigios tras su quema. Asimismo, es posible que el calentamiento gradual de esta cámara haya contribuido al proceso de tostación requerido para menas sulfuradas.

En las recomendaciones brindadas por Barba sobre las formas de fundir los minerales de plata, señala que este procedimiento puede realizarse utilizando minerales en trozos o finamente molidos, sin embargo el autor recomienda la primera estrategia. En sus palabras: "Lo más acertado fuera quemar en piedra el metal, pues se facilitará, como queda dicho, y ahorrará en parte la molienda, y cesaba el inconveniente de que la plata sutil volase con el humo" (1817 [1640]: 94). Pese a estas ventajas, también aclara que la quema se realizaría de una manera heterogénea en función del tamaño del mineral. Asimismo, comenta que los metalurgos podían controlar fácilmente el proceso de tostación a partir del cambio en la coloración de los humos de negro a blanco y la ausencia de olor que indicaría una correcta volatilización del azufre y antimonio contenido en la mena (Barba 1817 [1640]: 100-101).

En Quillay, durante la licuefacción del mineral, se irían agregando en función de las necesidades fundentes de arena o de cuarzo molido, a juzgar por su presencia en las escorias, contribuyendo a un fundido heterogéneo. Este material, fluiría por los conductos en sentido descendente hacia la cámara inferior. En su interior, se observó que este material presentaba un aspecto fluido y existían conexiones físicas, a través de 
una continuidad a la manera de la díada estalactita-estalacmita, entre los desechos contenidos en la cámara inferior y los conductos.

Respecto a la cámara inferior, nos preguntamos sobre la forma en que habría sido recuperado el metal obtenido y por qué espacios se realizaría el vaciado de los desechos. Para Quillay podemos avanzar hasta las siguientes inferencias que analíticamente podemos dividir en dos etapas. La primera, relativa a la preparación de la cámara inferior previo inicio de la fundición; y la segunda, a las actividades pirometalúrgicas propiamente dichas. La cámara inferior presenta una única abertura frontal de gran tamaño, lo que nos indica que por allí se controlarían ambos procedimientos.

Con relación al primer punto, a partir de los hallazgos localizados en el interior de la cámara inferior, proponemos que se habría diseñado una arquitectura de división un tanto rústica del espacio relacionada con distintas acciones. El abundante carbón localizado hacia la derecha indicaría que este sector estaba destinado a la producción y control de la combustión. Hacia el fondo, se registró un montículo artificial coronado por una gruesa capa de material calcáreo. Suponemos que habría sido construido luego de la limpieza del material residual de fundiciones previas y antes de la colocación de la leña a usar en un nuevo evento. En su construcción, se buscó una pendiente hacia el sector izquierdo para dirigir el material fundido, que drenaría desde los conductos superiores una vez funcionando el horno.

La segunda etapa, ya en el momento de la fundición, nos obliga a plantear al menos dos hipótesis sobre la manera en que habría sido colectado el cobre obtenido. La primera alternativa plantea un sistema donde la escoria fluiría hacia afuera de la cámara, aprovechando la pendiente generada en el sector izquierdo, que además, cuenta con una proyección hacia afuera a juzgar por la presencia de calcita. El cobre quedaría depositado en una especie de oquedad insinuada en el interior de la cámara (se remite a la figura 6.12), siendo recolectado al finalizar el proceso y una vez enfriado. Cabe aclarar que el mismo contendría aún restos de escoria adherida por lo cual es muy probable que necesitaran de nuevas refundiciones para purificarlo. Las evidencias con la que contamos para avalar esta posibilidad son los numerosos fragmentos de escoria de aspecto fluido que aparecen por fuera de cada horno, así como también fragmentos de material calcáreo de morfología tubular que darían cuenta de una alteración por temperatura y de movimiento direccional de la materia. 
La segunda posibilidad, implicaría que no existiera drenaje hacia afuera y que todo el fluido se dejara enfriar dentro del horno. El metal, de mayor densidad, se concentraría en la parte inferior de una posible cavidad calcárea, mientras que, por arriba, se concentraría la escoria. Una vez enfriado, el material sólido se extraería mecánicamente, fragmentando el producto en la búsqueda del metal. La presencia de escorias solidificadas in situ, podría estar dando cuenta de este hecho. Además algunas muestras superficiales presentan superficies fragmentadas (con fractura concoidal) que podría ser productos intencionales de esta instancia. No obstante, cabe la posibilidad que las fracturas se deban a alteraciones posdepositacionales por desplazamientos y choques generados por la escorrentía superficial o por el pisoteo animal.

Ambos mecanismos de vaciado del horno fueron descriptos por Barba en la fundición de minerales de plata realizados en hornos de reverbero (Barba 1817 [1640]). Salvando las diferencias morfológicas y temporales entre los hornos, es interesante poder recuperar los procedimientos de trabajo utilizados por los metalurgos indígenas al inicio de la colonia. El autor observó que a veces el metal "corre por una como acequia, que está señalada en el suelo con alguna decaída, y en ella se enfría, se quiebra en pedazos, y se recoge y guarda para refinar después" (p.187) y en otros casos observó que se dejaba enfriar la escoria que luego era quebrada fácilmente con un cincel, extrayendo finalmente el producto metálico contenido en una "carbonilla" - mezcla de carbón molido y tierra- con una especie de cucharas (Barba 1817 [1640]). La extracción mediante fragmentación ha sido una práctica habitual entre los metalurgos andinos en función de los estudios realizados en los hornos de Batan Grande (Shimada et al. 1982). Con estas referencias, creemos posible que las evidencias observadas en Quillay podrían corresponder a procedimientos de esta clase, aunque futuros estudios exprimentales serán los que nos posibilitaran evaluar estas hipótesis.

\subsection{Breve debate en torno a las categorías de hornos}

Ha sido frecuente que en trabajos de metalurgia andina se aplicaron categorías tecnológicas descriptivas. Por un lado, se han utilizado etnocategorías como es el caso de las wayras, así como el uso de categorías que refieren a principios tecnológicos - pe. hornos de cuba/reverbero; ventilación natural/forzada- usando el recurso de la analogía para comprender los atributos operativos de los hornos. En función de esto, es necesario poner en diálogo los usos dados a las categorías plasmadas en la bibliografía 
especializada. En el caso de Quillay, este debate se vuelve relevante dado que los antecedentes marcan que existió una sobreestimación del término wayra aplicado acríticamente (Raffino et al. 1996; Raffino et al. 2013). Siguiendo esta lógica de pensamiento, en este apartado nos proponemos indagar sobre las categorías de hornos metalúrgicos andinos que permiten evaluar los hornos de Quillay. En primer lugar, es necesario reflexionar críticamente sobre la clásica inclusión de estos ejemplares dentro de la categoría de wayra para luego reinsertar la discusión teniendo en cuenta categorías más abarcativas.

Con respecto a la etnocategoría de wayra, su uso está ampliamente difundido en las publicaciones sobre metalurgia andina para hacer referencia a una clase de hornos de fundición de épocas prehispánicas y coloniales. Las primeras menciones de estos ejemplares aparecen en los escritos del siglo XVI y XVII (Barba 1817 [1640]; Cieza de León 1922 [1553]; Capoche 1959 [1585]; entre otros). Sin embargo, la exploración de las crónicas nos sitúa frente a un panorama de descripciones múltiples de estas estructuras metalúrgicas que, siendo englobadas bajo el mismo término de wayra, exponen gran variedad de formas, materias primas y grado de transportabilidad (Bargalló 1967; Petersen 1970; Boman 1991 [1908]; De Nigris y Riart 2011; Téreygeol y Cruz 2014). Más allá de algunos detalles, en términos generales se ha planteado que eran hornos tronco-cónicos pequeños con diámetros menores a $1 \mathrm{~m}$, de planta circular o cuadrangular; fabricados en barro, piedra o combinados; con orificios en sus paredes generados por perforaciones o espacios dejados entre las rocas (ver Bargalló 1968). La mayoría de los cronistas sostienen que los observados en épocas coloniales eran portátiles, pero al sugerir que en épocas prehispánicas existiría una versión fija (Petersen 1970), se amplió aun más la diversidad morfológica.

Las variantes en las descripciones evidencian una gran complejidad en la relación tipológica que se establece en las crónicas que invita a pensar en el alcance de la categoría. Esto se debe a que la diversidad morfológica de estos hornos generó un marco interpretativo amplio que posibilitó incluir diversos tipos de vestigios arqueológicos dentro de esta categoría (ver ejemplos en el capítulo 3). Consideramos además que el estado de fragmentación de las evidencias arqueológicas tampoco contribuyó a profundizar en este debate. 
A pesar de ello, en décadas más recientes, algunos investigadores han sugerido que de las fuentes coloniales se pueden extraer ciertos atributos diagnósticos o distintivos del tipo wayra, considerando estas características como fundamentales para la identificación arqueológica de hornos de este tipo. Estos atributos son: 1 - la presencia de orificios que perforan la pared de los hornos, y 2- su localización en regiones con fuertes vientos, relacionado a zonas topográficamente altas (Van Buren y Mills 2005; Téreygeol y Cruz 2014). Ambos rasgos responderían a un conjunto de requerimientos técnicos, dado que la presencia de vientos fuertes en zonas altas y el ingreso constante de aire por los orificios, permitiría la circulación de los gases necesarios para las reacciones químicas en su interior y favorecería la combustión. De esta manera, las wayras funcionarían como hornos de ventilación natural (González 2004b; Van Buren y Mills 2005; entre otros). A partir de esta sistematización sería necesario reevaluar varios de los ejemplares tradicionalmente clasificados como wayras (p. ej. Viña del Cerro, Rincón Chico y Quillay) con la finalidad de que la categoría no enmascare la diversidad tecnológica.

Respecto a los hornos de Quillay, estos fueron históricamente referenciados como wayras andinas (Raffino et al. 1996; Raffino et al. 2013). Estos autores en sus primeras descripciones plantearon que presentaban "forma de torre abovedada, fijos al suelo y con paredes de adobe de $10 \mathrm{~cm}$ de espesor que se han ido cerrando hacia la parte superior" (Raffino et al. 1996: 64), luego indicaron la existencia de aberturas inferiores para la circulación de aire y para el drenaje de los materiales y finalmente sugirieron que "en el tercio superior existieran orificios para introducir sopladores" (Raffino et al. 1996: 64). Frente a esta propuesta, González cuestionó la localización de las perforaciones dado que dicha ubicación no habría favorecido el funcionamiento del horno (González 2004b: 116). Más allá de esta sugerencia, la propuesta sobre la necesidad de sopladores no sería concordante con la inclusión de estos hornos dentro de la categoría de wayras, porque justamente este tipo de horno emplearía ventilación natural. Pese a estas incongruencias, durante nuestros primeros trabajos de campo tampoco contábamos con elementos suficientes para asegurar la existencia de tales perforaciones, como fue planteado en uno de los primeros trabajos (Spina y Giovannetti 2014). Hoy a partir de las excavaciones es evidente que no existieron y que lo que observamos en algunos ejemplares (p. ej. Conjunto 4) corresponden a orificios accidentales productos del deterioro natural. 
Teniendo en cuenta la sistematización previamente señalada y los datos morfológicos presentados en este capítulo, se concluye que los hornos de Quillay no corresponden al tipo wayras por no presentar los atributos diagnósticos para este tipo. Por el contrario, estos hornos son estructuras fijas de arcilla con varias cámaras, de dimensiones mayores a aquellas propuestas por los cronistas, que no cuentan con los orificios de ventilación ni se encuentran ubicados en zonas de gran altitud.

\subsection{Los hornos de Quillay en el contexto andino}

En base a las características observadas en los hornos de Quillay y su reconocimiento como implementos utilizados para la fundición y reducción del mineral, se propone evaluar la semejanza de estos ejemplares con otros hornos conocidos en la región Andina. Para ello, es necesario atender a los criterios tradicionalmente utilizados para la distinción y clasificación de hornos metalúrgicos. Las perspectivas vigentes discriminan categorías y tipos de hornos en función de procedimientos tecnológicos. Por un lado, ya desde el tratado de Barba (1817 [1640]) se solían distinguir dos tipos de hornos según el contacto establecido entre los componentes de la carga (mineral, fundente y combustible). Por el otro, se suelen diferenciar los hornos según el principio de ventilación, es decir, si se empleó principalmente una ventilación natural o forzada (González 2004b).

En el tabla 6.11 pretendemos combinar estas propuestas sobre la base de las descripciones publicadas que refieren a hornos empleados para la metalurgia extractiva (dejando de lado los hornos para el trabajo del metal) y que presentan contextos inkaicos o coloniales tempranos. Siguiendo el primer criterio -contacto entre los elementos-, se agrupan varios hornos en los cuales el combustible entró en contacto directo con el mineral y los fundentes, pudiendo categorizarlos como "hornos de cuba" utilizando términos de la industria moderna (Grinberg y Palacios 1992). El segundo grupo, reúne aquellos hornos en los cuales los materiales estuvieron separados espacialmente en dos cámaras, impidiendo el contacto físico entre ellos. A este conjunto se lo suele denominar como "hornos de reverbero" (Barba 1817 [1640]; Agrícola 1912).

Dentro del primer grupo, existen una gran variedad de ejemplares arqueológicos que cumplieron con este principio. Al incorporar el segundo criterio tecnológico, se diferencian dos subgrupos y un tercero indeterminado (por falta de información específica en la publicación) en función del principio de ventilación. Además, cada 
subgrupo incluye una variedad de tipos morfológicos distintivos entre sí según sus formas, materiales constructivos y dimensiones ${ }^{7}$. Dentro de los hornos con ventilación forzada (subgrupo 1.A) que requirieron el uso de sopladores, se hallan los hornos de Batán Grande con una tradición metalúrgica bastante antigua que fue reapropiada por los Inkas (ver capítulo 3). Por otro lado, el grupo de hornos que emplearon el principio de ventilación natural (subgrupo 1.B) fue morfológicamente más diverso. Aquí se incluyen los hornos tipo wayras que cumplen con los atributos diagnósticos (1.B.1), otros que sólo presentan sus bases rocosas (1.B.2) y un tercer subtipo que agrupa ejemplares con morfologías novedosas que no fueron registradas por los cronistas (1.B.3). Aquí, queda en evidencia la importancia de los nuevos trabajos de campo arqueológicos para profundizar sobre el conocimiento metalúrgico andino.

Asimismo, se observa en la tabla que, además de las clásicas wayras de secciones circulares, se emplearon durante el Tawantinsuyu una multiplicidad de hornos para la fundición construidos con rocas y paredes angulosas que conforman plantas con distintas geometrías (rectangulares, subcirculares, en banqueta, en T, cuadrangulares). Si bien desde un punto de vista funcional, se ha planteado que las paredes circulares mejorarían los procedimientos metalúrgicos al asegurar un calentamiento homogéneo frente al enfriamiento que producirían las esquinas (González 2004b), es claro que no siempre la forma responde a criterios operativos, también estarían mediando otros razonamientos y elecciones culturales quizás relacionados a esferas simbólicas e identitarias.

\footnotetext{
${ }^{7}$ Un primer intento de clasificación de hornos andinos fue realizado por De Nigris y Riart (2011) en función de características estructurales y superestructuras de los hornos. Sin embargo, no serán tomadas aquí porque lo que buscamos es ordenar la diversidad de información disponible y ampliar el espectro hacia los hornos de influencia española porque creemos que pueden brindar algunos indicios de principios operativos. Aun así consideramos que el grupo 1 de hornos deberían ser recategorizados considerando las propuestas de este autor.
} 
Capítulo 6

\begin{tabular}{|c|c|c|c|c|c|c|c|c|c|c|}
\hline \multicolumn{4}{|c|}{ PRINCIPIO TECNOLOGICO } & \multicolumn{4}{|c|}{ CARACTERISTICAS } & \multirow[b]{2}{*}{ SITIO/REGIÓN } & \multirow[b]{2}{*}{$\begin{array}{c}\text { PERIODO } \\
\text { CRONOLÓGICO }\end{array}$} & \multirow[b]{2}{*}{$\begin{array}{l}\text { REFERENCIAS } \\
\text { BIBLIOGRAFICAS }\end{array}$} \\
\hline & $\begin{array}{l}\text { CONTACTO } \\
\text { CARGA }\end{array}$ & VEN & $\begin{array}{l}\text { TIPO } \\
\text { JTILACION }\end{array}$ & & $\begin{array}{c}\text { FORMA/ } \\
\text { CARACTERISTICAS }\end{array}$ & \begin{tabular}{|c|} 
MATERIAL \\
CONSTRUCTIVO
\end{tabular} & $\begin{array}{c}\text { DIMENSIONES } \\
(\mathrm{m})\end{array}$ & & & \\
\hline \multirow{13}{*}{ 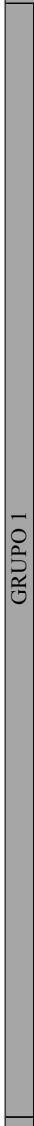 } & \multirow{13}{*}{$\begin{array}{l}\text { HORNOS DE } \\
\text { CUBA }\end{array}$} & 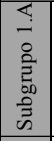 & FORZADA & & Pera - seriados & Arcilla refractaria & $\mid \begin{array}{c}0,3 / 0,35 \times 0,2 / 0,25 \\
\quad \times 0,25 / 0,3\end{array}$ & $\begin{array}{l}\text { Batán Grande } \\
\quad \text { (Perú) }\end{array}$ & $\begin{array}{l}\text { Sican- Chimú - } \\
\text { Inka }\end{array}$ & Shimada et al. 1982 \\
\hline & & \multirow{9}{*}{ 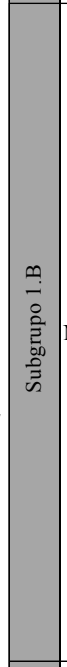 } & \multirow{9}{*}{ NATURAL } & \multirow{5}{*}{$\begin{array}{l}\stackrel{\oplus}{-} \\
\stackrel{\circ}{\rightleftarrows}\end{array}$} & Wayras & Arcilla & $\mathrm{S} / \mathrm{D}$ & \begin{tabular}{|c} 
Juku Huachana; \\
Huayrachina Alta \\
(Bolivia)
\end{tabular} & Inka- Colonial? & $\begin{array}{c}\text { Cohen et al. 2008; } \\
\text { Téreygeol y Castro } \\
2008\end{array}$ \\
\hline & & & & & Wayras & Roca y arcilla & $\begin{array}{c}0,07 \varnothing \\
\text { (perforaciones) } \\
\end{array}$ & Sitio 24 (Bolivia) & Colonial & $\begin{array}{c}\text { Van Buren y Mills } \\
2005 \\
\end{array}$ \\
\hline & & & & & Wayras & Arcilla & $\mid \begin{array}{c}0,2 / 0,3 \varnothing \text { (base) y } \\
0,02 / 0,07 \varnothing \\
\text { (perforaciones) }\end{array}$ & $\mid \begin{array}{c}\text { Tarapacá, Miño y } \\
\text { Camarones } \\
\text { (Chile) }\end{array}$ & Inka & $\begin{array}{c}\text { Zori et al. 2012; } \\
\text { Salazar et al. 2013; } \\
\text { Álvarez Miranda 1993 }\end{array}$ \\
\hline & & & & & Wayras & Rocas y barro & $1 / 2,71 \times 0,5$ & $\begin{array}{l}\text { La Encrucijada } \\
\text { (NOA) }\end{array}$ & Inka & $\begin{array}{c}\text { Rodriguez Orrero } \\
1979 \\
\end{array}$ \\
\hline & & & & & Wayras & Rocas y barro & $1,5 \varnothing$ (base) & $\begin{array}{l}\text { San Antonio de } \\
\text { Cobres (NOA) }\end{array}$ & Inka - colonial & Boman 1991 [1908] \\
\hline & & & & \multirow{2}{*}{ 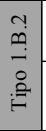 } & $\begin{array}{c}\text { Bases Circulares - } \\
\text { wayras? }\end{array}$ & Roca & $\begin{array}{c}3 \varnothing \text { (base) y } 0,3 \\
\text { altura }\end{array}$ & $\begin{array}{l}\begin{array}{c}\text { Viña del Cerro } \\
\text { (Chile) }\end{array} \\
\end{array}$ & Inka & Niemeyer et al. 1986 \\
\hline & & & & & $\begin{array}{c}\text { Bases Circulares - } \\
\text { wayras? }\end{array}$ & Roca & $0,50 \varnothing$ & $\begin{array}{l}\text { Rincón Chico } \\
\text { (NOA) }\end{array}$ & Inka & González 2002 \\
\hline & & & & \multirow{2}{*}{ 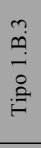 } & $\begin{array}{c}\text { Rectangulares - seriados } \\
\text { en tres }\end{array}$ & Roca caliza y barro & $3 \times 0,7 \times 0,3$ & Curamba (Perú) & Inka - Colonial & $\begin{array}{c}\text { Lechtman } 1976 \\
\text { Del Mar } 2006 \\
\end{array}$ \\
\hline & & & & & \begin{tabular}{|c|} 
Rectangulares, \\
semicírculo y en banqueta \\
- seriados \\
\end{tabular} & Roca granodiorita & $\begin{array}{l}4 / 10 \times 2 \times 0,10 \\
\text { (altura) }\end{array}$ & $\begin{array}{l}\text { Urija } 8,9,10 \text { y } \\
11 \text { (Chile) }\end{array}$ & Inka & $\begin{array}{l}\text { Figueroa et al. } 2016 \\
\text { Figueroa } \text { et al. } 2018\end{array}$ \\
\hline & & & & \begin{tabular}{|l|}
$\vec{u}$ \\
$\dot{0}$ \\
$\stackrel{0}{*}$ \\
\end{tabular} & Rectangular en $\mathrm{T}$ & Roca & $1,2 \times 0,80$ & $\begin{array}{l}\text { Tabladitas } 1 \\
\text { (NOA) }\end{array}$ & Inka? & $\begin{array}{c}\text { Angiorama y Becerra } \\
2010\end{array}$ \\
\hline & & 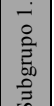 & $\mathrm{S} / \mathrm{D}$ & 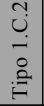 & $\begin{array}{l}\text { Subcuadrangular y } \\
\text { Circular }\end{array}$ & Roca y adobe & $1,5 \times 3$ & $\begin{array}{l}\text { Potrero } \\
\text { Chaquiaco } \\
\text { (NOA) }\end{array}$ & Inka-colonial & Williams 1995 \\
\hline & & & & 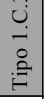 & Semicircular en U & Roca y barro & - & Pututaca (Bolivia) & Colonial & $\begin{array}{c}\text { Casanovas Rivera } \\
2008\end{array}$ \\
\hline \multirow{4}{*}{$\mid \begin{array}{l}1 \\
0 \\
\vdots \\
2 \\
2 \\
0 \\
0\end{array}$} & \multirow{4}{*}{$\begin{array}{l}\text { HORNOS DE } \\
\text { REVERBERO }\end{array}$} & 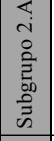 & FORZAD & & Tocochimpo & Adobe & $\mathrm{S} / \mathrm{D}$ & Porco (Bolivia) & Inka-colonial? & $\begin{array}{c}\text { Van Buren y Cohen } \\
\text { 2010; Casanovas } \\
\text { Rivera } 2008\end{array}$ \\
\hline & & \multirow{3}{*}{ 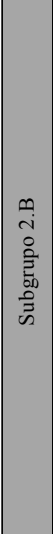 } & \multirow{3}{*}{\multicolumn{2}{|c|}{ NATURAL }} & $\begin{array}{c}\text { Solera circular y oval, } \\
\text { cámara de combustión } \\
\text { rectangular con parrilla } \\
\text { perforada por agujeros o } \\
\text { panes rectangulares y } \\
\text { chimenea } \\
\end{array}$ & $\begin{array}{l}\text { Roca exterior y } \\
\text { adobe interior }\end{array}$ & $\mathrm{e} / 1,2$ y $1,6 \varnothing$ & Porco (Bolivia) & Colonial & $\begin{array}{c}\text { Van Buren y Cohen } \\
2010\end{array}$ \\
\hline & & & & & $\begin{array}{c}\text { Chimenea cónica; caja } \\
\text { circular y abovedada con } \\
\text { orificios de ventilación y } \\
\text { sectores de carga; parrilla } \\
\text { de combustion con } \\
\text { perforaciones }\end{array}$ & Adobe? & $3,6 \times 2,3$ & $\begin{array}{c}\text { Berenguela y } \\
\text { Santa Isabel (Sur } \\
\text { Lipez - Bolivia) }\end{array}$ & Colonial- S XVI? & $\begin{array}{l}\text { Cruz y Teyeregoal } \\
2014\end{array}$ \\
\hline & & & & & $\begin{array}{c}\text { Boveda central con } \\
\text { aberturas superiores y } \\
\text { laterales conectada a una } \\
\text { caja de fuego prismática } \\
\text { y a la chimenea cónica }\end{array}$ & $\begin{array}{c}\text { Roca y argamasa } \\
\text { de barro }\end{array}$ & \begin{tabular}{|c|} 
e $/ 0,8$ y 3 \\
(bovedas), 4,4 \\
long total y 2,5 \\
diámetro externo
\end{tabular} & \begin{tabular}{|c} 
Fundiciones 1 y \\
2 , Pan de Azucar \\
1 y 26, \\
Casablanca \\
(Jujuy, NOA)
\end{tabular} & Colonial-s XVIII & $\begin{array}{c}\text { Angiorama y Becerra } \\
2010,2017\end{array}$ \\
\hline
\end{tabular}

Tabla 6.11. Hornos metalúrgicos de la región andina agrupados según criterios tecnológicos y morfológicos. 
Regresando al criterio de ordenamiento más general, el segundo grupo, contempla los hornos de tipo reverbero. Aquí, se agrupan una serie de estructuras que mediante diversos implementos separaron las zonas de combustión de aquellas de reducción o refinación, evitando la mezcla entre el combustible y el fundido. Hornos de este tipo han sido reconocidos principalmente en contextos con presencia colonial, por lo cual, se sugiere que ha sido una tecnología de influencia europea (Angiorama y Becerra 2010).

Respecto a los hornos denominados mediante la etnocategoría de tocochimbos (subgrupo 2.A), si bien, se ha propuesto su empleo en instancias de refinación de plata realizada por los metalurgos indígenas, aún no es clara si tienen un origen prehispánico o colonial (Van Buren y Cohen 2010). Por el momento, son casi inexistentes los contextos arqueológicos con evidencias de este tipo de estructura de refinación, siendo registrado únicamente dos posibles ejemplares en Bolivia. Específicamente, uno fue detectado en la región de Porco (Van Buren y Cohen 2010) y en el sitio Pututaca en la región de San Lucas (Rivera Casanovas 2008) pero de los cuales, por el momento, no se dispone de detalles morfológicos. No obstante, según las descripciones otorgadas por Grinberg y Palacios (1992), los tocochimbos fueron hornos pequeños en forma de cúpula que alojaron en su interior media vasija cerámica con agujeros -llamada muflaque posibilita la circulación de gases. La mufla presenta aberturas para la carga y descarga del metal y la cámara del horno contiene otros orificios que sirvieron el ingreso del combustible y de los sopladores.

El segundo subconjunto (subgrupo 2.B) agrupa hornos utilizados para la fundición primaria de minerales. En general, son estructuras que constan de tres elementos constitutivos interconectados: una bóveda central para la fundición que presenta orificios de ventilación y de carga; una caja de combustión conectada hacia un lateral y una chimenea adosada en el lado opuesto. Estos ejemplares arqueológicos presentan algunas diferencias respecto a las descripciones de los clásicos hornos de reverbero europeos otorgadas por Barba (1817 [1640]). Fundamentalmente en lo que refiere a la separación de la chimenea, que pasó a conformar una cámara lateral independiente de la bóveda, y por la perforación de la cámara de combustión (Cruz y Téreygeal 2014). Dichas variaciones son interpretadas como innovaciones realizadas por los metalurgos indígenas durante el proceso de apropiación de tecnologías europeas (Van Buren y Cohen 2010; Cruz y Téreygeal 2014). 
Respecto a las variantes locales, es interesante recuperar algunos caracteres de los hornos de la región del actual territorio boliviano, dado que las descripciones y fotografías otorgadas por los distintos investigadores señalan algunos elementos semejantes a los observados en Quillay. Justamente, respecto a los hornos de la región de Porco nombramos que uno de los caracteres diferenciales radica en el piso de la cámara de fuego. En dos hornos - U11 y U12- el piso se halló perforado por una serie de agujeros y un tercer ejemplar - U10- por una parrilla de adobes rectangulares (Van Buren y Cohen 2010). Los antecedentes más cercanos para esa región se remontan al Horizonte Medio. En el sitio Pulac 050 se identificó un horno de refinación en crisoles, que presenta conductos para la circulación de gases desde una cámara de combustión inferior hasta una banqueta (Lechtman et al. 2010) que fueron descriptos en detalle en el capítulo 3.

Regresando a la evaluación de los hornos de Quillay, es evidente que no se ajustan estrictamente a las propuestas clasificatorias previamente comentadas. Dado que no pretendemos imponer categorías forzadamente, se analizarán las distintas evidencias y características de estos ejemplares a la luz de la clasificación presentada. En primer lugar, desde un criterio estrictamente morfológico, la presencia de dos cámaras nos orienta a indagar en el segundo grupo de hornos. Aún así, los hornos de Quillay no se ajustan a las descripciones de los hornos de reverbero europeos, ni a aquellos considerados sincréticos por dos razones: por un lado, las dos cámaras principales se encuentran conectadas en sentido vertical, y no adosadas horizontalmente; por el otro, no se ha detectado una chimenea que sea estrictamente para estos fines.

En segundo lugar, considerando los ejemplares descriptos en el subgrupo 2.2 (ver tabla 6.11), en los ejemplares de Quillay la presencia de conductos que conectan las dos cámaras -superior e inferior- se asemeja a las perforaciones de la base de las cámaras de combustión de los hornos de Porco, así como a los canales registrados en el horno de Pulac 050. Sin embargo, en Quillay no sólo no se encuentran en la base de la zona de combustión, sino que consideramos que además de la conducción de gases calientes, estarían cumpliendo otras funciones dada la presencia de escorias adheridas a los laterales.

Por otro lado, pese a que en Quillay no hay evidencias para pensar en la presencia de influencia colonial, creemos importante recuperar el principio operativo de los 
hornos de reverbero, es decir, la separación espacial entre el combustible y el fundido. Las dos cámaras de Quillay nos permitieron proponer una separación inicial de los materiales, incluso, si bien hemos planteado que el material fundido se movilizó de un espacio a otro, esto no implicó necesariamente la mezcla con el combustible, que de hecho se colocó en un sector específicamente delimitado como se vió en la descripción presentada previamente. Esta idea encuentra sustento en que los restos de escoria encontrados hacia el interior de los $\mathrm{H} 14$ y H7 sólo se registraron por sobre el estrato calcáreo, que dada sus cualidades antihaderentes habría servido para segmentar los procesos. Además, en los montículos internos con carbón y ceniza, no se hallaron vestigios de escorias metalúrgicas ni restos metálicos como para pensar en una mezcla de materiales.

Para resumir, desde un punto de vista estrictamente operativo y en función de los datos actuales creemos que es posible proponer que el principio de separación entre los componentes de la carga existió, asemejándose así a hornos de tipo reverbero. Sin embargo, morfológicamente no encuentran análogo dentro de los hornos metalúrgicos conocidos. Solamente podemos recuperar, salvando las distancias temporales, la semejanza en los conductos observados en Pulac 050 y en los hornos sincréticos del periodo colonial temprano. Esta situación puede indicar la existencia de conocimientos similares respecto al principio tecnológico de conducción de gases. Por el otro, podría remitir a una elección tecnológica que circuló entre los pueblos del altiplano boliviano y que más tarde podría haber llegado hasta el NOA de la mano de los especialistas inkaicos, tal como alcanzó los periodos coloniales en su región. Por otro lado, son llamativas las semejanzas aparentes, entre los hornos de Pututaca y los aquí presentado, al menos en lo que refiere a la forma observada en superficie.

Para cerrar el capítulo, quisiéramos remarcar un aspecto que sale a la luz a partir del tabla 6.11 y del mapa regional de hornos utilizados durante el Tawantinsuyu. Los nuevos hallazgos de estructuras metalúrgicas en el Qollasuyu están ampliando, complejizando y diversificando el conocimiento sobre las tecnológicas metalúrgicas empleadas durante el periodo inkaico. Ya no se cuenta con un panorama homogéneo dónde primaría la tradición de fundir con implementos del tipo wayras. Por el contrario, cada vez es más claro que existió una multiplicidad de estructuras y de procedimientos tecnológicos producto de innovaciones tecnológicas inkaicas, de sincretismos o bien por continuidades de tradiciones locales, según cada caso. Es posible que la fuerte 
regionalización observada de las estructuras de fundición utilizadas, esté señalando el rol activo de los artesanos locales a la hora de seleccionar los medios y procedimientos metalúrgicos. Tal como ha sido sugerido por Van Buren y Mills (2005: 23) “... perhaps variability in smelting technology under the Inkas is attribute able to differences in the techniques employed by workers drafted from distinct ethnic groups". Sin embargo, para el caso de Quillay, a nivel regional aún no se cuenta con antecedentes que indiquen el empleo de hornos con fines metalúrgicos para momentos preinkaicos. Las tradiciones tecnológicas de los pueblos tardíos señalan, por el contrario, que la fundición se realizaba en crisoles dispuestos sobre fogones abiertos (González 2004b). En el valle de Hualfín, los objetos metálicos de colección marcan que existió una antigua tradición metalúrgica en concordancia con los desarrollos que acontecieron en otros valles aledaños.

No obstante, a nivel regional existen varias evidencias que señalan el uso de hornos para fines distintos a los metalúrgicos. Por ejemplo, estructuras bicamerales de adobe (con cámara principal y antecámara) han sido registrados en Batungasta y La Troya para la coccion de vasijas cerámicas (Ratto et al. 2002; Feely 2011) y otros hornos en Ranchillos cuya función aún esta en discusión (Laguens 1993). También en La Rioja existen vestigios arqueológicos que señalan el uso de estructuras unicamerales de barro (se han observado p. ej. en Vinchina) pero aún no han sido estudiados (ver figura 52 - Anexo IV). En este sentido, es posible que en Quillay estemos ante la superposición de saberes que provienen desde regiones lejanas del norte y también desde el sur que, sumados a aquellos conocimientos metalúrgicos locales, podrían haber generado distintivos estilos tecnológicos en el marco del Tawantinsuyu. Esta idea será retomada en las conclusiones finales. 


\section{APORTES BREVES SOBRE ALGUNOS OBJETOS DE METAL}

\subsection{Introducción}

Las investigaciones arqueológicas efectuadas en Quillay en el marco de esta tesis, no aportaron evidencias sobre instancias de manufactura de objetos ni piezas metálicas terminadas que pudieran ser analizados con el objetivo de evaluar la estandarización en el trabajo del metal durante el Tawantinsuyu a nivel local. Aunque esto es un aporte en sí mismo, dado que brinda la posibilidad de reconocer que los Inkas regionalizaban la producción por etapas, no permite abordar las etapas finales de elaboración en su contexto productivo. Por ello, con el fin de estudiar las prácticas manufactureras inkaicas, se realizó un análisis de objetos metálicos disponibles en colecciones de museos. Sin embargo, es importante remarcar que la mayoría de las piezas alojadas en los depósitos analizados no disponían de datos de procedencia ni contextos de hallazgo, fundamentales para una adecuada y específica asignación geográfica y cronológica de los objetos.

Frente a esta realidad, se abordó un relevamiento exploratorio de piezas de colección siguiendo criterios tipológicos-morfológicos para la asignación de objetos de tiempos inkaicos. Como se ha desarrollado en los antecedentes (capítulo 3), los intensos trabajos realizados por González $(1979,1992)$ finalizaron en un ordenamiento temporal de cientos de piezas originarias del NOA. Dicho autor, basado en objetos que poseían contexto arqueológico, diferenció varias de las piezas metálicas del periodo Inka, atendiendo a que muchos de los objetos de periodos tardíos se continuaron fabricando posteriormente (González 1979). Incluso, diversas investigaciones en talleres metalúrgicos han aportado información respecto a la manufactura local de piezas de morfotipos inkas (González 2002, 2010; Angiorama 2004, 2011; Otero y Ochoa 2011) en algunos casos realizadas junto a objetos de tradiciones locales del Noroeste argentino (González 2010).

Entre los objetos que habrían sido incorporados al NOA durante el Tawantinsuyu se incluyen: tumis, gruesas hachas en forma de $\mathrm{T}$ y otras con orejas, hachas en forma de ancla, masas estrelladas, topus, bolas o liwi, placas circulares con pedúnculo, ornamentos para la 
cabeza -cañipu y tincurpa-, brazaletes de oro, espejos, lauraques y figurinas antropomorfas y zoomorfas (González 1979; Raffino 1981; González 2004b; Angiorama y Taboada 2007; Horta 2008). El relevamiento de piezas en museos se realizó entrecruzando estos grupos tipológicos y, cuando estaba disponible, la información contextual.

\subsection{Colecciones museológicas estudiadas}

Se ha tenido la oportunidad de realizar el relevamiento de objetos de metal de las colecciones disponibles en el depósito 25 de la División de Arqueología del Museo de Plata en la provincia de Buenos Aires; en el Museo de Cóndor Huasi de la ciudad de Belén en la provincia de Catamarca; y en el Museo del Sitio Arqueológico El Shincal de Quimivil en la localidad de Londres, también en Catamarca.

Respecto al primer repositorio, se analizaron piezas correspondientes a las colecciones "Moreno ${ }^{\circ} 1$ " y "Museo". Lamentablemente, el origen de estos bienes es desconocido, ya que pueden proceder tanto de la colección privada de Moreno como de las expediciones arqueológicas encomendadas por él, cuando el museo estaba bajo su dirección entre fines del siglo XIX y principios del XX (Farro 2009). Los tradicionales mecanismos de obtención de bienes para aquellas épocas eran por compra directa o por expediciones arqueológicas (Farro 2009). Sea cual haya sido el caso, la realidad muestra que los inventarios de las piezas metálicas observadas en el museo brindan escasísima información sobre el origen de cada pieza. Por lo general, las fichas indican que las piezas proceden de la región Calchaquí, sin mayores especificaciones.

En relación con la procedencia, es preciso aclarar que inicialmente se planteó que el análisis estuviera orientado hacia el relevamiento de piezas inkas originarias de Catamarca con el objetivo de conocer la clase de bienes que se movilizaron por esta región y sus prácticas manufactureras. Sin embargo, hemos incluido aquellas piezas procedentes de la "Región Calchaquí" dado que hasta mediados del S. XX se utilizaba ese término para hacer referencia a un área que abarcaba el espacio geográfico de la actual provincia de Catamarca, como así también aquellos del sur de Salta y las partes montañosas de Tucumán y de La Rioja (Boman 1923; Ambrosetti 2011 [1904]). 
La segunda colección analizada se aloja en el museo provincial de Cóndor Huasi, bajo la denominación "Cura". Su nombre se explica en la génesis del repositorio, el cual fue producto de la estatización de las colecciones privadas del Sr. Eduardo Prudencia Cura. Respondiendo a las lógicas del coleccionismo de mediados del siglo pasado, Cura obtuvo las piezas mediante la compra a lugareños y/o por sus excavaciones para luego ser expuestas en su museo privado ${ }^{1}$. Posiblemente, sea por esta razón que la documentación de las piezas de metal de este museo presenta, en su mayoría, datos de procedencia referidas a diversas localidades del departamento de Belén. Incluso, varias de ellas se sitúan en valle de Hualfín (Villa Vil, Pozo de Piedra, Condorhuasi, Las Barrancas, Los Nacimientos) o en su límite sur donde el río Belén confluye con el valle de Quimivil (Londres). Esta situación es favorable a los fines de este estudio dado que restringe el universo geográfico a nuestra zona de estudio. Aun así, no es posible discriminar qué pieza fue obtenida de primera mano y cuál comprada a terceros. En este último caso, hay que considerar que quizás la localidad donde fue comprada no fue el lugar exacto de hallazgo. En este sentido, para este estudio se parte del presupuesto que las piezas podrían ser originarias de los sitios ubicados en la región.

Dentro de la colección Cura, el inventario de las piezas metálicas alcanza los 179 objetos que fueron principalmente fabricados en bronce, cobre y en menor frecuencia en oro y plata. Siguiendo la clasificación y seriación de objetos metálicos propuesta por González $(1979,1992)$, a partir de la información inventariada se podría considerar que algunas piezas corresponden a aquellas asignadas a Periodos Tempranos y Medios (placas ovales de oro, hachas de mando), pero la gran mayoría corresponden a piezas de momentos Tardíos (campanillas piramidales, placas circulares, discos, manoplas, etc.). También se registran varios cinceles, espátulas, agujas, aros, pulseras y anillos de difícil adscripción cronológica por la falta de información contextual. Finalmente, se reconocieron cuatro objetos que remiten al repertorio incorporado al NOA durante la expansión del Tawantinsuyu.

\footnotetext{
${ }^{1}$ Información extraída de la documentación del museo Cóndor Huasi producido por Álvarez Sergio
} (ms). 
Por último, se analizaron las colecciones de metal disponibles en el museo del sitio Inka El Shincal de Quimivil. Gran parte de las piezas son originarias de las excavaciones efectuadas en las estructuras arquitectónicas del sitio, pudiendo ser contextualizadas en función de la información disponible en la bibliografía que refiere a sus excavaciones (Raffino et al. 1997; Raffino 2004).

\subsection{Metodología de relevamiento y criterios adoptados}

La metodología para el análisis de piezas metálicas de colección siguió las propuestas y procedimientos delineados por Campbell (2004), Latorre (2009) y Plaza (2010). De esta manera, para el relevamiento individual de cada objeto se combinó, con leves modificaciones, el modelo de ficha utilizada por Campbell (2004) y Plaza (2010), la cual aborda datos de procedencia, morfológicos, tecnológicos y alteraciones naturales y culturales.

De esta forma, para el análisis de los objetos de metal se desarrollaron una serie de actividades con el objetivo de realizar una descripción detallada y evaluar cada pieza de manera individual. Entonces se indagaron varios parámetros que fueron completados en los siguientes ítems de la ficha (anexo III):

I- Procedencia: la información relevada en este apartado se relaciona con dos clases de datos. Por un lado, aquellos referidos a la ubicación actual de la pieza, es decir la Institución museológica y el nombre de la colección en donde se halla resguardada, así como las referencias de catalogación. Por el otro, el lugar que nos remite al origen de la pieza (provincia, localidad, sitio y contexto arqueológico). Como ya se ha comentado, los datos relativos a la procedencia de origen fueron escasos o nulos, rastreando para el caso de piezas arqueológicas la información complementaria disponible en publicaciones científicas. Asimismo, se consultó en la bibliografía especializada la existencia de otros investigadores que hayan aportado información respecto a los objetos analizados.

II- Descripción General: para ello se realizó una observación macroscópica de la pieza y se efectuó su caracterización contemplando variables relativas a formas generales, segmentos que constituyen el objeto, medidas morfométricas (largo, ancho y espesores) y presencia o ausencia de decoración. Paralelamente, se tomaron fotografías y se dibujaron 
los objetos al menos en tres vistas (anterior, posterior y perfil). Para su gráfica, las piezas se ubicaron verticalmente siguiendo el eje de mayor longitud. Además, en el caso de los objetos clasificados como topu, se posicionó el segmento de cabeza hacia la porción superior del papel de gráfica y, en el caso de la categoría tumi, la hoja de la pieza se orientó hacia el segmento inferior. En el caso de poseer implementos para la suspensión, éstos se ubicaron hacia arriba. Los dibujos fueron realizados a escala y de forma manual, siendo posteriormente editados con programas de diseño gráfico como CorelDraw X6 y Adobe Photoshop CS3. Posteriormente, las piezas se clasificaron según las clases artefactuales reconocidos para momentos inkas y se estableció una posible función siguiendo la información disponible para cada tipo de objeto en la bibliografía especializada.

Por otro lado, se realizó una aproximación a la materia prima empleada para la fabricación de los objetos. Para ello se utilizó como indicador el color superficial de la pieza y las características de la corrosión (Latorre 2009; Plaza 2010). En este estudio, la mayoría de las piezas analizadas fueron fabricadas utilizando como metal base el cobre. Las variantes en sus coloraciones y en las características superficiales sirvieron para distinguir tres clases de materias primas, siguiendo las propuestas realizadas por Campbell (2004) y Latorre (2009): 1- cobre o aleaciones con altos contenidos en cobre; 2- bronces o aleaciones de cobre y estaño y 3- hierro. En este punto, conviene subrayar que para una identificación composicional estricta se requieren realizar análisis químicos sobre las piezas. Al no disponer de equipos portátiles, se imposibilitó avanzar en este sentido. Aun así, para dos piezas se han podido efectuar análisis composicionales por la técnica de Fluorescencia de Rayos X.

III - Condición: en este tópico se registró el estado de conservación general de la pieza. Se han diferenciado tres tipos de alteraciones que afectan la preservación de los objetos metálicos. Por un lado, se distinguen las alteraciones químicas producto de la degradación natural de la materia prima. En especial, a causa del empleo de metales reducidos por procesos de fundición, el material obtenido reacciona inmediatamente con el medio ambiente circundante y comienza un proceso de degradación paulatina, ya que el material tiende a volver a su estado natural. Este proceso se denomina oxidación. Para el caso de metales de base cobre, producto de estas reacciones, las superficies suelen presentar 
pátinas de coloración negruzca (producto de la oxidación de la tenorita); verde oscura (de la malaquita o azurita) y/o rojiza (de la cuprita) que tienden a estabilizar las piezas, o bien, exhiben una corrosión activa de cloruros manifestada por segmentos de aspecto pulverulento de coloración verde esmeralda (oxidación de la atacamita) (Porto Tenreiro 2000). Por su parte, los metales con altos contenidos en hierro reaccionan rápidamente con la atmósfera y se oxidan, generando pátinas marrones claras que alteran fuertemente la estructura original del material.

Por otro lado, se clasificaron como alteraciones mecánicas a las modificaciones del material producidas por la acción de esfuerzos físicos. Estos pueden generar fisuras, fracturas o quiebres del metal por fragmentación. Finalmente, se distinguieron las alteraciones antrópicas como aquellas marcas intencionalmente producidas por el hombre. En los casos analizados consisten principalmente en inscripciones de rotulación, limpiezas abrasivas y rayados, éstos últimos posiblemente realizados para eliminar los productos de corrosión con el fin de observar el material metálico.

En función de la identificación de estas alteraciones, se evaluó el estado general del metal estableciendo tres categorías relativas: 1- bueno, cuando el metal presenta un pátina homogénea y estable de corrosión sin otro tipo de alteración o bien, si ésta fue mínima y se halló en un sólo sector de la pieza; 2- regular, cuando posee varios sectores en proceso de corrosión activa, segmentos fragmentados y/o con alteraciones antrópicas; 3- malo, cuando la pieza presenta un alto grado de corrosión y/o fragmentación impidiendo el análisis parcial o total del objeto.

III- Manufactura: en este segmento se especificaron las interpretaciones respecto a los modos en que los objetos fueron fabricados. A partir de la observación macroscópica y a lupa binocular a aumentos de entre $10 \mathrm{X}$ y $30 \mathrm{X}$, se relevaron las huellas superficiales dejadas por las técnicas implementadas para la realización de las piezas (Tabla 7.1). Las técnicas y los procedimientos de manufactura inferidos, fueron posteriormente cotejados con la información bibliográfica disponible sobre estudios metalográficos realizados a morfotipos de características similares a los estudiados. 
En el capítulo 2, se han presentado los procedimientos técnicos implementados tradicionalmente para la manufactura de objetos de metal. Estos suelen variar en función del material original- sea éste metal nativo o fundido-, de las cualidades maleables de cada metal, así como de las propiedades mecánicas, sonoras y visuales buscadas en los objetos finales. Seguramente, una adecuada interrelación entre estas variables fue fundamental para los artesanos a la hora de tomar decisiones y seleccionar las técnicas que permitirían alcanzar sus metas.

Para dar forma al material existen dos procesos básicos que pueden usarse tanto de forma individual o combinada. Por un lado, se puede trabajar el metal de forma líquida utilizando el proceso de fundición, por el otro, de forma sólida basado en el principio de deformación plástica (Carcedo de Mufarech 1998). En el primer caso, se utiliza la técnica de vaciado en molde y en el segundo, se emplean variadas técnicas de martillado sobre un elemento pasivo. De acuerdo con esto, para guiar el análisis se diferenciaron tres procedimientos generales de trabajo del metal, siguiendo las propuestas realizadas por Latorre (2009):

1- Secuencia de intensos procesos de deformación plástica ${ }^{2}$ por medio del martillado de masas de metal fundidos que no poseen una relación formal con la pieza a fabricar (prills, nódulos amorfos o lingotes).

Para ello, existen dos técnicas principales que varían según la dirección de la fuerza mecánica aplicada sobre el material y la forma que se quiere otorgar a la pieza (Pifferetti 1999). Por un lado, la técnica de laminado utiliza golpes y presiones de martillos contra una superficie plana para deformar, estirar y adelgazar el metal con el fin de conformar láminas delgadas y de espesores uniformes (Carcedo de Mufarech 1998). La técnica de trefilado se emplea para alargar longitudinalmente y reducir en sección el metal mediante tracción del material. Esto se logra aplicando fuerzas opuestas en sentido paralelo o trasversal al eje horizontal del material (Pifferetti 1999). Para ello, se puede aplicar percusión directa

\footnotetext{
${ }^{2}$ La deformación plástica del metal se logra gracias a los sucesivos eventos de martillado que producen deslizamientos de la estructura atómica del material. Esto genera que el metal vaya perdiendo su plasticidad o ductilidad y se suelen requerir instancias cortas de calentamiento (llamados recocidos) que liberan la tensión acumulada y restauran la maleabilidad del metal, evitando así su fragmentación (Scott 1991). Los eventos de recocido dejan su huella únicamente en la microestructura de los metales, pudiendo ser abordados solamente mediante estudios metalográficos específicos que requieren alterar la superficie de la pieza.
} 
utilizando un martillo sobre un yunque o bien pasar sucesivamente el metal por un orificio pequeño (Pifferetti 1999; Plaza 2010).

2- Utilización de preformas, es decir forma base producidas por la técnica de vaciado en molde que otorga un aspecto similar a la morfología buscada. Luego, se emplean instancias intermedias de deformación plástica para finalizar partes concretas del objeto (como filos o cabezas), pero cuya intervención no altera en gran medida las dimensiones originales de la preforma;

3- Proceso de fundición para conformar el objeto final mediante la técnica de vaciado en molde. A veces, pueden incluir escasos procesos de martillado para el acabado final sin alterar la forma original otorgada por el molde.

La etapa final del trabajo suele incluir tratamientos de acabado y de decoración. Los primeros consisten en pulidos para eliminar rebabas, homogeneizar la pieza y otorgar un mayor brillo. También implican recortes de metal, uniones y perforaciones en función de la pieza a fabricar (Latorre 2009). La decoración puede ser realizada durante el proceso de fundido, es decir, cuando el diseño está previamente inscripto en el molde, o bien por técnicas posteriores de repujado, grabado, filigrana, entre otras (Ravines 1978 en Latorre 2009).

\begin{tabular}{ll}
\hline Técnicas de manufactura & Huellas superficiales \\
\hline Martillado & Concavidades \\
& Rebordes y rebabas \\
& Acanaladuras centrales \\
\hline Laminado & Concavidades \\
& Líneas gruesas paralelas tipo "facetado" \\
& Rebordes y rebabas \\
& Alteraciones diferenciales en los espesores \\
& de las piezas \\
\hline Trefilado & Acanaladura central en cuerpo de sección \\
& circular \\
\hline
\end{tabular}




\begin{tabular}{cl}
\hline $\begin{array}{c}\text { Vaciado } \\
\text { Molde univalvo }\end{array}$ & $\begin{array}{l}\text { Diferencias entre superficies del objeto } \\
\text { (plana/convexa) } \\
\text { Cantos rectos }\end{array}$ \\
Moldes bivalvos & $\begin{array}{l}\text { Línea de costura producto de la unión de } \\
\text { las dos caras del molde } \\
\text { Cantos rectos }\end{array}$ \\
Moldes complejos (Ej. & $\begin{array}{l}\text { Sin líneas de costura } \\
\text { cera perdida) }\end{array}$ \\
\hline $\begin{array}{l}\text { Figuras tridimensionales con detalles del } \\
\text { diseño }\end{array}$ \\
\hline Pulido & Microestrías homogéneas unidireccionales \\
\hline
\end{tabular}

Tabla 7.1. Sistematización de huellas tecnológicas. Información extraída de Campbell (2004), Latorre (2009) y Plaza (2010).

\subsection{Caracterización de los objetos museísticos analizados}

\subsubsection{Las piezas metálicas de la colección Moreno nº 1 y Museo (MLP - D25)}

En esta colección se han identificado 16 objetos que responden a morfotipos inkas que se dividen en 3 clases de piezas: tupu, tumi y lauraque, cuyas características se presentan a continuación.

- TUPU: son objetos caracterizados por presentar una vara larga -o alfiler- que finaliza hacia un lado en un extremo aguzado y hacia el otro, en una cabeza que suele adquirir formas zoomorfas o geométricas. Asimismo, en la mayoría de los casos, el sector de la cabeza contiene implementos para el sostén del objeto (orificios de pasaje). Dentro de las piezas analizadas en estas colecciones se han distinguido siete tipos (Figura 7.1):

1- Tupu de cabeza circular (piezas 013 y 014);

2- Тири circular con cabeza cola de pez (piezas 006 y 007);

3- Tири de cabeza semicircular (piezas 008 y 015);

4- Tupu de cabeza de camélido (pieza 009); 
5- Tupu en arandela (pieza 010);

6- Tupu circular con apéndices (pieza 011);

7- Тири con cabeza indeterminada (pieza 012).

Considerando los objetos que se encontraban completos, se puede apreciar en la Tabla 7.2 que la variabilidad en esta clase de piezas no sólo se aprecia en las formas que adquieren las cabezas sino también en sus dimensiones máximas, existiendo ejemplares pequeños, medianos y otros de grandes dimensiones como las piezas 013 y 014 . Por otro lado, la mayoría de los tupu con cabezas laminares presentan orificios localizados hacia la porción centro-inferior de la misma, cercano a la zona de unión con el alfiler. Por su parte, el objeto con cabeza de llama presenta un sector de pasaje de localización lateral (Figura $7.2)$.

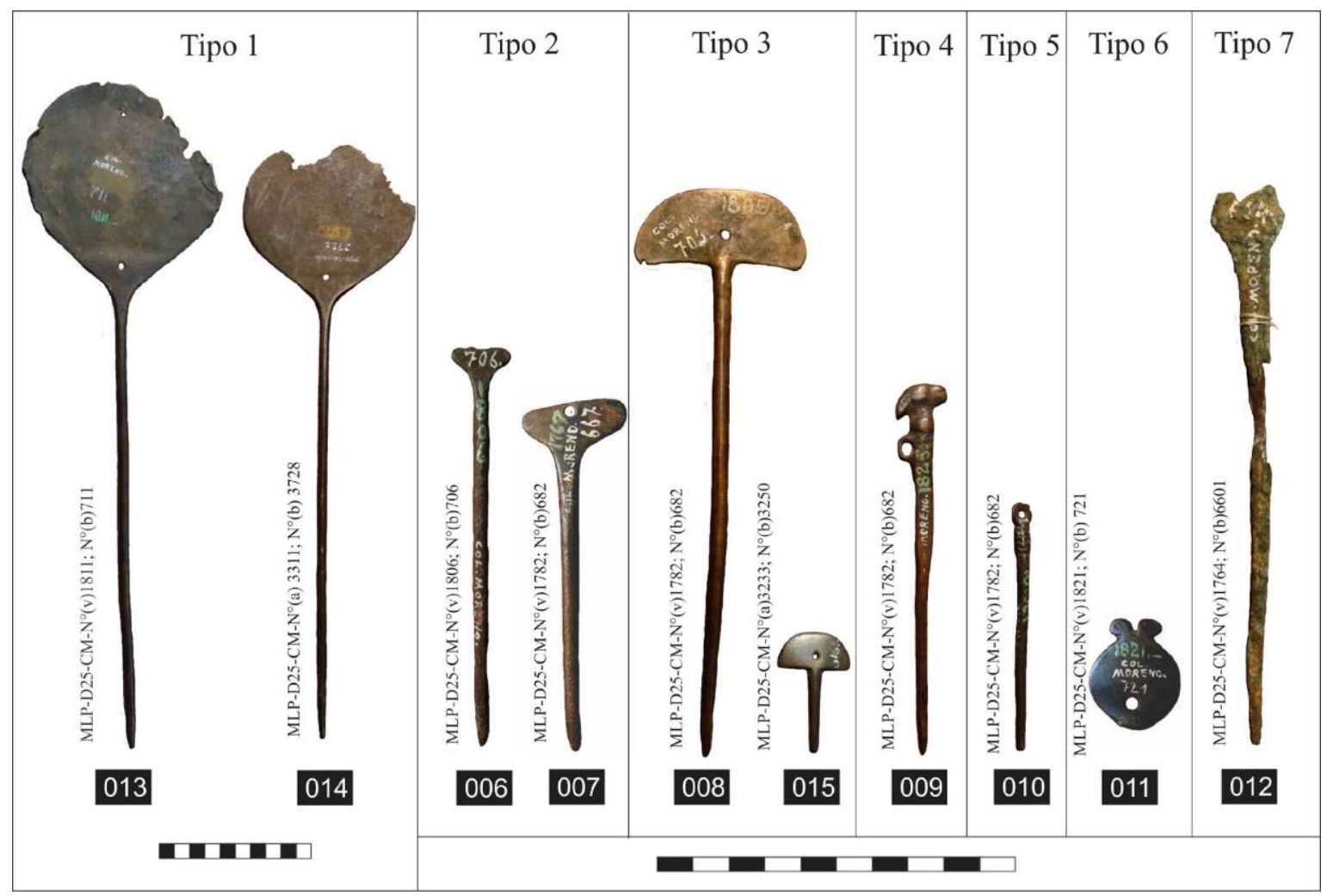

Figura 7.1. Tирu de las colecciones del Museo de La Plata. 


\begin{tabular}{|c|c|c|c|c|c|c|c|c|c|c|c|}
\hline \multirow{2}{*}{ Segmento } & \multirow{2}{*}{ Dimensión } & \multicolumn{10}{|c|}{$\mathrm{N}^{\circ}$ Pieza / Medidas (cm) } \\
\hline & & 006 & 007 & 008 & 009 & 010 & 011 & 012 & 013 & 014 & 015 \\
\hline \multirow{3}{*}{ Alfiler } & Largo & 10,7 & 8 & 14,2 & 8,9 & 6,3 & - & 13,5 & 29,7 & 28,8 & 2,4 \\
\hline & Ancho & 0,45 & 0,6 & 0,6 & 0,6 & - & - & - & 0,7 & 0,6 & 0,45 \\
\hline & Espesor* & 0,45 & 0,4 & 0,5 & 0,3 & 0,45 & - & 0,5 & 0,65 & 0,6 & 0,4 \\
\hline \multirow{3}{*}{ Cabeza } & Alto** & 0,6 & 1,2 & 2,2 & 1,7 & - & 3,3 & 1,8 & 12,3 & 12,9 & 1,2 \\
\hline & Ancho & 1,8 & 2,9 & 5 & 1,6 & 0,6 & 2,8 & 2,2 & 11,8 & 12,5 & 2,2 \\
\hline & Espesor & 0,2 & 0,2 & 0,2 & 0,6 & 0,2 & 0,2 & 0,3 & 0,2 & 0,1 & 0,35 \\
\hline \multicolumn{2}{|c|}{ Largo total*** } & 11,1 & 8,2 & 16,4 & 10,5 & 6,9 & - & 15,3 & 42 & 41,7 & 3,6 \\
\hline
\end{tabular}

Tabla 7.2. Medidas de los tupu del Museo de La Plata

Respecto al procedimiento de manufactura, las huellas observadas en este conjunto permitieron diferenciar dos posibles secuencias de tratamiento:

A- Los ejemplares 009, 010, 011 y 015 posiblemente se realizaron directamente por vaciado en el molde, el cual les brindó sus características finales aplicándose luego técnicas de pulido para su acabado final. Sin embargo, dentro de este conjunto se pudieron diferenciar algunas particularidades. Por ejemplo, la pieza 009 posiblemente se realizó por la técnica de cera perdida que posibilitó obtener la figura de un camélido de carácter tridimensional con los detalles que conforman su rostro (Figura 7.2). Por otro lado, la pieza 011 está conformada por el segmento de cabeza que presenta una forma circular con dos apéndices superiores. La ausencia de fractura en la zona de unión con la vara, sugiere un proceso de fabricación por separado de los dos segmentos que luego conformaría el objeto final, es decir: la cabeza y la aguja. Estos serían unidos, posiblemente por medios mecánicos.

B- En el caso de las piezas 006, 007, 008, 013 y 014 se observaron huellas que señalan intensos procesos de laminado por martillado realizados sobre el segmento de cabeza de una preforma obtenida por vaciado en molde. Se observaron rebabas en los laterales y un marcado adelgazamiento en la zona de la cabeza que, en algunos casos, es posible que haya contribuido a la fragilidad y fractura de la lámina. Esta situación podría indicar, asimismo, que las instancias de recocido fueron escasas reduciendo la ductilidad 
del metal. Por otro lado, en los alfileres de sección circular se observaron indicios de acanaladuras centrales y líneas paralelas en el cuerpo, propias de procesos de elongación logrados por la técnica de trefilado (Figura 7.2: 1 y 3).

Respecto a los orificios de estas piezas, se han realizado tanto por percusión directa, manifestado en puntos de impacto observadas en las caras posteriores $(013,014)$, así como por perforación $(007,008)$ utilizando una especie de instrumental cónico a juzgar por la diferencia en los diámetros de ambas caras y el pulimento observado hacia el interior de los orificios (Figura 7.2: 4a y 4b). Ambas formas de fabricar esta clase de objetos han sido demostradas mediante estudios metalográficos realizados en piezas de este tipo originarias de Perú (Vetter Parodi 2007).

Por otro lado, las superficies de los objetos presentan coloraciones que varían de tonos cobrizos hasta los más dorados. Contienen pátinas negras homogéneas y sectores de coloración verde esmeralda, ambos generados por procesos corrosivos del cobre. Teniendo en cuenta ambas variables, se clasificó un $90 \%$ como objetos fabricados en metal de cobre o aleaciones con alto contenido en este metal y un $10 \%$ se especificaron como bronces. Respecto a las alteraciones, todas las piezas presentaron rotulados y algunas exhibieron alteraciones mecánicas por fisuras, dobleces y fracturas (Figura 7.2: 6 y 7). En líneas generales el $40 \%$ de este conjunto exhibe un buen estado de conservación, el $50 \%$ un estado regular y el $10 \%$ tiene material fuertemente alterado por la corrosión, lo cual imposibilitó su análisis tecnológico. 


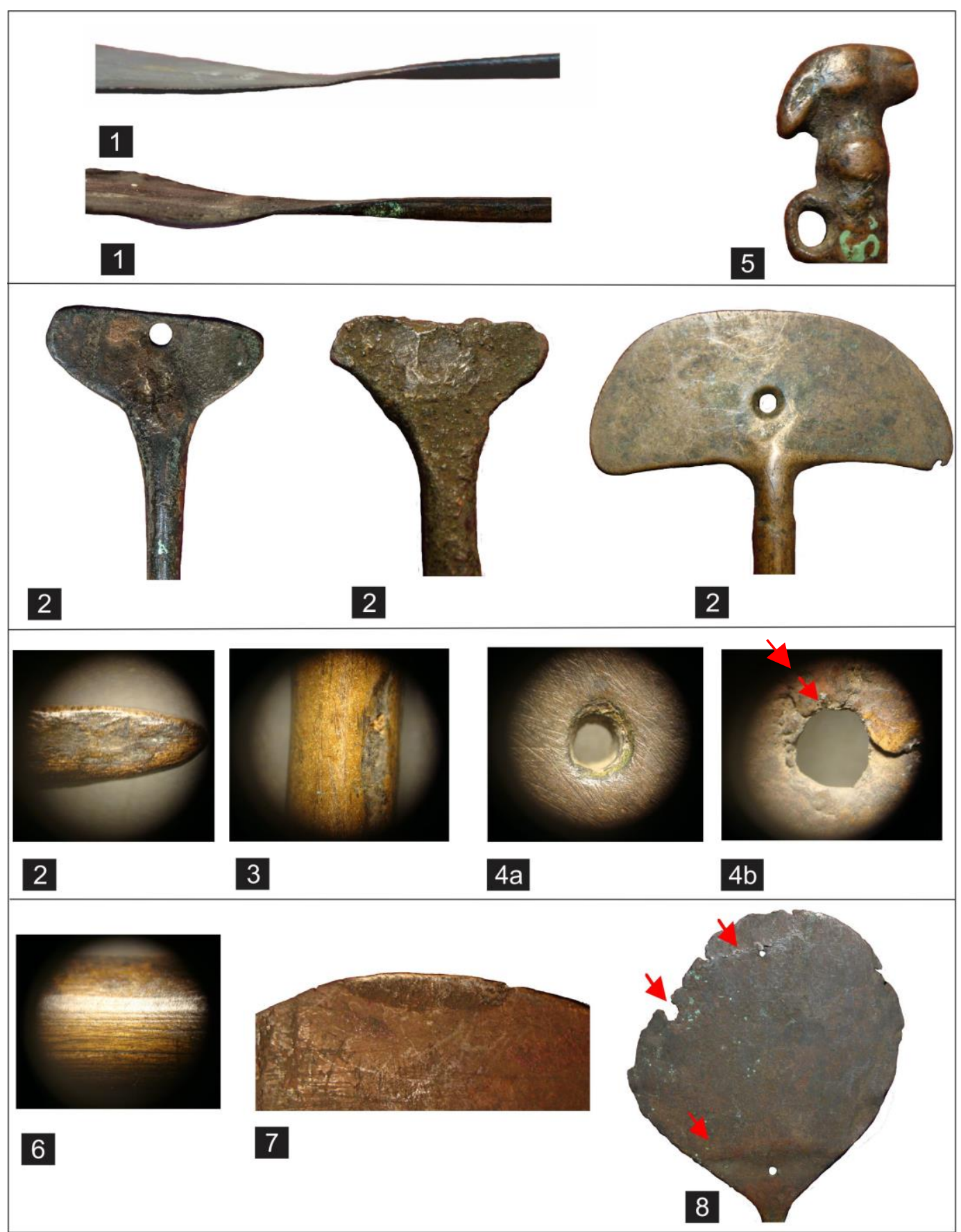

Figura 7.2. Huellas de manufactura observadas en los tupu del MLP. 1. Adelgazamiento sector de unión del segmento de cabeza y alfiler; 2. Concavidades producto del martillado; 3. Acanaladura; 4. Sección cónica del orificio realizado por perforación (a) y sector de impacto del percutor (b); 5. Vaciado en molde; 6. Estrías de pulido. Alteraciones mecánicas: 7. Dobles; 8. Dobles, fractura y fragmentación. 
- TUMI: esta clase de objetos están constituidos por dos segmentos: una hoja que puede adquirir forma semilunar, elipsoidal, rectangular o trapezoidal, y un mango dispuesto de manera perpendicular a la primera, que presentan terminaciones superiores diversas (González et al. 1998-1999). La variabilidad observada en dichas terminaciones fue expuesta inicialmente por Nordenskiold (1921: Figura 21), siendo posteriormente descritas por González et al. (1998-1999) de la siguiente manera: a- Tumi con mango plegado que conforma un ojal; b- Tumi con mango liso; c- Tumi con mango con cabezas modeladas (zoomorfas); d- Tumi con mango liso y agujero de suspensión; e- Tumi con mango que finaliza en un botón circular.

En las colecciones analizadas se han identificado dos tumi que responden al primer tipo con hojas elipsoidales alargadas (piezas 001 y 004); un caso del tipo "d" que asimismo se encuentra plegado y tiene una hoja con forma semilunar (pieza 003); un tumi de tipo "b" y de mango muy grueso (pieza 005) y por último una pieza de hoja subrectangular con mango indeterminado por encontrarse actualmente fragmentado (pieza 002) (Tabla $7.3 \mathrm{y}$ Figura 7.3).

\begin{tabular}{|l|c|c|c|c|c|}
\hline \multirow{2}{*}{\multicolumn{1}{c|}{ Dimensión }} & \multicolumn{5}{|c|}{$N^{\circ}$ Pieza / Medidas (cm) } \\
\cline { 2 - 6 } & $\mathbf{0 0 1}$ & $\mathbf{0 0 2}$ & $\mathbf{0 0 3}$ & $\mathbf{0 0 4}$ & $\mathbf{0 0 5}$ \\
\hline Largo & 10,2 & 11 & 7,2 & 10,3 & 8,4 \\
\hline Ancho & 10 & 7 & 6,7 & 7,4 & 8,1 \\
\hline Espesor promedio & 0,3 & 0,4 & 0,2 & 0,3 & 0,9 \\
\hline
\end{tabular}

Tabla 7.3. Medidas de los tumi del Museo de La Plata.

3 La pieza 005 difiere de los otros ejemplares ya que posee un cuerpo tridimensional, con espesores homogéneos donde no se observa una marcada reducción de la hoja. Una pieza similar fue identificada en Bolivia para momentos Inkas, fabricada por fundición (Fernández Murillo 2016) 


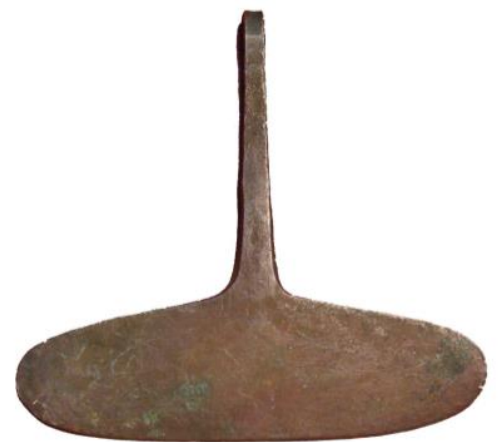

001

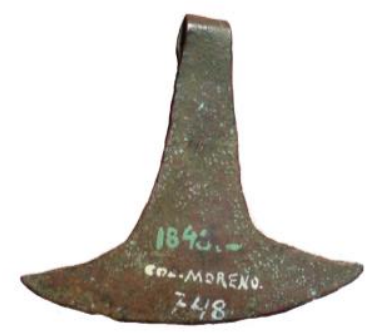

003

MLP-D25-CM-N ${ }^{\circ}(\mathrm{v}) 1848 ;$ (b) 748

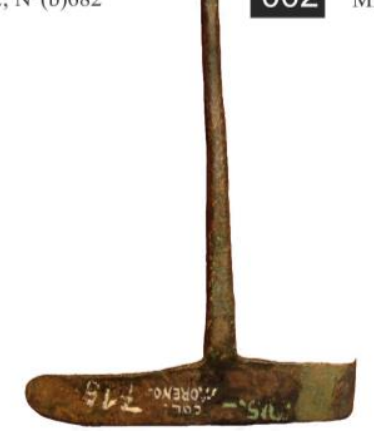

ood

MLP-D25-CM-N ${ }^{\circ}(v) 1815 ; \mathrm{N}^{\circ}(\mathrm{b}) 715$

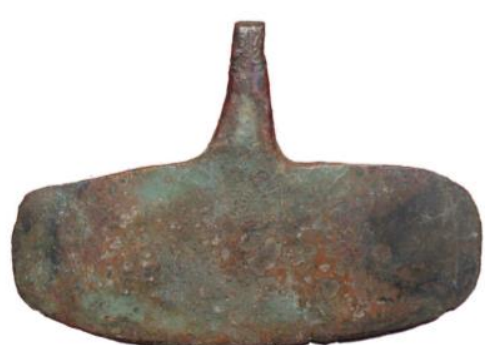

002

MLP-D25-CM-N ${ }^{\circ}$ (v) 1791; $\mathrm{N}^{\circ}$ (b) 691

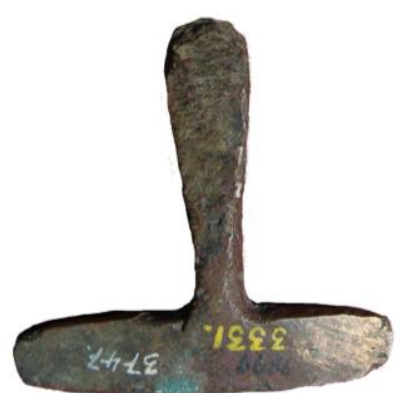

005

MLP-D25-CM-

$\mathrm{N}^{\circ}$ (a) $3331 ; \mathrm{N}^{\circ}$ (b) $3747 ; \mathrm{N}^{\circ}$ (n) 8899

Figura 7.3. Objetos tumi de las colecciones del Museo de La Plata.

Las piezas presentan superficies con coloraciones cobrizas a anaranjadas y cubiertas con pátinas negras, sectores verdes esmeralda y otras capas de coloración blanquecina que indican una materia prima rica en cobre, estando conformadas por metal puro o aleaciones con un alto contenido en este metal.

Respecto a la manufactura de estas piezas, las mismas fueron fabricadas por la técnica de vaciado en molde siguiendo tres posibles secuencias operativas. Por un lado, las piezas 001 y 004 sugieren intensos procesos de martillado sobre una preforma, a partir de lo cual se estiró y dio forma a la lámina que conforma la hoja, evidenciado por el adelgazamiento observado entre el mango y la hoja, así como la presencia de concavidades y rebordes en la superficie de la hoja (Figura 7.4: 1, 3 y 4). Esta reducción del espesor también se observó en el segmento de mango doblado para conformar el ojal, junto a las concavidades producidas por el martillado. Sus mangos posiblemente fueron realizados tanto por vaciado en molde dado los cantos rectos y la sección rectangular (001), como por 
trefilado en el caso de mangos de sección circular (004) los cuales exhiben vestigios de una acanaladura central.

Por el otro, la pieza 002 y 005 presentan espesores más homogéneos y cantos rectos en el sector de unión de la hoja y el mango (Figura 7.4: 5). Sólo se observaron sectores de adelgazamiento en el filo del primer ejemplar, señalando escasos procesos de martillado para su conformación. Asimismo, en el sector del mango fragmentado, se observa una acanaladura y rebordes generados por procesos de martillado (Figura 7.4: 3, 6 y 7).

Respecto a la pieza 003 es posible que haya sido fabricada por la técnica de laminado mediante intensos procesos de martillado a partir de una masa amorfa fundida, dada las concavidades y quiebres observados en el cuerpo. Asimismo, en estas piezas se observaron huellas de uso manifestadas en perfiles dentados, así como en estrías que siguen una dirección oblicua y transversal al filo (Figura 7.4: 6 y 7).

Lo observado en los tumi analizados, está en concordancia con las técnicas de manufactura reconocidas para objetos de esta clase tanto en el NOA (González et al. 19981999) como en Chile (Latorre 2009). 


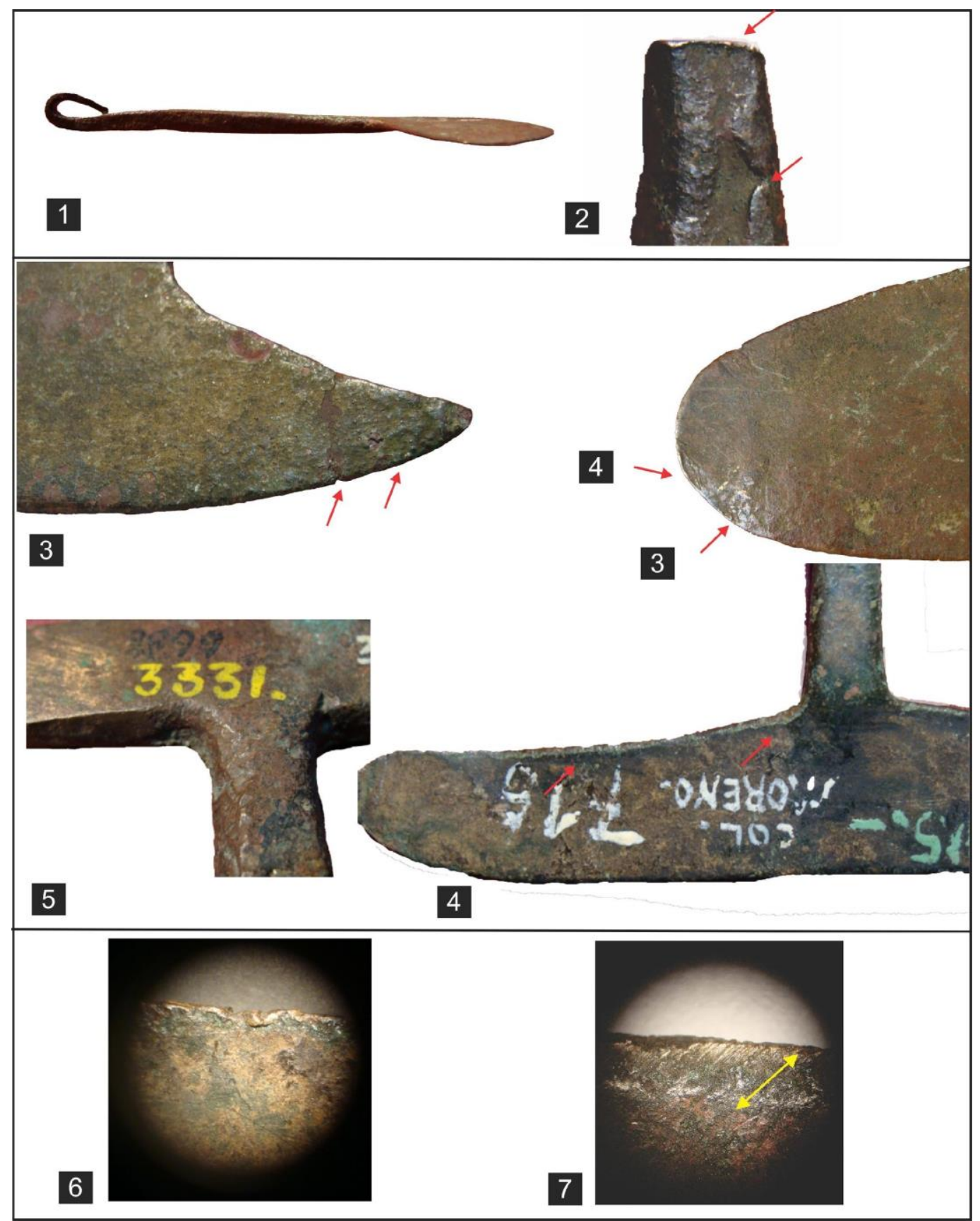

Figura 7.4. Huellas de manufactura observadas en los tumi del MLP. 1. Adelgazamiento sector de unión del segmento de hoja y mango; 2. Acanaladura y rebordes; 3. Concavidades; 4. Rebordes; 5. Cantos rectos. Huellas de uso: 6. Dentado en filo; 7. Microestrías oblicuas al filo. 
- LAURAQUE: este término se utiliza para designar una clase de pendiente modelado con forma antrópica. El ejemplar resguardado en el Museo de La Plata presenta un cuerpo de 5,8 cm de largo con un orificio de pasaje en la cara posterior y un diseño que representa una Figura humana, posiblemente femenina (Figura 7.5). Asimismo, desde la vista posterior la protuberancia del orificio podría estar representando un tocado.

En vista anterior, el diseño de la pieza exhibe rasgos que delimitan un rostro con nariz protuberante y detalles de la boca. Luego, presenta una línea curva que podría ser interpretado como el mentón o bien el segmento de cuello con un collar. Hacia el lateral, se delinean los brazos en posición flexionada que, en la cara anterior, se juntan en la zona abdominal en dos protuberancias que insinúan las manos, aunque sin mayores detalles morfológicos. En el espacio entre manos y boca se distinguen asimismo dos protuberancias circulares que pueden representar los caracteres sexuales secundarios femeninos (mamas). El segmento inferior de la pieza es liso y adquiere una forma trapezoidal. Presenta en la cara posterior una línea divisoria central que podría indicar la separación de las dos extremidades inferiores.

La pieza presenta un buen estado de conservación, mantiene una coloración anaranjada de brillos dorados y con una superficie algo ennegrecida. Fue fabricada a partir de la técnica de vaciado en molde, posiblemente por cera perdida, dado el trazo redondeado de la decoración y posteriormente fue pulida para su acabado. Los análisis químicos por fluorescencia señalan que el metal utilizado fue un bronce estannífero $(\mathrm{Cu}: 83.2 \% \mathrm{wt}$; Sn: $16.8 \% \mathrm{wt}){ }^{4}$

\footnotetext{
${ }^{4}$ Los datos de composición química fueron brindados por la Mg. Teresa Plaza.
} 
Pieza 016: LAURAQUE

MLP-D25-CM-N ${ }^{\circ}(v) 1827 ; N^{\circ}(b) 727$

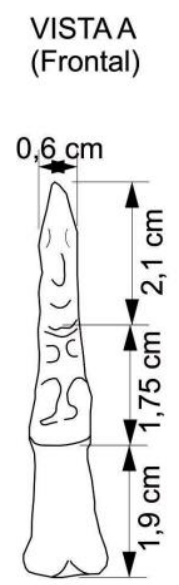

VISTA PERFIL

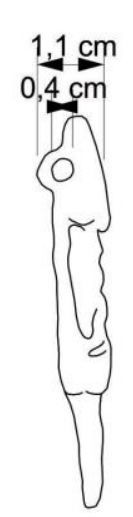

VISTA B

(Posterior)

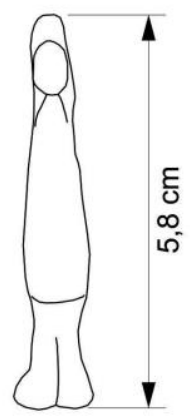

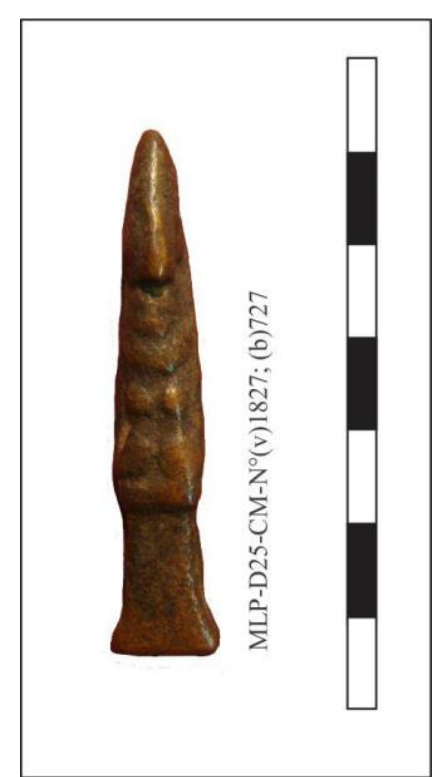

Figura 7.5. Lauraque del Museo de La Plata. Izquierda: dibujo a escala; derecha: fotografía.

\subsubsection{Las piezas metálicas de la colección Cura (MCH)}

Como se ha comentado anteriormente, aquí hemos identificado sólo cuatro piezas de raigambre Inka que, como se verá, responden cada una a distintas clases de objetos:

- HACHA en "T": este morfotipo de objeto está conformado por un cuerpo central alargado y de gran espesor que finaliza hacia un lado en un filo y hacia el otro, en un mango transversal que se aloja de forma perpendicular al cuerpo. De esta manera el objeto adquiere una forma de "T" (Figura 7.6). Las dimensiones de la pieza 017 se presentan en la Tabla 7.4 .

En cuanto a las técnicas de manufactura, se infiere que la pieza fue fabricada mediante la fundición en molde dado que en los laterales de la pieza se ha observado una línea de costura que indica el sector de unión de las dos caras opuestas de un molde bivalvo (Figura 7.7: 1). Por otro lado, en la cara posterior y en el extremo con filo se observaron faltantes de material que señalan fallas en el drenaje del metal líquido durante el proceso de vaciado del molde (Figura 7.7: 3). Asimismo, la presencia de poros en varios sectores del cuerpo estaría señalando dificultades en la eliminación de gases durante la solidificación del metal (ver ficha 017 en anexo III). 
La superficie de la pieza presenta una coloración anaranjada tendiendo al dorado y una pátina negra con sectores de oxidación activa materializada en sectores puntuales con coloraciones verde esmeralda y de aspecto pulverulento, así como segmentos con pátinas rojizas. A partir de esto, se infiere que el objeto ha sido fabricado con una aleación de base cobre, específicamente en bronce. Por último, se han observado marcas de alteración antrópica por inscripciones de su rótulo con un marcador negro indeleble sobre resina.

No se poseen datos sobre la localidad de procedencia de esta pieza.

\begin{tabular}{|c|c|c|}
\hline \multicolumn{3}{|c|}{ Pieza 017} \\
\hline Segmento & Dimensión & $\begin{array}{c}\text { Medida } \\
\text { (cm) }\end{array}$ \\
\hline \multirow{3}{*}{$\begin{array}{c}\text { Transversal } \\
\text { (mango) }\end{array}$} & Ancho & 9 \\
\hline & Alto* & 2,4 \\
\hline & Espesor & 2,3 \\
\hline \multirow{3}{*}{ Cuerpo central } & Largo & 12,6 \\
\hline & $\begin{array}{l}\text { Ancho } \\
\text { máximo }\end{array}$ & 4,2 \\
\hline & Espesor & 2,6 \\
\hline Filo & Espesor & 0,5 \\
\hline \multicolumn{2}{|c|}{ Largo total } & 15 \\
\hline
\end{tabular}

Tabla 7.4. Medidas del hacha en T (0180), Museo Condor Huasi.

- MASA ESTRELLADA: estos objetos consisten en cuerpos macizos con forma de estrella compuesta por 6 a 8 puntas que se distribuyen alrededor de un agujero central para el enmangue (Ambrosetti 2011 [1904]). La pieza 018, tiene 9,5 cm de largo y está conformada por seis puntas que finalizan en extremos redondeados o romos (Tabla 7.5). Cada una de ellas presenta sutiles variaciones en sus dimensiones, pero conservan una homogeneidad métrica (ver ficha 018 en anexo III). Sus características dimensionales son compartidas con otras masas estrelladas registradas en el NOA (Trucco 1965; Ambrosetti 2011 [1904]: 87) que estaría señalando cierta tendencia a la estandarización de este tipo morfológico. 
Las observaciones realizadas en esta pieza no permitieron detectar sectores de unión del cuerpo que señale una manufactura mediante moldes bivalvos, como sí se han reconocido en otras masas estrelladas (Ponce 2002). La superficie presenta un aspecto rugoso producto del drenaje, lo sugiere que fue fabricada mediante la técnica de cera perdida utilizando una aleación de base cobre, posiblemente bronce estannífero. También se han observado huellas de instrumentos punzantes que pueden deberse a acciones de uso $\mathrm{o}$ alteraciones postdepositacionales (ver ficha 018 en anexo III).

No se poseen datos sobre la localidad de procedencia de esta pieza.

\begin{tabular}{|l|c|}
\hline \multicolumn{2}{|c|}{ Pieza 018 } \\
\hline \multicolumn{1}{|c|}{ Dimensiones } & Medidas (cm) \\
\hline $\begin{array}{l}\text { Largo máx. con } \\
\text { puntas }\end{array}$ & 9,5 \\
\hline $\begin{array}{l}\text { Ancho segmento } \\
\text { entre puntas }\end{array}$ & 4,8 \\
\hline Espesor puntas & 1,6 \\
\hline Diámetro agujero & 2,4 \\
\hline Espesor agujero & 3 \\
\hline
\end{tabular}

Tabla 7.5. Medidas de la masa estrellada (2779), museo Condor Huasi.

- TOPU: la pieza 019 tiene un alfiler alargado de sección cuadrangular que se encuentra fragmentado hacia el extremo inferior y hacia el otro, finaliza en una cabeza de forma circular (Figura 7.6). Posee dimensiones de tamaños intermedios (Tabla 7.6) respecto a aquellos resguardados en el Museo de la Plata. Otra diferencia radica en la ausencia en este ejemplar de orificios de pasaje.

La superficie de la pieza presenta una pátina de color negra y en el sector del mango se observan segmentos de coloración verde esmeralda que indica procesos de corrosión activa. La pieza fue fabricada con cobre o una aleación con alto contenido en este metal. Respecto a las técnicas de manufactura, se han observado restos de una acanaladura y rebordes pronunciados en el alfiler y un adelgazamiento marcado hacia la lámina que conforma la cabeza. Asimismo, el sector perimetral de ésta última exhibe concavidades producto de procesos de martillado (Figura 7.7: 2, 4 y 5). A partir de estas huellas, se 
infiere que la pieza fue fabricada a partir de una preforma vaciada en molde y sujeta a posteriores eventos de martillado para el conformado de la cabeza y su acabado final.

Esta pieza proviene de la localidad de Condorhuasi, Las Juanitas o Las Barracas ubicadas en el sector inferior del valle de Hualfín, sobre la margen derecha del río Belén.

\begin{tabular}{|c|c|c|}
\hline \multicolumn{3}{|c|}{ Pieza 019 } \\
\hline \multirow{2}{*}{ Segmento } & Dimensión & Medida (cm) \\
\hline \multirow{3}{*}{ Alfiler } & Largo & 5,9 \\
\cline { 2 - 3 } & Ancho & 0,3 \\
\cline { 2 - 3 } & Espesor* & 0,2 \\
\hline \multirow{3}{*}{ Cabeza } & Alto** & 2,4 \\
\cline { 2 - 3 } & Ancho & 2,1 \\
\cline { 2 - 3 } & Espesor & 0,1 \\
\hline \multicolumn{2}{|c|}{ Largo total*** } & 8,3 \\
\hline $\begin{array}{l}\text { *Calculado en el sector medio del mango, luego se reducen } \\
\text { hacia el extremo inferior. } \\
* * \text { Representa el segmento de cabeza continua al eje } \\
\text { longitudinal del mango } \\
* * * \text { Resulta de la sumatoria del largo del mango y alto de la } \\
\text { cabeza }\end{array}$ \\
\hline
\end{tabular}

Tabla 7.6. Medidas del topu (1842), Museo Cóndor Huasi.

- TUMI: la pieza 020 corresponde al primer tipo descrito por Nordenskiold (1921:51, tipo $a$ ), es decir aquella pieza donde su mango finaliza en un segmento doblado sobre sí mismo, el cual se encuentra actualmente fragmentado. Hacia el extremo opuesto, el mango de sección rectangular se ensancha paulatinamente hasta finalizar en una hoja delgada de forma elipsoidal (Figura 7.6 y Tabla 7.7). La presencia de cantos rectos y caras planas sugiere un proceso de manufactura por vaciado en molde y unas pocas instancias de martillado, para estirar la hoja y para producir el doblez observado en el mango (Figura 7.7: 2, 4, 5 y 6). Por otro lado, la superficie presenta una coloración cobriza con amplios sectores ennegrecidos y pequeños vestigios de coloración verde claro, a partir de lo cual se infiere que fue fabricado en cobre. 
Esta pieza también proviene de la localidad de Condorhuasi; Las Juanitas o Las Barracas.

\begin{tabular}{|c|c|}
\hline \multicolumn{2}{|c|}{ Pieza 020 } \\
\hline Dimensiones & Medida (cm) \\
\hline Ancho & 7,5 \\
\hline Largo & 7,8 \\
\hline Espesor mango & 0,3 \\
\hline Espesor hoja & 0,2 \\
\hline Espesor filo & 0,2 \\
\hline
\end{tabular}

Tabla 7.7. Medidas del tumi (1812), Museo Cóndor Huasi.

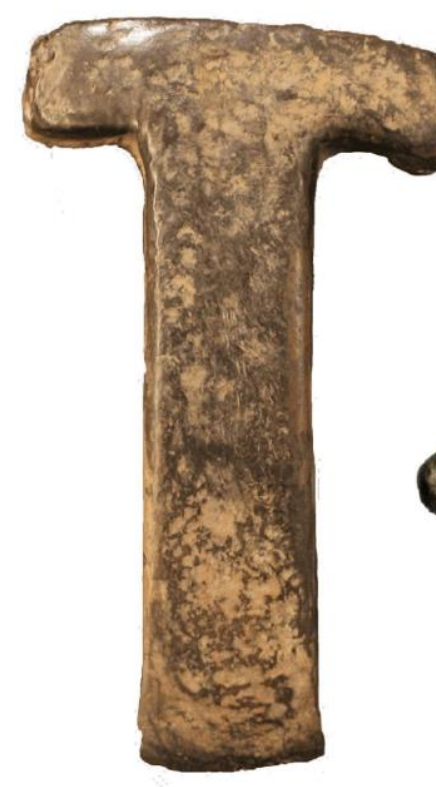

017 мСн-СC-N 0180

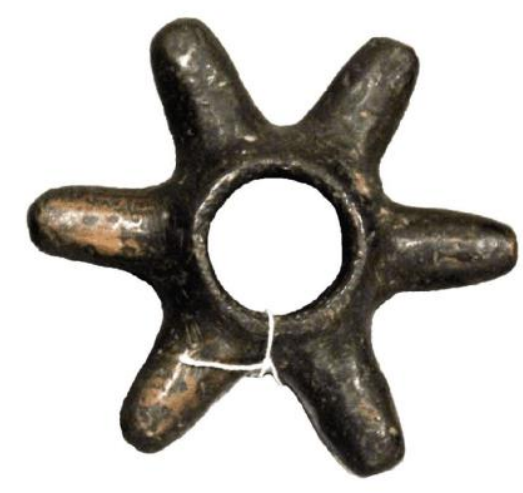

018 мСн-СC-No2779

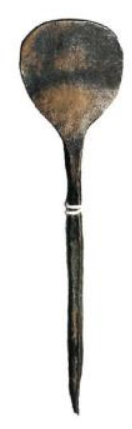

019 MCH-CC-N 1842

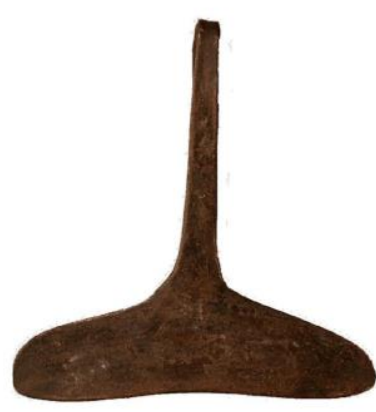

$020{ }_{\text {MCH-CC-N } 1812}$

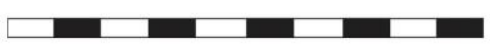

Figura 7.6. Objetos Inka de la colección Cura, Museo Cóndor Huasi. 


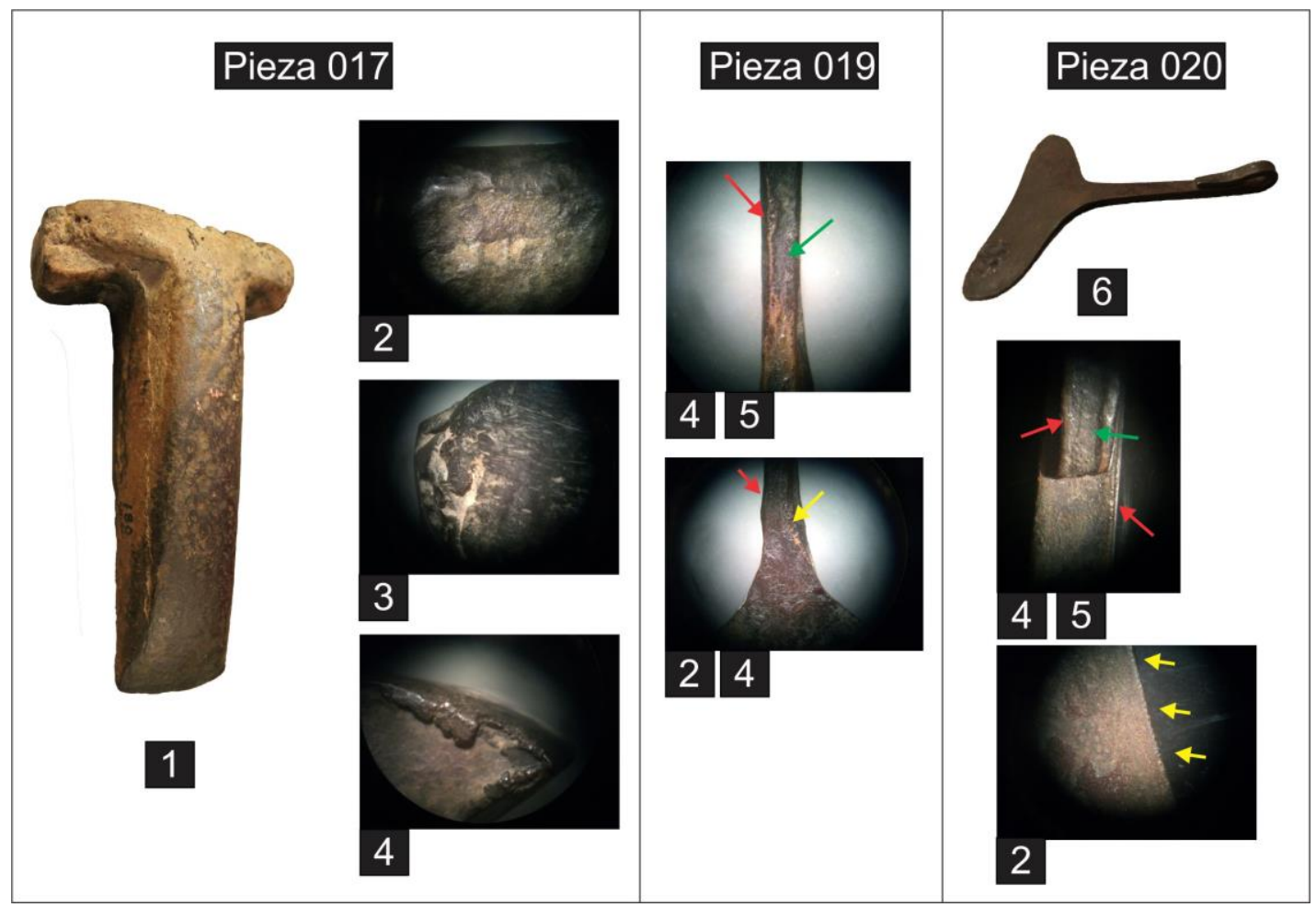

Figura 7.7. Huellas de manufactura observadas en piezas del MCH. 1. Costura lateral de molde bivalvo. 2. Concavidades (flecha amarilla); 3. Fallas drenaje; 4. Rebordes (flecha roja); 5. Acanaladura por martillado (flecha verde); 6. Cantos rectos.

\subsubsection{Las piezas metálicas del museo de sitio del "Shincal de Quimivil"}

\subsubsection{Piezas de recolección superficial}

- TUMI: este objeto presenta un mango de sección rectangular cuyo extremo es redondeado y presenta un orificio de suspensión de $0,4 \mathrm{~cm}$ de diámetro (tipo $d$ de Nordenskiold 1921: 51). El segmento de hoja tiene forma elipsoidal y presenta un perfil curvo hacia la cara posterior (Figura 7.8). Sus dimensiones se presentan en la Tabla 7.8.

La pieza 021 fue manufacturada a partir de una preforma fundida con instancias intermedias de martillado para su acabado final. La pieza presenta caras planas, cantos del mango rectilíneos y cierta uniformidad en su espesor, lo que sugiere la utilización de un molde. Por otro lado, en el sector del filo se han observado concavidades que sugieren instancias de martillado para su conformación (ver ficha en anexo III). 
Este objeto fue recuperado durante las prospecciones realizadas en el sector de tumbas del sitio arqueológico dirigidas por el Dr. Giovannetti. La presencia de incisiones zigzagueantes en la hoja de la pieza, seguramente se debe a alteraciones recientes, dada la aparente frescura de estas huellas. Respecto a las alteraciones químicas, la superficie de la pieza está ennegrecida y presenta sectores puntuales de coloración verde esmeralda y aspecto pulverulento. Utilizando como criterio la coloración superficial y de la corrosión, asignamos a esta pieza dentro del grupo de metales elaborados con cobre o aleaciones con alto contenido de este metal, que ha podido ser corroborado a partir del análisis químico realizado con la técnica de FRX. Este estudio dio como resultado que la pieza está conformada $100 \%$ en cobre. Se incorpora así a la reducida lista del NOA que refiere a tumi inkas manufacturados en cobre, sin ningún tipo de aleación (Angiorama 2013).

\begin{tabular}{|c|c|}
\hline \multicolumn{2}{|c|}{ Pieza 021 } \\
\hline Dimensiones & Medida (cm) \\
\hline Ancho & 2 \\
\hline Largo & 4,9 \\
\hline Espesor mango & 0,3 \\
\hline Espesor hoja & 0,2 \\
\hline Espesor filo & 0,1 \\
\hline Diámetro orificio & 0,4 \\
\hline
\end{tabular}

Tabla 7.8. Medidas del tumi del sitio El Shincal de Quimivil.

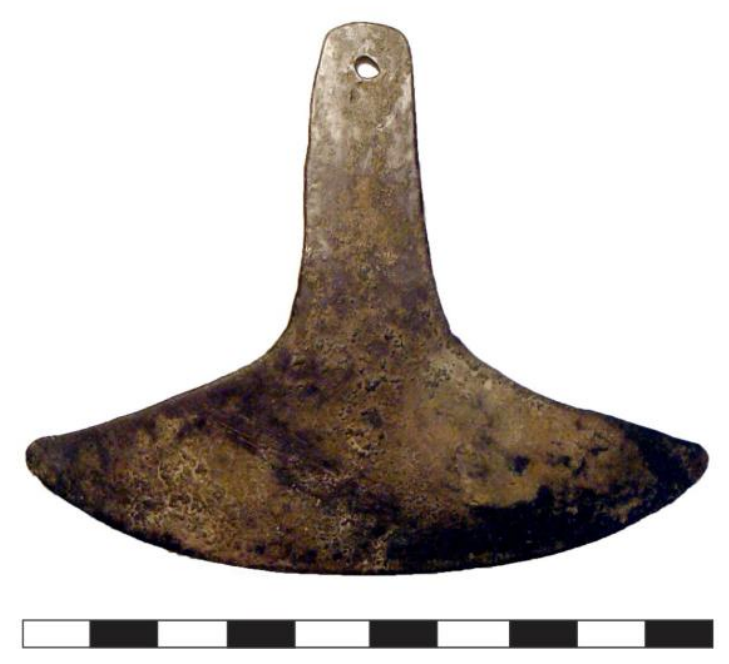

Figura 7.8. Tumi de El Shincal 


\subsubsection{Piezas de excavación con contexto de hallazgo}

- AGUJA: es un objeto metálico alargado de $9,5 \mathrm{~cm}$ de longitud que finaliza en el extremo inferior en una punta aguzada y en el opuesto presenta un ojal de forma ovalado (Figura 7.9 y Tabla 7.9). En este último sector, el cuerpo exhibe una sección subcuadrangular que luego se va redondeando. La pieza está curvada hacia el sector aguzado, posiblemente producto del uso o de alteraciones postdepositacionales.

Fue manufacturada a partir de un nódulo amorfo o una preforma fundida de bronce, a la cual se le aplicó la técnica de trefilado mediante intensos eventos de martillado para alargar el material, reducir su espesor y redondear parte del cuerpo. Esto se infiere dado que en el sector medio e inferior de la pieza se observaron vestigios de una acanaladura central (Figura 7.10:1). Además, el sector con el ojal está levemente achatado producto del impacto del martillo. Por otro lado, la presencia de microestrías longitudinales y paralelas entre sí, sugieren que el objeto fue posteriormente pulido, borrando muchas de las marcas de fabricación (Figura 7.10: 2). La aguja presenta alteraciones antrópicas por rotulado y corrosivas manifestadas en una superficie ennegrecida de manera uniforme y en sectores pulverulentos con coloraciones tanto verde esmeralda como rojizas, propias de la reacción de carbonatos y sales.

La pieza 022 fue recuperada en las excavaciones realizadas en el ushnu del sitio. Se halló asociada a materiales de origen prehispánicos (estatales y locales) como hispánicos que fueron registrados en las unidades estratigráficas 10 a 26 (1-2,4 m de profundidad) (Raffino et al. 1997; Raffino 2004).

\begin{tabular}{|c|c|c|}
\hline \multirow{3}{|c|}{ Pieza 022 } \\
\hline Segmento & Dimensiones & Medida (cm) \\
\hline \multirow{3}{*}{ Ojal } & Ancho & 0,1 \\
\hline \multirow{3}{*}{ Cuerpo } & Largo & 0,5 \\
\hline & Ancho & 0,3 \\
\cline { 2 - 3 } & Largo & 9,5 \\
\cline { 2 - 3 } & Espesor Máx. & 0,2 \\
\cline { 2 - 3 } & Espesor Mín. & 0,1 \\
\hline
\end{tabular}

Tabla 7.9. Medidas de la aguja hallada en el ushnu del sitio El Shincal de Quimivil. 
- BIRIMBAO: con este término se designa a un instrumento musical idiófono. Suelen estar conformados por una barra de metal curvada y en el sector medio presentan una lengüeta del mismo material de fabricación, que al moverla, genera tonos musicales por la vibración de su propio cuerpo (Varela De Vega 1981) ${ }^{5}$. En el caso de la pieza analizada, el cuerpo adquiere una forma similar a una horquilla. Está conformado por una barra fundida de sección cuadrangular que fue curvada en el sector medio hasta adquirir forma de arco que finaliza en dos extremos alargados. Allí, se observan achatamientos y rebordes señalando que fue fabricado mediante eventos de martillado sobre una barra fundida (Figura 7.10- 3 y 4). La lengüeta actualmente está ausente por quiebre y los extremos inferiores de la pieza están fragmentados, por lo tanto, si bien presentamos las medidas en la Tabla 7.9, la longitud original de la pieza es la que publicara Schávelzon e Igareta (2009). Por otro lado, la superficie del objeto exhibe una coloración oscura, con oxidaciones blanquecinas y marrón claro que sugiere una composición química de hierro. Asimismo, se han observado segmentos puntuales de color verde que indicar contenidos de sales producto de la contaminación.

Esta pieza también fue recuperada en el ushnu del sitio, en el contexto que remite al período de contacto hispano-indígena (Raffino et al. 1997; Raffino 2004)

\begin{tabular}{|c|c|}
\hline \multicolumn{2}{|c|}{ Pieza 023 } \\
\hline Dimensiones & Medidas (cm) \\
\hline Ancho & 1,9 \\
\hline Largo & 4,2 \\
\hline Espesor Máx. & 0,7 \\
\hline Espesor Mín. & 0,2 \\
\hline
\end{tabular}

Tabla 7.9. Medidas del birimbao del sitio El Shincal de Quimivil.

\footnotetext{
${ }^{5}$ Fuente: http://www.cervantesvirtual.com/obra-visor/anotaciones-historicas-sobre-el-birimbao-2/html/ Consulta Marzo 2017.
} 
- CASCABEL: la pieza 024 presenta una forma semicircular conformada por dos mitades unidas (semiesferas) que en el interior alojan dos pequeñas bolitas de metal de hierro. La mitad superior posee la argolla de suspensión formada por una cinta plana curvada que se une hacia el centro de la semiesfera. La otra mitad, posee en la cara opuesta, una hendidura transversal al cuerpo que finaliza en circunferencias hacia ambos lados (Figura 7.9).

El objeto presenta un estado de corrosión avanzado, con una superficie prácticamente cubierta por una sustancia blanquecina. Sin embargo, algunos segmentos han permitido reconocer una superficie irregular con concavidades, lo que permite pensar que las semiesferas han sido fabricadas a partir de láminas martilladas que fueron curvadas posiblemente por la técnica de embutido. Luego, las dos mitades se unirían por presión mecánica y calentamiento. Si bien es difícil de observar por la corrosión, es posible que la hendidura haya sido lograda por recortes del metal y la argolla adherida al cuerpo por algún mecanismo de unión mecánica. En dicho sector, no se han observado variaciones metálicas que indicasen soldaduras, pero sí depresiones y abolladuras en las zonas de unión que, además, se encuentran corroídas señalando posibles instancias de martillado (Figura 7.10 $3,5$ y 6$)$.

Además de la sustancia blanquecina, la pieza está ennegrecida y presenta oxidaciones puntuales de coloraciones verdes y rojizas, propias de las alteraciones producto de las sales de cobre. También se observan concreciones marrones localizadas en el sector de la hendidura, que se asemejan a las corrosiones características de compuestos con hierro. A través de la hendidura se aprecian las dos bolitas de hierro fuertemente oxidadas (ver ficha 024 Anexo III).

Cascabeles con una morfología similar fueron registrados en colecciones museológicas procedentes de la región Calchaquí en el NOA (Gluzman y González 2008: Fig. 2). Los estudios metalográficos realizados por los autores, indican procesos de manufactura coincidentes con las observaciones macroscópicas aquí presentadas (Gluzman y González 2008). 
Respecto a la procedencia, la misma fue hallada en el ushnu del sitio dentro de las unidades arqueológicas del evento hispano-indígena (Raffino et al. 1997; Raffino 2004)

- CLAVOS: se han registrado cinco clavos de hierro con un avanzado estado de oxidación ${ }^{6}$. Los clavos son piezas conformadas por tres sectores: una cabeza, un cuerpo alargado y una punta aguzada. Como se puede observar en la Figura 7.9, una de las piezas sólo presenta el segmento de cuerpo de sección circular al encontrarse fragmentado en ambos extremos (pieza 026.1). Otros tres clavos ostentan cabezas y cuerpos circulares (pieza 026.2, 3 y 4) y un único ejemplar tiene cabeza rectangular y cuerpo de sección cuadrangular (pieza 026.5). En la Tabla 7.10 se presentan las medidas aproximadas, dado que los productos de corrosión han avanzado sustancialmente sobre la estructura del metal generando levantamientos y concreciones de óxidos ferrosos. Aun así, en general, las longitudes máximas de todos los ejemplares señalan que son clavos relativamente grandes $(<5 \mathrm{~cm})$.

Al igual que las piezas anteriores, los cinco clavos proceden del evento hispanoindígena identificado en el ushnu del sitio (Raffino et al. 1997; Raffino 2004).

\begin{tabular}{|l|c|c|c|c|c|}
\hline \multirow{2}{*}{ Dimensiones } & \multicolumn{5}{|c|}{$\mathbf{N}^{\circ}$ Pieza 025/ Medidas (cm) } \\
\cline { 2 - 6 } & $\mathbf{1}$ & $\mathbf{2}$ & $\mathbf{3}$ & $\mathbf{4}$ & $\mathbf{5}$ \\
\hline Ancho cabeza & - & 1,4 & 1,2 & 1,2 & 1,3 \\
\hline Largo total & 3,7 & 4,8 & 3,3 & 3 & 2 \\
\hline Espesor cuerpo & 0,5 & 1,2 & 0,5 & 0,8 & 0,5 \\
\hline
\end{tabular}

Tabla 7.10. Medidas de los clavos del sitio El Shincal de Quimivil.

- LÁMINAS: la pieza 026 está constituida por dos fragmentos de metal de aspecto laminar que se hallan fragmentados cuyas medidas se presentan en la Tabla 7.11. Si bien los segmentos de lámina no remontan entre sí, sus cualidades formales señalan que fueron

\footnotetext{
${ }^{6}$ Se ha realizado una única ficha nombrada como pieza 026 para los cinco ejemplares de clavos, dado que el avanzado estado de corrosión no permitió detectar huellas dejadas por los procesos tecnológicos.
} 
parte del mismo objeto, seguramente un brazalete dado su curvatura. Las láminas fueron fabricadas a partir de una masa fundida con intensos procesos de martillado para deformar plásticamente el metal. Quizás, este objeto haya sido manufacturado siguiendo la secuencia propuesta por Carcedo (1999) donde el metal se trabaja sobre un yunque para producir un alargamiento longitudinal y estirar el metal. Esta sería la causa de la planicidad observada en una de sus caras, así como de su curvatura final y la presencia de rebordes hacia los laterales. Además, en una de sus caras, a lo largo de toda la superficie se identificaron incisiones paralelas en sentido longitudinal, como una especie de facetado (Figura 7.10- 7 y 8). Estos surcos presentan laterales y fondo recto que podría indicar que se utilizó un cincel con este tipo de punta para el estiramiento de la lámina. También se observaron bordes con fisuras y fracturas que pueden tener su origen tanto en causas tecnológicas, de uso o bien postdepositacionales.

El segmento A presenta alteraciones antrópicas por rotulado con un marcador negro y ambos segmentos tienen alteraciones químicas generadas por procesos corrosivos, así como alteraciones mecánicas por fracturas y fragmentación. Las láminas fueron fabricadas en cobre o una aleación con alto contenido en este elemento.

Estas piezas metálicas proceden del ushnu, pero fueron registradas en la unidad estratigráfica 6 y 7 (10-80 cm) asociada al evento Inka (Raffino et al. 1997; Raffino 2004).

\begin{tabular}{|l|c|c|}
\hline \multirow{2}{*}{ Dimensiones } & \multicolumn{2}{c|}{$\begin{array}{c}\mathbf{N}^{\circ} \text { Pieza 026/ } \\
\text { Medidas (cm) }\end{array}$} \\
\cline { 2 - 3 } & $\mathbf{A}$ & $\mathbf{B}$ \\
\hline Ancho & 1,4 & 1,4 \\
\hline Largo & 4 & 5,9 \\
\hline Espesor & 0,1 & 0,1 \\
\hline
\end{tabular}

Tabla 7.11. Medidas de las láminas del sitio El Shincal de Quimivil. 


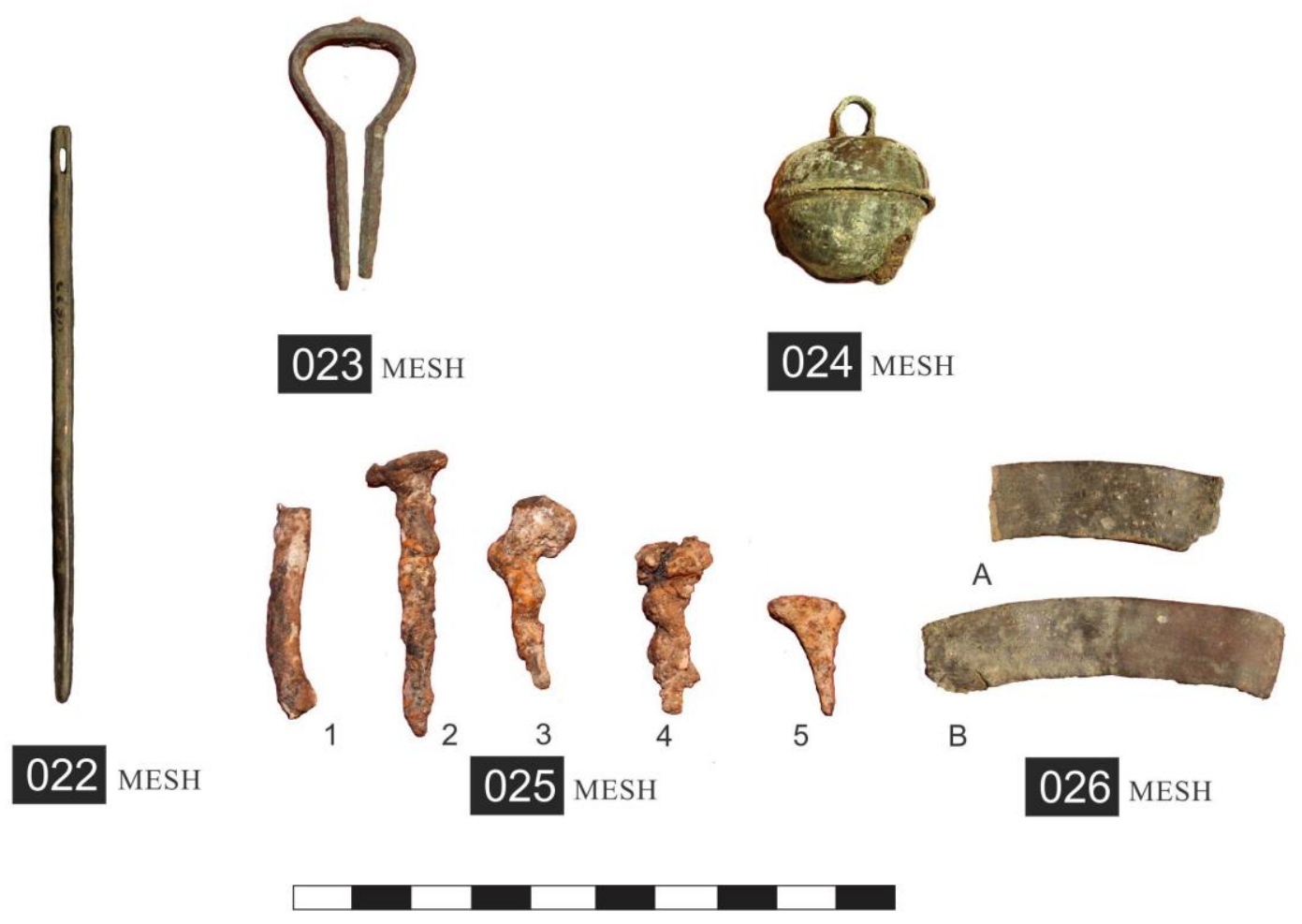

Figura 7.9. Objetos de metal hallados en el ushnu del sitio El Shincal de Quimivil.
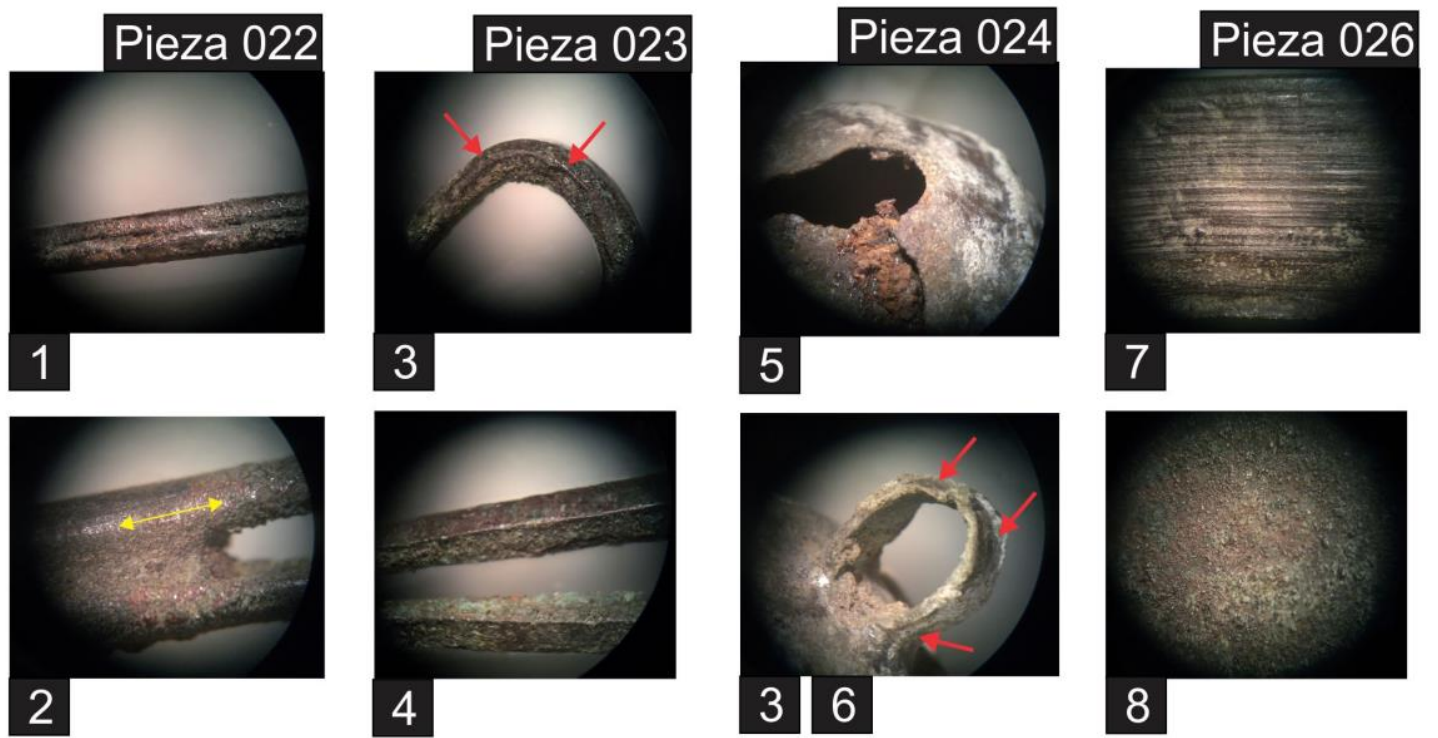

Figura 7.10. Huellas de manufactura y de uso observadas en piezas del ESH: 1. Acanaladura central; 2. Microestrías longitudinales y paralelas 3. Rebordes laterales; 4. Cantos rectos; 5. Oxidación hierro; 6. Concavidades. 7. "Facetado"; 8. Superficie lisa cara opuesta del facetado. 


\subsubsection{Piezas sin contexto de hallazgo}

- CINCELES: se han registrados dos cinceles (pieza 027 y 028) del mismo tipo, es decir de un sólo extremo activo, pero con distintas medidas (Tabla 7.12). Son piezas que se conforman de un cuerpo alargado que finaliza en una punta aguzada hacia el extremo proximal, denominado "talón" (sensu Gluzman 2008: 200) y en el extremo opuesto se ensanchan conformando una pequeña hoja en abanico con filo. Ambas piezas analizadas presentan filos con perfiles simétricos.

\begin{tabular}{|l|c|c|}
\hline \multirow{2}{*}{\multicolumn{2}{|c|}{ Dimensiones }} & \multicolumn{2}{c|}{$\begin{array}{c}\text { No Pieza / } \\
\text { Medidas (cm) }\end{array}$} \\
\cline { 2 - 3 } & $\mathbf{0 2 7}$ & $\mathbf{0 2 8}$ \\
\hline Ancho talón & 0,3 & 0,3 \\
\hline Ancho hoja & 1,1 & 1,5 \\
\hline Ancho cuerpo & 0,6 & 0,5 \\
\hline Espesor talón & 0,1 & 0,2 \\
\hline Espesor cuerpo & 0,3 & 0,3 \\
\hline Espesor filo & 0,1 & 0,1 \\
\hline Largo total & 12 & 6,2 \\
\hline
\end{tabular}

Tabla 7.12. Medidas de cinceles del sitio El Shincal de Quimivil.

Respecto a la forma de fabricación, se infiere que ambas piezas fueron obtenidas a partir de eventos intermedios de martillado sobre una preforma fundida de dimensiones similares a las finales. Se observan cantos rectos con rebordes, concavidades a lo largo del cuerpo y adelgazamientos en los extremos distales producto de los martillados para la formalización de las hojas en abanico y del filo (Figura 7.11).

La pieza 027 presenta una coloración dorada con marcadas alteraciones químicas de tonos rojizos y verde esmeralda, siendo fabricada posiblemente de bronce. La pieza 028 parece pertenecer a un cobre o aleación con alto contenido en este metal. Por otro lado, es interesante remarcar la presencia de huellas de uso manifestadas en microestrías oblicuas al filo (pieza 028) y en el desgaste diferencial del extremo activo que presenta superficies asimétricas y bordes dentados (pieza 027). Por otro lado, en la pieza 027 se observaron estrías continuas y paralelas a lo largo de toda la longitud del cuerpo, el cual presenta una 
superficie brillante. Asociamos estas marcas con alteraciones antrópicas contemporáneas producto de limpiezas con algún agente abrasivo (Figura 7.11).

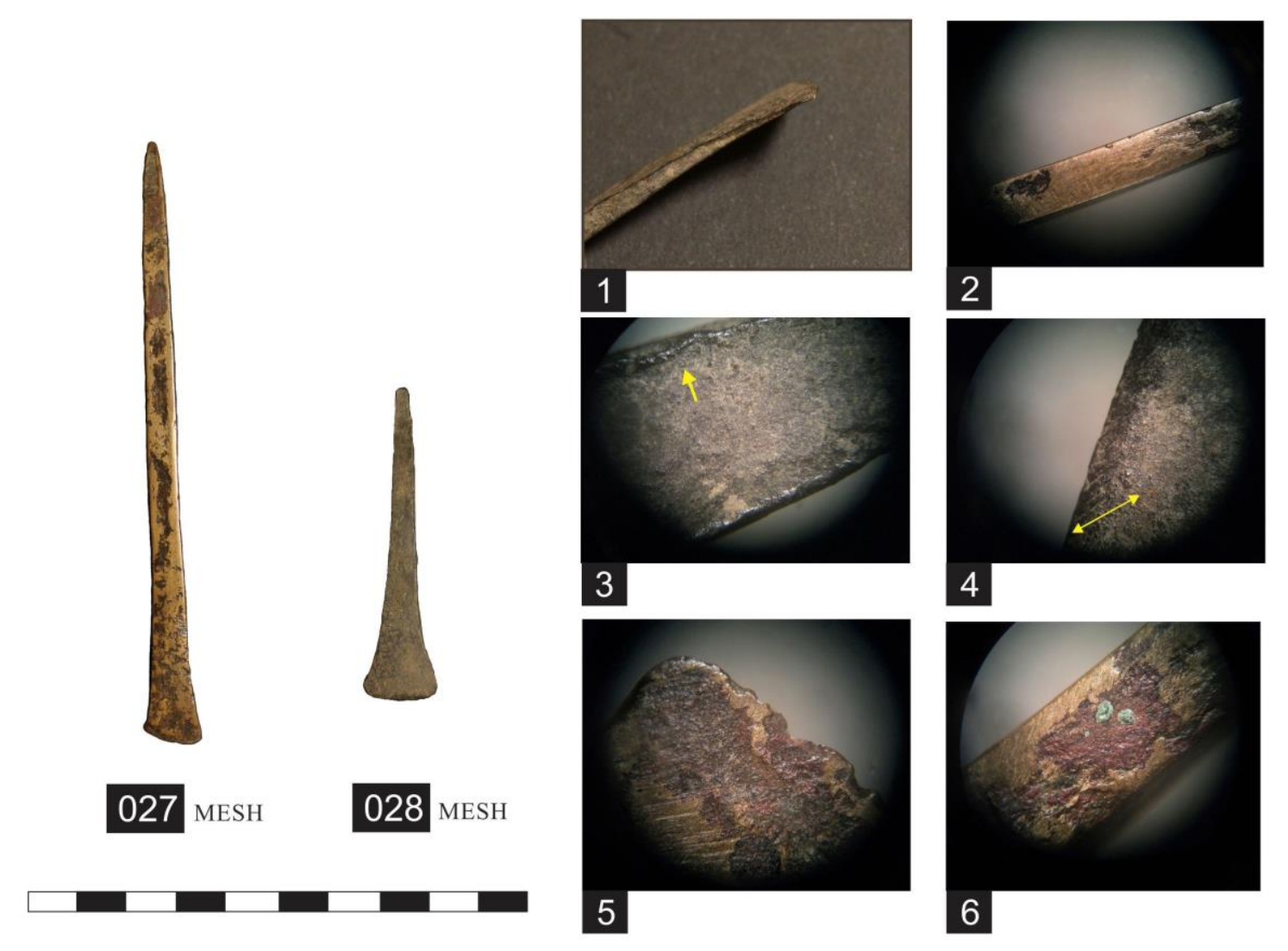

Figura 7.11. Izquierda: fotografía de los cinceles de ESH. Derecha: Huellas de manufactura: 1. Adelgazamiento sector hoja, cantos rectos y rebordes en laterales; 2. Cantos rectos; 3. Rebordes. Huellas de uso: 4. Microestrías oblicuas al filo; 5. Filo dentado. Alteraciones químicas: 6. Óxidos de sales y cloruros de cobre.

- HACHAS: en este caso se han identificado dos morfotipos de hachas en "T". Una se corresponde con las hachas conformadas por cuerpos de gruesos espesores y la otra a los tipos más delgados, siguiendo la distinción realizada por Mayer (1986) (Figura 7.12). Asimismo, como se puede observar en la Tabla 7.13 presentan grandes diferencias en sus tamaños. 


\begin{tabular}{|c|c|c|c|}
\hline \multirow[t]{2}{*}{ Segmento } & \multirow[t]{2}{*}{ Dimensiones } & \multicolumn{2}{|c|}{$\begin{array}{c}\mathbf{N}^{\circ} \text { Pieza / } \\
\text { Medidas (cm) }\end{array}$} \\
\hline & & 029 & 030 \\
\hline \multirow{3}{*}{$\begin{array}{c}\text { Transversal } \\
\text { (mango) }\end{array}$} & Ancho & 7,6 & 4,1 \\
\hline & Alto* & 1,6 & 0,7 \\
\hline & Espesor & 2,5 & 0,5 \\
\hline \multirow{3}{*}{ Cuerpo central } & Largo & 10,7 & 6,3 \\
\hline & $\begin{array}{l}\text { Ancho } \\
\text { máximo }\end{array}$ & 3,3 & 4,2 \\
\hline & Espesor & 2,5 & 0,7 \\
\hline Filo & Espesor & 0,2 & 0,2 \\
\hline \multicolumn{2}{|c|}{ Largo total } & 12,3 & 7 \\
\hline
\end{tabular}

Tabla 7.13. Medidas de las hachas en T del sitio El Shincal de Quimivil.

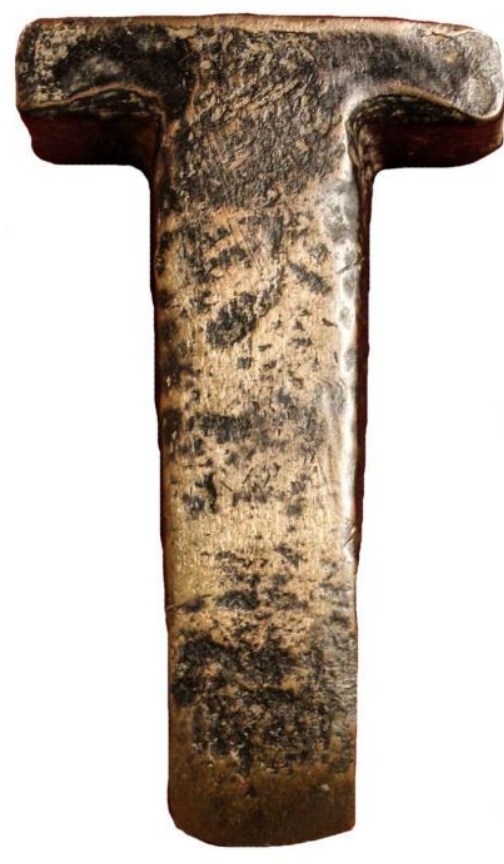

029 MESH

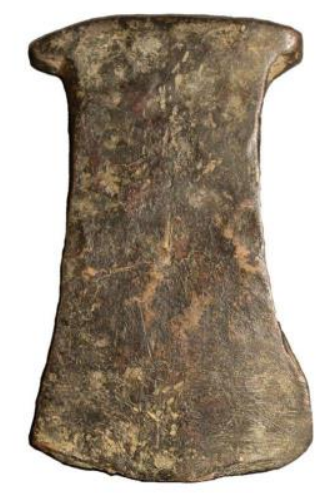

$030 \mathrm{MESH}$

Figura 7.12. Hachas en $\mathrm{T}$ del sitio El Shincal de Quimivil. 
Respecto a la primera (pieza 029), se observa un cuerpo rectangular de gran volumen que finaliza en un extremo inferior aguzado en forma de cuña y muy delgado. En el extremo superior, el segmento transversal al cuerpo mantiene el espesor de éste último. La pieza posiblemente fue fabricada a partir de su vaciado en un molde simple que habría brindado su forma final, pero que aún así requeriría de posteriores instancias de martillado para su terminación. Esto se infiere dado que el objeto presenta un perfil plano-convexo señalando que, al menos una de sus caras, estuvo en contacto directo con la superficie del molde. Además, presenta cantos bien conformados con superficies rectas (en especial en el segmento transversal) así como rebabas en los laterales y zonas cercanas al filo producto de la reducción del espesor y acabado de la pieza (Figura 7.13). Presenta una coloración anaranjada a dorada característica de objetos realizados en bronce. Por otro lado, se ha observado en la cara anterior, incisiones aisladas de sección oblicua que podrían estar señalando marcas de uso o bien alteraciones postdepositacionales.

La segunda hacha (pieza 030) presenta un cuerpo de aspecto trapezoidal que finaliza en un filo de sección redondeada. El segmento transversal presenta sus extremos laterales redondeados. Esta hacha es morfológicamente similar a las piezas 273 y 274 -originarias del NOA- del catálogo de Mayer (1986: Lámina 14) y que posteriormente González asignó a momentos inkaicos (2004b: 308).

La pieza 030 posiblemente fue manufacturada a partir de una preforma fundida, pero con sucesivos eventos de martillado para dar forma trapezoidal al cuerpo central. Se observaron cantos rectos producto del contacto con el molde. Además, a lo largo de la superficie presenta concavidades producto del martillado y rebordes, en especial en zonas de adelgazamiento del segmento que se abre en abanico. Asimismo, se han identificado cercanas al filo fisuras, rebordes y en el segmento transversal una fractura (Figura 7.13). Estas alteraciones mecánicas pudieron ser generadas por causas tecnológicas, posiblemente producto de la deformación plástica y las tensiones acumuladas durante el martillado. Por otro lado, la pieza presenta varias huellas de utilización en su filo materializadas en depresiones, sectores abollados y desgastes diferenciales. 
Respecto a las alteraciones químicas, si bien presenta una pátina uniforme de coloración negra, en el filo se observaron oxidaciones discretas de coloración verde esmeralda y, en los laterales del cuerpo, alteraciones en tonos rojizos. Las coloraciones de los productos de oxidación y los sectores limpios que muestran un color dorado sugieren que se trata composicionalmente de bronce.

En lo relativo a la procedencia de ambas hachas, no se han encontrado referencias en los registros de la colección ni en los datos bibliográficos bajo esta categoría de objetos. Sin embargo, creemos posible que se correspondan con las piezas de bronce referenciadas equívocamente como "tumi" en las publicaciones donde se presentan los resultados de las excavaciones realizadas en el sitio con hallazgos de elementos metálicos (Raffino et al. 1997; Raffino 2004). Sugerimos esto, dado que en el reestudio de las piezas de metal registradas en el ushnu ninguna respondería al morfotipo tumi, habiéndose reconocida las restantes sin inconvenientes. Incluso, en la pieza 030, la observación a lupa binocular permitió detectar vestigios de pintura negra que, posiblemente, esté dando cuenta del rótulo de la pieza. El tipo de tinta se asemeja a los rastros de rotulación observados en los otros ejemplares originarios de la excavación del ushnu (Figura 7.13: 9). También, es sugerente que en el museo de sitio históricamente se las haya presentado junto a las piezas registradas en el ushnu y que en los relatos orales se plantea que son estas piezas, aquellas recuperadas en la plataforma ceremonial. Si realmente estamos ante los objetos de bronce recuperados en el ushnu, siguiendo la información disponible en las publicaciones, las hachas se corresponden tanto a la fase Inka como al evento asociado al periodo hispano-indígena. 


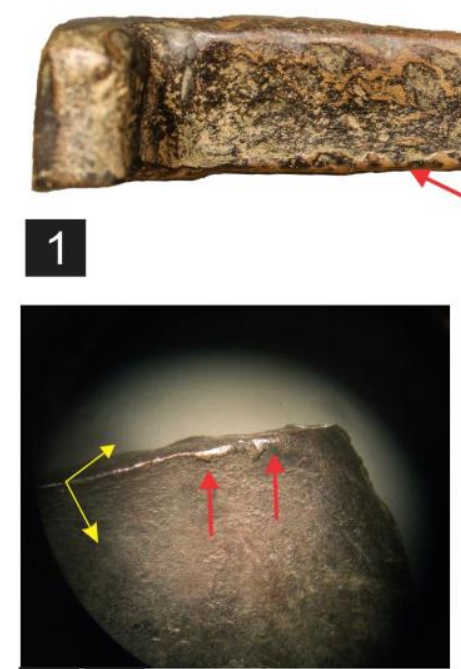

$2 \mid 3$

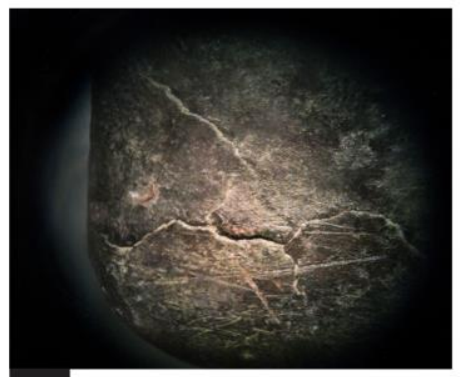

6

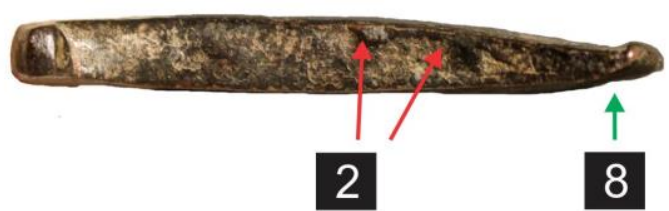

2

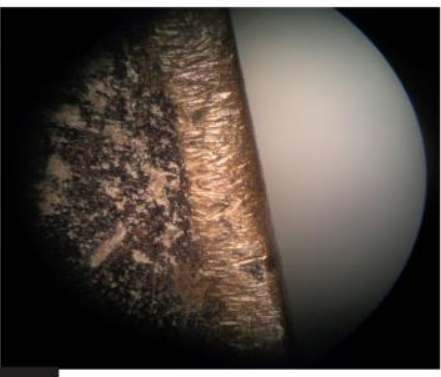

4
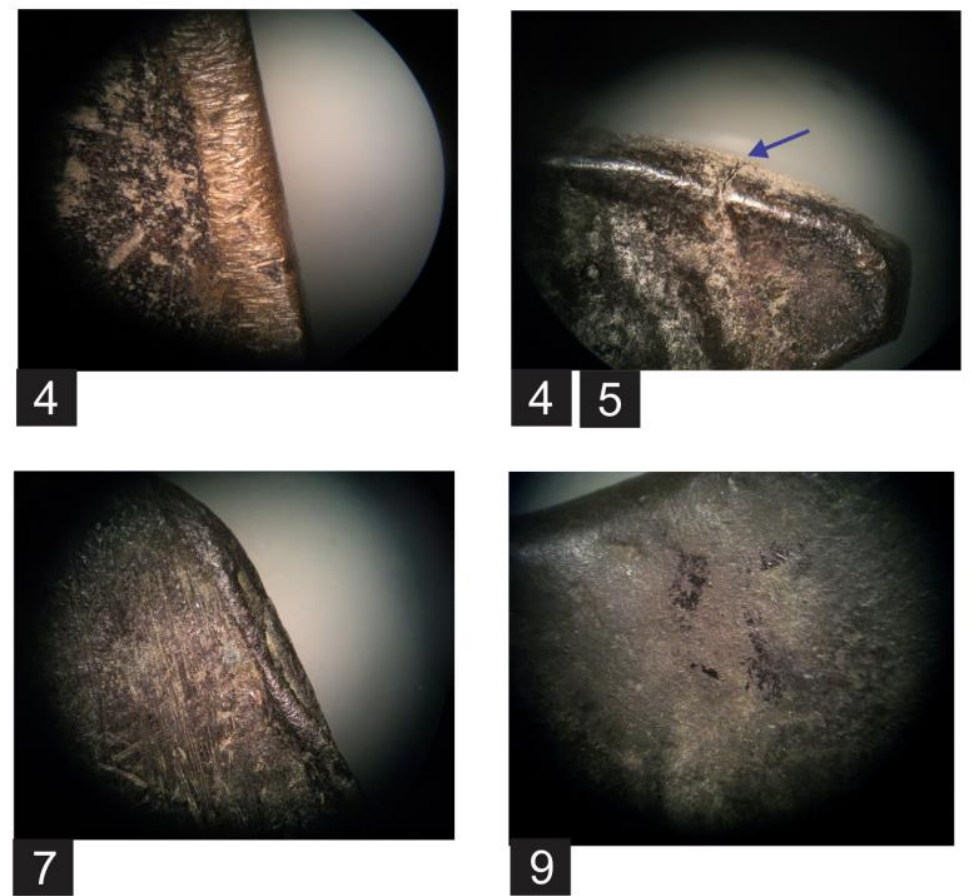

Figura 7.13. Huellas de manufactura de las Hachas de ESH: 1. Perfil plano-convexo; 2. Rebordes (flechas rojas); 3. Cantos rectos (flecha amarilla); 4. Concavidades en cuerpo por el martillado. Huellas de uso: 5. Fractura (flecha azul); 6. Fisuras; 7. Abolladura; 8. Dobles (flecha verde). Alteraciones: 9. Vestigio de pintura negra (¿rótulo?).

\subsection{Datos sobre la funcionalidad de las piezas}

En las distintas colecciones se han identificado varias categorías de objetos de raigambre inka. Basados en sus características morfológicas, en datos etnohistóricos, etnográficos y en menor medida tecnológicos, diversos autores han otorgado funciones distintivas para cada clase de objetos metálicos, aunque la función "utilitaria" nunca se disocia de su función simbólica y el valor sacro-sagrado otorgado a estas piezas.

Dentro del repertorio registrado en las colecciones analizadas, se han reconocido piezas que servirían como herramientas con funciones de corte, desbaste, grabado, cincelado, repujado, sujeción, costura, etc. Estas serían los usos prácticos asociados a 
categorías como tumi o cuchillos, cinceles, clavos y agujas. Por otro lado, las hachas en T y las masas estrelladas son interpretadas como armas de guerra (Ambrosetti 2011 [1904], Mayer 1986; Ponce 2002) y los objetos clasificados como cascabel y birimbao consisten en piezas sonoras empleadas para actividades musicales (González y Gluzman 2008; Schávelzon e Igareta 2009). Por último, piezas de tipo tupu, lauraques y brazaletes desempeñan, incluso hasta la actualidad, funciones ornamentales asociadas principalmente al género femenino.

Específicamente, los tири son adornos utilizados tradicionalmente para sostener la vestimenta de las mujeres. Han sido empleados de manera individual para sostener la manta o saya a la altura del pecho, o bien de a pares, uno a la altura de cada hombro (Vetter Parodi 2007; Sagárnaga 2007). Sin embargo, los datos etnohistóricos también señalan que, en el pasado existieron posibles usos complementarios de los tupu tanto como espejos, cuchillos e instrumentos con funciones astronómicas o de defensa personal (Vetter Parodi 2007; Sagárnaga 2007).

Los lauraques son adornos que utilizan en sus cabellos las mujeres de las comunidades Uru-Chipayas del altiplano boliviano y son símbolos de distinción social (Fernández Murillo 2016). Si bien en dichos territorios, se han empleado desde épocas preinkaicas, en otras regiones se plantea que fue un objeto introducido por los Inkas. Este sería el caso para las piezas halladas tanto en Santiago del Estero (Angiorama y Taboada 2008) como en el Norte de Chile (Álvarez Miranda 1993; Schiappacasse y Niemeyer 2002) y la aquí presentada.

Lo dicho hasta aquí supone situar la mirada en la utilidad, en la función práctica y material de estos objetos, es decir, en su uso como herramientas, armamentos, instrumentos musicales y accesorios de vestimentas. La presencia de huellas de uso como estrías, desgastes, abolladuras y dentados que fueron observados en los filos de algunas de las piezas analizadas - p. ej. en hachas, cinceles y tumi-aportan datos en este sentido ya que sugieren que fueron utilizadas para modificar otros materiales. No obstante, estos objetos fueron percibidos como bienes simbólicos y sacralizados dotando de estatus y poder a quien los poseyera, como ya ha sido propuesto para los objetos tradicionalmente 
identificados bajo el rótulo de "utilitarios" como los cinceles (Gluzman 2008). En este sentido, el significado que adquirieron los elementos metálicos sólo puede ser abordado a partir de la reconstrucción de las prácticas sociales en las cuales estos bienes fueron utilizados. Para esta investigación la ausencia de contextos arqueológicos para la mayoría de las piezas, limita las posibilidades de avanzar en este sentido. Sin embargo, a partir de un conjunto significativo de piezas del sitio El Shincal de Quimivil es posible conocer algunos de los espacios sociales y prácticas que involucran el uso de estos bienes. Esto se debe a que el $72 \%$ de los objetos de metal del museo de sitio poseen información sobre los contextos de hallazgo y los materiales asociados (Tabla 7.14).

\begin{tabular}{|c|c|c|}
\hline Objeto de metal & Contexto de hallazgo & Materiales asociados \\
\hline $\begin{array}{l}\text { “tumi” de bronce } \\
\text { (¿Pieza } 029 \text { o 030?) } \\
\text { Adorno de bronce } \\
\text { (pieza 026) }\end{array}$ & $\begin{array}{l}\text { Ushnu - Evento Inka } \\
(0,70-100 \mathrm{~cm}) \\
\text { LP 735:550 } \pm 50 \text { (UE8) }\end{array}$ & $\begin{array}{l}\text { Cerámica Inka, Famabalasto negro } \\
\text { grabado, Belén N/R y ordinarias. } \\
\text { Vértebras y molares humanos. } \\
\text { Materiales líticos de obsidiana, cuarzo y } \\
\text { rodocrosita. } \\
\text { Placas de quirquincho, huevos de suri; } \\
\text { escamas de pescados y restos óseos de } \\
\text { camélidos, aves y roedores. } \\
\text { Cuentas de collar. } \\
\text { Restos botánicos de maíz, poroto, } \\
\text { zapallo, maní y coca. } \\
\text { Mullu y cornamenta de cérvido. }\end{array}$ \\
\hline $\begin{array}{l}\text { “Tumi” de bronce } \\
\text { (¿Pieza 029 o 030?) } \\
\text { Aguja } \\
\text { (Pieza 022) } \\
\text { Alambre }- \text { n/d } \\
\text { Birimbao } \\
\text { (Pieza 023) } \\
\text { Cascabel } \\
\text { (Pieza 024) } \\
\text { Clavos de hierro } \\
\text { (Pieza 025) }\end{array}$ & $\begin{array}{l}\text { Ushnu - Evento } \\
\text { hispano-indígena } \\
(100-240 \mathrm{~cm}) \\
\text { LP-699:310 } 40 \\
(\text { UE17) }\end{array}$ & $\begin{array}{l}\text { Lozas españolas y cerámicas } \\
\text { Caspinchango. } \\
\text { Vidrio; peine de madera; rodocrosita y } \\
\text { cáscara de suri. } \\
\text { Restos óseos de camélidos, zorros, } \\
\text { bovinos y equinos. } \\
\text { Restos botánicos de poroto, maíz y trigo } \\
\text { o cebada. } \\
\text { Incisivo humano } \\
\text { Cobre nativo. }\end{array}$ \\
\hline
\end{tabular}

Tabla 7.14. Contexto arqueológico de los objetos de metal registrados en el ushnu del sitio El Shincal de Quimivil. Datos extraídos de Raffino et al. 1997. 
Las excavaciones realizadas en 1996 y 1997 en el ushnu de El Shincal brindaron claros contextos arqueológicos cuyas asociaciones materiales y fechados radiocarbónicos permitieron distinguir dos eventos: el primero relativo al periodo Inka y el segundo al contacto hispano-indígena de la primera mitad del siglo XVII (Raffino et al. 1997). Para ambos momentos temporales, existe un cuerpo de datos considerable que permite proponer que este escenario fue objeto de prácticas rituales realizadas en el marco de ceremonias y fiestas indígenas (Raffino et al. 1997; Raffino 2004; Lynch et al. 2010; Giovannetti 2015b). Durante las mismas se ofrendaron diversos objetos votivos, de los cuales se destacan un conjunto de bienes ya sea por su origen alóctono o rareza, como ser: el prisma de cuarzo, las cuentas y placas de rodocrosita, un peine óseo, restos malacológicos originarios del Océano Pacífico (mullu y gasterópodos) y finalmente los objetos metálicos previamente analizados.

El ushnu es una plataforma sobreelevada construida en el centro de la plaza principal (haukaipata) del sitio. Se considera que estas estructuras fueron escenarios centrales durante las actividades políticas, ceremoniales y militares auspiciadas por el incario (Zuidema 1980; Hyslop 1991; Williams 1985; Raffino 2007). Dado que en las sociedades andinas lo político y la espiritualidad estaban fuertemente ligados, en estos espacios los líderes oficiaban negociaciones, pactos y ceremonias imbuidos de sacralidad, según documentan las fuentes etnohistóricas, etnográficas y arqueológicas (Zuidema 1980; Hyslop 1991; Raffino et al. 1997; Pino Matos 2004; Lynch et al. 2010; Sotil Monteverde 2011; Giovannetti 2015b). De las evidencias arqueológicas registradas en distintos ushnu, incluso en el de El Shincal, se destacan la presencia de distintivas características arquitectónicas con orientaciones astronómicas, su disposición central en los asentamientos y su vinculación con otros hitos sagrados del paisaje circundante (Pino Matos 2004, 2005; Raffino et al. 1997; Giovannetti 2015b). También la presencia de elementos recurrentes como tiyanas o "asiento del Inka", pozos con cantos rodados, canales y evidencias de prácticas rituales de libaciones, así como de ofrendas, sacrificios y objetos sagrados que exhiben un despliegue amplio de rituales oficiados por personas de élite durante las fiestas andinas (Pino Matos 2001; Lynch et al. 2010; Monteverde Sotil 2011; Giovannetti 2015b). Todas estas características sugieren que los ushnu fueron el centro de las ceremonias más importantes para el estado (Hyslop 1991; Pino Matos 2005, Giovannetti 2015b). Este papel 
central, está relacionado con la concepción de esta estructura como axis mundi, es decir, un espacio sacralizado que permite establecer conexiones entre los tres planos de la realidad andina: el supramundo -Hanan Pacha-, el mundo terrenal -Kay Pacha-y el inframundo Uku Pacha- (Zuidema 1980; Hyslop 1991; Espinosa Soriano 1997; Pease 2004).

Respecto a las clases de piezas metálicas ofrendadas en el ushnu del Shincal, consisten en cinco piezas de bronce: láminas (pieza 026), una aguja (pieza 022), dos posibles hachas en $\mathrm{T}$ (pieza 029 y 030) y un cascabel (pieza 024). Este último presentó una combinación de materiales, estando el cuerpo de la pieza fabricado con una aleación de cobre y las bolitas internas en hierro. Otras seis piezas eran de hierro: un birimbao (pieza 023) y los cinco clavos (pieza 025). Estas últimas dos clases de objetos responden a morfotipos de origen estrictamente europeo. En cuanto a los bienes de bronce, dos fueron identificados en el contexto inkaico y los restantes en las unidades de momentos coloniales. Es posible que estos últimos, hayan sido ofrendados intencionalmente durante los ritos realizados por los diaguitas históricos dado que, para las restantes ergológicas, también se observa una combinación de elementos indígenas con los europeos. Sin embargo, también podrían haber sufrido alteraciones y movimientos producto de la excavación realizada para delimitar el pozo de la ofrenda, que finalmente atravesó las ancestrales ofrendas Inkas.

Por otro lado, diremos también que al enmarcar los bienes metálicos en el contexto socio-político de beligerancia que imperaba a mediados del siglo XVII son llamativas las clases de objetos ofrecidos como dones. Dentro de la clase de piezas ofrendadas, se destaca que ellas no se relacionan específicamente con elementos utilizados para la guerra, a excepción del hacha. Sin embargo, cabe la posibilidad que los instrumentos musicales, como el birimbao y el cascabel, hayan sido empleados por los actores oficiantes como una de las tantas formas para alcanzar los estados de trance, siendo posteriormente ofrendados (Giovannetti 2015b). Por otro lado, es posible que la presencia de morfotipos de objetos hispánicos en las ofrendas rituales del periodo colonial, esté relacionando a la acción ritual que busca la protección durante los enfrentamientos armados mediante la inhibición del accionar de los contrincantes, cuestionamiento ya formulado por Lynch et al. 2010. 
En resumen, diremos que resulta significativo que, en las sucesivas excavaciones realizadas en distintas estructuras del sitio durante más de dos décadas, únicamente se registraron elementos de metal en la plataforma ceremonial, es decir, en uno de los espacios sacralizados por excelencia. Además, otros espacios físicos por donde podrían haber circulado los bienes metálicos son las tumbas, a juzgar por el hallazgo superficial de un tumi (pieza 021) en un sector del sitio donde predominan este tipo de estructuras. Esto sugiere, que en El Shincal los bienes metálicos circularon por espacios sociales sagrados para las comunidades andinas, en especial en aquellos que permitían establecer nexos con los distintos planos de la realidad y las divinidades.

\subsection{Discusión y conclusiones del capítulo}

El relevamiento de piezas realizado en las cuatro colecciones permitió caracterizar treinta y tres bienes metálicos que circularon por el Noroeste argentino principalmente durante período Inka y algunos durante el periodo colonial temprano. A partir de las descripciones realizadas en cada objeto, se observa que los morfotipos inkaicos más representados son los tupu, los tumi y las hachas en $\mathrm{T}$, mientras que se identificó un solo ejemplar de otra clase diferente (Figura 7.14).

El análisis de objetos tipo tupu у tumi ha permitido reconocer la variabilidad morfológica hacia el interior de cada categoría que refleja lo que fuera planteada por otros investigadores para amplios sectores del Tawantinsuyu (Nordenskiold 1921; Sagárnaga 2007; Vetter Parodi 2007; Fernández Murillo 2016). En lo que respecta a los tupu, la diversidad está materializada en las formas que adquieren sus cabezas como en sus medidas máximas. Mientras que el conjunto de tumi estudiados exhiben dimensiones máximas similares, pero varían en las formas en que finalizan sus mangos.

Dentro de los parámetros tecnológicos es posible sostener que todas las piezas fueron fabricadas en cobre o aleaciones de este metal, con excepción de las piezas hispánicas manufacturadas en hierro. Para el caso de las aleaciones, si bien no se dispone de análisis químicos que permitan conocer su tipo específico, es esperable que se traten de bronces estanníferos, dado que se plantea que fue la aleación imperial para este metal (Lechtman 1978). 


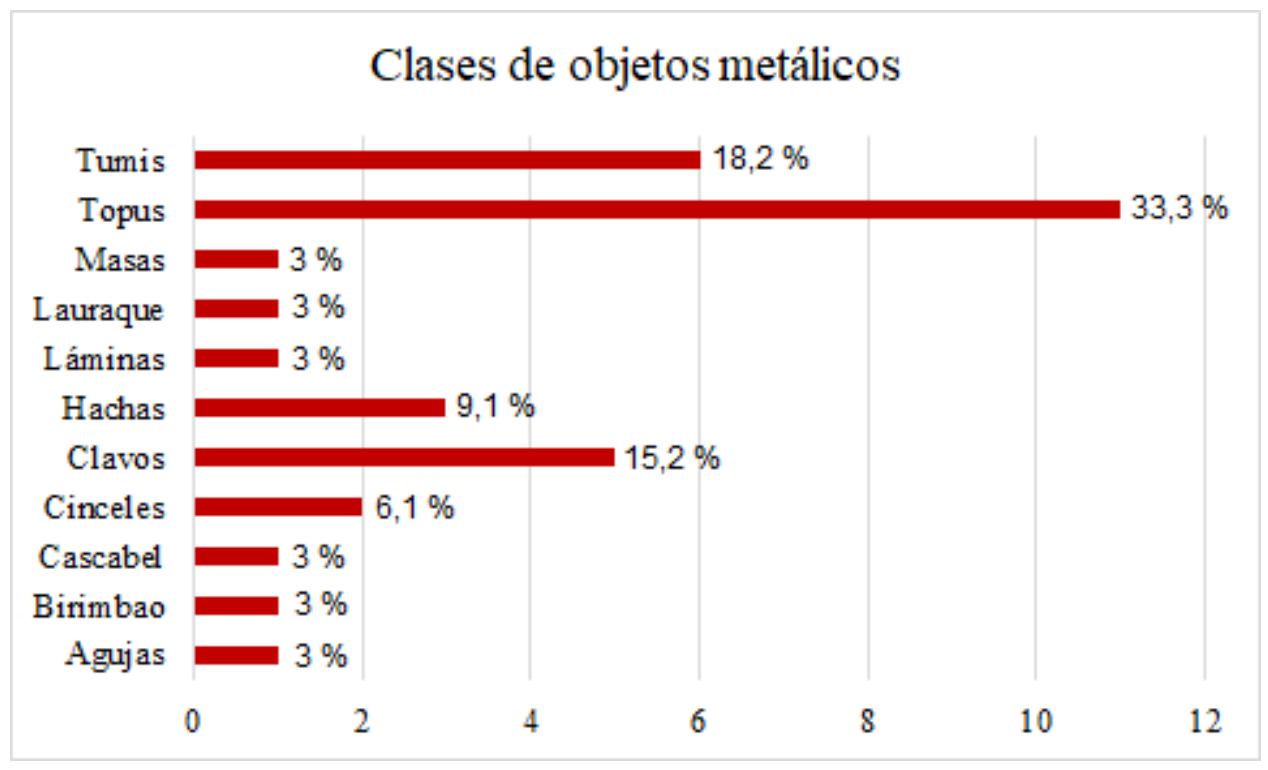

Figura 7.14. Frecuencia numérica y porcentual por cada categoría de objetos metálicos.

Respecto a las prácticas de manufactura de las piezas, los procedimientos y técnicas de trabajo del metal inferido para cada tipo morfológico se sistematizan en la Tabla 7.15. Al considerar la totalidad de los objetos analizados, se observa que priman las modalidades de trabajo orfebre basadas en el proceso de fundición. En algunos casos, fue utilizado como único procedimiento al conformar las piezas por la técnica de moldeado (33,4\%), mientras que, en la mayoría de los ejemplares esta técnica fue combinada con instancias intermedias de deformación plástica $(39,4 \%)$. Dicho proceso fue utilizado secundariamente para dar forma final a algún segmento concreto de la pieza. En menor frecuencia, se identificaron objetos realizados sólo por mecanismos de deformación plástica (9\%). Si bien, con la información disponible no es posible conocer si las piezas inkas fueron importadas desde Cusco o manufacturadas localmente, de ser esto último, su fabricación habría seguido la experticia de los metalurgistas locales dado que los registros de sitios de la provincia de Catamarca dan cuenta de una amplia trayectoria histórica en el trabajo del metal por técnicas de moldeado (González 2002, 2004b, 2010). 


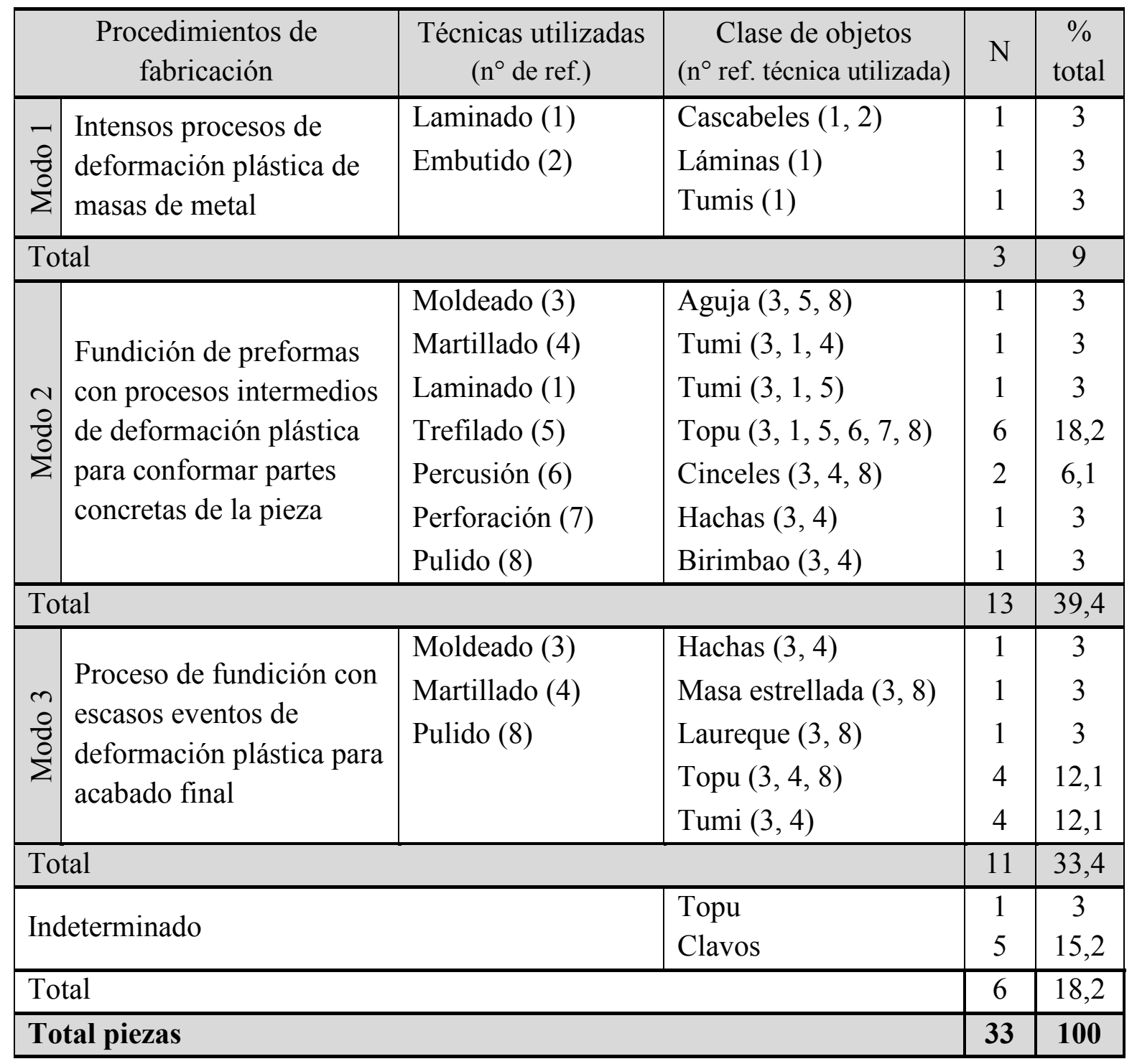

Tabla 7.15. Procesos de manufactura inferidos para cada clase de objetos.

Por otro lado, al puntualizar en las piezas de una misma clase, se observa que se combinaron y aplicaron técnicas distintas con el fin de dar forma a cada una de las partes que constituyen los objetos. Esto se observó en los tupu, los tumi y las hachas. Dan cuenta así del amplio abanico de posibilidades disponibles y de las elecciones técnicas realizadas por los artesanos a la hora de fabricar los objetos. En este sentido, es posible que la elección de la técnica con la que fue realizada cada parte de la pieza, esté relacionada con las cualidades físicas y formales buscadas por los artesanos. A modo de ejemplo, en las piezas tipo tumi se observó que, para manufacturar ejemplares con mango de sección cuadrangular 
se implementaron técnicas de martillado o bien fueron formatizados utilizando los ángulos rectos de las cavidades del molde. Mientras que, en tumi con mangos de sección circular, se utilizó la técnica de trefilado que redondeó y alargó el material por fricción contra otra superficie. En lo que respecta a las hojas, fueron realizados por la técnica de laminado que posibilitó estirar el material para dar forma plana al segmento y lograr espesores homogéneos.

En cuanto a las propiedades físicas de las piezas, los segmentos activos de tumi, hachas y cinceles, presentan rastros de haber sido trabajados por martillado. Este proceso de deformación plástica es un tratamiento que produce un aumento en la dureza del metal y por lo tanto mejora su resistencia (Scott 1991; Lindenvald 2007). Dichos efectos han sido demostrados para los tipos morfológicos previamente nombrados gracias a la combinación de estudios metalográficos y de dureza (Trucco 1965; González et al. 1998-1999). Como resultado, las cualidades mecánicas logradas podrían haber sido ventajosas para aquellos bienes que fueran a ser utilizados para modificar otros materiales, a juzgar por las huellas de uso que pudieron observarse en algunos de los ejemplares.

No obstante, conviene subrayar, que la deformación plástica genera al mismo tiempo una reducción de la tenacidad, es decir, de la resistencia a la rotura frente a esfuerzos físicos, que podría haber contribuido a una vida útil relativamente corta. En este sentido, las abolladuras, desgastes y dentados en filos pueden haber sido generados por una excesiva presión sobre materiales con mayor dureza, como ha sugerido Gluzman (2008) para el caso de los cinceles.

En resumen, los análisis realizados permitieron conocer la variabilidad de prácticas de manufactura de piezas metálicas. Las múltiples combinaciones de procedimientos y técnicas del trabajo del metal pueden haber respondido tanto a criterios estilísticos como funcionales. Estos datos, sumado al reducido número de piezas relevadas para cada categoría de piezas no permite, por el momento, sostener una estandarización en las prácticas manufactureras. Para ello será necesario continuar el análisis incrementando la cantidad de piezas para cada tipo morfológico y contrastar hacia el interior de cada clase, ejemplares cuyas partes constitutivas presenten cualidades formales similares. 
Por otro lado, la presencia de los clásicos bienes metálicos inkas en las provincias sureñas del estado, respondería a lógicas de visibilización y ostentación de aquellos bienes que remiten a una ideología Inka y que posibilitaría legitimar su poder. En este sentido, las piezas que provienen de excavaciones sistemáticas demuestran que los metales circularon por espacios y contextos sociales sacralizados por el Inka y fueron bienes ofrendados en distintos ritos y prácticas ceremoniales que denotan el poder sagrado de los metales. La producción metalúrgica, en todas sus etapas operativas, implica entramar distintos tipos de saberes y conocimientos técnicos especializados, tanto aquellos relativos a la transformación del metal como los que posibilitan establecer vínculos con las entidades sagradas para el buen curso de las actividades (Lechtman 1978, 1999; González 2004a, 2010). Así, los objetos metálicos resultantes de dichas operaciones, se transforman en bienes suntuarios al materializar mensajes sagrados, es decir, aquellos que los objetos en sí mismo portan y significan (Miller 2005), dado que los metales se vinculan inexorablemente a las fuerzas sobrenaturales desde el mismo momento de su fabricación. Como se ha remarcado, en el Shincal de Quimivil, sólo se han identificado depósitos intencionales de piezas metálicas en el ushnu y probablemente en las tumbas, dotando y reforzando el poder político de los actores que oficiaban los ritos sagrados y que tenían la jerarquía social para manipular bienes suntuarios. 


\section{CAPÍTULO 8}

\section{CONCLUSIONES GENERALES}

A lo largo de esta investigación se desarrolló un estudio sistemático del sitio arqueológico Quillay. Esto permitió caracterizar la tecnología de producción metalúrgica local e interpretarlas en el marco de lógicas organizativas y socio-políticas promovidas por el estado Inka. Conjugar múltiples líneas de evidencias y abordajes metodológicos fue la base para alcanzar los objetivos específicos delineados inicialmente para esta tesis. Así, en los sucesivos capítulos se presentaron y discutieron los resultados obtenidos de los análisis efectuados sobre las estructuras arquitectónicas y productivas del sitio, las cerámicas tradicionales y las refractarias, los materiales líticos, los restos botánicos y faunísticos de índole comestibles, estructuras de combustión y desechos metalúrgicos, entre otros.

Este capítulo final será estructurado en dos partes relacionados con los objetivos específicos delineados en esta investigación. La primera, circunscribe las reflexiones a nivel del sitio e integra los resultados parciales obtenidos con el fin de reconstruir las dinámicas, actores y prácticas sociales referidas a la producción artesanal y a la vida cotidiana en Quillay (objetivos específicos 1, 2 y 3). En la segunda parte, ya desde una perspectiva suprarregional se propondrá una interpretación respecto a la inserción del sitio dentro de la geopolítica Inka y las dinámicas de articulación social entre el Estado y los pueblos locales a partir de la producción metalúrgica y los bienes manufacturados (objetivos específicos 4, 5 y 6).

\subsection{Quillay, un taller de extracción metalúrgica en el valle de Hualfín (Catamarca)}

El estudio realizado permite proponer al sitio arqueológico Quillay como un taller especializado en la metalurgia extractiva de cobre que funcionó durante el período Inka con una producción a gran escala. La presencia de decenas de hornos de fundición lo posiciona como el núcleo productivo inkaico de mayores dimensiones en todo el NOA, siendo secundado por la Encrucijada en el valle Calchaquí Norte. Esto parece confirmar la propuesta realizada por numerosos investigadores que sitúa la búsqueda de recursos minero-metalúrgicos como una de las principales motivaciones de expansión territorial de los Inkas hacia esta región (González 1980; Raffino 1990, 2007). 
Desde una perspectiva antropológica sobre la tecnología (Lechtman 1977; Lemonnier 1992; Dobres y Hoffman 1999) entendemos a la metalurgia como un fenómeno socio-cultural de carácter holístico e integrador (Shimada et al. 2007). Por lo tanto, esta investigación indagó, utilizando varias metodologías, sobre los recursos materiales, los implementos o herramientas, los procedimientos técnicos de fabricación y las identidades de los actores sociales que intervinieron en las prácticas de producción metalúrgica acontecidas en el sitio. Asimismo, esta información permite reflexionar sobre las particulares dinámicas que adquirieron la gestión de recursos y la organización del trabajo, así como las relaciones entre los grupos sociales de acuerdo con el contexto sociopolítico regional y el sistema cultural.

En los capítulos 5, 6 y 7 se presentaron un conjunto de evidencias que permiten reconstruir las actividades artesanales específicas desarrolladas en el sitio. En este sentido, los resultados obtenidos indican que Quillay fue un taller metalúrgico donde se realizaron tareas de molienda secundaria, fundición primaria de minerales y refinación de metales, es decir, operaciones técnicas correspondientes a la tercera etapa de la cadena productiva descritas en el capítulo 2 (Figura 8.1). Áreas específicas con instrumentos para la molienda con vestigios de polvo mineral; amplios sectores que nuclean decenas de hornos metalúrgicos con escorias de fundición, así como la presencia de materiales refractarios con adherencias metálicas, dan cuenta de la puesta en práctica de estas operaciones técnicas.

La conspicua presencia de más de una treintena de hornos junto a los análisis de los residuos metalúrgicos sugiere que las actividades artesanales en el sitio se focalizaron en la reducción de minerales de cobre. Las menas procesadas fueron sulfuros, óxidos y carbonatos de cobre, como la bornita y la azurita. Teniendo en cuenta la información mineralógica de la región, es posible que estas menas hayan sido transportadas desde fuentes de aprovisionamiento localizadas en los yacimientos cupríferos de Capillitas, a una distancia aproximada de $40 \mathrm{~km}$ del sitio.

Por otro lado, ya se ha comentado que la lista de insumos indispensables para desarrollar el proceso metalúrgico contempla no sólo recursos minerales sino también otros materiales que actúan como fundentes y elementos combustibles. Entre los primeros, a partir de los análisis de las escorias se ha propuesto que se utilizó como fundente un material rico en cuarzo. Por lo tanto, durante las operaciones de reducción, 
es posible que los metalurgistas hayan agregado arena rica en este material o cuarzo molido, ampliamente disponibles en los cursos de agua cercanos, como también aprovechado las propias impurezas de la mena para favorecer la separación de la ganga. Con respecto a los combustibles, se utilizaron maderas de buena calidad para la combustión como el Prosopis sp., la Bulnesia sp. y el Parkinsonia sp. Los recursos forestales se encontraban disponibles a nivel intrasitio, dado que allí se emplaza un bosque de algarrobales que crece ampliamente a la vera del río Hualfín.

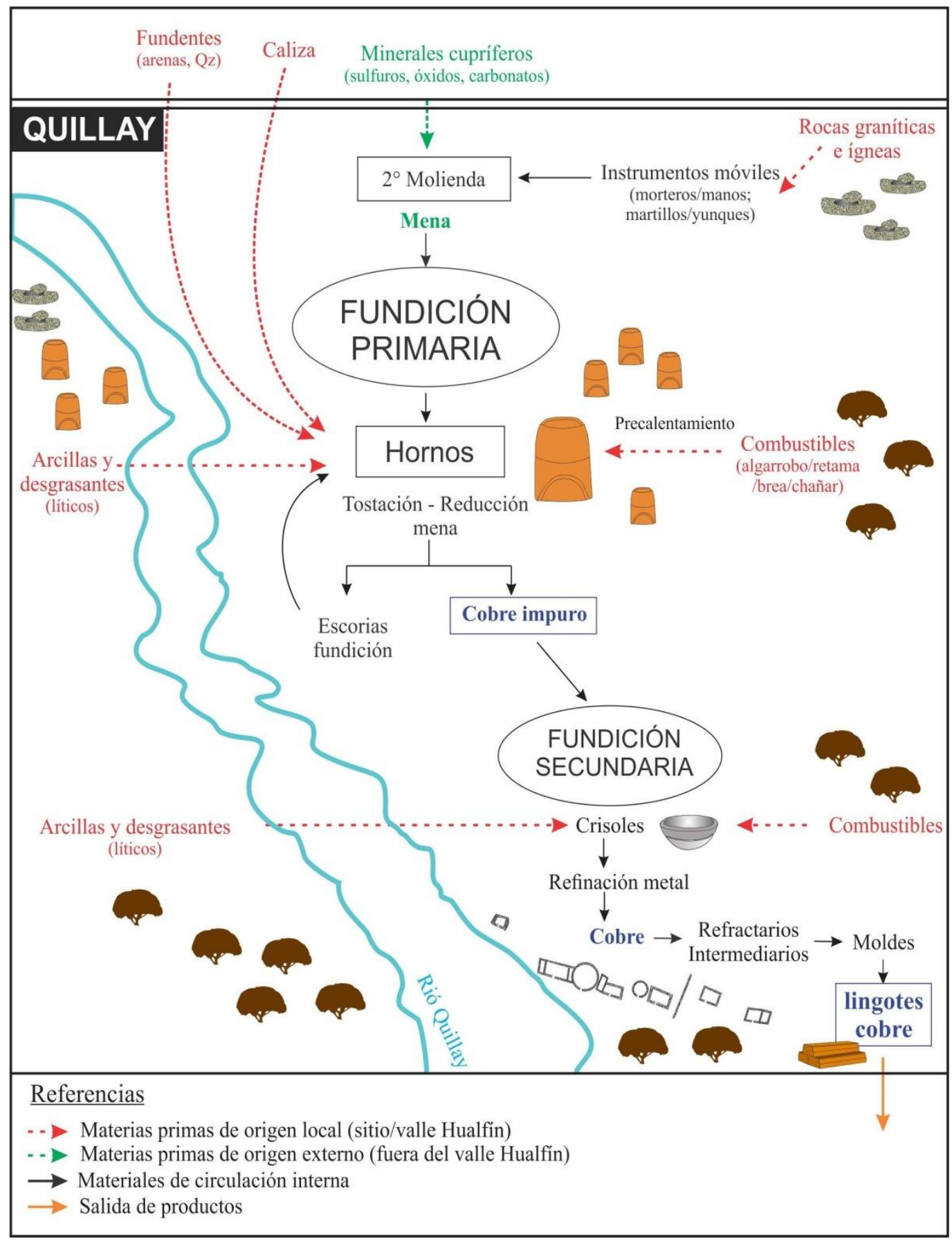

Figura 8.1. Cadena de operaciones técnicas y flujo de materiales en el sitio Quillay 
Para resumir, a partir de la integración de los resultados parciales obtenidos a lo largo de este trabajo, se propone que las actividades desarrolladas en este taller se especializaron en la metalurgia extractiva de metal de cobre. Tanto los vestigios minerales de carbonatos de cobre identificados en los instrumentos de molienda (capítulo 4), las inclusiones de sulfuros y óxidos de cobre registradas en las escorias de fundición (capítulo 6) y la presencia de cobre metálico adheridos a los materiales refractarios (capítulo 5) permiten afirmar que, en este taller, las prácticas metalúrgicas estuvieron orientadas a la obtención de este metal. Como se muestra en la figura 8.1 dentro de la cadena de producción metalúrgica, en Quillay se desarrollaron de manera secuencial las siguientes operaciones técnicas:

\section{Operación 1: Molienda secundaria}

La trituración principal de los minerales cupríferos debió realizarse por fuera del sitio, posiblemente en los mismos lugares donde fuera extraído. Luego, las evidencias señalan que en Quillay se habría realizado una molienda secundaria de la mena para reducir aún más su tamaño, lo cual favorece las posteriores reacciones físicas y químicas de reducción. Estas actividades se realizaron, al menos, en dos áreas cercanas a los conjuntos de hornos $\mathrm{n}^{\circ} 1$ y 2 , que se localizan hacia el norte y al sur del río Quillay respectivamente. Allí, se agrupan varios instrumentos móviles que servirían para el tratamiento mecánico de la mena, como manos, morteros, martillos y yunques de rocas granitoideas e ígneas, con evidencias de procesamiento mineral.

\section{Operación 2: Fundición primaria}

Posteriormente, para efectuar las operaciones principales de fundición primaria de la mena para su reducción a metal, los artesanos utilizaron como instrumentos hornos metalúrgicos. Es importante destacar que el empleo de hornos con fines metalúrgicos en el NOA resulta ser una innovación tecnológica impulsada por los Inkas dado que, los registros arqueológicos a nivel regional, señalan que las comunidades locales solían fundir en crisoles calentados en estructuras de combustión abiertas (González 2004b; Zagorodny et al. 2015). Incluso, la utilización de hornos metalúrgicos fue una práctica común en los talleres artesanales identificados a lo largo de la extensión territorial del Tawantinsuyu, como puede notarse a partir de la información presentada en el capítulo 3. Sin embargo, los hornos de Quillay presentan un diseño único dentro de las estructuras de fundición conocidas hasta el momento para la región Andina. Por 
consiguiente, es posible sostener que la práctica de fundición en este taller adquirió una modalidad tecnológica distintiva.

Con relación a esta tecnología, a lo largo de los capítulos 5 y 6 se presentaron las características morfométricas de los hornos de Quillay. A modo de síntesis diremos que son complejas estructuras semicerradas y semienterradas construidas con materiales arcillosos. Presentan una forma cónica-tubular que alcanza los dos metros de altura y el metro de diámetro. Están compuestas de dos cámaras -superior e inferior- conectadas entre sí por conductos cilíndricos verticales y poseen además una antecámara en el segmento inferior del horno.

En el capítulo 6, se contrastó la estructura de los hornos hallados con la de otros ejemplares de la región andina identificando que, ciertos atributos morfológicos y características constructivas recuerdan a elecciones técnicas realizadas por diversos grupos sociales. En particular, se ha propuesto que los conductos de los hornos aquí estudiados, remiten a principios de circulación de gases que eran frecuentes en las tradiciones tecnológicas de las comunidades locales del altiplano boliviano. A partir de lo cual, se sugiere que estos saberes y su aplicación práctica podrían haber sido apropiadas por los artesanos de Quillay por influencia de los Inkas.

Por otro lado, si bien no existen evidencias de utilización de hornos metalúrgicos en las tradiciones tecnológicas locales que permitieran trazar continuidades $o$ transformaciones en las prácticas de fundición, es posible establecer vinculaciones en términos de aplicación de "saberes técnicos" involucrados en otras tecnofacturas. En particular, nos referimos a las modalidades de construcción de los hornos y a las formas de trabajar los materiales. Este procedimiento involucró la preparación de arcillas con agregados de inclusiones líticas de tamaño arena; el uso de la técnica constructiva basada en panes de arcilla superpuestos que fueron modelados bajo el principio de cámara. Estas "formas de trabajar" los materiales arcillosos y construir estructuras semicerradas con el fin de obtener un mayor control del fuego, de las temperaturas y de las atmósferas, son prácticas ampliamente utilizadas en las tecnologías alfareras de regiones cercanas (ver i.e. Feely 2011; De La Fuente y Vera 2013).

En este sentido, siguiendo las propuestas de Hagstrum (1992) la alfarería y la metalurgia pueden ser consideradas "tecnologías intersectadas", ya que los conocimientos y recursos técnicos adquiridos en un campo tecnológico se comparten y 
utilizan para otros fines. Es decir, los artesanos disponían de conocimientos específicos a sus prácticas alfareras como el "saber hacer" pastas cerámicas, estructuras de combustión, fuegos controlados, atmósferas oxidantes y/o reductoras, así como objetos en materiales arcillosos. Todos ellos son saberes latentes que formaron parte de la memoria social de estos grupos y que habrían sido puestos en práctica en el campo de la tecnología metalúrgica. Tal como sostiene Lemonnier (1992: 6) "las tecnologías en una sociedad pueden estar relacionadas debido a que comparten los mismos actores, los mismos lugares, los mismos artefactos, los mismos materiales, las mismas secuencias de gestos, o los mismos procesos tecnológicos".

Respecto a los actores que pusieron en ejecución estos saberes técnicos, el predominio de cerámicas de estilo Belén en el sitio nos lleva a proponer que tanto la construcción de los hornos como su uso estuvieron en manos de los artesanos locales del valle. Por lo tanto, dada las características previamente comentadas, proponemos que las elecciones tecnológicas referidas a la producción metalúrgica en Quillay conllevaron la conjugación de saberes locales preexistentes con las ideas que comenzaron a circular desde la llegada de los inkas a la región, como ser la práctica de fundición en hornos y los principios de conducción de gases. Así, siguiendo la perspectiva antropológica sobre la tecnología (Lemonnier 1992; Lechtman 1977), en el marco de la conquista Inka y de las nuevas posibilidades disponibles, los artesanos de Quillay habrían realizado elecciones técnicas que implicaron resignificar y transformar sus propios saberes tradicionales, aunque siempre sobre esta base, al mismo tiempo que se apropiaron de los nuevos, posiblemente como producto de la relación sociopolítica que mantenían con los agentes estatales. Estas decisiones y elecciones se habrían traducido en innovadoras prácticas metalúrgicas, como lo fue la tecnología de fundición puesta en marcha en Quillay.

Con respecto al funcionamiento de los hornos de Quillay, en el capítulo 6 se propusieron algunas hipótesis referidas a este tema. Allí, se sugirió que la cámara superior estaría involucrada en las operaciones de carga del mineral y fundentes y en las reacciones químicas y físicas que conllevan la fundición propiamente dicha. Los conductos que comunican las dos cámaras cumplirían roles de ventilación y drenaje. De esta manera, habrían contribuido al tiraje del calor y de gases en sentido ascendente y en sentido inverso, habrían conducido el flujo del material fundido. Por otro lado, la 
cámara inferior habría funcionado como espacio para la combustión y para el vaciado del horno.

El proceso de fundición comenzaría con la carga de mineral triturado por la cámara superior. En cuanto al procedimiento de fundición, es posible que como primera instancia se efectuaran tareas de preparación de áreas de drenaje mediante la construcción de un montículo de caliza en la cámara inferior. Luego, por la antecámara se iría introduciendo la leña para generar el calentamiento paulatino del horno. Se ha propuesto, que los gases calientes, que ascenderían por los conductos desde la cámara inferior del horno, podrían haber contribuido al proceso inicial de tostación de los sulfuros de cobre para la posterior reducción. Luego, se irían agregando los fundentes que facilitan la separación del metal de las impurezas. Finalmente, por la cámara inferior se recuperaría el metal obtenido y las escorias metalúrgicas que requerirían una refundición posterior.

Los diversos análisis realizados en los materiales de desechos y paredes de hornos (ver capítulo 6) permiten sostener que en los hornos se redujeron minerales de cobre a temperaturas elevadas que alcanzaron entre 1100 y $1300^{\circ} \mathrm{C}$. Sin embargo, como se discutió en dicho capítulo, es necesario realizar nuevos análisis para poder evaluar la eficacia de este procedimiento. Por último, es importante remarcar que, en el mundo andino, el resultado alcanzado por estas operaciones no sólo radica en los conocimientos y en la experticia de los artesanos para efectuar una técnica, sino también en los saberes y prácticas ceremoniales (Lechtman 1979; González 2002, 2004a). Así lo estrictamente operativo no se encontraba escindido de lo espiritual, sino que debieron conjugarse simultáneamente para alcanzar el éxito de los procedimientos metalúrgicos. En este sentido, la presencia de un textil en este contexto productivo, cuyas cualidades formales lo vinculan a prácticas rituales relacionadas con las entidades no humanas, puede ser tomado como una referencia a este tipo de prácticas en Quillay, exhibiendo que las actividades técnicas y ceremoniales estuvieron entramadas simbólicamente en la dinámica de producción metalúrgica.

\section{Operación 3: fundición secundaria}

Finalmente, la última operación técnica realizada en el taller fue la refundición para refinar el metal obtenido en los hornos. Este proceso posiblemente haya sido realizado en el sector de recintos dado que en sus inmediaciones se registraron un 
conjunto de evidencias que nos orientan en este sentido (ver capítulo 5). Entre ellas se destacan: la presencia de crisoles con adherencias de metal de cobre, sectores abiertos con superficies rojizas termoalteradas y un único horno unicameral con restos de carbones. Por otro lado, la ausencia de otros elementos metálicos -como Sn, As, Au o Ag- en las composiciones químicas de las adherencias en refractarios sugiere que, en estos cuencos se habrían realizado nuevas instancias de fundición de cobre para su refinación, antes que tareas de aleación.

Por otro lado, las adherencias metálicas identificadas en los refractarios intermediarios - tapones y cucharas- que suelen utilizarse para el vaciado del metal en los moldes, sumado al fragmento de lingotera y a la lámina de cobre, conducen a proponer que con el metal refinado se conformaron reservas de masas metálicas para un trabajo posterior. Sin embargo, la ausencia de evidencias arqueológicas que remitan a actividades del trabajo del metal en el sitio, sugiere que las reservas de cobre obtenidas fueron trasladadas a otros talleres para la manufactura de objetos conforme a los principios organizativos de la economía socio-política del Tawantinsuyu, como será retomado más adelante.

Con respecto a los implementos utilizados para la operación de refinación, se observó que los materiales refractarios reproducen saberes y prácticas técnicas tradicionales de las comunidades locales. Como se analizó en el capítulo 5, los "modos de hacer" los implementos refractarios en lo relativo a: morfologías, formas de sujeción, tratamientos de pastas cerámicas y recubrimientos superficiales con hueso molido, responden todas ellas a elecciones técnicas habituales entre los artesanos de los pueblos locales. Con respecto a los insumos necesarios para su fabricación, como materiales arcillosos y los antiplásticos líticos, son recursos que se hallaban disponibles a nivel local. En este sentido, se habrían mantenido, al menos en las actividades de refinación, las prácticas locales de fusión de metal en crisoles calentados sobre un fuego controlado. Por otro lado, si bien aún resta avanzar en las excavaciones para reconstruir contextos y la forma en que fue realizada la refinación, a modo de conjetura proponemos que el horno $\mathrm{n}^{\circ} 33$-localizado en el sector de recintos- podría haber sido utilizado para controlar el fuego y las atmósferas durante este procedimiento técnico. 


\subsubsection{La organización de la producción metalúrgica}

Para el desarrollo de los procesos productivos en Quillay, los Inkas y sus delegados estatales debieron gestionar, por un lado, una serie de materiales percibidos como recursos y por el otro, la mano de obra con habilidades para este tipo de tecnofactura. Con respecto a los primeros, ya se ha comentado las clases y el tipo de materias primas que se utilizaron en el proceso de fundición en este taller. La distribución geográfica de las posibles fuentes de aprovisionamiento de materias primas, sugiere que existieron circuitos de abastecimiento y redes de transporte tanto de orden interno como externo, que confluyeron en el taller para dar curso a las actividades metalúrgicas. En este sentido, el tipo de combustible empleado y los materiales líticos con que fueron fabricados los instrumentos de molienda, son recursos que se hallan disponibles en las inmediaciones del sitio. En cambio, las fuentes de los materiales arcillosos empleados para la construcción de los hornos, del carbonato de calcio y de materiales fundentes están disponibles en un radio menor a $20 \mathrm{~km}$. Por último, los recursos minerales debieron ser obtenidos de los yacimientos cupríferos ubicados por fuera de los límites del valle.

Dentro de este esquema de loci de abastecimiento y redes de transporte de materias primas, es de gran importancia identificar las potenciales fuentes madereras. Esto se debe a que estudios experimentales del proceso de fundición han demostrado que el consumo de combustible supera ampliamente la cantidad de mena utilizada (González 2004b). Por lo tanto, es lógico pensar que los sitios de fundición se localicen próximos a recursos forestales, aunque esto implique relegar la cercanía a yacimientos mineros, como ya ha sido sugerido por varios investigadores para sitios productivos de otras regiones (Lechtman 1976, Shimada et al. 1982, González 2002). Por lo tanto, dentro del esquema de circulación de materiales, se puede sostener que la localización de Quillay es estratégica, al estar situado en las inmediaciones de un bosque de maderas óptimas para la combustión. Esta situación da cuenta de una gran eficiencia del Estado para la gestión de recursos a diferentes escalas.

Otro factor a considerar es la gestión y organización de la mano de obra del taller. Las evidencias materiales señalan que los operarios metalúrgicos habrían sido artesanos del valle originarios de los asentamientos Belén de los alrededores del sitio y no mitmakunas trasladados desde regiones distantes. El asentamiento local Campo de 
Carrizal (Zagorodny et al. 2015) aporta información sobre prácticas metalúrgicas locales de carácter doméstico que señalan la existencia de saberes técnicos para el procesamiento de minerales sulfurados y el uso de implementos refractarios afines a los identificados en Quillay. En este sentido, es posible que, en épocas específicas del año ciertos miembros de las comunidades locales con habilidades artesanales concurrieran al sitio para trabajar en las operaciones metalúrgicas como forma de tributar al estado. Durante estas jornadas laborales, es probable que los operarios vivieran en los recintos y se dedicaran exclusivamente a la producción de metal durante el tiempo que durara la prestación de sus servicios.

En Quillay, no se han encontrado evidencias que sugieran la producción simultánea de otros bienes artesanales, ni actividades que indiquen la producción de recursos con fines alimenticios, tales como estructuras para la agricultura o cría de animales. No obstante, en el sector habitacional del sitio se registra una única área de actividad doméstica comunal para la preparación y cocción de alimentos, posiblemente destinadas al mantenimiento de los artesanos residentes en el taller. Entre las prácticas culinarias manifestadas en el taller, predominó el uso de recursos silvestres provenientes, principalmente, de la recolección de algarroba y de la caza de animales pequeños, complementada con productos domesticados de maíz, zapallo, poroto y carne de camélido. Al menos éstos últimos, debieron ser provisionados desde fuentes externas a la unidad del taller aprovechando la estructura socio-económica de la región.

La supremacía del fruto de algarrobo en el repertorio dietario de las poblaciones del NOA ha sido ampliamente documentada tanto para contextos domésticos como ceremoniales desde épocas muy tempranas (Giovannetti et al. 2008). Al parecer, su relevancia dietaria no sólo redundaría en la producción de bebidas alcohólicas sino fundamentalmente en su consumo como alimento (Williams 1994). Incluso, durante el Tawantinsuyu, en el valle Hualfín y sus inmediaciones, los recursos silvestres continuaron siendo de suma importancia en las comidas de las comunidades locales anexadas al Estado, tanto en lo que refiere al consumo cotidiano durante la mit'a, como en las bebidas ofrecidas en las festividades auspiciadas por el Estado (Giovannetti 2015a). Los vestigios alimenticios en el taller de Quillay materializan los hábitos culinarios de las comunidades Belén, cuya continuidad en contextos estatales es significativa a la hora de interpretar las relaciones de poder entre los grupos sociales, al 
ser la comida, tal como sostiene Bray (2003), un medio básico y fundamental de la interacción social humana.

\subsection{La actividad metalúrgica en la dinámica sociopolítica del estado Inka}

Durante la expansión Inka hacia el NOA, el estado modificó el paisaje sociopolítico instalando numerosos asentamientos estatales en espacios libres o bien transformando aquellos poblados tardíos que fueron incorporados al Tawantinsuyu (Raffino 1978; Williams 2000, 2010; González y Tarrago 2005). En lo que refiere específicamente a la producción metalúrgica, los Inkas crearon algunos talleres especializados como Quillay y La Encrucijada, y en aquellas comunidades locales con arraigadas prácticas metalúrgicas, introdujeron algunas modificaciones en la producción que no alteraron sustancialmente sus prácticas tecnológicas (Angiorama 2004; González 2010). Las transformaciones impulsadas por el Estado en el NOA, se dieron principalmente en la tecnología de fundición utilizada, en el tipo de bienes manufacturados y en la forma de organizar la producción que respondieron a las lógicas e intereses estatales. Como ya se ha dicho, los Inkas promovieron el empleo de hornos metalúrgicos que facilitó el aumento en la escala de producción y, por otro lado, la fabricación de objetos de morfotipos inkaicos.

Con respecto a la organización de la producción metalúrgica, es interesante señalar que las investigaciones en el NOA muestran que durante la ocupación Inka, la especialización artesanal y la separación territorial de las distintas etapas de la cadena de producción metalúrgica fue la regla más que la excepción (ver capítulo 3). Es decir, los distintos talleres artesanales se especializaron en algunas de las tareas involucradas dentro del proceso productivo como ser: la minería y la molienda; la fundición y la refinación (sitios como Quillay, La Encrucijada y Rincón Chico) o bien, en la fusión y aleación de metales y la posterior manufactura de piezas (sitios como Potrero Chaquiago, Rincón Chico, Potrero de Payogasta, Los Amarillos y Tilcara).

Esto implicó necesariamente la articulación de los asentamientos que estaban dispersos a través del espacio geopolítico Inka, los cuales fueron entramados mediante caminos, tambos y centros administrativos. A partir de ellos, habría sido posible controlar y gestionar el abastecimiento de materias primas, el movimiento de productos intermedios y de bienes manufacturados, así como de mano de obra especializada (Costin 1996). De la misma manera que plantea Murra (1999 [1978]) para la economía 
de subsistencia, siguiendo lógicas andinas de complementariedad y reciprocidad, los Inkas habrían logrado mantener el control y administrar la producción de bienes metálicos a lo largo del Qollasuyu.

Teniendo en cuenta este esquema socio-político y económico, el asentamiento de Quillay, al ser un taller especializado en la extracción de metal de cobre, debió entrar en vinculación con numerosos poblados y actores sociales que formaron parte del complejo tejido social del Tawantinsuyu. A escala local, a través de la producción metalúrgica, Quillay articuló con las poblaciones de las comunidades Belén (p.e. Campo de Carrizal, Loma de los Antiguos, Cerro y Cerrito Colorado, El Molino) y con los centros administrativos inkaicos del mismo valle como Hualfín Inka y El Shincal. A nivel suprarregional, es posible que este taller estuviera vinculado con otros poblados que materializan actividades complementarias dentro de la cadena de producción metalúrgica o bien directamente con la capital del estado.

Con respecto al primer punto, es indiscutible que las comunidades locales jugaron un papel central en las actividades productivas del sitio según lo expresan las diversas materialidades identificadas. Los artesanos habrían tributado al Estado mediante la prestación de su fuerza laboral para la extracción de metal bruto (mit'a). Dado que la producción estuvo modelada por las relaciones socio-políticas imperantes entre ambas partes, consideramos que las decisiones y elecciones técnicas realizadas por los artesanos Belén estarían demostrando el sistema de negociaciones políticas dentro de las nuevas dinámicas y estructuras de poder (Pfaffenberger 1992; Dobres y Hoffman 1999). Tal como sostiene Dobres (1999: 129) mediante las prácticas tecnológicas "los agentes construyen identidades sociales y forjan relaciones de poder mientras producen y usan objetos utilitarios con fines prácticos”. De ahí que nos preguntamos ¿cuál sería el tipo de interacción social entre los grupos Belén y el Estado reflejada a partir de la tecnología de Quillay?

$\mathrm{Al}$ respecto, diremos que el registro arqueológico del sitio expone, por un lado, un contexto social donde se continuaron desarrollando ciertas prácticas locales manifestadas en:

- las elecciones técnicas relativas a la tecnología refractaria,

- los patrones decorativos de la cerámica local usada en todos los contextos,

- la técnica constructiva de las estructuras arquitectónicas residenciales, 
- las prácticas culinarias.

Por el otro, se observa una marcada influencia Inka en la dinámica social a partir de:

- la tecnología de fundición utilizando hornos metalúrgicos,

- la especialización artesanal del taller,

- la producción metalúrgica a gran escala,

- el abastecimiento externo de minerales y la salida de los productos metálicos obtenidos,

- la presencia de cerámica Inka,

- la disposición de las estructuras en el patrón de asentamiento.

De esta manera, podríamos decir que la coexistencia de elecciones y prácticas tecnológicas locales e inkaicas estaría señalando una interacción social flexible en el marco del sistema de producción metalúrgico. Incluso, como se ha desarrollado anteriormente, los hornos de fundición materializan innovaciones tecnológicas que son producto de la conjunción de ideas y saberes locales, pero también externos, que pueden estar expresando la alianza entre ambas partes. Esta hibridación puede ser considerada una estrategia política de integración social. Así, en este taller no estamos frente a un contexto socio-productivo donde se impuso forzosamente una tecnología originaria de un contexto externo, como podría ser el uso de la clásica wayra andina, que evidenciaría una fuerte política de aculturación estatal y asimilación pasiva por parte de las poblaciones locales anexadas. Por el contrario, las características distintivas que adquirieron las prácticas de fundición materializan un novedoso estilo tecnológico que cristaliza un mecanismo de integración donde, posiblemente, primaron las acciones de negociación y cooperación entre los grupos Belén y los Inkas. Por consiguiente, proponemos que los artesanos locales habrían alcanzado un cierto grado de libertad para realizar innovaciones en la tecnología de fundición y para mantener sus propias prácticas sociales y enseres cotidianos aún bajo lógicas y un sistema estatal de producción y organización del trabajo, así como de control de los bienes metálicos generados. Pero ¿cuáles serían los beneficios alcanzados por estos grupos para cooperar con el nuevo orden estatal? 
Teniendo en cuenta que toda acción social está condicionada por el contexto en el que tiene lugar, es necesario situarlas dentro de las dinámicas sociopolíticas locales al momento de la llegada de los Inkas. En el valle de Hualfín, las comunidades Belén habitaban sitios de vivienda localizados en ambientes topográficos diversos - tanto en el piedemonte como en zonas bajas y elevadas-, algunos de ellos con características defensivas y mantenían un modo de vida agropastoril, cuyos campos de cultivo y obras hidráulicas se distribuían por todo el valle (Balesta et al. 2011). Se ha propuesto que entre los distintos grupos Belén existirían tensiones y conflictos permanentes por mantener el control de cada territorio y lograr un mejor acceso a los recursos (Wynveldt y Balesta 2009; Balesta et al. 2011). En este contexto de fragmentación política y competición por liderazgos, es posible que algunos de estos grupos hayan encontrado en la alianza con los Inkas una estrategia política para alcanzar legitimidad y protección en el marco de una compleja estructura estatal, actuando los líderes locales como intermediarios entre ambas partes. Este rol habría implicado una doble función: por un lado, los curacas debían representar a su comunidad y mantener los tradicionales vínculos sociales y por el otro, se transformaron en agentes estatales responsables de tributar al estado bajo el sistema de mit'a, reconociendo así la autoridad de los Inkas (Rostworowski 1999; Sternfeld 2007). Además, como señala Rostworowski (1999) posiblemente fueron estas negociaciones las que permitieron que cada grupo social anexado mantuviera sus propias prácticas cotidianas. Al mismo tiempo, el Estado se beneficiaría no sólo por las rentas económicas obtenidas sino también al evitar poner en marcha su ejército militar para concretar la anexión de nuevos territorios y grupos étnicos.

Por otro lado, los registros etnohistóricos han documentado ampliamente que las alianzas realizadas entre las comunidades locales y los Inkas estaban regidas por el principio andino de reciprocidad. Según el mismo, las obligaciones de servicios adquiridas por los grupos anexados eran compensadas con regalos de bienes suntuarios hacia los líderes locales y con fiestas colectivas donde se ofrecían bebidas y comidas en abundancia (Murra 1999 [1978]; Rostworowski 1999). De ahí, que la presencia de vasijas de estilo Inka provincial en el taller de Quillay podría estar relacionado con las prácticas de reciprocidad a través de dones que formaron parte de la ideología y la política estatal. Estos bienes, habrían actuado como símbolos de alianza y legitimación que, al ser ofrecidos a los líderes locales, reforzaron sus posiciones de estatus al mismo 
tiempo que recordaban las obligaciones recíprocas a aquellos actores sociales encargados de controlar las actividades productivas del sitio.

De igual forma podría ser interpretada la parafernalia cerámica identificada en aquellas tumbas del valle de Hualfín que presentan ajuares con piezas de estilo inka junto a otras de estilos locales (Wynveldt 2009). Incluso los objetos metálicos de morfologías inkas provenientes de este valle, que fueron objeto de análisis en el capítulo 7, podrían estar reflejando dichas prácticas de reciprocidad estatal, siendo regalos suntuarios entregados a personas de elite como símbolos de alianzas y emblemas que otorgaron status y poder a sus portadores.

Otro punto de análisis, refiere a la articulación de Quillay con los otros asentamientos inkaicos del valle como Hualfín Inka y El Shincal, localizados hacia el norte y sur respectivamente. Ambos sitios presentan todas las características y cualidades arquitectónicas, así como elementos de la cultura material que han permitido clasificarlos como grandes centros ceremoniales y político-administrativos en el valle de Hualfín (Raffino 1981, 2004, 2007; Lynch 2013). Morris y Thompson han propuestos que "la creación de los centros administrativos tuvo como uno de sus fines confirmar las lealtades políticas y la colaboración económica necesaria" (1985 citado en Rostworowski 1991: 75). Por lo tanto, estos sitios podrían haber articulado con las actividades en Quillay, oficiando las fiestas rituales para celebrar los pactos y reafirmar las alianzas con los pueblos locales al mismo tiempo que se establecieron las formas, cantidades y fechas del tributo, entre otras actividades.

En este sentido, tanto El Shincal como Hualfín Inka exhiben un amplio y rico registro arqueológico que señala la congregación de personas de diferentes etnias y la realización de fiestas y rituales andinos con abundante bebida y comida. Entre ellos se destaca la presencia de grandes plazas o haukaypata para reunir personas, ushnu dónde los gobernantes solían presidir y oficiar rituales y también presentan decenas de depósitos o qollqas que permitieron almacenar productos de subsistencia y/o bienes suntuarios para ser ofrecidos como dones (Raffino 1981, 2004; Lynch 2013; Lynch et al. 2010). Además, El Shincal exhibe un contexto de producción masiva de bebidas fermentadas de chicha y aloja cristalizado arquitectónicamente en un amplia infraestructura de riego y de cultivo y numerosos morteros múltiples dispersos en los alrededores del sitio (Giovannetti 2015a); asimismo posee un sector específico donde 
fueron desechadas la amplia parafernalia cerámica inka utilizada para servir bebidas y comidas durante las fiestas andinas (Giovannetti et al. 2013); así como numerosos elementos simbólicos distribuidos en el radio del sitio que refieren a un paisaje sagrado fuertemente ritualizado (Giovannetti 2015b).

De esta manera, desde una perspectiva regional durante la ocupación Inka en el valle de Hualfín, los tres sitios inkas se habrían complementado funcionalmente y estarían conectados entre sí por un hipotético ramal del capacñam, según indican los estudios de Raffino et al. (1982). Así, tanto la celebración de pactos y alianzas políticas enmarcadas en congregaciones festivas, rituales y ceremonias sagradas que fueron empleadas como estrategia de control político; la distribución de los turnos de mit'a a cada población para el trabajo en Quillay, como la redistribución de los bienes metálicos podrían ser algunas de las tantas actividades realizadas en estos centros administrativos y ceremoniales. De ahí que la cercanía de Quillay a dos grandes núcleos estatales, sería fundamental para la fructífera organización de la producción metalúrgica, en especial, en lo concerniente a la distribución de los turnos mit'a, al abastecimiento de materias primas y a la captación de los productos de metal obtenidos en Quillay para su posterior traslado hacia otros talleres artesanales con el fin de manufacturar objetos, como podría ser el caso de Rincón Chico, Potrero Chaquiago, Tilcara o Los Amarillos (ver capítulo $3)$.

Teniendo en cuenta las redes de circulación de materiales y productos, hay al menos tres puntos interesantes a remarcar que contribuyen a establecer la relación entre los tres asentamientos inkaicos en el valle de Hualfín. En primer lugar, el sitio Hualfín Inka se vincula por su estrecha cercanía con los yacimientos cupríferos de Capillitas, en especial con la región donde se hallan las minas actuales de Farallón Negro y La Alumbrera (Raffino et al. 1982; Lynch 2013). En segundo lugar, desde ambos centros administrativos parten tramos del camino inkaico que los vinculan inter-regionalmente con otros asentamientos estatales. Dentro del entramado vial, los grandes centros administrativos de las distintas provincias habrían servido como nodos articuladores entre talleres distantes con evidencias de procesamiento metalúrgico a lo largo del Qollasuyu. Por ejemplo, desde Hualfín Inka hacia el noreste a través del capacñam se entra en contacto con el valle de Yocavil y a partir de allí el camino se vincula con el valle Calchaquí y por otro ramal con la puna catamarqueña. Por el sur, El Shincal 
articula hacia el sudoeste con el valle de Abaucán y luego vía la actual provincia de la Rioja se conecta con la región de Copiapó en Chile. En las palabras de Raffino:

"Las tres instalaciones se vinculan entre sí por medio de segmentos de la red vial Inka, integrados en un eje longitudinal con dirección Noreste Sudoeste. Los puntos de enlace más importantes son, por el Noreste La Punta de Balasto que, en el extremo Sur del valle de Santa María recibe el camino proveniente del valle Calchaquí: Hualfín, con la alternativa de que el camino pasara por el Ingenio del Arenal; luego Quillay, en el tramo medio del valle de Hualfín: sigue El Shincal, y de allí, por la Cuesta de Zapata (Tambillos de Zapata) a Watungasta. Desde este último sitio se continúa a Costa de Reyes, Tambería de Los Cazaderos (entrando en el actual territorio riojano) y Tambería del Inca en Chilecito, dejando a un costado la Pampa Real en la Sierra de Famatina, a la que se accedería por un ramal secundario. La instalación de Hualfín es, a la vez, con fluencia de por lo menos un ramal más, proveniente de la puna. Por su parte, Watungasta sirve como enlace de otros dos ramales; uno de los cuales comunica con la región trasandina de Copiapó, alternativamente a través de los pasos de San Francisco o del de Los Patos; mientras que el otro enlaza La Troya con las instalaciones Inka de Mishma y Ranchillos" (Raffino et al. 1982: 495)

En tercer lugar, existe un registro etnohistórico realizado a fines del siglo XVI por el gobernador de Tucumán Juan Ramírez de Velazco, quien relata una escena de transporte de lingotes en el valle para ser tributados al estado Inka, que fuera observado por Almagro casi un siglo antes:

"De estos Ingas de César he oído decir que eran los que estaban poblados en $\underline{\text { Londres, }}$ que cobraran en oro y plata los tributos y los mandaban al Inga del Cusco sacados de las minas de este Londres y que al tiempo que pasó el adelantado Almagro al reino de Chile, estos Ingas enviaban una parte del tributo a su señor el Inga en noventa andas, que llaman acá anganillas y cada anganilla llevaban en hombros veinte o treinta indios y para remuda y su guarda llevaban cuatro veces tantos indios. Que el oro lo llevaban en tejuelos marcados con la marca del Inga y cada tejuelo pesaba sesenta y dos pesos de oro. Y marchaban por el camino real Inga de cincuenta pies de ancho, labrado a mano y pasaba por el tambo del Toro.” (Citado por Montes 1959: 88-89, el subrayado es mío) 
Con respecto a este relato, es importante destacar que en la localidad de Londres se emplaza el sitio El Shincal, desde dónde podrían haber partido los lingotes por el capacñam con destino a Cusco o con mayor probabilidad hacia otros asentamientos del Tawantinsuyu. Por otro lado, la constante referencia al oro y a la plata por parte de los españoles podría estar enmascarando la diversidad de metales que circularon bajo el sistema económico inkaico. Esto puede deberse al conocido interés por las riquezas mineras que fue motor de las campañas de conquista europea en toda Sudamérica con el fin de capitalizar los metales preciosos previamente nombrados, considerados por aquellas épocas como los más valiosos desde los parámetros occidentales (Bakewell 1989).

En este marco, el relato de Velazco, puede ser interpretado como un recurso discursivo utilizado con la intención de reforzar en el imaginario social la posibilidad de hallar dicho tipo de bienes en un contexto de constantes conflictos armados con la población nativa. Incluso, como señaló Levillier "si bien la información referida a metales preciosos es escasa, también es continua y poco precisa y cuando aparece, sólo es para inducir a las autoridades de España a que se encomienden nuevas conquistas" (1955 citado por Gluzman 2007: 166). Por lo tanto, sin la intención de forzar el relato previamente citado, intentamos sugerir como posibilidad que producto de este contexto socio-político la existencia de lingotes de cobre haya sido invisibilizada. Sobre todo, al considerar los resultados obtenidos a lo largo de esta investigación relativo a la producción de cobre en el sitio Quillay, que serían posteriormente trasladado a otros asentamientos según los intereses del estado Inka.

Finalmente, los objetos metálicos confeccionados en otros talleres luego participarían dentro de dinámicas sociopolíticas vinculados a esferas sagradas, como fue analizado a partir de los hallazgos en El Shincal (capítulo 7). La presencia de las clásicas piezas metálicas inkaicas en el valle de Hualfín, como los tumis, topus y hachas, expresa la importancia de la circulación de distintos tipos de bienes estatales en los territorios más lejanos, como una estrategia política para la materialización y visibilización del vínculo establecido con el estado (Lechtman 2007). Al mismo tiempo, al ser piezas realizadas en bronce podrían estar reflejando el control estatal ya que esta aleación fue considerada como un emblema de su dominio (Lechtman 1978, 2007; D'Altroy y Earle 1994). Por otro lado, las piezas que provienen de excavaciones sistemáticas demuestran que los metales circularon por escenarios fuertemente 
sacralizados por el Inka, como los ushnus y los contextos funerarios, siendo bienes ofrendados en los distintos ritos y prácticas ceremoniales que denotan el poder simbólico de los metales. En estos contextos sagrados, los bienes metálicos oficiaron como mediadores entre las prácticas sociales y los principios políticos estatales, reforzando y legitimando la estructura social del Tawantinsuyu, mediante la reivindicación de alianzas con el estado y con las divinidades.

Para finalizar diremos que Quillay se constituye como una expresión más del complejo tejido social del Tawantinsuyu. La tecnología metalúrgica vincula con todas las dimensiones de la vida social al ser un sistema integrado por lo político, lo social y lo sagrado. Implementada como política estatal, la producción metalúrgica demuestra que los modos de poder fueron variables en función de los grupos sociales intervinientes. Las prácticas de producción en el sitio, muestran un entramado de relaciones sociales dinámicas en el cual, tanto los agentes estatales como las poblaciones locales, pusieron en juego sus propias ideas sobre las formas adecuadas de realizar operaciones técnicas como parte del habitus compartido por cada grupo social, al mismo tiempo que reestructuraron prácticas, crearon nuevas y negociaron relaciones políticas como producto de la interacción social generada con la llegada de los Inkas al valle de Hualfín durante la primera mitad del siglo XV. 


\section{Bibliografía}

Absi, P. 2005. Los Ministros del Diablo. El Trabajo y sus Representaciones en las Minas de Potosí. PIEB, IRD, IFEA, La Paz.

Acuto, F. 1999. Paisaje y Dominación: la Constitución del Espacio Social en el Imperio Inka. En Teoría Social en la Arqueología Latinoamericana Contemporánea, editado por Zaranquin, A. y F. Acuto, pp: 33-75. Ed. Del Tridente, Buenos Aires.

Acuto, F. 2009. Colonizando los Andes en tiempos del Tawantinsuyu: Paisajes, experiencias rituales y los Inkas como ancestros. En Parentesco, patronazgo y Estado en las sociedades antiguas, editado por M. Campagno, pp: 267-296. Ed. De la Facultad de Filosofía y Letras, Universidad de Buenos Aires.

Álvarez Miranda, L. 1993. Metalurgia prehispánica Inca en un sector costero marginal del imperio. Diálogo Andino, $N^{\circ} 11 / 12:$ 67-76.

Ambrosetti, J. B. 2011 [1904]. El bronce en la Región Calchaquí. Re-edición, Editorial de la Facultad de Filosofía y Letras, Universidad de Buenos Aires

Angelelli, V. 1984. Yacimientos metalíferos de la República Argentina. Volumen I. Comisión de Investigaciones Científicas de la provincia de Buenos Aires.

Angiorama, C. I. 2001. De Metales, Minerales y Yacimientos. Contribución al Estudio de la Metalurgia Prehispánica en el Extremo Noroccidental de Argentina. Estudios Atacameños 21: 63-88

Angiorama, C. I. 2004. Acerca de Incas y Metales en Humahuaca. Producción Metalúrgica en Los Amarillos en Tiempos del Tawantinsuyu. Relaciones de la Sociedad Argentina de Antropología XXIX: 39-58.

Angiorama, C. I. 2006. ¿Mineros Quebradeños o Altiplánicos? La Circulación de Metales y Minerales en el Extremo Noroccidental de Argentina (1280-1535 A.D.). Intersecciones en Antropología 7: 147-161.

Angiorama, C. I. 2011. Impacto de la Conquista Inca en la Metalurgia de Los Amarillos (Quebrada de Humahuaca, Jujuy). Andes 22. 
Angiorama, C. I. 2013. La metalurgia en tiempos del Inka: estudios de objetos metálicos hallados en Esquina de Huajra (quebrada de Humahuaca, Jujuy). En: Al borde del imperio, paisajes sociales, materialidad y memoria en áreas periféricas del noroeste argentino, editado por V. I. Williams y M. B. Cremonte, pp. 93-108. Sociedad Argentina de Antropología, Buenos Aires.

Angiorama, C. I. y C. Taboada. 2008. Metales andinos en la llanura santiagueña (Argentina). Revista Andina 47: 117-150.

Angiorama, C. I., Brizuela, H. G. y Nieva N. 1999. Aspectos de la metalurgia prehispánica en la Quebrada de Humahuaca (Jujuy). Anales SAM: 174-177.

Angiorama, C. I. y M. F. Becerra. 2010. Antiguas evidencias de minería y metalurgia en Pozuelos, Santo Domingo y Coyahuayma (puna de Jujuy, Argentina). Boletín del Museo Chileno de Arte Precolombino 15:81-104.

Angiorama, C. I. y M. F. Becerra. 2017. Reverberatory furnaces in the Puna of Jujuy, Argentina, during colonialtimes (from the end of the 16th to the beginning of the 19th century A.D.). Journal of Anthropological Archaeology 48: 181-192.

Angiorama, C. I. y C. Taboada. 2007. La producción metalúrgica en un contexto doméstico de Los Amarillos (Jujuy, Argentina). En Metalurgia en la América Antigua. Teoría, arqueología, simbología y tecnología de los metales prehispánicos, editado por R. Lleras Pérez, pp. 409-420. Fundación de Investigaciones Arqueológicas Nacionales Banco de La República, Instituto Francés de Estudios Andinos.

Aschero, C. 1975. Ensayo para una clasificación morfológica de artefactos líticos aplicada a estudios tipológicos comparativos. Informe al CONICET. MS.

Ávila, J. C. y J. E. Lazarte. 2010. Mineralización en el basamente Metamórfico de bajo grado de Catamarca y Norte de La Rioja, Argentina. Serie correlación geológica, 26(2): 85-102.

Babot, M. P. 1999. Recolectar para moler. Casos actuales de interés arqueológico en el Noroeste Argentino. En Los tres reinos: prácticas de recolección en el cono sur de América, editado por C. Aschero, A. Korstanje y P. Vuoto, p. 161-170, Instituto de Arqueología y Museo, Tucumán. 
Bachmann, H.G. 1982. The Identification of Slags from Archaeological Sites. London Institute of Archaeology, Vol. 28. Occasional Publication $\mathrm{N}^{\circ} 6$.

Bakewell, P. 1989. Mineros de la Montaña Roja. El trabajo de los indios en Potosí, 1545-1650. Alianza. Madrid.

Baldini, M.I. 2012. Alberto Rex González, antropólogo: su dimensión como hombre y como científico. In Memoriam. Atek Na 2: 7-12.

Balesta, B. y C. García Mancuso. 2010. Entierros infantiles en una habitación del Cerro Colorado de La Ciénaga de Abajo. En Investigaciones Arqueológicas en La Ciénaga (Catamarca, Argentina), editado por B. Balesta y N. Zagorodny, pp. 241-276. Ediciones Al Margen. La Plata.

Balesta, B., N. Zagorodny, F. Wynveldt. 2011. La Configuración del Paisaje Belén (Valle de Hualfín, Catamarca). Relaciones de la Sociedad Argentina de Antropología XXXVI: 149-175.

Balfet, H., M-F Fauvet-Berthelot, S. Monzon. 1992. Normas para la descripción de vasijas cerámicas. Traducción de M-F. Pauvet-Berthelot y S. Monzon. Centro de Estudios Mexicanos y Centroamericanos.

Barba, A.A. 1817 [1640]. Arte de los Metales. Tribunal de Minería de Lima, Lima.

Bárcena, J. R. 2007. El periodo Inka en el Centro-Oeste y Noroeste argentino: aspectos cronológicos en el marco de la dominación del kollasuyu. En Sociedades Precolombinas Surandinas. Temporalidad, interacción y dinámica cultural en el NOA en el ámbito de los Andes Centro-Sur, editado por V. I. Williams, B.N. Ventura, A. Callegari y H. Yacobaccio, pp. 251-282. Buenos Aires.

Bárcena, R. 2008. Infraestructura y significado en la dominación inka del cetro oeste Argentino (COA), extremo austral del Tawantinsuyu. Espacio, tiempo y forma. Serie I, Nueva Época, Prehistoria y Arqueología 1: 321-336.

Bargalló, M. 1967. La "guayra", horno de fundición del antiguo Perú. Estudio de las referencias de los cronistas. Minería 79: 43-49. 
Becerra, M. F. 2014 “'Para labrar y poblar'... Prácticas minero-metalúrgicas en la puna de Jujuy durante el período Colonial (siglo XVII-XVIII). Tesis Doctoral inédita, Facultad de Filosofía y Letras, Universidad Nacional de Buenos Aires.

Becerra, M. F., Angiorama, C. I y Nieva, N. 2011. Estudios arqueométricos de evidencias de producción minero-metalúrgica durante la época colonial en Fundiciones 1 (Departamento de Rinconada, Jujuy, Argentina). Intersecciones en Antropología 12: $5-16$.

Becerra, M.F., N. Nieva y C.I. Angiorama. 2014. Hornos, minerales y escorias: una aproximación a la metalurgia extractiva en la Puna de Jujuy en época prehispánica y colonial. Revista Arqueología 20: 13-29.

Behrensmeyer, A. 1978. Taphonomic and Ecology Information from Bone Weathering. Paleobiology 4: 150-162.

Berthelot, J. 1984. The extraction of precios metals at the time of the Inka. En Anthropological History of Andean Polities, editado por J. Murra, N. Wachtel y J. Revel pp. 69-88. Unversity Press.

Biloni, H., F. Kiss, T. Palacios y D. Vasallo. 1990. Análisis metalográfico de la placa de Lafone Quevedo. Serie Difusión 7, CIC, Buenos Aires.

Binford, L. 1981. Bones: Ancient Men and Modern Myths. Academic Press, New York.

Biswas, A.K. y W.G. Davenport. 1994. Extractive Metalurgy of Copper. Third Edition, PERGAMON.

Biurrun, E., L. Galetto, A. M. Anton y F. Biurrun. 2007. Plantas silvestres comestibles utilizadas en poblaciones rurales de la Provincia de La Rioja (Argentina). Kurtziana 33: 121-140.

Bocek, B. 1986. Rodent Ecology and Burrowing Behavior: Predicted Effects on Archaeological Site Formation. American Antiquity 51(3): 589-603.

Boman, E. 1923. Los ensayos de establecer una cronología prehispánica en la Región Diaguita (República Argentina). Boletín de la Academia Nacional de Historia, VI, (1517): $1-31$. 
Boman, E. 1991 [1908]. Antigüedades de la Región Andina de la República Argentina y del Desierto de Atacama. Universidad Nacional de Jujuy, San Salvador de Jujuy.

Bourdieu, P. 2007. El sentido práctico. Siglo XXI.

Bourdieu, P. y Wacquant, L. 2005. Una invitación a la sociología reflexiva. Buenos Aires: Siglo XXI editores.

Bourgarit, D. Rostan, P., Burger, E., Carozza, L., Mille B. y Artioli, G. 2008. The Biginning of Copper mass Production in the Western Alps: the Saint-Véran Mining Area Reconsidered. Historical Metallurgy 42(1): 1-11.

Bouysse-Cassagne, T. 2005. Las minas del centro-sur andino, los cultos prehispánicos y los cultos cristianos. Bulletin de l'Institut français d'études andines, 34 (3): 443-462.

Bovisio, M. A. 2014. Supuestos y conceptos acerca de la imagen precolombina del noroeste argentino en la obra de Samuel Lafone Quevedo, Adán Quiroga y Juan Ambrosetti. Estudios Sociales del NOA, 14: 151-185.

Brain, C.K. 1981. The Hunters or the Hunted? An Introduction to African Cave Taphonomy. University of Chicago Press, Chicago.

Bray, T. L. 2003a. Inka Pottery as Culinary Equipment: Food, Deasting and Gender in Imperial State Design. Latin American Antiquity, 14(1): 3-28.

Bray, T. L. 2003b. The Archaeology and Politics of Food and Feasting in Early States and Empires. Kluwer Academic/Plenum Publishers, New York.

Bray, T. L. 2004. La Alfarería Imperial Inka: Una Comparación entre la Cerámica Estatal del área de Cuzco y la Cerámica de las Provincias. Chungara, Revista de Antropología Chilena, Vol. 36, N²: 365- 374.

Brooks, W.E y L. Vetter Parodi. 2012. Antigua fundición de plomo en el sitio inca de Curamba, departamento de Apurímac, Perú. Bulletin de l'Institut Francais d'Études Andines, vol. 41, N²: 197-208.

Cabanillas, E., L. R. González y T. Palacios. 1996. Metalurgia Colonial en el Noroeste Argentino. Estudio de Escorias. En Actas CONAMET IX-IBEROMET IV :1800-1806. Santiago. 
Cabanillas, E.D., González, L. R., Palacios T.A. y Piferetti, A. 2006-2009. Entre granos y elementos. El estudio de los metales antiguos. Xama 19-23: 263-282.

Cabrera A. L. y A. Willink. 1973. Biogeografia de América Latina. Organización de los Estados Americanos. Washington, DC

Calderari, M. y V. Williams. 1991. Re-evaluación de los estilos cerámicos incaicos en el noroeste argentino. Comechingonia II, año 9: 75-97.

Caminos, R. 1979. Sierras Pampeanas Noroccidentales, Salta, Tucumán, Catamarca, La Rioja y San Juan. Geología Regional Argentina, Acad. Nac. Ciencias: 225-282. Córdoba.

Campbell, R. 2004. El trabajo de metales en la Araucanía (S. X-XVII dC.) Memoria para optar el título de Arqueólogo, inédita. Departamento de antropología, Facultad de Ciencias Sociales, Universidad de Chile.

Campbell, R. y E. Latorre. 2003. Rescatando una materialidad olvidada: síntesis, problemáticas y perspectivas en torno al trabajo prehispánico de metales en Chile central. Boletín de la Sociedad Chilena de Arqueología, N³5/36: 47-61.

Capoche, L. 1959 [1585]. Relación General de la Villa Imperial de Potosí, 1585. Ed. De Lewis Hanke, Tomo CXXII. Biblioteca de autores españoles, Madrid.

Capparelli, A. 2007. Los Productos Alimenticios derivados de Prosopis chilensis (Mol.), Stunztz y P. flexuosa DC., Fabaceae, en la vida cotidiana de los habitantes del NNOA y su paralelismo con el algarrobo europeo. Kurtziana. Tomo 33 (1): 1- 19.

Capparelli, A. 2008. Caracterización cuantitativa de productos intermedios y residuos derivados de alimentos del algarrobo (prosopis flexuosa y p. chilensis, fabaceae): aproximación experimental aplicada a restos arqueobotánicos desecados. Darwiniana 46(2): 175-201.

Carandini, A. 1997 [1991]. Historias en la Tierra. Manual de Excavación Arqueológica. Traducción de Xavier Dupré Raventos. Crítica, Barcelona.

Carcedo de Mufarech, P. 1998. Boletín del Museo de Oro, º44-45: 240-270. 
Cieza de León, P. 1922 [1553]. La Crónica del Perú. Calpe, Madrid.

Civalero, M. 2006. De roca están hechos: introducción a los análisis líticos. En El Modo de Hacer las Cosas. Artefactos y Ecofactos en Arqueología. Editado por C. Pérez de Micou, pp. 35-65. Departamentito de Ciencias Antropológicas, FFyL, UBA.

Cohen, C., T. Rehren y M. Van Buren. 2008. La huayrachina por dentro y por fuera: un estudio arqueo-metalúrgico de la tecnología de fundición de plomo en Porco-Potosí, Bolivia. En Mina y metalurgia en los Andes del Sur desde la época prehispánica hasta el siglo XVII, editado por P. Cruz y J. J. Vacher, pp. 29-56. Institut de Recherche pour le Développement, Instituto Francés de Estudios Andinos, Sucre.

Comendador Rey, B. 2010. Una perspectiva antropológica para la interpretación de la metalurgia. En Manual de arqueometalurgia, coordinado por Ignacio Montero Ruiz, pp. 269-300. Museo Arqueológico Regional; Colegio Oficial de Doctores y Licenciados en Filosofía y Letras y en Ciencias, Sección de Arqueología.

Costin, C. L. 1996. Craft Production and Mobilization Strategies in the Inka Empire. En Craft Specialization and Social Evolution: In Memory of V. Gordon Childe, editado por B. Wailes, pp. 211-225. Philadelphia: University of Pennsylvania Museum of Archaeology and Anthropology.

Cremonte, M. B, M. A. Zaburlin, S. M. Peralta. 2005. Ordenamiento Espacial y Arquitectura del sitio Incaico Agua Hedionda. Cuadernos FHyCS- UNJu, N²9: 23-42.

Cruz, P. 2009-2011. El brillo del señor sonriente. Miradas alternativas sobre las placas metálicas surandinas. Mundo de Antes $N^{\circ}$ 6-7: 97-131.

Cruz, P. y F. Téreygeol. 2014. Yanaconas del rayo. Reflexiones en torno a la producción de metales en el espacio surandino (Bolivia, siglos XV-XVI). Estudios Atacameños, $\mathrm{N}^{\circ} 49$ : 19-44.

Cruz, P. y P. Absi. 2008. Cerros ardientes y wayras calladas. Potosí antes y durante el contacto. En Minas y Metalúrgias en los Andes del Sur, entre la época prehispánica y el siglo XVII, editado por Cruz, P. y J. Joinville Vacher, pp: 91-121. Instituto Francés de Estudios Andinos (IFEA) - Institut de Recherche pour le Développement (IRD). Sucre. 
Cruzate, G., Moscatelli, G. y Panigatti, J. 2011. Suelos y Ambiente de Catamarca. www.inta.gob.ar/documentos/caracteristicas-suelos-de-catamarca, Septiembre 2016

D’Altroy, T y K. Schreiber. 2004. Andean Empires. En Andean Archaeology, editado por H. Silverman, pp. 255-278. Oxford: Blackwell Publishing.

D’Altroy, T, Earle, T., Browman, D. L., La Lone, D., Moseley, M.E., Murra, J.V., Myers, T., Salomon, F, Schreiber, K. y J.R. Topic. 1985. Staple Finance, Wealth Finance, and Storage in the Inka Political Economy. Current Anthropology, vol. 26, $\mathrm{N}^{\circ} 2: 187-206$.

D'Altroy, T. 1994. Public and private economy in the Inka empire. En The Economic Anthropology of the State, pp. 171-222. Brumfiel, University Press of América.

D'Altroy, T. 2003. Los Inkas. Ed. Ariel. Barcelona.

De La Fuente, G. A. y S. D. Vera. 2013. Evidencias de Sobrecocción y Vitrificación en las Estructuras de Combustión (Hornos de Cerámica) y en Cerámica Arqueológica procedentes del sitio arqueológico de Costa de Reyes $\mathrm{N}^{\mathrm{o}}$ 5: Una Aproximación a través de la Petrología Cerámica, MEB-EDS y DRX. En Actas del XI Congreso y Exposición Internacional de la Industria Cerámica, del Vidrio, Refractarios y Suministros: ATACER, pp. 351 - 356. Universidad Nacional del Centro de la Provincia de Buenos Aires.

De Nigris, M. R. y O. Puche Riart. 2011. El uso de los hornos de pachamanca y guayra para la fundición en los Andes. De Re Metallica 16: 21-31.

De Nigris, M. R. y O. Puche Riart. 2013. Molinos mineros de tradición andina. De Re Metallica, $\mathrm{N}^{\circ} 20$ : 1-12.

De Rosa, H., Gluzman, G. A., González, L. R. y Svoboda, H. 2008. Caracterización de fragmentos de cascabel del noroeste de Argentina. Actas del $8^{\circ}$ Congreso Internacional Conamet-Sam.

Del Mar Ismodes, Raúl. 2006. Curamba. Centro de producción metalúrgica de época Inka. Arqueología y Sociedad, N¹7: 293-312. 
Del Papa, L. M. 2012. Una aproximación al estudio de los sistemas de subsistencia a través del análisis arqueofaunístico en un sector de la cuenca del río Dulce y cercanías a la sierra de Guasayán. Tesis Doctoral inédita. Facultad de Ciencias Naturales y Museo, UNLP.

Delfino, D, V. E. Espiro, A. Barale, R. A. Díaz y M. G. Pisani. 2016. Contribución Arqueológica al Conocimiento de las Minerías de Aguas de Dionisio (Dto. Hualfín, Dpto. Belén, Prov. de Catamarca, Argentina). Ms. www.academia.edu/4008357

Demaio, P.; U. O. Karlin y M. Medina. 2002. Árboles nativos del centro de Argentina. Ed. L.O.L.A. Buenos Aires.

Dobres, M. A. 1999. Technology's Links and Chaines: The Processual Unfolding of Technique and Technician. En The Social Dynamics of Technology. Practice, Politics and World Views, editado por Dobres M. A y C. R. Hoffman, pp: 124-146. Smithsonian Institution Press.

Dobres, M. A. y C. R. Hoffman. 1994. La agencia social y la dinámica de la tecnología prehistórica, Journal of Archaeological Method and Theory, vol 1(3): 211- 258.

Dobres, M. A. y C. R. Hoffman. 1999. The Social Dynamics of Technology. Practice, Politics and World Views. Smithsonian Institution Press.

Earle, T. 1994. Wealth Finance in the Inka Empire: Evidence from the Calchaqui Valley, Argentina. American Antiquity, Vol. 59, No. 3: 443-460.

Farro, M. 2009. La formación del Museo de La Plata. Coleccionistas, comerciantes, estudiosos y naturalistas viajeros a fines del siglo XIX. Rosario: Prohistoria ediciones.

Feely, A. 2011. Caracterización de Estructuras de Doble Cámara para la Cocción de Artefactos Cerámicos en La Troya (Tinogasta, Catamarca). Relaciones de la Sociedad Argentina de Antropología XXXVI: 325-330.

Fernández Murillo, M. S. 2016. Alianzas de metal. La colección de minería y metales del Museo Nacional de Etnografía y Folklore, según la cadena de producción. MUSEF, La Paz. 
Fester, G y J. A, Retamar. 1956. Examen de piezas metálicas procedentes de Catamarca. Revista de Ingeniería Química XXV, 39: 161-171.

Fester, G. 1962. Copper and copper alloys in ancient Argentina. Chymia, 8: 21-31.

Figueroa, G.G. y M. Dantas. 2006. Recolección, Procesamiento y Consumo de Frutos Silvestres en el Noroeste Semiárido Argentino. Casos Actuales con Implicancias Arqueológicas. La Zaranda de Ideas, Revista de Jóvenes Investigadores en Arqueología 2:35-50. Buenos Aires.

Figueroa, V., Mille, B., Salazar, D., Berenguer, J., Menzies, A., Sapiains, P., Cifuentes, A. y D. Joly. 2018. A major prehispanic copper production center identified at Collahuasi, southern Tarapacá altiplano (Chile). Chungará, Revista de Antropología Chilena (online).

Flores, M. C y B. Balesta. 2011. Identificación y Procedencia de Obsidianas en Sitios del Período de Desarrollos Regionales/Inka en el valle de Hualfín (Catamarca). En Libro de Resúmenes del IV Congreso Argentino de Arqueometría, s/n, Luján.

Flores, M. y M. Morosi. 2010. ¿De Dónde Vienen?: Obsidianas de la Localidad de Azampay (Dto. de Belén, Catamarca). En La Arqueometría en Argentina y Latinoamérica, editado por S. Bertolino, R. Cattáneo y A. D. Izeta, pp. 177-182. Facultad de Filosofía y Humanidades, Córdoba.

Fraresso, C. 2010. Estudio Arqueometalúrgico de un Taller de Transformación de Cobre y de Aleaciones Tumbaga en el Sitio de Huacas de Moche. Boletín del Instituto Francés de Estudios Andinos, vol. 39, núm. 2: 351-387.

Fuentes, S.E.; F. E. Vilchez, R. F. Palacios. 1998. Consideraciones preliminares sobre las rocas de aplicación del Oeste de la Provincia de Catamarca y posible uso para la construcción de viviendas e industria. En Actas Congreso Regional de Ciencia y Tecnología Sección: Ambiente y Recursos Naturales, Secretaría de Ciencia y Tecnología, Universidad Nacional de Catamarca

Gadamer, H.G. 2005 [1975]. La historicidad de la comprensión como principio hermenéutico. Verdad y Método I, Ediciones Sígueme, Salamanca. 
Gándara, M. 1992. El Análisis Teórico: Aplicaciones al Estudio del Origen de la Complejidad Social. Boletín de Antropología Americana 22:37.

Geogakopoulou, M. Bassiakos, Y. y Philaniotou, O. 2011. Seriphos surfaces: A Study of Copper Slags Heaps and Copper Sources in the Context of Early Bronze Age Aegean Metal Production. Archaeometry 53 (1): 123-145.

Giddens, A. 1995. La construcción de la sociedad. Bases para la teoría de la estructuración. Amorrortu editores.

Giménez, A.M.; J. G. Moglia; P. Hernández, P. y R. Gerez. 2000. Anatomía de Madera. Facultad de Ciencias Forestales. Universidad Nacional de Santiago del Estero.

Giovannetti M. A. 2015a. Agricultura regadio y molienda en una capital inkaica: Los sitios El Shincal y Los Colorados, Noroeste Argentino. BAR International Series.

Giovannetti, M. A. 2015b. Fiestas y ritos inka en El Shincal de Quimivil: la presencia del Tawantinsuyu en la provincia de Catamarca. Punto Encuentro, Buenos Aires.

Giovannetti, M. A. J. Spina, G. Cochero, G. Corrado, L. Aljanati y M. Valderrama. 2012. Nuevos Estudios en el Sector "Casa del Kuraka" del Sitio El Shincal de Quimivil (Dpto. Belén, Prov. Catamrca, Argentina). Inka Llaqta. Revista de Investigaciones Arqueológicas y Etnohistóricas Inka. Año 3, º3: 161-190.

Giovannetti, M. A., J. Spina, M. C. Páez, G. Cochero, A. Rossi, P. Espósito. 2013. En busca de las festividades del Tawantinsuyu. Análisis de los tiestos de un sector de descarte de El Shincal de Quimivil. Intersecciones en Antropología, Vol. 14: 67-82.

Giovannetti, M. A., V. S. Lema, C. G. Bartoli, A. Capparelli. 2008. Starch grain characterization of Prosopis chilensis (Mol.) Stuntz and P. flexuosa DC, and the analysis of their archaeological remains in Andean South America. Journal of Archaeological Science 35: 2973-2985.

Gluzman, G. 2007. Minería y Metalurgia en la Antigua Gobernación del Tucumán (Siglos XVI-XVII). Memoria Americana 15: 157-184.

Gluzman, G. 2008. Producción metalúrgica de bienes utilitarios en el noroeste argentino prehispánico. En Estudios arqueológicos en Yocavil, Tarrago, M. N. y González, L. edres. Asociación de amigos del Museo Etnográfico, Buenos Aires. 
Gluzman, G. 2017. Una tecnología olvidada: cerámicas metalúrgicas en el Noroeste argentino prehispánico: Una revisión desde la arqueometalurgia. Intersecciones en antropología, 18(1): 19-30.

Gluzman, G. A y L. R. González. 2005. Estudios sobre Antiguos Asentamientos Metalúrgicos en el Sur del Valle de Yocavil (Provincia de Catamarca). Actas Congreso Binacional SAM-CONAMET, Mar del Plata

Gluzman, G. A. y González, L. R. 2008. El contacto hispano-indígena a través de la metalurgia del antiguo noroeste de Argentina. Actas VII Congreso Iberoamericano de Arqueometría: 522-530.

Gómez Gutiérrez, A. S. C. Schnabel, J. F. Lavado Contador. 2011. Procesos, Factores y Consecuencias de la Erosión por Cárcavas; Trabajos Desarrollados en la Península Ibérica. Boletín de la Asociación de Geógrafos Españoles, №55: 59-80.

González A. R. y G. Cowgil. 1975. Cronología del valle de Hualfín, pcia de Catamarca, Argentina. Obtenida mediante el uso de computadoras. Actas del Primer Congreso de Arqueología Argentina, pp. 383-395. Universidad Nacional de Rosario, Rosario.

González Bonorino, F. 1950. Geología y Petrografía de las Hojas 12d (Capillitas) y 13d (Andalgalá). Boletín Dirección General de Industria Minera 70: 1-100, Buenos Aires.

González Carvajal, P. 2004. Arte Visual, Espacio y Poder: Manejo Incaico de la Iconografía Cerámica en Distintos Asentamientos de la Fase Diaguita Inka en el Valle de Illapel. Chungara, Revista de Antropología Chilena, Vol. 36, º2: 375-392.

González Dubox, R., F. Wynveldt, V. Val, y M. L. Mateo. 2011. Análisis Espacial del Cerrito Colorado de La Ciénaga de Arriba (Dpto. Belén, Catamarca). La Zaranda de Ideas. Revista de Jóvenes Investigadores en Arqueología 7: 23-48.

González L. R. y M. N. Tarragó. 2004a. Producción tecnológica e identidad durante el dominio incaico en el Noroeste argentino. Boletín de Arqueología PUCP, No8: 191207.

González L. R. y M. N. Tarragó. 2004b. Dominación, resistencia y tecnología: la ocupación incaica en el Noroeste argentino. Chungara, Revista de Antropología Chilena, Vol. 36, N²: 393-406. 
González L. R. y M. N. Tarragó. 2005. Vientos del sur. El Valle de Yocavil (Noroeste argentina) bajo la dominación incaica. Estudios Atacameños, N²9: 67-95

González, A. R. 1955. Contextos culturales y cronología relativa en el área central del NO argentino (nota preliminar). Anales de Arqueología y Etnología 11: 7-32.

González, A. R. 1959. Breve Noticia de las Investigaciones Arqueológicas Efectuadas en el Valle de Hualfín, Campaña 1952. Revista del Museo de Ciencias Naturales y Tradicional de Mar del Plata. Vol. 1 (1): 79-81.

González, A. R. 1979. La metalurgia precolombina del NOA. Secuencia histórica y proceso cultural. Actas Jornadas del Noroeste. Universidad del Salvador, Buenos Aires.

González, A. R. 1980. Patrones de Asentamiento Incaico en una Provincia Marginal del Imperio. Implicancias Socio-culturales. Relaciones de la Sociedad Argentina de Antropología XIV, N¹: $63-82$.

González, A. R. 1992. Las placas metálicas de los Andes del Sur. Contribución al estudio de las religiones precolombinas. KAVA. Berlín.

González, A. R. Cuaderno de campo, expediciones a Catamarca, 1951, 1952 y 1957. Repositorio DILA. URL: http://www.caicyt-conicet.gov.ar/dila/items/show/7972.

González, A. R. y H. Lagiglia. 1973. Registro nacional de fechados radiocarbónicos: necesidad de su creación. Relaciones de la Sociedad Argentina de Antropología VII: 291-312.

González, L. R. 1992. Fundir es Morir un Poco. Restos de Actividades Metalúrgicas en el Valle de Santa María, pcia. De Catamarca. Palimpsesto, Revista de Arqueología, 2: $51-70$.

González, L. R. 2002. Heredarás el Bronce. Incas y Metalurgia en el Sur del Valle de Yocavil. Intersecciones en Antropología 3: 55-68.

González, L. R. 2004a. Historias de poder, brillos y colores: el arte del cobre en los Andes prehispánicos. En El arte del cobre en el mundo Andino, catálogo de la exhibición, editado por J. Berenguer, pp. 8-59. Museo Chileno de Arte Precolombino, Santiago. 
González, L. R. 2004b. Bronces sin Nombre. La metalurgia prehispánica en el Noroeste argentino. Fundación Ceppa, Bs As.

González, L. R. 2006. Metales y metalurgistas del Noroeste argentino prehispánico. En El modo de hacer las cosas. Artefactos y ecofactos en Arqueología, editado por Cecilia Pérez de Micou, pp. 129-169. Univ. de Buenos Aires.

González, L. R. 2007. Tradición tecnológica y tradición expresiva en la metalurgia prehispánica del noroeste argentino. Boletín del museo chileno de arte precolombino, Vol. 12, $\mathrm{N}^{\circ} 2: 33-48$

González, L. R. 2010. Fuegos Sagrados. El Taller Metalúrgico del Sitio 15 de Rincón Chico (Catamarca, Argentina). Boletín del Museo Chileno de Arte Precolombino. Vol. 15, $\mathrm{N}^{\circ} 1: 47-62$.

González, L. R. 2012. Los metales precolombinos del noroeste argentino. En Fuego de los dioses: los metales precolombinos del Noroeste argetnino, editado por M. Goretti, p. 18-151. Fundación CEPPA.

González, L. R. y G. Gluzman. 2009. Agárrame si puedes. Métodos de sujeción de crisoles en el taller metalúrgico prehispánico del sitio 15 de Rincón Chico. Anuario de Arqueología 1 (1): 139-152.

González, L. R., Cabanillas, E. D. y T. A. Palacios. 1998-1999. El Pozo y el Tumi: arqueometalirhia del sur del valle de Yocavil. Cuadernos del Instituto Nacional de Antropología y Pensamiento Latinoamerica, 18: 207-222.

González, L.R y A. M. Vargas. 1999. Tecnología metalúrgica y organización social en el Noroeste argentino prehispánico. Estudio de un disco. Chungara, Vol. 31, N¹: 5-27.

González, L.R y H. Buono. 2007. Hachas y cetros de metal del Noroeste argentino prehispánico. Revista Andina, ํ44: 175-198.

Graffam, G., Carevic, A. y M. Rivera. 1997. Evidencias metalúrgicas de fundición de cobre en el sitio formativo tardío de Ramaditas, quebrada de Guatacondo, Provincia de Iquique, Chile. Estudios Atacameños, $N^{\circ} 12:$ 47-59. 
Guerrero Hernández, C. J. 2001. Rocas calizas, formación, ciclo del carbonato, propiedades, aplicaciones, distribución y perspectivas en la mixteca Oxaqueña. Temas de Ciencia y Tecnología, Vol 5. № 14: 3-14.

Gutiérrez, A. A., G. D. Chong y S. Espinoza. 2006. Niveles de Exposición de Yacimientos del Distrito Minero Agua de Dionisio (YMAD), Catamarca. Revista de la Asociación Geológica Argentina 61 (2): 269-278.

Gutiérrez, A. A., N.S. Guerra y M.C. Alderete. 2002. Zonación Geoquímica del distrito minero Agua de Dionisio (YMAD), Argentina. XI Congreso Peruano de Geología. Trabajos Científicos Sociedad Geológica del Perú: 1-15.

Haber, A. 1994. Supuestos teóricos-metodológicos de la etapa formativa de la arqueología en Catamarca (1875-1900). Cuadernos de Investigaciones de la Facultad de Filosofía y humanidades 47: 31-54.

Hagstrum, M. B. 1992. Intersecting Technologies: Ceramics, Metallurgy and the Organization of Specialized Craft Production in the Inka State. Ceramic Ecology '92 American Anthropological Association 91 st Annual Meeting, S. Fco. California (ms).

Hauptmann, A. 2007. The Archaeometallurgy of Copper: Evidence from Faynan, Jordan. Springer, Berlin.

Hauptmann, A., Rehen Thilo y Schmitt-Strecker Sigrid. 2003. Early Bronze Age copper metallurgy at Shahr-i Sokhta (Iran) reconsidered. En Man and Mining (Mensch und Bergbau), editado por Stoellner, T., Koerlin, G, Steffens, G y Cierny, J., pp. 197 - 213. Deutsches Bergbau-Museum: Bochum, Germany.

Heather, M y L. Miller. 2007. Archaeological Approches to Technology. ELSEVIER. Academic Press Publication.

Hein, A., V. Kilikouglou, V. Kassianidou. 2007. Chemical and Mineralogical Examination of metallurgical ceramics from a Late Bronze Age Copper smelting site in Cyprus. Journal of Archaeological Science, 34: 141-154.

Hoffman, C. R. y M. A. Dobres. 1999. Conclusion: Making Material Culture, Making culture Material. En The Social Dynamics of Technology. Practice, Politics and World 
Views, editado por Dobres, M. A. y C. R. Hoffman, pp. 209-222. Smithsonian Institution Press.

Horta, H. 2008. Insignias para la frente de los nobles Incas: una aproximación etnohistórica-arqueológica al principio de dualidad. En Leguajes Visuales de los Incas, editado por P. González Carvajal y T. L. Bray, pp 71-89.BAR International Series 1848.

Hosler, D. 2013. Sound, Color and Meaning in the Metallurgy of Ancient West Mexico. World Archaeology, vol. 24, N¹: 100-115.

Hyslop, J. 1990. Inka Settlement Planning. University of Texas Press, Austin.

Ingold, T. 1990. Sociedad, naturaleza y el concepto de tecnología. En: Archaeological Review from Cambridge 9 (1).

Kang, K-W, Echarri J.M. y Llorente, C.L. 2013. Servicio de microscopía electrónica de barrido y microanálisis del LIMF - Facultad de Ingeniería - UNLP. Actas Segundas Jornadas de Investigación y Transferencia: 660 - 665.

Kierczak, J. y A. Pietranik. 2011. Mineralogy and composition of historical $\mathrm{Cu}$ slags from the Rudawy Janowickie Mountains, southwestern Poland. The Canadian Mineralogist 49: 1281-1296.

Klein, C. y C. S. Hulrbut. 1996. Manual de Mineralogía. Ed. Reverté

Lafone Quevedo, S. A. 1890. Notas arqueológicas a propósito de un objeto de arte indígena. Revista del Museo de la Plata, tomo I (Arqueología): 1-13.

Lafone Quevedo, S.A. 1888. Londres y Catamarca. Buenos Aires.

Latorre Blanco, E. 2009. De adornos y herramientas nacidos del fuego: una caracterización del trabajo de metales en la Cultura Diaguita (c.a. 900-1536 dC.). Memoria para optar el título de Arqueólogo, inédita. Departamento de antropología, Facultad de Ciencias Sociales, Universidad de Chile.

Latorre Blanco, E. 2013. Moldes Metalúrgicos en Materiales no Tradicionales: Experimentación y un Ejemplo Arqueológico en la Costa del Norte Grande de Chile. En: XVIII Congreso Nacional de Arqueología Argentina, editado por J. R. Bárcena y S. E. Martín. INCIHUSA, CONICET. 
Lazarte J.E. y F. Guidi. 1998. Geología de los granitoides de las sierras de Zapata y Cordón de los Colorados. Revista del Instituto de Geología y Minería de Jujuy 12(1):1734.

Lazarte, J. E., J. C. Ávila, A. S. Fogliata y M. Gianfrancisco. 2006. Granitos Evolucionados Relacionados a Mineralizaciones Estanno-Wolframífera en Sierras Pampeanas Occidentales. INSUGEO, Serie Correlación Geológica, 21: 75-104.

Lechtman, H. 1976. A Metallurgical Site Survey in the Peruvian Andes. Journal of Field Archaeology, Vol. 3, No. 1: 1-42.

Lechtman, H. 1977. Style in Technology: Some Early Thoughts. En Material Culture: Styles, Organization, and Dynamics of Technology, editado por H. Lechtman y R. S. Merrill, pp. 3-20. West Publishing Co., St. Paul, Minn.

Lechtman, H. 1978. Temas de Metalurgia Andina. En Tecnología Andina, compilado por R. Ravines, pp. 489-520. Instituto de Estudios Peruanis, Lima.

Lechtman, H. 1984. Andean value systems and the development of prehistoric metallurgy. Technology and Culture 25: 1-36.

Lechtman, H. 1991. La metalurgia precolombina: tecnología y valores. Los Orfebres olvidados de América: 9-18. Museo Chileno de Arte Precolombino.

Lechtman, H. 1993. Technologies of power: The Andean case. En Configurations of Power in Complex Societies, editado por J. Henderson y P. Netherly, pp. 243-280. Cornell University Press, Ithaca.

Lechtman, H. 1999. Afterword. En The Social Dynamics of Technology. Practice, Politics and World Views, editado por Dobres, M. A. y C. R. Hoffman, pp: 223-232. Smithsonian Institution Press.

Lechtman, H. 2007. The Inca and Andean Metallurgical Tradition. En Variations in the Expression of Inka Power, editado por R. Burger, C. Morris y R. Matos, pp: 313-355. Washington, DC: Dumbarton Oaks.

Lechtman, H., P. Cruz, A. Macfarlane y S. Carter. 2010. Procesamiento de metales durante el horizonte medio en el altiplano surandino (Escaramayu, Pulacayo, Potosí, Bolivia). Boletín del Museo Chileno de Arte Precolombino 15: 9-27. 
Leibowicz, I. y Jacob, C. 2011. Producción metalúrgica doméstica en el Intermedio Tardío. El caso de Juella, Jujuy-Argentina. Revista Haucaypata, Investigaciones arqueológicas del Tahiantinsuyo. 45-59.

Lemonnier, P. 1992. Elements for Anthropology of Technology. University of Michigan Leroi-Gourhan, A. 1971. El gesto y la palabra. Traducido por Felipe Carrera. Ediciones de la Biblioteca, Universidad Central de Venezuela.

Lindenvald, N. 2007. La estructura de los metales. Editorial Dunken

Llamazares, A.M. y C. Martínez Sarasola 2006. Reflejos de la cosmovisión originaria. Arte indígena y chamanismo en el Noroeste argentino prehispánico. Tesoros Precolombinos del Noroeste Argentino: 63-91. Fundación CEPPA, Buenos Aires

Lobo, P. 2008. La Hidrografia y Agua en Catamarca. Editorial La Isla

Lorandi, A. y R. Boixados. 1988-1989. Etnohistoria de los valles Chalchaquíes en los siglos XVI y XVII. Runa, Vol. XVII y XVIII: 263-420.

Lyman, R. L. 1994. Vertebrate Taphonomy. Cambridge University Press, Cambridge.

Lynch, J. 2013. Construcción y Organización del Espacio Incaico al Norte del Valle de Hualfin, Catamarca, Argentina. BAR International Series 2506.

Lynch, J. 2014. Sitio Villavil: una Aproximación a la Dinámica Local Estatal al Norte del Valle de Hualfín, Catamarca. Intersecciones en antropología, 15(2), 491-496.

Lynch, J., M. Giovannetti, M.C. Páez. 2010. Ushnus las Provincias del Sur del Tawantinsuyu. Comparación entre las Estructuras de los Sitios El Shincal y Hualfín Inka en el Centro de Catamarca (Argentina). Revista De Arqueología Americana 28: 4981.

Magaña, H.O. 2013. El uso de la cal en la conservación de los monumentos arqueológicos e históricos: de la teoría a la práctica. En: La Cal: Historia, Propiedades y Usos, editado por Barba Pingarrón, L. y I. Villaseñor, p. 139- 159. Instituto de Investigaciones Antropológicas, Universidad Nacional Autónoma de México, Asociación Nacional de Fabricantes de Cal. 
Makowski, K. y M. I. Velarde. 1993. Taller de Yécala (s. III/IC d. C.): observaciones sobre las características y organización de la producción metalúrgica Vicús. Boletín Museo del Oro, $\mathrm{N}^{\circ} 4$ : 99-117.

Maksaev, V. J. 2001. Reseña Metalogénica de Chile y de los Procesos que Determinan la Metalogénesis Andina.

Malpass, M. y S. Alconini. 2010. An archaeological perspective on the Inka provincial administration from the South Central Andes. En Distant Provinces in the Inka Empire: Toward a Deeper Understanding of Inka Imperialism, editado por M. Malpass y S. Alconini, pp. 44-74. University of Iowa Press, Iowa City.

Márquez-Zavalía, M. F. 2002. Mina Capillitas, un Depósito Epitermal del Noroeste Argentino. En IANIGLA, 30 años de investigación básica y aplicada en ciencias ambientales: 249-253. Mendoza.

Marsh, E. J. 2016. ¿Cuándo llegaron los incas a Mendoza? Una reevaluación de los fechados radiométricos mediante un modelo bayesiano. Actas del XIX Congreso Nacional de Arqueología Argentina, Serie Monográfica y Didáctica, Vol. 54: 19061913.

Mauss, M. 1979. El Concepto de la Técnica Corporal. En Sociología y Antropología, pp: 336-358. Editorial Tecnos, Madrid.

Mayer, E. 1986. Armas y herramientas de metal prehispánicas en Argentina y Chile. Munchen: Materialen zur Allgemeinen und Vergleichenden Archalogie. Band 38.

McGuire, R. H. 1981. A Consideration of Style in Archaeology. Atlatl, Vol 2: 13-29. Arizona.

Mei, J. y T. Rehen. 2005. Copper smelting from Xinjiang, NW China. Part I: Kangcun village, Kuche County, c18th century AD. Historical Metallurgy 39:96-105.

Melgarejo, J. C. Proenza, J. A., Galí, S. y Llovet, X. 2010. Técnicas de Caracterización Mineral y su aplicación en exploración y exploración minera. Boletín de la Sociedad Geológica Mexicana, Vol. 62 (1): 1- 23. 
Mengoni Goñalons, G. L. 1988. Análisis de Materiales Faunísticos de Sitios Arqueológicos. Xama 1: 71-120.

Mengoni Goñalons. G. L. 2010. Zooarqueología en la Práctica: Algunos Temas Metodológicos. Xama 19-23: 79-109.

Merkel, J. y Shimada, I., 1988. Arsenical copper smelting at Batán Grande, Peru. Newsletter of the Institute for Archaeo-Metallurgical Studies, 12: 4-7.

Metraux, A. 1961. Los Incas. Centro editor de América Latina, Buenos Aires.

Miller, D. 2005. Materiality. Duke University Press, Durham, NC.

Miller, D. y D. Killick. 2004. Slag Identification at Southern African Archaeological Sites. Journal of African Archaeology 2: 23-47.

Miotti, L. 1998. Zooarqueología de la meseta central y costa de la provincia de Santa Cruz. Un enfoque de las estrategias adaptativas aborígenes y los paleoambientes. Museo Municipal de Historia Natural. Secretaría de Gobierno. Mendoza.

Mohen, J. P. J. 1992. Metalúrgica Prehistórica. Introducción a la Paleometalurgia. Barcelona.

Montes, A. 1959. El Gran Alzamiento Diaguita (1630-1643). Revista del Instituto de Antropología I: 81-159.

Moreno Onorato, A., Contreras cotés, F., Renzi, M., Rovira Llorens, S., Cortés Santigao, H. 2010. Estudio Preliminar de las Escorias y Escorificaciones del Yacimiento Metalúrgico de la Edad del Bronce en Peñalosa (Baños de la Encina, Jaén). Trabajos de Prehistoria 67 (2): 305 -322.

Mórlans, M. C. 1995. Regiones Naturales de Catamarca: Provincias Geológicas y Provincias Fitogeográficas. Revista de Ciencia y Tecnología de la UNCa. Vol. I, No.2:1-42.

Murra J. V. 1999 [1978]. La organización Económica del Estado Inca. Traducido por D. R. Wagner. Siglo XXI 
Nielsen, A. y W. Walker. 1998. Conquista ritual y dominación política en el Tawantinsuyu. El caso de los Amarillos (Jujuy, Argentina). En Sed non satiata. Teoría social en la Arqueología Latinoamericana Contemporánea, editado por A. Zarankin, y F. Acuto, pp. 153-169. Ediciones del Tridente, Buenos Aires.

Nielsen, y C. I. Angiorama. 2008. Los metales de Laqaya: aproximación a la metalurgia prehispánica tardía del norte de Lípez (Potosí, Bolivia). En Mina y metalurgia en los Andes del Sur desde la época prehispánica hasta el siglo XVII, editado por P. Cruz y J. J. Vacher, pp. 121-138. Institut de Recherche pour le Développement, Instituto Francés de Estudios Andinos, Sucre.

Niemeyer, H, M. Cervellino y E. Muñoz. 1983. Viña del Cerro, expresión metalúrgica inca en el valle de Copiapó. Revista Creces 4 (4): 50-57.

Niemeyer, H. 1981. Dos Tipos de Crisoles Prehispánicos del Norte de Chico, Chile. Boletín del Museo Arqueológico de La Serena 17: 92-109.

Nordenskiold, E. 1921. The Copper and Bronze Age in South America. Comparative Ethnographical Studies 4. Goteborg.

Núñez Regueiro, V. 1992. La metalurgia Condorhuasi-Alamito (siglos III al V dC.). Anales de Arqueología y Etnología, 46: 107-164.

Núñez, L. A., Agüero, C., Cases, B. y H. Patricio de Souza. 2003. El campamento minero Chuquicamata-2 y la explotación cuprífera prehispánica en el Desierto de Atacama. Estudios Atacameños, N²5: 7-34.

Orton, P. T. y A. Vince. 1997. La cerámica en Arqueología. Traducido por R. Barceló y J. A. Barceló. Ed. Crítica.

Otero, C. 2013. Producción, usos y circulación de bienes en el Pucará de Tilcara (Quebrada de Humahuaca, Jujuy). Tesis Doctoral inédita. Facultad de Filosofía y Letras, Universidad de Buenos Aires, Buenos Aires.

Otero, C. y P. A. Ochoa. 2011. Primeras aproximaciones a la materialización del tiempo y las prácticas productivas especializadas en Tilcara (Quebrada de Humahuaca, Jujuy). Estudios sociales del NOA, nueva serie, $\mathrm{N}^{\circ} 11: 101-123$. 
Páez, M.C. y M. A. Giovannetti. 2010. Material Piroclástico en Vasijas Srqueológicas: Replicación y Experimentación en la Búsqueda de Caracterizar la Cerámica de Tiempos Inka en el Noroeste Argentino. Boletín de Arqueología Experimental № 8: 62-71.

Páez, M.C. y M. Arnosio. 2009. Inclusiones Piroclásticas en Pastas Cerámicas del Valle de Tafí (Tucumán, Argentina): Implicancias para las Prácticas de Producción. Estudios Atacameños 38: 5-20.

Palamarczuk, V. 2014. Variante "de tres Colores" Tardías en la Alfarería de Yocavil, Noroeste Argentino. Aportes para la diacronía de un estilo regional. Revista Española de Antropología Americana, Vol. 44 (1): 65- 90.

Palmieri, C. N., M. I. Carma y A. Quiroga. 2008. Las Ecorregiones Presentes en Catamarca. Gobierno de la Provincia de Catamarca. ETISIG Catamarca-WEB: $\underline{\text { www.atlas.catamarca.gov.ar }}$

Paulides, C. 2006. El Núcleo de la Cuestión. El análisis de los Núcleos en los Conjuntos Líticos. En El Modo de Hacer las Cosas. Artefactos y Ecofactos en Arqueología, editado por C. Pérez de Micou, pp. 67-97. Facultad de Filosofía y Letras, UBA.

Pease, F. 2004. Los últimos Incas del Cuzco. Instituto Nacional de Cultura del Perú.

Petersen, G.G. 1970. Minería y Metalurgia en el Antiguo Perú. Arqueológicas 12: 1152.

Pfaffenberger, B. 1988. Technological Fetishised Objects and Humanised Nature: Towards Anthropology of Technology. Man, New Series, Vol. 23, No. 2 pp. 236-252

Pfaffenberger, B. 1992a. Social Anthropology of Technology. Annual Review of Anthropology, Vol. 21: 491-516.

Pfaffenberger, B. 1992b. Technological Dramas. Science, Technology \& Human Values, Vol. 17, $\mathrm{N}^{\circ} 3:$ 282-312.

Pifferetti, A. 1993. Limpieza y conservación de restos arqueológicos metálicos. Revista de la Escuela de Antropología, 1: 73-78. 
Pifferetti, A. A. 2001. La tecnología metalúrgica del periodo formativo del Noroeste argentino. Memorias Mesa Redonda Tecnologías Metalúrgicas en Amércia Prehispánica: 117-128. UNAM, México.

Pifferetti, A.A. 2004. Las Cucharas de Colada por el Fondo en la Metalurgia Prehispánica. Actas del Congreso CONAMET/SAM, La Serena, Chile.

Pino Matos, J. L. 2004. El Ushnu Inka y la Organización del Espacio en los principales Tampus de los Wamani de la Sierra Central del Chinchaysuyu. Chungara, Revista de Antropología Chilena, Vol. 36 (2): 303- 311.

Plaza, M.T. 2010. Estudio sobre la metalurgia Incaica en Chile Central durante el periodo Alfarero Tardío. Memoria para optar el título de Arqueólogo, inédita. Departamento de antropología, Facultad de Ciencias Sociales, Universidad de Chile.

Plaza, M.T. y M. Martinón-Torres. 2015. Metallurgical Traditions Under Inka Rule: A Technological Study of Metals and Technical Ceramics From the Aconcagua Valley, Central Chile. Journal of Archaeological Science, Vol. 54: 86-98.

Ponce, E. L. 2002. Mazas prehispánicas de metal: sir de Perú y extremo norte de Chile. Chungara, Revista de Antropología Chilena, Vol. 34, N²: 215.223.

Porto Tenreiro, Y. 2000. Medidas Urgentes de Conservación en Intervenciones Arqueológicas. CAPA: Cuadernos de Arqueología y Patrimonio, $\mathrm{N}^{\circ} 13: 1$ - 38.

Primera Convención Nacional de Antropología. 1966. Primera Parte. Publicaciones Nueva Serie, Instituto de Antropología, $n^{\circ}$ 1. Universidad Nacional de Córdoba, Córdoba.

Putz, H. W. H. Para y D. Topa. 2009. A Contribution to the Knowledge of the Mineralization ar Mina Capillitas, Catamarca. Revista de la Asociación Geológica Argentina 64 (3): 514-524.

Quiroga, A. 1929. Folklore Calchaquí. Revista de la Universidad de Buenos Aires V.

Raffino, R. 1978. La ocupación Inka en el N.O. argentino: actualización y perspectivas. Relaciones de la Sociedad Argentina de Antropología, Vol. XII: 95-121. 
Raffino, R. 1981. Los Inkas del Kollasuyu. Origen, naturaleza y transfiguraciones de la ocupación Inka en los Andes Meridionales. Ed. Ramos Americana.

Raffino, R. 1994. El NOA y la integración Inka (1476-1535 d.C.). Rumitacana 1: 43-48.

Raffino, R. 2004. El Shincal de Quimivil. Sarquis, Catamarca.

Raffino, R. 2007. Poblaciones Indígenas en Argentina. Urbanismo y Proceso Social Precolombino. Emecé Editores, Buenos Aires.

Raffino, R. A. y R. Stehberg. 1997. El Tawantinsuyu y sus fronteras. Actas y trabajos científicos, XI Congreso del hombre y la cultura andina «Augusto Cardich», vol. I: 338361. Universidad Nacional Hermilio Valdizán de Huánuco/Universidad Nacional de La Plata-Argentina/Centro de Estudios Histórico-Militares del Perú, Lima.

Raffino, R., D. Gobbo, R. Vázquez, A. Capparelli, V. Montes, R. Iturriza, C. Deschamps y M. Mannasero. 1997 El ushnu de El Shincal de Quimivil. Tawantinsuyu 3:22-39.

Raffino, R., R. Iturriza, A. Iácona, A. Capparelli, D. Gobbo, V. Montes y R. Vázquez. 1996. Quillay: centro metalúrgico Inka en el Noroeste Argentino. Tawantinsuyu 2: 5969.

Raffino, R., R.J. Alvis, L.N. Baldini, D.E. Olivera y M.G. Raviña. 1982. Hualfín-El Shincal-Watungasta. Tres casos de urbanización Inka en el N.O. argentino. Actas del IX Congreso Nacional de Arqueología, pp. 470-497. Sociedad Chilena de Arqueología. Museo Arqueológico de La Serena, Chile.

Raffino, R.A., D.J. Gobbo, A. Iácona y R.A. Moralejo. 2013. La minería y metalurgia de los Inkas del Kollasuyu. Actas del V Congreso Nacional de Arqueología Histórica, Tomo 1, pp. 187-216. Editorial Académica Española. Buenos Aires.

Revuelta, C.M., S.A. Carosio y J.P. Aguilar. 2010-2012. Formas y Representaciones Tardías. Aproximaciones a una mirada Integral al Estilo Cerámico SanagastaAngualasto. Anales de Arqueología y Etnología 65-67: 59- 87.

Rice, P. M. 2005 [1987]. Pottery Analysis. Ed. Universidad de Chicago. 
Rivera Casanovas, C. 2008. Aproximación inicial a la explotación minera y metalurgia prehispánica en la región de San Lucas, Chuquisaca. En Mina y Metalurgia en los Andes del Sur, desde la Época Prehispánica hasta el siglo XVII, editado por P. Cruz y J.J. Vacher, pp. 139-200. Institut français d'études andines e Institut de la recherche pour le développement, Sucre.

Rodríguez Orrego, L. 1979. La Encrucijada: survey of site of metallurgical activity in Northwest Argentina. En Pre-Columbian Metallurgy in South America, editado por E. Benson, pp. 203-207. Dumbarton Oaks, Washington, DC.

Rostagno, C.M., H. F. Del Valle y D. Buschiazzo. 2004. La Erosión Eólica. En Peligrosidad geológica en Argentina, editado por M. A. González y N.J. Bejerman. ASAGAI.

Rostworowski, M. 1999. Historia del Tawantinsuyu. Lima: IEP, Promperú.

Rovira, S. 2005. Metalurgia de Crisol: La Obtención de cobre en la Prehistoria de la Penínsulo Ibérica. De Re Metallica, 5: 87- 94.

Rowe, J. H. 1945. Absolute Chronology in the Andean Area. American Antiquity 10 (3): 265-284.

Sáez, R., F. Nocete, J. M. Nieto, M.A. Capitán, S. Rovira, A. Ruiz-Conde, P.J. SánchezSoto. 2001. Metalurgia del Cu en Cabezo Juré (Alosno, Huelva): Estudio mineralógico de escorias del 3er milenio a.n.e. Boletín de la Sociedad Española de Mineralogía: 171-179.

Sáez, R., F. Nocete, J. M. Nieto, M.A. Capitán, S. Rovira. 2003. The Extractive Metallurgy of Copper from Cabezo Juré Hualva, Spain: chemical and Mineralogical Study of Slags Dated to the Third Milenium B.C. The Canadian Mineralogist, Vol. 41: 627-638.

Sagárnaga, J.A. 2007. Genealogía y desarrollo del topo en los Andes circum lacustres. En Metalurgia en la América Antigua. Teoría, arqueología, simbología y tecnología de los metales prehispánicos, editado por R. Lleras Pérez, pp. 83-100. Fundación de Investigaciones Arqueológicas Nacionales/Banco de la República/Instituto Francés de Estudios Andinos. 
Salado Paz, N., A. S. Fogliata, J. C. Ávila y N. Montenegro. 2011. Veta Esperanza Sudeste. Un Caso Particular de Enriquecimiento Supergénico en el Yacimiento Alto de La Blenda, Distrito Minero Agua de Dionisio, Prov. De Catamarca. Revista de la Asociación Geológica Argentina 68 (2): 185-194.

Salazar, D y F. Vilchez. 2014. La arqueología de la minería en el centro-sur andino: Balance y perspectivas. Estudios Atacameños, № 48: 5 - 21

Salazar, D. Figueroa, V. Mille, B., Morata, D y H. Salinas. 2010. Metalurgia prehispánica en las sociedades costeras del norte de Chile (quebrada Mamilla, Tocopilla). Estudios Atacameños, N40: 23-42.

Salazar, D., B. Mille, V. Figueroa, F. Balestro, C. Perlés, C. Perles, J. Berenguer, D. Bourgarit, P. Corrales, L. Carroza y A. Burens. 2013. Metalurgia indígena en el distrito Miño-Collahuasi, Norte de Chile (Siglos X a XVII): Tecnología y organización de la producción de cobre. Ponencia presentada en el XVIII Congreso Nacional de Arqueología Argentina, La Rioja.

Salazar, D., Berenguer, J y G. Vega. 2013. Paisajes minero-metalúrgicos incaicos en Atacama y el altiplano sur de Tarapacá (norte de Chile). Chungara, Revista de Antropología Chilena, Vol. 45: 83-103.

Sánchez Días, A. 1909. Aleaciones. El bronce en la Región Calchaquí. Buenos Aires.

Scatollin, M. C. y V. Williams. 1992. Actividades Minero Metalúrgicas Prehispánicas en el Noroeste Argentino. Nuevas evidencias y su significación. Bull. Inst. fr. Études andines 21 (1): 59.87.

Schávelzon, D. y A. Igareta. 2009. Música y mercenarios en la fundación de ciudades argentinas: birimbaos del siglo XVII en Buenos Aires y Catamarca. Revista de Arqueología Histórica Argentina y Latinoamericana, N³: 69-81.

Schiappacasse, V. y H. Niemeyer. 2002. Ceremonial Inca provincial: el asentamiento de Saguara (cuenca de Camarones). Chungara, Revista de Antropología Chilena, vol. 34, $\mathrm{N}^{\circ} 1: 53-84$.

Schiffer, M. B. 1976. Behavorial chain analysis: activity, organization and the use of space. Fieldiana Anthropology, vol. 65: 103-119. 
Schiffer, M. B. 1992. Los Procesos de Formación del Registro Arqueológico. Boletín de Antropología Americana, No. 23: 39-45.

Schiffer, M. B. 2010. Behavioral Archaeology. Principles and Practice. London: Equinox.

Schlanger, N. 2005. The Chaine Operatoire. En Archaeology: the key concepts, editado por C. Renfrew y P. Bahn, pp. 25-31. London: Routledge.

Scott, D. A. 1991. Metallography and Microstructure of Ancient and Historic Metals. The Getty Conservation Institute in the J. Paul Getty Museum, Tien Wah Press, Ltd.

Sellet, F. 1993. Chaine Operatorie: the concept and its applications. Lithics technology, vol. $18, \mathrm{n}^{\circ} 1-2$ : 106-112.

Shimada, I, S. Epstein y A. K. Craig. 1982. Batán Grande: A Preshitoric Metallurgical Center in Peru. Science, Vol. 216: 952-959.

Shimada, I. 1987. Aspectos tecnológicos y productivos de la metalurgia Sicán, costa norte del Perú. Gaceta Arqueológica Andina 13: 15-21.

Shimada, I. 1996. Sican metallurgy and its cross-craft relationships. Boletín del Museo del Oro 41: 27-61.

Shimada, I. y A. Craig. 2013. The style, technology and organi-zation of Sicán mining and metallurgy, northern Peru: insights from holistic study. Chungara, Revista Chilena de Antropología 45(3): 3-31.

Shimada, I., D. J. Goldstein, U. Wagner y A. Bezúr. 2007. Pre-hispanic sicán furnaces and metalworking: Toward a holistic understanding. En: Metalurgia en la América Antigua: Teoría, arqueología, simbología y tecnología de los metales prehispánicos, editado por Lleras Pérez, R., pp. 337-361. Bogotá: Institut français d'études andines.

Shipman, P., G. Foster y M. Shoeninger. 1984. Burnt Bones and Teeth: an Experimental Study of Color, Morphology, Crystal Structure and Shrinkage. Journal of Archaeological Science 11: 301-325.

Shobinger, J (comp). 2001. El santuario incaico del cerro Aconcagua. EDIUNC, Mendoza. 
Sotil Monteverde, L. R. 2011. La configuración arquitectónica de los ushnus como espacios de libaciones y ofrendas líquidas durante el Tahuantinsuyo. Bulletin de l'Institut français d'études andines, 40: 31-80

Spina, J. y G. Gluzman. 2017. Hacia una Comprensión de las Cerámicas Metalúrgicas. Caracterización Morfológica y Funcional de Moldes y Crisoles de dos Sitios del Noroeste Argentino. En Investigaciones arqueométricas: técnicas y procesos, editado por A. Rocchietti, F. Ribero y D. Reinoso, pp. 91-104. Editorial Aspha, Buenos Aires.

Spina, J. y M. A. Giovannetti. 2014. Metalurgia Prehispánica en el Valle de Hualfín: Nuevos Datos Sobre Quillay. Intersecciones en antropología, 15(2): 473-477.

Sternfeld, G. 2007. La organización laboral del imperio Inka. Las autoridades locales básicas. Iberoamericana, Vervuert. Madrid, Frankfurt.

Tarragó, M. 2012. Al doctor Alberto Rex González. Relaciones de la Sociedad Argentina de Antropología XXXVII (2): 227-230.

Tarragó, M. y L. González. 2003. Los Graneros: un Caso de Almacenaje Incaico en el Noroeste Argentino. Runa XXIV: 123-149.

Téreygeol, F. y C. Castro. 2008. La metalurgia prehispánica de la plata en Potosí. En Mina y metalurgia en los Andes del Sur desde la época prehispánica hasta el siglo XVII, editado por P. Cruz y J. J. Vacher, pp. 11-28. Institut de Recherche pour le Développement, Instituto Francés de Estudios Andinos, Sucre.

Téreygeol, F. y P. Cruz. 2014. Metal del viento. Aproximación experimental para la comprensión del funcionamiento de las wayras andinas. Estudios Atacameños. Arqueología y Antropología Surandinas 48: 39-54.

Thomas, J. 2006. The trouble with material culture. En: Overcoming the modern invention of material culture, editado por V. J. Oliveira y J. Thomas, Proceeding of the TAG session Exeter, Journal of Iberian Archaeology, vol. 9-10: 11-24.

Tortorelli, L. A. 2009 [1956]. Maderas y Bosques Argentinos. Orientación Gráfica, Tomo I. 
Trigger, B.G. 1992 [1989]. Historia del pensamiento arqueológico. Editorial Critica, Barcelona.

Trucco, B. 1965. Contribución al conocimiento de la metalurgia del Noroeste argentino. Tesis de doctorado en Ciencias Naturales. Facultad de Ciencias Naturales y Museo de la Universidad Nacional de La Plata.

Tylecote, R. 1979. A History of Metallurgy. Metals Society, London.

Valencia, A. 1978. La platería tradicional en un pueblo del sur del Perú. En Tecnología andina, pp. 535-554 Lima, Instituto de Estudios Peruanos.

Van Buren, M. 2003. Un estudio etnoarqueológico de la tecnología de fundición en el sur de Potosí, Bolivia. Textos Antropológicos, vol. 14, N²: 133-148.

Van Buren, M. y B. H. Mills. 2005. Huayrachinas and tocochimbos: Traditional smelting technology of the southern Andes. Latin American Antiquity 16: 3-25.

Van Buren, M. y C. R. Cohen. 2010. Technological changes in silver production after the spanish conquest in Porco, Bolivia. Boletín del Museo Chileno de Arte Precolombino, vol. 15, $\mathrm{N}^{\circ}$ 2: 29-46, Santiago de Chile.

Vetter Parodi, L. 2007. La evolución de los tupus en forma y manufactura desde los Incas hasta el siglo XIX. Metalurgia en la América Antigua. Teoría, arqueología, simbología y tecnología de los metales prehispánicos, editado por R. Lleras Pérez, pp. 101-128. Fundación de Investigaciones Arqueológicas Nacionales Banco de La República, Instituto Francés de Estudios Andinos.

Vetter Parodi, L., Petrick Casagrande, S., Huaypar Vasquez, Y. y M. Mac Kay Fulle. 2008. Los hornos metalúrgicos del sitio Inca de Curamba (Perú): estudio por DRX, espectroscopia Mossbauer y datación por métodos de luminiscencia. Bulletin de l'Institut Français d'Études Andines 37(3): 451-475.

Williams, V. 1994. Jerarquización y funcionalidad de centros estatales incaicos en el área valliserrana central. Shincal 4: 11-34. 
Williams, V. 1995. Arqueología Incaica en la Región Centro - Oeste de Catamarca (República Argentina). Tesis Doctoral inédita. Universidad Nacional de La Plata. Facultad de Ciencias Naturales y Museo.

Williams, V. 2000. El imperio Inka en la provincia de Catamarca. Intersecciones en Antropología, 1: 55-79.

Williams, V. 2003. Nuevos datos sobre la prehistoria local en la Quebrada de Tolombón. Pcia de Salta. Argentina. Revista Anales, Vol. 6: 163-210.

Williams, V. 2004. Poder estatal y cultura material en el Kollasuyu. Boletín de Arqueología, PUCP, N8: 209-245.

Williams, V. 2010. El uso del espacio a nivel estatal en el sur del Tawantinsuyu. En El habitat prehispánico. Arqueología de la arquitectura y de la construcción del espacio organizado, editado por M.E. Albeck, M.C. Scatollin y M.A. Korstanje, pp:77-114. Universidad Nacional de Jujuy, San Salvador de Jujuy.

Williams, V. I., M. P. Villegas, M. S. Gheggi y M. G. Chaparro. 2005. Hospitalidad e Intercambio en los Valles Mesotermales del Noroeste Argentino. Boletín de Arqueología PUCP, $\mathrm{N}^{\circ}$ 9: $335-372$.

Williams, V. y T. N. D’Altroy. 1998. El sur del Tawantinsuyu: un dominio selectivamente intensivo, Tawantinsuyu, vol. n5: 170 - 178. The Australian National University, Canberra.

Wynveldt, F y B. Balesta. 2009. Paisaje socio-político y beligerancia en el Valle de Hualfín (Catamarca, Argentina). Antípoda 8: 143-167.

Wynveldt, F, N. Zagorodny, M. Morosi. 2005. Tendencias Morfométricas y Caracterización Composicional de la Cerámica Belén en el Valle de Hualfín (Belén, Catamarca). Actas del Primer Congreso Argentino de Arqueometría, pp. 95-106. Rosario: Humanidades y Artes Ediciones.

Wynveldt, F. 2007. La Estructura del Diseño Decorativo en la Cerámica Belén (Noroeste Argentino). Boletín del Museo Chileno de Arte Precolombino, Vol. 12, N²: 49- 67. 
Wynveldt, F. 2008. Tecnología Cerámica Belén: Caracterización Macroscópica y Conceptualización en la Manufactura Alfarera. Intersecciones en Antropología 9: 157172

Wynveldt, F. 2009. Los Contextos Funerarios de Azampay entre el Periodo de Desarrollos Regionales y la conquista Inkaica (valle de Hualfín, Catamarca). Arqueología 15: 127-147.

Zagorodny, N., C. Angiorama, M. F. Becerra, M. J. Pérez Pieroni. 2015. Evidencias de actividades metalúrgicas en el sitio Campo de Carrizal (Belén, Catamarca). Intersecciones en Antropología 16: 439-450.

Zori, C., P. Tropper y D. Scott. 2013. Copper production in late prehispanic northern Chile. Journal of Archaeological Science 40: 1165-1175.

Zuidema, T. 1981 Inca observations of the solar and lunar passages through zenith and anti-zenith at Cuzco. En Archaeoastronomy in the Americas, editado por $\mathrm{R}$. Williamson, pp. 319-342. Ballena Press, Los Altos, California 


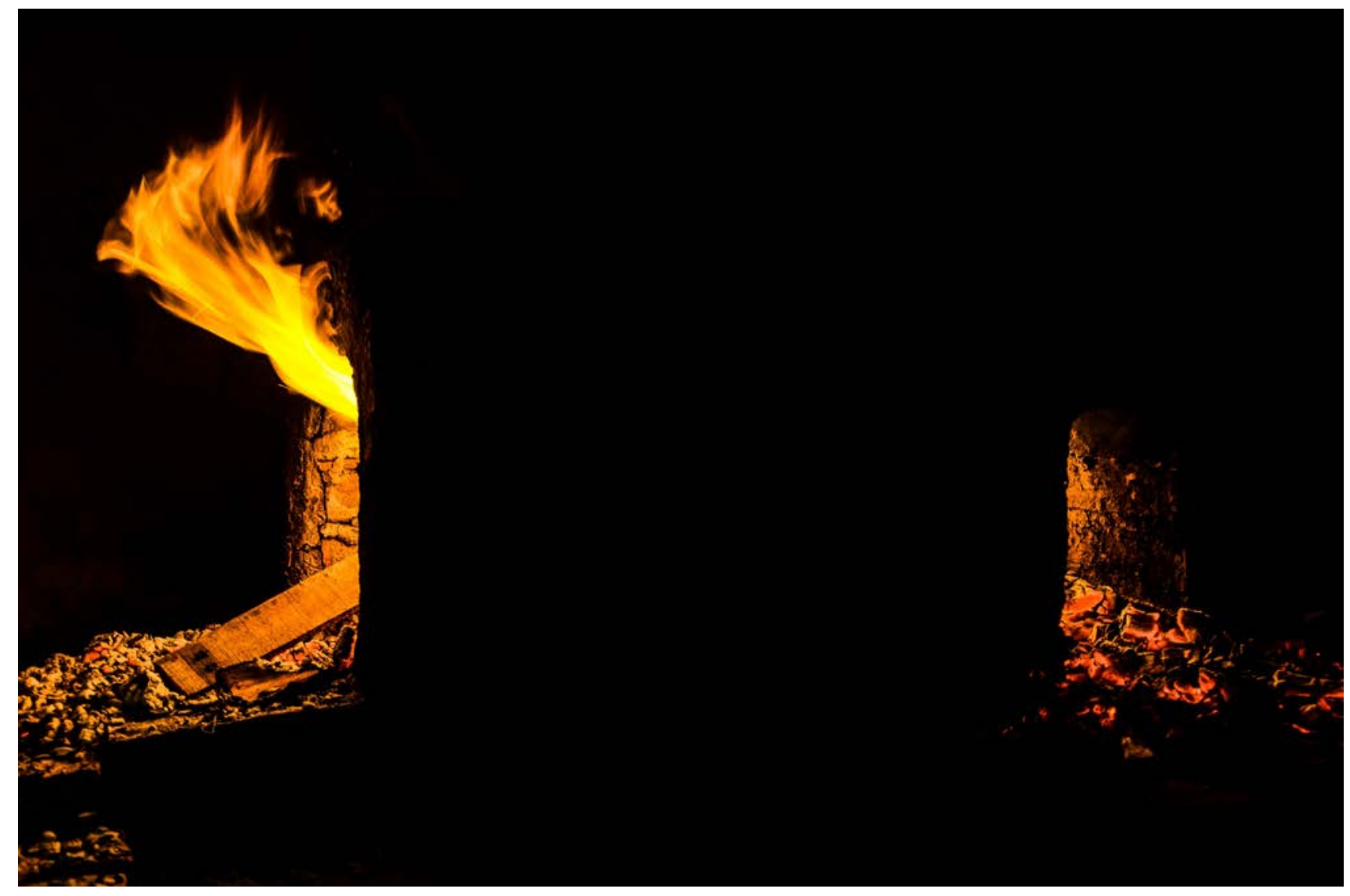

Momento de encendido.

Horno cerámico contemporáneo realizado con material arcilloso. Foto: Kuyen fotografia 